UNIVERSIDADE DE SÃO PAULO

FACULDADE DE FILOSOFIA, LETRAS E CIÊNCIAS HUMANAS

DEPARTAMENTO DE GEOGRAFIA

ORgANIZAÇÃo dO ESPAÇO E POLÍTICAS PÚBLICAS AMBIENTAIS NO

MUNICÍPIO DE SÃo JOSÉ DOS CAMPOS - SP

REGINA TORTORELLA REANI

Versão Corrigida

O exemplar original se encontra disponível no CAPH da FFLCH

Centro de Apoio à Pesquisa Histórica

São Paulo, 2012 
UNIVERSIDADE DE SÃO PAULO

FACULDADE DE FILOSOFIA, LETRAS E CIÊNCIAS HUMANAS

DEPARTAMENTO DE GEOGRAFIA

\title{
ORGANIZAÇÃo dO ESPAÇO E POLÍTICAS PÚBLICAS AMBIENTAIS NO MUNICÍPIO DE SÃo JOSÉ dOS CAMPOS - SP
}

\author{
Regina Tortorella Reani
}

Tese apresentada ao programa de Pós-Graduação em Geografia Humana, do Departamento de Geografia, da Faculdade de Filosofia, Letras e Ciências Humanas da Universidade de São Paulo, para obtenção do título de Doutora em Geografia.

Orientador: Prof. Dr. Reinaldo Paul Pérez Machado 
Ao meu esposo Tiago, que esteve presente em todos os momentos desse doutorado, trazendo forças, incentivo e motivação;

E aos meus pais Roberto e Luzia que sempre me acompanharam, com amor e carinho. 


\section{Agradecimentos}

Em primeiro lugar, agradeço a Deus por ajudar a trilhar meu caminho.

Ao meu orientador, pela oportunidade de realizar o doutorado em Geografia Humana na USP, pela sua confiança e orientação.

Aos professores(as) da banca de defesa: Mario de Biasi (USP), Ailton Luchiari (USP), Claudete de Castro Silva Vitte (UNICAMP) e Cláudia Maria de Almeida (INPE), pelo cuidado com avaliação e atenção ao trabalho apresentado. À Prof ${ }^{-a}$ Neli Aparecida Melo, pelas suas excelentes aulas e pelas contribuições no exame de qualificação.

Aos meus pais, Roberto e Luzia pela educação que me deram, pelo incentivo para a realização deste doutorado e por toda ajuda e amor que sempre me acompanharam. Às minhas irmãs, Paula e Fernanda, por estarem sempre do meu lado, por serem minhas amigas e torcerem por mim, e também, ao meu cunhado Juninho e ao Carlos Augusto.

Ao meu esposo Tiago, que sempre esteve disposto a ajudar, sempre dizendo palavras de conforto e motivação, e pelo seu carinho e amor. E a toda sua família, Fatima Regina, Odelcio, Luis e Maria Clara, pelo apoio.

Aos funcionários da Prefeitura Municipal de São José dos Campos, que contribuíram com a disposição de dados e informações, em especial à Rosana Mayumi (SEMEA), ao Donato, ao Paulo (Arquivo Público Municipal) e ao João (SEPLAN).

À Rubia bibliotecária, da Univap, pela ajuda com a bibliografia, e também, à amiga Maria José, pelos livros emprestados.

Ao Governo do Estado de São Paulo, pela bolsa de estudo concedida no último ano de pesquisa.

A todos os amigos, colegas, familiares, e também, aos funcionários da secretaria de pósgraduação e professores do departamento de geografia da USP, que de uma forma ou outra contribuíram para a realização deste trabalho. 


\section{Sumário}

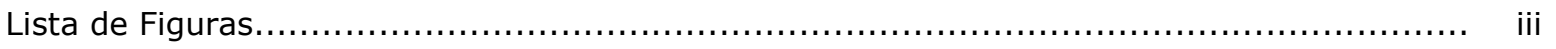

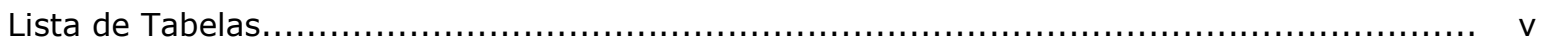

Lista de Siglas e Abreviações $\quad$ vi

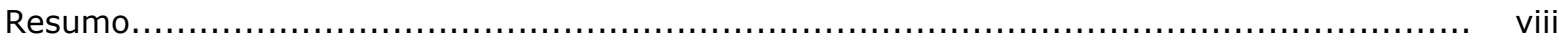

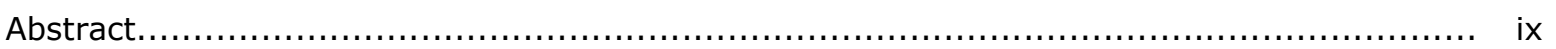

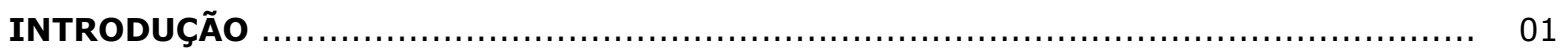

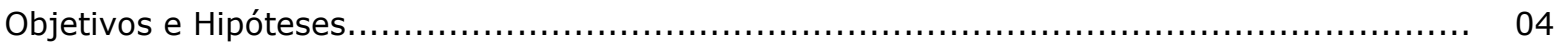

PARTE I

geografia, PLANEJAMENTO URBANO E MEIO AMBiENTE

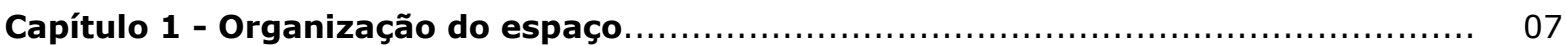

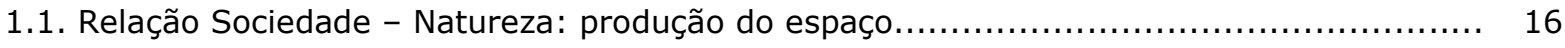

1.2. O Estado e a produção do espaço............................................................ 19

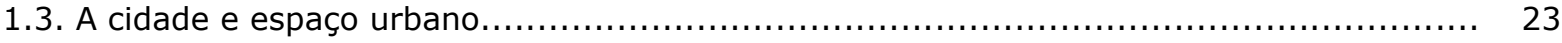

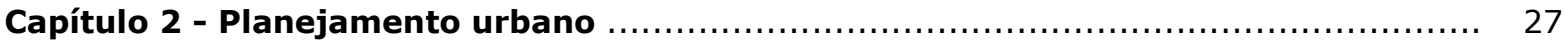

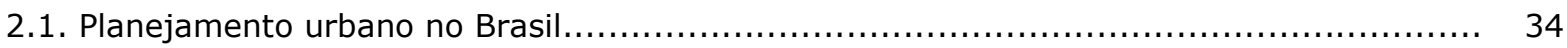

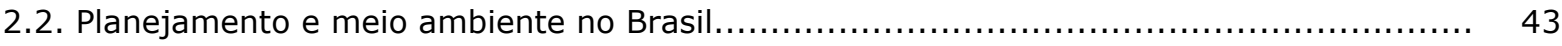

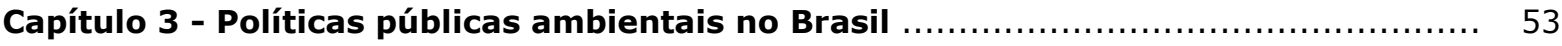

PARTE II

POLÍtICAS PÚBLICAS AMBIENTAIS NO PLANEJAMENTO URBANO

DE SÃO JOSÉ DOS CAMPOS

Capítulo 4 - Caracterização do Município de São José dos Campos...................... 63

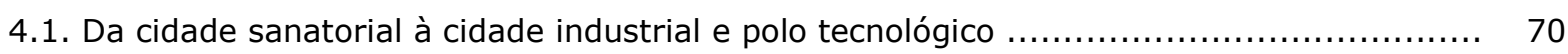

4.2. Organização do espaço e o planejamento urbano em São José dos Campos ............... 79

Capítulo 5 - Legislação Urbanística e Ambiental em São José dos Campos.............. 88

5.1. Estudo dos Planos Diretores de São José dos Campos: $1960-2010 \ldots \ldots \ldots \ldots \ldots \ldots \ldots \ldots \ldots$

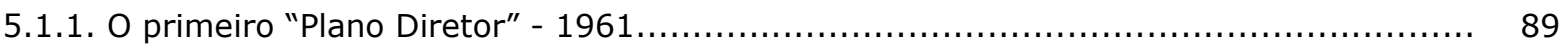

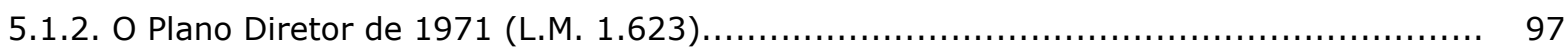


5.1.3. O Plano Diretor de 1995 (L.C. 121).

5.1.4. O Plano Diretor de 2006 (L.C. 306).

5.2. Zoneamento urbano: legislação de parcelamento, uso e ocupação do solo do município de São José dos Campos...

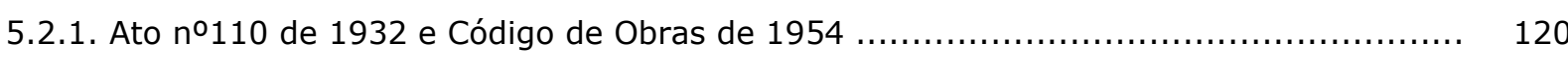

5.2.2. Zoneamento de Massa e Plano Diretor 1961

5.2.3. Leis municipais no 1.575/70, no 1.576/70, no 1.578/70 - Parcelamento, uso do solo e Zoneamento.

5.2.4. A Lei de Zoneamento Urbano de 1971 (L.M. 1.606)...

5.2.5. A Lei de Zoneamento Urbano de 1980 (L.M. 2.263)...

5.2.6. A Lei de Zoneamento Urbano de 1990 (L.M. 3.721)....

5.2.7. A Lei de Zoneamento Urbano de 1997 (L.C. 165).

5.2.8. A Lei de Zoneamento Urbano de 2010 (L.C. 428).

5.2.9. As Leis de Anistia....

5.3. A Legislação Ambiental de São José dos Campos.

\section{Capítulo 6 - As Políticas Públicas Ambientais: discurso e prática em São José dos} Campos.

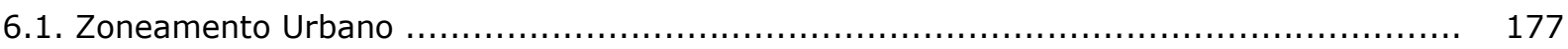

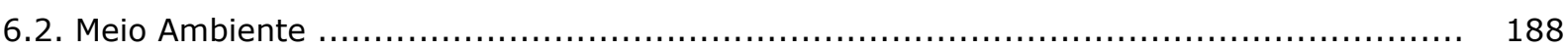

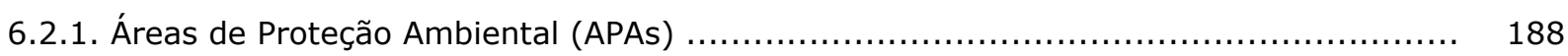

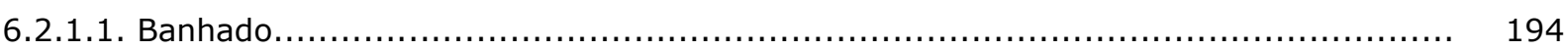

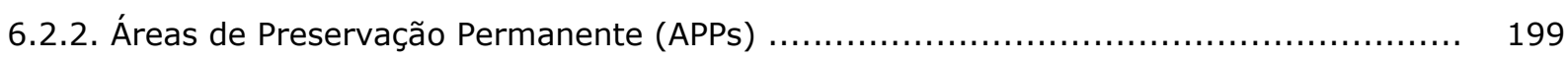

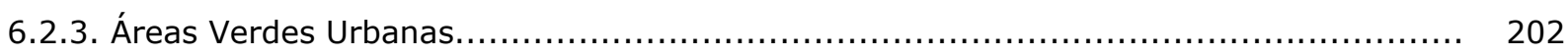

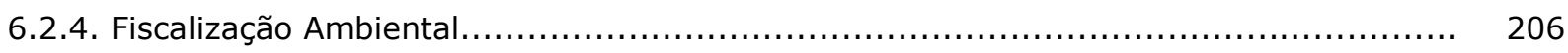

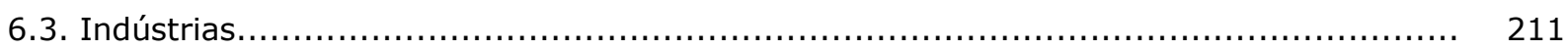

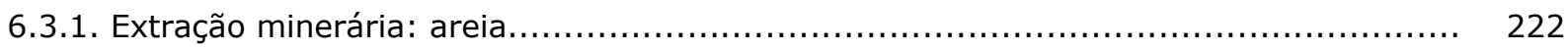

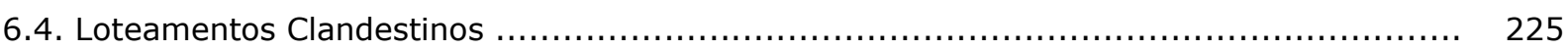

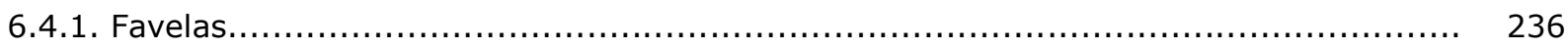

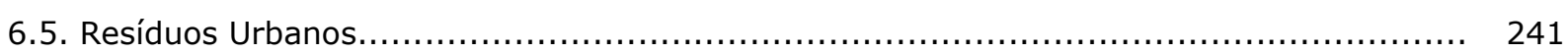

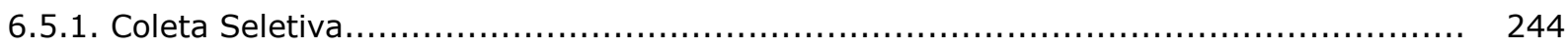

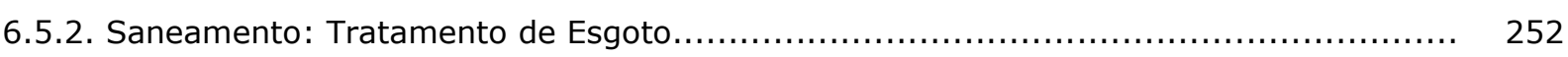

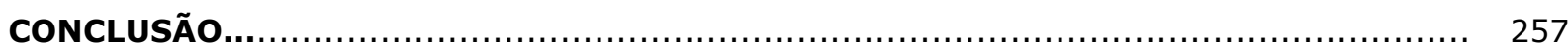

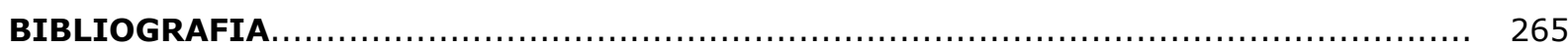

Anexo: Tabela 9 - Análise da Legislação de São José dos Campos......................... 275 


\section{Lista de Figuras}

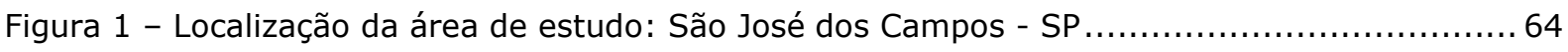

Figura 2 - São José dos Campos: perímetro urbano e regiões administrativas .......................... 64

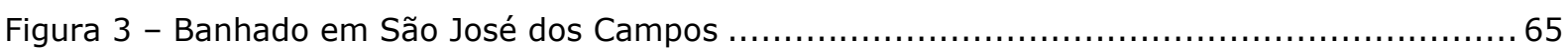

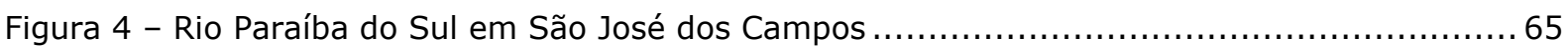

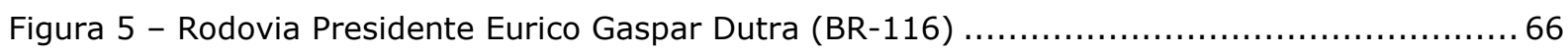

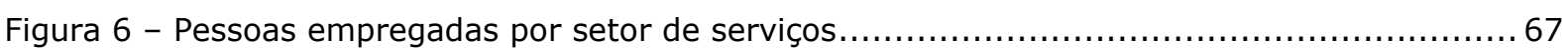

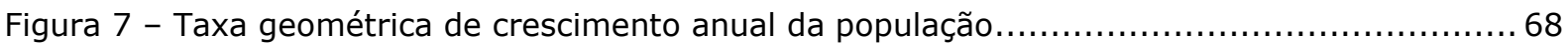

Figura 8 - Evolução da expansão urbana em São José dos Campos ................................... 69

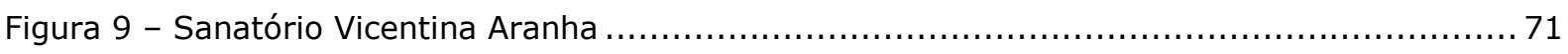

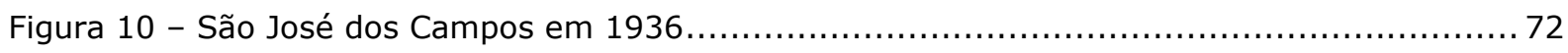

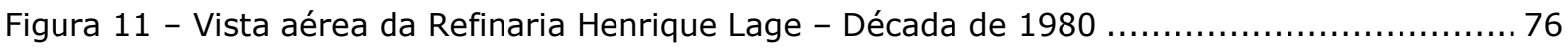

Figura 12 - Instalação de indústrias no município de São José $(1940-2003) \ldots \ldots \ldots \ldots \ldots \ldots \ldots \ldots \ldots \ldots . \ldots 77$

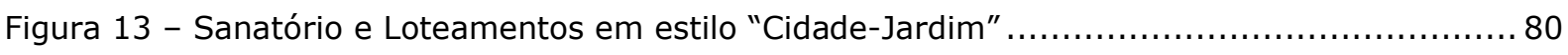

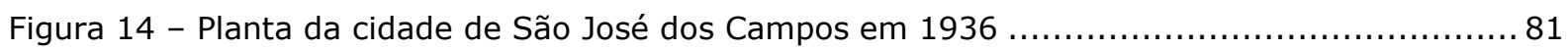

Figura 15 - Zoneamento de Massa e Setorização .......................................................... 92

Figura 16 - Localização da Favela da "Linha Velha" ....................................................... 93

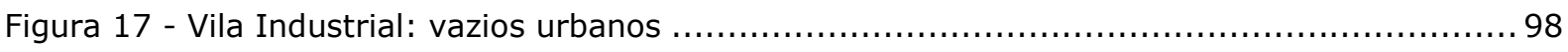

Figura 18 - Jardim Esplanada, Vila Ema, Sanatório Ezra: ocupações dispersas com vazios ..........98 98

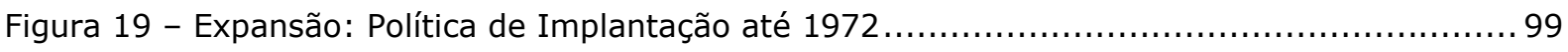

Figura 20 - Expansão: Política de Implantação 1973 - 1980 ............................................ 99

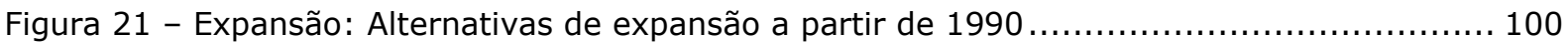

Figura 22 - Carta das Unidades Territoriais de Características Físicas e Antrópicas Homogêneas 107

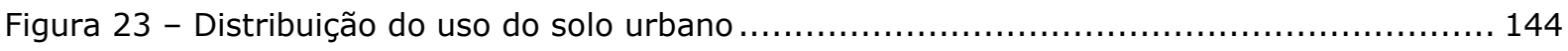

Figura 24 - Verticalização em São José dos Campos....................................................... 145

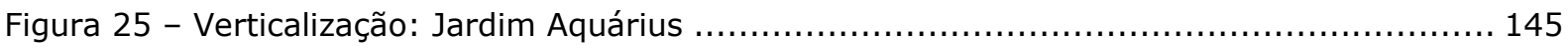

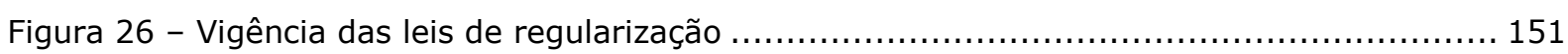

Figura 27 - Evolução das Leis de Zoneamento Urbano em São José dos Campos.................... 180

Figura 28 - Evolução das áreas nas Leis de Zoneamento de São José dos Campos.................... 181

Figura 29 - Carta das Unidades, PDDI-1995, PDDI-2006 e "Zoneamento 2010" ..................... 185

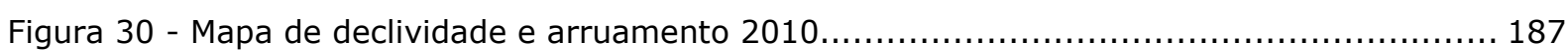

Figura 31 - Áreas de Proteção Ambiental em São José dos Campos .................................... 190

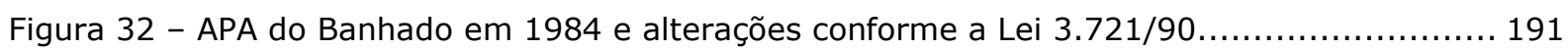

Figura 33 - APA IV definida no PDDI-1995 e as mudanças em sua área conforme as Leis de

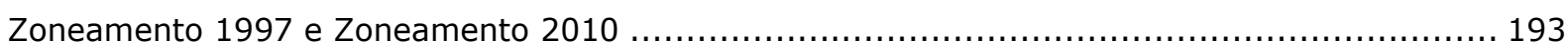

Figura 34 - Banhado próximo a área central de São José dos Campos ............................. 194

Figura 35 - Área não edificante no Banhado (Lei 1606/71) ............................................... 195 
Figura 36 - Zona não edificante- Talude do Banhado (Lei 2.263/80) ................................ 196

Figura 37 - Loteamentos de Alto Padrão na APA do Banhado …................................... 197

Figura 38 - "Favela Vila Nova Esparança" na APA do Banhado ....................................... 198

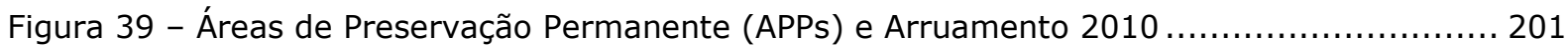

Figura 40 - Mapa da área de carência de áreas verdes............................................ 204

Figura 41 - Mapa Parques Urbanos previstos em São José dos Campos .............................. 206

Figura 42- Autos de Infração Ambiental (AIA) de São José dos Campos ............................. 208

Figura 43 - Bonadio S.A. - Fábrica de Louças Santo Eugênio ......................................... 211

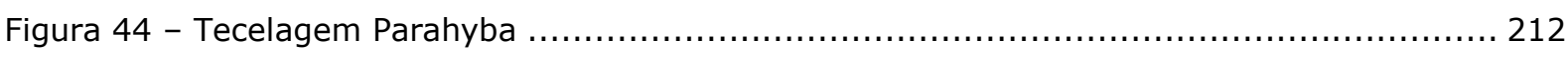

Figura 45 - Vista parcial das instalações da Rhodia as margens do Rio Paraíba ....................... 213

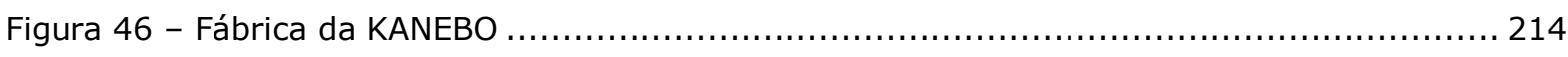

Figura 47 - Zoneamento de massa e indústrias na década de 1960 e1970 …..................... 215

Figura 48 - Plano Diretor de 1971 (loteamento aprovado) e REVAP instalada em 1980............ 216

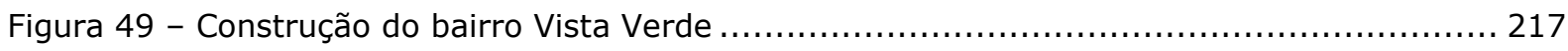

Figura 50 - Indústrias de grande porte, APA e APPs .................................................. 219

Figura 51 - Indústrias e fontes de poluição atmosférica em São José dos Campos .................... 221

Figura 52 - Zoneamento Ambiental para Atividade de Extração de Areia na Várzea do Rio Paraíba

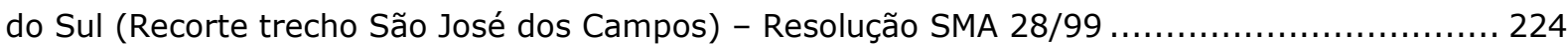

Figura 53 - Loteamentos Clandestinos em São José dos Campos - 1977 ............................ 226

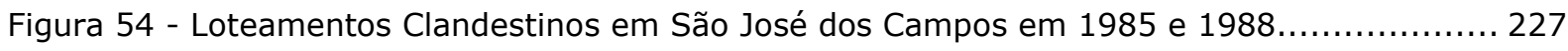

Figura 55 - Mapa da Localização dos Loteamentos Clandestinos em 1995 ........................... 229

Figura 56 - Loteamentos Clandestinos em São José dos Campos em 1997 ............................ 230

Figura 57 - Densidade das Ocupações Clandestinas (\%) .......................................... 231

Figura 58 - Área Urbana Legal x Área de Loteamento Clandestino ................................. 232

Figura 59 - Loteamentos Clandestinos, APAs e Cursos d'água ...................................... 234

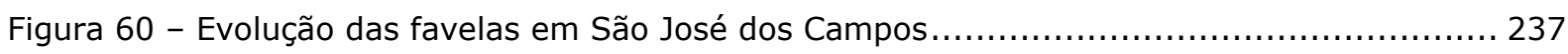

Figura 61 - Localização da "Favela Santa Cruz" ................................................... 238

Figura 62 - Localização de favelas em São José dos Campos, APA e Cursos d'água .................. 239

Figura 63 - Estação de Tratamento de Resíduos Sólidos em São José dos Campos.................. 241

Figura 64 - Fachada do Ponto de Entrega Voluntária instalado no Jardim Satélite................... 243

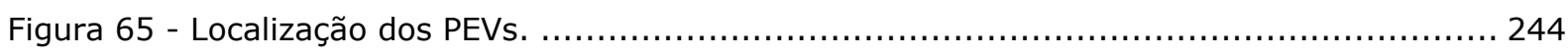

Figura 66 - Coleta seletiva e Coleta comum em toneladas/dia ................................... 247

Figura 67 - Escala de Coleta Seletiva (ton/mês) .................................................... 248

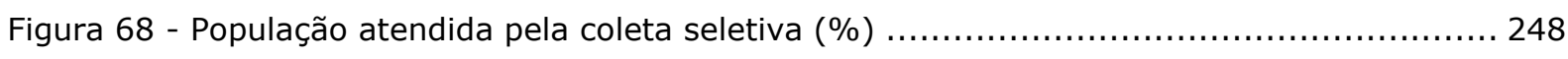

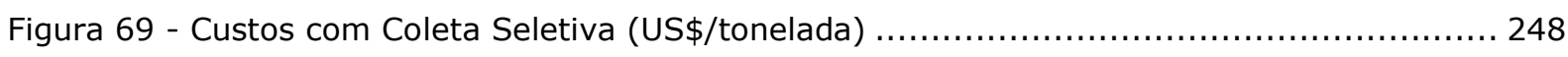

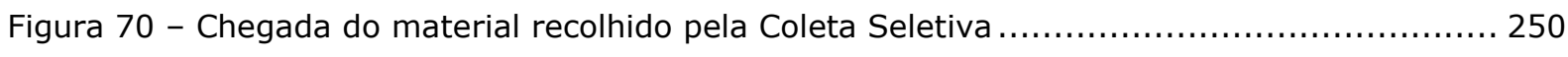

Figura 71 - Separação do material reciclável nas esteiras .......................................... 251

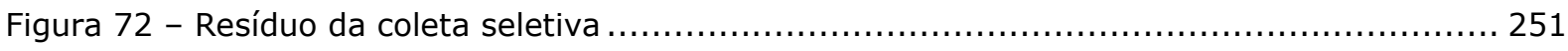

Figura 73 - Caminhão carregado com material reciclável .......................................... 251

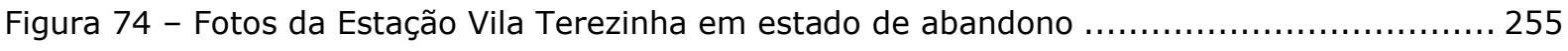




\section{Lista de Tabelas}

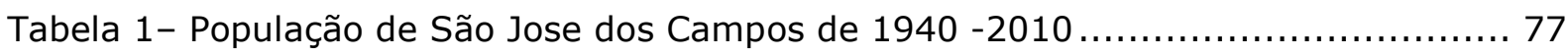

Tabela 2 - Zoneamento urbano: agrupamento de zonas e classe final....................178

Tabela 3 - Evolução das áreas em $\mathrm{km}^{2}$ nas Leis de Zoneamento de São José dos Campos

Tabela 4 - Evolução das áreas em porcentagem nas Leis de Zoneamento de São José dos Campos. 182

Tabela 5 - Índice potencial de áreas verdes por habitante por setor socioeconômico...205

Tabela 6- Fiscalização pela Secretaria Municipal do Meio Ambiente 208

Tabela 7 - Avaliação do sistema de coleta seletiva .................................... 245

Tabela 8 - Evolução dos resíduos coletados em São José dos Campos ......................247

Tabela 9 - Análise da Legislação de São José dos Campos ..................................275 


\section{Lista de Siglas e Abreviações}

\begin{tabular}{|c|c|}
\hline AIA & Auto de Infração Ambiental \\
\hline APA & Área de Proteção Ambiental \\
\hline APP & Área de Preservação Permanente \\
\hline $\begin{array}{l}\text { CEMPRE } \\
\text { CETESB }\end{array}$ & $\begin{array}{l}\text { Compromisso Empresarial para Reciclagem } \\
\text { Companhia Ambiental do Estado de São Paulo }\end{array}$ \\
\hline COMAM & Conselho Municipal de Meio Ambiente \\
\hline CONAMA & Conselho Nacional do Meio Ambiente \\
\hline CPEU & Centro de Pesquisa e Estudos Urbanísticos \\
\hline CTA & Centro Técnico Aeroespacial \\
\hline ETRS & Estação de Tratamento dos Resíduos Sólidos \\
\hline $\begin{array}{l}\text { FAU } \\
\text { GRAPROHAB }\end{array}$ & $\begin{array}{l}\text { Faculdade de Urbanismo } \\
\text { Grupo de Análise e Aprovação de Projetos habitacionais do Estado } \\
\text { de São Paulo } \\
\text { Instituto Brasileiro de Meio Ambiente e dos Recursos Naturais }\end{array}$ \\
\hline IBAMA & Renováveis \\
\hline IBGE & Instituto Brasileiro de Geografia e Estatística \\
\hline INPE & Instituto Nacional de Pesquisas Espaciais \\
\hline IPT & Instituto de Pesquisas Tecnológicas \\
\hline ITA & Instituto Tecnológico de Aeronáutica \\
\hline MMA & Ministério do Meio Ambiente \\
\hline NEPO/UNICAMP & Núcleo de Estudo de População/ Universidade de Campinas \\
\hline NPRF & Núcleo Passível de Regularização Fundiária \\
\hline ONGs & Organizações Não Governamentais \\
\hline PDDI & Plano Diretor de Desenvolvimento Integrado \\
\hline PEV & Pontos de Entrega Voluntária \\
\hline PMSJC & Prefeitura Municipal de São José dos Campos \\
\hline REVAP & Refinaria Henrique Lage - Petrobrás \\
\hline SABESP & Companhia de Saneamento Básico do Estado de São Paulo \\
\hline SEADE & Fundação Sistema Estadual de Análise de Dados \\
\hline SEMEA & Secretaria Municipal de Meio Ambiente \\
\hline SMA & Secretaria do Meio Ambiente do Estado de São Paulo \\
\hline URBAM & Urbanizadora Municipal S/A \\
\hline $\begin{array}{l}\text { ZAI } \\
\text { ZC }\end{array}$ & $\begin{array}{l}\text { Zona de Assentamento Informal } \\
\text { Zona Central }\end{array}$ \\
\hline $\mathrm{ZCH}$ & Zona de Chácara \\
\hline $\mathrm{ZCHR}$ & Zona de Chácaras de Recreio \\
\hline ZDCA & Zona de Domínio dos Cursos D'água \\
\hline
\end{tabular}


ZE

ZEA

ZEIS

ZEPA

ZEPH

ZESFX

ZETI

ZI

$Z M$

ZPA

$Z P C$

$\mathrm{ZPH}$

ZPI

$Z P M$

ZQA

$Z R$

ZUC

ZUD

ZUE

ZUPI

ZVU
Zona Especial

Zona Especial Aeroportuária

Zona Especial de Interesse Social

Zona Especial de Proteção Ambiental

Zona Especial de Preservação do Patrimônio Histórico, Paisagístico e Cultural

Zona Especial de São Francisco Xavier

Zona Especial de Transição Industrial

Zona Industrial

Zona Mista

Zonas de Proteção Ambiental

Zona de Predominância Comercial

Zona de Predominância Habitacional

Zona de Predominância Industrial

Zona de Proteção de Mananciais

Zona de Qualificação

Zona Residencial

Zonas de Urbanização Controlada

Zona de Uso Diversificado

Zona de Urbanização Especifica

Zona de Uso Predominante Industrial

Zona de Vazio Urbano 


\section{Resumo}

REANI, Regina Tortorella. Organização do espaço e políticas públicas ambientais no município de São José dos Campos - SP. 2012. 287f. Tese (Doutorado) - Faculdade de Filosofia, Letras e Ciências Humanas, Universidade de São Paulo, São Paulo, 2012.

Com o intuito de contribuir para os estudos geográficos sobre a cidade, com enfoque na organização e produção do espaço, planejamento urbano e nas políticas públicas ambientais, este trabalho busca elucidar a relevância da Geografia para o estudo do meio urbano. Parte-se do estudo do espaço geográfico, como produto do trabalho humano. A ação humana transforma a Natureza Primeira em Natureza Segunda, que é assim entendida como natureza socializada. O espaço é, também, marcado por políticas adotadas pelo Estado, que atua como um fator por excelência de elaboração do espaço. Por meio de políticas territoriais, o Estado é o dotador dos grandes equipamentos e infraestrutura, sendo o grande indutor da ocupação e organização do espaço. O Planejamento Urbano se torna, assim, um importante instrumento na produção e organização do espaço, por meio de políticas públicas desenvolvidas pelo Estado junto à participação dos cidadãos, que exerçam sua cidadania, visando a um meio ambiente saudável e equilibrado. Desta forma, este trabalho estuda a efetivação das políticas públicas ambientais na escala local, tendo como unidade territorial de análise o município de São José dos Campos, sendo um município de grande porte, com alto desenvolvimento tecnológico e de destaque econômico no território nacional. O espaço urbano joseense sofreu grande intervenção do Estado. Embora a cidade tenha crescido com certo planejamento, nem sempre este ocorreu de forma justa e igualitária, o que é visível nos inúmeros problemas sociais e ambientais existentes no município. Por meio da análise da legislação urbanística e ambiental, em especial Planos Diretores e Leis de Zoneamento Urbano, além de trabalhos de campo, entrevistas, levantamento cartográfico e pesquisa documental, analisa-se a efetivação das políticas ambientais no município, se verifica se o que foi planejado em lei, está sendo executado na prática, se as questões ambientais estão sendo planejadas na escala local, com objetivo de alcançar as cidades sustentáveis, o desenvolvimento social e ambiental.

Palavras-chave: organização do espaço, planejamento urbano, meio ambiente, políticas ambientais, São José dos Campos. 


\section{Abstract \\ Space Organization and environmental public policies in São José dos Campos - SP}

In order to contribute to the geographical studies of a city, emphasizing the space organization, urban planning and public environmental policies, this paper attempts to elucidate the relevance of geography as a science for studying the urban environment. The geographical space is understood as a result of the human action. The human action changes the "First Nature" into "Second Nature", which is then understood as socialized nature. The space is also marked by politics adopted by the State, which acts as a main factor to construct the space. By means of territorial policies the State becomes the great provider of equipment and infrastructure acting as the great inductor of the occupation and organization of the space. The urban planning then becomes an important instrument for the production and organization of the space, through public policies developed by the State with the citizens participation, seeking a healthy and balanced environment. Hence, this paper presents the studies of the effectuation of environmental public policies in local scale, using as territorial unit for analysis, the municipality of São José dos Campos, a large city, with high technological development and an economical reference in national territory. The urban space of São José has been subjected to major state intervention. Although the city has grown guided by some planning, this was not always happened in an equitable way, binging about many social and environmental problems in the municipality. Through the analysis of urban and environmental lawmaking, in particular Master Plans and Zoning Laws, field research, interviews, mapping and documental research, the effectuation of environmental public policies in the municipality is analyzed, and it is verified if what was planned in the law is being executed, if the environment issues are being planned in the local scale, with the objective of achieve sustainable cities, social and environmental development.

Keywords: space organization, urban planning, environment, environmental policies, São José dos Campos. 


\section{Introdução}

Os conflitos entre crescimento populacional, equidade social, desenvolvimento econômico e preservação ambiental tem sido uma das principais problemáticas na administração pública. A busca pela compatibilidade entre esses elementos se torna um dos principais desafios no que se refere ao planejamento urbano e ambiental das cidades.

Na última década, o Brasil tem direcionado novas políticas para a escala local, dando cada vez mais autonomia aos municípios no tratamento de questões sociais, econômicas e ambientais. Temos como destaque a criação do Ministério das Cidades, a aprovação do Estatuto da Cidade, o Sistema Nacional de Recursos Hídricos e Comitês de Bacias, a ampliação da autonomia da CETESB na esfera municipal.

Nesse contexto, temos também a consolidação de novos instrumentos da política pública como o planejamento ambiental, o zoneamento ambiental, a regularização fundiária, gestão participativa das cidades, gestão dos recursos hídricos, e ainda, a ampliação de novos mecanismos e tecnologias que auxiliam no ordenamento territorial, como o sensoriamento remoto, fotos aéreas e o geoprocessamento.

Desta forma, a adoção de novos instrumentos, novas tecnologias e novas políticas podem contribuir para o melhor planejamento urbano das cidades. Entretanto, para que o planejamento urbano alcance o desenvolvimento harmônico entre os elementos da cidade, é importante a presença de um estado socializante, de novas práticas de cidadania pela sociedade, que busque uma maior participação e ação para o bem estar social. Torna-se cada vez mais importante considerar a esfera ambiental no planejamento, visando à integração entre desenvolvimento e meio ambiente, equilíbrio ambiental e bem estar social. 
Os problemas ambientais urbanos são muitos, como o destino dos resíduos sólidos, a poluição do ar, das águas e do solo, a ausência de áreas verdes urbanas, ocupação irregular de encostas e de áreas de proteção e preservação ambiental, moradias em áreas de risco, enchentes, alagamentos, indústrias com grande periculosidade, excessivo número de veículos e congestionamentos (São Paulo polui mais pelos automóveis do que pelas indústrias). No entanto, todos esses problemas demandam novas práticas sociais e políticas, e o trabalho conjunto entre Estado e cidadãos. O cidadão precisa ampliar as práticas de cidadania. É preciso ir além da observação é preciso agir, tirar o foco de problemas e dificuldades para focar em habilidades e potencialidades. É preciso sair da visão paternalista, para uma visão de corresponsabilidade e cidadania. É preciso buscar soluções para os problemas. Para que assim seja possível a integração entre meio ambiente e desenvolvimento, ou seja, o desenvolvimento sustentável da cidade.

O Estado tem um papel importante a cumprir, a exemplo do caso da SABESP, em que foi comprovado que $32 \%$ das águas tratadas e limpas são perdidas pelo caminho, nos encanamentos da central até as casas. O país adotou um modelo econômico que é o de reconstrução e não o de reaproveitamento e com isso, milhares de toneladas de resíduos sólidos são produzidos por ano. Para onde vai esse resíduo? Assim, é preciso planejar a cidade para que esta seja eficiente, é preciso adotar novas práticas de cidadania, e através da eficiência poder alcançar a sustentabilidade.

A ciência geográfica, que tem como objetivo o estudo das relações entre sociedade e natureza, se torna fundamental para o estudo do planejamento urbano, organização e produção do espaço. A forma como o homem se relaciona com a natureza e as mudanças que ele impõe ao meio interferem na organização espacial. O espaço é produto do homem, o espaço é social. É preciso refletir e agir de forma diferente em relação à natureza, para que o espaço seja mais bem planejado.

O espaço não tem apenas um papel passivo, constitui um dado ativo, e não simplesmente reflexo da sociedade. É no espaço geográfico, no território, que a cidadania se dá como ela é hoje, ou seja, incompleta. Como afirma Milton Santos (2007), é preciso mudanças no uso e na gestão do território para criarmos uma nova cidadania.

Milton Santos (2007, p. 139) aponta que: "em nosso país, o acesso aos bens e serviços essenciais, públicos e até mesmo privados é tão diferencial e contrastante, que uma grande maioria de brasileiros, no campo e na cidade, acaba por ser privada desses bens e serviços”. Como afirma o autor, é preciso fortalecer o direito à cidade, o direito de uma vida decente para todos, independente do lugar onde se encontre. 
Neste sentido, este trabalho pretende aprofundar o estudo das políticas públicas ambientais e a sua efetivação na escala local, como um meio de analisar se o discurso teórico, as mudanças na política brasileira na esfera municipal, os novos instrumentos da política urbana e as novas tecnologias têm se aplicado efetivamente às cidades brasileiras e se as cidades brasileiras estão sendo planejadas em consonância com o desenvolvimento social e ambiental. O estudo almeja analisar, também, se essas políticas públicas trabalharam em prol de conseguir efetivamente alcançar as cidades sustentáveis, ou seja, o direito à terra urbana, à moradia, ao saneamento ambiental, à infraestrutura urbana, ao transporte e aos serviços públicos, ao trabalho e ao lazer, para as presentes e futuras gerações, como preconiza o Estatuto da Cidade (Lei 10.257/01, Art. 2, inciso I), e desta forma trazer melhor qualidade ambiental e condições de vida à população que vive nas cidades. O município de São José dos Campos foi utilizado como área de estudo, visto o seu papel de pólo regional e a grande ação do Estado em seu desenvolvimento. Busca-se, desta forma, considerar as políticas públicas ambientais previstas neste município e sua efetivação, com o intuito de analisar o desenvolvimento do planejamento urbano, e se as políticas adotadas foram benéficas à população e ao meio ambiente.

Este trabalho foi dividido em duas partes. Na primeira parte, aborda-se a importância da ciência geográfica no estudo da organização do espaço e como esta pode contribuir com as políticas públicas, o planejamento urbano e ambiental das cidades. Na segunda parte, estudase o município de São José dos Campos, procura-se analisar como as políticas públicas, através das leis urbanísticas e ambientais, principalmente, por meio do estudo dos Planos Diretores e Leis de Zoneamento Urbano, se efetivam na cidade, buscando analisar as políticas públicas previstas e as políticas realmente efetivadas no município e seus resultados.

No Capítulo 1, faz-se uma breve análise do papel da geografia e a importância desta ciência no estudo da organização do espaço, como a sociedade e o Estado interferem na produção do espaço, bem como as mudanças ocorridas na cidade e no espaço urbano. No Capítulo 2, analisa-se a história do planejamento urbano e como este vem sendo aplicado no Brasil e a sua contribuição para a organização do espaço. No Capítulo 3, estuda-se as políticas públicas ambientais adotadas no Brasil e como estas contribuem para a organização do espaço e planejamento urbano.

A partir do Capítulo 4, este trabalho se volta para o estudo do caso do município de São José dos Campos, sendo que este tem destaque entre os municípios brasileiros pelo seu papel de polo tecnológico e aeroespacial e por possuir iniciativas de planejamento urbano e forte intervenção do Estado desde a década de 1930. Assim, este capítulo discorre sobre a 
caracterização da área de estudo, a sua história, e as principais características do planejamento urbano e organização do espaço no município.

No Capítulo 5, analisa-se as políticas públicas em São José dos Campos, dando ênfase às Leis de Zoneamento Urbano, Planos Diretores, Leis Ambientais e Lei Orgânica Municipal, e para tanto, realizou-se o levantamento de leis municipais, junto ao Arquivo Público Municipal, Secretaria Municipal de Planejamento Urbano e Câmara dos Vereadores de São José dos Campos. No Capítulo 6, analisa-se a efetivação das políticas previstas no município, buscando evidenciar quais normas e diretrizes foram seguidas pelo município. Com base no estudo da legislação existente e nos problemas ambientais urbanos levantados, este capítulo foi dividido em cinco temas: Zoneamento, Meio Ambiente, Indústrias, Loteamentos Clandestinos e Resíduos Urbanos, em que se destaca qual a situação atual de cada tema perante as políticas públicas adotadas pelo município.

\section{Objetivo}

Este trabalho tem como objetivo analisar a inserção de políticas públicas ambientais no planejamento urbano e organização do espaço, e como estas se efetivam na prática local. Para tanto, adota-se como unidade territorial de análise o município de São José dos Campos, no período de 1930 a 2010. Este período se delimita, com base na fase de maior crescimento e investimento em São José dos Campos até a data de desenvolvimento da pesquisa.

\section{Objetivos específicos:}

- Discutir a organização do espaço, em especial o espaço urbano, no pensamento geográfico.

- Analisar a evolução do planejamento urbano e evidenciar a relevância da dimensão ambiental e a importância da sua prática na escala local.

- Caracterizar a história, os aspectos sociais, econômicos e ambientais de São José dos Campos no período de 1930 a 2010.

- Analisar como as políticas públicas ambientais, através das leis urbanísticas e ambientais, principalmente, por meio do estudo dos Planos Diretores, Leis de Zoneamento Urbano e Ambientais, especificamente analisando o caso de São José dos Campos, se efetivam na esfera local e no planejamento urbano.

- Levantar os problemas ambientais urbanos em São José dos Campos através dos métodos de representação cartográfica, imagens de satélite, fotografias, entrevistas e trabalho 
de campo, com o intuito de averiguar se as políticas públicas ambientais previstas e o planejamento urbano tem se concretizado positivamente no município.

\section{Hipóteses}

1) As políticas públicas influenciaram as características do planejamento urbano e as formas de organização do espaço nas cidades brasileiras.

2) Os mecanismos adotados para o desenvolvimento de São José dos Campos, como região produtiva e pólo tecnológico, privilegiaram os interesses econômicos comprometendo os processos sociais e ambientais do espaço e da paisagem.

3) O planejamento urbano não ocorre de uma forma justa e igualitária, e as questões ambientais e sociais não são analisadas com coerência, o que fica evidente na divisão entre a cidade legal e cidade ilegal e nos inúmeros problemas ambientais urbanos existentes. 


\section{PARTE I}

GEOGRAFIA, PLANEJAMENTO URBANO E MEIO AMBIENTE

“Quando a natureza se torna natureza social, cabe à geografia perscrutar e expor como o uso consciente do espaço pode ser um veículo para a restauração do homem na sua dignidade” (SANTOS, 1978, p. 219) 


\section{Organização do Espaço}

O intuito deste trabalho é inserir o planejamento urbano na discussão da organização do espaço, e, desta forma, analisar o planejamento urbano na perspectiva da ciência geográfica. O planejamento urbano é uma forma de fazer uso consciente e ordenado do espaço, e assim, propiciar maior bem estar e melhores condições de vida para aqueles que vivem na cidade.

Todavia, inicialmente, é fundamental discutir o conceito de espaço. O espaço é o objeto de estudo da Geografia, ou melhor, o espaço geográfico. De maneira simplificada pode-se dizer que o espaço geográfico é o espaço humano, o espaço socializado - é o espaço trabalhado pelo homem.

Compreender o significado de espaço é compreender o objeto de estudo da ciência geográfica, e assim, compreender o que é Geografia e qual o seu papel, a sua função. Como aponta Santos (2008, p.21),

[...] O que se torna residual é considerado como 'dado' e, desse modo, expulso do sistema central. Cada vez que um geógrafo decide trabalhar sem se preocupar previamente com o seu objeto, é como se para tudo fossem 'dados', e se entrega a um exercício cego sem uma explicitação dos procedimentos adotados, sem regras de consciência, adequação e pertinência.

Desta maneira, para que tudo não seja apenas "dados", inicia-se este trabalho discutindo o conceito de espaço, para assim compreender a organização do espaço e o planejamento urbano no município de São José dos Campos. 
Milton Santos, com o livro "Por uma Geografia Nova", publicado em 1978, busca discutir o sentido da ciência geográfica, qual o seu fundamento. Este livro está ligado ao movimento de renovação da Geografia que se inicia no final da década de 1960. O autor coloca que a Geografia por muito tempo não teve o seu objeto de estudo definido, assim, ele procura defini-lo, para então discutir a Geografia, de modo que esta seja uma Ciência crítica, e não mais somente descritiva. Neste sentido, esta tese tem como fundamento os pensamentos de Milton Santos e da Geografia Crítica acerca do espaço geográfico, logo, procura-se não apenas descrever o espaço urbano de São José dos Campos, mas também, explicá-lo e compreendê-lo.

O espaço geográfico é a natureza modificada pelo homem através do seu trabalho. A concepção de uma natureza natural onde o homem não existisse ou não fora o seu centro, cede lugar à idéia de uma construção permanente da natureza artificial ou social, sinônimo de espaço humano. (SANTOS, 1978, p.119).

O espaço humano, é a morada do homem, é o seu lugar de vida e de trabalho. (SANTOS, 1978, p.120).

O espaço geográfico, é também, o espaço social (SANTOS, 1978, p.120).

O espaço deve ser considerado como um conjunto de relações realizadas através de funções e de forma que se apresentam como testemunho de uma história escrita por processos do passado e do presente. Isto é, o espaço se define como um conjunto de formas representativas de relações sociais do passado e do presente e por uma estrutura representada por relações sociais que estão acontecendo diante de nossos olhos e que se manifestam através de processos e funções. O espaço é, então, um verdadeiro campo de forças cuja aceleração é desigual. Daí porque a evolução espacial não se faz de forma idêntica em todos os lugares (SANTOS, 1978, p.122).

O conceito de espaço foi sendo construído ao longo da história. A Geografia estuda o espaço humano, este só passa a existir a partir do aparecimento do Homem. Assim, o conceito de espaço está diretamente relacionado à vida humana. $\mathrm{O}$ espaço é produto do Homem.

Se a Geografia deseja interpretar o espaço humano como um fato histórico que ele é, somente a História da sociedade mundial, aliada a da sociedade local, pode servir como fundamento à compreensão da realidade espacial e permitir a sua transformação a serviço do homem. Pois a História não se escreve fora do espaço e não há sociedade aespacial O espaço, ele mesmo, é social. (SANTOS, 1978, p.4). 
O espaço é objeto de estudo de várias ciências, como a Física e a Filosofia, a definição de espaço é um tema recorrente na literatura científica e não existe um consenso, uma única definição. No entanto, a ciência geográfica possui a sua própria definição, delimitando o conceito ao espaço geográfico, como o seu objeto de estudo.

Um grande número de autores modernos e clássicos afirma que o espaço é apenas um reflexo da sociedade, uma tela de fundo onde os fatos sociais se inscrevem à vontade, na medida em que acontecem. Contudo, alguns discordam, pois para muitos, o espaço intervém no processo histórico. $\mathrm{O}$ cientista Paul Vieille faz questionamentos em que procura entender o sentido real do espaço: "Será a organização espacial apenas um reflexo, ou projeção da organização social que se define independentemente dela e de maneira autônoma, ou o espaço intervém (e como?) no processo histórico?” (VIEILLE, 1974, p.3, apud SANTOS, 1978, p.126).

O geógrafo Milton Santos, na sua busca pelo entendimento do objeto de estudo da Geografia, responde tal pergunta da seguinte forma: "Quando se considera o espaço como um mero reflexo, o estamos colocando sob o mesmo plano da ideologia, ainda que não haja a intenção de classificá-lo como uma estrutura”. Para ele, este pensamento é influenciado pelo Positivismo, que durante muito tempo dominou as ciências sociais. O autor prossegue seu raciocínio ao afirmar que: “A verdade, porém, é que o espaço está muito longe de ser esse quadro neutro, vazio, imenso, em que o vivente pode produzir-se" (SANTOS, 1978, p.126).

Segundo Durkheim (1962), “o espaço é, pois uma coisa; ele existe fora do indivíduo e se impõe tanto ao indivíduo como à sociedade considerada como um todo. Assim, o espaço é um fato social $^{1}$, uma realidade objetiva. Como um resultado histórico, ele se impõe aos indivíduos. [...] Sendo um produto, isto é, um resultado da produção, o espaço é um objeto social como qualquer outro. [...] Quando se admite que o espaço é um fato social, é o mesmo que recusar sua interpretação fora das relações sociais que o definem. Muitos fenômenos, apresentados como se fossem naturais, são de fato, sociais. [...] Nessa expressão, natureza socializada, deve-se identificar aquilo que os geógrafos chamam normalmente de espaço ou espaço geográfico" (DURKHEIM, 1962, apud SANTOS, 1978, p.130).

Desta maneira, nota-se que o conceito de espaço evolui através da discussão de diferentes autores, para então a Geografia formar o conceito de espaço geográfico como se conhece hoje:

O espaço é a matéria trabalhada por excelência. Nenhum dos objetos sociais tem tanto domínio sobre o homem, nem está presente de tal forma no cotidiano dos indivíduos. A

\footnotetext{
1 Fato social é todo meio de ação, fixo ou não, capaz de exercer sobre o indivíduo uma coação externa (DURKHEIM, 1962, apud SANTOS, 1978, p128).
} 
casa, o lugar de trabalho, os pontos de encontro, os caminhos que unem entre si estes pontos, são elementos passivos que condicionam a atividade dos homens e comandam sua prática social (SANTOS, 1978, p. 137).

[...] O espaço portanto é um testemunho; ele testemunha um momento de um modo de produção pela memória do espaço construído, das coisas fixadas na paisagem criada. Assim, o espaço é uma forma, uma forma durável, que não se desfaz paralelamente à mudança de processos; ao contrário, alguns processos se adaptam às formas preexistentes enquanto que outros criam novas formas para se inserir dentro delas (SANTOS, 1978, p. 138).

No entanto, temos que o espaço faz parte da vida humana e exerce grande influência sobre ela, de modo a comandar a vivência do homem: a casa, os caminhos percorridos. O espaço é marcado pela produção do próprio espaço, através de processos sociais históricos, possui uma forma que é durável, mas não é permanente, é dinâmico. O espaço é decorrente da junção de fatos históricos e formas sociais, ele não é independente e nem estático, mas é limitativo, podendo se dispor ao social.

Deste modo, o espaço é a junção de fatores sociais passados e presentes, ele se forma pelos modos de produção passada e se transforma pelos modos de produção atuais, mas não deixa de existir e de se fazer presente na tomada de decisões, é o que mostra Santos (1978, p. 145), "o espaço como estrutura social, capaz de agir e de reagir sobre as demais estruturas da sociedade sobre esta como um todo. As determinações sociais não podem ignorar as condições espaciais concretas preexistentes. Um modo de produção novo ou um novo momento de um mesmo modo de produção não pode fazer tabula rasa das condições espaciais preexistentes".

Assim, percebe-se que o espaço tem papel ativo na evolução da sociedade. "Quando se consideram os processos econômicos e sociais, o espaço é, em realidade, uma dimensão dos mecanismos de transformação, da prática dos grupos sociais, de suas relações; ele contribui a produzir, reproduzir, transformar os modos de produção. O espaço é, assim, uma dimensão ativa no devir das sociedades" (VIEILLE, 1974, p.30 apud SANTOS, 1978, p. 149).

O espaço, como descreve Lefebvre (1974, p88-89), “é o resultado de uma série, de um conjunto de operações, e não pode ser reduzido a um simples objeto [...] Efeito de ações passadas, ele permite ações, as sugere ou as proíbe". Vê-se assim que o espaço é muito mais que um simples objeto de ação humana; ele tem papel fundamental na sociedade. Santos (2008, p.63) coloca ainda que: 
O espaço é formado por um conjunto indissociável, solidário e também contraditório, de sistemas de objetos e sistemas de ações, não considerados isoladamente, mas como o quadro único no qual a história se dá. No começo era a natureza selvagem, formada por objetos fabricados, objetos técnicos, mecanizados e, depois, cibernéticos, fazendo com que a natureza artificial tenda a funcionar como uma máquina. Através da presença desses objetos técnicos: hidroelétricas, fábricas, fazendas modernas, portos, estradas de rodagem, estradas de ferro, cidades, o espaço é marcado por esses acréscimos, que lhe dão um conteúdo extremamente técnico.

A natureza é transformada pelo homem, que passa a produzir e reproduzir espaço, transformando a Primeira Natureza em Segunda Natureza, ou Natureza Social, modificando a organização do espaço. Como acrescenta Corrêa (2007):

Os campos cultivados, os caminhos, os moinhos e as casas, entre outros, são exemplos de segunda natureza. Estes objetos fixos ou formas dispostas espacialmente (formas espaciais) estão distribuídos e/ou organizados sobre a superfície da Terra de acordo com alguma lógica. O conjunto de todas essas formas configura a organização espacial da sociedade. A organização espacial é a segunda natureza, ou seja, a natureza primitiva transformada pelo trabalho social (Corrêa, 2007, p.54).

Deste modo, o espaço vai sendo marcado pelo desenvolvimento técnico realizado pelo Homem, através de objetos e ações que vão modificar e criar o espaço, e nele se organizar. A presença do Homem sobre a Terra, faz com que a Natureza esteja sempre sendo redescoberta, desde o fim de sua história natural à criação da Natureza Social. O espaço geográfico é constantemente modificado e reorganizado, muda-se o espaço e a sociedade.

É possível compreender melhor a relação espaço-sociedade e as mudanças no espaço geográfico através da obra de Moreira (2008). O geógrafo faz um estudo onde aponta as relações entre espaço e sociedade ao longo do tempo e para tanto, apóia-se na obra de La Blache (1954), Brunches (1962), Claval, Marx (1985), Reclus, Santos (1994), e Sorre (1967). Segundo o autor, existem diferentes espaços, que se diferenciam conforme o desenvolvimento da sociedade no tempo, sendo assim, ele estabelece uma divisão em nove espaços, tendo como base as mudanças da sociedade no espaço e no tempo.

O primeiro espaço surge da relação Homem - Natureza. O fogo e a agricultura foram dois fatores importantes no processo de organização do espaço pelo homem. No início, o Homem vivia da coleta, caça e pesca; com as técnicas agrícolas, o homem desenvolve outras 
atividades: o cultivo e o pastoril. O surgimento dessas novas atividades altera a relação do homem com o seu ambiente, daí um novo espaço. Esse espaço era marcado por atividades agrícolas e pastoris, em que o animal fundamenta a vida. O movimento se dava por cavalos, bois, camelos e ovelhas. Cada civilização vai marcar a paisagem do seu espaço de uma forma, vai se enraizar em um local. Surge a identidade com o local e a territorialidade, o modo de vida amadurece e a civilização se implanta.

O segundo espaço está relacionado à elevação da produtividade do trabalho, que vem do aperfeiçoamento da técnica seletiva, dá origem ao excedente. Conforme Moreira, “o excedente libera parte da população para o exercício de atividades não-agrícolas e introduz a divisão social do trabalho. Nasce a cidade" (MOREIRA, 2008, p. 44).

A cidade vai trazer uma nova estruturação do espaço, um novo modo de vida, e com ela vêm também às relações de tensão. Surgem novos meios de transporte e comunicação, que até então estava baseado na tração animal. O veículo de rodas e os barcos. Cada civilização se desenvolve de formas diferentes, cada uma com características próprias e uma territorialidade definida. As técnicas se ampliam e se desenvolvem cada vez mais, e se diferenciam entre as civilizações.

O terceiro espaço é marcado pela ampliação da divisão social do trabalho e do excedente, o aparecimento da propriedade e suas formas de apropriação, diferenciando e estratificando socialmente a população dentro da comunidade. As lutas de classes ganham espaço. Surge o Estado, que deita raízes sobre o território e cuida de abafar os conflitos. Diferentes paisagens surgem, como os feudos na Europa.

$\mathrm{O}$ quarto espaço é possível pensar no período do século $\mathrm{X}$, onde tem lugar um conjunto de mudanças de efeitos estruturais, consequente da evolução das trocas e início da formação dos espaços modernos. Assim, “está em desenvolvimento o espaço moderno, em que organizar e arrumar a forma do habitat para produzir excedente com o fim de acumular capital vira a regra" (MOREIRA, 2008, p. 48). O Estado vai ser o grande agente nesse espaço. Há o desenvolvimento dos meios de transportes, o barco a vela, a bússola, as estradas.

O quinto espaço está relacionado às grandes trocas de longa distância e o contínuo intercâmbio de plantas e animais entre os diferentes continentes do mundo. O tabaco, a cana, o trigo, o café, a ovelha, o boi do velho mundo vão cruzar longas distâncias com a batata, o milho do novo mundo. Essas trocas vão mudar os ambientes, as paisagens, e os gêneros de vida.

O sexto espaço é resultado da acumulação mercantil e da Revolução Industrial do século XVIII, onde as técnicas se ampliam cada vez mais, com grande desenvolvimento. A 
atividade artesanal dá lugar à fábrica, surge a cidade industrial moderna, muda totalmente a configuração do espaço, leva à concentração territorial da população e das atividades econômicas. A ferrovia será de extrema importância nesse espaço, juntamente com o transporte marítimo, que vão ampliar o mercado da indústria. Cria-se uma economia mundial.

Assim, as mudanças no espaço pela Revolução Industrial foram significativas. Conforme Moreira “o capital leva o Estado nacional a substituir as civilizações como referência de demarcação dos espaços, num novo quadro geográfico de vida da humanidade. A demarcação territorial das civilizações dá lugar a uma superfície terrestre dividida num mapa político baseado nos Estados nacionais” (MOREIRA, 2008, p. 50).

Tais mudanças geram a crise agrária, o campo vê-se desestruturado; de um lado, as famílias camponesas, e de outro, as grandes monoculturas e a desvalorização do trabalho rural. O êxodo rural será marcante nesse espaço. A divisão territorial do trabalho é o esqueleto de toda essa nova arrumação do espaço. A sociedade passa a ser cada vez mais estratificada (proletariado x burguesia). Separam-se campo e cidade por sua diferença funcional.

O sétimo espaço está relacionado à Segunda Revolução Industrial. "No campo da energia, o motor e a flexibilidade conferida pela hidroeletricidade e, a seguir, pelo petróleo, à localização da indústria, liberando-a da tirania do carvão" (MOREIRA, 2008, p. 52). Assim, a indústria pode expandir seu território e se espalhar pelo mundo.

Os meios de transportes avançam, dando maior fluidez aos deslocamentos. Ciência e técnica caminham juntas. A sociedade muda sua forma de se relacionar com a natureza. Os meios de comunicação e informação se desenvolvem cada vez mais, com o surgimento do rádio e da televisão.

As mudanças são muitas e vão proporcionar uma grande dinâmica ao espaço. Como nos mostra Moreira, "a rapidez dos deslocamentos reduz o tempo, encurta as distâncias, integra os signos monetários, une as escalas, completa a dissolução das fronteiras regionais, quebra os limites nacionais, e unifica sob um só padrão de uniformidade técnica o arranjo das paisagens em todo o mundo" (MOREIRA, 2008, p. 54).

O oitavo espaço é dominado pela mídia e pelo poder dos meios de comunicação, ocorre a homogeneização das sociedades, seja pelo tipo de alimento, vestimentas, gosto de consumo, músicas etc. Torna o espaço homogêneo com os mesmos padrões de técnica e consumo. O espaço é despersonalizado.

O nono espaço marca a entrada das sociedades na terceira revolução industrial, na virada do século XX para o XXI, onde se destaca três elementos: a globalização, a complexificação e biorrevolução. Moreira explica melhor esses três elementos: 
A globalização é a escala geográfica segundo a qual a sociedade, acompanhando o desenvolvimento dos meios de transferência e a integração dos lugares em rede, uma vez tornada mundial, passa a se organizar. A complexificação é a reunião numa só organização empresarial de setores de atividades nos quais, antes, cada empresa se especializa dentro da divisão do trabalho e das trocas, e que nessa fusão soa transformadas num complexo empresarial, cada empresa virando um complexo de rede que no plano das relações de troca forma uma rede de complexos, cujo melhor exemplo são o complexo agroindustrial e o complexo produção-revendafinanciamento do consumo, hoje comum no âmbito das montadoras de automóveis. O todo da economia virando um complexo de complexos. A biorrevolução, por fim, é a nova base material, a forma nova de força e relação de produção dessa sociedade globalizada e estruturalmente complexificada (MOREIRA, 2008, p. 56).

Com o apoio à biorrevolução, estão a engenharia genética e a informática, interligados pela microeletrônica. Assim, a biorrevolução leva à transformação na vida e organização espacial da sociedade.

Conforme nos mostra Ruy Moreira, espaço e sociedade estão em constante transformação, as mudanças que ocorrem na sociedade se refletem no espaço e as mudanças que ocorrem no espaço se refletem na sociedade. O espaço é social. Essas mudanças ocorrem ao longo do tempo e imprimem uma nova dinâmica à organização espacial.

A forma como a geografia estuda o espaço também passou por mudanças. Desde a sua sistematização como ciência até os dias atuais, o pensamento geográfico passou por grandes reflexões, bem como o estudo do espaço.

Conforme Corrêa (2006), o conceito de espaço em relação à ciência geográfica e à própria Geografia passa por questionamentos e transformações, dando um novo sentido a esta ciência. Da geografia tradicional até a geografia contemporânea, o conceito de espaço foi amplamente discutido e avaliado.

A chamada geografia tradicional, que se estende de 1870, quando a geografia se torna uma disciplina institucionalizada, até a década de 1950, quando ocorre a denominada revolução teorética/quantitativa, tinha como foco o estudo dos conceitos de paisagem e região. Neste período a ciência geográfica foi marcada fortemente pela influência da corrente positivista; os principais geógrafos eram deterministas, possibilistas, culturais e regionais, pouco se dedicavam ao estudo espacial, que era mais voltado para a localização das atividades dos homens e fluxos.

O espaço não era um conceito-chave na geografia tradicional, embora esteja presente na obra de Ratzel e Hartshone, sendo que o primeiro desenvolve a teoria do espaço vital e 
território. Hartshone aponta os conceitos espaciais como fundamentais para a geografia, sendo tarefa do geógrafo descrever e analisar a interação e integração de fenômenos em termo de espaço (CORRÊA, 2006).

Na visão de Hartshone, o espaço é absoluto, “[...] é um conjunto de pontos que têm existência em si, sendo independente de qualquer coisa. É um quadro de referencia que não deriva da experiência, sendo apenas intuitivamente utilizado na experiência. Trata-se de uma visão kantiana, por sua vez influenciada por Newton, em que o espaço (e o tempo) associa-se a todas as dimensões da vida" (CORRÊA, 2006, p. 18). Para Hartshorne, o espaço é empregado no sentido de área:

[...] é somente um quadro intelectual do fenômeno, um conceito abstrato que não existe em realidade [...] a área, em si própria, está relacionada aos fenômenos dentro dela, somente naquilo que ela os contém em tais e tais localizações (HARTSHORNE, 1939, p. 395, apud CORRÊA, 2006, p. 19).

Segundo Hartshorne, todas as áreas são únicas. No entanto, como afirma David Harvey, diferentes práticas humanas estabelecem diferentes conceitos de espaço. Desta forma, o conceito de espaço passa a ser retrabalhado. Com a geografia teorético-quantitativa, sob forte influência do neopositivismo, calcada em modelos matemáticos e nas ciências naturais, houve grandes mudanças epistemológicas na ciência geográfica.

A geografia passa a atuar no plano prático, através do planejamento público e privado e o espaço passa a ser o conceito-chave. No entanto, o espaço passa a ser visto como relativo, como coloca Harvey, "o espaço relativo é entendido a partir de relações entre os objetos, relações estas que implicam em custos - dinheiro, tempo, energia - para se vencer a fricção imposta pela distância" (CORRÊA, 2006, p. 21).

Conforme Corrêa (2006), esta visão de espaço é limitada, pois de um lado privilegia a variável distância em excesso e, por outro lado, as contradições, os agentes sociais, o tempo e as transformações são inexistentes ou relegadas a um plano secundário.

Na década de 1970, temos o surgimento da geografia crítica fundada no materialismo histórico e na dialética, com forte influência das teorias marxistas e das questões sociais. $\mathrm{O}$ espaço reaparece como conceito-chave da geografia, e passa a se discutir se o espaço está presente ou ausente e qual a natureza e o significado do espaço.

Conforme Soja (1993, apud CORRÊA, 2006) o espaço e a espacialidade têm papel fundamental para a constituição e o devir da sociedade, já Harvey (1992) estabelece conexões entre espaço e tempo ao discutir a pós-modernidade. Lefebvre (1974) afirma que o espaço não 
é absoluto e nem funcional, o espaço é o lócus da reprodução das relações sociais de produção. Santos (1978) afirma que o espaço organizado pelo homem é uma estrutura subordinada-subordinante (CORRÊA, 2006).

Neste sentido, observamos que o espaço geográfico, objeto de estudo da geografia, teve várias definições e interpretações, até chegar à definição que se conhece hoje. O espaço é subordinado e subordinante à sociedade; o espaço e a sociedade sofrem transformações ao longo do tempo, pois são interdependentes. A maneira como a Geografia interpreta e estuda o espaço também se modificou ao longo de sua história e o pensamento geográfico passou por transformações que vão impor diferentes formas de ver e compreender o espaço.

\subsection{Relação Sociedade - Natureza: produção do espaço}

O Homem não pode criar sem a natureza, pois ela é a matéria-prima. A natureza é condição de (re)produção do próprio homem. A natureza primeira é, assim, transformada em natureza social (CARLOS, 2007).

O processo de transformação da natureza é longo, mas ao se pensar na idade da Terra (4,6 bilhões de anos), vemos que a história do Homem é recente. Os primeiros hominídeos surgem há 7 a 8 milhões de anos. Porém, o homem sapiens sapiens, o homem moderno, está na Terra há aproximadamente 45.000 anos.

No início, a história da presença humana sobre a Natureza era um momento de entrosamento e cooperação entre o Homem e o meio, como descreve Milton Santos (1996, p. 5) "não importa que as trevas, o trovão, as matas, as enchentes possam criar o medo: é o tempo do homem amigo e da natureza amiga". Assim como Michelet escreveu no Tableau de Ia France (1833): "A natureza é atroz, o homem é atroz, mas parecem entender-se".

Santos (1996) faz uma interessante análise sobre o início da relação homem-natureza até o desenvolvimento dessa relação nos dias atuais, vejamos:

No começo dos tempos históricos, cada grupo humano construía seu espaço de vida com as técnicas que inventava para tirar do seu pedaço de natureza os elementos indispensáveis à sua própria sobrevivência. Organizando a produção, organizava a vida social e organizava o espaço, na medida de suas próprias forças, necessidades e desejos. A cada constelação de recursos correspondia um modelo particular. Pouco a pouco esse esquema se foi desfazendo: as necessidades de comércio entre coletividades introduziam nexos novos e também desejos e necessidades e a organização da sociedade e seu espaço tinha de se fazer segundo parâmetros estranhos às necessidades íntimas ao grupo. 
Essa evolução culmina, na fase atual, onde a economia se tornou mundializada, e todas as sociedades terminaram por adotar, de forma mais ou menos total, de maneira mais ou menos explícita, um modelo técnico único que se sobrepõe à multiplicidade de recursos naturais e humanos.

Sem o homem, isto é, antes da história, a natureza era una. Continua a sê-lo, em si mesma, apesar das partições que o uso do -planeta pêlos homens lhe infligiu. Agora, porém, há uma enorme mudança. Una, mas socialmente fragmentada, durante tantos séculos, a natureza é agora unificada pela História, em benefício de firmas, Estados e classes hegemônicas. Mas não é mais a Natureza Amiga, e o Homem também não é mais seu amigo (MILTON SANTOS, 1996. p. 6).

Nota-se, que o homem trouxe profundas mudanças à Natureza, de amigo passou a ser seu explorador. A evolução da história do Homem sobre a Natureza nos leva à fase atual, onde as sociedades estão mundializadas, as técnicas exploram cada vez mais os recursos naturais. A organização do espaço é fragmentada, as desigualdades sociais e a degradação ambiental ressaltam em meio às sociedades. Esta mudança na relação sociedade - natureza está relacionada ao desenvolvimento da técnica, de forma lenta, o homem vai desenvolvendo novas técnicas, e a cada nova técnica ele dá um passo à frente e se apropria cada vez mais da natureza. Temos a transformação da primeira natureza em segunda natureza.

[...] as formas de apropriação da natureza são, em si mesmas, construções históricas. Nesse sentido, tal relação é sempre determinada pela consciência do recurso pela disponibilidade de tecnologias que permitam sua utilização. A técnica é, assim, uma mediação básica entre a humanidade e os recursos naturais. Em consequiência, o valor natural dos lugares varia bastante historicamente (MORAES, 2005, p. 102).

Assim, é possível compreender que o espaço só é produzido e é produto com o desenvolvimento da técnica. O desenvolvimento de novas técnicas é que permite a utilização dos recursos naturais; o Homem se utiliza dessa técnica, para assim, explorar cada vez mais a natureza, se apropriar e produzir espaço. Esse processo é longo e contínuo, sua origem remonta ao aparecimento do Homem na Terra.

O homem animal se torna homem social quando se torna o centro da natureza, devido à produção de instrumentos de trabalho. "Nesse momento, a natureza deixa de comandar as ações do homem, e a atividade social começa a ser uma simbiose entre o trabalho do Homem e uma natureza cada vez mais modificada por esse mesmo trabalho. Esta fase da história não 
poderia realizar-se se não houvesse um mínimo de organização social e sem uma organização paralela do espaço" (SANTOS, 1978, p. 161).

O espaço humano, isto é o espaço geográfico, seja qual for o período histórico, é resultado da produção humana. "Isto marca a evolução do homem animal a homem social, ou seja, ocorre quando ele começa a produzir. Produzir é retirar da natureza os elementos indispensáveis à vida. Este fato só é possível pelo desenvolvimento de técnicas e instrumentos de trabalho" (SANTOS, 1978, p. 161).

\begin{abstract}
A produção é a utilização consciente dos instrumentos de trabalho com um objetivo definido. [...] Nenhuma produção, por mais simples que seja, pode ser feita sem que se disponha de meios de trabalho, sem vida em sociedade, sem divisão do trabalho. A partir dessa primeira organização social, o homem se vê obrigado para todo o sempre a prosseguir uma vida em comum, uma existência organizada e "planificada" (SANTOS, 1978, p. 162).
\end{abstract}

A produção possui ritmos e formas que são impostos à vida do Homem eassim nos vemos cercados de ritmos diários. "Essa nova disciplina que o homem até então não conhecia, implica uma utilização disciplinada do tempo e do espaço" (SANTOS, 1978, p. 162).

Criam-se, ritmos de vida e de atividades, as horas dedicadas ao trabalho, as horas de descanso, e os ritmos próprios à produção: período de preparação da terra, período de plantio, período da colheita, da estocagem. "Cada atividade tem um lugar próprio no tempo e um lugar próprio no espaço" (SANTOS, 1978, p.162). Assim, essa ordem espaço-tempo que se estabelece não é aleatória, mas é resultado das necessidades próprias à produção.

Como aponta Santos, op. cit. produzir e produzir espaço são dois atos indissociáveis. Para produzir, o Homem precisa de espaço. Assim, ele transforma a Natureza. A Natureza Primeira, é aquela onde não há ação humana, dá lugar à Natureza Segunda, que é a natureza transformada, ou socializada. O autor conclui que "o ato de produzir é, ao mesmo tempo, o ato de produzir espaço" (SANTOS, 1978, p.163). Côrrea (2007) complementa afirmando que,

A organização espacial é assim constituída pelo conjunto das inúmeras cristalizações criadas pelo trabalho social. A sociedade concreta cria seu espaço geográfico para nele se realizar e reproduzir, para ela própria se repetir. Para isto, cria formas duradouras que se cristalizam sobre a superfície da Terra (CÔRREA, 2007, p. 57). 
O espaço está sempre sendo produzido e reproduzido. A organização espacial se dá pelo trabalho humano, que cria espaço. O Homem cria novas técnicas e novas formas, que criam um novo espaço, uma nova organização do espaço, e um novo modo de vida.

[...] Basta que uma nova planta seja domesticada e incorporada à produção, para que se imponha um novo comando sobre o tempo; e isso impõe ao mesmo tempo localizações novas, isto é, uma nova organização do espaço. [...] Eventualmente, uma nova técnica pode ser paralelamente descoberta (aumento da produtividade). Dessa forma, o homem aumenta o rendimento do seu trabalho reduzindo paralelamente o tempo que consagra ao trabalho. [...] Cada vez que o uso social do tempo muda, a organização do espaço muda igualmente. Toda técnica nova é revolucionária quanto ao comando do espaço pelo homem (SANTOS, 1978, p. $163)$.

As novas técnicas e novas atividades exigem um novo lugar no espaço e impõem uma nova organização do espaço. Tem-se assim, a produção do espaço, que vai colocar ritmos e formas à vida humana. O comércio e a moeda vão colocar diferenças, estabelecendo diferentes classes sociais. Posteriormente, o espaço vai ser determinado não somente pela produção, mas também, pela política adotada pelo Estado, construção de estradas, infraestrutura e defesa militar, que vão influenciar na localização e organização espacial.

\subsection{O Estado e a produção do espaço}

A organização do espaço ocorre de maneiras variadas nas diferentes sociedades, isto resulta de processos históricos diferentes. A forma de trabalho humano imprime características únicas a cada sociedade, devido à evolução técnica diferenciada. Algumas civilizações utilizaram técnicas diferenciadas em tempos também diferentes, sendo responsáveis pela produção de artefatos também diferenciados. "A acumulação desigual dessas técnicas resultantes de tempos também desiguais fez com que cada uma delas deixasse impressa na paisagem marcas e formas de apropriação próprias e singulares" (ARAUJO, 2008, p. 10). As diferenças entre as inúmeras sociedades espalhadas pelo planeta se acentuam cada vez mais, seja na cultura, na economia, ou na produção do espaço.

Assim, as sociedades se diferenciam por muitos aspectos: etnia, língua, capacidade técnica e tecnológica, algumas são marcadas pela desigualdade social e extrema pobreza, outras pelo elevado desenvolvimento tecnológico e riquezas. Porém, as variadas formas de 
organização espacial, em geral, são marcadas pelas relações que se processaram entre os grupos sociais ao longo da história.

O ponto comum entre as diferentes sociedades é a existência de um poder político. Esse poder político se representa através do Estado. Segundo Santos (1978, p. 189), “um Estado-Nação é essencialmente formado de três elementos: 1. o território; 2. um povo; 3 a soberania". A utilização do território pelo povo cria o espaço. As relações entre o povo e seu espaço e as relações entre os diversos territórios nacionais são reguladas pela função da soberania.

O estudo sobre o Estado é uma tradição na Filosofia, sendo um dos conceitos mais estudados desde os gregos. No entanto, na ciência geográfica, o estudo sobre o Estado surge através de Ratzel, com a geografia política em sua obra "Politische Geographie", no final do século XIX, a qual trabalha com o conceito de Estado como organismo vivo, ou seja, uma entidade dotada de vida própria. Todavia, a Geografia Política atual, principalmente Paul Claval e Claude Raffestin, ressaltam novas posturas interpretativas para a análise geográfica do poder, estando mais preocupados no estudo das novas formas de exercício do poder e sua relação com o espaço (COSTA, 1988).

Contudo, um ponto comum na Geografia é o reconhecimento de que o Estado tem no território seu espaço de autoafirmação, pois é "praticamente impossível nos referirmos a um Estado sem território" (SANTOS e SILVEIRA, 2001, p. 19). Segundo Trinca (1996), o Estado atual tem como funções básicas preservar a unidade nacional e a integridade territorial, porém o desenvolvimento tecnológico vem impondo novas funções ao Estado.

\footnotetext{
Desta forma, preservar a unidade nacional e a integridade territorial se transforma em funções básicas do Estado, as quais ele vem cumprindo, não sem muitos altos e baixos, até a atualidade, quando a nova composição que mostra a mundialização das relações econômicas e na qual o componente tecnológico parece desempenhar um papel de primeira ordem, estaria exigindo mudanças significativas no acionar do Estado e, em conseqüência mudanças na percepção e cumprimento de suas funções (TRINCA, 1996, p. 110-111)
}

Conforme Harvey (2005), o renascimento do interesse pelo Estado demorou muito para acontecer, pois o Estado sempre esteve presente para o funcionamento da sociedade capitalista; apenas suas formas e modos de funcionamento mudaram conforme o capitalismo amadurecia. Segundo o autor, "há pouquíssimos aspectos da produção e do consumo que não estão profundamente afetados, direta ou indiretamente, por políticas do Estado”, o autor complementa ainda que "a noção de que o capitalismo alguma vez funcionou sem o 
envolvimento estreito e firme do Estado é um mito que merece ser corrigido" (HARVEY, 2005, p. $79-92)$.

Como aponta Todesco (2010), possíveis mudanças na percepção e no cumprimento das funções estatais na nova composição das relações globais são compreendidas como consequências do crescimento e amadurecimento do capitalismo, no qual o Estado nunca deixou de ser o agente central para o seu funcionamento, pois conforme Harvey (2005, p. 84), "a garantia do direito da propriedade privada dos meios de produção e da força de trabalho, o cumprimento dos contratos, a proteção dos mecanismos de acumulação, a eliminação das barreiras para a mobilização do capital e do trabalho e a estabilização do sistema monetário (via Banco Central, por exemplo) estão todos no campo da ação do Estado".

Milton Santos (1978) aponta que o Estado tem papel fundamental no ordenamento do espaço, seja no seu surgimento ou nos dias atuais. Antigamente, o espaço era marcado somente pela produção, pelo trabalho do Homem. Hoje, o espaço também é marcado por políticas adotadas pelo Estado, como a construção de ferrovias, rodovias, aeroportos, ocupação e defesa militar:

A escolha pelo poder de forma de satisfação das necessidades coletivas constitui um elemento de reorganização espacial; quer dizer que cada opção realizada pelo Estado em matéria de investimento, mesmo improdutivo, atribui a um determinado lugar uma vantagem que modifica imediatamente os dados da organização do espaço. Assim, se tomamos os problemas do ponto de vista das relações internacionais ou se levamos em consideração os problemas da vida cotidiana do mais modesto cidadão, o Estado aparece como um fator por excelência de elaboração do espaço e deve, pois, ser considerado como elemento fundamental de estudo, mesmo se a ação do Estado, quanto à reformulação do espaço, é marcada por contingências e por limitações (SANTOS, 1978, p. 184).

Moraes (2005, p. 140) complementa afirmando que "o grande agente de produção do espaço é o Estado, por meio de suas políticas territoriais. É ele o dotador dos grandes equipamentos e das infraestruturas, o construtor dos grandes sistemas de engenharia, o guardião do patrimônio natural e o gestor dos fundos territoriais ${ }^{2}$. Por estas atuações, o Estado é também o grande indutor na ocupação do território. Um mediador essencial, no mundo moderno, das relações sociedade-espaço e sociedade-natureza".

\footnotetext{
2 Os fundos territoriais são áreas de soberania nacional ainda não incorporada no tecido do espaço produtivo (MORAES, 2005, p. 139).
} 
Para Todesco (2007, p. 61), “a ação do Estado, carregada de intencionalidade, seleciona entre as possibilidades existentes em cada período quais irão tornar-se existência, o que significa que a concretização de uma possibilidade se efetua em detrimento de outras, pois em cada situação concreta sempre há caminhos possíveis maiores que as escolhas que foram feitas". A autora complementa ainda afirmando que "o Estado é essencial, portanto, para se compreender a produção do espaço e consequentemente as desigualdades regionais; é o Estado, em última instância, quem legitima as formas de uso do território, sendo sua ação e "não ação" contundentes nesse processo, que é social e histórico" (TODESCO, 2007, P. 61). O Estado, desta forma, assume papel fundamental no estudo da organização do espaço, pois através das políticas adotadas, o espaço é produzido e reproduzido.

No entanto, é importante refletir sobre os apontamentos de Harvey (2005), que ao fazer uma análise sobre a teoria marxista do Estado, destaca que o Estado não pode ser abordado apenas de forma abstrata, como se fosse um ente imaginário capaz de organizar os espaços da forma que lhe convém. Harvey op.cit. nos mostra que quando se passa do abstrato e genérico para o concreto e específico, há que se de adaptar nosso modo de pensar e analisar.

Neste sentido, se tornam evidentes o papel e a ação do Estado no ordenamento do espaço, sendo que as políticas e ações do governo influenciam a produção e reprodução do espaço. A sociedade, instituições e corporações, também, exercem papel no processo de organização espacial. O conjunto de ações da sociedade e do Estado é o grande agente da organização espacial. Portanto, é essencial que estas ações sejam planejadas, em conjunto entre Estado e sociedade, para que se produzam cidades mais justas e igualitárias.

No município de São José dos Campos, área de estudo desta pesquisa, o papel do Estado é evidente, seja no incentivo à construção de sanatórios para receber os doentes de tuberculose no início do desenvolvimento da cidade, ou mesmo na construção do CTA e criação do polo tecnológico aeroespacial. O Estado investiu massivamente na produção do espaço joseense. A cidade só é o polo regional de hoje, com grande despontamento econômico no território nacional, devido às ações do Estado, que são marcantes no município.

O Estado é o grande agente intervencionista no espaço joseense, investiu economicamente, criando as condições necessárias para o desenvolvimento industrial e tecnológico do município. Abriu estradas, criou uma base tecnológica e estimulou a vinda de indústrias para a região, através de incentivos fiscais. O Estado mudou toda a configuração espacial da cidade. As condições geográficas do município, também, possibilitaram esse 
grande crescimento, no entanto, somente com a intervenção do Estado, São José dos Campos, se tornou o polo tecnológico aeroespacial, de grande desenvolvimento econômico e industrial.

Os investimentos do Estado em São José dos Campos, no entanto, privilegiaram em específico o setor econômico, pois o município, mesmo com toda sua riqueza e desenvolvimento tecnológico, apresenta grandes disparidades sociais. Os investimentos massivos do Estado pouco atingiram o setor social e ambiental; o planejamento urbano realizado não atendeu às demandas socioambientais no município, ou, muitas vezes, o que foi planejado não se faz cumprir nem pelo Estado e nem pela sociedade. A produção do espaço urbano joseense ocorre de forma desigual, gerando diversos conflitos socioambientais.

\subsection{A cidade e espaço urbano}

A produção do espaço se torna mais evidente na cidade ${ }^{3}$. A cidade é a revelação mais forte da paisagem humanizada. Na cidade, a transformação da primeira natureza em segunda natureza é evidente, a ponto de esquecermos o que é a "natureza" quando vivemos em uma cidade. Como aponta Lefebvre (1974), o espaço natural é reduzido e transformado em um produto social.

Assim, podemos afirmar que a cidade é a transformação máxima da primeira natureza. A sua origem é remota, porém a sua evolução é constante, o homem se afasta cada vez mais da natureza primeira.

As cidades mudaram muito no decorrer da história. Como coloca Davis (1972) no livro Urbanização da Humanidade, "as sociedades urbanizadas, nas quais a maioria das pessoas vive agrupada em cidades, representam um estágio novo, e fundamental, da evolução social" (DAVIS, 1972, p. 13).

As sociedades primitivas iniciaram o longo processo de evolução, as chamadas cidades pré-industriais, há mais de um milênio, transformando-se em sociedades cada vez mais complexas, estabelecendo-se em vilas, organizando-se e aperfeiçoando suas técnicas. A cidade como se conhece hoje, com toda sua estrutura, organização e aglomerações humanas,

\footnotetext{
${ }^{3} \mathrm{Em}$ um estudo sobre o conceito de cidade e urbano, Lencioni (2008) esclarece que o conceito de cidade é antigo, ele consta em dicionários antigos, já o conceito de urbano não, é algo mais recente. O conceito de cidade no Brasil refere-se a um aglomerado sedentário que se caracteriza pela presença de mercado (troca) e que possui uma administração pública, este conceito se altera segundo referências e segundo o tempo histórico. Já o conceito de espaço urbano está relacionado à sociedade capitalista industrial. Segundo a autora op. cit., "o desenvolvimento de uma sociedade pós-industrial, ou seja, de uma sociedade que "nasce da industrialização e a sucede", como diz Léfèbvre e que ele denomina de sociedade urbana e, de maneira sintética, de urbano (LENCIONI, 2008, p.118).
} 
são características da Revolução Industrial e ganharam proporção a partir de meados do século XIX.

Pode-se destacar como elementos importantes dessa evolução a capacidade de estocar alimentos (uso da metalurgia, arado e da roda), o uso da escrita (realizar registros) e uso de fontes de energia (exemplo: moinho) (SJOBERG, 1972, apud DAVIS, 1972). Já a cidade industrial moderna é associada a um terceiro nível de complexidade na organização humana, caracterizado pela educação das massas, sistemas de classes fluidos e, o mais importante, segundo Sjoberg (1972), um tremendo avanço tecnológico que usa novas fontes de energia.

Sjoberg (1972, p. 41 apud Davis, 1972), faz a seguinte afirmação: “[...] Em todas as regiões, [...] brotaram e morreram cidades, mas a vida urbana, uma vez estabelecida, nunca chegou a desaparecer". Hoje, a cidade industrial é a forma urbana praticamente dominante em todo o mundo, mas a formação das cidades de hoje ocorreu de forma rápida, reflexo do processo de industrialização, e como consequência desse fenômeno urbano, surgiu uma nova configuração e estruturação das cidades, e também, novos problemas urbanos.

Carlos (2007, p.20), ao fazer uma leitura geográfica sobre a cidade, mostra que a cidade é uma produção humana, formada por ações passadas e presentes, e está relacionada à vida humana:

\footnotetext{
A ideia de cidade como construção humana, produto histórico-social, contexto no qual a cidade aparece como trabalho materializado, acumulado ao longo de uma série de gerações, a partir da relação da sociedade com a natureza. Expressão e significação da vida humana, a cidade a revela ao longo da história, como obra e produto que se efetiva como realidade espacial concreta em um movimento cumulativo, incorporando ações passadas ao mesmo tempo em que aponta as possibilidades futuras que se tecem no presente da vida cotidiana. Assim, o sentido e a finalidade da cidade (enquanto construção histórica) diz respeito à produção do homem e à realização da vida humana, de modo que, se a construção da problemática urbana se realiza no plano teórico, a produção da cidade e do urbano se coloca no plano da prática sócio-espacial, evidenciando a vida na cidade.
}

A autora op. cit. ainda afirma que há uma indissociabilidade entre espaço e sociedade, uma vez que as relações sociais se materializam em território real e concreto, e desta forma, ao produzir a sua vida, a sociedade produz e reproduz um espaço através da prática sócioespacial. Como aponta a autora op.cit., “[...] Tal fato torna o processo de produção do espaço 
indissociável do processo de reprodução da sociedade - neste contexto, a reprodução continuada da cidade ocorre fundamentando-se na reprodução ininterrupta da vida" (CARLOS, 2007, P. 21).

Harvey (2005) complementa afirmando que a cidade pode ser considerada como a expressão concreta de processos sociais na forma de um ambiente físico construído sobre o espaço geográfico; como expressão de processos sociais, a cidade reflete as características da sociedade.

Segundo Corrêa (2005), o espaço urbano é fragmentado e articulado, reflexo e condição social, e campo simbólico de lutas. $\mathrm{O}$ espaço urbano refere-se às diferentes formas de uso da terra e ao modo como esses usos se organizam espacialmente na cidade. Usos diferentes (indústria, comércio, moradias, ruas etc.) que muitas vezes entram em conflito, refletindo o modo de vida da sociedade.

Neste sentido, Carlos (2007, p.30) aponta que "[...] a cidade revela-se concretamente através do uso que dá sentido à vida, revelando o conteúdo da prática socioespacial. É pelo uso (como ato e atividade) que a vida se realiza [...] O espaço urbano representa, antes de mais nada, um uso, ou ainda, um valor de uso, e desta maneira, a vida se transforma, com a transformação dos lugares de realização de sua concretização, que a norma se impõe e que o Estado domina a sociedade, organizando, posto que normatiza os usos através dos interditos e das leis" (CARLOS, 2007, P.30).

Cada lugar representa uma realidade social. Nele, estão embutidas as características locais, a cultura, os costumes, formas especiais que revelam um sentimento, laços de afeição, possíveis de proporcionar alegrias e tristezas ao homem. Ou seja, o espaço urbano passa a ter dimensões e significados variados segundo as diferentes classes e grupos sociais. Portanto, "o espaço da cidade é, também, o cenário e o objeto das lutas sociais, pois estas visam, afinal de contas, o direito à cidade, à cidadania plena e igual para todos" (CORRÊA, 1993, p. 151).

No entanto, a produção do espaço urbano é desigual, pois é também na cidade onde podemos presenciar a grande desigualdade social e segregação espacial. O espaço urbano capitalista é reflexo da sociedade de classes e das lutas sociais, sendo assim, profundamente desigual. Existe um conjunto de forças que atuam na organização do espaço e que permitem localizações, relocalizações e permanência das atividades e população sobre o espaço urbano; estas são guiadas por diferentes atores que modelam a organização do espaço, como os proprietários dos meios de produção, proprietários de terras, empresas imobiliárias e de construção, associadas ou não ao grande capital, e o Estado (CORRÊA, 2005). 
Neste sentido, o urbano, como aponta Carlos (2008), reproduz-se, de um lado, de forma "espontânea", no livre jogo do mercado, e outro, "planejada", na medida em que o Estado passa a intervir cada vez mais na produção da infraestrutura ou na criação de leis de zoneamento urbano. No entanto, as ações do Estado capitalista favorecem a classe dominante e o capital, e tornam ainda mais profundas, as desigualdades sociais e a luta de classes.

O Estado tem papel fundamental na produção do espaço. "O Estado interfere diretamente no processo de produção do espaço, seja como produtor direto, seja como criador de infraestrutura, de mecanismos de 'planificação', ou ainda através de leis e decretos" (CARLOS, 2008, Pp. 201).

A organização espacial da cidade está sempre sendo modificada. O Estado cria leis, regras, normas, infraestrutura, objetos e ações, que vão intervir na produção do espaço e na sua organização, a sociedade tenta se adaptar a estas leis, e está constantemente produzindo o espaço urbano. Porém, vê-se na cidade uma "desorganização", expressa nos conflitos sociais, na segregação espacial, e nos inúmeros problemas urbanos, violência, trânsito, saneamento básico, enchentes e outros. O Estado capitalista atual não intervém no espaço de forma justa e igualitária, age conforme interesses próprios e do capital.

Acreditamos que é preciso uma nova postura do Estado e da sociedade, intervindo na organização e produção do espaço urbano de forma planejada, através de políticas públicas urbanas e ambientais mais justas e igualitárias. Por meio do planejamento urbano participativo e democrático, é possível produzir uma melhor organização do espaço, de forma a favorecer o bem estar social e o equilíbrio ambiental da cidade como um todo. É preciso refletir sobre as questões de como planejar e para quem planejar, uma vez que o planejamento urbano praticado até o momento, quase sempre permeia os interesses do capital e do Estado, e não os anseios da população em suas diferentes classes sociais.

O município de São José dos Campos é um exemplo de planejamento pautado nos interesses do capital e do Estado, isto é perceptível ao se ver o seu grande desenvolvimento econômico e industrial, porém, as esferas sociais e ambientais não fazem parte deste planejamento; é possível ver na cidade a grande segregação urbana e degradação do meio ambiente. 


\section{Planejamento Urbano}

Como foi apresentado no início desta tese, o espaço é produto do trabalho humano. $\mathrm{O}$ espaço é produto e está sempre sendo produzido e organizado pelo Homem. No entanto, o Estado desempenha papel fundamental na organização espacial. O Estado intervém no espaço, de forma a produzi-lo e ordená-lo. Desta forma, acreditamos que se as intencionalidades colocadas pelo Estado no espaço forem planejadas de forma justa e igualitária, participativa e democrática, juntamente com a adoção de novas práticas de cidadania, teremos um melhor ordenamento do espaço, propiciando melhores condições de vida, bem estar e equilíbrio ambiental.

O planejamento urbano é um instrumento importante para se estabelecer ordenamento e organização do espaço pelo Estado e pela sociedade, com maior equidade e justiça social, isto em tese, uma vez que o Estado não é neutro. Pode-se dizer que o Planejamento Urbano é algo recente, ao pensar na origem do espaço urbano, temos que as cidades industriais surgem no século XVIII, já o planejamento urbano começa a existir somente no final do século XIX e início do século XX. Ele nasce na Europa e Estados Unidos, como uma das respostas aos problemas urbanos surgidos na cidade industrial.

Desde o surgimento do Planejamento Urbano até os dias atuais, foram muitas as mudanças em suas técnicas, métodos e conceitos, mas ainda é preciso pensar sobre um planejamento urbano que seja mais participativo, justo e igualitário. O planejamento urbano, engajado numa postura crítica, social e ambiental, dirigido pelo Estado, mas apoiado nas 
diferentes classes sociais, de forma participativa e democrática, é um dos caminhos para a produção de cidades sustentáveis.

Pode-se definir planejamento urbano como um processo contínuo, que envolve a elaboração de planos com objetivo de ordenar o espaço, e assim, obter o seu melhor aproveitamento para o bom desenvolvimento da vida humana, dotando-o de bens, serviços, equipamentos e infraestrutura, de modo a respeitar o equilíbrio do meio ambiente e o bemestar da população. Assim, para que o planejamento exista, é preciso que ocorra a intervenção governamental e que os indivíduos aceitem a regulação pelo bem público.

Segundo Souza (2004, p. 17), "o planejamento urbano, como qualquer tipo de planejamento, é uma atividade que remete sempre para o futuro. É uma forma que os homens têm de tentar prever a evolução de um fenômeno ou de um processo, e, a partir deste conhecimento, procurar se precaver contra problemas e dificuldades, ou ainda aproveitar melhor possíveis benefícios".

A busca por um melhor planejamento das cidades, procura ordenar o espaço, e também, trazer uma melhor qualidade de vida à população. Assim, quanto maior for a ordenação do espaço, melhor será o padrão de qualidade de vida urbana ${ }^{4}$. Figueiredo (2001) coloca que o planejamento urbano deve ser efetivado através do atendimento das necessidades da população, a partir de ações dirigidas com a finalidade de superar os problemas detectados, atendendo aos diferentes níveis de necessidade dos indivíduos.

Campos Filho (2001) expõe a ideia inicial do que seria o planejamento urbano numa definição bastante simplificada; ele coloca que para alguns o planejamento urbano é ordenar as cidades e resolver seus problemas. Para tanto, bastaria listar os problemas e estabelecer uma ordem de prioridades na implantação de sua solução, através de técnicas adequadas, dependendo dos recursos disponíveis. Seguindo este método, o objetivo seria alcançado, desde que perseguido honestamente.

Contudo, o arquiteto e urbanista Campos Filho (2001), dando continuidade ao seu pensamento, coloca que o planejamento urbano pode ser estudado por uma abordagem técnico-científica, e para sua implantação de forma adequada seria preciso reforçar os centros de pesquisa, os órgãos técnicos governamentais de decisão e implementação das políticas orientadoras de soluções e excluir os desonestos do processo decisório.

\footnotetext{
${ }^{4}$ Segundo Troppmair (1992), "qualidade de vida são os parâmetros físicos, químicos, biológicos, psíquicos e sociais que permitam o desenvolvimento harmonioso, pleno e digno da vida". Assim, uma boa qualidade de vida possibilita ao homem uma melhor convivência entre este e seu meio.
} 
Foi com base nesse princípio que se desenvolveu na Europa e nos Estados Unidos, no final do século XIX, uma grande ação prática e teórica: o urbanismo técnico-setorial. Este era baseado na racionalidade da organização e na qualidade estética (visual) dos espaços, pouco se importando com a organização social.

Foi este urbanismo que prevaleceu no período, onde as cidades industrializadas sofriam processo de deterioração. Conhecido também como urbanismo sanitarista, produziu o saneamento de áreas inundáveis, que principalmente nos bairros populares, corriam no meio das ruas, produzindo vários surtos epidêmicos, como a varíola.

Esse urbanismo também tinha como preocupação a abertura de novas vias, a criação de quadras com densidade máxima, densidade mínima, espaços verdes etc. Assim, desde o final do século XIX, passou-se a estabelecer normas legais que se constituíram, aos poucos, em códigos de regulamentos urbanísticos quanto às edificações e ao uso, à ocupação e ao parcelamento do solo para fins urbanos e as políticas de transporte correspondentes que equivalem aos atuais códigos de obras, trazendo normas para as edificações, parcelamento e uso do solo, ou seja, o zoneamento.

Como o próprio arquiteto e urbanista Campos Filho (2001) coloca, esse tipo de planejamento urbano não leva em consideração os problemas sociais:

Essa vertente do urbanismo, que não punha em causa as raízes dos males existentes nas cidades, teve uma aceitação crescente, embora combatida, como ocorre ainda hoje, por aqueles que vêem nesses regulamentos administrativos um cerceamento do direito ao uso irrestrito da propriedade imobiliária urbana (CAMPOS FILHO, 2001, p. 7).

Paralelo ao urbanismo técnico-setorial ou sanitarista, surge, também, nas cidades europeias e norte-americanas o urbanismo estético-viário. Este tinha como preocupação a criação de grandes espaços abertos centrais (praças e grandes avenidas) destinados à manifestações cívicas burguesas, que abrigavam em seu entorno edificações monumentais, sede dos poderes governamentais e civis mais importantes. "O barão Haussman, em Paris, é o seu maior expoente, e a Étoile (estrela) de avenidas tendo ao centro o Arco do Triunfo, sua maior expressão" (CAMPOS FILHO, 2001, p.15).

Outra corrente urbanística moderna, classificada por Françoise Choay como progressista, teve como principal representante o arquiteto e urbanista Le Corbusier. Esta corrente também ignorou as diferenças entre as classes sociais, pois, se baseava na criação de 
áreas verdes e edificações verticais, com alta densidade urbana, redutora de custos de urbanização pela menor extensão da infraestrutura e equipamentos urbanos.

Brasília indiretamente, por intermédio do urbanista Lúcio Costa, e Chandighard (capital de um Estado do Norte da Índia), diretamente saída de plano urbano de Le Corbusier, foram os frutos maiores desse urbanismo racionalista-progressista [...] Já Belo Horizonte (1886) e Goiânia (1930) nasceram sob orientação do urbanismo técnico-setorial, tanto sanitário como estético-viário (CAMPOS FILHO, 2001, p. $11)$.

Essa corrente urbanística também não foi capaz de resolver os problemas urbanos, se pautava principalmente na construção e na desconstrução de bairros inteiros. Não era capaz de perceber a lógica da desordem urbana, da deterioração ambiental, das habitações precárias, da falta de infraestrutura generalizada.

Conforme Choay (1965), a corrente progressista, pregava um espaço amplamente aberto, rompido por vazios e verdes, como exigência da higiene. "O verde oferece particularmente um quadro para os momentos de lazer, consagrado a jardinagem e à educação do corpo" (CHOAY, 1965, p. 8). O ar, a água e a luz devem ser igualmente distribuídas a todos. Nesta corrente, o espaço urbano é traçado conforme uma análise das funções humanas, em locais distintos, segundo as funções de habitar, trabalho, lazer e cultura. Temos assim, uma análise funcional exaustiva e racionalista, com grande preocupação com as estruturas estéticas e técnicas. Na visão de Choay op. cit., tal modelo propõe uma localização fragmentada, apresentando sistemas limitadores e repressivos.

O modelo progressista, a partir de 1928, tem como órgão de difusão um movimento internacional, o CIAM (Congresso Internacional de Arquitetura Moderna), que em 1933 escreve e divulga a Carta de Atenas, que vai ser o documento base da arquitetura moderna. Este prega que a cidade deve desempenhar quatro funções principais: habitar, recrear, circular e trabalhar. Conforme Maricato (2000), os encontros dos CIAMs foram os grandes agentes do urbanismo moderno, havia uma grande discussão sobre a solução dos "problemas urbanos", principalmente sobre habitação.

Nos países europeus, onde a industrialização e urbanização estavam mais avançadas, surgem as correntes socialistas utópicas, que vão de encontro ao urbanismo e planejamento urbano até então proposto na época. Estes buscam pensar na sociedade como um todo, e não mais somente no indivíduo, são denominados por Choay de culturalistas. A corrente 
culturalista apresenta uma origem nostálgica, vive do passado. O ponto ideológico desta corrente não é mais o progresso, mas o de cultura.

Entre estes, o estudo mais importante foi o do inglês Ebenezer Howard, que no final do século XIX publicou: Garden-cities for tomorrow (Cidades-jardim para o amanhã).

Howard propôs uma propriedade coletiva da terra com uma organização produtiva agrícola e industrial de pequena escala, em uma cidade jardim de 32 mil habitantes, proposta como modelo universal e antídoto para os males causados por uma industrialização selvagem (CAMPOS FILHO, 2001, p. 10).

A Cidade-Jardim tinha como objetivo unir a vida no campo e na cidade, focando as vantagens da vida mais ativa na cidade e toda a beleza e as delícias do campo. Este modelo valorizava as áreas verdes, as belas paisagens, os bons ares e a vida em meio à natureza, buscando fugir dos problemas de saneamento e degradação humana trazidos pelas cidades industriais (CHOAY, 1965).

Choay destaca também a corrente naturalista, que traz o modelo de cidade de nome Broadacre-City desenvolvida pelo americano F. L. Wright em 1931 a 1935. Segundo o pensamento deste urbanista, "a grande cidade industrial é acusada de alienar o indivíduo no artifício. Só o contato com a natureza pode devolver o homem a si mesmo e permitir um harmonioso desenvolvimento da pessoa como totalidade". Tal corrente prioriza o individualismo, a democracia e a liberdade do homem. A arquitetura está subordinada à natureza.

Todavia, tanto a corrente progressista como a culturalista e a naturalista imaginavam a cidade como um modelo, ao invés de pensá-la como processo ou problema, e acabam tornando-a utópica, e sendo assim, temos que estas correntes deram origem a um pequeno número de realizações concretas, empreendidas numa escala reduzida (Choay, 1965). O urbanismo moderno progressista está presente até hoje em diferentes países, nem tanto pela sua estética, mas sim pelo funcionalismo existente no zoneamento do uso do solo.

No entanto, é possível notar que a preocupação com as áreas verdes, com o sistema de saneamento e higiene estão presentes na origem do planejamento urbano. A falta de salubridade e falta de higiene trazida com a cidade industrial geraram graves problemas de saúde pública e precárias condições de vida. Já no início do século XX, os urbanistas modernos demonstram preocupação em ampliar os espaços de área verde nas grandes cidades, e passam a incorporar as áreas verdes e a preocupação com a natureza e sua relação com o Homem no planejamento urbano das cidades. Neste sentido, o planejamento urbano se torna 
um instrumento importante que busca mudar a situação vivida nas cidades no início do século $\mathrm{XX}$.

O planejamento urbano modernista ganhou proporções durante os anos do Welfare State, 1945-1975. O Estado combinou controle legal sobre o trabalho com políticas que lhe asseguraram elevação do padrão de vida. Houve um aumento na qualidade de vida e investimento em políticas sociais. Sob influência fordista e keynesiana, o planejamento urbano passa a ter o Estado como figura central e controladora, para assegurar o equilíbrio econômico e social. O Estado assume o papel de portador da racionalidade e assegurador do equilíbrio social e econômico (MARICATO, 2000).

As grandes mudanças nas relações internacionais, crise do petróleo (1973), avanço da globalização, propagação das grandes corporações, geram modificações no poder centralizador do Estado e o desmonte do welfare state, passando para um "Estado mínimo", Neoliberal. Aumentam as disparidades entre os países ricos e pobres. O planejamento urbano passa a ser criticado, pelo seu modelo funcionalista, que leva a grande segregação espacial, o espaço passa a ser marcado pela desigualdade. Temos a partir deste momento, década de 1980, o enfraquecimento do planejamento urbano. As cidades passam a ser planejadas numa hierarquia de redes local/global, sendo que algumas cidades passam a concentrar grande riqueza e poder. As cidades passam a receber grande importância e autonomia.

Segundo Souza (2003), o enfraquecimento do planejamento moderno (racionalistacentralizador) se faz acompanhar pela popularização do termo gestão, os problemas passam a ser pensados "aqui e agora", operando no curto e médio prazo, temos o triunfo do imediatismo e do Estado mínimo. O planejamento regulatório e o planejamento pautado em investimentos públicos começam já no final da década de 1970 e início de 1980 a perder lugar para novos modelos de planejamento, que são denominados de pós-moderno, em destaque o planejamento mercadófilo, subordinado às tendências de mercado, o planejamento de facilitação, que estimula a iniciativa privada com vantagens e regalias, e o planejamento de administração privada, que se baseia em parcerias público/privado, onde a administração de espaços públicos é delegada à iniciativa privada.

Assim, algumas cidades têm adotado o "Planejamento mercadófilo" - extremamente amigo do mercado e do empresarialismo - que segundo SOUZA (2003, p. 53) "não enfatiza o controle do uso do solo por meio de leis e normas; sua preocupação é menos com o ordenamento do espaço urbano que com o aumento da competitividade econômica da cidade". Este tipo de planejamento, segundo Souza op. cit., tem substituído o plano diretor, por planos 
estratégicos, que não contém regras e instrumentos com o objetivo de preservação ambiental e não consiste numa lei. É um conjunto de intenções e metas, como grandes obras e projetos urbanísticos que visam à maior atração de investimento pelo mercado financeiro.

O que Souza (2003) denomina de "planejamento mercadófilo" é também conhecido como planejamento estratégico, embora o autor, não considere os dois termos como sinônimos. Segundo Vainer (2009), o planejamento estratégico foi inspirado nos conceitos do planejamento de empresas para o planejamento urbano, pois as cidades estão submetidas às mesmas condições e desafios que as empresas. A cidade de Barcelona é o principal modelo de planejamento estratégico bem sucedido e este modelo vem sendo exportado para diferentes lugares do mundo.

Para Castells (1990), o planejamento estratégico é uma imposição do ambiente de concorrência: "A flexibilidade, globalização e complexidade da nova economia do mundo exigem o desenvolvimento do planejamento estratégico, apto a introduzir uma metodologia coerente e adaptativa face à multiplicidade de sentidos e sinais da nova estrutura de produção e administração” (CASTELLS, 1990, p. 14, apud VAINER, 2009, p. 76).

Castells em sua obra "A questão urbana" aponta que se antes a questão urbana girava em torno de temas como o crescimento desordenado, reprodução da força de trabalho, equipamentos de consumo coletivo, movimentos sociais urbanos, racionalização do uso do solo, atualmente a nova questão urbana está relacionada a problemática da competitividade urbana.

Vainer (2009) se propõe a fazer um rigoroso estudo sobre o planejamento estratégico, onde ele observa a cidade sobre três pontos: a cidade é uma mercadoria, a cidade é uma empresa, a cidade é uma pátria. Assim, sob a ótica dos neoplanejadores, a cidade é uma mercadoria que passa a ser vendida, num mercado competitivo, onde outras cidades também estão à venda.

A cidade não é uma simples mercadoria, mas sim uma mercadoria de luxo, destinada a um grupo de elite, ao grande capital. Porém, aqueles indivíduos que não possuem o capital suficiente para fazer parte deste grupo de elite, ficam à margem deste processo. Vainer (2009), ressalta ainda, que a cidade vista como empresa passa a ser sujeito e ator econômico, instaurando uma nova lógica que pretende legitimar a apropriação direta dos instrumentos de poder público por grupos empresariais privados, afastando o plano político e democrático da tomada de decisões, bem como a negação da cidadania.

Desta forma, Vainer (2009) afirma que o planejamento estratégico urbano implica na apropriação da cidade por interesses empresariais globalizados e depende, em grande medida, 
do banimento da política e da eliminação do conflito e das condições de exercício da cidadania. No entanto, como aponta Souza (2003), existem exemplos de aplicações progressistas do planejamento estratégico, bem sucedidas, como o desenvolvido por Carlos Matus, e que teve nítida influência na administração petista em Porto Alegre a partir de 1989, onde um ambiente politicamente crítico e a participação da sociedade foi bastante favorável.

Assim, uma nova corrente que vem ganhando cada vez mais espaço no planejamento urbano é a gestão participativa, como coloca Souza: "os próprios cidadãos devem poder decidir sobre os destinos dos espaços em que vivem, por meio de debates livres, abertos e transparentes. Os técnicos e estudiosos podem e devem participar, mas na qualidade de "consultores populares" que possam aconselhar, principalmente, quanto aos meios, cabendo a discussão e a decisão política sobre os fins aos próprios cidadãos, não a uma instância de poder que decida por eles e delibere em seu nome" (SOUZA, 2004, p. 14). Assim, vê-se uma forte tendência à descentralização e democratização do planejamento urbano.

O planejamento urbano vem passando por grandes mudanças, as teorias e conceitos desenvolvidos durante o chamado urbanismo moderno estão sendo repensados e analisados, existem novas correntes do planejamento urbano, chamadas por alguns autores de pósmodernas. Estas novas correntes deixam evidente o fortalecimento da esfera local, a maior atenção aos problemas ambientais urbanos e a importância da igualdade no processo de tomada de decisões, de forma democrática.

\subsection{Planejamento urbano no Brasil}

O Planejamento Urbano no Brasil nunca ocorreu de forma concreta, muito do que foi planejado ficou apenas no papel; na maioria das vezes foram adotadas medidas que se aplicavam em curto prazo, mais no intuito de corrigir do que planejar, privilegiando os interesses da elite brasileira, num processo onde surge a cidade legal, aquela onde as leis são aplicadas, e a cidade ilegal, onde não existem planos.

Conforme Maricato (2000), o planejamento urbano brasileiro copiou o modelo seguido pelos países desenvolvidos, sendo que muito dos conceitos vividos nestes países não se aplicavam à realidade brasileira. Assim, adota-se um urbanismo modernista funcionalista apoiado na racionalidade do Estado, porém sendo aplicado a apenas uma parte das nossas grandes cidades, a chamada cidade legal ou formal, marcando assim as cidades brasileiras por uma urbanização incompleta ou excludente. 
No entanto, Villaça ressalta que é preciso ter atenção ao se comparar o planejamento urbano no Brasil com a Europa e Estados Unidos, pois nestes locais, o planejamento corresponde, em parte, à ação concreta do Estado; já no Brasil, o que se configura como planejamento urbano (plano diretor e zoneamento urbano), muitas vezes, fica apenas no papel e no discurso, não são colocados em prática.

Nos anos 1970 e 1980, o Estado teve grande atuação nos campos de saneamento, transporte e habitação. Porém essas medidas tomadas pelo Estado não são o que caracterizamos como planejamento urbano, pois não tinham como objetivo a organização e a ordenação do espaço urbano e não foram formuladas e aplicadas para cada cidade individualmente. São medidas pontuais para solucionar problemas momentâneos, sem se pensar em longo prazo (VILLAÇA, 1999).

Como explica Scarlato (1995), o planejamento urbano no Brasil sempre foi pouco aplicado. A ação do Estado quase não se manifestou, enquanto se verificava a grande urbanização/industrialização que comandava a produção do espaço urbano. Sua ação deu-se sempre no sentido de intervir para ajustar a desordem, e não para suprimi-la.

Como nos aponta Maricato op.cit., o Brasil passou por um processo político e econômico que construiu uma das sociedades mais desiguais do mundo, e teve no planejamento urbano modernista/racionalista um instrumento de dominação ideológica: “ele contribuiu para ocultar a cidade real e para a formação de um mercado imobiliário restrito e especulativo" (MARICATO, 2000, p. 124). Os abundantes aparatos regulatórios, como leis de zoneamento, plano diretor, código de obras e etc, convivem com as constantes anistias à cidade ilegal.

Conforme Maricato (2000), o planejamento no Brasil não tem cumprimento com a realidade concreta, mas com uma ordem que diz respeito a uma parte da cidade, apenas, pois, apenas uma parte da cidade é planejada, reafirmando e reproduzindo privilégios; já a cidade ilegal $^{5}$, representada pela ocupação ilegal do solo urbano é ignorada, não há planos e nem ordem.

Esta ilegalidade apresenta uma funcionalidade, pois de um lado temos relações políticas arcaicas e clientelistas, para um mercado imobiliário restrito e especulativo, e políticas de favor, porém, de outro lado, é bastante disfuncional: para a sustentabilidade

\footnotetext{
${ }^{5}$ Ermínia Maricato(2000) aponta alguns dados sobre a cidade ilegal: "mais de $50 \%$ dos moradores de São Paulo estão em favelas, loteamentos ilegais e cortiços (p. 140) [...] mais de $20 \%$ da população do Rio de Janeiro, Belo Horizonte e Porto Alegre moram em favelas, $28 \%$ da população de Fortaleza, e $33 \%$ da população de Salvador [...] 40\% da população de Recife moram em favelas" (p. 152-153)
} 
ambiental, para as relações democráticas e mais igualitárias, para a qualidade de vida urbana, para a ampliação da cidadania. Maricato afirma que "a segregação territorial e todos os corolários que a acompanham - falta de saneamento ambiental, riscos de desmoronamentos, riscos de enchentes, violência- estão a ele vinculados” (MARICATO, 2000, p. 123).

Analisando a história do planejamento urbano no Brasil, temos que entre 1875 e 1930 , os planos urbanos discutidos pela elite brasileira se limitavam ao melhoramento e embelezamento das cidades, herdeiros da forma urbana monumental que exaltava a burguesia e que destruiu a forma urbana colonial, buscavam atender os anseios da elite e afastar as "áreas feias" ("as favelas") dos centros urbanos. A partir de 1930, a ciência e a técnica começam a substituir os conceitos de embelezamento e melhoramento, busca-se a solução dos “problemas urbanos", pois a cidade da produção precisava ser eficaz. (MARICATO, 2001; VILLAÇA, 1999).

No entanto, o planejamento urbano desenvolvido a partir de 1930 é caracterizado como o plano intelectual, tem base cientifica e é correto cientificamente, porém, é chamado por Villaça (1999) de plano-discurso, que satisfaz a sua própria verdade e não se preocupa com sua operacionalização e sua exeqüibilidade. Representado, principalmente, pela figura do Plano Diretor.

Como nos aponta Flávio Villaça (1995, p. 45), no Brasil, o que se pode chamar de "planejamento urbano" tem dois componentes fundamentais e bastantes independentes um do outro. Um é o zoneamento, e o outro, o planejamento representado pela figura do plano diretor e seus equivalentes.

Conforme expõe o Instituto Pólis (2005, p. 25),

O planejamento - principalmente por meio de Planos Diretores e de zoneamentos estabelece uma cidade virtual, que não se relaciona com as condições reais de produção da cidade pelo mercado, ignorando que a maior parte das populações urbanas tem baixíssima renda e nula capacidade de investimento [...] Desta forma, definem-se no âmbito local os interlocutores dos planos e zoneamentos, destinando para os mais pobres o espaço da política habitacional e a gestão da ilegalidade. [...] Perpetua-se assim uma dinâmica altamente perversa sob o ponto de vista urbanístico - de um lado, áreas reguladas, são produzidos "vazios" e áreas subutilizadas; de outro, reproduz-se ao infinito a precariedade dos assentamentos populares. A despeito de sua aparente irracionalidade urbanística, esta dinâmica tem alta rentabilidade política. 
A política de zoneamento urbano é o principal instrumento para o planejamento das cidades brasileiras nas últimas décadas. Villaça (1995, p. 45) o define como: "a legislação urbanística que varia no espaço urbano". Em sua forma mais "completa", toda a área urbana e de expansão urbana é dividida em zonas, sendo que para cada uma a lei define: o coeficiente máximo de aproveitamento dos terrenos (relação entre a área total construída e a área do terreno); a taxa máxima de ocupação dos terrenos (relação entre área ocupada por edificações e a área do terreno); e finalmente, os usos (atividades que vão ser desenvolvidas no terreno ou na edificação) permitidos e proibidos na zona.

No final do século XIX, existiam várias leis que proibiam cortiços ou vilas operárias apenas em algumas partes da cidade, mas não em outras (VILLAÇA, 1999). O zoneamento sofreu menos influência estrangeira, teve pouca elaboração teórica, o que se desenvolve no Brasil corresponde a interesses e soluções específicas das elites brasileiras. Como afirma Villaça:

[...] o zoneamento é a prática de planejamento urbano lato sensu mais difundida no Brasil. Nos seus quase cem anos de existência entre nós, quase que exclusivamente serviu para atender a interesses claros e específicos, particularmente os bairros da população de mais alta renda (VILLAÇA, 1999, p. 178)

O zoneamento se tornou um instrumento de grande relevância para o planejamento urbano, presente em diferentes países do mundo. Porém, o planejamento não se esgota nesse recurso. No Brasil, grande parte do planejamento urbano já realizado, se pauta somente neste instrumento, priorizando os interesses da elite.

A história do zoneamento urbano passa ao largo dos planos diretores, este instrumento é implantado através de leis independentes desses planos. Muitos erroneamente chamam o zoneamento urbano de plano diretor, já outros o consideram parte indispensável de um plano diretor. Villaça (1995, p. 45) afirma que "o zoneamento resulta de claros conflitos de interesses e da ação concreta dos governos municipais [...] O zoneamento insere-se, portanto, na esfera da política. O plano diretor, não”.

Villaça (1995) afirma que o plano diretor está em crise. Inicialmente, o plano diretor surge no país no início do século XX com o objetivo de "melhoramento e embelezamento", porém não atingia a cidade e a sociedade como um todo, mas sim os bairros de interesse das elites da época. No entanto, estes planos tinham continuidade e eram executados.

Porém, estes planos são executados até a década de 1930 e 1940, e a partir de 1950, os planos só passam a existir no papel. Villaça (1998), aponta que a partir de 1930, e mais 
fortemente na década de 1950, era visível a crise no planejamento urbano. O Plano Diretor passa a ser substituído por um plano que "nunca atingirá seus objetivos e que passará a ser, como ainda é hoje, o plano discurso, o plano inconsequente" (VILLAÇA, 1998, p. 46). O autor destaca como elementos que levaram à crise: a falta de um consenso quanto ao que venha a ser um plano diretor, a alta carga ideológica e tecnocrática facilitando a dominação das classes populares, a descrença e falta de ação dos políticos quanto aos planos diretores.

Existe no Brasil um imenso abismo entre o discurso do plano diretor e a sua prática. Villaça (1999, p. 224) coloca que, "pelo menos durante cinquenta anos - entre 1940 e 1990 o planejamento urbano brasileiro encarnado na ideia de plano diretor não atingiu minimamente os objetivos a que se propôs. A absoluta maioria dos planos foi parar nas gavetas e prateleiras de obras de referência."

Como aponta Maricato (2000), foi durante o regime militar que a atividade de planejamento urbano mais se desenvolveu no Brasil ${ }^{6}$. As diretrizes foram dadas pela PNDU Política Nacional de Desenvolvimento Urbano, prevista no II PND - Plano Nacional de Desenvolvimento, elaborado para o governo do General Ernesto Geisel, em 1973, onde foram criados dois órgãos importantes, a SAREM (Secretaria de Articulação entre Estados e Municípios), e o SERFHAU (Serviço Federal de Habitação e Urbanismo). Mais adiante, foram também criadas a Comissão Nacional de Política Urbana (CNPU), a Fundação Nacional de Desenvolvimento Urbano (FNDU) e a Empresa Brasileira de Transporte Urbano (EBTU). Assim, o Brasil tinha um sistema de diretrizes de planejamento que vigoraram até 1980. Nesse período, uma grande quantidade de Planos Diretores foi elaborada, porém, a maioria foi elaborada por especialistas pouco engajados na realidade sociocultural local, a população não foi ouvida, e nem mesmo os técnicos municipais.

Assim, muitas cidades têm plano diretor, mas muitas vezes estes são extremamente técnicos e pouco utilizados, como coloca Maricato (2000, p. 124), "não é por falta de Planos Urbanísticos que as cidades brasileiras apresentam problemas graves (...), mas por que seu crescimento se faz ao largo dos planos aprovados nas Câmaras Municipais, que seguem interesses tradicionais da política local e grupos específicos ligados ao governo de plantão".

Assim, hoje existe uma abundante legislação urbanística e ambiental e aparatos regulatórios que normatizam a produção do espaço urbano no Brasil - leis de zoneamento, parcelamento dos solos, proteção de mananciais - e não é por falta dessas que as cidades crescem de forma caótica. Segundo Maricato (2000, p. 147), "a ineficácia dessa legislação é,

\footnotetext{
${ }^{6}$ De fato, foi durante o Estado Novo e o regime militar que ocorreu o maior desenvolvimento e planejamento territorial no município de São José dos Campos, objeto de estudo desta pesquisa.
} 
de fato, apenas aparente, pois, constitui um instrumento fundamental para o exercício arbitrário do poder além de favorecer pequenos interesses corporativos", como a autora coloca: "a ocupação ilegal da terra urbana é não só permitida como faz parte do modelo de desenvolvimento urbano no Brasil".

Nos anos de 1980 várias entidades se unem e encaminham ao Congresso Nacional uma emenda popular à Constituição, com mais de 160 mil assinaturas, reivindicando propriedade imobiliária urbana, habitação, transporte e gestão urbana, consolidava-se assim, o Movimento Nacional de Reforma Urbana. Conforme Ribeiro e Cardoso (1994: 87), as características básicas do movimento são:

a) Diagnóstico centrado nas desigualdades e nos direitos sociais. Estabelece uma distinção entre ganhos lícitos e ilícitos na produção da cidade. A exclusão social e política das camadas populares é o eixo do discurso; b) O objetivo de intervenção é a propriedade privada da terra, o uso do solo urbano e a participação direta das camadas populares (e/ou sociedade civil) na gestão da cidade.

Entre várias emendas apresentadas, foram poucas as que persistiram, estando presentes nos artigos 181 e 182, que trata da política urbana, na Constituição Federal de 1988. O artigo 182 torna obrigatório Plano Diretor para cidades com mais de 20 mil habitantes, e torna facultativo o uso dos seguintes instrumentos no plano diretor: o parcelamento ou edificação compulsórios; imposto sobre a propriedade predial e territorial urbana progressiva no tempo; desapropriação com pagamento mediante títulos da divida pública. No entanto, pelo fato desses instrumentos serem facultativos, eles não aparecem na grande maioria dos planos diretores, houve pouco avanço neste sentido. O artigo 181 prevê o domínio de área urbana de até $250 \mathrm{~m}^{2}$, ocupada por cinco anos ininterruptamente, e coloca ainda, que os imóveis públicos não serão adquiridos por usucapião (REANI, 2007).

A Constituição Federal de 1988 atende algumas das metas pretendidas pelo movimento da reforma urbana, instituindo a função social da propriedade e dando maior autonomia aos Municípios, porém, deixa muitas outras de lado, principalmente, em relação à gestão participativa da cidade e instrumentos de regulação urbanística, além de continuar produzindo efeitos favoráveis para os interesses dos agentes responsáveis pela especulação imobiliária e efeitos negativos para a promoção de uma reforma urbana. Muitas das metas requeridas pelo movimento só serão atendidas mais tarde com o Estatuto da Cidade, em 2001 (REANI, 2007).

A Lei $n^{\circ} 10.257$ - Estatuto da Cidade - foi aprovada em 10 de julho de 2001. O Estatuto da Cidade incorpora conceitos, objetivos e diretrizes contidas na Agenda 21 e na Agenda 
Habitat, documentos resultantes de Conferências Mundiais promovidas pelas Nações Unidas na década de 1990, tendo como princípio o desenvolvimento sustentável da cidade, garantindo um meio ambiente equilibrado e melhor qualidade de vida (REANI, 2007).

O Estatuto da Cidade foi encarregado pela constituição de definir o que significa cumprir a função social da cidade e da propriedade urbana. Conforme Rolnik (2001, p.5), “a nova lei delega esta tarefa para os municípios, oferecendo para as cidades um conjunto inovador de instrumentos de intervenção sobre seus territórios, além de uma nova concepção de planejamento e gestão urbanos”. Como coloca Saule Jr. e Rolnik (2001,p.10),

O Estatuto da Cidade é uma lei inovadora que abre possibilidades para o desenvolvimento de uma política urbana com a aplicação de instrumentos de reforma urbana voltados a promover a inclusão social e territorial nas cidades brasileiras, considerando os aspectos urbanos e sociais e políticos de nossas cidades.

Em seu Capítulo I "Diretrizes Gerais”, no artigo 1º, parágrafo único, dispõe: "Estatuto da Cidade, estabelece normas de ordem pública e interesse social que regulam o uso da propriedade em prol do bem coletivo, da segurança e do bem-estar dos cidadãos, bem como do equilíbrio ambiental". Neste sentido, essa nova lei, Estatuto da Cidade, apóia os municípios na execução da Política Nacional de Desenvolvimento Urbano, com base em princípios que estimulam processos participativos de gestão territorial e ampliam o acesso à terra urbanizada e regularizada, principalmente beneficiando grupos tradicionalmente excluídos (Ministério das Cidades, 2004).

As inovações contidas no Estatuto situam-se em três campos, como mostra Rolnik (2001, p.5), “um conjunto de novos instrumentos de natureza urbanística voltados para induzir não, mais do que normatizar, as formas de uso ocupação do solo; uma nova estratégia de gestão que incorpora a ideia de participação direta do cidadão em processos decisórios sobre o destino da cidade e a ampliação das possibilidades de regularização das posses urbanas, até hoje situadas na ambígua fronteira entre o legal e o ilegal”. A autora Rolnik op. cit. complementa afirmando que a nova lei estabelece formas possíveis de diálogo entre planejamento e gestão, planejamento e política.

O Estatuto da Cidade tem como objetivo ordenar as cidades de forma mais justa e eqüitativa, com a distribuição de bens e serviços à população, através de uma gestão democrática e participativa. Para tanto, pode se utilizar dos instrumentos de regulação e 
ordenação urbanística, produzindo assim, cidades sustentáveis. Entre os instrumentos da política urbana, Capítulo II, Seção I, Artigo 4º, podemos destacar:

III - planejamento municipal, em especial:

a) Plano Diretor;

b) disciplina do parcelamento do uso e da ocupação do solo;

c) zoneamento ambiental;

f) gestão orçamentária participativa;

IV - institutos tributários e financeiros:

a) imposto sobre a propriedade predial e territorial urbana - IPTU;

V - institutos jurídicos e políticos:

e) instituição de unidades de conservação;

f) instituição de zonas especiais de interesse social;

g) concessão de direito real de uso;

h) concessão de uso especial para fins de moradia;

i) parcelamento, edificação ou utilização compulsórios;

j) usucapião especial de imóvel urbano;

1) direito de superfície;

m) direito de preempção;

n) outorga onerosa do direito de construir e de alteração de uso;

o) transferência do direito de construir;

p) operações urbanas consorciadas;

q) regularização fundiária;

VI - estudo prévio de impacto ambiental (EIA) e estudo de impacto de vizinhança (EIV).

O Estatuto da Cidade, segundo Saule Jr. e Rolnik (2001), define quais são as ferramentas que o Poder Público, especialmente o Município, deve utilizar para enfrentar os problemas de desigualdade social e territorial nas cidades. Os instrumentos previstos no Estatuto da Cidade tentam, assim, coibir a lógica da formação de preços do mercado imobiliário, de áreas vazias e subutilizadas; como o IPTU progressivo no tempo e à edificação e parcelamento compulsórios, tentando assim, controlar a expansão horizontal das cidades, que invadem as áreas rurais e de preservação ambiental. Boa parte dos instrumentos depende de planos diretores ou leis municipais específicas para serem aplicados; assim, fica fácil prever a dimensão dos obstáculos que surgirão para suas aprovações em qualquer Câmara (ROLNIK, 2001).

O Estatuto da Cidade pode ser um poderoso instrumento dos municípios para a promoção do desenvolvimento urbano. Como aponta Moreira (2001),

[...] este poderá ser utilizado para evitar a ocupação de áreas não suficientemente equipadas, evitar a retenção especulativa de imóveis vagos ou subutilizados, preservar o patrimônio cultural ou ambiental, exigir a urbanização ou ocupação compulsórias de imóveis ociosos, captar recursos financeiros destinados ao desenvolvimento urbano e exigir a reparação de impactos ambientais. 
Desta forma, os Municípios encontram no Estatuto da Cidade importante subsídio para ordenar o crescimento da cidade, amenizando os impactos socioambientais existentes e os problemas urbanos. A nova lei favorece o planejamento urbano participativo e democrático, a diminuição da segregação urbana e desigualdade social, além de prever o equilíbrio ambiental e melhores condições de vida, dando novos rumos ao planejamento urbano no Brasil.

Como afirma Braga (2008), o Estatuto da Cidade é uma espécie de antídoto à crise urbana, social, econômica e ambiental. Esta nova lei vem colocar-se como instrumento de promoção da função social da cidade e da sustentabilidade urbana. "Os até então desacreditados Planos Diretores ressurgem como desejados portadores de uma nova ordem urbana, socialmente mais justa e ambientalmente mais equilibrada" (BRAGA, 2008, p.02).

Nesse sentido, o Estatuto da Cidade consagrou o Plano Diretor não só como instrumento de política urbana, mas como instrumento de reforma urbana. Ele surge como um instrumento eminentemente político, com o objetivo de dar transparência e democratizar a política urbana, sendo um instrumento de gestão democrática da cidade. Como afirmam Carvalho e Braga (2001, p.98), “o aspecto da democratização é fundamental, pois só ele garante a transparência necessária das regras do jogo. A democratização efetiva do planejamento se dá pela participação da sociedade no processo, o que, pelo menos em tese, é garantido pela Constituição Federal (no Artigo 29) e, como se verificou, pelo Estatuto da Cidade".

Através do Estatuto da Cidade e de seus instrumentos, torna-se possível uma mudança no planejamento urbano. A ação democrática e participativa, novas práticas de cidadania, apoiadas em ações mais justas e igualitárias pelo Estado, e na preservação do meio ambiente, torna possível o ordenamento e organização das cidades, e assim, uma melhor qualidade de vida urbana e um ambiente mais saudável. No entanto, é importante, haver a consciência de que a existência de um dispositivo jurídico, não é o suficiente para garantir uma melhora no nosso ambiente urbano, é preciso a efetivação política, participação e ação de diferentes atores.

Como afirma Silva-Sánchez (2000, p. 26):“O estatuto de sujeito de direito que se pretende para as gerações futuras e para a própria natureza implica, pois, a construção de uma cidadania de tipo novo. O conteúdo dessa cidadania será definido pela luta política e prática concreta; uma disputa histórica, que pressupõe a politização da relação sociedade-natureza. Apenas uma politização desse tipo pode garantir tal projeto, cujo objetivo fundamental é a extensão do conceito de cidadania para as futuras gerações e para a natureza". 
Maricato (2005, p. 02), complementa afirmando que "a construção de uma esfera com participação direta, se não dá conta de todos esses problemas, ainda é a forma mais eficaz de persegui-los. [...] Trata-se da construção de paradigmas que articulam conhecimento técnico e crítico, fruto da produção acadêmica e profissional com conhecimento trazido pelos que vivem e produzem a cidade".

É importante que a cidadania faça parte da vida de todo cidadão. A população exercer a sua cidadania se torna fundamental para um planejamento urbano renovado. Como aponta Jacobi (1999, p. 35), “A nova dimensão da cidadania inclui, de um lado, a constituição de sujeitos sociais ativos, e de outro, para a sociedade como um todo, um aprendizado de convivência com esses cidadãos emergentes que recusam permanecer nos lugares que lhes foram definidos social e culturalmente”. A participação do cidadão é essencial para os ideais democráticos.

Segundo Carvalho e Braga (2001, p. 98), "só a participação ativa das entidades representativas da sociedade na elaboração do plano diretor garante sua legitimidade e propicia condições para sua efetiva implementação".

Neste sentido, temos que o Estatuto da Cidade trouxe uma nova abertura ao planejamento urbano e ambiental no Brasil, porém, é essencial que seus instrumentos não apareçam somente na lei maior, mas também nos planos diretores e se façam cumprir na prática. Para tanto, é necessário uma nova postura cidadã, novas práticas sociais, garantindo a gestão democrática e participativa da cidade; só assim será possível a efetivação do planejamento urbano no Brasil.

\subsection{Planejamento e meio ambiente no Brasil}

O surgimento do planejamento urbano no final do século XIX e início do século XX está relacionado à precariedade e péssimas condições de vida, à falta de saneamento e higiene e à proliferação de doenças na cidade industrial. Assim, o planejamento urbano já nasce com preocupações urbano-ambientais, Como visto anteriormente o urbanismo modernista ressalta em suas diferentes correntes a importância da existência de áreas verdes em meio à cidade, sendo estas áreas fundamentais para o bom desenvolvimento da vida humana.

A preocupação com o meio ambiente ganhou uma dimensão cada vez maior diante do acelerado processo de urbanização e industrialização e de seus efeitos negativos sobre o meio ambiente. As grandes cidades vivem uma situação conflitante, enfrentando vários problemas ambientais urbanos, como enchentes e alagamentos, que causam congestionamentos e/ou o 
desalojamento de centenas de famílias; deslizamentos de terras e desmoronamentos, que geram mortes e desabrigam inúmeras pessoas; lixões e aterros sanitários lotados, poluição do ar, da água e do solo, gerando inúmeros problemas de saúde pública, ilhas de calor, falta de saneamento básico e outros. Nesse sentido, o discurso do planejamento urbano é cada vez mais acompanhado do discurso ambiental, passando a caminharem juntos. A questão ambiental se torna fundamental no planejamento das cidades.

No entanto, a preocupação com o futuro do meio ambiente já vem ocorrendo a longo tempo. No ano de 1913, ocorreu a Primeira Conferência Internacional sobre a Proteção das Paisagens Naturais, na cidade de Berna na Suíça (GEORGE, 1973). De lá para cá, as questões ambientais se tornam cada vez mais graves e passam a ganhar maior amplitude, o número de conferências e congressos para discutir o tema se tornam mais frequentes.

A questão ambiental ganha grande repercussão nos anos de 1970, quando ocorrem as primeiras crises advindas da diminuição da produção de petróleo no Oriente Médio. Alguns cientistas apontaram a necessidade de contenção das taxas de natalidade, evitando um superpovoamento e a escassez dos recursos energéticos. A publicação de "Os Limites do Crescimento", pelo Clube de Roma, grupo formado por especialistas em diversas áreas do conhecimento, originado do Instituto de Tecnologia de Massachusetts, trouxe uma visão bastante alarmista das condições ambientais do planeta, que, em termos gerais, evidenciava uma visão malthusiana, opondo crescimento populacional em ampliação ao uso dos recursos naturais existentes.

Nos últimos anos, o meio ambiente, ou melhor, os problemas ambientais têm repercussões cada vez maiores, seja na mídia ou nos meios acadêmicos. Quando falamos em degradação do meio ambiente, logo vem o discurso de desenvolvimento sustentável. Os termos desenvolvimento sustentável e sustentabilidade ambiental fazem parte de quase todo discurso político. Estes termos adquiriram muita visibilidade nas últimas décadas; estão relacionados a algo positivo, a uma proposta ou prática social. Porém, estes não são sinônimos e possuem especificações.

O termo desenvolvimento sustentável surgiu em 1987, sendo resultado dos trabalhos da Comissão Mundial sobre Meio Ambiente e Desenvolvimento (CMMAD), criada pela ONU em 1983.Os trabalhos desse congresso ficaram conhecidos como Relatório Brundtland ${ }^{7}$,

\footnotetext{
${ }^{7}$ Este trabalho foi presidido pela então primeira-ministra da Noruega, Gro Harlen Brundtland, motivo pelo qual ficou conhecido como Comissão Brundtland. O documento foi publicado como "Our comom future", em 1987 na Inglaterra e nos Estados Unidos.

Anterior a CMMAD, em 1972, ocorre em Estocolmo a I Conferência sobre o Meio Ambiente Humano, já mostrando preocupação com o modelo de desenvolvimento econômico atual.
} 
publicado no Brasil em 1988, com o título "Nosso futuro comum”. Esse documento apresenta a definição de desenvolvimento sustentável:

O desenvolvimento que procura satisfazer as necessidades da geração atual, sem comprometer a capacidade das gerações futuras de satisfazerem as suas próprias necessidades, significa possibilitar que as pessoas, agora e no futuro, atinjam um nível satisfatório de desenvolvimento social e econômico e de realização humana e cultural, fazendo, ao mesmo tempo, um uso razoável dos recursos da terra e preservando as espécies e os habitats naturais.

Assim, tem-se que a definição de desenvolvimento sustentável está relacionada à ideia de desenvolvimento que é capaz de garantir as necessidades do presente sem comprometer a capacidade das gerações futuras atenderem também às suas (CMMAD, 1988). Nesse sentido, o relatório destaca três componentes fundamentais do novo modelo de desenvolvimento sustentável: proteção ambiental, crescimento econômico e equidade social.

Já se passaram mais de 20 anos desde o surgimento do termo desenvolvimento sustentável. Vemos que este aparece cada vez mais forte nos discursos políticos e sociais, porém, na prática, a adoção do desenvolvimento sustentável se aplica em passos muito mais lentos, estando ainda muito longe de ser atingido. Todos concordam que o desenvolvimento atual é "insustentável", porém não existe o mesmo consenso entre quais são as causas do problema, assim como as soluções e estratégias propostas são bastante diferenciadas e, inclusive, antagônicas.

O desenvolvimento sustentável na esfera local, ou seja, a busca pelas cidades sustentáveis, é algo que vem sendo incorporado no planejamento urbano. A preocupação em desenvolver um ambiente urbano mais saudável e em equilíbrio com a natureza tem sido foco de várias conferências internacionais. O próprio Relatório Brundtland (1988), além de ter definido o discurso-padrão sobre o desenvolvimento sustentável, ocupa-se, no Capítulo 9, da parte II, em discutir os problemas urbanos.

Já em 1976, havia sido realizada, na cidade de Vancouver, no Canadá, a Conferência das Nações Unidas sobre Assentamentos Humanos (Habitat I), na qual ficou reconhecido que a relação econômica dos países pobres tornou-se injusta pela própria forma de inserção de cada qual na divisão internacional de trabalho e que o indivíduo só se desenvolve a partir do desenvolvimento local no qual ele está inserido no mundo. A partir desse momento, fica evidente a importância de cuidar do meio ambiente na esfera local em detrimento ao global.

Em consequência do Habitat I, começam a serem discutidas as condições básicas que devem estar presentes no ambiente urbano promotor do desenvolvimento urbano, e entre estas 
estão as condições mínimas de habitação e infraestrutura básica. Coloca-se, também, a importância da estrutura urbana, com a implantação de equipamentos de consumo coletivo escolas, hospitais, áreas de lazer, comércio, serviços e segurança. É destacada a importância da geração de emprego e renda, o fim da segregação socioespacial e da concentração fundiária. Em 1996, vinte anos após a primeira edição, ocorreu o Habitat II. Nesta conferência, os governos se comprometeram a criar formas de intervenção no ambiente urbano, visando dotá-los de condições 'sustentáveis' de permanência e crescimento.

Nesse sentido, fica evidente a importância da esfera ambiental no planejamento urbano. Atualmente, tem-se que mais da metade da população mundial vive em cidades. $\mathrm{O}$ grande contingente de pessoas vivendo nas cidades acentua cada vez mais os problemas ambientais urbanos. A necessidade de um planejamento urbano apoiado no desenvolvimento sustentável se torna fundamental para o futuro das cidades, para a melhor qualidade de vida urbana e um meio ambiente saudável.

O Brasil vive um acelerado processo de urbanização, onde atingimos a marca de $84,4 \%$ de população urbana, sendo que de cada dez brasileiros, oito vivem em cidades (IBGE, 2010). Torna-se essencial pensar no equilíbrio ambiental urbano, no desenvolvimento das cidades, em como é a qualidade com que elas crescem, pois o que se vê é que cidades pequenas e médias reproduzem os problemas enfrentados nas grandes cidades e metrópoles, enquanto nestas últimas os problemas ambientais se agravam cada vez mais.

Segundo o Instituto Pólis (2005), a vertiginosa urbanização brasileira produziu cidades com um novo e dramático significado, além de evocar progresso e desenvolvimento, estas passam a retratar e a reproduzir as injustiças e desigualdades da sociedade, e são evidenciadas nas diferenças entre as áreas centrais e periféricas, entre a cidade legal e a ilegal.

Como apontam muitos estudiosos do espaço urbano (Maricato, Villaça, Rolnik, Carlos), a cidade passa a se dividir em cidade legal e cidade ilegal. A cidade legal é aquela cuja apropriação e uso do solo urbano ocorreram dentro das normas técnicas, dos códigos de obras garantidas pelas formas regulares do direito à propriedade. A cidade ilegal resulta de formas de grilagem e de loteamento feitos por empresas imobiliárias que atuam na clandestinidade, ou descumpridoras das exigências legais, ou ainda, de ocupações de terrenos públicos e privados por pessoas impelidas pela necessidade de um lugar para morar (SCARLATO, 1995).

Tem-se que degradação ambiental e a desigualdade social são resultantes do processo de (re)produção das relações dominantes de produção (Lefebvre, Harvey, Gottdiener, Singer). Na sociedade capitalista, que busca o lucro máximo, o solo tem valor de troca e não de uso, 
sendo uma mercadoria. O mercado de terras gera a produção de localizações, diferenciação de investimentos públicos e privados, gera especulação imobiliária e segregação urbana.

A cidade ilegal é construída em desacordo com as leis vigentes, ocupa áreas de preservação ambiental (córregos, encostas) e não possui infraestrutura, muitas vezes essa ocupação é permitida, não pela necessidade de moradia, mas pela ação da especulação imobiliária, que mais tarde incorpora essas áreas à cidade legal, objetivando o lucro, sendo um dos motivos do agravamento da proliferação dos problemas ambientais urbanos.

A questão ambiental deve ser entendida como um produto da intervenção humana sobre a natureza, sendo que todos nós, seres humanos, estamos intervindo nesta natureza, modificando-a. Assim, a questão ambiental diz respeito não apenas a problemas relacionados à natureza, mas às problemáticas decorrentes da ação social (RODRIGUES, 2005).

Os problemas ambientais urbanos são muitos, como a poluição das águas continentais, falta de água potável, ar atmosférico irrespirável, aumento da temperatura nas áreas centrais das cidades (ilhas de calor), efeito estufa, chuva ácida, grande produção de resíduos sólidos e a falta de local para o seu depósito, enchentes, deslizamento de terras. Todos esses problemas ocasionam aos seres humanos vários tipos de enfermidades, como doenças respiratórias, intoxicação, câncer de pele etc. A este conjunto de problemas, denominam-se problemas ecológicos, ambientais, problemática ambiental, questão ambiental. Estes problemas mostram a forma predatória como os seres humanos vêm se apropriando da natureza (RODRIGUES, 2005).

No Brasil, a ocupação periférica em áreas de mananciais vem trazendo grande impacto ambiental para as cidades, uma vez que muitas dessas ocupações não oferecem água encanada, serviço de rede de esgoto e coleta de lixo. No crescimento desordenado, a ampliação das áreas impermeabilizadas, devido ao crescimento urbano, afeta a capacidade de infiltração das águas no solo. Tal fator favorece o escoamento superficial, a concentração de enxurradas e cheias. Há ainda a degradação dos recursos hídricos a partir da destruição dos rios agravada pelo assoreamento dos mesmos e desmatamento das áreas de nascentes e dos pontos de infiltração, interferindo em toda a rede hidrológica local e contribuindo na desorganização da rede regional. A alteração climática, local e regional, com o alto índice de desmatamento, interferindo no conforto térmico, também são problemas comuns às periferias (MARCONDES, 1999).

Esses problemas ambientais e socioeconômicos atingem não só a população local que vive em um meio ambiente degradado e não compartilha qualquer qualidade de vida, como 
também atinge toda a sociedade, uma vez que sendo o meio ambiente sistêmico, a degradação local pode interferir em uma escala maior.

No Brasil, onde o planejamento urbano sempre teve pouca funcionalidade, os problemas ambientais urbanos ganham maior amplitude. A dimensão ambiental pouco esteve presente nas políticas públicas locais, ou não houve a fiscalização e vontade necessária para que estas fossem cumpridas. A cidade avançou sobre áreas verdes, mananciais, córregos e áreas de encosta. Os vales, rios, vegetação e o ar nas grandes cidades hoje se apresentam altamente degradados.

Ao analisarmos o planejamento e a questão ambiental no Brasil, veremos uma forte ligação com a história da formação do país. O Brasil é um país que passou pela colonização de exploração, a motivação da conquista de espaços e exploração de recursos está na gênese do país. (MORAES, 1999).

Como aponta Moraes (2005), persiste na nossa história a idéia de "construir o País", levar a civilização ao interior selvagem. Tal ideia tem por pressuposto uma ação colonizadora, isto é, a ocupação dos fundos territoriais não explorados, que se legitima pela ação de um Estado forte e ativo, que conduzirá esse processo. O povo é percebido como mero instrumento do processo, evidenciando assim outra determinação colonial.

Nesse sentido, MORAES (1999, p.44), reforça o papel do Estado como explorador do território e a falta de políticas públicas que pensem no povo:

Já disse um presidente brasileiro: "governar é abrir estradas". Tal frase traduz em muito a concepção das elites governamentais: o país sendo visto como um espaço (e não como uma nação), e um espaço que deve ser conquistado e explorado. $\mathrm{O}$ mote colonial da conquista repõe-se cotidianamente na prática estatal. O território, e não o povo, sendo o alvo prioritário das políticas públicas.

Desta maneira, o Estado em nosso país tem uma função essencialmente geopolítica, que é garantir a soberania e a integridade de todo território, mesmo aqueles não ocupados efetivamente. Assim, o Estado tem por referência o domínio do território e não o bem estar do povo. Como afirma Moraes (2005, p. 15), "este Estado é um aparelho político dos proprietários de terras, um Estado patrimonial". A sociedade brasileira é marcada pelo regime escravista de trabalho, assim, herdou a vigilância e a violência, a exclusão e a desigualdade social em suas raízes.

Após a década de 1930, inicia-se o processo de constituição do Brasil contemporâneo, isto é, da sociedade que vivemos hoje. A partir desse momento, a ideia de "construir o país" 
está fortemente atrelada à ideia de "modernização". Dessa forma, construir um país moderno vai ser a meta dos governos a partir de Vargas. Assim, a partir da década de 1930 tem-se um desenvolvimento cada vez maior da tecnologia, a modernização do mundo ocorre a passos largos. O processo de globalização se intensifica, como aponta Moraes: "revalorizam-se as periferias no reordenamento da divisão internacional do trabalho no pós-guerra” (MORAES, 2005, p. 17).O autor complementa, afirmando ainda:

\begin{abstract}
As determinações externas atuam continuamente na história do Brasil, pois as economias periféricas são estruturalmente "áreas de ajuste", que necessitam de tempos em tempos adequar sua produção às inovações empreendidas no centro do sistema mundial. Cada redefinição das matrizes produtivas nos países hegemônicos reverbera nos territórios da periferia, estimulando ou contendo fluxos, direcionando explorações, intensificando ou estagnando atividades.
\end{abstract}

A modernização realizada nos países de primeiro mundo passa a ser perseguida pelos países de terceiro mundo. Nos países periféricos, a modernização é induzida, principalmente pelo Estado, que utilizará como instrumento estatal básico para realizar a modernização do país o planejamento. Desta forma, o plano representa a proposta de distribuição das inovações no espaço nacional.

Durante o Governo Vargas, principalmente no Estado Novo, são criados vários órgãos públicos na esfera federal interessando a intervenção sobre o território, em que se destaca a criação do Instituto Brasileiro de Geografia e Estatística (IBGE), com o objetivo de levantamento de dados e informações do território para o seu planejamento. Porém, não sepode dizer que houve um planejamento governamental integrando vários setores. Um maior avanço no planejamento territorial ocorre no segundo governo Vargas com o Plano Salt (medidas na área de saúde, alimentação e transporte), eeste é seguido pelo Plano de Metas no governo de Juscelino Kubitschek. Embora estes, trouxessem grande desenvolvimento para o país não pode ser considerado um exemplo de planejamento integrado, pois, se trata mais de um conjunto de políticas econômicas de infraestrutura requeridas pelo crescimento industrial, com destaque ao arrojado plano viário e a construção da nova capital: Brasília (MORAES, 2005).

Como aponta Fiori (1995, apud SILVA-SÁNCHEZ, 2000) “a industrialização brasileira foi resultado de um projeto desenvolvimentista, cuja estratégia envolvia a presença ativa do Estado como planejador, produtor de insumos e fornecedor de infraestrutura básica, em síntese, uma ação intervencionista no campo econômico, quase sempre marcada por características centralizadoras, conservadoras e autoritárias". 
No governo de Goulart, em 1962, é criado o ministério do Planejamento, que teve como ministro o economista Celso Furtado, ocorre certo avanço nessa área, porém, em 1964, o golpe militar põe fim a tais inspirações, e o país passa por uma nova fase de centralização do poder.

Esse novo regime político propõe uma série de ações visando o planejamento integrado do território. Entre eles se destaca o Plano Nacional de Desenvolvimento (PND), dividido em três versões, com a primeira versão publicada em 1970, tendo forte apoio de capital estrangeiro. Esses planos tiveram aplicação no território, e propunham um melhor ordenamento do espaço, porém era um planejamento tecnocrático, autocrático e hipercentralizado. "[...] O país é pensado como um espaço a se ganhar e não como uma sociedade" (MORAES, 2005, p. 21).

O Brasil entra na década de 1980 com grandes mudanças. Deixa de ser um país rural para ser um país urbano, apresentando aceleradas taxas de crescimento populacional e de urbanização. A modernização alcançada aumenta a concentração de renda, as disparidades regionais e as desigualdades sociais no país. Todavia, no sentido do planejamento, como coloca Moraes: "a crise do regime militar se faz acompanhar de uma pulverização de ações e programas, os quais vão espalhar-se pelo diferentes órgãos da administração federal" (MORAES, 2005, P. 21). A chamada "década perdida" vai ter pouco desenvolvimento, o planejamento na esfera nacional passa por uma profunda setorização, os programas e ações adotados são cada vez mais específicos, autônomos e desarticulados entre si. Faltam políticas públicas que atuem de forma integrada.

Contudo, tem-se nesse período o maior desenvolvimento da política ambiental, com uma progressiva estruturação e ampliação de seu campo de atribuições. Na visão de Moraes (2005), passa-se de uma visão preservacionista para uma perspectiva bem mais ampla de intervenção e o amadurecimento do pensamento ambientalista no país, que de uma preocupação ecologista evolui para conceitos de qualidade de vida e desenvolvimento sustentável. A elaboração da Política Nacional do Meio Ambiente (Lei nº 6938/81) e a criação do IBAMA mostram o desenvolvimento das questões ambientais no país na década de 1980 .

Os ecos da democratização começam a se fazer sentir na estrutura setorial. Nessa segunda fase, a concepção imperante prioriza as ações de conservação e preservação de áreas dotadas de condições naturais pouco alteradas pela ação antrópica. São criadas inúmeras unidades de conservação, e uma visão biologista predomina no setor. Cabe assinalar também o início de uma presença mais significativa dos organismos internacionais (públicos e privados) nas ações e discussões interessando o meio ambiente no Brasil (MORAES, 1999, p. 18). 
Uma nova fase na política ambiental pode ser observada com o projeto "Nossa Natureza", o qual cria o Instituto Brasileiro de Meio Ambiente e dos Recursos Naturais Renováveis (IBAMA), agrupando os vários órgãos dedicados às matérias existentes no governo federal, como o Instituto Brasileiro de Desenvolvimento Florestal e a Superintendência de Desenvolvimento da Pesca. A criação de um ministério específico para tratar do tema e, principalmente, a escolha do Brasil como sede da Conferência das Nações Unidas sobre Meio Ambiente e Desenvolvimento, em 1992, completam a nova orientação do setor, que terá por guia teórico a noção de "desenvolvimento sustentável".

Todavia, a área ambiental foi montada como mais um setor do aparelho governamental, tem-se, assim, uma performance ainda insatisfatória no setor ambiental, pois um bom planejamento e execução de políticas ambientais requerem diálogos variados e uma articulação entre diversos interlocutores na área pública e privada. Assim, fica cada vez mais claro que é necessário que exista uma inter-relação entre os órgãos do governo, no tratamento das políticas públicas ambientais. Na visão de Moraes, “o ambiental deve ser, assim, concebido como um vetor que necessita internalizar-se nos diversos programas e ações estatais dando-lhes também um elemento de articulação" (MORAES, 2005, p. 24). Segundo o mesmo autor, a área ambiental pode ser uma alavanca da retomada de um planejamento global e articulado no país.

A Política Nacional de Meio Ambiente traz instrumentos importantes para o planejamento e gestão ambiental, que vão encontrar apoio no planejamento urbano. As políticas públicas ambientais se tornam mais presentes no país, ganhando espaço na esfera nacional, regional e local. No entanto, a ação do Estado, através da gestão democrática e participativa, bem como a ação de Organizações Não Governamentais (ONGs) e sociedade civil organizada são primordiais para a efetivação de políticas públicas mais justas e igualitárias, que visem a melhor qualidade de vida e ao equilíbrio ambiental urbano.

No Brasil, não há uma tradição de política ambiental na esfera municipal, sendo assim, o Plano Diretor como instrumento de gestão territorial urbana e é também um instrumento de gestão ambiental urbana. Em 2001, o Estatuto da Cidade coloca elementos mínimos, além de garantir a participação da sociedade na elaboração e implementação do Plano Diretor através de audiências públicas, debates e publicidade e acesso aos documentos produzidos (CARVALHO; BRAGA, 2001).

Conforme exposto, os problemas ambientais urbanos são muitos e se agravam cada vez mais diante do intenso processo de urbanização e industrialização vivenciadas no país, é fundamental que novas práticas sociais e ambientais se concretizem na esfera local. $\mathrm{O}$ 
planejamento urbano no Brasil carece de novas práticas. O Estatuto da Cidade, os Planos Diretores e a Política Nacional do Meio Ambiente, entre outros, são essenciais para uma mudança no planejamento urbano, no entanto, fazem-se necessárias também, novas práticas de cidadania, que visem à melhor qualidade de vida urbana e a um meio ambiente saudável para todos. 


\section{Políticas Públicas Ambientais No Brasil}

As demandas ao meio ambiente se tornam maiores com a mesma dinâmica em que a sociedade se transforma. As novas técnicas desenvolvidas pelo Homem exploram cada dia mais a natureza, este passa de amigo a explorador. O Homem se apropriou da natureza, causando danos irreversíveis. A primeira Revolução Industrial impôs mudanças na paisagem e nas relações sociais. As cidades cresceram, e com elas, os problemas urbanos. Vivemos hoje em de uma sociedade de consumo que exige cada vez mais da natureza e pouco lhe oferece em troca.

Face às mudanças econômicas e sociais, as políticas públicas desenvolvidas pelos governos assumem papel crucial para auxiliar a preservação do planeta.

O estudo de políticas públicas no Brasil é algo muito incipiente, porém nas últimas décadas, vem crescendo esta área de estudo nos meios acadêmicos. Não só a ciência política, mas várias outras áreas do conhecimento têm pesquisado sobre o que o governo faz ou deixa de fazer.

Conforme Souza (2003) a análise de política pública é, por definição, estudar o governo em ação. No entanto, Mead (1995, apud SOUZA, 2007, p. 68) "a define como um campo dentro do estudo da política que analisa o governo à luz de grandes questões públicas" e Lynn (1980) como um conjunto de ações do governo que irão produzir efeitos específicos. Peters (1986) segue o mesmo veio, ao afirmar que: "política pública é a soma das atividades dos governos, que agem diretamente ou por delegação, e que influenciam a vida dos cidadãos. 
Dye (1984) sintetiza a definição da política pública como "o que o governo escolhe ou não fazer"”' (SOUZA, 2003, p.68).

Neste sentido, a autora Celina Souza op. cit. resume política pública como o campo do conhecimento que busca, ao mesmo tempo, colocar o "governo em ação" e/ou analisar essa ação (variável independente) e, quando necessário, propor mudanças no rumo ou curso dessas ações (variável dependente) (SOUZA, 2007, p.69).

Para Boneti (2006), política pública pode ser definida como:

[...] o resultado da dinâmica do jogo de forças que se estabelece no âmbito das relações de poder, relações essas constituídas pelos grupos econômicos e políticos, classes sociais e demais organizações da sociedade civil. Tais relações determinam um conjunto de ações atribuídas à instituição estatal, que provocam o direcionamento (e/ou redirecionamento) dos rumos de ações de intervenção administrativa do Estado na realidade social e/ou de investimentos. Nesse caso, pode-se dizer que o Estado se apresenta como um agente repassador à sociedade civil das decisões saídas do âmbito da correlação de forças travada entre os agentes do poder (BONETI, 2006, p. 74).

Conforme Carvalho (2002), as políticas públicas devem ter ação coletiva que concretize os direitos sociais declarados e garantidos em lei. São mediante políticas públicas que são distribuídos ou redistribuídos bens e serviços sociais, em reposta às demandas da sociedade. A Constituição Federal, no Art. 2, determina que as políticas públicas devem promover a participação do cidadão na elaboração, aplicação e fiscalização dessas políticas.

Segundo Moraes (2005), as políticas públicas podem ser agrupadas em três grandes campos: políticas econômicas (cambial, financeira, tributária etc.), políticas sociais (educação, saúde, previdência etc.) e políticas territoriais (urbanização, regionalização, transportes etc.). Para Moraes, as políticas territoriais são aquelas que produzem espaço, e as políticas ambientais podem ser consideradas políticas territoriais, sendo que o ambiental passa a ser considerado como mais um fator na modelagem do espaço terrestre. "[...] o ambiental não se homogeneíza num só alvo de ação, antes se difunde como uma faceta inerente a todo ato de produzir espaço" (MORAES, 2005, p. 32).

No Brasil, a preocupação com políticas públicas de cunho ambiental têm maior importância a partir da década de 1970, quando os problemas ambientais ganham ampla atenção na esfera mundial, após a I Conferência sobre o Meio Ambiente Humano, em 1972.

Em um estudo sobre a questão ambiental no Brasil, Cunha e Coelho (2003), estabelecem uma periodização das políticas ambientais brasileiras: $1^{\text {a)}}$ ) de 1930 a 1971, 
marcado pela construção de uma base de regulação dos usos dos recursos naturais; $2^{\mathrm{a}}$ ) de 1972 a 1987, em que a ação intervencionista do Estado chega ao ápice, ao mesmo tempo em que aumenta a percepção de uma crise ecológica global; $3^{\text {a }}$ ) de 1988 até os dias atuais, processo de democratização e descentralização decisórias, rápida disseminação da noção de desenvolvimento sustentável.

Cunha e Coelho (2003) apontam três tipos de políticas ambientais no Brasil: as regulatórias, as estruturadoras e as indutoras de comportamento. As políticas regulatórias tratam de normas e regras de uso e acesso ao ambiente natural e seus recursos e de aparatos institucionais que garantam o cumprimento da lei. As políticas estruturadoras implicam na intervenção direta na proteção do meio ambiente, como por exemplo a criação de unidades de conservação. As políticas indutoras de comportamento são ações que objetivam influenciar o comportamento de indivíduos ou grupos sociais, representam iniciativas destinadas a aperfeiçoar a alocação de recursos, sendo as certificações ambientais exemplos de política indutora.

Na década de 1930, são criadas políticas regulatórias destinadas à proteção da natureza e de seus recursos, na esfera federal. O Decreto $\mathrm{n}^{\mathrm{o}}$ 23.793/34 - Código Florestal, previa a criação de parques nacionais e proteção de florestas. Em 1937, é criado o Parque Nacional de Itatiaia. Nas décadas de 1950 e 1960 são criadas unidades de conservação, sendo a maioria delas na Mata Atlântica, e a primeira Floresta Nacional na Amazônia, a FLONA de Caxuanã. Além do Código Florestal, também são criados em 1934, o Código de Águas e das Minas. O primeiro definiu o direito de propriedade e os usos dos recursos hídricos, e também, as normas de proteção da quantidade e qualidade das águas territoriais. Já o Código de Minas definiu critérios para a prospecção e exploração de jazidas e dissociou o direito de propriedade do solo do direito de exploração do subsolo (SILVA-SÁNCHEZ, 2000)

Em 1938, é criado o primeiro código de pesca (Decreto nº794, de 19/10/38), substituído pelo Decreto-lei n²21, de 28/02/1967, que declarou a fauna e a flora das águas territoriais brasileiras pertencentes ao domínio público e fixou princípios e modalidade para a pesca. O Código Florestal é revisto (Lei n $\mathrm{n}^{\circ}$ 4.771/65: institui o novo Código Florestal), entre as principais ações, destacam-se a criação de Áreas de Preservação Permanente (APPs) e a Reserva Legal de $80 \%$, na propriedade rural situada em área de floresta localizada na Amazônia Legal; 20\%, na propriedade rural em área de campos gerais localizada em qualquer região do País. Em 1958, o governo federal criou a Fundação Brasileira para a Conservação da Natureza (FBCN), que tinha como objetivo principal defender a fauna marítima, a flora 
aquática e fiscalizar a pesca no litoral. Em 1967, é criado o Instituto Brasileiro de Desenvolvimento Florestal (IBDF) e a Lei de Manejo e Proteção da Fauna.

Como aponta Silva-Sánches (2000), esta fase da política ambiental foi marcada pela racionalização do uso e exploração dos recursos naturais e a definição de áreas de preservação ambiental, estabelecendo alguns limites à propriedade privada. O principal objetivo era a regulamentação da apropriação dos recursos naturais na esfera federal. Esta política surge de forma tímida durante o período Vargas, e sem a participação da sociedade, com base em um Estado centralizador, autoritário e desenvolvimentista.

O segundo momento descrito por Cunha e Coelho op. cit., que vai de 1972 a 1987, foi fortemente influenciado pelos escritos do Clube de Roma (1971) e pela I Conferência das Nações Unidas sobre Meio Ambiente (1972). O país passou a sofrer pressão dos movimentos ambientalistas e de organismos financeiros internacionais contra a acelerada degradação do patrimônio natural, passa a existir uma contradição entre as políticas modernizantes (abertura de estradas, barragens, redes de transmissão de energia etc.) e as políticas ambientais. Os Planos Nacionais de Desenvolvimento (PNDs), entre 1975 e 1985, foram pressionados a realizar estudo de impacto ambiental (CUNHA E COELHO, 2003).

Nesse período, foram criadas a Secretaria Especial do Meio Ambiente (SEMA), no âmbito do Ministério do Interior, em 1973; a Companhia de Desenvolvimento do Vale do São Francisco, em 1974, e o Ministério do Desenvolvimento, Urbanização e Meio Ambiente, em 1985. A criação de parques e unidades de conservação, também, aumentou neste período, surgindo novas categorias, como, reservas biológicas, estações ecológicas, áreas de proteção ambiental e outros, com o objetivo de preservação de biomas diversos.

Conforme Mello (2006), durante a década de 1970, a SEMA serviu para popularizar a temática ambiental, fomentando a criação de órgãos estaduais e os Conselhos Municipais de Meio Ambiente e aumentando o número de Unidades de Conservação. Houve pouca fiscalização e aplicação da legislação. Na década de 1980, as políticas ambientais foram descontínuas e ocorreram mais no âmbito federal, porém, a existência de um conjunto de normas, somada à participação ativa de organizações ambientalistas e a atitudes mais agressivas dos segmentos ambientalistas não governamentais respaldaram as conquistas constitucionais (MELLO, 2006).

A promulgação da Política Nacional de Meio Ambiente (Lei $n^{\circ}$ 6.938/81) foi um grande ganho para o meio ambiente no Brasil. Conforme Mello (2006), esta legislação foi bastante significativa pela sua abrangência e por procurar maneiras de introduzir a variável ambiental em outros setores da economia. Tal legislação alterava os papéis dos poderes 
públicos, descentralizando as decisões e ampliando a participação na formulação e implementação de políticas na escala municipal, estadual e federal.

Com criação do SISNAMA (Sistema Nacional do Meio Ambiente) e do seu órgão consultivo e deliberativo o CONAMA (Conselho Nacional do Meio Ambiente), assegura-se a participação de representantes da sociedade organizada nas decisões e a cooperação interinstitucional, garantindo o crescimento e consistência da política ambiental (MELLO, 2006).

Desta forma, a Política Nacional de Meio Ambiente tinha como objetivo "a preservação, melhoria e recuperação da qualidade ambiental propícia à vida, visando assegurar, no País, condições ao desenvolvimento socioeconômico, aos interesses da segurança nacional e à proteção da dignidade da vida humana" (Art. $\left.2^{\circ}\right)$. Como escreve Mello (2006, p. 62), "seu principal objetivo refletia as discussões internacionais sobre ecodesenvolviemento, pois tratava da compatibilização do desenvolvimento econômico e social com a preservação da qualidade do meio ambiente e do equilíbrio ecológico". Esta legislação reconhecia as diversidades locais e o imperativo do envolvimento de todos os níveis de governo e segmentos da sociedade, e também, a importância de incorporar a questão ambiental às políticas públicas.

Em 1985, é promulgada a lei da ação civil pública de responsabilidade por prejuízos causados ao meio ambiente, ao consumidor, a bens e direitos de valor artístico, estético,

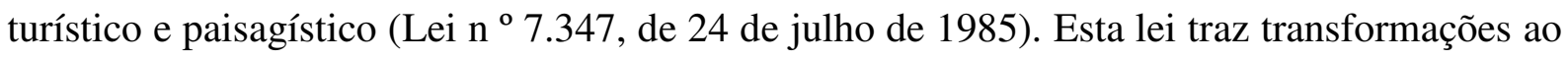
direito tradicional e ressalta a característica democrática, sendo um dos avanços mais importantes ocorridos nos últimos anos para a defesa do meio ambiente (SILVA-SÁNCHEZ, 2000).

E, finalmente, o terceiro momento apontado por Cunha e Coelho (2003), que vai de 1988 até os dias atuais, é marcado pelo processo de redemocratização do país e a promulgação de uma nova Constituição, com forte tendência descentralizadora, além do fortalecimento das questões ambientais no mundo. O envolvimento da sociedade local nas questões ambientais passou a ser estimulado, os municípios passam a ter maior autonomia, o papel dos diferentes atores sociais na reformulação das políticas públicas passa a ser discutido.

A Constituição Federal de 1988 trata, no Capítulo VI especificamente do meio ambiente. Declara a Mata Atlântica, a Floresta Amazônica e o Pantanal como patrimônio nacional. Obriga a recuperação dos ambientes degradados e cria os royalties, que objetiva compensar à União, estados e municípios pela exploração de recursos naturais. A 
Constituição consolida os avanços da política ambiental e vai situar o meio ambiente no mesmo nível dos direitos e garantias fundamentais, ao estabelecer no Art. 225, que "todos têm direito ao meio ambiente ecologicamente equilibrado, bem de uso comum do povo e essencial à sadia qualidade de vida, impondo-se ao Poder Público e à coletividade o dever de defendêlo e preservá-lo para as presentes e futuras gerações”.

Em 1989, é criado o Instituto Brasileiro de Meio Ambiente e Recursos Naturais (IBAMA), o governo federal lança em 1990 o Sistema de Vigilância da Amazônia (SIVAM) e o Sistema de Proteção da Amazônia (SIPAM), com o objetivo de contribuir com o controle ambiental na Amazônia. Em resposta às críticas de desmatamento na Amazônia, o governo lança o projeto de Zoneamento Econômico Ecológico da Amazônia com apoio do PPG7 (grupo dos sete países mais ricos do mundo).

Em 1992, foi criado o Ministério do Meio Ambiente (MMA), que assumiu o compromisso de seguir as recomendações da Rio-92. No ano de 1997, é instituída a Política Nacional de Recursos Hídricos, (Lei no 9.433/97) que cria o Sistema Nacional de Gerenciamento de Recursos Hídricos e regulamenta a gestão dos recursos hídricos, descentralizando o controle sobre as bacias hidrográficas. No ano seguinte, é promulgada a Lei de Crimes Ambientais (Lei $n^{\circ}$ 9.605/98), que estabelece penalidades na implantação de qualquer empreendimento potencialmente poluidor sem as devidas autorizações e licenças ambientais. No ano de 1999, é sancionada a Lei Federal n 9.795, que cria a Política Nacional de Educação Ambiental, que responsabiliza o Poder Público por promover a educação ambiental em todos os níveis de ensino e a conscientização pública para a preservação do meio ambiente. Em 2000, é criada a Agência Nacional da Água (ANA) e o Sistema Nacional de Unidades de Conservação (SNUC- Lei nº 9.985/00).

Conforme Cunha e Coelho (2003), na década de 1990, consolidam-se as políticas do tipo indutor do desenvolvimento sustentável. Há uma maior ação de ONGs e movimentos ambientalistas, que passam a buscar formas participativas e democráticas nas políticas públicas ambientais. O Estado, no entanto, continua a formular e a implantar políticas antagônicas, ditando tanto normas de proteção ambiental quanto estabelecendo leis contraditórias de incentivos fiscais e anistias, que acabam acelerando a exploração florestal e a devastação dos recursos naturais.

Vemos a efetivação de diversas leis urbanísticas e ambientais a partir da década de 1980 que vão possibilitar a inserção da dimensão ambiental no planejamento urbano, como a Política Nacional de Meio Ambiente (1981), que traz instrumentos como o licenciamento ambiental, avaliação de impacto ambiental, zoneamento ambiental e a criação de espaços 
protegidos (APAs); a Constituição Federal de 1988, que dá maior autonomia aos municípios; a Política Nacional de Recursos Hídricos (1997), que descentraliza a tomada de decisões através dos comitês de bacias; o Estatuto da Cidade (2001), que cria instrumentos como, plano diretor, zoneamento ambiental e o planejamento participativo, a Lei $n^{\circ} 6766 / 79$, que regulariza o parcelamento do solo, entre outras. Desta maneira, as políticas públicas ambientais ganharam maior autonomia na esfera urbana, nota-se uma maior ação dos órgãos municipais e da sociedade em relação às questões ambientais.

Como destacam Cunha e Coelho (2003, p. 68), “o setor ambiental é um dos mais influenciados pela atuação das organizações não governamentais, seja em ações de financiamento de projetos, do exercício de pressão sobre o Estado ou em realização de pesquisas que influenciam a elaboração posterior de políticas". Os conceitos de desenvolvimento sustentável, manejo de recursos naturais, democratização e descentralização de decisões tornam-se influentes. Desta forma, a maior pressão sobre as questões ambientais acarreta na orientação de novas políticas públicas ambientais e torna a dimensão ambiental cada vez mais presente no planejamento.

Segundo Cunha e Coelho (2003), as políticas ambientais recentes, como a política nacional de recursos hídricos e a criação de reservas extrativistas, revelam um novo conjunto de idéias e valores. "Noções de comanejo ou de gestão participativa, baseadas numa estratégia conservacionista de proteção da natureza e numa visão instrumental/reformista dos mecanismos regulatórios do uso dos recursos naturais, passam a ser dominantes no setor" (CUNHA E COELHO, 2003, p. 75).

Mello (2006) complementa ainda, afirmando que:

[...] nesse novo contexto, assistimos ao nascimento de um processo de governabilidade, mesmo em lugares em que a presença da estrutura estatal é frágil, seja por meio de experiências realizadas em parcerias com ONGs, seja pelo debate mais socializado, fatores estes que tem induzido à elaboração de políticas com maior factibilidade de serem implantadas, isto é, comparadas com aquelas que foram formuladas durante os anos em que as decisões estavam centralizadas na esfera federal. Todo esse processo de participação, de compartilhamento de decisões e de co-responsabilidades em ações dá origem a políticas alternativas, como as políticas estaduais embasadas no conceito de desenvolvimento sustentável (MELLO, 2006, p. 188)

O governo brasileiro avançou muito na incorporação dos conceitos de sustentabilidade ambiental e participação social. No entanto, ainda é preciso avançar mais na elaboração e 
execução de políticas públicas no país, pois tais políticas são ainda bastante fragmentadas e setorizadas. É necessário integrar as políticas públicas ambientais e a redefinição dos papéis do Estado, das empresas, das ONGs e da sociedade civil na definição de políticas ambientais e de modelos participativos de planejamento (MELLO, 2006).

Vivemos um momento onde o Estado não pode se prestar somente a defender os interesses dos grupos dominantes, "le passage $d u$ singulier au pluriel territorial" (GRATALOUP, 2000 apud MELLO, 2006). Novos valores se impõem, modelados a novos atores locais que almejam o reconhecimento de suas relações com o território.

O ex- Ministro do Meio Ambiente, Gustavo Krause, em 1997, afirma que a experiência tem lhe ensinado que, "cada passo da gestão ambiental dado na direção correta corresponde, na maioria das vezes, a um enfrentamento de interesses cristalizados, de uma ordem empedernida e de velhas práticas reiteradas" (KRAUSE, 1999, p. 17, apud Cavalcanti, 1999).

Krause op. cit. afirma ainda que muito pouco é possível, caso não aconteçam transformações amplas nas relações políticas entre o Estado, a sociedade e os mecanismos clássicos da democracia representativa; sem que se amplie consideravelmente a consciência ambiental; sem que se busque uma reelaboração interdisciplinar dos saberes e, finalmente, sem que se proceda a uma reorganização transetorial da administração pública (KRAUSE, 1999).

Para Krause, é importante a construção de uma "cultura da sustentabilidade", para tanto, ele afirma que é fundamental uma sólida consciência social em relação ao direito a um ambiente saudável e produtivo; o reconhecimento universal quanto ao valor da biodiversidade; o respeito a uma ética inter e intrageracional; ênfase às prioridades voltadas às necessidades básicas, a qualidade de vida e a inclusão social; práticas de descentralização econômica e gestão participativa; a incorporação de uma dialética que aproxime o universal do particular, o local do global.

Silva-Sánchez (2000) afirma que tem sido construída uma cidadania ambiental no país, por meio de uma sociedade que começa a ser capaz de reivindicar seus direitos e exigir que sejam cumpridos. O movimento ambientalista inseriu no debate político a questão da participação democrática da sociedade no processo de decisão acerca da apropriação dos recursos naturais e da formulação de políticas que garantam a qualidade de vida.

É importante ressaltar, também que, o desenvolvimento de novas tecnologias, como a internet; o geoprocessamento; as imagens de satélite e fotos aéreas em alta resolução; os instrumentos de monitoramento do ar, da água, do solo e do desmatamento, entre outros, têm 
favorecido em muito a análise ambiental, a efetivação de políticas públicas e o melhor planejamento das cidades.

$\mathrm{Na}$ esfera local, vêm-se novas políticas públicas ambientais apoiadas, na política ambiental, e também, nos novos instrumentos trazidos pelo Estatuto da Cidade, no Plano Diretor, no Zoneamento Urbano e nas novas tecnologias. A atuação de ONGs em meio ao espaço urbano se torna cada vez mais presente, bem como a ação de Conselhos Municipais, que, no entanto, muitas vezes tem apenas ação consultiva. As audiências públicas, as associações de amigos do bairro e a sociedade civil organizada têm atuado na busca do planejamento participativo e preservação do meio ambiente no espaço urbano, e se colocam como uma renovação, um novo caminho, para o planejamento urbano no Brasil.

No entanto, é fundamental que o Estado reflita sobre a capacidade de suporte, limites e sustentabilidade do meio, pois são categorias ecológicas com enorme significação em termos das relações entre o processo econômico e o ecossistema. A política de governo para o desenvolvimento sustentável não pode desconhecê-las (CAVALCANTI, 1999).

Neste sentido, é fundamental que o governo desenvolva políticas com uma nova orientação das ações públicas motivada pelo reconhecimento da limitação ecológica dos recursos naturais, sem os quais nenhuma atividade humana pode se realizar. Como escreve Cavalcanti (1999, p. 30),

[...] isto implica a necessidade quer de utilização cuidadosa da base biofísica, ambiental da economia, quer uma reorientação na maneira como os recursos da natureza são empregados e os correspondentes benefícios, compartilhados. O problema estratégico aqui consiste em encontrar um fluxo metabólico (ou um throughput) sustentável, que possa elevar o bem estar social sem causar danos às funções e serviços ambientais. Em outras palavras, o nível do produto social deve ser garantido, do mesmo modo que a qualidade do meio ambiente natural e a qualidade de vida.

O Estado deve assim, refletir sobre as políticas públicas ambientais, de modo a incorporar os conceitos de desenvolvimento sustentável, e estas devem ser pensadas, também, em relação à esfera local. É preciso desencorajar aquilo que cause ameaça ao meio ambiente e qualidade de vida da população. As políticas regulatórias, estruturadoras, e principalmente, indutoras devem estar sempre sendo revisadas e aplicadas, de modo a garantir o desenvolvimento de cidades sustentáveis. 


\title{
PARTE II
}

\section{POLÍTICAS PÚBLICAS AMBIENTAIS NO PLANEJAMENTO URBANO DE SÃO JOSÉ DOS CAMPOS - SP}

\author{
Bem sei que, muitas vezes, \\ O único remédio \\ É adiar tudo. É adiar a sede, a fome, a viagem, \\ A dívida, o divertimento, \\ $\mathrm{O}$ pedido de emprego, ou a própria alegria. \\ A esperança é também uma forma \\ De continuo adiamento. \\ Sei que é preciso prestigiar a esperança, \\ Numa sala de espera. \\ Mas sei também que espera significa luta e não, apenas, \\ Esperança sentada. \\ Não abdicação diante da vida. \\ (Cassiano Ricardo, "A rua”)
}




\section{Caracterização do Município de São José dos Campos - SP}

A cidade de São José dos Campos originou-se como aldeia, estando ligada às relações entre jesuítas e indígenas. Em 1767, a Aldeia de São José foi elevada à condição de Vila. A "Vila de São José da Parayba", como era chamada, permaneceu pacata e com uma economia apenas de subsistência até meados de 1850, quando se dá a expansão do café no Vale do Paraíba. São José é elevada à categoria de cidade em 1864, ganhando Comarca própria em 1872 (PAPALI; ALMEIDA; ACEDO DEL OMO, 2011).

Atualmente, São José dos Campos possui população de 627.544 habitantes (IBGE CENSO, 2010), sendo uma das maiores e mais importantes cidades do Estado de São Paulo, estando em sétimo lugar em tamanho populacional do estado. O município faz parte da Região Metropolitana do Vale do Paraíba e Litoral Norte (Lei 1.166/12), que compreende 39 municípios, sendo São José dos Campos o município sede.

A área total do município é $1.099,60 \mathrm{~km}^{2}$, sendo $361,95 \mathrm{~km}^{2}$ na área urbana e 737,65 $\mathrm{km}^{2}$ na área rural (SEADE, 2009). São José dos Campos possui dois distritos, o de São Francisco Xavier $^{8}$ e o de Eugênio de Melo, como mostra a Figura 1. A área urbana do município é dividida em seis regiões geográficas: Região Norte, Região Oeste, Região Centro, Região Leste, Região Sul e Região Sudeste (Figura 2).

\footnotetext{
${ }^{8}$ O Distrito de São Francisco Xavier não fez parte do objeto de estudo desta pesquisa. As leis, mapas e dados relacionados a este distrito não foram analisados.
} 


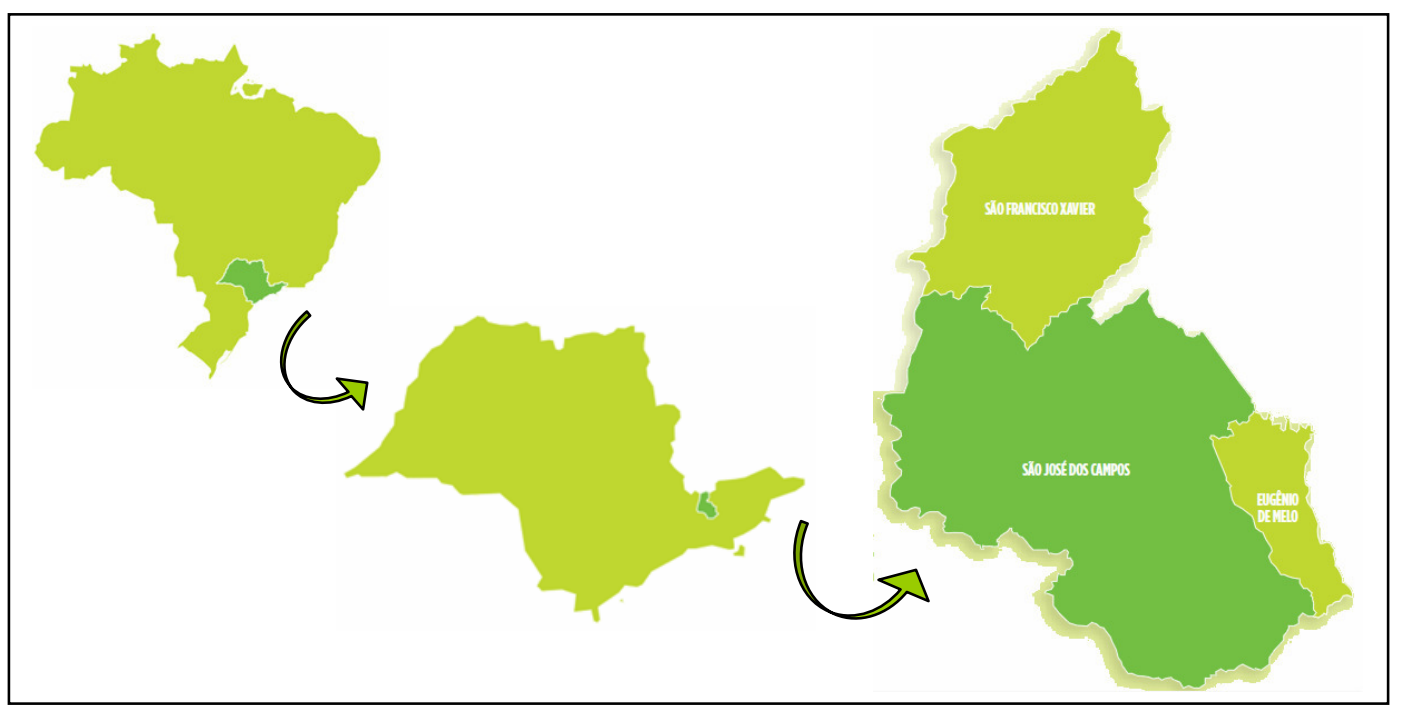

Figura 1 - Localização da área de estudo: São José dos Campos - SP

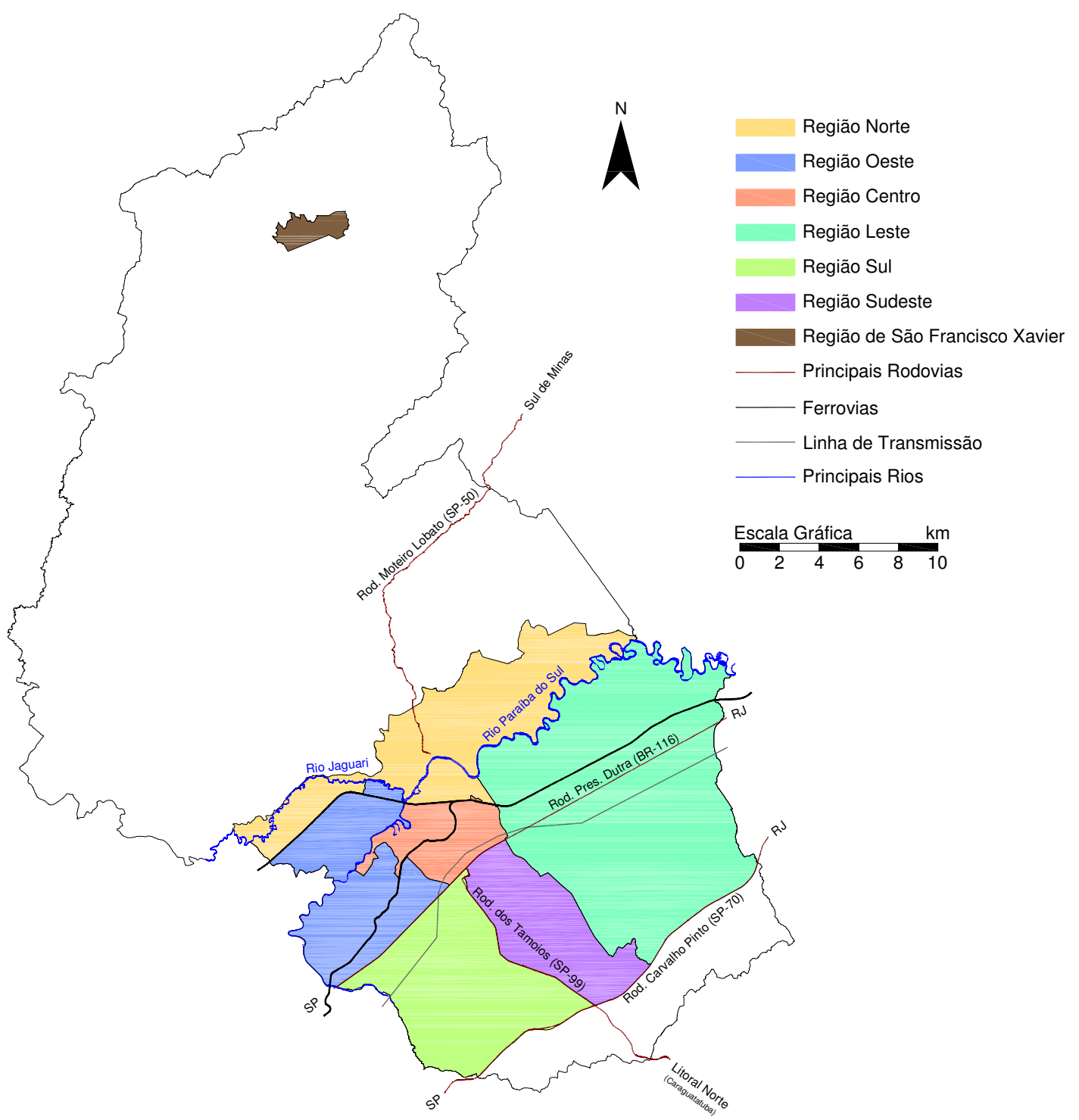

Figura 2 - São José dos Campos: perímetro urbano e regiões administrativas 
O Rio Paraíba do Sul corta a região de São José dos Campos e dá beleza especial às características físicas e à paisagem, com a formação do Banhado, uma imensa área verde com cerca de 4,32 milhões de metros quadrados, contígua ao centro urbano, localizada na Avenida São José (Figura 3 e Figura 4). O Banhado "constitui-se em um anfiteatro que se abre após o declive abrupto que cai sobre a várzea próxima, mantendo suas feições de extensa planície, que se alonga até o Rio Paraíba do Sul, compondo um cenário único totalmente integrado à paisagem urbana local" (PMSJC, 2008, p.43).

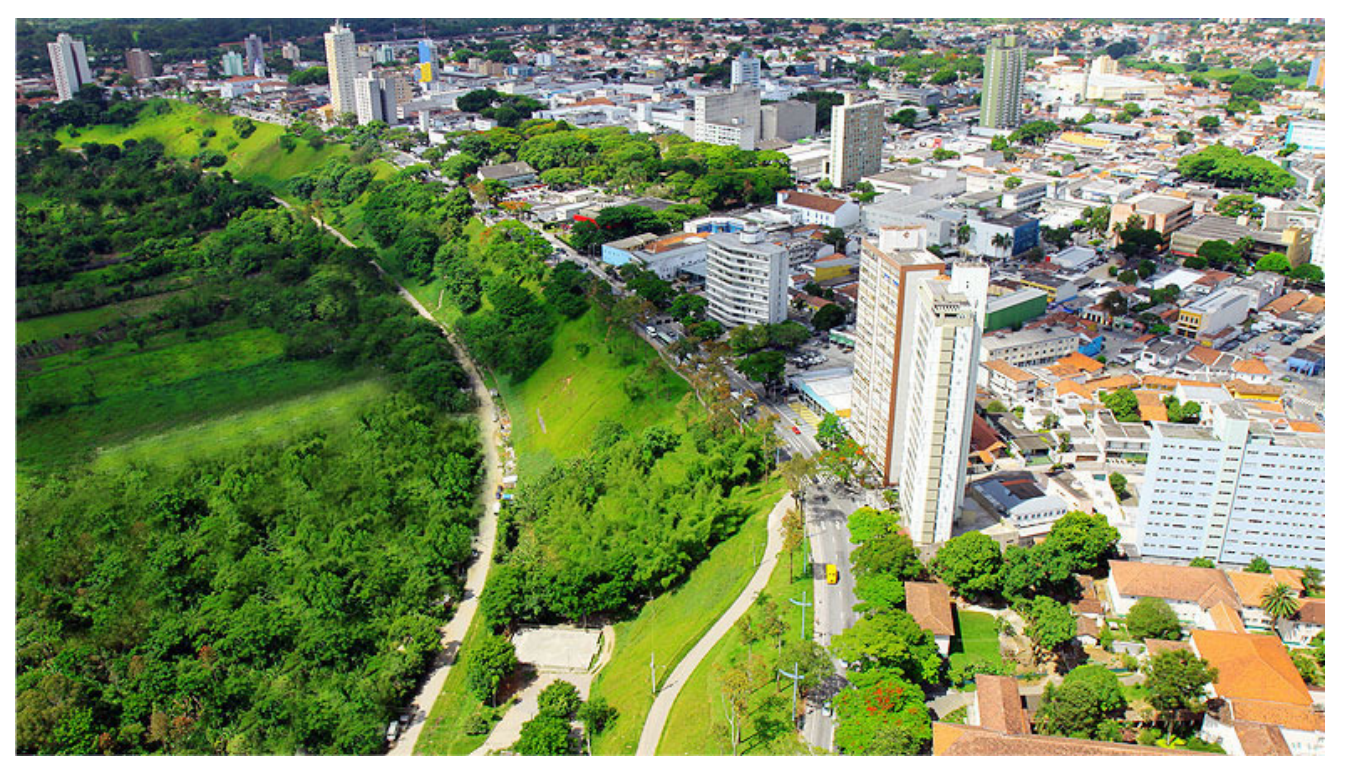

Figura 3 - Banhado em São José dos Campos.

Fonte: PMSJC ( 2010).

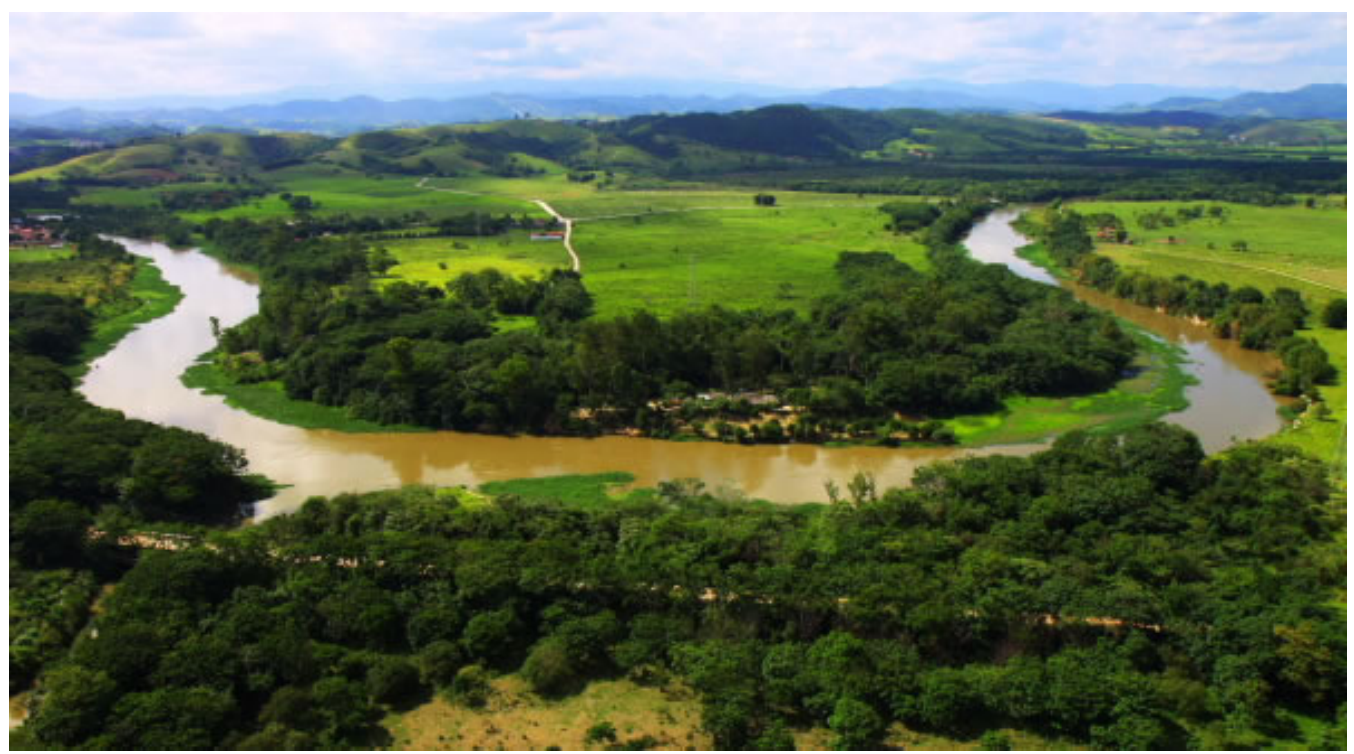

Figura 4 - Rio Paraíba do Sul em São José dos Campos.

Fonte: PMSJC ( 2010). 
O município de São José dos Campos está situado no Planalto Atlântico, a cidade se estende por uma grande planície, sendo contornada pela Serra da Mantiqueira. A altitude média é de 600 metros. O município possui mais de 300 mananciais e vertentes que formam riachos, rios e córregos. Na região, predomina o clima subtropical, com temperatura média anual de $21^{\circ} \mathrm{C}$ e umidade relativa em torno de $76 \%$ (PMSJC, 2008).

Os principais eixos de expansão urbana na região do Vale do Paraíba acompanham o Rio Paraíba do Sul ou a Rodovia Presidente Dutra (BR-116), assim, os diversos centros de expansão se estruturaram a partir do mesmo eixo viário, facilitando a comunicação e o processo de conurbação e integração funcional entre as cidades, onde São José dos Campos exerce o papel de polo regional (IPEA et al., 2001).

O município é marcado pela presença da Rodovia Federal Presidente Eurico Gaspar Dutra (BR-116), como mostra a Figura 5, uma das mais importantes do país, que liga as duas metrópoles: São Paulo e Rio de Janeiro. A Rodovia Estadual SP-50 liga São José dos Campos ao Sul de Minas Gerais e a Campos do Jordão (principal destino de turismo de montanha do estado). Pelo município, passam também a Rodovia dos Tamoios (SP-99) que liga São José dos Campos ao Litoral Norte e a Rodovia Carvalho Pinto (SP -70). O município possui aeroporto e tem fácil acesso aos aeroportos internacionais de Guarulhos e Congonhas e aos portos de Santos e São Sebastião.

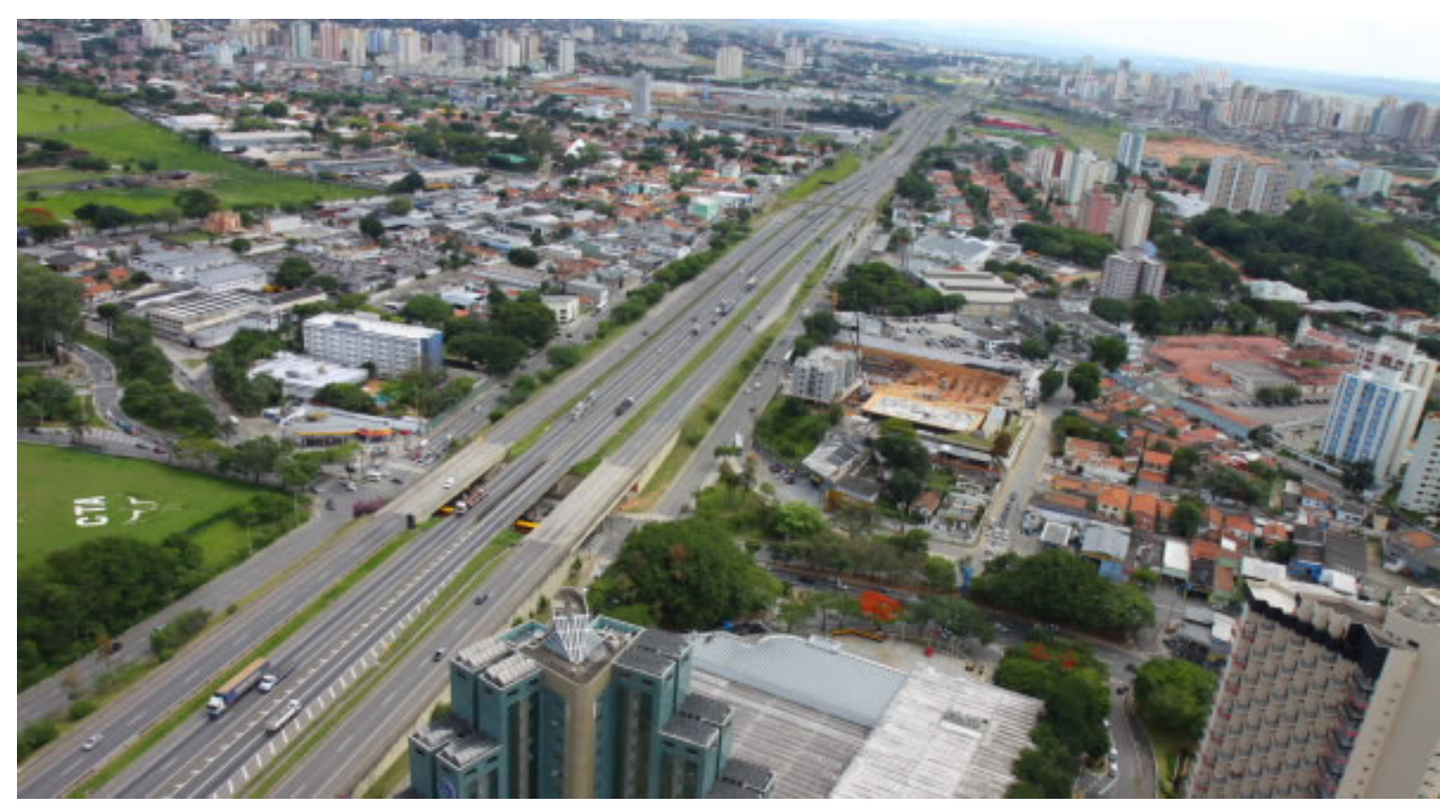

Figura 5 - Rodovia Presidente Eurico Gaspar Dutra (BR-116).

Fonte: PMSJC (2010). 
Além desses fatores, a proximidade de São José dos Campos à capital do estado (97 km), contribuiu para o desenvolvimento econômico da região, a alta industrialização, e também, o título que a cidade recebe hoje de "Polo Tecnológico" nos setores bélico, eletrônico e aeroespacial.

A aglomeração urbana de São José dos Campos possui mais de um milhão de habitantes. A localização da aglomeração entre os principais centros consumidores do país, a presença de centros de pesquisa (INPE, ITA), a disponibilidade de mão de obra qualificada e a alta infraestrutura transformaram a cidade de São José dos Campos em um dos principais eixos de localização industrial do estado atualmente (IPEA et al., 2001).

O município apresenta o $8^{\circ}$ maior PIB do estado de São Paulo (IBGE, 2010). Dados do Ministério do Desenvolvimento, Indústria e Comércio Exterior (MDIC), referente ao primeiro trimestre de 2008, revelam que São José dos Campos é a segunda maior exportadora do país, ficando atrás apenas da cidade de São Paulo (IBGE, 2005; SEADE, 2005; SOUZA, 2008).

Como mostra o gráfico da Figura 6, o maior número de pessoas empregadas é no setor de serviços $(47,46 \%)$ e em segundo lugar aparece a indústria, que emprega $24,06 \%$ da população, seguida pelo comércio $(18,52 \%)$, construção civil $(9,43 \%)$ e, com baixa participação, a agropecuária (0,53\%) (SEADE, 2009).

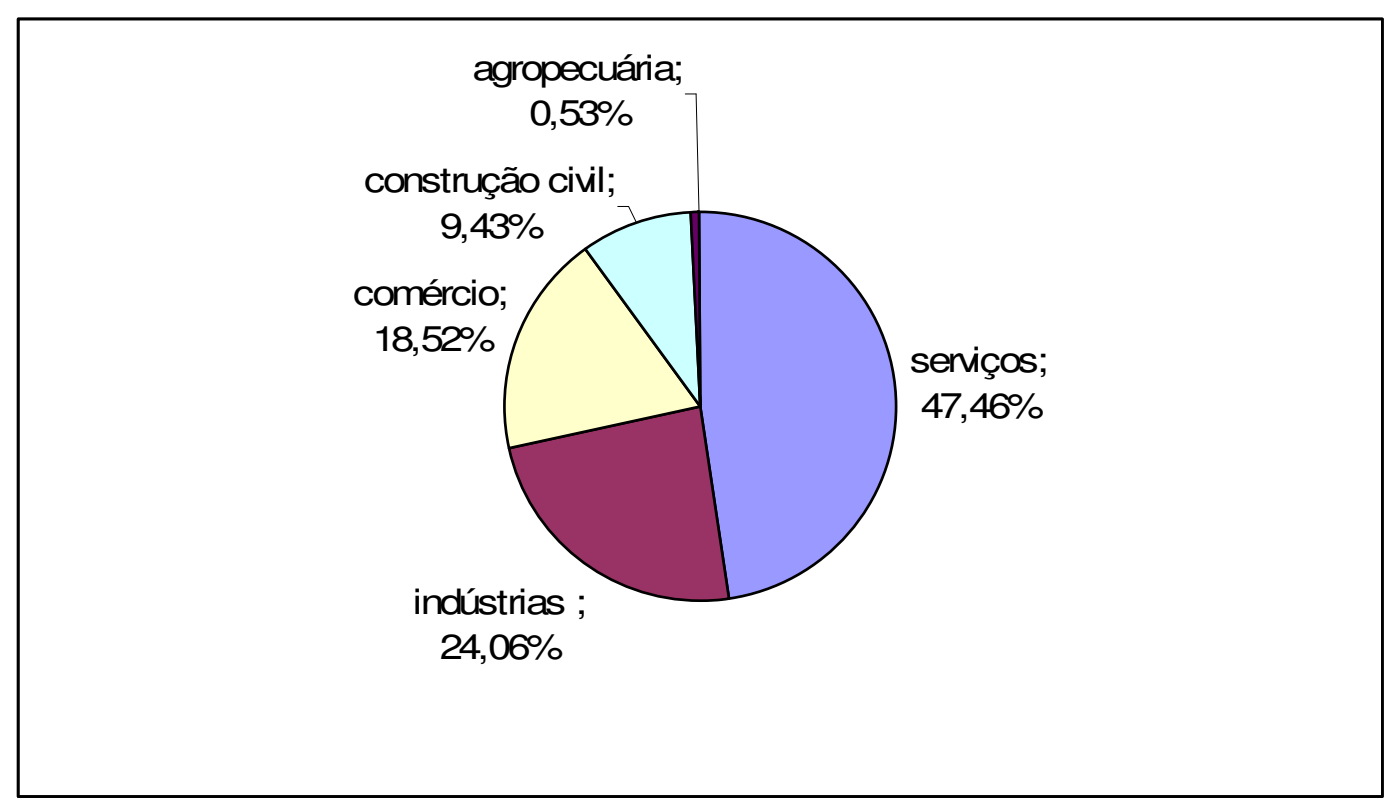

Figura 6 - Pessoas empregadas por setor de serviços.

Fonte: SEADE (2009). 
A Figura 6 mostra o gráfico com a taxa geométrica de crescimento anual da população. O maior crescimento foi entre as décadas de 1940 e 1980; a partir daí, a taxa de crescimento diminui o seu ritmo, porém a população continua crescendo, sendo que a taxa de crescimento em 1991/2000 foi de 2,23\% e em 2000/2010 foi de 1,79\%, sendo a maior da região de governo $(1,60 \%)$ e maior que a média do Estado (1,32\%). O índice de desenvolvimento humano é 0,849 superior à média do Estado, que é de 0,814, o que o deixa em $11^{\circ}$ lugar no ranking dos municípios paulistas. A renda per capita do município é uma das maiores do Estado. O município apresenta uma das maiores densidades demográficas 584,58 (habitantes $/ \mathrm{km}^{2}$ ), sendo que na região de governo, a média é de 260,96, e no Estado, de 169,76. O município passou por um processo de urbanização acelerado, sendo que o grau de urbanização é de 98,98 \% (SEADE, 2010).

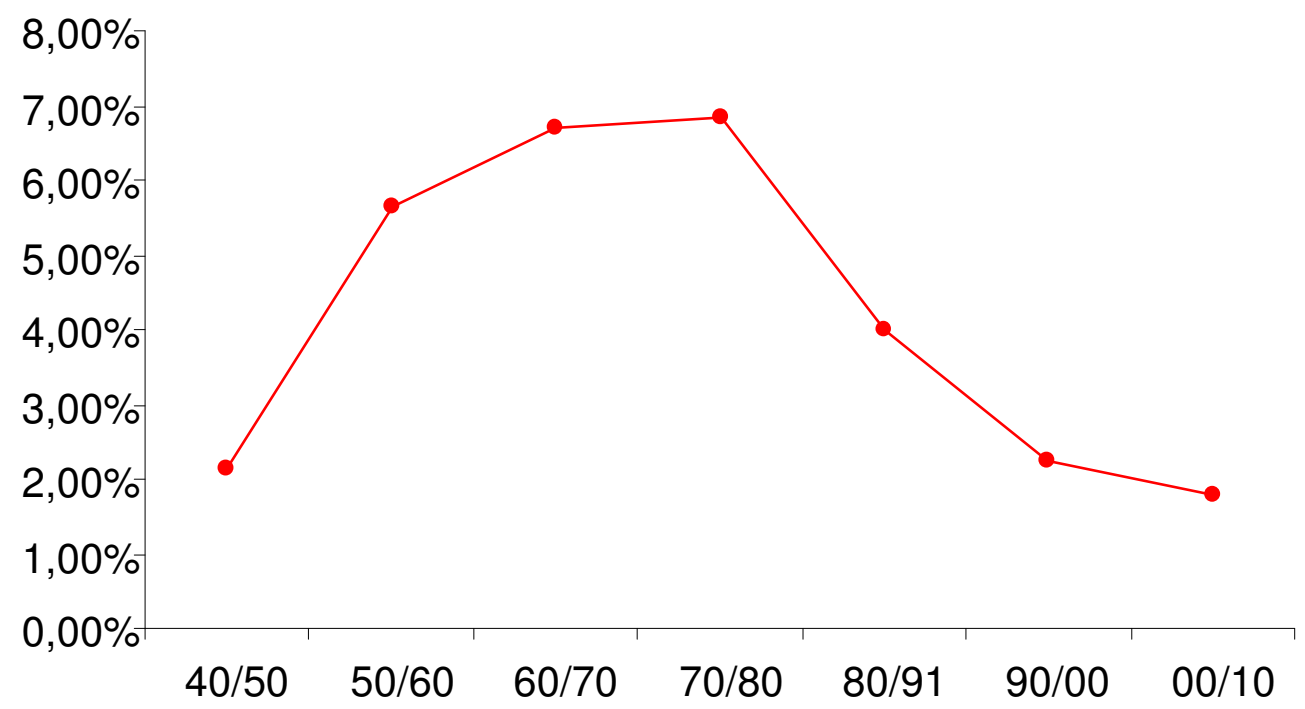

Figura 7 - Taxa geométrica de crescimento anual da população.

Fonte: SEADE, 2009.

Nota-se através desses dados que o município passou por um acelerado crescimento populacional, principalmente nas décadas de 1950 a 1980, e elevado grau de urbanização. Embora nas últimas décadas o ritmo de crescimento tenha diminuído, a cidade apresenta alta taxa de crescimento se comparada a outras cidades do Estado de São Paulo.

O crescimento populacional foi acompanhado pela expansão da área urbana do município, como mostra a Figura 8. De 1953 para 1962, aproximadamente 10 anos, a cidade cresceu 250\%, de 1962 a 1973, cresceu 77,5\%, de 1973 a 1985 cresceu 121,2\%, de 1985 a 1997 cresceu 44,4\%. A Figura 8, a seguir, retrata esse rápido crescimento do município. 


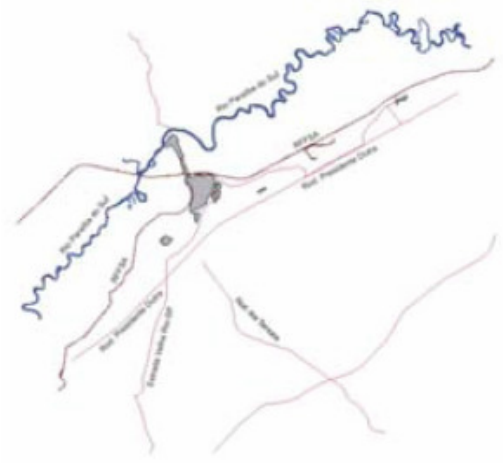

$1953-2,8 \mathrm{~km}^{2}$

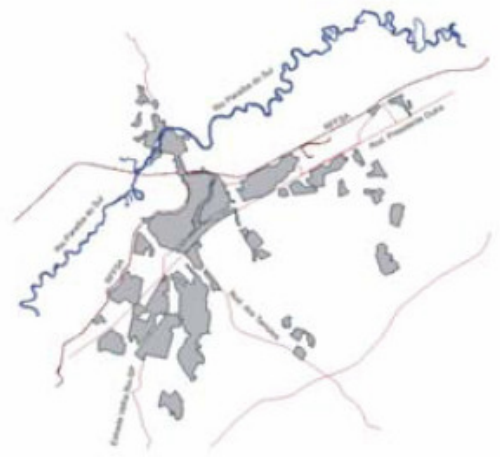

$1985-38,5 \mathrm{~km}^{2}$

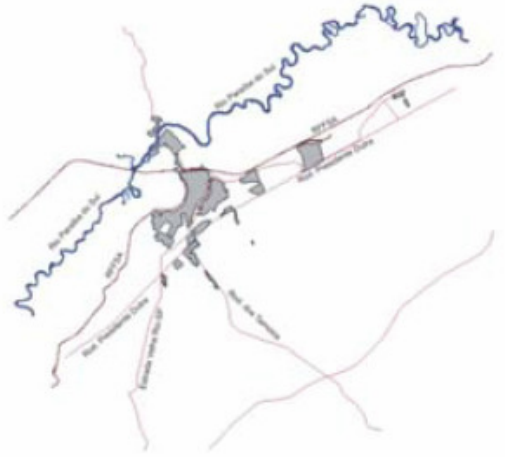

$1962-9,8 \mathrm{~km}^{2}$

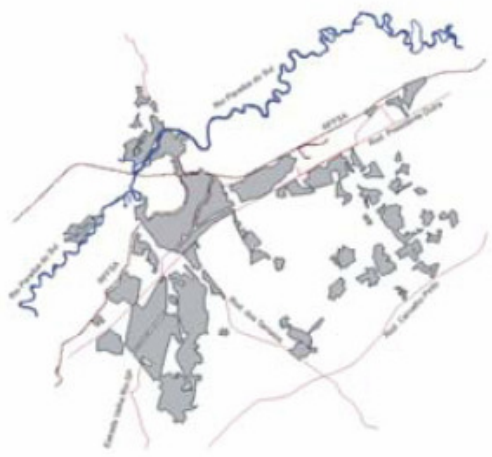

$1997-55,6 \mathrm{~km}^{2}$

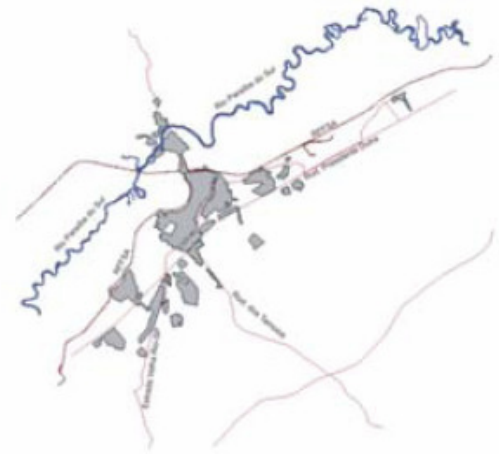

$1973-17,4 \mathrm{~km}^{2}$

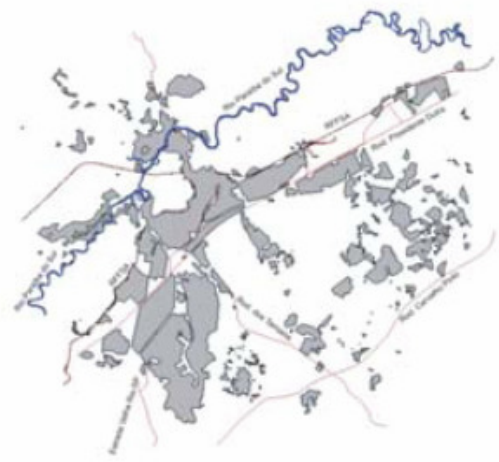

$2000-65,6 \mathrm{~km}^{2}$

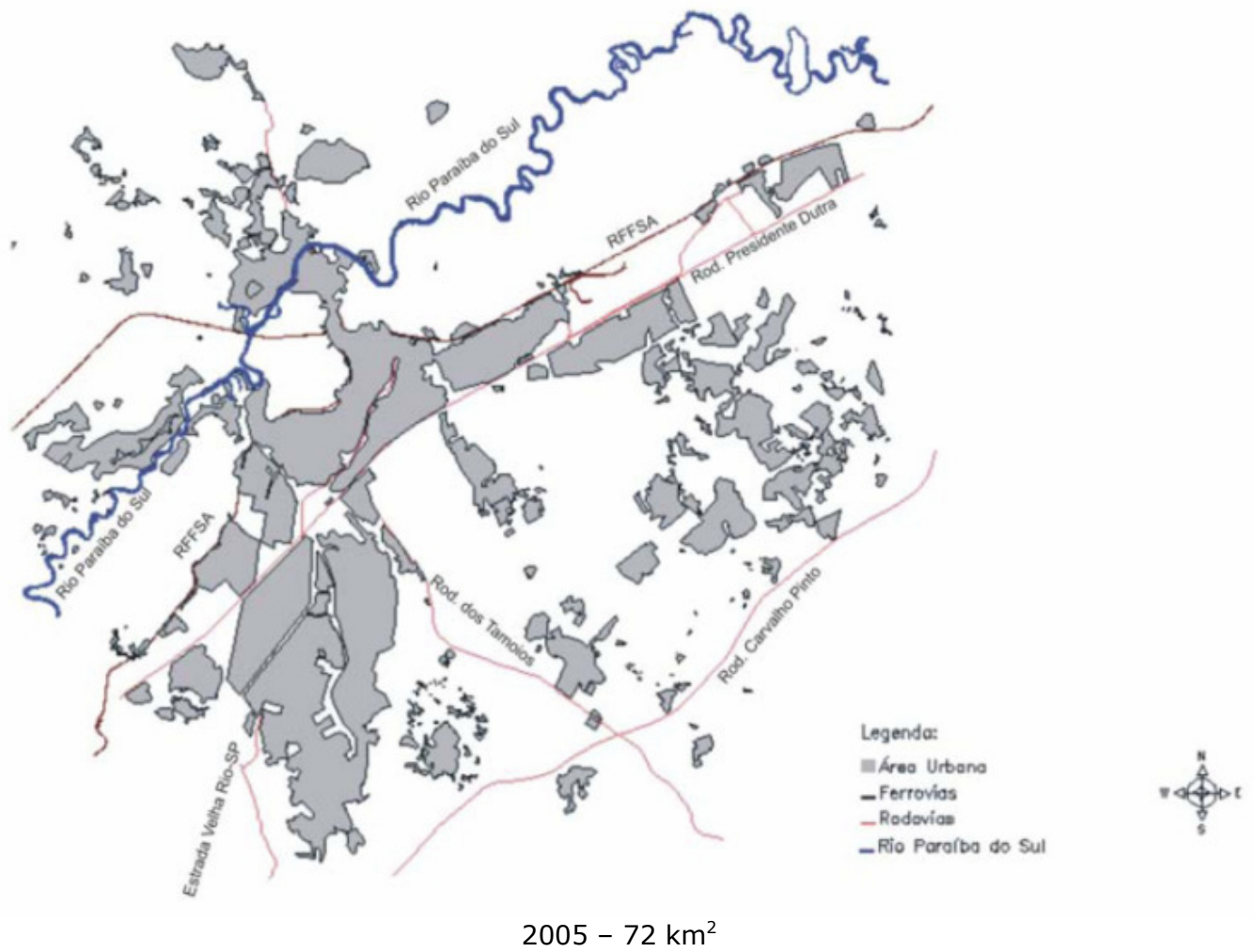

Figura 8 - Evolução da expansão urbana em São José dos Campos.

Fonte: Souza (2008, p. 46). 
Face ao desenvolvimento tecnológico e econômico existente na cidade de São José dos Campos, bem como ao acelerado crescimento populacional e expansão urbana, torna-se importante estudar práticas de planejamento urbano que visem a um melhor ordenamento do espaço urbano, bem como à manutenção do equilíbrio ambiental, produzindo assim um ambiente saudável para a sociedade.

\subsection{Da cidade sanatorial à cidade industrial e polo tecnológico}

Quando se pensa no Vale do Paraíba, logo se lembra do café e da sua decadência. O café no Vale do Paraíba chegou a representar a $88 \%$ da produção nacional em meados do século XIX, porém já no final do século, apresentava um decréscimo em relação a região oeste do estado; em 1920, sua produção representava apenas 4\% da produção nacional, e a região foi descrita com propriedade por Monteiro Lobato como "cidades mortas" (LESSA, 2008).

Porém, hoje essa situação já faz parte do passado. A Rodovia Presidente Dutra (BR116), que corta o Vale do Paraíba, é cercada de aglomerações urbanas, compondo uma rede de cidades vivas, com grande fluxo de pessoas, mercadorias e capital, com alta concentração de indústrias, comércio e serviços.

De acordo com as considerações de Lessa (2008), São José dos Campos não tem o seu desenvolvimento e o seu crescimento como consequência do café. Houve um período vazio entre o café e a industrialização da cidade, o que levou São José a se tornar o polo regional que é hoje foi a fase sanatorial que a cidade viveu.

Desta forma, a história do Vale do Paraíba está relacionada à expansão do café, o que trouxe riquezas para a região. Porém, o despontamento da cidade de São José dos Campos ocorreu mais tarde, com a cidade sanatorial que atuou fortemente no setor terciário, através da instalação de serviços variados para atendimento dos doentes com tuberculose, ganhando espaço para o planejamento urbano e políticas públicas.

Cano (1998) aponta que a Estrada de Ferro Central do Brasil, inaugurada em 1876, ligando o Rio de Janeiro, então capital do país, a São Paulo, com o objetivo de comercialização do café, acabou tendo outro uso, já que o café estava em decadência na região, esta serviu para fortalecer o comércio na região, e mais tarde, possibilitou a vinda de doentes de tuberculose.

Desta forma, São José dos Campos acabou se desenvolvendo primeiramente na atividade econômica ligada à área da saúde, que trouxe grandes benefícios e retorno ao 
município nesse momento, que foi a chamada fase sanatorial, onde pessoas vindas da capital e outras regiões procuravam a cidade para o tratamento da tuberculose ${ }^{9}$.

Os primeiros sanatórios da cidade tiveram financiamento da Câmara Municipal de São José dos Campos, que comprou uma chácara de 488.000 m2; da Câmara Municipal de São Paulo, que subsidiou a construção do sanatório Vicentina Aranha (Figura 9); do Governo Federal e de fundos beneficentes angariados pela elite paulistana (CARVALHO, 2009).

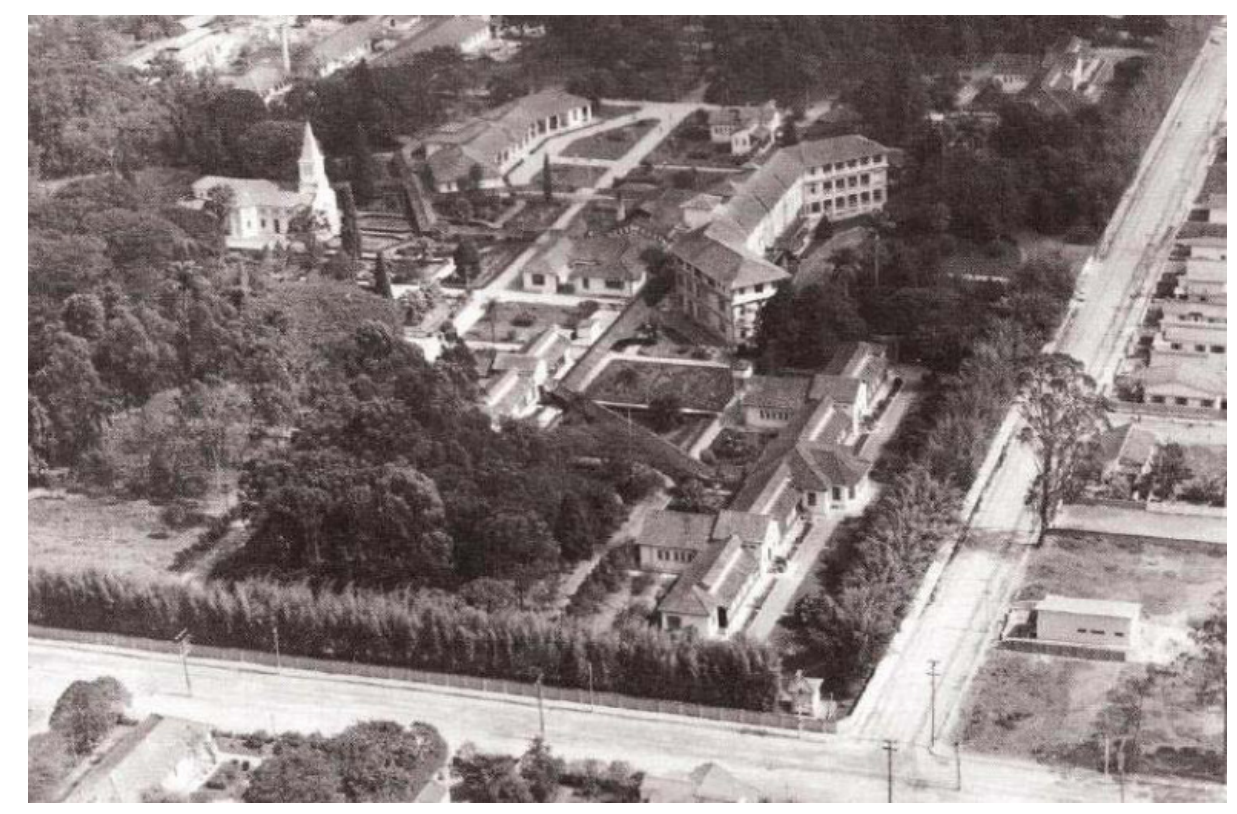

Figura 9 - Sanatório Vicentina Aranha

Fonte: Bittencourt, 1998 (apud CARVALHO, 2009, p. 63)

Assim, nesse momento, São José dos Campos, passa a receber os doentes da capital paulista e seus familiares ${ }^{10}$ e a receber verbas do governo municipal, e principalmente, do governo do estado, para investimentos na área de saúde e em melhorias urbanas, o que levou a cidade se desenvolver positivamente do aspecto urbanístico, com ruas largas e arborizadas.

Em 1935, o município passou a ser considerado Estância Climatérica e Estância Hidromineral (Decreto Estadual n. 7.007/35 e Lei Orgânica do Município n. 2.848/35), devido a sua posição geográfica, que lhe garantiram condições climáticas e relevo

\footnotetext{
${ }^{9}$ Na década de 1890 a febre amarela foi a doença que mais matou no estado de São Paulo, 36,5\% dos óbitos eram pela doença. A partir de 1898 a tuberculose tornou-se a doença de maior peso individual entre as verificadas no estado de São Paulo (SOUSA; SOARES, 2002).

10 "Neste período, o interesse do Estado era o de dispersar da capital paulista, principal centro urbano-industrial do país, o excedente de tuberculosos da cidade de São Paulo que, nesta época, vivia um momento de concentração de mão-de-obra e unidades produtivas. Assim, o papel de São José dos Campos foi o de acolher doentes que representavam risco à Metrópole, transformando-se em cidade sanatorial" (CARVALHO, 2009, p.63)
} 
privilegiado. Segundo Lessa (2008, p. 130), “o Decreto 7.007 de 13 de março de 1935 criou a Estância de São José dos Campos, nos termos do Decreto 6.501/34 que disciplinava as estâncias hidrominerais. A cidade não somente passou por um processo de regulamentação da ocupação do solo estabelecendo o zoneamento, como também recebeu dinheiro do Estado".

São José passou a ser a cidade de maior receita do Vale do Paraíba, pois além das receitas municipais, recebia também verba do Estado. Assim, a contemplação de São José dos Campos como Estância Climatérica e Hidromineral foi de grande vantagem para o município, que recebeu maiores investimentos e possibilitou o seu melhor desenvolvimento.

Como mostra a Figura 10, houve expansão no número de sanatórios, hotéis, pensões e no número de moradias, pois os doentes na maioria das vezes não vinham sozinhos, eram acompanhados de parentes e recebiam visitas, o que fortaleceu o setor terciário, através da instalação de serviços variados para atendimento dos doentes e de seus acompanhantes.

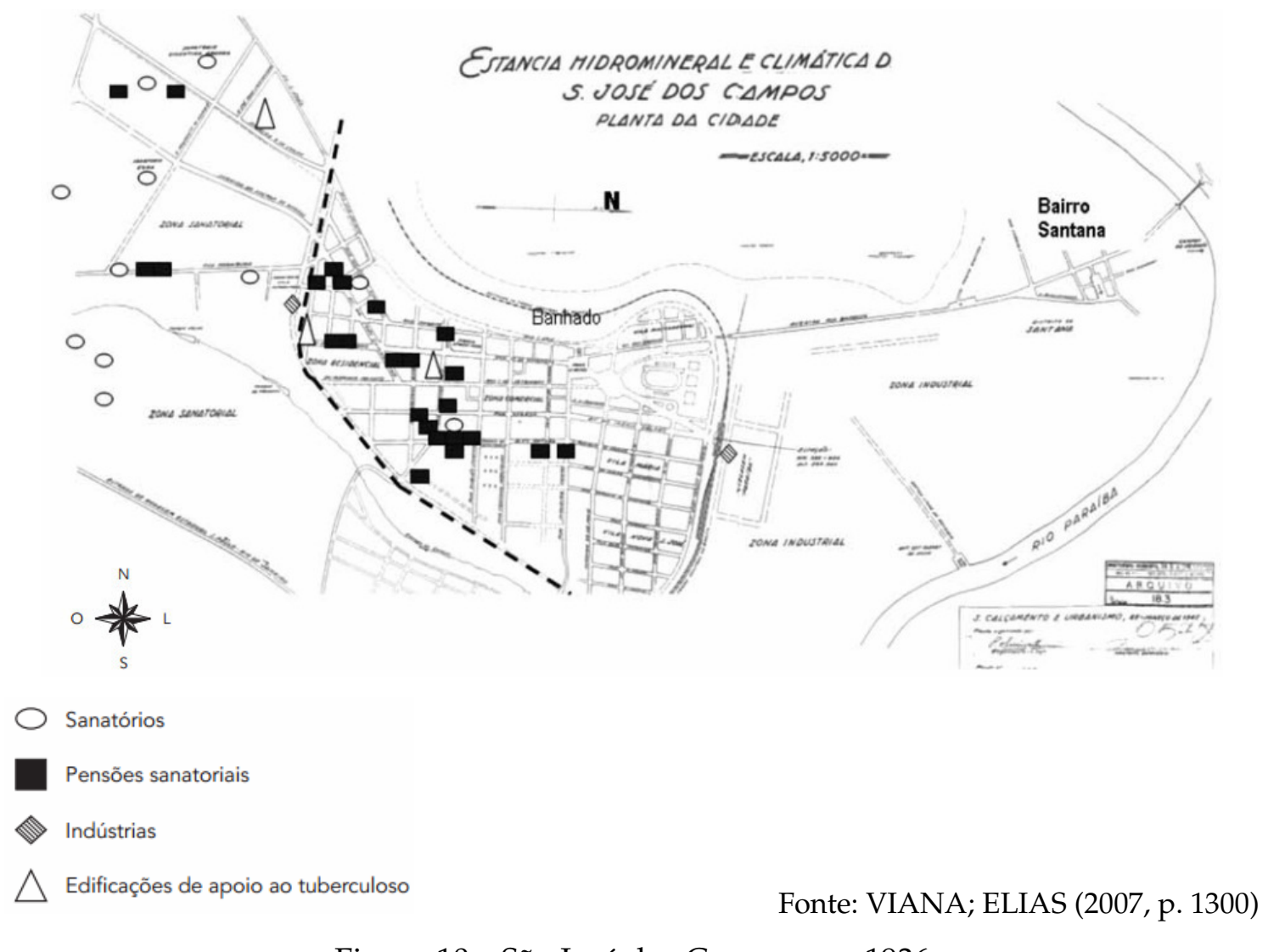

Figura 10 - São José dos Campos em 1936

Nesse período, houve um rápido crescimento da cidade, a todo o momento chegavam novos doentes acompanhados de familiares, o que levou a necessidade de uma normalização do espaço e das condutas em relação à doença e ao doente. Como aponta Lessa (2008, p. 128), 
"A presença dos alojamentos de doentes em áreas de uso residencial e comercial, destinados a receber os tuberculosos, levou a uma política de zoneamento da cidade".

A cidade passou a receber melhorias urbanísticas, como ruas mais largas, arborizadas, praças, jardins e saneamento básico, buscando transmitir um ambiente agradável, fortalecendo os bons ares e a paisagem urbana, em atenção ao momento sanatorial.

No entanto, os grandes investimentos realizados na cidade sanatorial propiciaram o melhor desenvolvimento da cidade industrial. O Estado fez uma grande intervenção no município, transformou a sua forma urbana e configuração social, e inseriu a região num novo lugar na divisão social e territorial do trabalho, e também, no processo de descentralização dos problemas urbanos da capital paulista.

Não se sabe ao certo quando começou e quanto terminou a fase sanatorial, mas registros e diversas pesquisas apontam que o início foi na década de 1920, e seu fim foi gradativo, a medida que a cidade se industrializava cada vez mais, os sanatórios foram desaparecendo. Por meio de pesquisa no Arquivo Público Municipal, no Jornal "Correio Joseense" ${ }^{11}$, observamos um grande número de propagandas de pensões e sanatórios para tuberculosos, sendo que em 17 de março de 1957, o jornal traz uma reportagem sobre a "Cidade Contaminada", mostrando que a fase sanatorial se estendeu por um longo período. A partir de 1958, praticamente não há mais notícias sobre os sanatórios no referido Jornal.

De acordo com Lessa (2008), "sobre a estrutura da cidade sanatorial e seus conflitos, outros projetos estatais se sobrepunham. A industrialização e a ação planejadora do estado passaram a agir sobre a cidade e a região com grande intensidade a partir do Estado Novo" (LESSA, 2008, p. 130).

Nesse período da cidade sanatorial, a cidade industrial marca o crescimento populacional na região.

São José dos Campos se adiantou ao processo de industrialização do país, e já em 1920, a Câmara Municipal baixou a resolução $n^{\circ}$ 4, em 18 de maio, que dava isenção fiscal por 25 anos para as indústrias que se instalassem na região, que tivessem um capital mínimo de 50 Contos de Réis e gerassem mais de 100 empregos (CARVALHO, 2009).

Assim, logo nesse período, duas grandes indústrias se instalaram na região, a primeira foi em 1921, a "Fábrica de Louças Santo Eugênio", com uma área de 9.000m². Logo em seguida, no ano de 1925, se instalou na cidade a fábrica "Tecelagem Parahyba", produzindo inicialmente brim, e depois, cobertores. A alta produtividade de cobertores e mantas fez com

\footnotetext{
${ }^{11}$ Foi realizada pesquisa junto ao Arquivo Público Municipal de São José dos Campos, no Jornal Correio Joseense no período de 1935 a 1967, porém nem todas as publicações foram arquivadas, somente parte do jornal foi analisada. A "última" noticia sobre os sanatórios em São José dos Campos, arquivada neste jornal, é de 1957.
} 
que a Tecelagem Parahyba liderasse o mercado nacional, e na década de 1970, já exportava para países como Canadá e Estados Unidos (SOUZA, 2008).

No período de 1930 a 1945, São José passa por muitas modificações e um processo de aparelhamento dos equipamentos urbanos e infraestrutura para a industrialização da cidade.

A cidade passou por um segundo período de industrialização, com forte intervenção do Estado, onde houve um grande aumento no número de indústrias na região, tendo como marco a instalação do Centro Técnico Aeronáutica - CTA, em 1948, e a Rodovia Presidente Dutra (BR-116) em 1951. Estes dois eventos marcaram a cidade e a colocaram entre as grandes cidades brasileiras. A partir desse momento o crescimento populacional em São José dos Campos desponta no Estado de São Paulo; os investimentos feitos pelo governo federal e estadual, a reestruturação econômica produtiva e descentralização industrial da metrópole paulista levam ao acelerado crescimento e desenvolvimento do município de São José dos Campos.

Como coloca Lessa (2008, p. 118),

A história de São José dos Campos, hoje no coração de uma das áreas mais industrializadas e urbanizadas do país, nos traz uma outra narrativa na qual os agentes principais das transformações urbanas e regionais são o Estado, o capital nacional e internacional, atuando por meio do uso do instrumental do Planejamento Territorial.

O estado de São Paulo se destaca em relação à industrialização do país. A produção cafeeira por muito tempo foi a principal atividade econômica do estado, gerando investimento em infraestrutura no setor ferroviário, comercial e bancário e em indústrias vinculadas ao desenvolvimento da economia cafeeira. Conforme Cano (1998, p. 137), "nos períodos de alta produtividade e de intensa comercialização do café, dá-se a transferência de parte dos lucros da 'atividade nuclear para a indústria', isto é, o capital cafeeiro transforma-se também em capital industrial".

Com a crise do café, a industrialização do estado começa a se fortalecer cada vez mais, principalmente na capital paulista. A partir de 1950, a concentração industrial da Grande São Paulo começa a se dispersar, atingindo um raio de $100 \mathrm{~km}$ da metrópole até os municípios de Campinas, Sorocaba e São José dos Campos (LENCIONI, 1998).

O panorama econômico nacional juntamente com a intervenção do Estado impulsionou a industrialização da cidade. O governo municipal, através da promulgação de 
diversas leis ${ }^{12}$ de incentivos fiscais, buscou atrair indústrias, dando preferência àquelas que trouxessem grande número de empregos e maior valor investido, ocasionando a acelerada industrialização da cidade. São José dos Campos, em 1960, já ocupava o $9^{\circ}$ lugar em industrialização entre os municípios do Estado de São Paulo (LESSA, 2001), tornando-se a principal cidade do Vale do Paraíba, posição ocupada anteriormente por Taubaté (SOUZA, 2008).

Nesse período, conforme o censo industrial, o município contava com 72 indústrias ${ }^{13}$. Foram várias as indústrias de grande porte que se instalaram no município: Companhia Rhodosá de Rayon, a Rhodia, primeira indústria transnacional instalada na cidade (1946); Johnson \& Johnson S.A. (1954); Ericsson do Brasil Ltda. (1954); Tecelagem Kanebo do Brasil S.A. (1956); General Motors do Brasil (1957); Eaton Corporation do Brasil (1957); Alpargatas S.A. (1959); Indústrias Reunidas Matarazzo (1962); Kodak Brasileira (1969), entre outras. Na década de 1960, também ocorre a duplicação da Rodovia Presidente Dutra (BR-116) e a instalação de várias indústrias do setor aeroespacial, em destaque a Empresa Brasileira de Aeronáutica S.A. - Embraer (1969) ${ }^{14}$.

Com a instalação da Embraer, começa a se configurar no município um Arranjo Produtivo Local cujo núcleo era formado pelo CTA, pelo INPE e pela Embraer, que promovia ensino, pesquisa e desenvolvimento tecnológico. Este processo levou ao surgimento de várias pequenas e médias empresas ligadas a este setor na região e em outras localidades do país (CARVALHO, 2009).

A fim de tornar São José dos Campos um polo industrial e tecnológico, em 1971, uma série de leis ${ }^{15}$ e instrumentos de política urbana se volta para o setor industrial, nesse mesmo ano, é inaugurado o Parque Santos Dumont no local onde era o Sanatório Ezra, pondo fim à fase sanatorial. Em 1977, o município perde o título de Estância Climática, vemos uma mudança no uso do meio, antes a cidade era bem vista pelos seus bons ares e suas

\footnotetext{
${ }^{12}$ Lei n. 155 de 14/04/1952; Lei n.243 de 02/09/1953; Lei n. 581 de 16/12/1958. Ttodas essas leis municipais tratam de incentivos fiscais para atração de industrias, visando ao aumento no número de empregos e valor investido em São José dos Campos.

${ }^{13}$ A maioria das empresas que se instalaram no município nas décadas de 1950 e 1960 ocupou as margens da Rodovia Presidente Dutra (BR-116).

${ }_{14} \mathrm{O}$ alta concentração de indústrias, tecnologias e centros de pesquisa propiciam o desenvolvimento aeronáutico na região, como coloca Souza (2008), "as atividades de pesquisa e de inovação tecnológica desenvolvidas pelos institutos do CTA e pelo INPE envolveram pesquisadores, cientistas, professores e técnicos de várias regiões do país e do mundo, com repercussão para o desenvolvimento do setor aeroespacial no município. Dos laboratórios do ITA e das atividades dos seus professores e alunos, surgiu o primeiro protótipo do avião Bandeirante, cuja produção, iniciada em 1969, deu origem à Empresa Brasileira de Aeronáutica, a Embraer (SOUZA, 2008, p. 49).

${ }^{15}$ Lei Municipal no. 1.533 de 06/02/1970 e Lei Municipal no. 2.102 de 13/11/1970. A primeira trata da isenção do pagamento dos Impostos Predial, Territorial Urbano e sobre Serviços de Qualquer Natureza pelo prazo de dez anos, e a segunda trata da isenção em favor das indústrias ligadas às atividades aeroespaciais, gerando ICM em benefício de São José dos Campos, incentivos fiscais e patrimoniais (CARVALHO, 2009).
} 
características físicas, porém, passa-se a valorizar o ambiente construído, o desenvolvimento tecnológico e industrial.

Assim, na década de 1970, foi registrada no município, a existência de 284 estabelecimentos industriais, representando um crescimento de $395 \%$ no número de indústrias em relação à década anterior. Dentre as indústrias instaladas nesse período, destacam-se: Panasonic do Brasil Ltda. (1970); Hitachi Ar Condicionado do Brasil Ltda. (1972); Phillips do Brasil Ltda. (1974); Monsanto (1974), entre outras (SOUZA, 2008).

Na década de 1970, foi elaborado o segundo Plano Diretor de Desenvolvimento Integrado de São José dos Campos, coordenado pelo arquiteto Jorge Wilhem. Tal lei ressalta a importância do desenvolvimento econômico e incremento da produção no setor industrial, e também, a necessidade de reforçar a imagem da cidade como polo regional do Vale do Paraíba (COSTA, 2007).

Na década de 1980, foi instalada no município a estatal Refinaria Henrique Lage REVAP, da Petrobras (Figura 11), dentro das metas previstas pelo II Plano Nacional de Desenvolvimento (II PND), que visava suprir a demanda dos estados de São Paulo, Mato Grosso do Sul e partes dos estados de Minas Gerais e Paraná, em relação aos derivados de petróleo. A instalação da refinaria consolidou a região como importante polo químico e petroquímico integrado.

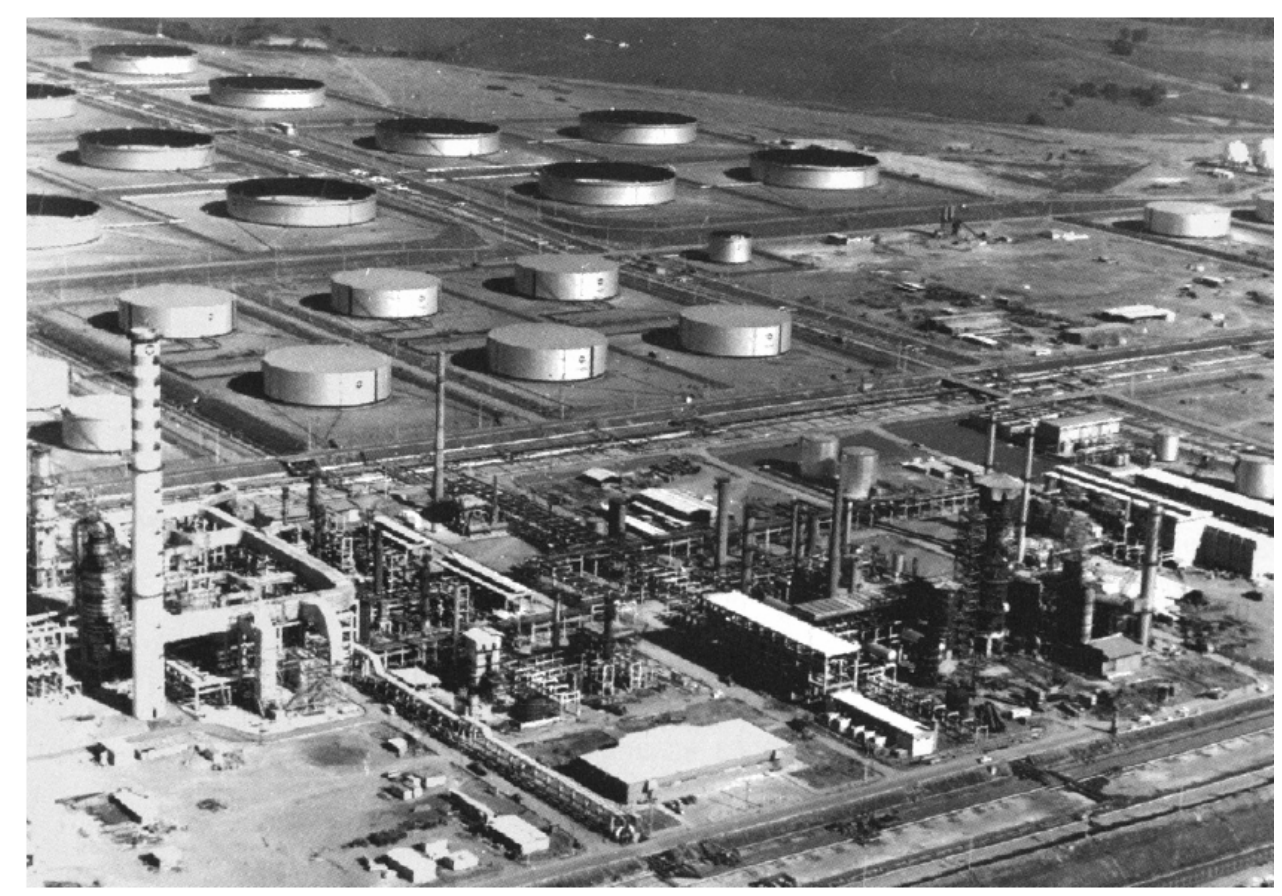

Figura 11 - Vista aérea da Refinaria Henrique Lage - Década de 1980.

Fonte: Regato e Assaz (apud SOUZA, 2008). 
Todo esse crescimento industrial que ocorreu de forma intensa entre as décadas de 1950-1990 levou, também, a um acelerado crescimento populacional, como se pode notar na Tabela 1.

Tabela 1- População de São José dos Campos de 1940 -2010

\begin{tabular}{c|ccc}
\hline Ano & População total & População urbana & População rural \\
\hline 1940 & 36.279 & 14.474 & 21.805 \\
1950 & 44.804 & 26.600 & 18.204 \\
1960 & 77.533 & 56.882 & 20.651 \\
1970 & 148.332 & 132.482 & 15.850 \\
1980 & 287.513 & 276.901 & 10.612 \\
1991 & 442.370 & 425.515 & 16.855 \\
2000 & 539.313 & 532.717 & 6.596 \\
\hline 2010 & 627.544 & 615.610 & 11.934 \\
\hline
\end{tabular}

Fonte: IBGE, 2010

No final da década de 1980 e início da década de 1990, a região passou por uma recessão, relacionada à crise fiscal do Estado, à desmobilização do investimento privado e à redução de investimentos públicos. O fato levou à redução no número de empregos, à demissão em massa de trabalhadores, agravamento dos problemas sociais do município e à queda e consequente diminuição dos investimentos nos setores públicos e privados (PMSJC PDDI, 2006).

No entanto, apesar da crise, o município registrou 390 unidades fabris em 1980 e 454 em 1985, com o crescimento de $161 \%$ do número de instalações industriais de 1980 para 1990. A década de 1990 foi marcada pelo avanço tecnológico e pelo aumento do desemprego. Porém, como mostra o gráfico na Figura 12, o crescimento no número de indústrias é constante. Em meados da década de 1990, há uma retomada no processo de industrialização, e é alcançada a estabilidade econômica; novas empresas passam a se instalar no município (PMSJC - PDDI, 2006).

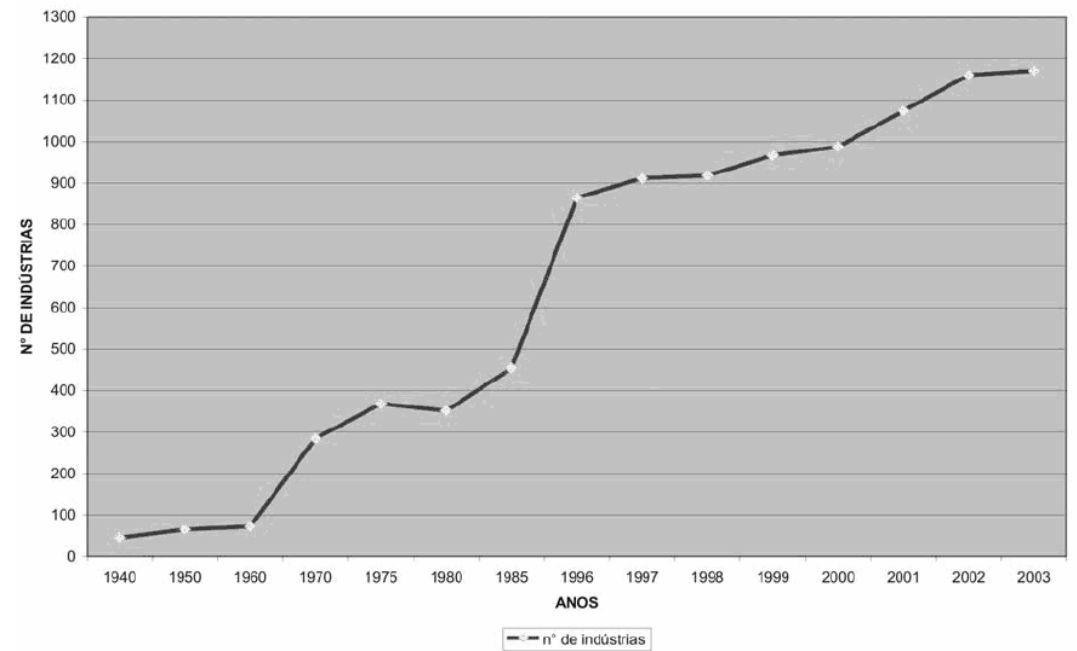

Figura 12 - Instalação de indústrias no município de São José (1940-2003). Fonte: SOUZA (2008). 
A cidade de São José dos Campos passou por uma trajetória de transformações, levando-a de cidade sem maior expressão na região do Vale do Paraíba do Sul a polo regional do estado de São Paulo e do Brasil. De acordo com Santos (1996, p. 10):

[...] São José dos Campos sempre foi uma cidade laboratório feita a partir de estímulos externos. Foi assim na primeira metade do século XX com a fase sanatorial. A cidade era um depósito dos balões de ensaio de instituições paulistanas como a Santa Casa de Misericórdia. Depois da implantação do CTA [Centro Tecnológico Aeroespacial], da Dutra, dos investimentos multinacionais e militares, São José dos Campos descaracteriza-se totalmente. É quando se processa a transformação da cidade-sanatório para a cidade-indústria bélica e multinacional, situação acentuada gradativamente ao longo da década de 60, acelerada em 70, mantendo o ritmo, em boa parte dos anos 80 .

Assim, de 1940 a 1990, o município de São José dos Campos passou de cidade sanatorial a cidade industrial, e a produtora e difusora de alta tecnologia aeroespacial. A presente configuração do município está relacionada ao processo de reestruturação produtiva vigente e com especial incidência em São Paulo. Trata-se de processo mais complexo, que envolve mudanças significativas na qualidade do processo produtivo, bem como na estrutura industrial como um todo. Podemos destacar em São José dos Campos a instalação do Centro Técnico de Aeronáutica (CTA), desde 2006, Comando-Geral de Tecnologia Aeroespacial; o Instituto Tecnológico de Aeronáutica (ITA) e o Instituto de Pesquisa e Desenvolvimento (IPD); à Implantação do Instituto Nacional de Pesquisas Espaciais (INPE), a criação da Empresa Brasileira de Aeronáutica S.A. (Embraer) e os investimentos no desenvolvimento de Ciência e Tecnologia (C\&T) e Pesquisa e Desenvolvimento (P\&D) realizados pelos setores públicos e privados. Por meio dessas instituições, o município estabelece interações com diversas localidades do país e com outros países da América, da Ásia, da Europa e da África (SOUZA, 2008).

O Instituo de Pesquisa Econômica Aplicada (IPEA, 2001), através de estudos recentes, compara São José dos Campos a Seatle nos Estados Unidos, e Toulouse, na França, no que trata o nível de projeção regional e internacional que possuem - em razão da especialização produtiva, também "polos aeronáuticos" -, e ao nível de influência que exercem sobre lugares localizados além dos limites de seus respectivos hinterlands.

O final da década de 1990 e início da década de 2000 é marcado pela transição econômica do município, como reflexo do próprio processo de globalização, com o forte desenvolvimento do setor terciário, onde comércio e serviço juntos transformam o município 
em centro regional de compras e serviços do Vale do Paraíba, Litoral Norte e Sul de Minas Gerais, compreendendo o atendimento a aproximadamente dois milhões de habitantes (PMSJC - PDDI, 2006).

\subsection{Organização do espaço e o planejamento urbano em São José dos Campos}

Podemos afirmar que o Planejamento Urbano no Brasil foi pouco desenvolvido, no entanto, São José dos Campos apresenta uma realidade diferente. Andando pela cidade podese ver as diversas formas de intervenção e atuação do Estado. A começar pela presença da Rodovia Federal Presidente Dutra, que atravessa a cidade, ligando as duas maiores cidades do Brasil: São Paulo e Rio de Janeiro, o Centro Tecnológico Aeroespacial (CTA), o Instituto Nacional de Pesquisas Espaciais (INPE), a EMBRAER, os antigos sanatórios, as ruas largas e arborizadas.

A história de São José dos Campos, hoje no centro de uma das áreas mais industrializadas e urbanizadas do país, mostra que os principais agentes das transformações urbanas e regionais são o Estado, o capital nacional e internacional atuando por meio do uso do instrumental do Planejamento Territorial (LESSA, 2001). Vê-se em São José dos Campos a forte presença da intervenção estatal.

A fase sanatorial que a cidade viveu teve grande influência no seu planejamento urbano. A elevação da cidade a Estância Climatérica trouxe recursos financeiros do Estado para o local; a cidade passou por um processo de embelezamento e higienização, com a abertura de avenidas largas, praças e arborização, e mais tarde, saneamento básico. A organização do espaço urbano de São José dos Campos passa por uma série de transformações, como coloca Gomes da Silva et al. (2009, p. 123):

\footnotetext{
Sem dúvida, foram o alinhamento e o alargamento das ruas que mais contribuíram para a transformação da paisagem urbana joseense. O mesmo se pode afirmar sobre $\mathrm{o}$ afastamento entre as laterais dos novos prédios e o alinhamento dos mesmos, que tiveram como parâmetro as idéias higienistas, para a limpeza e melhoria da circulação de ar das ruas e maior propagação dos raios de sol, e as idéias de modernidade, para o ordenamento e racionalização na produção e controle do espaço. Nas ruas recém-alargadas as novas construções de prédios deveriam estar adequadas aos novos padrões de arquitetura. ${ }^{16}$
}

\footnotetext{
16 As medidas urbanísticas eram discutidas na Câmara Municipal: "Na Avenida Marechal Floriano Peixoto, a colocação dos prédios deverá se distante do alinhamento vinte palmos, ficando uma área para ajardinamento (Ata da câmara, 15/03/1909, apud GOMES DA SILVA et al., 2009).
} 
A partir de 1942, a cidade passou a ter um traçado pautado pela continuidade espacial, com ruas amplas, ensolaradas, arborizadas e arejadas. Nesse período, foram aprovados os loteamentos Jardim Nova América, Jardim Europa e Jardim Esplanada I, baseados nos conceitos da Cidade-Jardim, de Ebenezer Howard (como mostra a Figura 13). Esses espaços privilegiados estavam incrustados na Zona Sanatorial, com ruas verdes e projeto paisagístico avançado, sendo habitado por população de alta renda (COSTA, 2007).

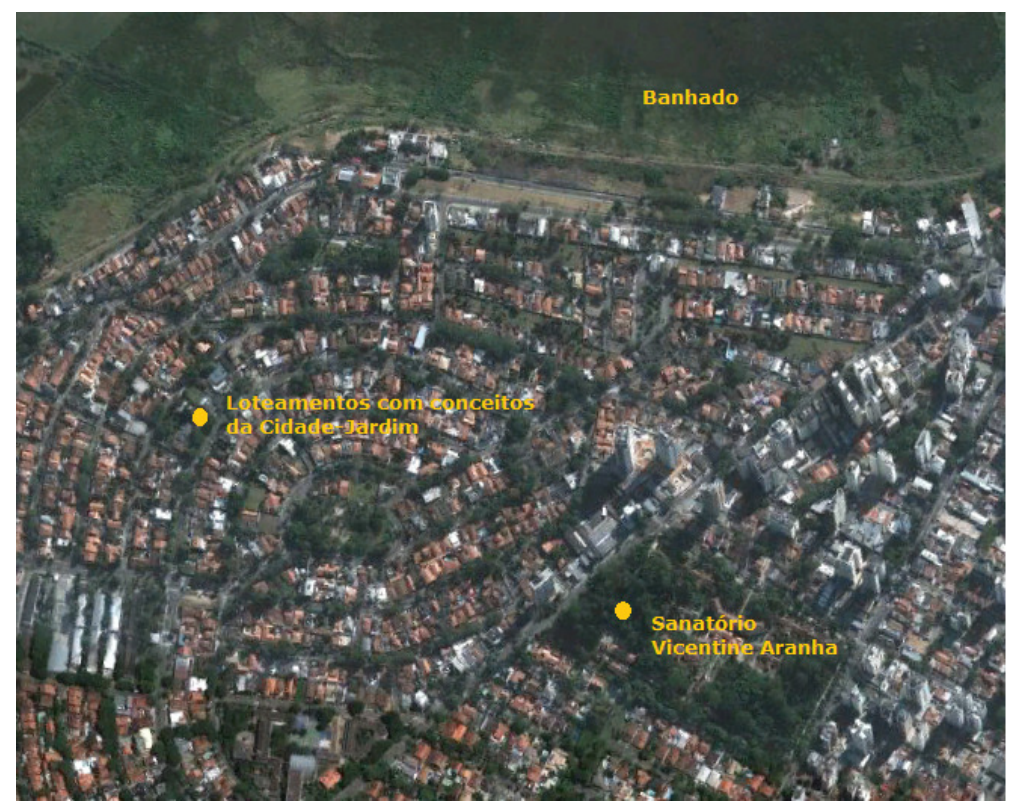

Figura 13 - Sanatório e Loteamentos em estilo "Cidade-Jardim"

Fonte: Google Earth, 2012.

A fase sanatorial foi benéfica urbanisticamente, levando a cidade a pensar na sua organização espacial e no seu planejamento. Os investimentos criados nessa fase possibilitaram o melhor desenvolvimento econômico do município. As benfeitorias criadas atraíram novos investimentos, e o governo passou a ter atuação cada vez mais forte na região.

Como coloca Vianna (2004, p. 180), “A cidade da década de 1920 abria suas portas para a modernização, representada pelas reformas urbanas e urbanísticas, pela regulação dos espaços e normalização dos comportamentos, pelas facilidades conferidas aos "capitalistas" que sensivelmente percebessem as vantagens do próspero município".

Assim, é no espaço sanatorial que vão se concentrar os investimentos públicos em infraestrutura, equipamentos e serviços, e que terá suas finalidades transformadas, bem como a área de moradia da população mais rica. É nesse espaço que ocorre a influência da especulação imobiliária, os sanatórios perdem lugar, e o crescimento da industrialização 
aponta uma nova realidade econômica, a área central, espaço dos sanatórios, dotada de infraestrutura passa a se valorizar cada vez mais.

O município em 1932 já possuía plano de zoneamento. Pelo Ato no. 110, a cidade era dividia em três zonas urbanas: a comercial, a sanatorial e a residencial (LESSA, 2008). A ratificação do plano em 1935 acrescentou a zona industrial, como pode-se ver na planta da cidade, na Figura 14.

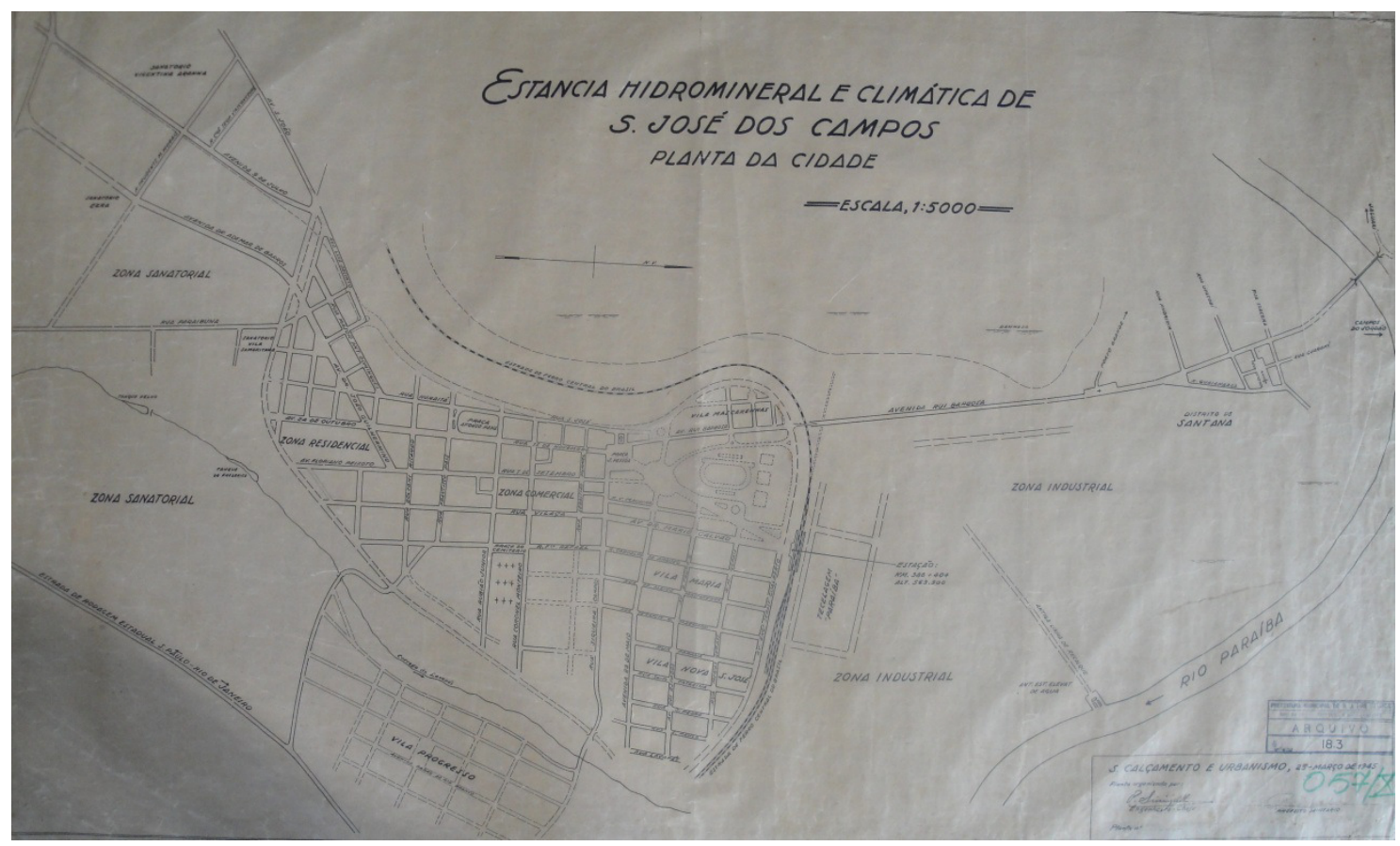

Figura 14 - Planta da cidade de São José dos Campos em 1936 Fonte: Arquivo Público Municipal (ARQ. 18.2 PMSJC)

Assim, nesse momento, houve uma grande transformação na forma urbana da cidade, sendo o zoneamento a primeira intervenção propriamente urbanística em São José dos Campos. A cidade foi separada em zonas que buscavam disciplinar a ocupação do espaço, as áreas destinadas aos doentes foram segregadas na periferia da cidade, porém muitos sanatórios ainda estavam na área central. Outro ponto de grande importância foi a intervenção na Avenida São José, que contorna a orla do platô voltada para o Banhado, o que possibilitou a abertura da vista para essa região, assim a rua suja e os velhos casarios, deram lugar a uma bela avenida com vista privilegiada. Ainda dentro das intervenções urbanísticas, tem-se o aumento das praças, alargamento das ruas, retificações de vias públicas, novas ruas, mudanças de nomes das ruas etc. (LESSA, 2008). 
A ação do Estado sempre esteve presente, de maneira bastante forte, no município de São José dos Campos. Na década de 1930, durante o período governado por Vargas, o Estado adotou uma política ditatorial e intervencionista, que buscava o "planejamento regional" e o controle estatal. Tal política era baseada no governo de Roosevelt: o New Deal, principalmente, o TVA - Tennessee Valley Authority. A bacia hidrográfica é adotada como referência territorial. O primeiro plano para o Vale do Paraíba partiu de uma lei em 1938, ainda na fase sanatorial, chamada Lei de Reerguimento do Vale do Paraíba.

Como afirma Costa (2007), o Estado Novo foi benéfico à Região do Vale do Paraíba. O presidente Vargas lançou vários programas para o desenvolvimento do país que beneficiaram a região. Em 1934, foi elaborado o Plano Geral de Viação Nacional, onde foi planejada a criação da Rodovia Presidente Dutra (BR-116), construída entre 1944 e1951, o que levou a rápida transformação industrial e configuração do espaço do Vale do Paraíba, sendo a Rodovia Presidente Dutra o principal caminho que liga São Paulo e Rio de Janeiro.

O Decreto $n^{\circ} 9.716$ assinado por Vargas, em 09 de novembro de 1938, previa uma série de investimentos e o reerguimento econômico para a região do Vale do Paraíba. O plano trazia incentivo a empreendimentos na área da agropecuária, indústria e comércio, através do cooperativismo e previa ainda a criação de estações experimentais e hortos florestais sob a responsabilidade do Instituto Agronômico de Campinas (IAC). O estudo realizado pelo devido Instituto trouxe como resultado e sugestões a ocupação rural das várzeas do Rio Paraíba do Sul com a plantação de hortifrutigranjeiros e o gado leiteiro em minifúndios para o abastecimento do mercado da capital e o melhor aproveitamento hídrico da região.

Analisando a política econômica do país, nesse período, tem-se a criação da Companhia Siderúrgica Nacional (CSN) em Volta Redonda, inaugurada em 1946, a Petrobras em 1953 e o Banco Nacional de Desenvolvimento Econômico (BNDE) em 1952. Em meados da década de 1950, tem-se a abertura do capital estrangeiro, efetivada pelo então presidente Juscelino Kubitschek (Plano de Metas), e assim, a isenção de impostos permitiu a importação de máquinas e equipamentos de grande porte e criou condições para a produção de bens de consumo duráveis, promovendo a vinda de indústrias automobilísticas para o país.

Conforme destaca Cano (1995), “A partir da década de 1930 o estado brasileiro foi se transformando num estado estruturante, preocupando-se com o desenvolvimento do progresso industrial e material do país, formulando políticas setoriais de industrialização, um inteligente manejo da política econômica e institucionalizando a organização dos mercados de trabalho" (Cano, 1995, p. 24). 
Desta forma, a transformação de São José dos Campos em polo tecnológico teve início no final da década de 1940, marcada pelo autoritarismo, durante dois períodos ditatoriais: o Estado Novo e a Ditadura Militar. Através do Ministério da Aeronáutica, criado em 1941, o governo brasileiro escolheu o município para a instalação de uma estrutura propícia à capacitação tecnológica e industrial do País para o setor aeronáutico.

Durante a ditadura Vargas, foram construídas a Rodovia Presidente Dutra (BR-116) e o CTA - Centro Técnico Aeroespacial, e o desenvolvimento do Plano do Reerguimento do Vale do Paraíba pelo IAC — Instituto Agronômico de Campinas. Na Ditadura Militar, foram desenvolvidos outros projetos para região, o CODIVAP - Consórcio de Desenvolvimento Integrado do Vale do Paraíba e o Macro- Eixo, período de maior crescimento da estrutura do CTA; instalação de transnacionais e da indústria bélica (LESSA, 2001, p. 4).

Os militares tiveram grande ação no desenvolvimento de São José dos Campos, com a instalação do CTA no final da década de 1940 e posteriormente com a indústria bélica. O CTA se configurou como o principal projeto aeronáutico do país, sendo planejado para atuar como núcleo de formação e produção especializada, tornou-se o embrião da indústria aeronáutica, bélica e aeroespacial brasileira, além de formar especialistas em mecânica, eletrônica e informática (LESSA, 2001). A criação do CTA, Rodovia Dutra e CSN, grandes projetos estatais, apontavam para a importância do papel do Estado brasileiro neste processo de transformação regional.

A crescente urbanização e industrialização do Brasil a partir da década de 1950 colocam novos agentes em cena; a ação militar passou a atuar cada vez mais nas instâncias de planejamento e políticas públicas que afetaram substancialmente a formação social, política e territorial de São José dos Campos.

A construção do CTA associado à Rodovia Dutra (BR-116) marcou uma grande transformação na configuração do espaço joseense, rompendo com a cidade sanatorial. A presença de técnicos militares na cidade levou a uma agitação e uma nova relação com o moderno. A arquitetura de Oscar Niemayer presente no CTA trouxe o modernismo à cidade.

A construção do CTA foi fundamental para a multiplicação das fábricas em São José dos Campos. Quando o CTA chega à cidade, existiam muitos sanatórios e apenas duas ou três fábricas, mas esse quadro passa a se modificar cada vez mais. Como afirma Bondesan (correspondente do Jornal o Estado de São Paulo), "sem o CTA não teríamos o nosso atual surto industrial, ou conseguiríamos a longo tempo e com maiores dificuldades. Sem a sua assistência, o seu pessoal altamente especializado, sua aparelhagem, tudo seria mais penoso" (BONDESAN, 1967, p. 182). 
A construção do Instituto Tecnológico Aeronáutico (ITA) em 1947, do Instituto Nacional de Pesquisas Espaciais (INPE) em 1961, e da EMBRAER em 1969, pelo governo federal, foram fundamentais para a formação de uma base intelectual e constituição do polo aeroespacial de São José dos Campos.

O período do governo militar representou a fase de maior crescimento do CTA. Entre 1948 e 1950, o crescimento foi de $11 \%$, de 1951 a 1960 foi de 8\%, e entre 1961 e 1980 foi de 64\% (LESSA, 2001). São José dos Campos passou a fazer parte do projeto de "Segurança Nacional", como importante centro industrial de produção bélico.

A organização do espaço passa por um novo rearranjo; o planejamento urbano gira em torno do Centro Tecnológico Aeroespacial, a cidade passa a fazer parte do processo de desconcentração industrial da metrópole de São Paulo, bem como do mercado internacional.

Neste sentido, pode-se perceber que a ação do Estado, principalmente no período militar, foi fundamental para o desenvolvimento de São José dos Campos; foram os investimentos estatais, através de ações planejadas, que favoreceram o processo de industrialização do município, de forma ordenada, seguindo princípios do urbanismo modernista.

Vê-se o desenvolvimento urbanístico da cidade, não somente nas suas novas ruas, avenidas e pontes, mas nos arrojados projetos arquitetônicos de casas e instalações fabris e comerciais. As avenidas que abrem o fundo do vale e as pontes e viadutos que o cortam são acompanhadas das casas de linhas retas, de concreto aparente, seguindo a linha de Niemayer para o projeto do CTA, incorporadas à paisagem, como havia observado Martins (apud VIANNA, 2004). Instalações comerciais, como um hipermercado que traduz o conceito moderno de compra e serviços reunidos no mesmo local (não por acaso, inaugurado à margem da via Dutra) seguem também este padrão visual e, além de representar o novo padrão de comportamento urbano, ao nomear a região onde se instalam, ratificam sua importância como símbolos da estrutura social e econômica que se modificara (VIANNA, 2004, p. 180).

$\mathrm{O}$ projeto de Niemayer, ganhador do concurso, mantinha uma ligação entre a área militar e a civil, através da Avenida Nelson D’Ávila, que liga o CTA ao centro da cidade. O CTA ganhou uma arquitetura diferenciada. A arquitetura moderna influenciou outros setores da cidade, casas e prédios e imprimiu aos conterrâneos a necessidade de modernidade; outros arquitetos de renome também passaram por São José, como Ícaro de Castro Mello, Rino Levi, Roberto Burle Marx etc. (LESSA, 2001).

São José dos Campos passou a fazer parte de um dos principais planejamentos regionais já desenvolvidos pelo Estado Nacional, dotando a região de infraestrutura, com base 
no desenvolvimento no setor militar aeronáutico, levando a cidade se caracterizar hoje como uma região produtiva ${ }^{17}$, com especialização no setor aeroespacial.

Como aponta Lessa (2001), o planejamento regional emergente nas décadas de 1930 e 1940, tomou como base o diagnóstico do meio físico, principalmente a partir do estudo das bacias hidrográficas, agregando os estudos sociológicos e econômicos. Mudou a abordagem feita ao conceito de meio, da perspectiva do sanitarismo, para o meio visto como meio geográfico território sob a ação do Homem. "Nessa mudança a preocupação não era mais com a ação do meio sobre o homem, mas do homem sobre o meio a partir do uso da técnica. Seu suporte é a geomorfologia, os elementos físicos do meio e as tecnologias apropriadas para manipulá-lo" (LESSA, 2001, P. 136).

É possível ver como o meio assume várias perspectivas. A cidade sanatorial atraía pelos seus bons ares, enquanto que a cidade industrial se fixa pela infraestrutura e benfeitorias dotadas na paisagem. Vê-se a substituição do meio natural e do meio técnico pelo meio técnico-científico-informacional. A evolução da técnica ${ }^{18}$ modifica as características do meio.

Como apontado por Milton Santos:

As atividades mais modernas, na cidade e no campo, passam a exigir adaptações do território, com a adição ao solo de acréscimos cada vez mais baseados nas formulações da ciência e na ajuda da técnica. O meio ambiente construído se diferencia pela carga maior ou menor de ciência, tecnologia e informação, segundo regiões e lugares: o artifício tende a se sobrepor e substituir a natureza (MILTON SANTOS, 1994, p. 73)

Desta maneira, São José dos Campos perde as características da fase sanatorial, bons ares, clima, sol, e ganha uma nova face, a da indústria, do desenvolvimento técnico, dos novos meios de produção.

\footnotetext{
${ }^{17}$ Como escreve Milton Santos: "O território é formado por frações funcionais diversas. Sua funcionalidade depende de demandas de vários níveis, desde o local até o mundial. A articulação entre diversas frações do território se opera exatamente através dos fluxos que são criados em função das atividades, da população e da herança espacial. [...] Mas é preciso não esquecer que a unidade espacial de trabalho é, aqui, o que se convencionou chamar de região produtiva. Defini-la, pois, vai exigir o reconhecimento das suas relações internas e externas mais importantes. [...] Na verdade, cada região produtiva se liga de forma maior ou menor a áreas externas do Estado. Os níveis e a intensidade dessa interação para dentro e para fora e cada Estado variam com o tempo. Pode-se dizer, também, que a cada momento histórico a definição das disparidades regionais muda. Esses dois princípios, o da mudança da natureza das disparidades regionais e o do tipo de relações, internas ou externas, mantidas pela região produtiva, constituem também um dos elementos complementares à compreensão da significação atual das redes de cidades, que, de uma maneira ou de outra, presidem às relações existentes. (SANTOS, 2008)

18 "A técnica é a grande banalidade e o grande enigma, e é como enigma que ela comanda nossa vida, nos impõe relações, modela nosso entorno, administra nossas relações com o entorno" (MILTON SANTOS, 1994, p.30).

"A base técnica da sociedade e do espaço constitui hoje um dado fundamental da explicação histórica, já que a técnica invadiu todos os aspectos da vida humana, em todos os lugares" (MILTON SANTOS, 1994, p. 67)
} 
A transformação de São José dos Campos em meio técnico-científico-informacional é evidente. Como aponta Vianna (2004), a cidade "não apenas participa da remodelação do território nacional- baseada na combinação de ciência, tecnologia e informação- como também, amparada pelo Estado, é polo difusor de inovação, possibilitando essa transformação. Articulando ciência e tecnologia, e utilizando ambos no setor produtivo, a fim de dinamizar a economia, a cidade de São José dos Campos se beneficiou da política instituída com o I Plano de Desenvolvimento Nacional do período ditatorial. A estratégia tecnológica visava fortalecer o poder de competição nacional em setores prioritários, com foco em áreas tecnológicas específicas. Seguindo essas diretrizes, a atuação do governo foi ordenada e acelerada; áreas tecnológicas prioritárias foram definidas e desenvolvidas (incluindo a pesquisa espacial); a infraestrutura tecnológica e a capacidade de inovação das empresas nacionais foram fortalecidas; a transferência de tecnologia foi acelerada e se promoveu a integração entre a indústria, a pesquisa e a Universidade, a partir da qual se estruturou um eixo de desenvolvimento centrado na educação, ciência e tecnologia ligada às empresas" (VIANNA, 2004, p. 155).

São José dos Campos se desenvolveu sob a disciplina sanitária e, a seguir, se estruturou sob uma organização de cunho militar. Essa hierarquização e sistemas de poder, as relações sociais e os interesses econômicos, geraram uma segregação do espaço urbano, como coloca Vianna, "encobrindo o que não pode ser revelado, a lógica econômica desenhou o território; sua apropriação, no entanto, se deu sob a ideologia de desenvolvimento, apaziguadora e disciplinadora, que encobriu as desigualdades que o constituíram e ainda o alimentam" (VIANNA, 2004, p. 180).

Todavia, tem-se que a ação do Estado é essencialmente política e econômica, os problemas sociais no município são ignorados, e as preocupações com o meio ambiente ficam em segundo plano.

O Primeiro Plano Diretor de São José, já na década de 1960, ressaltou diversos problemas apresentados pela cidade, como o excesso de verticalização, dificuldades na circulação, déficit de saneamento e o problema social das favelas, problemas estes que persistem até os dias atuais. As políticas públicas pouco fizeram, buscando solucionar tais problemas. A ação do Estado, sempre esteve pautada nos aspectos econômicos, estando distante das questões sociais.

Em um estudo do NEPO/Unicamp, realizado a pedido da Prefeitura de São José dos Campos em 2004, sobre as condições de vida da população joseense, pudemos observar a grande desigualdade social e segregação urbana no município. A maior parte da população 
joseense, 66\%, pertence às classes $\mathrm{C}$ e D. Consta ainda que, da população pertencente a classe A, 56\% vivem na região do Urbanova/Aquarius, mostrando a concentração da riqueza em apenas uma pequena parte do território. A pesquisa ainda mostra que $43 \%$, quase metade da população joseense, tem renda familiar mensal de 1 a 3 salários mínimos.

Segundo a PMSJC (2006), existem na cidade 11 núcleos de favelas, alguns bem antigos, como a Santa Cruz (Linha Velha) e o Banhado. O déficit habitacional é de 2.500 residências. São inúmeros os loteamentos clandestinos e irregulares espalhados no município, concentrando-se, principalmente na zona rural, ocupando áreas de proteção ambiental e mananciais, causando vários danos ao meio ambiente.

A cidade apresenta hoje inúmeros problemas ambientais, como córregos e rios poluídos, pior qualidade do ar, áreas de alagamento e ocupação ilegal, tanto de baixa renda como de alta renda, em áreas de proteção e preservação ambiental. Tais fatores, além de prejudicar o meio ambiente, trazem danos à qualidade de vida da população.

Nesse sentido, vê-se que o município de São José dos Campos passou por uma série de transformações no espaço urbano; a sua organização espacial sofreu grandes alterações como reflexo da produção do espaço, decorrente da plantação do café, da era sanatorial, da fase industrial, e do atual desenvolvimento tecnológico e informacional. Porém, em todas essas fases, o meio urbano apresentou problemas, e muitos deles não foram solucionados, persistindo até os dias atuais. Estes problemas se tornam maior no que trata do "meio ambiente natural".

Os problemas ambientais da atualidade remetem à importância de proteger a natureza e manter o equilíbrio ambiental no desenvolvimento das cidades, tornando-se importante inserir com maior atenção a dimensão ambiental no planejamento urbano. É fundamental que o planejamento urbano e as políticas públicas se efetivem, também, na esfera social e ambiental, pois estas são essenciais para que a cidade cresça em equilíbrio com o meio ambiente, aliado a uma melhor qualidade de vida de seus habitantes. O desenvolvimento do município deve estar apoiado em políticas socioambientais. 


\section{Legislação Urbanística e Ambiental em São José dos Campos}

Neste capítulo, será analisado a legislação urbanística e ambiental do município de São José dos Campos, através do estudo dos planos diretores, zoneamento urbano, leis ambientais e Lei Orgânica.

Para tanto, foi feito levantamento da legislação na Secretaria de Planejamento Urbano, Arquivo Público Municipal e Câmara dos Vereadores. Busca-se analisar a legislação existente, relacionada ao tema da pesquisa, no período de 1940 a 2010.

A legislação foi analisada com intuito de evidenciar as políticas públicas ambientais que se impõem ao município, e também, em relação às leis que direta ou indiretamente influenciam nos aspectos ambientais do município.

\subsection{Estudo dos Planos Diretores de São José dos Campos: 1960 - 2010}

Inicia-se está análise partindo do estudo dos Planos Diretores. O primeiro Plano Diretor de São José dos Campos foi desenvolvido entre 1958-1961. Desde então a cidade teve quatro planos diretores. Busca-se destacar quais os principais problemas levantados em cada plano e as medidas previstas para solucionar tais problemas, principalmente em relação aos aspectos ambientais. 


\subsubsection{O primeiro "Plano Diretor" - 1961}

Em 1957, o governo do estado de São Paulo, através do Decreto $\mathrm{n}^{\circ} 28.399$, passa a vincular as dotações orçamentárias aos municípios considerados Estâncias Hidrominerais à existência de um Plano Diretor.

Neste contexto, a então Estância Climatérica e Hidromineral de São José dos Campos foi uma das primeiras cidades do Brasil a possuir plano diretor. A cidade contava com investimentos do governo federal e estadual, sendo que no final da década de 1940 e início de 1950, ocorre a implantação de duas grandes obras: o CTA e a Rodovia Dutra. Neste período, se inicia uma acelerada urbanização do município, com um alto crescimento no número de indústrias de grande porte na cidade, levando a um crescimento espraiado da cidade. Conforme é destacado no relatório do plano preliminar:

Tornou-se evidente a necessidade de ordenar este crescimento, embora, muita coisa errada já estivesse concretizada; mas ainda era tempo para se colocar um ponto final nos abusos e tentar planejar o desenvolvimento municipal de forma a evitar que a cidade viesse a padecer dos males que as grandes metrópoles atuais padecem. Foi então que surgiu a idéia de se preparar um plano de desenvolvimento para o município (PLANO PRELIMINAR, 1961, p.7)

O plano preliminar foi redigido entre 1958 e 1961, sendo financiado pelo Governo Estadual. Desta forma, se estabeleceu convênio entre a Secretaria da Viação e Obras Públicas do Estado de São Paulo, o CPEU-FAU-USP e a Prefeitura. A secretaria do estado ficou com os encargos financeiros e o CPEU responsável pelo convênio e toda a orientação técnica para os trabalhos. O plano foi então elaborado pelo Centro de Pesquisa e Estudos Urbanísticos (CPEU), da Faculdade de Arquitetura e Urbanismo (FAU), da Universidade de São Paulo (USP), tendo como diretor Anhaia Mello, e como assistente, L. B. Birkhoz, dois renomados arquitetos, urbanistas e professores.

A prefeitura designou um arquiteto e formou duas comissões, uma com representantes técnicos da prefeitura municipal e outra com representantes de classes e instituições joseenses, sendo que esta última era formada por dez participantes com representantes de diferentes setores da sociedade: Lavoura e pecuária, Lions Club, Rotary Club, Comércio e Indústria, Comerciários, Magistérios, Classes liberais e Setores culturais. É possível observar que a elaboração do plano teve contribuição de diferentes agentes, técnicos e sociedade, porém apenas uma parcela da sociedade se fez representar nesse momento: a de maior poder econômico e influência social. 
O Plano foi dividido nas seguintes partes: - I Problemas do planejamento regional e rural: planejamento regional, criação de um consórcio entre prefeituras, caracterização das indústrias do Vale do Paraíba, planejamento rural. - II Áreas habitacionais: contenção da favela, fundo municipal de habitação, planejamento para as áreas habitacionais, mercados e feiras, rede escolar. - III Plano de circulação para São Jose dos Campos: tráfego de passagem, congestionamento na área central, pedestres, implantação. - IV Administração municipal. - V Zoneamento industrial. - VI Área central. - VII Saneamento. - VIII Legislação urbanística.

O Plano Preliminar traz a caracterização geral do município de São José dos Campos, levantando aspectos históricos, sociais, físicos e econômicos, mostrando em linhas gerais os pontos benéficos e os pontos críticos da cidade. É destacado o rápido crescimento urbano, que ocorre desordenadamente. As indústrias se instalaram sem nenhum critério lógico, prejudicando as condições de vida da população. Novos loteamentos surgiram, para atender à crescente mão-de-obra industrial, invadindo as zonas rurais, com uma crescente especulação imobiliária:

São José dos Campos vem tendo nesta última década um desenvolvimento acelerado e desordenado. Novas indústrias afluíram ao município sem qualquer critério racional de localização, prejudicando muitas vezes o interesse peculiar das populações locais. Loteamentos se sucederam invadindo as zonas rurais, periféricas ao atual núcleo urbanizado, transformando-as também sem critério racional, de áreas produtivas em lotes pseudos urbanos que dificilmente serão habitados (PLANO PRELIMINAR, 1961, P.007).

Assim, o CPEU propõe medidas para solucionar os problemas mais urgentes, sendo algumas delas acatadas pelo poder público, e regulamentadas na forma de decretos-leis, conforme consta no plano:

- A primeira medida tomada foi a criação da comissão do plano diretor, e em seguida a implantação de um zoneamento de massa com caráter emergencial, tal medida foi aprovada na forma de lei, através do Decreto no 250 em 31/10/1958. Neste decreto, é colocada a importância de separar a poluição industrial das áreas residenciais e preservar a captação de água para a população.

Criada que foi a comissão do plano pelo decreto n 246 de 10/9/1958, atendendo-se a crescente industrialização do município, pensou-se desde logo, em estabelecer a grosso modo, um zoneamento de massa, procurando fixar as indústrias que aqui viessem se instalar de forma a preservar de eventual poluição, não só a zona habitacional da cidade, mas também a captação de água para o consumo da 
população, como se faz através do decreto de $\mathrm{n}^{\circ} 250$ de 31/10/1958 (PLANO PRELIMINAR, 1961).

Tal legislação considera o regime dos ventos predominantes no município, objetivando preservar a zona habitacional da cidade da poluição do ar: "Artigo $1^{\circ}$, fica interditada a instalação de indústrias cujo processo de fabricação importe no lançamento na atmosfera de gases tóxicos ou, por qualquer forma incômoda ou molesta a população, nas áreas abaixo discriminadas".

○ A comissão do plano elabora, e posteriormente promulga, a Lei $\mathrm{n}^{\circ} 5.261$ de 1959: contra a especulação imobiliária.

- Lei $n^{\circ}$ 657/60: proíbe loteamentos sem condições mínimas de benefícios públicos como rede de água e luz elétrica.

Э Lei $n^{\circ}$ 664/60: estabelece coeficientes de aproveitamento dos lotes, capacidade de habitação, e outros requisitos urbanísticos, de modo a propiciar uma densidade residencial adequada ao município.

- Decreto $\mathrm{n}^{\circ}$ 286/54: delimitou o loteamento de uso urbano e rural.

Decreto $\mathrm{n}^{\mathrm{o}}$ 286/59 e artigo 165 da Lei no 281/54 (código de obras): discrimina zona rural e zona urbana.

Desta forma, tem-se nesse momento a regulamentação de leis que vão contribuir para o planejamento urbano da cidade, propiciando um melhor ordenamento do território. Destacando-se o zoneamento de massa que cria zonas de uso e ocupação do solo, separando as indústrias das residências, levando-se em consideração o porte das indústrias, o potencial poluidor e a direção dos ventos (Figura 15). Outro ponto positivo do PDDI foi a delimitação da zona rural e urbana, buscando evitar o crescimento desordenado e espraiado, ressaltando a importância da zona rural para o abastecimento da cidade. Destacamos também a regulamentação, da lei que proíbe loteamentos sem condições mínimas de benefícios públicos como rede de água e luz elétrica, procurando ordenar o crescimento da cidade. 


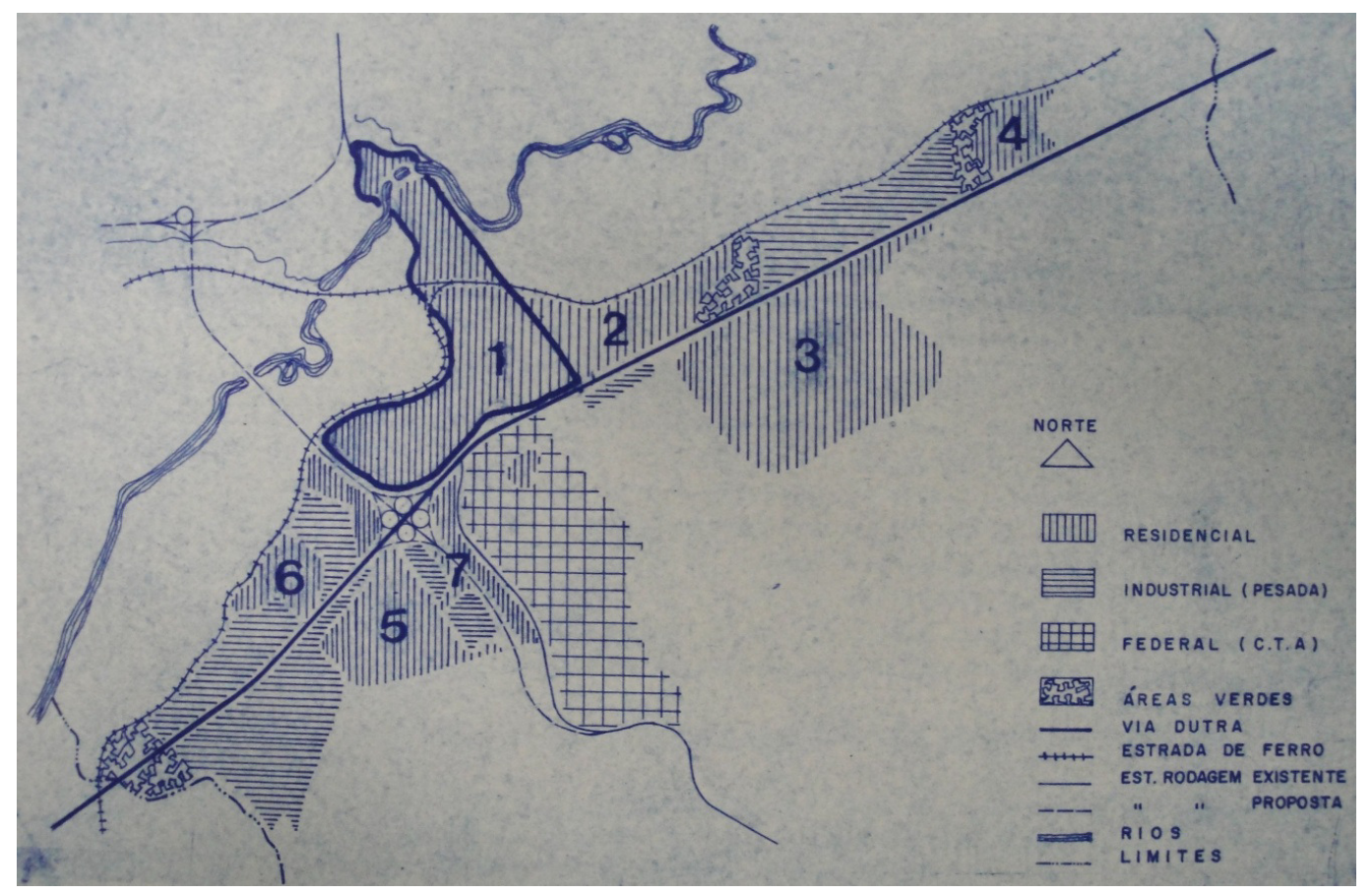

Figura 15 - Zoneamento de Massa e Setorização.

Fonte: Plano Preliminar (1961, vol.1, p. 0068).

Essas regulamentações realizadas pelo Plano Diretor de 1961 foram benéficas ao município em alguns pontos, mas em outros não se conseguiu solucionar o problema de forma efetiva, mas de modo geral os resultados do plano preliminar foram bastante positivos, embora muitos dos decretos e leis não tenham tido aplicação na prática.

Como é apontada no relatório do plano preliminar, a legislação urbanística criada após 1958, quando se dá a formação da comissão do plano diretor, é elogiada pelo CPEU, e também, pela Folha de São Paulo, que em 15 de janeiro de 1961, na coluna Assuntos Municipais, escreve o seguinte sobre a legislação de São José dos Campos: "digna de imitação pelos demais municípios brasileiros”.

Em continuidade ao plano diretor preliminar, foram elaborados, pelo CPEU, Planos setoriais entre 1961-1964. Esses planos estão contidos em dois volumes denominados "Estudos e Planos Setoriais". Nesta fase, assume como diretor do CPEU o Prof. Dr. Lauro Bastos Birkholz, e como Instrutor o Arquiteto Breno Cyrino Nogueira.

O plano final propõe um consórcio para o Vale do Paraíba com base na Constituição Estadual, sendo que na década de 1970, ocorreu a criação do Consórcio de Desenvolvimento do Vale do Paraíba (CODIVAP), e também, a criação de um órgão específico para tratar do planejamento na zona rural. É proposto ainda a criação de um órgão de planejamento urbano, com poder deliberativo, ligado direto ao prefeito. Porém, na prática, esses órgãos de 
planejamento rural e de planejamento urbano, com poder deliberativo nunca chegaram a existir.

Outras medidas colocadas pelo primeiro plano diretor de São José dos Campos que merecem destaques, em relação ao tema desta tese, é na área de habitação que prevê um plano de desfavelamento, para a única favela que existe na cidade até o momento, a favela denominada "Linha Velha" que se instalou onde corria os trilhos da Estação de Ferro Central do Brasil que se encontrava desativada. Assim, foi elaborado um plano de habitação que prevê o desfavelamento, busca melhorar o nível de vida do favelado (educação, assistência...), impede que novos moradores instalem-se na favela, e prevê a construção de casas. Propõe ainda parceria entre a prefeitura e a Caixa Econômica para financiamento de imóveis, doação de terras da prefeitura e a criação de um fundo municipal para habitação.

A favela "Linha Velha" possuía na época (1961), extensão de terra de sete metros de largura e três quilômetros de comprimento, seguindo o traçado da Rede Ferroviária Federal, com aproximadamente 218 moradias, sendo143 casas de pau-a-pique, 14 de madeira e 61 de tijolo. O abastecimento de água era feito por poços e bicas públicas, não havia água encanada, sendo que na maioria das vezes esses poços encontravam-se próximos às fossas, 97 casas usavam fossa em comum, e 121 casas não tinham fossa. A população total da Linha Velha era de 967 habitantes, sendo que de cada três habitantes, um não tinha cama (PLANO PRELIMINAR, VOL.1. 1961-1964). Esses dados levantados pelo CPEU mostram a precariedade das habitações e péssimas condições de vida que a população vivia, o relatório destaca ainda a alta criminalidade na área e o grande número de jovens grávidas e de solteiras com filhos. A Figura 16 mostra a localização da "Favela Linha Velha".

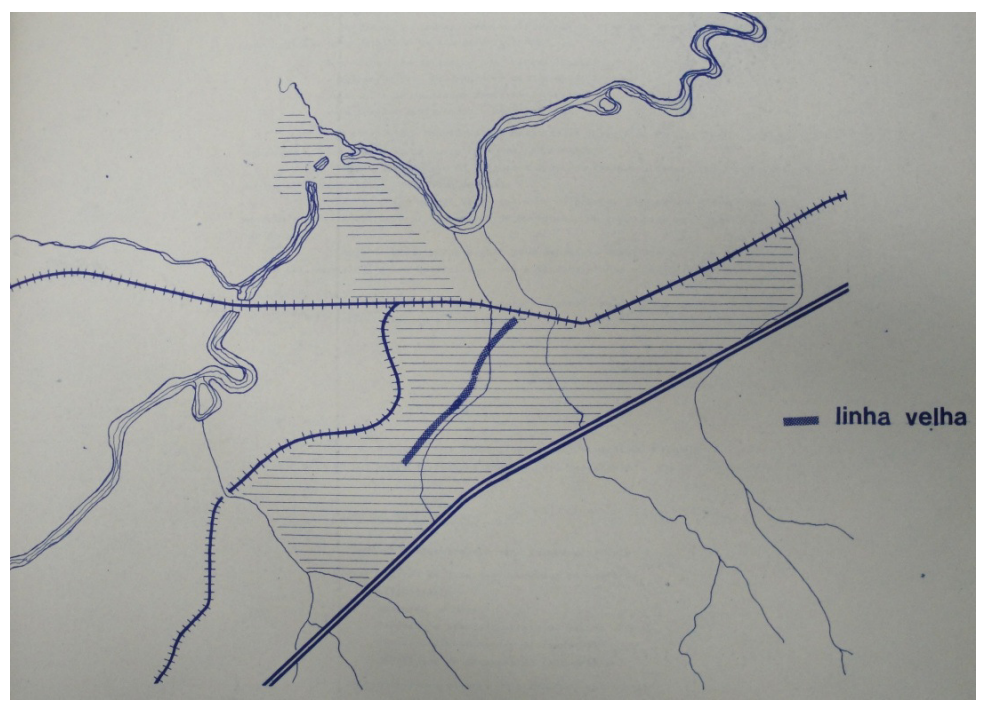

Figura 16 - Localização da Favela da "Linha Velha". Fonte: Plano Preliminar (1961, vol.1, p. 0063). 
No entanto, como aponta Bologna (2000, p. 96), "as medidas de ordenamento territorial, tão avançadas para a época, não foram acompanhadas de medidas efetivas para a área habitacional. Pelo contrário, a formulação de estratégias e diretrizes são muito incipientes, basicamente limitando-se ao desfavelamento da "Linha Velha"'. A favela com o passar do ano sofreu várias intervenções, principalmente quando foi criado o anel viário no final da década de 1970, parte dela foi removida para dar lugar a via expressa. Porém, hoje, mais de 50 anos passados, ainda existem resquícios da favela, conhecida atualmente como Santa Cruz, grande parte dos problemas ainda persistem no local.

Ao mesmo tempo em que o Plano Diretor estipula um plano para Habitação, elabora um plano para Circulação, que prevê a construção de uma via no local da favela, buscando afastar o tráfego do centro urbano da Rodovia Dutra e da estrada de Campos do Jordão. Existia na cidade um grande problema com os "veículos de passagem", que saíam das rodovias em alta velocidade e geravam trânsito. Assim, foi pensado um desvio através de anéis de ligação das autovias, contornando a cidade, e a criação de avenida ao longo do córrego Lavapés, para ligação com Campos do Jordão e a Rodovia Dutra.

Vê-se dessa forma a imposição do econômico ao social, o problema da favela não foi resolvido, mas o sistema viário na cidade de São José dos Campos é um dos melhores do país. O sistema viário mais tarde contribuiu para a vinda de novas indústrias, crescimento e desenvolvimento da cidade, o que atraiu um grande número de trabalhadores e o surgimento de novas favelas e loteamentos ilegais. No jornal Estado de São Paulo de 21 de maio de 1958, é publicada matéria que relata a grande atração de pessoas a São José dos Campos com a instalação das fábricas: Rodosá e General Motors e a dificuldade das empresas em relação ao alojamento de seus funcionários (PLANO PRELIMINAR, VOL.1. 1961-1964, p. 0056).

Destaca-se também a questão do saneamento básico, trabalhado separadamente no Plano, entre abastecimento de água e sistema de esgoto. O plano preliminar destaca os problemas com abastecimento de água. Eram poucas as casas que possuíam rede de água, que se restringia apenas a área central. Em 1935, relatórios mostram que já existia o abastecimento domiciliar, mas a água não era tratada. Em 1941, se inicia o serviço de abastecimento com água tratada, a população urbana da cidade era de 14.695 habitantes, e o abastecimento já era insuficiente. Em 1961, são instalados hidrômetros nas casas, e é observada uma grande redução, de 36\%, no desperdício de água. Assim, se destaca a necessidade de ampliação da captação e da adução; ampliação da rede de distribuição e ampliação do sistema de controle e eliminação das perdas e do desperdício. Segundo o relatório do plano, era necessário realizar um zoneamento da cidade, pois o "zoneamento 
estabelece níveis máximos de ocupação do solo, permite a definição de áreas de maior acúmulo de população, como o dimensionamento dos sistemas de abastecimento de água e esgoto" (PLANO PRELIMINAR, 1961, p. 0015).

Em relação ao sistema de esgoto, os lançamentos eram feitos no Rio Paraíba do Sul, o tratamento era feito desde 1941, com duas estações. A rede de esgoto abrangia somente 37,21\% da área urbana total. O plano de 1961 destaca a insuficiência da estação de tratamento, colocando a necessidade de ampliar e investir na estação, e também, ampliar a abrangência do sistema de rede de esgoto (PLANO PRELIMINAR, 1961).

Desta forma, em 1963, foi executada a lagoa de oxidação para o tratamento de esgotos, a primeira do país. Em 1968, a Prefeitura contratou uma empresa especializada e concluiu o novo Plano de Abastecimento de Água e Esgoto para a cidade, cumprindo as diretrizes do PDDI (BOLOGNA, 2000).

No entanto, o Plano Diretor final entregue em 1964, em dois volumes, não foi promulgado na forma de lei, sendo que muitos dos seus trabalhos, orientações e ajustes ao planejamento urbano da cidade não foram colocados em prática. Como vimos, algumas das sugestões foram acatadas na forma de decretos/leis, mas grande parte do trabalho e estudos realizados não foi efetivada. Todavia, o primeiro plano diretor de São José dos Campos, contribui no sentido de nortear o desenvolvimento da cidade, foi bastante positivo do ponto de vista teórico e pode instrumentalizar, e guiar os técnicos da prefeitura para um melhor ordenamento da cidade.

Nesse sentido, foi feita a organização do cadastro imobiliário, através de levantamento aerofotogramétrico e pesquisa de campo, regulamentação do perímetro urbano, o zoneamento de massa, a regulamentação de normas para a implantação de loteamentos, elaboração de plano setorial de saneamento e lagoa de tratamento de esgoto.

Por outro lado, a fixação do perímetro urbano, as exigências de infraestruturas mínimas, associadas ao zoneamento contribuíram para a elevação do custo da terra. Posteriormente, através dos Decretos 1437/71, 1792/74, 1826/75 a Prefeitura concedeu alvará de construção para vinte e um loteamentos irregulares. "Portanto, o fato de a prefeitura não reconhecer as construções existentes em loteamentos não dotados de água e luz não impediu que esses fossem ocupados por edificações "clandestinas", demonstrando a dissociação entre a produção da cidade real e as diretrizes do Plano" (BOLOGNA, 2000, P. 97).

Quanto à ocupação do solo, a Lei 664, de 18/02/60, que estabelecia o coeficiente de aproveitamento dos lotes, e fixava gabaritos de altura para as edificações e exigência de reserva de áreas para estacionamento teve sua aprovação revogada no 
ano seguinte, por iniciativa da Câmara de Vereadores, não sendo possível encontrar o motivo para sua revogação. (BOLOGNA, 2000, P. 97).

Neste sentido, foi possível observar, como aponta Bologna op. cit., por meio de análise de foto aérea da cidade de 1973, a malha urbana continuava a ter uma configuração descontínua e bastante extensa.

O Planejamento viário previsto pelo PDDI de 1964 foi parcialmente implantado, foram reservadas faixas "non aedificandi" ao longo das rodovias, permitindo a implantação de vias projetadas ao longo dos anos, o que é algo bastante positivo do ponto de vista do ordenamento espacial da cidade.

No entanto, muitos dos estudos técnicos realizados pelo CPEU foram barrados ao serem colocados em prática. Houve uma descompatibilidade entre os estudos realizados e as ações do Prefeito. À medida que as ações eram criticadas por parte da sociedade, o Prefeito passa a cancelar as implantações, sem consultar os técnicos do CPEU. Conforme Bologna op. cit., há uma falta de identidade entre os objetivos do planejamento e as verdadeiras intenções da administração pública. Sendo assim, nem todas as diretrizes previstas no PDDI foram cumpridas na prática.

Segundo Bologna (2000, p. 99), “de um total de 21 programas/projetos, 33,33\% foram executados; $4,76 \%$ foram parcialmente executados; 47,66\% não foram executados e a execução de $14 \%$ deles não foi possível de ser identificada”.

Do ponto de vista ambiental, é importante ressaltar alguns aspectos considerados pelo plano; em primeiro, o zoneamento de massa estipulando a localização das indústrias em relação à direção dos ventos e a preocupação com a poluição do ar e das águas, e em segundo a preocupação com o tratamento de esgoto.

É importante destacar que logo na introdução do primeiro volume do plano diretor entregue em 1964, destacam-se os elementos do urbanismo moderno presentes na Carta de Atenas, enfatizando as quatro funções da cidade: trabalhar, recrear, habitar e circular. Assim, diferentemente de muitas cidades brasileiras, São José dos Campos inicia seu processo de industrialização e urbanização respaldada em um planejamento urbano, seguindo os princípios do urbanismo moderno.

Na análise do Primeiro Plano Diretor de São José dos Campos, vê-se a ação do Estado de forma planejada, através do Plano desenvolvido pelo CPEU/FAU/USP, técnicos da prefeitura e representantes da sociedade, procurando levar em consideração os aspectos econômicos, sociais e ambientais do município. Porém, o poder público local, através da 
figura do prefeito e vereadores, não segue as diretrizes previstas para o desenvolvimento da cidade, apenas uma parte do Plano é efetivada, por meio de decretos e leis, porém partes destes não se fazem cumprir; a especulação imobiliária, a indústria e o poder econômico falam mais alto.

\subsubsection{O Plano Diretor de 1971}

\section{(Lei Municipal 1.623 de 30 de novembro de 1971)}

Após a entrega do Primeiro Plano Diretor de São José dos Campos, o cenário político brasileiro passa por uma drástica mudança. Com o golpe militar de 1964, dá-se início a uma nova política nacional.

Durante o regime militar, foi criado o Banco Nacional de Habitação e o Serviço Federal de Habitação e Urbanismo (SERFHAU), e este órgão passa a financiar os planos de desenvolvimento local. No Estado de São Paulo, a lei estadual 9.842/67, designa os empréstimos financeiros apenas àquelas cidades que tivessem Plano Diretor. A partir desse momento, cresce o número de planos diretores nas cidades do estado de São Paulo.

Nesse período, o processo de urbanização se intensifica, e São José dos Campos, apresenta um número maior de indústrias e de habitantes. Nesse contexto, é elaborado o segundo Plano Diretor de São José dos Campos, encomendado à SERETE S/A Engenharia, sob direção do arquiteto Jorge Wilhein.

O Plano Diretor de 1971 foi redigido em três volumes, sendo o primeiro o plano preliminar (1969), com a caracterização dos aspectos históricos, sociais, culturais, econômicos do município, o segundo volume com o plano propriamente dito e o terceiro volume com anexos e apêndices. O Plano de Desenvolvimento Integrado foi aprovado pela Lei Municipal no 1.623, em 30 de novembro de 1971.

O PDDI de 1971 é mais técnico e não faz nenhuma referência ao plano do CPEU, não teve nenhuma participação da sociedade, seguindo a linha do regime militar instituída na época. O novo PDDI está focado nas projeções de crescimento econômico, a cidade deveria ser eficiente para receber o capital industrial. A base do plano é o ordenamento do solo urbano por meio do zoneamento e da estruturação viária. O planejamento urbano é assim elaborado para a indústria e para o capital.

O plano limita-se a criticar o crescimento desordenado, observa-se que a criação de novos bairros periféricos, através de loteamentos, acarretaria fatalmente aumento da descontinuidade da ocupação urbana, maior isolamento social, elevação dos custos dos 
transportes e falência gradativa dos serviços públicos (BOLOGNA, 2000). O plano destaca a existência de muitos vazios urbanos na cidade. Nas Figura 17 e Figura 18 vêem-se áreas de grande vazio urbano a ser ocupado.

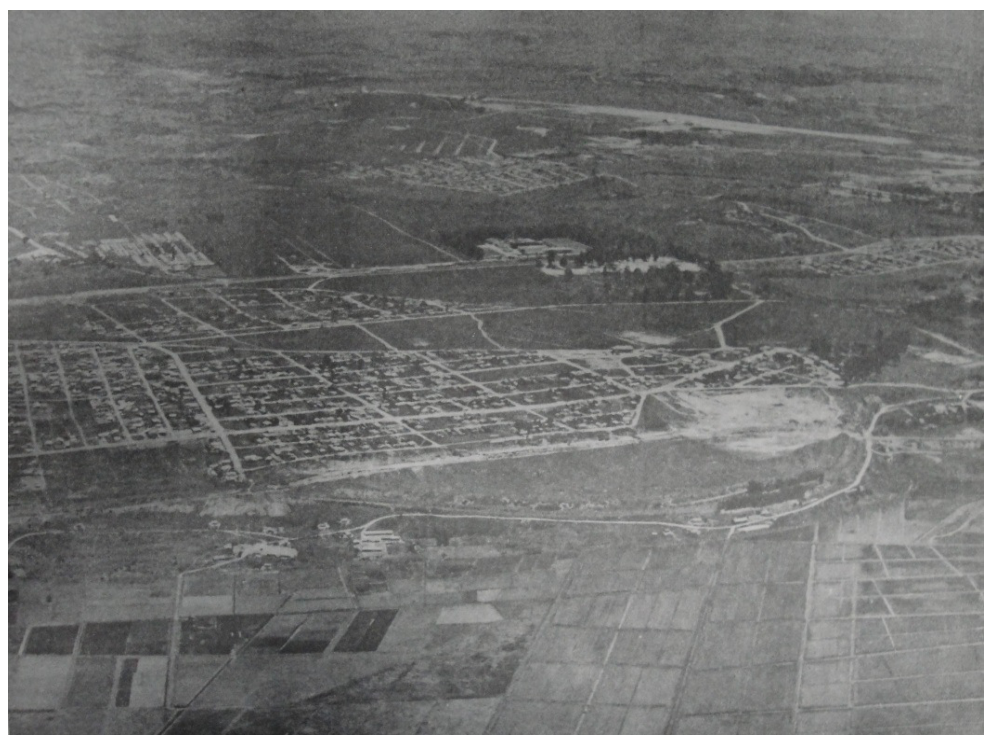

Figura 17 - Vila Industrial: vazios urbanos.

Fonte: Caderno do Plano de Desenvolvimento Integrado (1969).

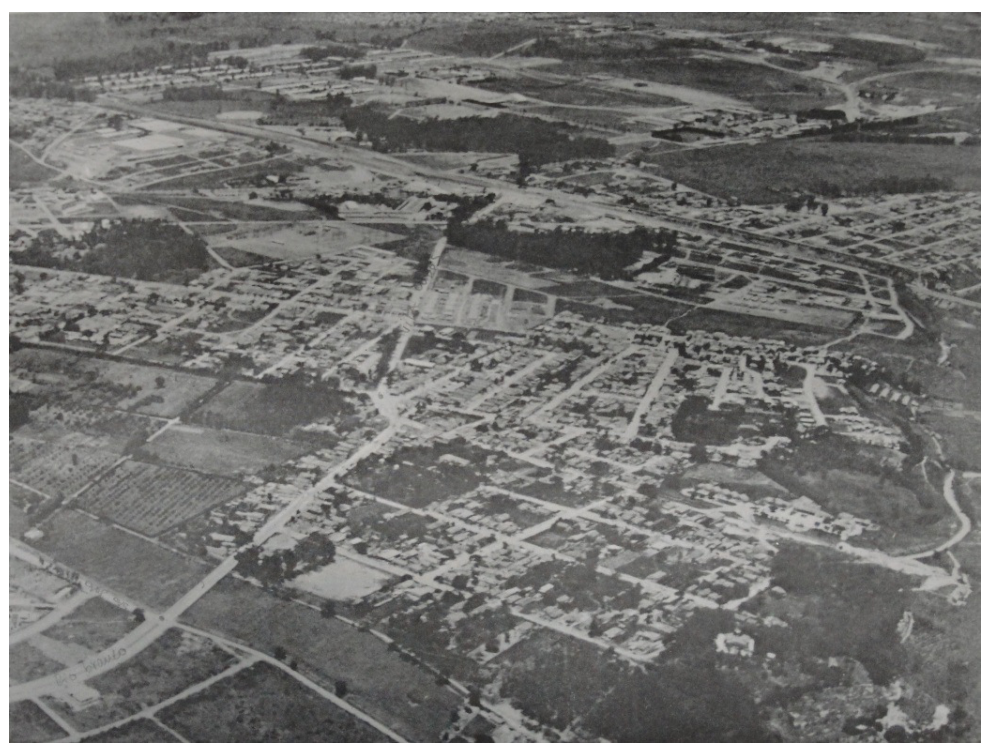

Figura 18 - Jardim Esplanada, Vila Ema, Sanatório Ezra: ocupações dispersas com vazios. Fonte: Caderno do Plano de Desenvolvimento Integrado (1969).

A expansão urbana do município foi pensada em três etapas: $1^{\text {a }}$ Etapa: ocupação dos vazios urbanos, 2a Etapa: ocupação dos vazios urbanos na região sul sentido Jacareí e $3^{\mathrm{a}}$ Etapa: ocupação da várzea do Rio Paraíba. A última etapa mostra a despreocupação do plano com o meio ambiente. Felizmente, a ocupação da $3^{\text {a }}$ etapa não foi realizada, como é possível visualizar nas Figura 19, Figura 20 e Figura 21. 


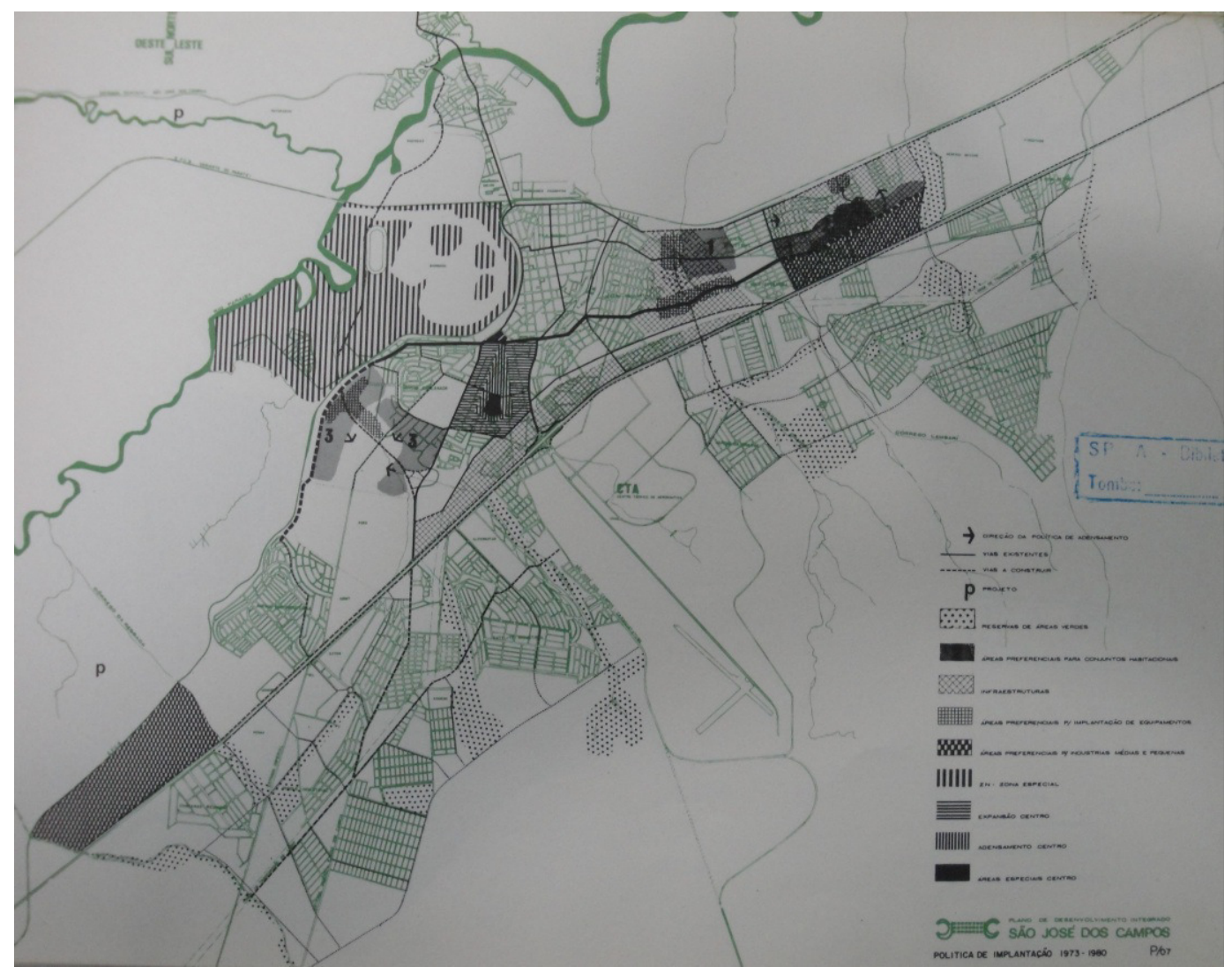

Figura 19 - Expansão: Política de Implantação até 1972.

Fonte: Caderno do Plano de Desenvolvimento Integrado, 1969.

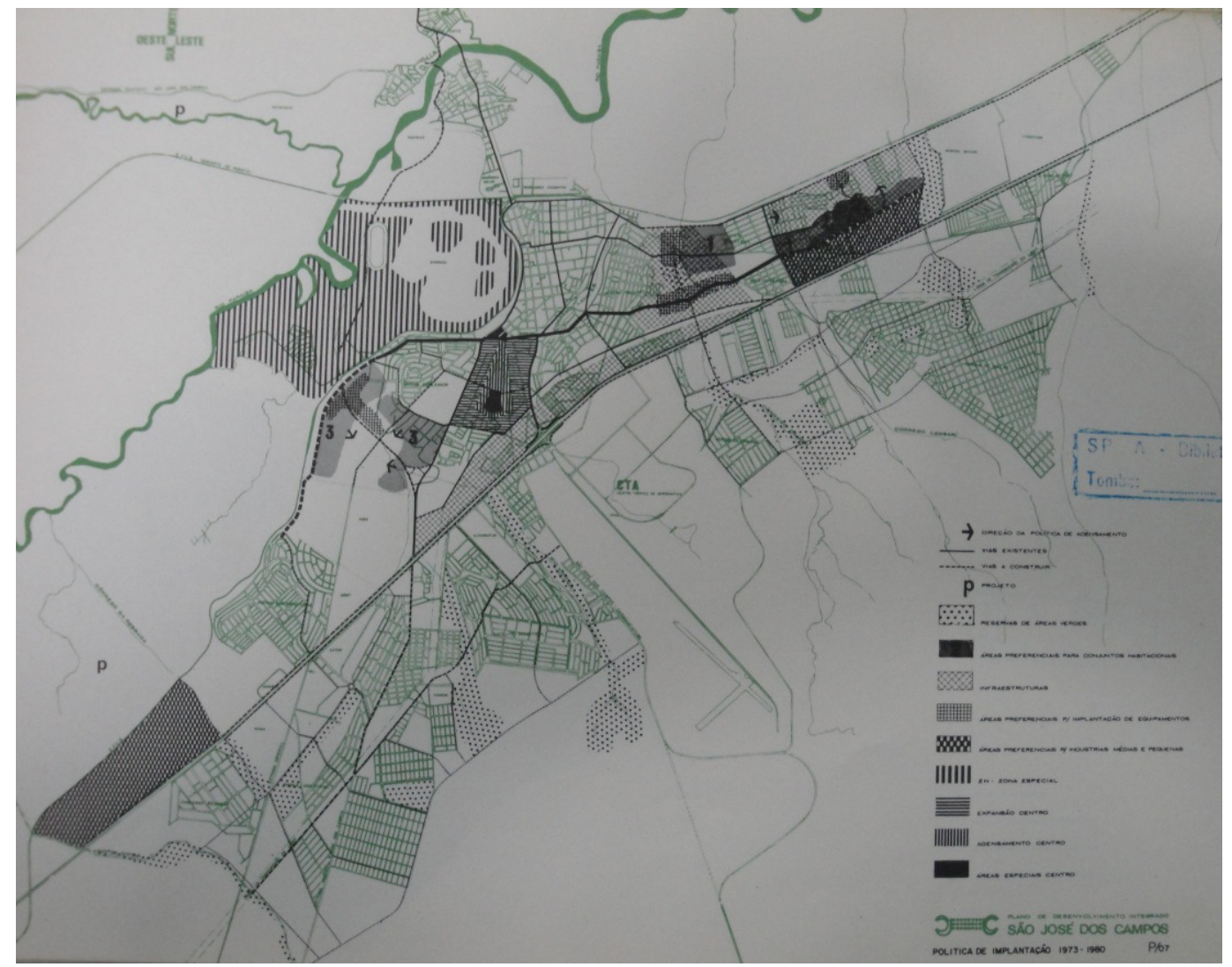

Figura 20 - Expansão: Política de Implantação 1973 - 1980.

Fonte: Caderno do Plano de Desenvolvimento Integrado, 1969. 


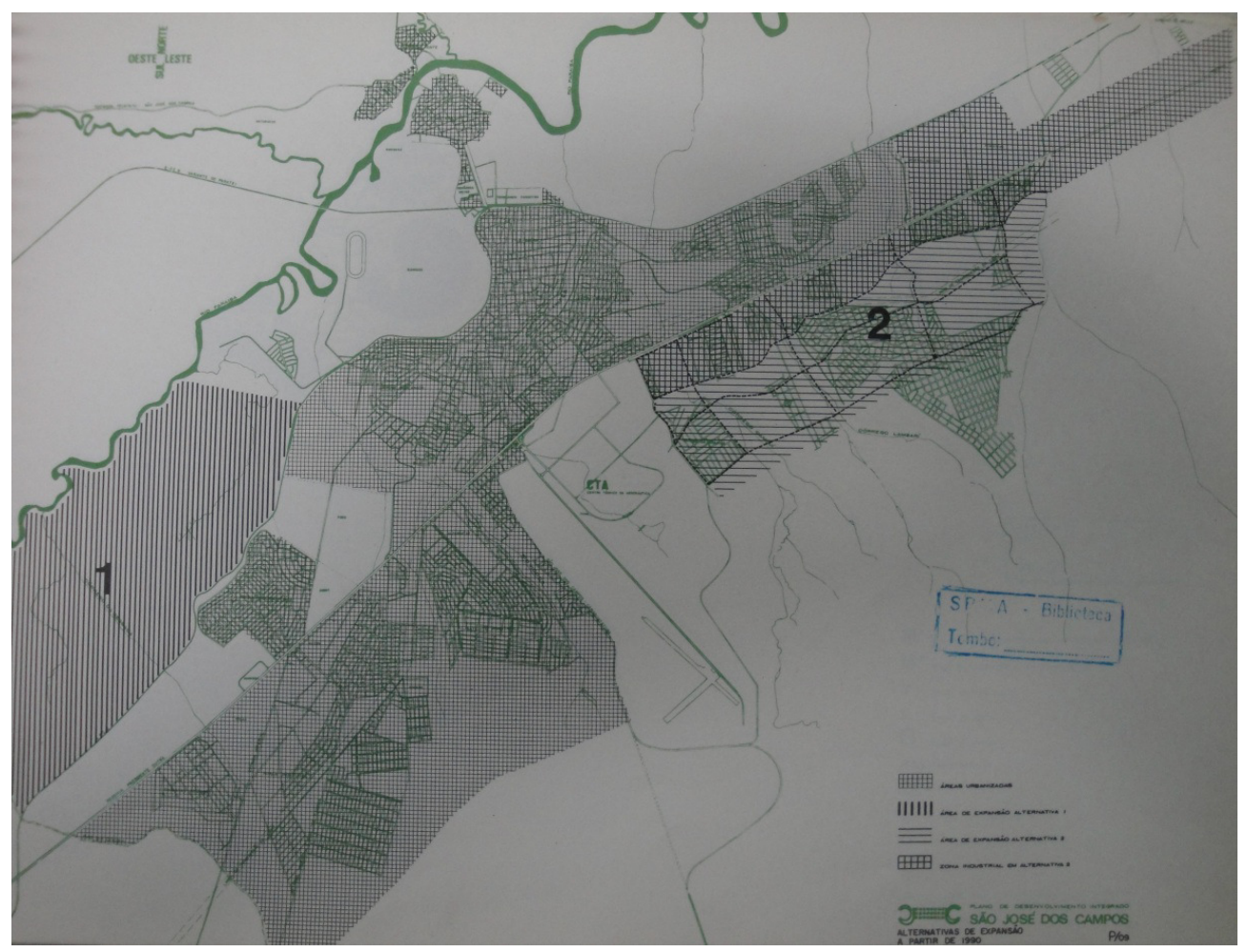

Figura 21 - Expansão: Alternativas de expansão a partir de 1990. Fonte: Caderno do Plano de Desenvolvimento Integrado, 1969.

Como aponta Bologna (2000, p. 111), “observa-se que não houve nenhuma referência às características do meio físico, quer urbano ou rural. Suas limitações não foram consideradas na definição da política de ocupação, quer urbana ou rural, motivo pelo qual na terceira etapa de expansão, referente ao crescimento urbano a sudoeste, foi prevista exatamente na várzea do Rio Paraíba do Sul"

O plano aponta estimativas para o crescimento de São José dos Campos, porém estas estimativas são muito inferiores àquelas que ocorrem na realidade. As projeções demográficas efetuadas pela SERET S.A. ficaram muito abaixo do crescimento real, segundo o diagnóstico realizado pela empresa, a população prevista para 1980 era de 194.000 , no entanto, a população real atingiu o número de 276.901 habitantes, ou seja, 82.901 habitantes, ou $40 \%$ a mais do que o previsto. O fato acabou gerando um subdimensionamento dos cálculos da expansão da malha urbana e equipamentos.

As três fases de expansão urbana prevista em curto, médio e longo prazo tiveram de ser antecipadas face às reais taxas de crescimento que superaram as projeções efetuadas. Porém, felizmente a ocupação da várzea do Rio Paraíba não ocorre (BOLOGNA, 2000). A expansão começa a ocorrer, mas ao nordeste do município sob influência de intervenções do governo do estado, que traz para a cidade a Refinaria de Petróleo Henrique Lage, ocupando uma gigantesca região, e atraindo mais serviços e mão-de-obra. Assim, a malha urbana é 
novamente estendida, e os vazios urbanos aumentam novamente. A cidade passa, então, a conviver com uma indústria de risco e altamente poluidora ao lado de bairros residenciais (BOLOGNA, 2000).

Conforme Bologna op.cit., a falta de uma política habitacional popular foi uma grande falha, em face do grande crescimento industrial iniciado na década de 1970, que em apenas quatro anos, elevou a população local de 148 mil para 252 mil habitantes. Os graves problemas sociais e ambientais, decorrentes da ausência de uma política para habitação popular, são agravados nas décadas seguintes.

O PDDI de 1971 procura inibir a expansão horizontal da cidade, com exceção nas áreas de vazio urbano, colocando normas e diretrizes bem restritivas, que acabam elevando o valor da terra. Neste período, há um grande aumento no número de loteamentos clandestinos, que vão ocupar principalmente a área rural, produzindo parcelamento do solo para fins urbanos em meio a área rural, desrespeitando a legislação vigente, produzindo um crescimento periférico, sem planejamento e ordenamento do território.

Neste período, há uma grande intensificação do tráfego na cidade. A Rodovia Dutra é usada pelo tráfego urbano local para alcançar bairros e locais de trabalho mais afastados, provocando grandes congestionamentos (tal fato ainda ocorre nos dias atuais). O mesmo acontecia com o acesso a Campos do Jordão.

A cidade passa por graves problemas, como grandes áreas de vazio urbano, descontinuidade da trama urbana, área urbana cortada por rodovia de tráfego pesado, falta de opções para tráfego, problemas de drenagem e de esgoto, carência de pavimentação e aumento dos loteamentos clandestinos (BOLOGNA, 2000).

Desta forma, a lei do Plano de Desenvolvimento Integrado (PDDI) de 1971 de São José dos Campos destaca como principais objetivos: racionalização do uso do solo, hierarquização do sistema viário, adotar diretrizes para expansão e adensamento urbano, estimular o desenvolvimento econômico de forma a consolidar a posição de polo da região do Vale do Paraíba, incentivar o desenvolvimento físico-territorial e socioeconômico do Município, aumentar os investimentos públicos, ampliar os serviços urbanos, elevar o atendimento nos setores de ensino, saúde e assistência social.

Como se vê, este novo plano não coloca entre seus objetivos o meio ambiente, e por outro lado, enaltece a questão econômica, a importância do desenvolvimento do território, e a importância de consolidar São Jose dos Campos como município polo do Vale do Paraíba.

No item "zoneamento e uso do solo", é previsto no Art. $6^{\circ}$, a divisão do município em três áreas: área urbana, área de expansão urbana e área rural. O Art. $9^{\circ}$ coloca ainda que a 
Prefeitura por intermédio da Assessoria de Planejamento, regulamentará periodicamente as divisas de cada zona, sendo assim, os limites entre as zonas urbana e rural ficam sujeitos a mudanças por conta dos "interesses da Prefeitura".

O PDDI traz um capítulo sobre "Paisagismo", que determina a implantação do Sistema Verde, com objetivo de desenvolvimento das atividades ao ar livre e recreação, esse sistema ocorreria através da criação dos seguintes parques: I- instalação de Parques de Vizinhança; II - instalação de Parque, localizado no Banhado e com equipamentos esportivos, de recreação, culturais, estacionamentos, jardins zoológico e botânico, e recinto para feiras e exposições; III - implantação de viveiros municipais de plantas para arborização e ajardinamento, sendo um Central, localizado no Banhado e os de apoio junto aos Parques de Bairro; IV - remanejamento do conjunto formado pelas Praças Afonso Pena, Córrego Lima e João Mendes, com implantação de uma zona especial entre a Rua Francisco Rafael e a Avenida São José, criando uma seqüência de espaços livres de domínio do pedestre.

Porém, como aponta Bologna (2000), a implantação do Sistema Verde não teve êxito. Das 150 áreas verdes previstas para 1980, apenas três foram incluídas no Plano Plurianual e implantadas.

O PDDI, no Capítulo "Infraestrutura", aponta melhorias no sistema de esgoto sanitário e abastecimento de água, porém, sem nenhuma medida efetiva, que venha a solucionar o problema. Outro item abordado: "Diretrizes sócio-culturais", aponta a importância da educação infantil, a cargo da municipalidade, e a necessidade de criar mais salas de aula e colégios técnicos. Coloca como responsabilidade do Departamento de Educação e Cultura o desfavelamento, porém, não descreve o que será feito para solucionar o problema, apenas o cita.

Já no item "Diretrizes econômicas", são fixadas algumas diretrizes básicas, em que se destacam a primeira: "I - permanente colaboração para que o Município mantenha a sua posição de principal centro da indústria aeronáutica do país”. Vê-se assim, que o Estado intervém constantemente na criação do polo aeronáutico de São José dos Campos, sendo que o mesmo prevê a celebração de convênios e implantação de ensino técnico profissional ligado à aeronáutica.

Neste item, destaca-se também a importância de incentivar as atividades agropecuárias, de modo a assegurar o abastecimento de gêneros alimentícios à população.

Bologna (2000), em estudo realizado sobre avaliação dos Planos Diretores em São José dos Campos, constatou que: "de um total de 35 programas/projetos, 45,71\% deles foram executados; 22,85\% foram parcialmente executados; 22,85\% não foram executados, sendo 
que a execução de 8,57\% deles não pode ser identificada" (BOLOGNA, 2000, p. 146). É importante destacar que o PDDI foi acompanhado pela Lei de Zoneamento Urbano (Lei n. 1606/71), aprovada dois meses depois.

Deste modo, vemos no Plano de Desenvolvimento Integrado, certa regressão em relação ao plano anterior, no que se refere aos aspectos sociais e ambientais. O desenvolvimento econômico e a elevação da cidade a polo tecnológico aeroespacial é o elemento fundamental perseguido pelo PDDI de 71. Neste sentido, o planejamento urbano de São José dos Campos foi voltado para o desenvolvimento econômico, para a industrialização e para a modernização, produzindo um quadro de grandes contradições urbanas, de exclusão social e segregação.

\subsubsection{O Plano Diretor de 1995}

\section{(Lei Complementar n⿳121 de 27 de abril de 1995)}

O novo Plano Diretor de São José dos Campos foi aprovado após 24 anos da sua última revisão, em acordo com a Constituição Federal de 1988, que torna obrigatório o Plano Diretor para as cidades com mais de 20.000 habitantes, e a Lei Orgânica Municipal de $1990^{19}$.

O novo PDDI é desenvolvido num período onde as preocupações ambientais ganham grande destaque; tem-se o acontecimento da ECO-92, no Rio de Janeiro, e a propagação da ideia de desenvolvimento sustentável em diferentes meios, além da maior consolidação da Política Nacional do Meio Ambiente e novas posturas trazidas pela Constituição Federal de 1988. Assim, o PDDI é elaborado com um novo ideário de planejamento, no qual o desenvolvimento deve ocorrer de forma sustentável. Desta forma, o Plano segue calcado nas questões de ordem ambiental e social.

\footnotetext{
19 O Plano Diretor se torna obrigatório conforme a Lei Orgânica do município de 1990, que prevê ainda participação e debate com as entidades locais, como aponta o Art. 113: "O Município elaborará o seu Plano Diretor de Desenvolvimento Integrado, levando em consideração os aspectos físicos, econômicos, sociais e administrativos, devendo observar o Diagnóstico Ambiental, que estabelecerá os parâmetros para a execução do zoneamento.

$\S 1^{\circ} \mathrm{Na}$ elaboração do Plano Diretor de Desenvolvimento Integrado pelo órgão técnico da Administração Municipal, é indispensável a participação das entidades de representação no Município.

$\S 2^{\circ}$ Antes de remetido à Câmara Municipal, o Plano Diretor de Desenvolvimento Integrado será objeto de exame e debate com as entidades locais, sendo o projeto acompanhado das atas com críticas, subsídios e sugestões não acolhidas pelo Poder Executivo".

Cabe destacar ainda, o Artigo 16 da Lei Orgânica de São José dos Campos, pois torna obrigatório a realização de audiência pública nos seguintes casos:

I - projeto de licenciamento que provoque impacto ambiental, definido em lei;

II - atos que envolvam conservação ou modificação do patrimônio histórico, arquitetônico, artístico ou cultural do Município;

III - elaboração dos projetos de lei das Diretrizes Orçamentárias, do Orçamento Anual e do Plano Plurianual; IV - elaboração do Plano Diretor de Desenvolvimento Integrado;

V - elaboração ou alteração de legislação reguladora do uso e ocupação do solo.
} 
Este novo PDDI é elaborado em uma época de abertura política. No entanto, presencia-se uma política neoliberal de privatização de empresas estatais e a entrada de grandes multinacionais no país e capital privado. O município de São José dos Campos apresenta um cenário ainda bastante ressentido com a crise econômica que se desencadeou no final dos anos 1980 e início dos 1990, provocada principalmente pelas demissões em massa nas indústrias bélica, automobilística e aeronáutica. A cidade sofreu com o desemprego e conseqüentemente a falta de renda e fechamento de estabelecimentos.

Diante desta realidade, o PDDI-95 definiu como diretrizes: fortalecer e consolidar o Parque Industrial existente; incentivar a implantação de pequenas e micro empresas e fortalecer o desenvolvimento de tecnologia de ponta no Município, buscando o máximo de efeitos encadeadores na geração de empregos e serviços à população.

Para elaboração do Plano Diretor de Desenvolvimento Integrado (PDDI) de São José dos Campos de1995, foi elaborado o Caderno do Plano Diretor, iniciado em 1991 e finalizado em 1994. Este contém a caracterização geral do município, a descrição dos principais problemas enfrentados, diagnóstico, diretrizes, projetos e programas, medidas de intervenção para solucionar e/ou minimizar os problemas levantados.

Bem diferente do Plano Diretor de 1971, este novo plano teve uma maior participação da sociedade, através de audiências públicas. Envolveu o setor técnico de planejamento, diversos setores do governo e associações representativas do Município, sendo um trabalho em conjunto e participativo, tendo a assessoria de uma equipe de pesquisadores da UNESP na sua produção.

Neste sentido, o Caderno Diagnóstico do Plano Diretor de 1995 é muito mais aberto. Logo na mensagem inicial à população, ele faz referência às palavras: cidadania, justiça e equilíbrio socioambiental, sendo denominado "Um Plano da Cidade para a Cidadania". O diagnóstico do plano foi finalizado em 1994, e a lei do Plano Diretor de Desenvolvimento Integrado de São Jose dos Campos, Lei no 121, foi aprovada em 27 de abril de 1995, sendo elaborado para atuação num período de 10 anos.

O caderno diagnóstico do plano está dividido em três partes. A parte I traz a apresentação e os fundamentos para elaboração do plano. A parte II mostra a caracterização geral do município, descrevendo sua evolução história, localização e demografia. Já a parte III traz os objetivos e os temas abordados na análise do plano, com os diagnósticos, diretrizes e programas a serem trabalhados em cada tema. Os temas abordados no Plano Diretor são: desenvolvimento econômico, ocupação do solo, desenvolvimento social, finanças municipais e aspectos jurídicos. 
O conteúdo levantado e discutido no caderno diagnóstico foi incorporado ao Plano Diretor de Desenvolvimento Integrado (PDDI) do município de São José dos Campos. Assim, destacam-se aqui os principais itens discutidos no PDDI de 1995 relacionados ao tema desta pesquisa.

O Caderno do PDDI 1995, nas diretrizes para o desenvolvimento econômico urbano e rural, destaca a queda no setor agrícola e desvalorização da terra e o grande crescimento de loteamentos clandestinos desprovidos de infraestrutura e o aumento da silvicultura.

Os solos de São José dos Campos não são considerados férteis, mesmo porque houve uma grande exploração no período do café. A maior parte da área rural está em terrenos montanhosos, com exceção das várzeas do Rio Paraíba do Sul e do Rio Jaguari, que são utilizadas para plantio do milho, arroz e feijão. O consequente enfraquecimento do setor rural levou à descapitalização do produtor rural e ao aumento de terras ociosas nesta área, sendo que uma parte foi loteada de forma clandestina, e outra parte vem sendo arrendada para o cultivo de eucaliptos para abastecer as indústrias de celulose. No entanto, estudos recentes acusam danos que o cultivo de eucalipto traz aos recursos hídricos, através do esgotamento de córregos e mananciais, sendo que da área total cultivada do município, 10.812ha, a maior parte (10.340ha) é usada para silvicultura ${ }^{20}$.

Como o próprio caderno do plano aponta, "o setor primário (agropecuário) vem subexistindo precariamente num município que é predominantemente industrial" (Caderno Diagnóstico do PDDI 1995, p.56). Aliado a este fato, vê-se a degradação de áreas ambientais no município, sendo assim, o Plano Diretor propõe uma série de diretrizes e programas municipais que objetivam fortalecer o setor agrícola no município, e também, melhorar o abastecimento da cidade e diminuir o número de loteamentos clandestinos.

\footnotetext{
Art. $6^{\circ}$ - A Política Municipal de desenvolvimento econômico rural observará as seguintes diretrizes:

I - Promover e orientar o desenvolvimento sócio-econômico da zona rural do Município privilegiando a utilização racional de seus recursos naturais.

II - Fomentar a criação de instrumentos institucionais que viabilizem o fortalecimento do setor rural.

III - Fomentar uma política de incremento à produção, objetivando o aumento do valor agregado.

[...] Art. $7^{\circ}$ -

I - Promover o levantamento de dados físicos e sócio-econômicos visando o incremento da produção rural, objetivando a melhoria da condição de vida do produtor/trabalhador e o abastecimento do Município.

[...] Art. $8^{\circ}$ -

IV - Incrementar o setor agrícola principalmente no que se refere a produção de hortifrutigranjeiros.
}

\footnotetext{
${ }^{20} 1$ hectare (ha) $=10.000 \mathrm{~m} 2$.
} 
V - Propiciar a participação de pequenos produtores e comerciantes na oferta de hortifrutigranjeiros.

Quanto à questão dos loteamentos clandestinos, é algo que tomou grandes proporções no município, sendo que este problema é discutido em várias partes do Caderno do Plano (páginas 53, 55, 56, 65, 73, 74, 75, 80, 97, 107, 133, 140, 148, 191, 277), e também, na lei final. Estes loteamentos ilegais estão disseminados em várias regiões da cidade.

Os loteamentos clandestinos, caracterizados pelo parcelamento irregular do solo e sem autorização do poder público, tem sido uma característica marcante desde 1984 nos bairros rurais próximos ao limite urbano. Nestes loteamentos, concentra-se uma população de baixa renda, carentes de infraestrutura básica, desde saneamento até equipamentos comunitários. Conforme o Caderno Diagnóstico do PDDI 1995, existem 108 loteamentos clandestinos, localizados principalmente na região norte e leste do município.

Como aponta o Caderno do Plano, "a ocupação do território, vem se dando de modo inadequado, não observando as potencialidades e limitações do meio físico para a totalidade do território municipal" (Caderno Diagnóstico do PDDI-1995, p. 66).

Assim, propõe se a incorporação desses loteamentos à macrozona urbana na região sudeste, aumentando o número de terras urbanizáveis e a diminuição dos preços fundiários, e os demais loteamentos clandestinos serão delimitados em bolsões específicos para posterior inclusão no perímetro urbano e regularização urbanística e fundiária. No entanto, os loteamentos clandestinos só vieram a ser delimitados como Zonas de Especial Interesse Social (ZEIS) com a lei de zoneamento 165/1997, porém não foram regularizados e incorporados à área urbana, sendo marcados pela falta de infraestrutura e serviços.

Deste modo, no sentido de ordenar a ocupação do território, foi elaborada a carta das unidades territoriais, levando-se em consideração os fatores físicos do município, como carta de declividade, carta hipsométrica, carta da cobertura vegetal e hidrografia, mapa geológico, relatórios do INPE e IPT e leis ambientais do município.

Na Seção I "Das diretrizes específicas da ocupação territorial”, é posto que: “Art. 14 O território do Município será ordenado com base nas diretrizes constantes na 'Carta das Unidades Territoriais de Características Físicas e Antrópicas Homogêneas', que identifica as potencialidades e limitações para seu uso e ocupação". Desta forma, o ordenamento do município passa a ser realizado com base em estudos das características físicas do ambiente.

Assim, através desta carta das unidades territoriais, pode-se identificar as potencialidades e limitações para ocupação e uso do solo no município, o que levou à divisão 
do município em sete unidades (descrição com base no Art. 15 da referida lei), como mostra a Figura 22.

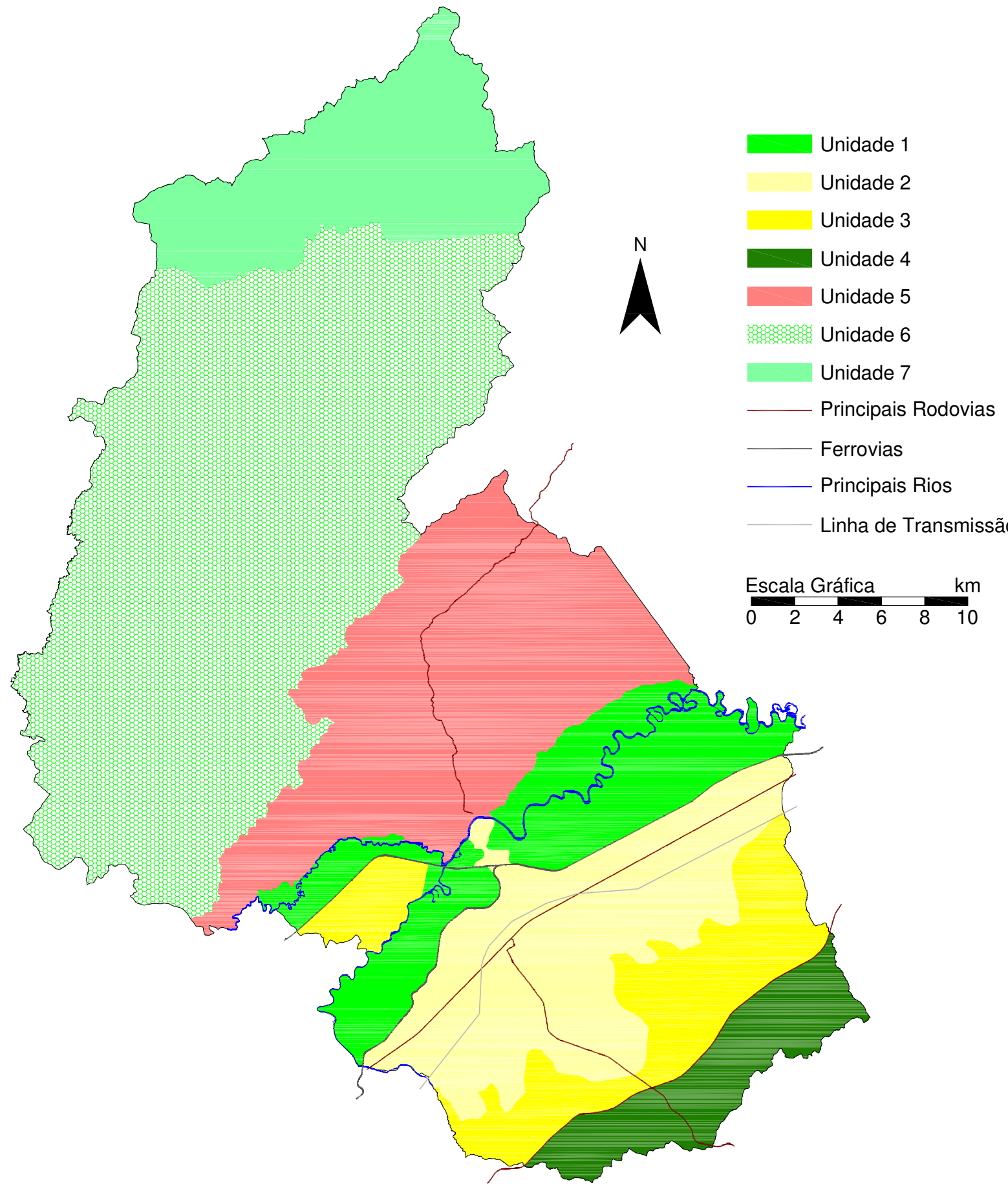

Figura 22 - Carta das Unidades Territoriais de Características Físicas e Antrópicas Homogêneas. Fonte: Caderno Diagnóstico PDDI-1995 (Digitalizado por Regina T. Reani). 
- Unidade 1: imprópria ao desenvolvimento urbano e à implantação de obras viárias, indicada para áreas agrícolas, com severas restrições de uso de agrotóxicos. Uso para lazer com restrições.

- Unidade 2: indicada para o desenvolvimento urbano intensivo, implantação de obras viárias. Restrição apenas quanto à ocupação dos fundos de vale, rejeitos sépticos, controle de emissões atmosféricas e fenômenos erosivos.

- Unidade 3: indicada ao desenvolvimento urbano. Com restrições quanto aos fundos de vale, cabeceiras de drenagem e encostas. Processos erosivos. Indicada também para o uso agrícola.

- Unidade 4: destinada à proteção de cabeceiras de drenagem, uso agrícola sem agrotóxicos, permite a silvicultura. Imprópria ao desenvolvimento urbano.

- Unidade 5: severas restrições ao desenvolvimento urbano devido às características geomorfológicas. Permite atividades de lazer e turismo, ocupação de baixa densidade, como chácaras. Permite, também, o uso agrícola.

- Unidade 6: imprópria ao desenvolvimento urbano, os terrenos devem ser destinados à proteção dos mananciais. Indicado o uso agropecuário, turismo e lazer.

- Unidade 7: absolutamente impróprias para o desenvolvimento urbano, devendo ser destinadas à proteção ambiental. Uso somente recreacional.

A partir da Carta das Unidades Territoriais, se estabeleceu o macrozoneamento urbano do município, dividindo-o em Macrozona Urbana, Macrozona de Expansão Urbana I e II, Macrozona Rural, e Área de Proteção Ambiental (APA) I, II, III e IV, sendo que a APA IV, está localizada dentro do perímetro urbano (Art. 16 e 17).

As Áreas de Proteção Ambiental (APAs) visam à proteção do meio ambiente, sendo que todas elas apresentam riscos geológicos graves e são inadequadas à ocupação urbana. A APA IV permite o uso urbano, mas com severas restrições.

O Plano apresenta um extenso diagnóstico ambiental, abordando estudos sobre resíduos sólidos, erosão urbana, cobertura vegetal, áreas verdes e arborização urbana. Aponta como meta programas de educação ambiental.

Destaca-se o problema econômico ambiental da exploração econômica mineral da areia no leito do Rio Paraíba do Sul. Esta exploração teve grande crescimento nas décadas de 1960 e 1970, com a construção do metrô em São Paulo, e as Rodovias Bandeirantes e Imigrantes. "A exploração é extremamente rentável para o setor privado, mas traz poucos 
lucros ao município e grandes danos ambientais" (PMSJC, 1995). O plano prevê a criação de um zoneamento minerário e a gestão integrada entre os municípios do Vale do Paraíba.

O Caderno do PDDI 1995 destaca demais problemas relacionados à ocupação do solo e à falta de cumprimento das leis pelo poder público; muitas das medidas previstas no Plano Diretor de 1971 e leis de uso do solo não foram efetivadas.

[...] o processo que definiu a atual configuração da cidade, não foi adequadamente acompanhado pelo poder público local, principalmente na última década em função da descontinuidade administrativa, apesar dos esforços de planejamento, coordenação de ações, planos setoriais e projetos urbanísticos oriundos do PDDI/70 e vários projetos setoriais elaborados até 1981 [...] Em função deste processo descontínuo, as ações de planejamento passaram a ter um papel mitigador, sempre defasado em relação às forças que produziam desestruturadamente a cidade. A exemplo disto, parte considerável da zona rural possui loteamentos clandestinos, bem como observa-se a ausência de espaços urbanizados adequados para abrigar pequenas e médias indústrias, faz com que estas continuem a se instalar em bairros residenciais, gerando conflitos de uso e limitando sua expansão. Tal situação, além das perversas relações sociais que refletem e reproduzem, implica também em entraves no desenvolvimento integrado da cidade (Caderno Diagnóstico do PDDI 1995, p. 97).

No intuito de minimizar o problema e realizar ações que possibilitem um melhor ordenamento do espaço e melhor uso do solo urbano, o plano previa a adoção de novos instrumentos da política urbana (Seção 2, Art. $22^{\circ}$, inciso VI) entre eles: parcelamento ou edificação compulsória (Art. 26 e 27), imposto predial e territorial progressivo no tempo (Art. 28 e 29), desapropriação (Art. 30), operações urbanas (Art. 31), operação interligada (Art. $32)^{21}$, zonas especiais de interesse social. No entanto, estes instrumentos não são viabilizados pela própria lei, e assim, os instrumentos que permitiriam reduzir a ação da especulação imobiliária e garantir a função social da propriedade urbana são postergados.

Durante o processo de discussão com o Legislativo, os agentes privados, ligados ao mercado imobiliário e à construção civil, fizeram sugestões para que os instrumentos de política urbana, especificamente o IPTU progressivo no tempo, o Parcelamento/Edificação Compulsórios e Desapropriação com o pagamento mediante títulos da divida pública, não fossem aplicados imediatamente após a aprovação do Plano. A alegação pautou-se na falta de regulamentação do Parágrafo

\footnotetext{
${ }^{21}$ Art. 32 - O Poder Público Municipal poderá promover mudanças urbanísticas referentes à ocupação e uso do solo definidos em lei, em troca de Habitação de Interesse Social - HIS ou equipamentos públicos definidos pelo órgão competente, ouvido o Conselho Municipal de Desenvolvimento Urbano, através do instrumento denominado "Operação Interligada".
} 
$4^{\text {o }}$, do Art.182, da Constituição Federal, que trata sobre a matéria (BOLOGNA, 2000, P. 77).

Há destaque também para a expansão urbana do município de forma desordenada, a malha urbana tem crescido sem planejamento, incorporando áreas tecnicamente inadequadas ao assentamento urbano, acarretando problemas de degradação do meio físico e expondo a população a riscos como: loteamentos em locais inadequados do ponto de vista geotécnico, aterro e ocupação de várzeas ao longo dos rios e córregos, expondo a população a inundações (Jd. Pararangaba, Vila Cristina, Vila Guarani), ocupação de morros e encostas (Vila São Bento, Vila Letônia, Jardim Guimarães). O caderno diagnóstico do plano ressalta ainda os problemas referentes a ordenação do uso do solo urbano, quanto à localização inadequada de algumas atividades, gerando muitas vezes conflitos de uso: - uso residencial x uso industrial: emissão de material particulado, odores, ruídos, - assentamento urbano em áreas de várzeas onde o uso destina essas áreas exclusivamente para uso agrícola, - conflitos de ocupação do solo das áreas de preservação permanente ao longo dos rios e córregos.

O PDDI discute ainda outro problema ambiental grave no município, que é a poluição e uso das águas. São José dos Campos utiliza como principal fonte de abastecimento as águas da Bacia do Rio Paraíba do Sul, porém, também aí são lançados os efluentes industriais e domésticos "in natura". O município coleta apenas $81 \%$ do esgoto doméstico e trata apenas 1,5\% do esgoto doméstico. Os rios e córregos urbanos, como Vidoca, Cambuí, Senhoria, entre outros, são altamente poluídos, praticamente mortos, pois recebem todo o esgoto da rede coletora da SABESP, e levam toda essa sujeira, como verdadeiras valas de esgoto a céu aberto, até o Rio Paraíba do Sul. Tal fato ainda favorece a proliferação de animais transmissores de doenças, como ratos, mosquitos, baratas, vetores da leptospirose, encefalite, hepatite, febre tifóide, entre outras.

O problema se torna ainda maior quando pensado em relação às demais cidades do Vale do Paraíba:

O problema da degradação dos recursos hídricos da Bacia do Paraíba do Sul, fica mais complexo a medida em que se dá o "lançamento de água a montante e a captação de água a jusante" pelos municípios situados às margens do rio Paraíba e seus afluentes. Este fato agrava-se devido as pequenas distâncias entre os pontos de lançamento e captação das redes urbanas, dificultando a auto-depuração da água e provocando como consequiência o acréscimo nos custos de tratamento da água a ser distribuída à população (Caderno PDDI 1995, p. 112). 
A disposição dos resíduos sólidos também é um problema para o município, uma vez que o aterro sanitário construído em 1986 possuía uma vida útil de 10 anos, e deste modo, na época da elaboração do novo plano, a vida útil do aterro já estava chegando ao fim. Neste mesmo ano, há a instalação de incinerador para o lixo hospitalar . O município apresentava diversos pontos de lixões em vários bairros, resíduos dispostos em margens de córregos e rios e vários locais sendo depositados entulhos de forma irregular. O plano não aponta nenhuma solução; são previstas somente medidas paliativas em relação aos problemas de infraestrutura urbana.

O município não apresentava poluição do ar grave, porém, o aumento na frota de veículos e o tráfego intenso na Rodovia Dutra têm aumentado a concentração de gases poluentes na atmosfera. A região leste, onde está localizada a Refinaria de Petróleo Henrique Lage, apresenta potencial de periculosidade (Caderno PDDI 1995).

Uma das medidas que o plano prevê para solucionar os problemas ambientais levantados é a educação ambiental. Neste sentido, a Prefeitura lançou em 1992 o "Programa de educação ambiental de "São José - Verde Limpa", que tinha como objetivo principal a coleta seletiva dos resíduos sólidos. Em 1994, foi lançado o Programa "Rio Paraíba: as relações sociedade-meio ambiente e as atividades espaciais", com atividades sobre o uso e ocupação do solo na Bacia Hidrográfica do Rio Paraíba do Sul, tendo como objetivo a proteção dos recursos hídricos. Porém, somente a Coleta Seletiva ganhou maior atenção no município, com o Projeto "Luxo do Lixo".

Quanto à questão da habitação, em 1974 foi realizada a primeira pesquisa para levantar o déficit habitacional do município. O objetivo era erradicar algumas favelas para viabilizar a execução de obras do sistema viário na área central e a construção do Paço Municipal. Assim, a desapropriação foi feita para a execução da Avenida Teotônio Vilela (Fundo do Vale) e foi concluído em 1976 o Conjunto Residencial Torrão de Ouro para atender parte da população da "favela da Linha Velha", porém, parte da favela ainda permanece no local.

Em 1978, o déficit habitacional era de 12.000 unidades, para famílias de renda até cinco salários mínimos. Com recursos públicos em 1979, foram construídos o Jardim Morumbi, Jardim Colonial e Bosque dos Eucaliptos, conhecido como Campo dos Alemães, uma área de 2.132.600,00 $\mathrm{m}^{2}$, e também o Conjunto Habitacional Nosso Teto do Putim, no Bairro Pernambucana. Em 1987, o déficit era de 13.700 famílias, de até três salários mínimos. Em 1990, foram construídos os Conjuntos Habitacionais D. Pedro I e D. Pedro II (com 3.777 
unidades). Em 1992, foi realizada a reurbanização da favela Vila Abel, área composta por 31 famílias. Em 1993, houve a ampliação do Conjunto Habitacional Nosso Teto (Putim).

No entanto, a intervenção do poder público ao longo de todo esse período foi marcada por ações pontuais não se configurando numa política habitacional que viesse a atender às necessidades do município. A demanda por habitação era muito maior que a oferta.

O Plano Diretor prevê a adoção de medidas para solucionar o problema da habitação, as quais seriam: criação de um conselho municipal de habitação, o fundo municipal de habitação e zonas de especial interesse social (ZEIS)

\footnotetext{
Art. 66 - São programas e projetos prioritários da Política Municipal de habitação: I - Construção de conjuntos habitacionais através de sistemas de mutirão, autoconstrução assistida tecnicamente por empreiteiras e sistema misto.

II - Produção de lotes urbanizados em áreas com infraestrutura urbana.

III - Recuperação física de áreas urbanas degradadas ocupadas por favelas, cortiços e loteamentos clandestinos e irregulares.

IV - Urbanização de favelas.

V - Elaboração e implantação do plano de regularização urbanística e fundiária em favelas, loteamentos clandestinos e irregulares.

VI - Criação do banco de terras destinado à habitação popular.

$[\ldots]$

IX - Elaboração de lei específica sobre habitação de interesse social.

XI - Criação e regulamentação das ZEIS.
}

Este novo plano coloca diretrizes que buscam traçar uma nova política de habitação, que inclui instrumentos novos, que procuram fazer cumprir a função social da propriedade. A questão da habitação é um problema grave no município e vem gerando vários danos sociais e ambientais, através do aumento no número de loteamentos clandestinos na área rural e áreas de proteção ambiental.

O PDDI de 1995 avança muito em relação ao Plano de 1971, com uma maior abertura política e gestão democrática. Há uma maior preocupação com as questões ambientais e sociais. São adotados novos instrumentos de política urbana. Porém, algumas questões ainda são discutidas de forma superficial, como o caso do tratamento do esgoto e a poluição dos córregos urbanos, sendo que muitas das medidas previstas, infelizmente se limitam ao plano teórico, na prática as mudanças foram poucas. Vê-se, porém, que nos últimos 24 anos que antecedem ao PDDI-1995, a cidade cresceu sem atender as normas previstas no Plano Diretor de 1971, os problemas persistem, como a falta de tratamento de esgoto, a proliferação dos loteamentos clandestinos, aumento das favelas e déficit habitacional. Muitos dos programas e planos previstos ficam somente no papel. 


\subsubsection{O Plano Diretor de 2006}

\section{(Lei Complementar no 306 de 17 de novembro de 2006)}

Passados onze anos da elaboração do último plano diretor, tem início a elaboração de um novo Plano Diretor de Desenvolvimento Integrado para o município. Para tanto, foi elaborado o Caderno Diagnóstico do Município, com 105 páginas, contendo mapas, tabelas, gráficos, dados e informações sobre São José dos Campos. Este caderno diagnóstico foi apresentado e discutido em quatorze audiências públicas, realizadas em diversas regiões da cidade.

Estas quatorze primeiras audiências públicas foram realizadas no mês de fevereiro de 2006, e contaram com a participação de aproximadamente 150 pessoas por audiência, sendo que foram coletadas 1.409 sugestões dadas pela população (PMSJC, Relatório Síntese, $1^{\text {a }}$ audiência, 2006) $)^{22}$.

Num segundo momento, foram realizadas mais quatro audiências públicas, que aconteceram em apenas uma semana, de 11 a 17 de setembro de 2006. Porém, estas últimas audiências ocorreram agora na Câmara dos Vereadores, centralizando as decisões, onde foram apresentadas as diretrizes para a elaboração do Plano Diretor e não o Projeto de Lei em si, o que está em desacordo com as normas de gestão participativa, onde o projeto de lei deveria ter sido discutido.

No decorrer destas quatro audiências finais, parte dos presentes apresentou muitas reclamações, como o fato de as reuniões não estarem mais ocorrendo nos bairros e a pressa em se finalizar o Plano Diretor, pois, "foram esperados 10 anos para se fazer o novo plano e este contém diretrizes para os próximos 10 anos, ou seja, para o futuro da cidade, e está sendo realizado com tanta pressa, em menos de um ano" (PMSJC, Relatório Síntese, $1^{\mathrm{a}}$ audiência, 2006). Os participantes reclamam ainda que a maioria das sugestões dadas nas audiências da primeira fase não foi incorporada na proposta do plano em discussão. Outra reclamação foi quanto à demora na resposta e prosseguimento das audiências, uma vez que as primeiras audiências foram realizadas em fevereiro e a segunda fase de audiências e discussões só foi retomada em setembro.

Após dois meses das últimas audiências, o Plano já estava pronto e aprovado. A Lei Complementar $n^{\circ} 306$, que institui o novo Plano Diretor de Desenvolvimento Integrado, foi aprovada em 17 de novembro de 2006, sendo que muitas das questões colocadas pela sociedade não foram atendidas.

\footnotetext{
22 Disponível em: <http://www.sjc.sp.gov.br/media/24529/1a\%20reuniao_fase2.pdf>. Acesso em: 27 de jul de 2011.
} 
Fazendo uma leitura do Caderno Diagnóstico, pode-se observar que vários problemas urbanos e ambientais antigos persistem em São José dos Campos. O Caderno diagnóstico está dividido em oito capítulos. O Capítulo 1 apresenta os princípios e objetivos do Plano Diretor de Desenvolvimento Integrado, os Capítulos 2 e 3 desenvolvem uma caracterização geral do município, desde os aspectos demográficos, desenvolvimento humano e história da cidade.

O Capítulo 4 discute a Organização Territorial; o Capítulo 5, Desenvolvimento Econômico; o Capítulo 6, o Desenvolvimento Social; o Capítulo 7, o Desenvolvimento Urbano-Ambiental, e por fim, o Capítulo 8, o Monitoramento e Controle do Plano Diretor.

Ao discutir a Organização Territorial do município, é utilizada a Caracterização do Município realizada através das Cartas das Unidades Territoriais desenvolvidas pelo INPE e IPT no plano de 1995, utilizando assim, a mesma base técnico-científica.

O problema dos loteamentos clandestinos é destacado novamente em 2006. A área rural do município possui terreno acidentado e pouco fértil, sendo utilizado para a pecuária leiteira e cultivo do eucalipto. $\mathrm{O}$ enfraquecimento econômico do setor primário propiciou uma ociosidade das terras rurais. Este fato, aliado ao grande crescimento demográfico de São José dos Campos, à falta de uma política habitacional e ao alto custo das terras urbanas, acarretaram grande especulação imobiliária nas terras rurais, contribuindo para 0 parcelamento irregular do solo e grande número de loteamentos clandestinos.

No item Desenvolvimento Econômico, há destaque para o incentivo ao empreendedorismo no município, com a criação de órgãos e associações de auxílio ao empreendedor. Houve incentivo para a abertura de novas empresas, melhoria na infraestrutura da cidade, ampliação das redes de fibra óptica e gás natural, a transformação do aeroporto para terminal internacional de cargas e melhoria no sistema viário, o que contribuiu para retomada no crescimento da cidade. Diminuindo os impactos da crise do final dos anos 1980 e início dos anos 1990, quando houve uma demissão em massa nas indústrias bélicas, automobilística e aeronáutica, a cidade sofreu com o desemprego, falta de renda e fechamento de vários estabelecimentos.

Com estes incentivos e melhoria na infraestrutura, houve crescimento no setor de comércio e serviços, pequenas e médias empresas, grandes redes, como Shoppings, hotéis, hipermercados, estabelecimentos de ensino técnico e superior, e aquecimento do mercado imobiliário e da construção civil. No entanto, o Município ainda tem sua economia fortemente apoiada no setor industrial.

No item Desenvolvimento Social, há destaque ao problema na habitação. O caderno destaca ações do poder público através da construção de conjuntos habitacionais e programas 
que visam retirar as favelas do município, e também, projetos de regularização fundiária que buscam regularizar os inúmeros loteamentos clandestinos existentes na cidade. No total, o município possui, segundo o PDDI-2006, 94 loteamentos clandestinos. Em relação à educação, o município apresenta um déficit de 5.916 vagas na educação infantil. Há destaque ao papel desempenhado pela FUNDHAS (Fundação Hélio Augusto de Souza), uma fundação do governo municipal que tem como objetivo o atendimento social a crianças e adolescentes carentes, com diversos projetos sociais. A Fundação atende 8.000 crianças e adolescentes e possuiu uma lista de espera de 12.000 interessados.

Quanto ao Desenvolvimento Urbano-Ambiental, é apresentada a caracterização geral de cada uma das regiões administrativas da cidade: Região Norte, Região Centro, Região Leste, Região Sul, Região Sudeste, Região Oeste e São Francisco Xavier, onde são levantados os problemas sociais e ambientais de cada uma das regiões, dando se destaque à questão dos loteamentos clandestinos e a existência de APA na região.

O sistema de abastecimento do município atende a $100 \%$ da área urbanizada composta pelos loteamentos regulares. Quanto aos loteamentos clandestinos, dos 94 existentes, apenas 32 estão servidos com rede de água. Já o sistema de esgotamento sanitário, apresenta dados bem diferentes. Houve avanço de 1995 para 2005; o percentual de esgoto tratado é de 45\%. Porém, para uma cidade tão desenvolvida como São José dos Campos essa porcentagem de esgoto tratado ainda é baixa. O plano coloca que está prevista a construção de uma nova estação de tratamento de esgoto, a Estação de Reversão da Bacia do Vidoca, e que com esta obra, o percentual de esgoto tratado passaria para $85 \%$. Porém, a obra estava prevista para ser finalizada em 2008, e somente foi entregue no final de 2011. Ainda neste tema, outro problema que se destaca é o fim da vida útil do aterro sanitário e a falta de definições para a resolução do problema.

O Caderno Diagnóstico é finalizado com a apresentação de um resumo dos impasses urbanos que serão focados no Plano Diretor. Destaca-se aqui os principais problemas relacionados ao tema deste trabalho, são eles:

\footnotetext{
- A ocupação descontínua das áreas de expansão urbana vem promovendo um distanciamento da infraestrutura, aumentando os custos de manutenção da Cidade e estabelecendo um processo de periferização.

- A utilização de um coeficiente de aproveitamento alto, em média três, permitido na quase totalidade da Cidade, possibilita que o processo de verticalização adense locais inadequados sob a ótica da infraestrutura urbana, propiciando a saturação do sistema viário, da ocupação de áreas ambientalmente frágeis, comprometendo a paisagem, o conforto ambiental urbano, e a descaracterização dos bairros residenciais.

- Ineficiência de critérios para coibir a ocupação inadequada dos fundos de vales, várzeas e áreas de recarga de aqüíferos.
} 
- O modelo atual de ocupação urbana no Município envolve altas taxas de impermeabilização, não considera os limites de sustentabilidade do sistema hídrico superficial e subterrâneo em especial, quanto à permeabilidade do solo.

- Implantação de loteamentos com tamanhos de lotes inadequados em relação à topografia.

- Ausência de critérios que garantam a proteção efetiva dos bosques e matas remanescentes públicos e privados.

Diante da caracterização e diagnóstico realizado, será feita a análise das diretrizes e normas estabelecidas no Plano Diretor de Desenvolvimento Integrado de 2006, dando maior atenção às questões sociais e ambientais, que são foco deste trabalho.

O PDDI segue a mesma estrutura do Caderno Diagnóstico, sendo que os capítulos que compõem o caderno diagnóstico foram colocados como sendo os capítulos em que se divide o Plano Diretor, com algumas alterações: Capítulo I - Princípios e Objetivos Gerais; Capítulo II - Organização Territorial (Macrozoneamento Territorial e Setorização Urbana); Capítulo III Política de desenvolvimento econômico (Desenvolvimento Econômico, Ciência e Tecnologia, Inovação e Qualificação Profissional; Indústria, Comércio, Serviços e Construção Civil; Rural, Turismo e Finanças), Capítulo IV - Desenvolvimento Social (Habitação, Saúde Pública, Educação, Esporte e Lazer, Cultura, Assistência Social, Serviços Públicos), Capítulo V - Desenvolvimento Urbano-Ambiental (Plano de Estruturação Urbana - PEU, Meio Ambiente, Transporte Público, Saneamento Ambiental, Sistema Viário, Macrodrenagem Urbana, Áreas Verdes e dos Sistemas de Lazer, Uso e Ocupação do Solo, Instrumentos da Política Urbana), Capítulo VI - Sistema Municipal de Informação e Capítulo VII - Controle e Revisão do Plano Diretor de Desenvolvimento Integrado.

No macrozoneamento, é dada continuidade ao Plano de 1995, porém são feitas modificações e incluída uma nova área de proteção, a Zona de Amortecimento da Reserva Florestal Augusto Ruschi - ZA-RFAR.

O PDDI apresenta várias normas e diretrizes visando ao desenvolvimento econômico da região, como a necessidade de aumentar a competitividade regional, estimular o surgimento de novos negócios, consolidar a posição do município como polo tecnológico, fortalecer e difundir a cultura empreendedora, consolidar a implantação do parque tecnológico, criar novo polo de desenvolvimento industrial ao longo da Rodovia Carvalho Pinto. Assim, existe uma longa lista de diretrizes em relação ao desenvolvimento econômico, muitas vezes se sobrepondo este ao desenvolvimento social e ambiental.

No que tange ao Desenvolvimento Rural, é apontada a importância em incentivar o pequeno agricultor e a agricultura familiar, e assim, a propriedade rural, bem como o uso de técnicas sustentáveis. Há incentivo ao desenvolvimento do turismo e à elaboração de um guia 
de turismo ambiental do município, e também, desenvolver o turismo aeroespacial, tecnológico, rural, ecológico e de negócios.

O Capítulo IV aborda a questão do Desenvolvimento Social, em que é colocada como diretriz a necessidade de incentivar a construção de unidades habitacionais para a população de baixa renda pela iniciativa privada. Quanto ao problema dos loteamentos clandestinos e favelas, são previstas as seguintes medidas:

\footnotetext{
$\mathrm{V}$ - estabelecer normas especiais de urbanização, de uso e ocupação do solo e de edificações para assentamentos de interesse social, regularização fundiária e urbanização de áreas ocupadas por população de menor renda;

VI - fortalecer a Política de Controle e Fiscalização dos loteamentos clandestinos e irregulares;

VII - continuar o processo de regularização fundiária e urbanização das áreas de assentamentos subnormais, adequando-as aos parâmetros urbanísticos e ambientais estabelecidos; e,

VIII - continuar o programa de formação de um banco de terras destinado à Política Habitacional do Município.

IX - promover a regularização fundiária de favelas localizadas em terrenos estaduais e federais, visando a execução de projeto de parcelamento e à titulação dos moradores;

$\mathrm{X}$ - promover o recenseamento, preferencialmente em área próxima ao local de origem, dos moradores das áreas de risco e das destinadas a projetos de interesse público ou dos desalojados por motivo de calamidade.
}

Não existe aprofundamento quanto a essas diretrizes habitacionais. As medidas são colocadas de forma bastante sucinta, não ficando claro de que maneira estas serão efetivadas na prática.

O Capítulo V trata do Desenvolvimento Urbano-Ambiental. Para garantir o desenvolvimento urbano-ambiental do município, foi instituído o Plano de Estruturação Urbana - PEU, que visa ordenar o desenvolvimento físico-territorial da cidade, estabelecendo um conjunto de diretrizes e projetos relativos ao Meio Ambiente, Transporte Público, Saneamento Ambiental, Estruturação Viária, ao Sistema de Macrodrenagem Urbana, ao Sistema de Áreas Verdes e de Lazer e ao ordenamento do parcelamento, uso e ocupação do solo, incluindo os aspectos relativos aos instrumentos de Política Urbana (PDDI, 2006).

Um importante item previsto no PEU-PDDI é a elaboração de uma Agenda 21 local e também, a reformulação e valorização do Conselho Municipal de Meio Ambiente. É prevista a elaboração de inventário das principais fontes fixas de poluição do ar, da água e dos resíduos sólidos instalados no município. O Plano prevê ainda regulamentar o Fundo Municipal de Conservação Ambiental -FUMCAM e reforçar a fiscalização ambiental, consolidar e ampliar a Guarda Ambiental prevista na legislação municipal. O Plano traz ainda como diretriz realizar estudo investigativo da ocorrência de ozônio em São José dos Campos e 
região, indicando, se necessário, planos de controle visando à qualidade do ar, bem como, promover a implantação de parques lineares, de lazer e/ou ecológicos.

No entanto, praticamente nenhuma dessas medidas previstas foi efetivada. A Agenda 21 Local não foi elaborada. Não foi feito o inventário das fontes fixas de poluição e nem mesmo o estudo investigativo da ocorrência de ozônio. O município não possui guarda ambiental, apenas fiscais ambientais, sendo que em 2005 existia apenas 1 fiscal e agora existem 3, ou seja, o número da guarda ambiental ainda é muito baixo. Quanto ao Conselho do Meio Ambiente, houve um aumento no número de integrantes, porém, em entrevista com a ONG CAMIN, foi informado que o Conselho está cada vez perdendo mais força, e o FUNCAM não foi viabilizado.

Em relação ao saneamento ambiental, são colocadas como principais medidas a implantação do emissário do Ribeirão do Vidoca até a Estação Elevatória Vidoca e demais obras que ampliem o abastecimento de água e a coleta de esgoto. Quanto aos resíduos sólidos, é previsto a ampliar o aterro sanitário municipal, ampliar a coleta seletiva de lixo, reconhecer e regulamentar a catação ambulante de materiais recicláveis no município.

O PDDI-2006 ressalta o papel dos Recursos Hídricos no município, desenvolvendo um plano de macrodrenagem urbana, buscando estabelecer um plano de uso e ocupação do solo das bacias hidrográficas, visando minimizar os problemas de impermeabilização do solo e proteção dos fundos de vales e córregos urbanos e melhor controle do escoamento das águas pluviais. Para tanto, cria o mapa de macrodrenagem urbana (mapa 6) e determina as zonas de domínio dos cursos d'água, planície aluvionar, pontos de retenção e áreas de controle a impermeabilização.

Ao abordar o tema áreas verdes, o PDDI prevê implantar áreas de lazer e recreação ao longo dos cursos d'água e das Áreas de Preservação Permanentes, e ainda, promover o aumento do índice de áreas verdes por habitante. Conforme o mapa 07, anexo ao Plano Diretor de 2006, estava prevista a criação de 15 parques urbanos em São José dos Campos. No entanto, somente um foi efetivado (Parque Senhorinha) e dois apenas parcialmente (Parque Paraíba do Sul e Parque Cambuí). Os outros doze parques urbanos previstos no PDDI 2006 não foram colocados em prática.

Quanto aos instrumentos da política urbana, é prevista a utilização de apenas alguns dos instrumentos estabelecidos pelo Estatuto da Cidade, como outorga onerosa do direito de construir, transferência do direito de construir, direito de preempção, zonas especiais de interesse social, operações urbanas consorciadas, estudo de impacto de vizinhança. Muitos dos importantes instrumentos de política urbana que visam a uma cidade mais justa e 
equitativa e que garantem a função social da propriedade urbana não foram acatados pelo PDDI, como o parcelamento, edificação ou utilização compulsórios, o IPTU progressivo no tempo, usucapião especial de imóvel urbano. Como aponta Lobão (2007, p. 355):

\begin{abstract}
No entanto, não há no Plano Diretor nem mesmo a delimitação das áreas onde os instrumentos poderão ser aplicados, tornando a inclusão dos instrumentos no plano, mera formalidade. Fica definido aplicação dos instrumentos previstos no PDDI2006 dependerá da regulamentação de legislação específica, conforme previsto no Estatuto da Cidade, ou Lei de uso, ocupação e parcelamento do solo que trate das disposições requeridas; mas não é feita nenhuma menção ao prazo estabelecido para a regulamentação destas leis.
\end{abstract}

A inclusão dos instrumentos de política urbana no PDDI de 2006 sem a definição dos mecanismos para sua implementação, não traz grandes avanços ao processo de planejamento urbano do município. O poder público municipal não avança no sentido de regulamentar um controle mais efetivo sobre o processo de produção e apropriação do espaço urbano, que possibilite o combate à especulação imobiliária e promova a ocupação dos vazios urbanos e o aumento da oferta de terras e moradias à população de baixa renda. Assim, ao postergar o estabelecimento dos instrumentos de política urbana, o município deixa de assumir, ao menos temporariamente, os princípios constitucionais contidos no Estatuto da Cidade (LOBÃO, 2007).

Cabe salientar a grande quantidade de vazios urbanos existente no município, que pouco é discutido no Caderno Diagnóstico, e não é nem mencionado no PDDI, como também a expansão dos condomínios horizontais fechados que levam à segregação urbana e obstruem o fluxo de passagem de veículos e pessoas. Tais problemas não são mencionados no PDDI2006.

Neste sentido, em relação ao PDDI de 1995, este novo Plano Diretor traz poucas mudanças. Como aspecto positivo, destaca-se o fato de utilizar a mesma base técnica e científica do plano anterior, como o uso das Cartas das Unidades Territoriais e manter em linhas gerais o mesmo macrozoneamento territorial. Porém, o PDDI de 2006 pouco avança do ponto de vista social e ambiental, não estabelecendo normas e prazos específicos para a realização dos problemas antigos enfrentados pelo município, como é o caso dos loteamentos clandestinos.

Uma vez que este plano foi elaborado após a aprovação do Estatuto da Cidade, o seu conteúdo fica aquém das expectativas. Os instrumentos de política urbana que deveriam ser seguidos pela população, e também, as diretrizes que deveriam ser seguidas pelo poder público não são aplicáveis a partir da aprovação do PDDI, pela ausência de dispositivos que obriguem sua implementação. Como aponta Lobão (2007, p. 358), "grande parte das 
diretrizes que apresenta são inócuas, apenas indicando 'possibilidades' futuras". Assim, o PDDI deixa a desejar, quando não aponta propostas de intervenção e previsão de recursos legais e financeiros para a implementação de propostas. Neste sentido, este novo PDDI de São José dos Campos não avança no sentido de incorporar as inovações do Estatuto da Cidade, mantendo os vícios dos planos elaborados anteriormente.

\title{
5.2. Zoneamento urbano: legislação de parcelamento, uso e ocupação do solo do município de São José dos Campos
}

\begin{abstract}
"O zoneamento é a operação feita sobre um plano de cidade com o objetivo de atribuir a cada função e a cada indivíduo seu justo lugar. Ele tem por bases a discriminação necessária entre as diversas atividades humanas, cada uma das quais reclama seu espaço particular: locais de habitação, centros industriais ou comerciais, salas ou terrenos destinados ao lazer. Mas se a força das coisas diferencia a habitação rica da habitação modesta, não se tem o direito de transgredir regras que deveriam ser sagradas, reservando só para alguns favorecidos da sorte o beneficio das condições necessárias para uma vida sadia e ordenada. É urgente e necessário modificar certos usos. É preciso tornar acessível para todos, por meio de uma legislação implacável, uma certa qualidade de bem-estar, independente de qualquer questão de dinheiro. É preciso impedir, para sempre, por uma rigorosa regulamentação urbana, que famílias inteiras sejam privadas de luz, de ar e de espaço" (CARTA DE ATENAS, 1933, p.08).
\end{abstract}

O zoneamento urbano se coloca como uma das principais políticas urbanas do país e uma das únicas formas de planejamento adotado pelas cidades brasileiras. São José dos Campos, como a maioria das cidades brasileiras, adota o zoneamento funcional, segundo os princípios do urbanismo moderno, como descrito na Carta de Atenas. Muitas vezes, esse zoneamento é desigual e segregacionista.

Na sequência será feita a análise das leis de zoneamento do município de São José dos Campos, procurando destacar os principais problemas relacionados às questões ambientais e as medidas apontadas para a solução destes problemas.

\subsubsection{Ato n ${ }^{0} 110$ de 1932 e Código de Obras de 1954}

Em 1932, São José dos Campos já possuía política de zoneamento, estipulada pelo Ato nº110 (LESSA, 2008; OLIVEIRA, 1999), que dividia a cidade em três zonas: sanatorial, 
residencial, comercial. Essa política foi revista em 1936, e a cidade ganhou uma nova zona: a zona industrial. No entanto, esse zoneamento foi consolidado somente em 1954, quando é implementado o Código de Obras do Município, através da lei $\mathrm{n}^{\circ} 281^{23}$, em 11 de janeiro. Tal legislação tinha, entre seus objetivos, ordenar o espaço urbano, proteger a população dos enfermos contaminados pela tuberculose, como também dos danos causados pelas indústrias que se instalavam no município.

O Código de Obras de 1954 dispõe sobre construções, abertura de ruas e loteamento. Traz as normas e diretrizes para o crescimento da cidade, colocando regras para a construção de moradias, loteamentos e edifícios.

O Capítulo VII das “Zonas, Bairros e Núcleos” estipula o zoneamento do município:

\begin{abstract}
Art. 162. O Município será subdividido em zona urbana e suburbana e rural.
Art. 163. As zonas urbanas e suburbanas da cidade serão subdivididas em: Zona Industrial; Zona Comercial; Zona Residencial; Zona Sanatorial; Zona Aeronáutica. Art. 164. Em nenhuma das Zonas Industrial, Comercial ou Residencial, será permitida a instalação de sanatórios, pensões sanatoriais e congêneres destinadas a manter pessoas de moléstia contagiosa.

Art. 165. Os perímetros das zonas e dos bairros serão fixados por ato do Prefeito e revestidos periodicamente.

Art. 168. Na Zona Industrial não são permitidos estabelecimentos hospitalares, colégios, asilos e indústrias perigosas e nocivas, ou incômodas.

Parágrafo único. As indústrias perigosas, nocivas, incômodas, os matadouros e entrepostos de inflamáveis e explosivos, serão localizados em núcleos de mercados na zona rural ou suburbana.

Art. 169. Nos bairros industriais a ocupação do lote não poderá ultrapassar 70\% (setenta por cento) da área total.
\end{abstract}

Com esta lei, é instituída a zona urbana e zona rural do município, porém a mesma passa a estar sujeita aos atos do Prefeito. Passa a existir um novo zoneamento, a Zona Urbana é dividida em: zona residencial, zona comercial, zona industrial, zona sanatorial e zona aeronáutica, sendo que esta última está diretamente ligada ao CTA. Na Zona Industrial, é determinado que as indústrias perigosas fossem localizadas na área rural. Neste sentido, vê-se preocupação quanto ao ordenamento da cidade e a separação das indústrias poluidoras da área residencial, porém, neste momento, ainda não há políticas que pensem no meio ambiente. No mais, a lei não apresenta mapa ou descrição detalhada quanto à delimitação entre a zona rural e urbana, e também, quanto aos limites entre as zonas urbanas, estando subordinada aos atos do prefeito.

\footnotetext{
${ }^{23}$ Esta Lei foi revogada pelo art. $4^{0}$ da Lei Municipal no 1.578 , de 07.10.1970
} 


\subsubsection{Zoneamento de Massa e Plano Diretor 1961}

O Plano Diretor de 1961 estipulou o zoneamento de massa e propôs uma nova divisão do município em zona residencial, zona industrial e áreas verdes. O conteúdo deste novo zoneamento já foi discutido juntamente com o estudo do Plano Diretor. Cabe destacar o fim da zona sanatorial, a não diferenciação entre a zona comercial e residencial, e do ponto de vista ambiental, um grande passo é a incorporação de áreas verdes. Como já colocado anteriormente, esta política urbana segue os princípios do urbanismo moderno, da Carta de Atenas.

A Carta de Atenas coloca como princípio do urbanismo moderno as quatro principais funções da cidade: Habitar, Circular, Trabalhar e Recrear. Para tanto, coloca que é fundamental que haja o descongestionamento da área central das cidades, o aumento das densidades, o aumento dos meios de circulação e aumento das áreas verdes. Essas idéias foram difundidas em diferentes partes do mundo e incorporadas em diversos planos urbanísticos em várias cidades.

Assim, o urbanismo moderno preconizava a cidade funcional, o desenho urbano, de modo a garantir um ordenamento, uma cidade salubre, uma espacialização das atividades de trabalho, de lazer, de habitação e a circulação de maneira a se alcançar um ordenamento do seu espaço. Havia uma grande preocupação com a forma urbana e com o planejamento físicoterritorial. As críticas apontam o urbanismo moderno como um planejamento tecnocrata, com um rígido zoneamento funcional das atividades. O Homem não era entendido em sua individualidade.

Pode-se perceber ao longo do estudo das diferentes leis de zoneamento de São José dos Campos, que este zoneamento funcional se faz presente, sendo que muitos dos seus princípios e idéias permanecem até hoje no zoneamento da cidade.

\subsubsection{Leis municipais $n^{\circ} 1.575 / 70, n^{0} 1.576 / 70, n^{\circ} 1.578 / 70$ - Parcelamento, uso do solo e zoneamento}

As leis municipais $\mathrm{n}^{\mathrm{o}} 1575^{24}$ e $\mathrm{n}^{\mathrm{o}} 1576^{25}$, ambas de 25 de setembro de 1970 , versam também sobre a questão do ordenamento do espaço urbano. A primeira trata das penalidades referentes ao descumprimento às prescrições do Código de Edificações, da Lei de

\footnotetext{
${ }^{24}$ Esta Lei foi revogada pelo art.216 da Lei Complementar n²67, de 16.12.2003.

${ }^{25}$ Esta Lei foi revogada pelo art. 69 da Lei Municipal no 2.263, de 04.01.1980.
} 
Loteamentos e da Legislação sobre uso do solo e zoneamento. Já a segunda trata das diretrizes a serem observadas pelos loteamentos urbanos e incorpora princípios urbanísticos:

\footnotetext{
CAPÍTULO II - DOS REQUISITOS URBANÍSTICOS PARA LOTEAMENTO

Art. $4^{\circ}$ Os loteamentos deverão atender, pelo menos, aos seguintes requisitos:

I - as Áreas destinadas a sistema de circulação, equipamento comunitário, bem como os espaços livres de uso público, serão no mínimo de trinta e cinco por cento (35\%) e, no máximo, de cinquenta por cento (50\%) do total da gleba;

II - à margem de águas correntes e dormentes, de faixas de domínio público de rodovias e dutos, serão reservadas faixas com largura estabelecida na legislação competente, nunca inferior a 15 (quinze) metros;

III - as vias do loteamento deverão articular-se com o sistema viário e harmonizarse com a topografia local;

IV - deverão ser destinadas áreas às:

a) vias de trafego e de passagens de canalização públicas, de esgotos e de águas pluviais nos fundos de vales;

b) passagem de canalizações públicas de esgotos e de águas pluviais, com largura mínima de dois metros nos fundos dos lotes, cujo desnível seja superior a um metro da frente aos fundos;

c) escola pública.

Art. $5^{\circ}$ A Prefeitura poderá exigir em cada loteamento reserva de faixa "non aedificandi" para rede de água, serviço de esgotos, energia elétrica, coleta de águas pluviais, rede telefônica ou outro equipamento urbano.

Art. $6^{\circ}$ Não serão admitidos loteamentos em terrenos alagadiços e sujeitos a inundações e onde as condições geológicas não sejam propicias à edificação.
}

Vê-se que há um grande avanço nessa legislação, colocando requisitos urbanísticos mínimos aos loteamentos e dando maior atenção ao meio ambiente, principalmente em relação à questão dos recursos hídricos, estabelecendo faixa não edificante de 15 metros à margem de águas correntes e dormentes.

Já a Lei no $1578^{26}$ de sete de outubro de 1970 dispõe sobre o Código de Edificações do Município de São José dos Campos. A lei é posterior às duas citadas anteriormente, embora essas anteriores regulamentem a lei $\mathrm{n}^{\circ}$ 1578. A nova lei avança no sentido de colocar normas e diretrizes para a construção de novos loteamentos, sendo mais exigente que a legislação $\mathrm{n}^{\circ}$ 281/54, principalmente quanto ao tamanho do lote e dimensões do compartimento, e também, quanto à construção de depósitos e indústrias.

\subsubsection{A Lei de Zoneamento Urbano de 1971}

\section{(Lei Municipal n⿳1.606 de 1971)}

A Lei n ${ }^{\circ} 1606$ de 13 de setembro de 1971 é considerada a primeira lei de zoneamento urbano do município de São José dos Campos, sendo elaborada em acordo com o Plano Diretor, Lei nº1623 de 1971. O Plano Diretor foi elaborado pela empresa SERETE S.A., cujos

\footnotetext{
${ }^{26}$ Esta Lei foi revogada pelo art. 320 da Lei Municipal no 3.039 , de 01.11.1985.
} 
estudos preliminares se iniciaram em 1968 e serviram de base para a elaboração da lei de zoneamento, que foi aprovada dois meses antes da Lei do Plano Diretor. É importante destacar que tanto o Plano Diretor, quanto a Lei de Zoneamento foram desenvolvidos e promulgados no auge da ditadura militar, um período de fechamento político, práticas antidemocráticas e grande repressão.

A lei de zoneamento urbano avança em relação à legislação existente até o momento, criando um novo padrão de organização territorial e colocando novos rumos para o crescimento urbano de São José dos Campos.

O município é dividido em área urbana, área de expansão urbana e área rural conforme o Artigo $1^{\text {o: }}$

\footnotetext{
Art. $1^{\circ} \mathrm{O}$ Município de São José dos Campos, para efeito de uso do solo e edificações, fica dividido em:

I - área urbana, assim considerada aquela que possuir os equipamentos mínimos exigidos pela legislação federal de modo que a afetem à destinação urbana.

II - área de expansão urbana, aquela que continuada à área urbana ofereça tendência e condições de ocupação às atividades urbanas,

III - área rural, assim considerada aquela que, por sua natureza e pelos equipamentos oferecidos ou propostos, se destine às atividades tipicamente rurais, nos termos da legislação federal.

Parágrafo único. A delimitação dos perímetros das áreas a que se refere este artigo será fixada por Lei Municipal, observadas suas respectivas peculiaridades.
}

A inclusão da área de expansão urbana no planejamento urbano de São José dos Campos é muito positiva, no sentido de orientar o crescimento da cidade e produzir a melhor organização do espaço, porém o seu estudo foi mal dimensionado, a população acabou crescendo mais do que era previsto, além do fato de a legislação considerar a várzea do Rio Paraíba do Sul como área de expansão, o que felizmente acabou não acontecendo.

A área urbana, por sua vez, foi dividida conforme o Artigo $4^{\circ} \mathrm{em}$ :

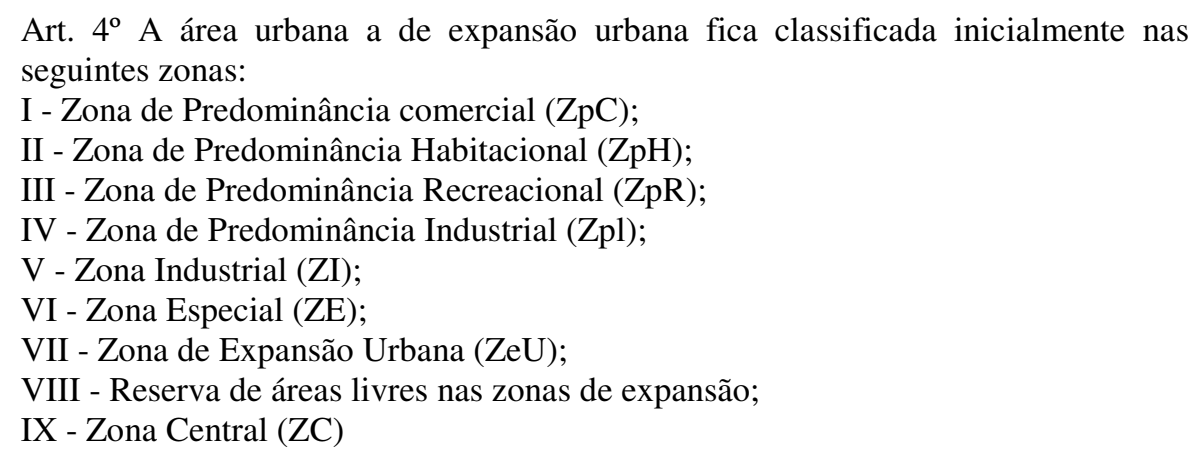

Vê-se, assim, que a área urbana passa a ter uma maior divisão no número de zonas do que nas políticas anteriores, deixando mais delimitados e especificados, os diferentes usos do solo no espaço urbano. A Zona de Predominância Habitacional ( $\mathrm{ZpH})$ se subdivide em ZpHA e $\mathrm{ZpHB}$, e estas se diferenciam pelo tamanho do lote, sendo que a $\mathrm{ZpHA}$ possui lotes maiores, 
destinada à classe média e alta, e a ZpHB, são lotes menores. Pela primeira vez, diferenciouse uma zona residencial, e esta segregação prevalece até os dias atuais. $\mathrm{Na} \mathrm{ZpH}$, é permitido o uso de atividades comerciais e serviços, como consultórios, salão de beleza, teatros, cinemas etc. Assim, vê-se que o zoneamento proposto não apresenta zona de uso exclusivo residencial, rompendo de certa forma com a idéia do zoneamento funcionalista.

As Zonas Especiais (ZE) são áreas de instalação de edifícios públicos ou serviços especiais. A concha do Banhado, é também, classificada como Zona Especial, passando a ser protegida. Assim, a lei 1.606/71 teve o mérito de impedir ações que pudessem descaracterizar essa região, o que veio a se tornar uma das áreas mais significativas para a população de São José dos Campos. As Zonas de Predominância Recreacional (ZpR), compreendem as áreas verdes e livres destinadas à recreação. No entanto, não possuem limites definidos e não são especificadas, existindo somente na teoria.

Por meio da distribuição das zonas de uso, vê-se que mais da metade do município, $65 \%$, é considerado zona industrial. Fica evidente a sua vocação industrial e o planejamento voltado principalmente para o setor econômico. O Estado intervém de modo a criar um polo industrial.

A preocupação com as indústrias poluidoras permanece nesta nova legislação, sendo colocadas na zona rural da cidade, como aponta o Artigo $7^{\circ}$ :

$\S 1^{\circ}$ São consideradas nocivas ou perigosas, as indústrias que produzem mau cheiro, ruídos incômodos, poluem água, ponham em risco a saúde dos habitantes ou ameacem as construções vizinhas.

$\S 2^{\circ}$ A Prefeitura Municipal indicará a localização das indústrias nocivas e/ou perigosas, preferencialmente em áreas que já possuem infraestrutura e adequação para esse fim, fora da área de expansão urbana.

A lei de zoneamento prevê ainda a criação da Zona de Predominância Recreacional (ZpR), e também, a Reserva de Áreas Livres nas Zonas de Expansão, estipulando assim, áreas verdes que deverão ser mantidas no território, com fins recreacional e paisagístico. Todavia, estas zonas não aparecem delimitadas.

Destaca-se, também, o estabelecimento das faixas não edificantes, como já havia sido colocado na Lei $\mathrm{n}^{\circ}$ 1576/70, e que é promulgada novamente nesta lei, conforme o Artigo 23:

Art. 23. Às margens de águas correntes e dormentes de faixas de domínio público ocupadas com ferrovias, rodovias e dutos de qualquer natureza serão reservadas faixas estabelecidas na legislação competente, mas, nunca inferiores a $15,00 \mathrm{~m}$ (quinze metros) onde nenhuma construção será permitida. 
Desta forma, observa-se que a Lei $\mathrm{n}^{\mathrm{o}}$ 1606/71 estipula a faixa não edificante ao longo dos cursos d'água, e também, ao longo de rodovias, ferrovias e dutos, priorizando o planejamento urbano do município em longo prazo, sendo esta uma medida importante para o melhor ordenamento da cidade. No entanto, a lei não acata as diretrizes previstas no Código Florestal de 1965 (Lei n 4771/65), que estipula Áreas de Preservação Permanente, as florestas e demais formas de vegetação naturais ao longo dos rios, cursos d'águas, nascentes e lagoas.

A lei de zoneamento visava coibir a expansão horizontal da cidade e incentivar a ocupação dos vazios urbanos. Eram exigidas todas as obras de infraestrutura por parte do loteador, com exceção da pavimentação.

Neste sentido, a lei trouxe grandes avanços do ponto de vista do planejamento urbano e organização do espaço, porém, muitas das diretrizes e normas apontadas no zoneamento urbano do município não foram acatadas pela população e/ou fiscalizadas pelo poder público. A cidade continuou apresentando um crescimento espraiado, com inúmeros vazios urbanos. As várias restrições, regras e normas colocadas na lei de zoneamento quanto à abertura de novos loteamentos acabou propiciando a expansão dos loteamentos clandestinos no município. Neste período, já surgem as primeiras leis municipais que vão tratar de construções clandestinas $^{27}$.

A regularização ou a anistia das construções irregulares e clandestinas aparece em 28 de novembro de 1974, com o decreto $\mathrm{n}^{\circ}$ 1792, que beneficiava a aprovação de vários loteamentos. "O texto dessa lei da regularização apresentava em seu artigo sexto, que os Departamentos de Fiscalização e de Obras e Viação deveriam desenvolver severa vigilância com o fim de evitar o surgimento de novos loteamentos clandestinos e coibir as construções sem alvará. No Artigo sétimo, reforçava-se a intenção de coibir os loteamentos clandestinos, pois determinava ao Departamento Jurídico a missão de promover e tomar as ações judiciais e policiais contra os responsáveis pela irregularidade" (CHUSTER, 2000). Porém, pouco foi feito, e os números de loteamentos ilegais aumentou cada vez mais, década após década.

No decorrer dos seus oito anos e três meses de vigência, várias alterações e modificações sucederam-se. Foram 36 leis e decretos, e desses últimos, vários alteravam o perímetro de determinadas zonas de uso (CHUSTER, 2000, p. 56).

\footnotetext{
${ }^{27}$ Leis de anistia as construções clandestinas na década de 1970: DECRETO 1.792 de 28 de novembro de 1974.

LEI MUNICIPAL No 2.030, DE 29/06/1978 - Pub. JBM nº 206, de 14/08/1978 - Dispõe sobre regularização de construç̃̃es clandestinas em loteamentos já inscritos no Registro Imobiliário.

LEI MUNICIPAL No 2.238, DE 30/10/1979 - Pub. BM No 228, de 03/01/1980 - Dispõe sobre regularização de construções clandestinas.
} 
As construções clandestinas se tornam um problema do ponto de vista social e ambiental, e também, em relação ao ordenamento do espaço. Os loteamentos clandestinos não respeitam a legislação, constituindo-se na chamada cidade ilegal e ocupando áreas de proteção e preservação ambiental; não possuem, muitas vezes, infraestrutura, como rede de esgoto, e se constituem como habitações precárias com péssimas condições de vida.

\subsubsection{A Lei de Zoneamento Urbano de 1980}

\section{(Lei Municipal n 2.263 de 1980)}

A Lei Municipal $\mathrm{n}^{\circ} 2.263$ de quatro de janeiro de 1980 dispõe sobre a divisão do território do município em zonas de uso e regula o parcelamento, uso e ocupação do solo. Assim, passados quase 10 anos, São José dos Campos ganha uma nova lei de zoneamento urbano, mais atualizada e abrangente. A atualização da legislação se fez importante, face ao vertiginoso crescimento e transformações no espaço urbano do município.

Diferentemente da lei anterior, esta não tem origem vinculada a um novo Plano Diretor. Fora contratada pelo poder público, a empresa Lucio Grinover Arquitetos Associados S.A. (empresa com sede na capital São Paulo), que tinha como objetivo não só elaborar a nova lei de zoneamento do município, como também dar assessoria no âmbito do planejamento urbano e desenho urbano, arquitetura, comunicação visual e desenho de produtos (COSTA, 2007).

A legislação de zoneamento urbano de São José dos Campos teve muita influência da

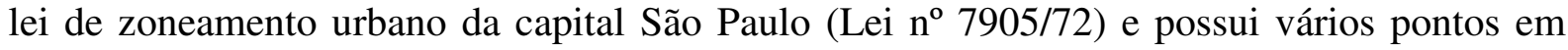
comum com a referida lei. Conforme Costa (2007), essa semelhança pode ser constatada quando as leis definem seus objetivos - os textos são idênticos.

Chuster (2000) faz uma análise comparativa entre a legislação de São Paulo e de São José dos Campos e constata a existência de inúmeros trechos copiados e/ou adaptados, destacando alguns pontos críticos, como no final do texto da lei 2.263/80 de São José dos Campos, que segundo Chuster op.cit., encontra-se o mais polêmico dos artigos, pois conferia ao prefeito o poder de decidir, permitindo ou não, aprovando ou não, qualquer caso omisso ou que não se enquadrasse nos termos dessa lei. $\mathrm{O}$ artigo 67 possui a seguinte redação:

\footnotetext{
"os casos omissos e aqueles que não se enquadrarem nos temos desta lei, relacionados com o parcelamento, uso e ocupação do solo do município, serão decididos pelo prefeito, ouvido o órgão competente da prefeitura".
} 
Conforme Chuster op.cit., a redação deste artigo foi baseada mais uma vez na legislação de São Paulo, pois o artigo 32 da lei 7.805/72 possuía praticamente a mesma redação, mudando apenas algumas palavras, porém colocava a responsabilidade de aprovação não somente ao prefeito, mas sim, à Coordenadoria Geral de Planejamento (COGEP) e à Comissão de Zoneamento.

A comparação entre ambas as redações nos mostra o que pode ser considerada uma cópia mal feita ou mesmo uma péssima adaptação. Enquanto uma legislação criava um instrumento coletivo, de maior representatividade [...] a outra simplesmente conferia ao alcaide, "ouvido o órgão competente, o poder supremo sobre as questões relativas ao parcelamento, uso e ocupação do solo de uma cidade" [...] A lei 2.263/80 sem dúvida nenhuma, mais do que basear-se na lei 7.805/72 de São Paulo, pode ser considerada como uma grande cópia, com alguma poucas e as vezes péssimas adaptações (CHUSTER, 2000 p.103).

De 47 artigos, 13 são cópias fiéis do texto paulistano, 24 são cópias com pequenas alterações e 10 não guardam qualquer semelhança à legislação de São Paulo (CHUSTER, 2000). Desta forma, vê-se que a legislação de São José dos Campos peca pela falta de originalidade, por ser uma adaptação mal feita de outra realidade, São Paulo, que possui características diferentes de São José dos Campos, e problemas específicos e particulares à cidade acabaram tendo um tratamento inadequado ou insuficiente.

No entanto, a legislação foi aprovada e promulgada. Cabe lembrar que esta legislação é posterior à Lei Lehman, $n^{\circ}$ 6766/79, que regulamenta o parcelamento do solo urbano no nível federal. Esta coloca requisitos urbanísticos mínimos, como reserva obrigatória de faixa não edificante e a proibição do parcelamento em terrenos com declividade superior a $30 \%$. A nova legislação de São José dos Campos, ao menos na teoria, cumpriu apenas parte do que a legislação Federal prevê, pois não determina a reserva de faixas não edificantes, como podemos ver no Artigo 3:

Parágrafo único. Nenhum parcelamento do solo, bem como destinação de áreas institucionais, será permitido em terrenos baixos, alagadiços e sujeitos a inundações, antes de tomadas, pelo requerente, as providências para assegurar-lhe o escoamento das águas; as obras necessárias para tal fim poderão ser projetadas, quando for o caso, juntamente com as das vias de circulação a serem abertas. Da mesma forma não será permitido o parcelamento de terrenos que tenham sido aterrados com materiais nocivos à saúde pública, sem que sejam previamente saneados. Do mesmo modo não será permitido o parcelamento de terrenos com declividade igual ou superior a $30 \%$ (trinta por cento). 
Comparando a lei 2.263/80 com a sua antecessora, vê-se que houve um aumento no número de artigos, sendo que antes eram 25 e agora são 47, ou seja, quase dobrou o número de artigos. O número de zonas de uso passou de 8 para 22, ou seja, quase triplicou, e foram criados 17 corredores, que na legislação anterior não existiam.

O Artigo 26 da legislação de zoneamento apresenta as zonas em que o território do município foi dividido:

Art. 26. As zonas de uso obedecerão à seguinte classificação, representadas por siglas e com as respectivas características básicas:

I - ZR.1, uso exclusivamente residencial [...]

II - ZR.2, uso predominantemente residencial de densidade baixa média;

III - ZR.3, uso predominantemente residencial de densidade média;

IV - ZC, de uso misto, de densidade média-alta e alta [...]:

a) ZC.1, de uso predominantemente residencial e de serviços;

b) ZC.2, de uso misto, de densidade média-alta;

c) ZC.3, de uso diversificado, de densidade alta;

d) ZC.4, de uso misto, de densidade média-alta.

V - ZE, de uso especial, com características próprias:

a) ZE.1, zona de fundo de vale, de uso diversificado e institucional;

b) ZE.2, zona de uso exclusivo de transportes de pessoas, mercadorias e equipamentos;

c) ZE.3, zona de banhado, de uso exclusivamente recreacional, cultural, esportivo e turístico;

d) Zona do CTA;

e) ZE.4, zona de uso institucional [...];

f) ZE.6, zona de uso para unidades habitacionais de caráter social e industrial, para implantação de distritos industriais;

g) ZE-7, Zona de Uso Residencial Unifamiliar, em Lotes individualizados, localizada próxima às zonas comerciais ou corredores de uso diversificado, permitindo somente atividades de pequeno porte como extensa da função habitacional;

h) ZE-8 - Zona Comercial, de âmbito sub-regional;

i) ZE-9 - Zona de uso misto diversificado de alta densidade, que por suas características de ocupação permitem a convivência harmoniosa entre as atividades residencial multifamiliar, comércio varejista diversificado, prestação de serviços, edificações verticalizadas e atividades de cultura e lazer de massa;

j) ZE-10 - Fica criada a zona (ZE-10), com as seguintes características: Zona de uso predominantemente residencial unifamiliar, com setores de comércio e prestação de serviço, integradas às funções habitacionais;

k) ZE-11 - Zona de uso predominantemente residencial unifamiliar, integrada às atividades de comércio e de prestação de serviços como extensão das funções habitacionais;

1) ZE-12 - Zona de uso misto, de densidade média, [...];

VI - ZI, de uso industrial, com características especificadas no Quadro Anexo no 3 e individualizadas pelas seguintes siglas:

a) ZI.3, de uso predominantemente industrial, de potencial poluidor médiobaixo, de Lotes de, no mínimo de $5.000 \mathrm{~m}^{2}$ (cinco mil metros quadrados) de área de construção de, no máximo $2.500 \mathrm{~m}^{2}$ (dois mil e quinhentos metros quadrados), sujeito a controle pelos órgãos competentes;

b) ZI.4, de uso exclusivamente industrial, de potencial poluidor médio-alto, com Lotes mínimos de $10.000 \mathrm{~m}^{2}$ (dez mil metros quadrados) com sistema de controle específico contra poluição determinados pelos órgãos competentes.

$\S 1^{\circ}$ As características de dimensionamento, ocupação e aproveitamento dos Lotes, bem como as categorias de uso permitidas, correspondentes a cada zona de uso, são aquelas constantes do Quadro 2, anexo desta Lei. 
Pode-se observar que houve uma grande divisão e subdivisão das zonas de uso. Há delimitação de zonas de uso exclusivo residencial, separado de comércio e serviços, prevalecendo o zoneamento funcional. A porcentagem de zona residencial se torna maior que a de zona industrial, ao contrário da lei de 1971. Porém, um pouco mais de um quarto do território joseense $(27,2 \%)$ é destinado às indústrias. As áreas verdes recebem pouca atenção, sendo apenas delimitadas algumas zonas específicas como a ZE-1: área de fundo de vale e ZE-3: área do Banhado, enfatizando a pouca atenção dada às questões ambientais.

Há uma subdivisão nas zonas industriais, com o objetivo da oferta de distritos industriais. As zonas industriais são classificadas, conforme o grau de poluição das indústrias, em ZI-3 com potencial poluidor médio-baixo, e ZI-4, com potencial poluidor médio-alto, cabendo aos órgãos competentes a físcalização da poluição. Houve uma grande discussão na câmara dos vereadores e Associação de Engenheiros e Arquitetos de São José dos Campos (AEASJC), sendo eliminada do texto da lei a zona de uso ZI-5, que abrigaria as indústrias de alto potencial poluidor, restringindo as indústrias poluidoras na cidade, sendo um grande ganho ambiental para o município, que teve a qualidade do ar afetada após a instalação da Refinaria de Petróleo Henrique Lage (REVAP) no final da década de 1970.

Vê-se que o zoneamento nesta nova legislação é bem mais específico, criterioso e detalhado que nas leis anteriores. São criados corredores e inseridas novas zonas residenciais, comerciais e de uso misto, dispersando o comércio de pequeno porte em vários pontos da cidade. Porém, a idéia do zoneamento funcionalista ainda persiste, a cidade é segmentada em usos cada vez mais específicos e delimitados.

Diferentemente das legislações anteriores, esta lei de zoneamento traz documentos em anexo, que mostram desde o quadro com as especificidades das vias de circulação, como o quadro das características de zonas de uso, com as características de dimensionamento, recuos, ocupação e aproveitamento do lote, quadro de multas e sanções, e também, quadro com a delimitação do perímetro de todas as zonas.

Deste modo, no quadro número oito, em anexo à lei, é estabelecida a descrição de 26 perímetros, como o perímetro urbano, o perímetro de expansão urbana, o perímetro industrial, e também, o perímetro de faixa não edificante do município, que se limita apenas a faixa do Talude do Banhado. A reserva de faixa não edificante nos córregos e cursos d'água não é prevista nesta lei.

Comparando a legislação anterior (1.606/71) com a legislação 2.263/80, vemos que houve uma grande expansão urbana do município. A área do perímetro urbano em 1971 era de aproximadamente $123 \mathrm{~km}^{2}$ e em 1980, o perímetro urbano possui uma área aproximada de 
$150 \mathrm{~km}^{2}$, ou seja, houve um aumento de $27 \mathrm{~km}^{2}$ na zona urbana do município, representando um acréscimo de 22\%. Comparando-se com o crescimento populacional, tem-se em 1970 uma população de 150.884 habitantes, e em 1980 essa população passa para 287.513 habitantes, ou seja, a população teve um crescimento de $90,05 \%$ em 10 anos.

Por meio desta nova legislação, houve um aumento nas áreas de uso residencial e comercial, que passam a representar $45 \%$ da área urbana, já a área de uso industrial diminui pela metade; a área do Banhado protegida praticamente dobra de tamanho.

Após a promulgação da lei de zoneamento em janeiro de 1980, esta passa por mais de 90 alterações e modificações, as principais mudanças eram alterar o zoneamento de uma determinada área ou região, a fim de permitir uma determinada atividade outrora não permitida, criar zonas de uso com parâmetros de uso e ocupação específicos, restringir a verticalização em determinados bairros, reduzir parâmetros de ocupação solo, e em outros incrementar a taxa de ocupação máxima ou o coeficiente de aproveitamento (COSTA, 2007).

"as alterações efetuadas formaram uma coletânea de leis e decretos promulgados em épocas diferentes, com revogações parciais, emendas de ordem aditiva e modificativa, formando em conseqüência uma legislação dispersa e de difícil consulta e compreensão" (PROJETO, 1989, apud CHUSTER, 2000, p. 135)

A maioria dessas mudanças na legislação ocorre por força da especulação imobiliária. O processo de verticalização invadia áreas de uso residencial unifamiliar e causava confrontos e conflitos. Como aponta (COSTA et al., 2008, p. 105), "o total de edifícios construídos no período de 1973 a 1988 saltou de 40 para 170 respectivamente, ou seja, num período de 15 anos, o número de edifícios construídos na cidade aumentou 425\%".

Ocorreu também a competição pelo espaço entre a indústria e o setor imobiliário, que transformava áreas industriais em áreas de urbanização residencial ou o contrário, áreas residenciais onde eram instaladas indústrias. Essa mudança no uso do solo representou a substituição do capital industrial pelo capital imobiliário de incorporações (COSTA, 2007). Este conflito de usos residencial e industrial é muito presente, principalmente na Região Leste do Município.

A lei de zoneamento urbano 2.263/80 ainda apresenta retração no perímetro urbano, no intuito de ocupar os vazios urbanos e reduzir as áreas disponíveis para o parcelamento do solo, evitando que as áreas distantes e sem infraestrutura sejam ocupadas, diminuindo o ônus da Prefeitura. 
No entanto, tais políticas levaram a uma explosão no número de loteamentos clandestinos no município na década de 1980, e acabaram agravando o crescimento do município e trazendo ainda mais gastos ao Poder Público. Estes loteamentos vão ocupar áreas destinadas ao uso industrial, áreas de preservação ambiental, como encostas de morro, margens de rios e córregos, trazendo grandes danos ambientais ao município, além de propiciar o crescimento desordenado e espraiado do território, sem o devido planejamento urbano e ordenamento do espaço.

No período de 1980 a 1989, no qual a referida lei esteve em vigência, foram promulgadas 21 leis municipais que dispunham sobre a regularização dos loteamentos clandestinos $^{28}$, sem contar os decretos. Neste sentido, a cidade passa a crescer sem o cumprimento de parte das políticas urbanas, o que leva à proliferação da cidade ilegal, à expansão real da área urbana de forma desordenada, ao aumento dos vazios urbanos, a periferização, à falta de infraestrutura nas novas áreas loteadas, ao aumento no número de moradias precárias, à construção de casas em áreas de proteção e de preservação ambiental e à falta de ordenamento do território; todos esses fatores vão ocasionar inúmeros problemas urbanos, sociais e ambientais, que passam a ser vividos pelo município, muitos deles até hoje sem resolução.

\subsubsection{A Lei de Zoneamento Urbano de 1990}

\section{(Lei Municipal no 3.721 de 1990)}

Passados 10 anos da elaboração da última lei de zoneamento, esta é substituída pela Lei $n^{\circ}$ 3721, aprovada em 25 de janeiro de 1990. A nova Lei de Zoneamento começou a ser formulada em 1987 por diversos técnicos da prefeitura. A sua elaboração visava regulamentar as inúmeras alterações feitas na lei anterior, e também, tornar a lei mais acessível à população.

Após a sua elaboração esta lei, passou por supervisão e discussão na Comissão de Zoneamento $^{29}$. A Comissão de Zoneamento era formada por representantes da Associação dos Engenheiros e Arquitetos de São José dos Campos (AEASJC), da Associação Comercial e Industrial (ACI), dos Empresários de Loteamentos (AELO), do Instituto Nacional de

\footnotetext{
${ }^{28}$ Levantamento de leis de anistia as construções clandestinas na década de 1980:

LEI MUNICIPAL No 2.287, DE 08/05/1980; LEI MUNICIPAL No 2.414, DE 20/02/1981; LEI MUNICIPAL No 2.629, DE 30/06/1982; LEI MUNICIPAL No 2.765, DE 06/12/1983 LEI MUNICIPAL No 2.752, DE 10/11/1983; LEI MUNICIPAL No 2.714, DE 14/07/1983; LEI MUNICIPAL No 2.692, DE 09/06/1983; LEI MUNICIPAL No 2.682, DE 02/05/1983; LEI MUNICIPAL No 2.921, DE 04/12/1984; LEI MUNICIPAL No 2.881, DE 16/10/1984; LEI MUNICIPAL No 2.808, DE 21/03/1984; LEI MUNICIPAL No 3.057, DE 05/12/1985; LEI MUNICIPAL No 3.051, DE 21/11/1985; LEI MUNICIPAL No 2.964, DE 04/06/1985; LEI MUNICIPAL No 3.176, DE 13/10/1986; LEI MUNICIPAL No 3.293, DE 07/12/1987; LEI MUNICIPAL No 3.665, DE 14/11/1989; LEI MUNICIPAL No 3.616, DE 28/09/1989; LEI MUNICIPAL No 3.540, DE 26/06/1989; LEI MUNICIPAL No 3.521, DE 30/05/1989; LEI MUNICIPAL NO 3.495 , DE 12/05/1989.

${ }^{29}$ A Comissão de Zoneamento foi criada a partir do Decreto Municipal n5.008/85.
} 
Pesquisas Espaciais (INPE), da Associação das Construtoras do Vale do Paraíba (ACONVAP), do Escritório Regional de Planejamento (ERPLAN), da Câmara Municipal e das Regiões Administrativas da Prefeitura. Foram realizadas 12 reuniões pela comissão, e em maio de 1988, foi encaminhado ao prefeito o texto da lei de parcelamento, uso e ocupação do solo do município (COSTA, 2007).

Porém, o ano de 1988 era ano de eleição e o projeto de lei não foi aprovado, sendo promulgado na forma de Lei somente em 1990. No entanto, ela não foi considerada uma nova lei sobre o zoneamento, mas sim uma consolidação e sistematização das várias alterações ocorridas na Lei de Zoneamento nº 2.263 de 1980 (COSTA, 2007; CHUSTER, 2000).

O projeto de lei de zoneamento formulado pela equipe técnica da prefeitura e analisada pela comissão de zoneamento foi objeto de cerca de 90 emendas apresentadas pelos vereadores. A lei de zoneamento, embora seja fundamental para organização espacial e desenvolvimento da cidade, teve pouca repercussão na mídia e quase nenhuma participação da sociedade.

O Artigo $1^{\text {o }}$ da lei de zoneamento urbano $n^{\circ} 3721 / 90$ coloca como sendo objetivos da nova legislação: promover a reserva de espaços para o desenvolvimento de diferentes atividades urbanas; promover um melhor controle do uso e aproveitamento do solo, ordenar e orientar o desenvolvimento urbano. Para tanto, a lei foi dividida em oito capítulos com 212 artigos, a legislação anterior de 1980 tinha 69 artigos e a lei de 1970 tinha somente 33 artigos. Neste sentido, fica claro que tal legislação se impõe no propósito de reafirmar todas as alterações ocorridas na lei anterior, durante a década de 1980.

A nova lei de zoneamento divide a cidade em mais de 30 zonas de uso do solo e vários corredores especiais. O número de zonas aumentou ainda mais de 1980 para 1990, e os corredores mais que quadruplicaram, sendo que antes eram 17 e agora passam de 70. Assim, esta lei, que pretendia ser mais acessível à população com um entendimento mais simples sobre o zoneamento da cidade, não atinge esse objetivo. Impõe-se um zoneamento extremamente funcionalista.

Do ponto de vista ambiental, pode-se destacar a criação de cinco zonas de APA, como previsto no Artigo 88:

XX - APA-1 - Zona de uso em área de proteção ambiental, que, por suas características, permite a implantação do uso residencial unifamiliar, de baixa densidade (chácaras urbanas), com parâmetros próprios de parcelamento e ocupação, admitida a implantação de clubes esportivos-sociais e uso institucional; XXI - APA-2 - Zona de uso em área de proteção ambiental, que, por suas características, permite a implantação do uso residencial unifamiliar, de baixa 
densidade (chácaras urbanas), com parâmetros próprios de parcelamento e ocupação, admitida a implantação de clubes esportivos-sociais;

XXII - APA-3 - Zona de uso em área de proteção ambiental, que, por suas características de várzea, composta por terrenos de formação hidromórfica ou de aluvião, se destina a usos agrícolas e seus complementares;

XXIII - APA-4 - Zona de uso em área de proteção ambiental que, por suas características, permite a implantação de usos de esporte, recreação e educação;

XXIV - APA-5 - Zona de uso em área de proteção ambiental, que, por suas características, permite a implantação de usos de serviços de hospedagem e turismo;

XXVI - ZDCA - Zona de Domínio de Cursos D'água - zona de uso lindeira a cursos d'água, sujeita a inundação iminente ou eventual, que por sua característica, admite ocupação de baixa densidade;

XXX - ZPM - Zona de Proteção de Mananciais - zona compreendida pela bacia hidrográfica do Rio Buquira, situada a montante da confluência do córrego do Bengalá, excluindo-se a bacia deste, constituída de glebas de médio e grande porte, não ocupadas, necessitando planejamento específico.

A preservação do meio ambiente por meio de criação de Área de Proteção Ambiental (APA) surge no município pela primeira vez em 1984, quando o Banhado passa a ser caracterizado como Área de Proteção Ambiental através da Lei 2.792/84. A Lei de zoneamento de 1990 vai contra muitos dos princípios e diretrizes previstas para a APA do Banhado. A lei 3.721/90 dividi a APA do Banhado em APA1, 2, 3, 4, e 5, sendo que na APA 1 e 2 passa a ser permitido o uso residencial de baixa densidade. Na APA 1 o lote mínimo é de $1.000 \mathrm{~m}^{2}$, na APA 2 é de $3.000 \mathrm{~m}^{2}$, e nas demais, o lote mínimo é de $5.000 \mathrm{~m}^{2}$. Neste sentido, a APA do Banhado é recortada por diferentes classes de uso, sendo que, usos antes não permitidos passam a ter menor restrição, em certas áreas.

$\mathrm{Na}$ Zona de Domínio dos Cursos D’água (ZDCA), é permitido o uso residencial (R1) de baixa densidade. A Zona de Uso de Proteção de Mananciais (ZPM), que, conforme o Código Florestal, é considerada Área de Preservação Permanente (APP), é mencionada na lei, mas não é delimitada no mapa de zoneamento.

Pode-se destacar a criação de mais uma zona de importância para o ordenamento do espaço: “XXVIII - ZVU - Zona de Vazio Urbano - Zona de uso compreendida por glebas de médio e grande porte, não ocupadas, constituindo vazios no perímetro urbano, necessitando de planejamento específico para sua ocupação". A ocupação da ZVU é fundamental para garantir a função social da propriedade urbana e planejamento da cidade, através de políticas 
de ocupação dessas áreas, evitando a expansão urbana e gastos com infraestrutura, aproveitando as já existentes.

A nova legislação é mais criteriosa e exigente quanto ao parcelamento do solo, há um perceptível aumento na preocupação com as questões ambientais, sendo que agora os loteamentos devem apresentar em seus projetos áreas verdes, áreas institucionais, localização dos cursos d'água na planta do loteamento, cuidados com as técnicas de terraplanagem, evitando assim a erosão do solo. Para o parcelamento do solo, deverá ser apresentado uma série de projetos na prefeitura: projeto de jardinagem, projeto de águas pluviais, projeto de esgotamento, projeto do sistema de coleta e outros. A Lei Municipal n ${ }^{\circ}$ 3.721/90 apresenta rígidos e diversificados parâmetros de distribuição de usos, recuos, frentes mínimas, coeficiente de aproveitamento e taxa de ocupação máxima.

A lei estabelece quatro padrões de loteamento residencial: A, B, C, D e loteamentos para fins industriais. Os loteamentos tipo A e B são destinados à classe média e à classe alta. O loteamento tipo C caracteriza-se como popular, o tamanho do lote é menor, o número de projetos e obras exigidas é menor. Os loteamentos tipo D caracterizam-se como de interesse especial, destinado a programas habitacionais governamentais. Tal regulamentação mostra uma maior preocupação, também, quanto às questões sociais e habitacionais no município.

O Artigo $4^{\circ}$ aponta que o parcelamento do solo não será permitido em:

I - Terrenos alagadiços e sujeitos à inundação, antes de tomadas pelo interessado as providências para assegurar-lhe o escoamento das águas. As obras necessárias para esse fim poderão ser projetadas, quando for o caso, juntamente com as das vias de circulação;

II - Em terrenos que tenham sido aterrados com material nocivo à saúde pública, sem que sejam previamente saneados;

III - Em terrenos com declividade superior a 30\% (trinta por cento), considerada a cota natural, respeitadas as disposições constantes da Seção VI deste Capítulo;

IV - Em áreas de preservação ecológica, assim declaradas por lei;

V - Em áreas onde a poluição impeça condições sanitárias suportáveis, até sua correção;

VI - Em áreas de preservação permanente, conforme estabelecido na Lei Federal $\mathrm{n}^{\circ}$ 4.771 (Código Florestal), alterada pela Lei Federal $n^{\circ} 7.803 / 89$, no que se refere aos itens "A", "B", "C" e "E".

A reserva de faixa "non edificandi" ao longo dos cursos d'água, e também ao longo de rodovias e ferrovias, é prevista nesta lei. Porém, agora as faixas ao longo das vias podem ser utilizadas no sistema viário, e as faixas ao longo dos cursos d'água poderão ser destinadas às áreas verdes.

Estabelecendo uma comparação entre a Lei 3.721/90 com a sua antecessora, a Lei 2.263/80, pode-se observar que houve um aumento quanto às áreas com zoneamento definido, que passa de $150 \mathrm{~km}^{2}$ para $215 \mathrm{~km}^{2}$, ou seja, apresenta um crescimento de $23,3 \%$. Ao se 
comparar com o crescimento populacional neste período, tem-se que, em 1980, São José dos Campos possuía 287.513 habitantes, e em 1990, a população aumenta para 442.370 habitantes. A população aumentou em quase dois terços o seu tamanho e teve um crescimento de 540\% em 10 anos. Neste período, tem-se um intenso processo de verticalização da cidade e proliferação dos loteamentos clandestinos.

Observa-se que por meio da Lei $\mathrm{n}^{\circ}$ 3.721/90, há aumento nas zonas de uso predominante residencial, que se caracterizam principalmente pela moradia de classe média e alta. As zonas de uso misto também aumentaram. A área de proteção ambiental do Banhado sofre diminuição da sua área, em 1980 ocupava 19,5\% do perímetro urbano e agora, com a nova legislação, ocupa apenas 13,6\%. Desta forma, houve diminuição nas restrições à ocupação de áreas de proteção, passa a ser permitido o uso residencial unifamiliar em várias partes da APA do Banhado.

Lembrando que esta lei de zoneamento é posterior à Política Nacional de Meio Ambiente (6938/81), lei que tem por objetivo:

\begin{abstract}
A preservação, melhoria e recuperação da qualidade ambiental propícia à vida, visando assegurar, no País, condições ao desenvolvimento sócio-econômico, aos interesses da segurança nacional e à proteção da dignidade da vida humana, atendidos os seguintes princípios: I - ação governamental na manutenção do equilíbrio ecológico, considerando o meio ambiente como um patrimônio público a ser necessariamente assegurado e protegido, tendo em vista o uso coletivo; II racionalização do uso do solo, do subsolo, da água e do ar; III - planejamento e fiscalização do uso dos recursos ambientais; IV - proteção dos ecossistemas, com a preservação de áreas representativas; V - controle e zoneamento das atividades potencial ou efetivamente poluidoras; VI - incentivos ao estudo e à pesquisa de tecnologias orientadas para o uso racional e a proteção dos recursos ambientais; VII - acompanhamento do estado da qualidade ambiental; VIII - recuperação de áreas degradadas; (Regulamento) IX - proteção de áreas ameaçadas de degradação; X educação ambiental a todos os níveis de ensino, inclusive a educação da comunidade, objetivando capacitá-la para participação ativa na defesa do meio ambiente.
\end{abstract}

A Política Nacional de Meio Ambiente foi um grande avanço em relação à política ambiental brasileira, sendo respaldada por importantes instrumentos, como o Zoneamento Ambiental, o Licenciamento e a revisão de atividades efetiva ou potencialmente poluidoras, Avaliação de Impacto Ambiental (Resolução Conama 001/86), criação de espaços territoriais protegidos, como as áreas de proteção ambiental. Neste contexto, o município de São José dos 
Campos estabelece áreas de proteção ambiental que visam proteger o meio ambiente. Em 1984, é criada a APA do Banhado, e se nota a partir deste momento uma maior preocupação quanto a delimitação das áreas de proteção ambiental, pelo menos em lei, porém na prática, as áreas de proteção ambiental acabam sendo alvos da especulação imobiliária, sendo ocupadas, sem um controle mais rígido pelo poder público.

A Lei de $n^{\circ} 3.721$ de 1990, que tinha como objetivo tornar o zoneamento mais acessível e simples para a população, acaba se tornando extremamente detalhista e criteriosa. As exigências com relação ao parcelamento do solo se tornam ainda maiores, o problema dos loteamentos clandestinos e do crescimento desordenado não consegue ser resolvido, a especulação imobiliária e o rápido crescimento urbano, aliados à falta de físcalização no cumprimento das leis urbanísticas e ambientais, geram a expansão urbana do município sem o planejamento urbano adequado. Vê-se assim, o crescimento da cidade ilegal perante a cidade legal.

Os loteamentos clandestinos têm ganhado grandes proporções no município. O poder público pouco atuou na fiscalização do cumprimento das leis; a cidade ilegal cresce sem regras. Foram mais de quinze Leis Complementares na década de 1990 que visavam a regulação de loteamentos clandestinos ${ }^{30}$, sendo que ocorreram, segundo Costa (2007) e Chuster (2000), mais de 90 alterações na Lei $n^{\circ}$ 3721/90, para beneficiar interesses pontuais que não favoreciam sociedade como um todo, mas sim interesses particulares.

A nova lei de zoneamento avançou do ponto de vista legislativo, promulgando novos requisitos urbanísticos e ambientais, trouxe em anexo a lei, mapas, tabelas e quadros que disciplinavam o parcelamento do solo, com o objetivo de promover o melhor ordenamento e organização do espaço, porém, na prática, a lei não atinge seus objetivos. Ela não é objetiva e clara como pretendia ser; a lei de zoneamento não é aplicada com rigor em todo o município. A cidade ilegal cresce sem leis.

\footnotetext{
${ }^{30}$ Levantamento de leis de anistia as construções clandestinas na década de 1990 : LEI MUNICIPAL No 3.795, DE 31/05/1990 LEI MUNICIPAL No 3.723, DE 26/01/1990 LEI COMPLEMENTAR No 008, DE 25/09/1999 LEI COMPLEMENTAR No 027, DE 14/05/1991 LEI COMPLEMENTAR No 066, DE 10/12/1992 LEI COMPLEMENTAR No 058, DE 28/08/LEI COMPLEMENTAR No 043, DE 07/04/1992 LEI COMPLEMENTAR No 093, DE 09/12/1993 LEI COMPLEMENTAR No 076, DE 29/04/1993 LEI MUNICIPAL No 4.602, DE 20/07/1994 LEI COMPLEMENTAR No 114, DE 22/12/1994 LEI MUNICIPAL No 4.693, DE 05/05/1995 LEI COMPLEMENTAR No 128, DE 04/08/1995 LEI MUNICIPAL No 4.872, DE 23/05/1996. LEI MUNICIPAL No 4.953, DE 17/10/1996. LEI COMPLEMENTAR No 139, DE 06/03/1996. LEI COMPLEMENTAR No 138, DE 06/03/1996 LEI COMPLEMENTAR No 168, DE 11/02/1998. LEI COMPLEMENTAR NO 194, DE 04/10/1999.
} 


\subsubsection{A Lei de Zoneamento Urbano de 1997 (Lei Complementar $\mathbf{n}^{0} 165$ de 1997)}

A Lei $n^{\circ} 3721 / 90$ sofre uma série de alterações e passa por uma nova revisão, agora incorporando os princípios e diretrizes previstos no Novo Plano Diretor de Desenvolvimento Integrado (PDDI) da cidade, Lei $\mathrm{n}^{\circ} 121 / 95$.

Assim, a nova lei de zoneamento urbano $\mathrm{n}^{\circ} 165$ de 15 de dezembro de 1997 passa a ser acompanhado dos estudos realizados para a elaboração do PDDI, entre eles o estudo das Cartas das Unidades Territoriais desenvolvido pelo INPE e IPT, e que dividiu a cidade em sete unidades, com base na análise das características físicas e antrópicas do território, como já visto no estudo do Plano Diretor de 1995.

Neste sentido, a política de zoneamento passa a caminhar junto com o Plano Diretor, sendo beneficiada por estudos mais aprofundados sobre o território e sua dinâmica espacial, o que também é um grande avanço do ponto de vista do planejamento urbano.

Destacam-se aqui alguns dos objetivos dessa nova legislação de zoneamento urbano, principalmente no que se refere a problemas já apontados nas leis de zoneamento anteriores, como descreve o Artigo $1^{\circ}$ : “[...] promover a prevalência do interesse coletivo sobre o particular em benefício de todos; respeitar as diretrizes urbanísticas estabelecidas no PDDI de 1995; proteger, preservar e recuperar a boa qualidade do meio ambiente natural; simplificar a linguagem, permitindo a democratização e acesso da legislação à população [...]”.

No intuito de coibir o parcelamento do solo na área rural e evitar a especulação imobiliária e a proliferação dos loteamentos clandestinos, são promulgados os seguintes artigos:

Art. $4^{\circ}$ Fica proibido o parcelamento do solo para fins urbanos na zona rural do Município.

Art. $5^{\circ} \mathrm{O}$ parcelamento para fins de Chácara de Recreio não se enquadra no conceito de imóvel rural, ficando sua aprovação subordinada às normas de loteamento para fins urbanos.

Art. $6^{\circ} \mathrm{O}$ projeto de loteamento para fins de Chácara de Recreio somente poderá ser aprovado em zona urbana ou de expansão urbana.

A maior parte dos loteamentos clandestinos em São José dos Campos é de classe baixa, com moradias precárias e pouca qualidade de vida, mas uma parte desses loteamentos clandestinos se caracteriza como chácaras de lazer, sendo uma segunda residência, usada para descanso nos fins de semana. No entanto, essas chácaras de recreio muitas vezes são 
construídas em áreas de relevância paisagística e ambiental, áreas de proteção e preservação ambiental, trazendo danos ao meio ambiente, como o assoreamento de cursos d'água, desmatamento e erosão. Desta forma, essas chácaras de recreio, que ocorrem em loteamentos clandestinos, pertencem a pessoas de renda média e alta, que prejudicam o meio ambiente e se apropriam de um bem comum que deveria ser de uso de todos em detrimento de interesses particulares.

Estabelecendo uma comparação entre a Lei 165/97 com a sua antecessora, a Lei 3.721/90, podemos observar que houve um aumento quanto às áreas com zoneamento definido, que passa de $215 \mathrm{~km}^{2}$ para $366 \mathrm{~km}^{2}$, ou seja, apresenta um crescimento de $70 \%$. Quanto às zonas de uso, há uma redução em seu número. Em 1990, existiam 34 zonas, e em 1997, esse número é reduzido para 22 zonas de uso. Há uma maior predominância das zonas mistas, para fomentar setores de comércio e serviço e reduzir deslocamentos na cidade. $\mathrm{O}$ novo zoneamento vai ao encontro do PDDI-1995, que divide a cidade em macrozona urbana e zona de expansão urbana I e II, que passa então a ser dividida em 22 zonas. Destacam-se aqui algumas delas:

III - ZCHR - Zona de Chácaras de Recreio: constitui-se de áreas de topografia acidentada, de solo frágil e vulneráveis a ocupação urbana intensiva por razões ambientais, nas quais se visa adensamento adequado às suas condições geomorfológicas, sendo apropriada ao uso residencial de Chácaras de Recreio, admitido o uso compatível com o uso residencial e a agroindústria;

IX - ZEPA1 - Zona Especial de Proteção Ambiental Um: constitui-se de área constituída por terrenos de topografia acidentada, medianamente erosivos em decorrência do relevo e das propriedades físico-químicas do solo, cuja atual forma de ocupação urbanística de Chácaras de Recreio deve ser mantida;

X - ZEPA2 - Zona Especial de Proteção Ambiental Dois: constitui-se de áreas compreendidas por terrenos inseridos em APA IV, instituídas pelo Plano Diretor de Desenvolvimento Integrado, que em decorrência de suas características físicas, destinam-se a ocupação urbana de baixa densidade, desde que associada a um sistema de drenagem adequado, bem como a um sistema de disposição de efluentes domésticos;

XI - ZEPA3 - Zona Especial de Proteção Ambiental Três: constitui-se de áreas, formadas por terrenos correspondentes a planície aluvial dos rios ou por grande concentração de nascentes, devendo ser preservada como patrimônio ambiental e paisagístico, destinando-se a atividades agrícola, pecuária e de lazer, com baixa taxa de ocupação e alta restrição quanto a impermeabilização do solo;

XIII - ZETI - Zona Especial de Transição Industrial: constitui-se de áreas destinadas a garantir a proteção das áreas circunvizinhas as ZUPIs contra possíveis 
efeitos residuais e acidentes, provenientes de atividades de risco ambiental significativo, tais como as indústrias petroquímicas, químicas, aterro sanitário, aterro industrial, admitindo-se o uso compatível com o uso residencial (UCR), uso sujeito a controle (USC) e industrial;

XV - ZVU - Zona de Vazio Urbano: constitui-se de áreas compreendidas por glebas de médio e grande porte, não ocupadas, constituindo vazios no perímetro urbano, necessitando de planejamento específico para sua ocupação;

XVII - ZEIS - Zona Especial de Interesse Social: constitui-se de áreas destinadas primordialmente para a implantação de programas e projetos destinados a população de baixa renda, enquadrando-se nesta categoria as áreas ocupadas por sub-habitações/favelas, loteamentos clandestinos onde haja interesse social em promover a regularização fundiária e urbanística e glebas ociosas no perímetro urbano;

XIX - ZEPA 4 - Zona Especial de Proteção Ambiental Quatro: constitui-se de áreas compreendidas por terrenos inseridos em APA IV, instituída pelo Plano Diretor de Desenvolvimento Integrado, que em decorrência de suas características físicas, permite o uso residencial unifamiliar e atividades de lazer, com baixa taxa de ocupação e alta restrição quanto à impermeabilização do solo, devendo ser associado a um sistema de drenagem adequado, bem como a um sistema de disposição de efluentes domésticos [...].

É possível observar que das 22 zonas de uso em que foi dividido o território nesta nova legislação de zoneamento urbano, quase metade delas estão relacionadas à proteção do meio ambiente, as quais se destacam acima. No entanto, o aumento no número de zonas de proteção não representa um avanço nas questões ambientais, pelo contrário. A APA IV promulgada pelo PDDI -1995, que deveria ter uso apenas agrícola e recreacional, é divida pela Lei de Zoneamento de 1997 em ZEPA 1, ZEPA2, ZEPA 3 e ZEPA 4, e, passa a ser permitida a ocupação de baixa densidade, com exceção da ZEPA 3, que ainda permite apenas o uso agrícola e recreacional. Nessas Zonas de Especial Proteção Ambiental, que são criadas em meio à APA IV (PDDI-1995), vão surgir condomínios fechados de alto padrão.

Observamos que com a Lei de Zoneamento 165/97, houve um grande aumento na área de zona mista. A área definida como zona industrial também sofre um grande aumento, praticamente dobra de tamanho em relação à lei de 1990. As áreas de proteção ambiental também apresentam um grande aumento e passam a representar 25,8\% do território, porém em relação ao que foi definido no PDDI-1995, pois, na realidade, a área de APA diminui. De 1990 para 1997 ,destaca-se a diminuição no número de vazios urbanos. 
A Zona de Vazio Urbano (ZVU) aparece novamente, como sendo algo importante a ser pensado para o planejamento da cidade, porém tanto no PDDI de 1995 como na lei de zoneamento, não são colocadas medidas efetivas para a ocupação dessas áreas. As áreas de vazio urbano passam a ser reconhecidas e delimitadas, mas na prática pouco é feito para ocupação dessas áreas, o que acaba levando à expansão da área urbana sobre a área rural e proteção ambiental.

A nova legislação incentiva a maior produção e oferta de lotes populares com a ampliação do perímetro urbano pelo Plano Diretor de 1995 até a Rodovia Carvalho Pinto, e houve a possibilidade de novos terrenos serem urbanizados.

Nesta nova legislação de zoneamento urbano, vê-se um avanço nas questões ambientais do ponto de vista legislativo, lembrando que esta legislação é posterior ao Código Florestal, à Lei Lehman, à Política Nacional de Meio Ambiente e à Eco-92. Porém, não são tomadas medidas efetivas para solucionar os problemas enfrentados pelo município, o parcelamento irregular do solo continua existindo, as áreas rurais e de proteção ambiental são ocupadas pela expansão urbana desordenada, os loteamentos clandestinos continuam se proliferando no município. Embora exista uma legislação de parcelamento do solo em vigor, essa sofre inúmeras alterações ${ }^{31}$, diante da regularização de loteamentos clandestinos, e assim, o parcelamento irregular do solo passa a ser regularizado por uma legislação específica, o que nos passa a impressão que a lei não é a mesma para todos. Falta uma política pública municipal que atinja a todos.

\subsubsection{A Lei de Zoneamento Urbano de 2010}

(Lei Complementar $n^{0} 428$ de 2010)

A Lei $n^{\circ} 165$ de 1997 sofreu mais de 100 alterações, desde a sua criação (PMSJC, 2010). Diante desta realidade, torna-se cada vez mais importante regulamentar a legislação do

\footnotetext{
${ }^{31}$ Levantamento das leis de anistia as construções clandestinas na década de 2000: LEI COMPLEMENTAR No 203, DE 18/05/2000; LEI COMPLEMENTAR No 271, DE 18/12/2003; LEI COMPLEMENTAR No 316, DE 22/03/2007; LEI COMPLEMENTAR No 347, DE 21/12/2007; LEI COMPLEMENTAR No 345, DE 19/12/2007; LEI COMPLEMENTAR No 335, DE 01/10/2007; LEI COMPLEMENTAR NO 322, DE 06/06/2007; LEI COMPLEMENTAR No 321, DE 06/06/2007; LEI MUNICIPAL No 7.531, DE 14/05/2008; LEI COMPLEMENTAR No 381, DE 12/12/2008; LEI COMPLEMENTAR No 379, DE 14/11/2008; LEI COMPLEMENTAR No 378, DE 13/11/2008; LEI COMPLEMENTAR No 377, DE 13/11/2008; LEI COMPLEMENTAR No 376, DE 13/11/2008; LEI COMPLEMENTAR NO 375, DE 03/11/2008; LEI COMPLEMENTAR NO 406, DE 20/08/2009; LEI COMPLEMENTAR No 401, DE 01/07/2009; LEI COMPLEMENTAR No 398, DE 22/06/2009; LEI COMPLEMENTAR No 394, DE 03/04/2009; LEI COMPLEMENTAR No 393, DE 03/04/2009; LEI COMPLEMENTAR No 390, DE $11 / 03 / 1999$.

*2010: LEI COMPLEMENTAR No 424, DE 05/05/2010; LEI COMPLEMENTAR No 417, DE 11/03/2010; LEI COMPLEMENTAR No 413, DE 06/01/2010.
} 
município, visando a um melhor ordenamento do espaço urbano. Assim, após 13 anos, São José dos Campos passa a contar com uma nova legislação de parcelamento, uso e ocupação do solo. A nova lei $n^{\circ} 428 / 2010$ avançou em relação às leis anteriores, tanto pela sua elaboração, que contou com a realização de audiências públicas, como pelas diretrizes e políticas previstas.

A equipe técnica da Secretaria de Planejamento Urbano elaborou um caderno diagnóstico, com 66 páginas, que discutia os temas: organização territorial do Plano Diretor de 2006, ocupação do espaço urbano de 1997 a 2008, desenvolvimento urbano e ambiental de 1997 a 2008 e valores para o ordenamento da cidade. O Caderno Diagnóstico apresentava os principais problemas enfrentados pela cidade e direcionava a atenção para os pontos mais graves, um trabalho bem feito e de fácil entendimento para a população.

A partir deste Caderno Diagnóstico, foram elaboradas cartilhas e uma apresentação com o resumo dos principais pontos a serem analisados na elaboração da nova lei de zoneamento. Este material foi apresentado em 13 audiências que ocorreram entre 26 de outubro a 25 de novembro de 2009. Segundo a PMSJC (2010), foram dadas 700 sugestões pela população, sendo que destas, 250 foram acolhidas pela proposta de Lei.

Após a elaboração da proposta de lei, foi realizada nova audiência no mês de março do ano de 2010, para apresentar tal proposta à população. Porém, nesta fase, surgiram vários atritos, uma vez que durante a apresentação da proposta de lei, não foram colocadas as principais alterações promulgadas na nova lei, além de haver pouco tempo para análise por parte da população desta nova legislação antes de sua aprovação, e ainda, foram aprovadas 27 emendas com 150 mudanças ${ }^{32}$ no último momento "às escuras", sem o conhecimento da sociedade. Diante destes eventos, a Justiça de São José dos Campos concedeu liminar suspendendo os trâmites da nova Lei de Zoneamento, em seis de julho de 2010. No entanto, mesmo sem a transparência necessária, a nova lei acabou sendo aprovada em 09 de agosto de 2010.

Tais acontecimentos nos dão a impressão de que a gestão participativa e democrática da cidade, como previsto pelo Estatuto da Cidade, ocorre parcialmente, segundo interesses individuais em detrimento dos interesses coletivos. Nas audiências públicas, não há a transparência necessária, a aprovação final da lei não passa pela análise da população, fica restrita aos políticos. É preciso avançar muito ainda quanto à gestão democrática e participativa da cidade.

\footnotetext{
${ }^{32}$ Informação extraída de entrevista da Vereadora Amélia (PT) ao jornal da BAND Cidade em 08/07/2010. (http://www.youtube.com/watch?v=Zwcw6UdGQ8k)
} 
A nova política de zoneamento, uso e ocupação do solo, $n^{\circ} 428 / 2010$, é elaborada e promulgada num período de estabilidade econômica, trazida pelo Plano Real, e de crescimento das exportações com aumento da participação de produtos manufaturados. Esses fatores aliados à abertura de novas empresas e qualificação da mão-de-obra, contribuíram para uma melhoria do cenário local. Os novos investimentos em infraestrutura urbana, como a ampliação das redes de fibra óptica e gás natural, e a adequação do sistema viário, favoreceram a retomada do crescimento econômico do município, que passou a contar com o aquecimento do setor de comércio e serviços, instalação de pequenas e médias empresas, shoppings, centros atacadistas, hipermercados, hotéis, estabelecimentos de ensino de nível técnico e superior e o crescimento do mercado imobiliário e da construção civil.

Estes fatores levaram à melhoria nos indicadores econômicos da cidade. Porém, a crise mundial que se iniciou em 2008 nos Estados Unidos teve repercussão na economia do município com novas demissões no setor aeronáutico e automobilístico. No entanto, a diversidade e a vitalidade do parque industrial de São José dos Campos, aliado à grande quantidade de pequenas e médias empresas e ao crescimento das atividades de comércio e serviços, possibilitaram que a cidade tivesse um saldo positivo perante a crise.

Neste sentido, observa-se que São José dos Campos passa por um grande desenvolvimento econômico, porém as questões socioambientais ficam à margem deste processo, pois este desenvolvimento não é acompanhado de políticas públicas sociais e ambientais, ocasionando conflitos no uso e ocupação do solo urbano, crescimento no número de loteamentos clandestinos, crescente dificuldade de locomoção, adensamento urbano, impermeabilização do solo e enchentes. No mais, ao longo dos 13 anos de atuação da Lei Complementar 165/97, ocorreram mais de 100 alterações na proposta original, dificultando sobremaneira sua aplicabilidade pelos técnicos e levando a compreensão muitas vezes desconexa face ao teor de diversas alterações (PMSJC, 2010).

Através da análise do Caderno Diagnóstico elaborado pela PMSJC (2010), foi possível conhecer os principais problemas que atingiam o município e que foram analisados para a elaboração da nova legislação de parcelamento e zoneamento urbano.

No período de 1997 (última lei de zoneamento) até 2009, foram aprovados 53 loteamentos pelo poder público municipal, sendo que a maioria, $80 \%$, pode ser considerada lotes populares, porém se concentraram na periferia da cidade. Segundo a PMSJC (2010), há falta de lotes intermediários na cidade. Existem $101 \mathrm{~km}^{2}$ de área não ocupada (vazios urbanos) dentro do perímetro urbano, equivalente a $28 \%$ do total de área urbanizada, segundo cálculos 
da Prefeitura; essa área tem um potencial de produção de 131.000 lotes. A Figura 23 mostra a distribuição do uso do solo em São José dos Campos.

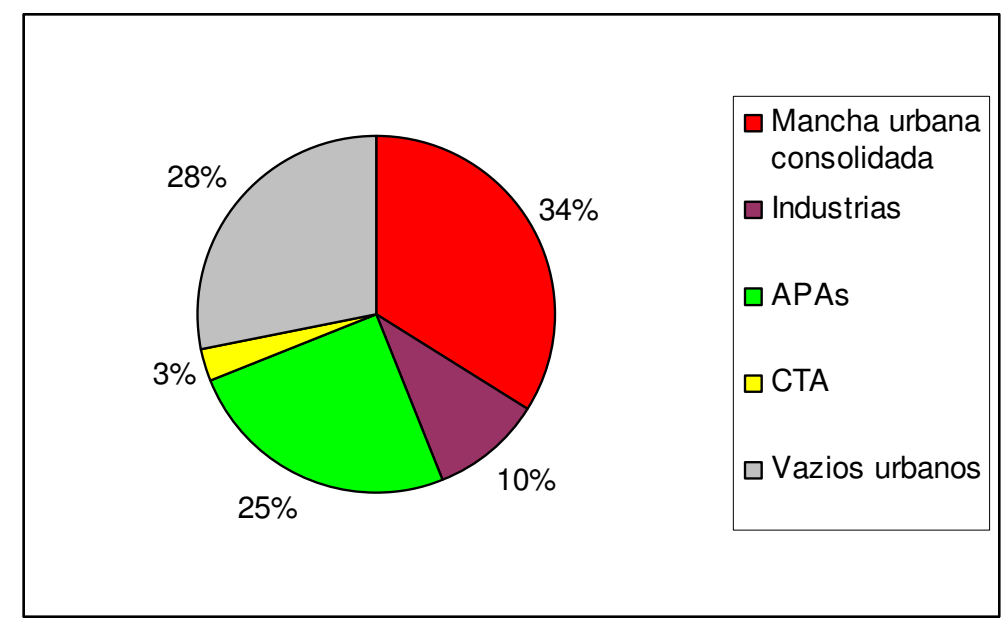

Figura 23 - Distribuição do uso do solo urbano.

Fonte: Caderno Diagnóstico Lei de Zoneamento (2010).

O Caderno Diagnóstico também destaca a grande verticalização do município. A Lei Municipal nº165/1997 permitia a verticalização em praticamente toda área urbanizada. Assim, a cidade teve um salto de 359 empreendimentos verticais em 1997 para 665 no ano de 2008, um crescimento de $85 \%$, se considerado os empreendimentos em construção esse número salta para 831 em 2008. Tal fenômeno acaba gerando conflitos em relação à residência horizontal, com a perda de privacidade, problemas de iluminação e circulação (Caderno Diagnóstico Lei de Zoneamento 2010).

A Figura 24 mostra que em grande parte da área urbanizada é permitida a verticalização, e com a predominância do coeficiente de aproveitamento 3,0. A Figura 25 mostra parte do Jardim Aquarius, local habitado pela população de alta renda, sofrendo grande verticalização entre 1997 e 2008. 


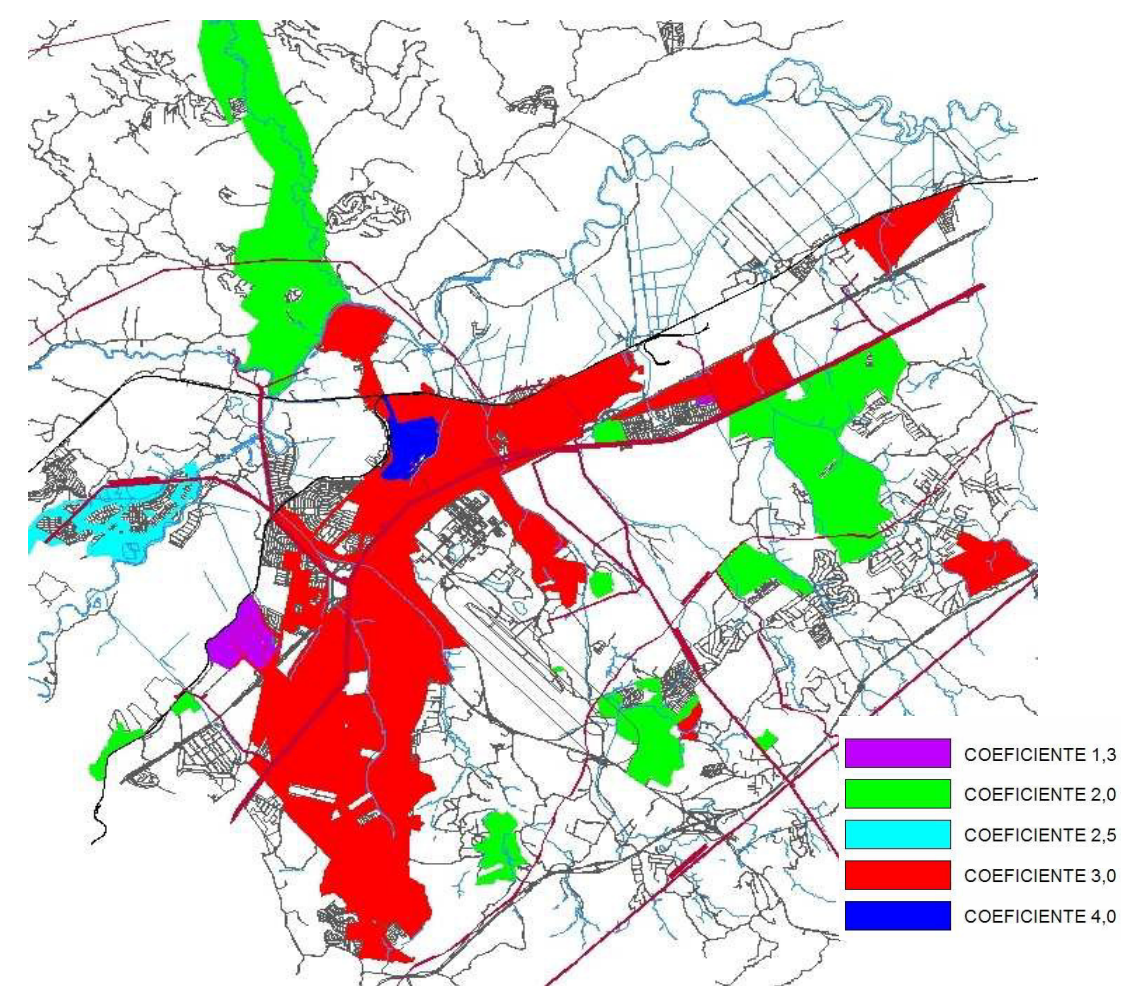

Figura 24 - Verticalização em São José dos Campos.

Fonte: Caderno Diagnóstico Lei de Zoneamento (2010).
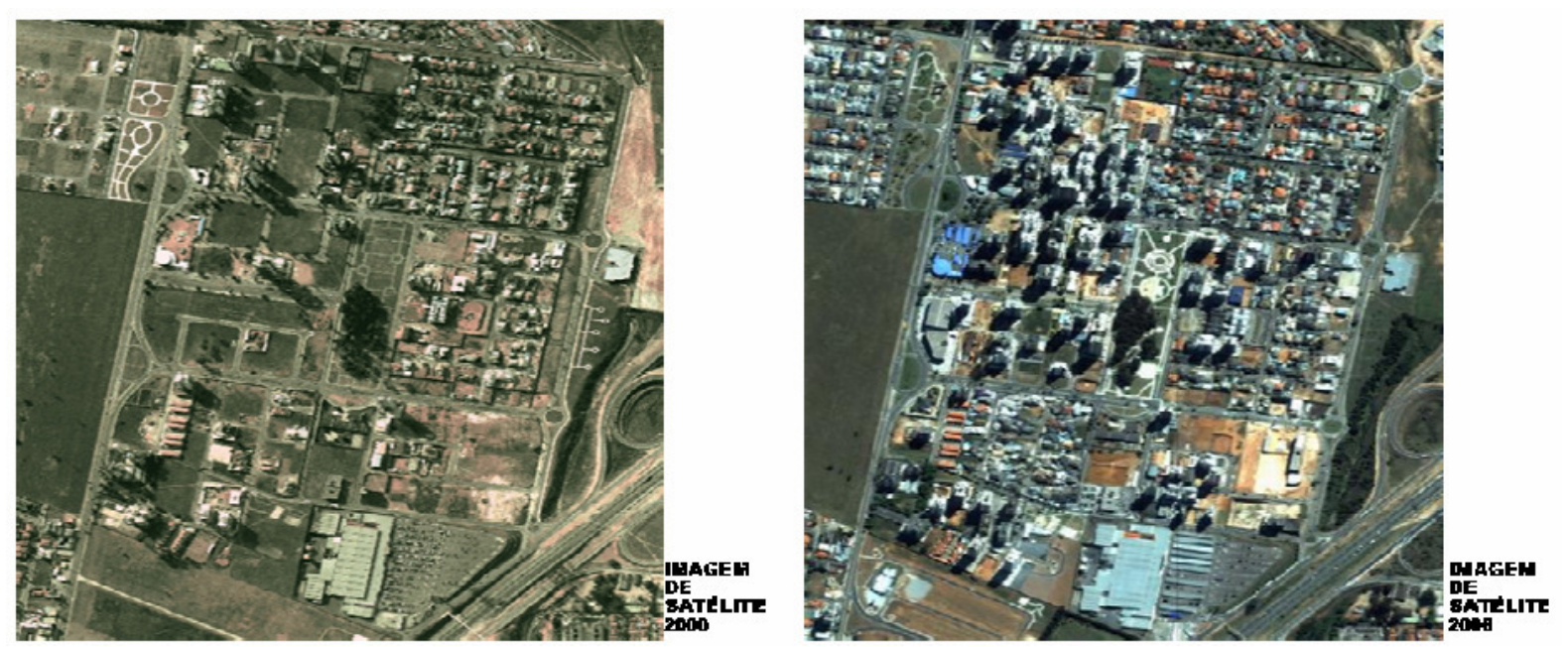

Figura 25 - Verticalização: Jardim Aquárius.

Fonte: Caderno Diagnóstico Lei de Zoneamento (2010).

Além dos problemas de verticalização e vazios urbanos, são também destacados: a proliferação dos loteamentos clandestinos na zona rural e Várzea do Rio Paraíba do Sul, e a necessidade de regularização fundiária; e ainda, o grande número de loteamentos fechados na cidade, o que prejudica a circulação; a ocupação de vales que compromete a dinâmica fluvial 
dos córregosl provocando enchentes e alagamentos; pressão urbana sobre áreas de vegetação nativa; a coleta de esgoto que só atinge $86 \%$ da população, sendo que desse montante apenas $45 \%$ é tratado (PMSJC, 2010).

Diante desse levantamento realizado, estudos técnicos, audiências públicas, do PDDI2006 e dos trâmites políticos, foi elaborada a nova lei de parcelamento, uso e ocupação do solo. A Lei Complementar 428/10 traz como principais objetivos:

I - promover o ordenamento da Cidade, respeitando as diretrizes urbanísticas estabelecidas no Plano Diretor de Desenvolvimento Integrado;

II - elevar a qualidade urbanística da Cidade e estender padrões para as áreas em processo de ocupação, respeitando as limitações e potencialidades do meio físico;

III - distribuir de maneira equilibrada as habitações e as atividades comerciais, industriais e prestadoras de serviços, considerando a capacidade da infraestrutura;

IV - preservar a qualidade de vida dos bairros a partir do controle de atividades incômodas, da manutenção da permeabilidade do solo e do atendimento do índice mínimo de área verde;

$\mathrm{V}$ - integrar as funções de moradia e trabalho evitando grandes deslocamentos de pessoas e veículos pela Cidade;

VI - preservar os valores naturais, culturais, paisagísticos, arquitetônicos, históricos e arqueológicos.

Como se pode observar os objetivos estão em acordo com os estudos realizados e visam ao respeito ao PDDI-2006, respeito ao meio físico, distribuir de forma equilibrada as habitações, manter o bom convívio nos bairros; melhorar a circulação; preservar o meio ambiente natural e construído.

O Capítulo II "Do parcelamento do solo para fins urbanos" determina que o parcelamento do solo para fins urbanos só poderá ocorrer dentro do perímetro urbano, e que quando a área parcelada não for contígua à área urbanizada, o empreendedor deverá executar as obras e serviços de infraestrutura urbana entre a área objeto do parcelamento e a área urbanizada. Desta forma, o poder público passa ao empreendedor os gastos com infraestrutura no loteamento e autoriza a criação de novos loteamentos, desde que sejam dotados de infraestrutura. Neste capítulo, fica ainda determinada a proibição de parcelamento do solo para fins urbanos na zona rural, e também, que os Loteamentos de Chácaras somente serão aprovados na zona urbana.

Neste sentido, a nova legislação busca coibir a criação de loteamentos para fins urbanos na zona rural, e também, o surgimento de loteamentos sem a infraestrutura adequada, como rede de água, esgoto, energia elétrica, ruas pavimentadas etc., pois, como acontece em 
todo o país, os empreendedores lucram com a venda de lotes sem infraestrutura, que posteriormente passa a ser exigida pela população que ali vive, e recaem sobre o poder público os investimentos em infraestrutura nos loteamentos urbanos, trazendo grandes gastos aos cofres públicos.

Na Seção II "Requisitos urbanísticos e ambientais", a legislação aponta uma série de restrições para o parcelamento urbano, visando à proteção ambiental e social. Assim, fica proibido o parcelamento do solo em terrenos alagadiços ou sujeitos a inundações, terrenos com declividade superior a $30 \%$, terrenos sem condições geológicas favoráveis, terrenos aterrados com materiais nocivos a saúde pública, terrenos onde incidem leis de proteção do meio ambiente e Áreas de Preservação Permanente. A lei ainda prevê uma série de procedimentos para os parcelamentos, que realizarão terraplanagem sobre a cota natural do terreno e projeto de drenagem e macrodrenagem.

Há um grande avanço do ponto de vista social e ambiental, a lei fica mais clara e objetiva quanto ao parcelamento do solo para fins urbanos, colocando restrições ambientais, procurando trazer menos impactos ao meio ambiente, aliado ao crescimento ordenado da cidade.

Quanto ao parcelamento do solo para fins industriais, o empreendimento, após aprovação do anteprojeto pela Secretaria de Planejamento Urbano, deverá apresentar Licença Prévia de Instalação emitida pelo órgão ambiental estadual competente. O parcelamento do solo para implantação de loteamento industrial só será aprovado com os requisitos urbanísticos: da área total da gleba, 35\% será para uso público, sendo que, 5\% para área institucional, $5 \%$ para área verde, $5 \%$ para sistema de lazer.

Desta forma, exigem-se maiores estudos para a instalação de novas indústrias no município, que deve ser acompanhada de laudo ambiental e reserva de áreas para uso público, permitindo um melhor planejamento do espaço urbano e maior cuidado com o meio ambiente. Há, também, uma maior restrição quanto à classificação das indústrias que podem se instalar no município.

O Art. 193 prevê que a implantação de atividade ou obra causadora de risco ambiental fica sujeita à apresentação do Estudo de Análise de Riscos (EAR), acompanhado do "Mapeamento das Áreas Vulneráveis" (extramuros). O artigo 195 acresce que nos casos em que a atividade também for considerada modificadora de meio ambiente, ou seja, estiver sujeita à elaboração do Estudo de Impacto Ambiental - EIA e respectivo Relatório de Impacto Ambiental - RIMA, nos termos da Lei Orgânica do Município e da legislação ambiental vigente, será realizada audiência pública. 
A legislação avança também ao colocar normas e diretrizes detalhadas para o licenciamento dos loteamentos, exige uma série de documentos e estudos, principalmente do ponto de vista ambiental, como a localização dos cursos d'água, indicação das APPs, localização e caracterização das fisionomias vegetais nativas, projeto de água e esgoto, laudo geotécnico e hidrogeológico, aprovação da CETESB e do GRAPROHAB, sistema de circulação e pavimentação de vias, calçamento e outros. Desta forma, a nova lei estipula requisitos urbanísticos e ambientais para a criação e aprovação de novos loteamentos, com grande foco na proteção do meio ambiente.

O desmembramento passa a ter normas mais rígidas e a receber mais atenção, para realizar a subdivisão de glebas em lotes, e também, para o desdobro do lote, se exige maior responsabilidade do proprietário. A Seção X aborda a fiscalização e penalidades para tal prática, colocando multa ao infrator e adequação ou demolição da construção.

No Capítulo III "Do zoneamento do território", é proposto um novo Macrozoneamento do Território, alterando aquele estipulado pelo PDDI- 2006 (Lei Complementar nº 306/06), as principais mudanças são a redução do perímetro urbano na região norte, no entorno da SP050, rodovia que leva a Campos do Jordão, e mudança na área da APA IV, área que vem sendo ocupada por loteamentos fechados de alto padrão.

Em relação à setorização do município, este passa a ser dividido nas seguintes zonas de uso:

- Zonas Residenciais (ZR1, ZR2 e ZR3), que se diferenciam pelo tamanho do lote e uso vertical ou horizontal;

- Zonas de Urbanização Controlada (ZUC1, ZUC2, ZUC3, ZUC4, ZUC5, ZUC6, ZUC7, ZUC8), as três primeiras são áreas residências e comerciais e as demais permitem também o uso industrial sem risco ambiental;

- Zona Central, centro tradicional e centro histórico da cidade;

- Zonas de Proteção Ambiental (ZPA1 e ZPA2), a primeira se caracteriza como unidade de conservação, permitindo o uso agrícola, e a segunda é uma área de topografia acidentada, mas que permite o uso residencial, comercial e de lazer;

- Zona de Chácara (ZCH), área de topografia acidentada, de solo frágil e vulnerável, permitido o uso residencial de chácara e lazer;

- Zona de Uso Diversificado (ZUD) são áreas destinadas a proteger o entorno das zonas industriais de risco ambiental, permitindo o uso comercial, institucional e de serviço;

- Zona de Uso Estritamente Industrial (ZI), área industrial de risco ambiental médio-alto;

- Zona de Uso Predominante Industrial (ZUPI), permite o uso comercial e institucional, além do industrial de risco médio-alto;

- Zona Especial de São Francisco Xavier (ZESFX), constitui o núcleo urbano de São Francisco Xavier; 
- Zona Especial de Preservação do Patrimônio Histórico, Paisagístico e Cultural (ZEPH);

- Zona Especial Aeroportuária (ZEA), compreende o CTA;

- Zona Especial de Interesse Social (ZEIS), área destinada a projetos residenciais voltados à população de baixa renda.

- Zona de Assentamento Informal (ZAI) são áreas de assentamentos urbano, não sendo de interesse social, localizados em áreas privadas, compreendendo os parcelamentos irregulares ou clandestinos;

- Zona de Qualificação (ZQA), glebas sem infraestrutura, de localização estratégica, para o crescimento urbano e desenvolvimento do município;

- Zona de Urbanização Especifica (ZUE), áreas em que se quer promover a proteção e a valorização dos elementos naturais.

Estabelecendo uma comparação entre a Lei Zoneamento 428/10 com a sua antecessora, a Lei 165/97, pode-se observar que houve uma diminuição quanto às áreas com zoneamento definido, que passa de $366 \mathrm{~km}^{2}$ para $361 \mathrm{~km}^{2}$, ou seja, apresenta uma redução de 1,3\%. Nesta nova lei vê-se uma redução no número de zonas de uso. Em 1997, eram 22 zona,s e na legislação atual, são 14. Há uma maior unificação das zonas de uso, o que fica mais claro e de mais fácil entendimento à população como um todo. As zonas são apresentadas de forma generalista no mapa que acompanha a lei, mas o texto da lei apresenta uma divisão mais detalhista para cada zona.

Do ponto de vista social, tem-se a delimitação das Zonas de Interesse Social (ZEIS), possibilitando a regularização fundiária para os assentamentos informais de baixa renda, e também, a delimitação dos loteamentos clandestinos de alto padrão (ZAI), que poderão ser regularizadas e incorporadas às zonas de uso. Na lei 165/97, os loteamentos clandestinos ocupavam uma área de 14,54 km², em 2010 esta área aumenta para 20,38 km², representando um crescimento de $40 \%$ na área ocupada por loteamentos clandestinos.

A lei amplia o perímetro do Parque Tecnológico, instituído pelo Decreto Municipal $n^{\circ}$ 12.367, de 04 de dezembro de 2006. O Parque Tecnológico de São José dos Campos tem como objetivo a instalação de empresas baseadas em conhecimento e inovação tecnológica e de outros empreendimentos. O Parque Tecnológico, instrumento básico do plano estratégico de desenvolvimento do município, faz parte do Sistema Paulista de Parques Tecnológicos criado por decreto do Governo do estado de São Paulo em seis de fevereiro de 2006. A criação do Parque Tecnológico reforça a vocação industrial e empreendedora de São José dos Campos e a forte ação do Estado no município. 
A nova lei prevê o fortalecimento dos corredores urbanos, incentivando o setor de comércio e serviços nestas áreas como uma alternativa para evitar grandes deslocamentos e facilitando a mobilidade urbana.

Há maior atenção quanto ao processo de verticalização; estipula-se a categoria residencial multifamiliar vertical, que impõe novos requisitos, como área mínima de lazer e área arborizada. É previsto um mínimo de distância entre um prédio e outro, e entre fachadas. A lei se torna mais rígida quanto à verticalização, restringindo as áreas onde esse processo pode ocorrer e determinando o número máximo de pavimentos. Na ZUC-3, ZUC-6, ZUC-7 fica determinado o número máximo de quatro pavimentos, na ZR-3, ZC-4, ZUC-8 e ZUD fica determinado o número máximo de oito pavimentos, e na ZC-1, ZC-2 e ZUC-5, fica determinado o número máximo de quinze pavimentos. Nas demais zonas, não são permitidas a construção de prédios e edifícios.

Desta forma, vê-se que houve avanço na legislação, que passou a ser mais criteriosa e pontual, estabelecendo normas e diretrizes para os problemas diagnosticados pela equipe técnica da prefeitura, mas vemos claramente pontos em que o capital fala mais alto que o ambiental, quando zonas de proteção ambiental se tornam zonas residenciais. O meio ambiente, que é um bem coletivo, de usufruto de todos, passa a ser usurpado por alguns.

\subsubsection{As leis de anistia}

A primeira lei de anistia de São José dos Campos foi registrada em 1974, favorecia poucos loteamentos situados na periferia da cidade, beneficiando em tese a população de baixa renda. Segundo Chuster (2000), a justificativa para a anistia foi o fato de a cidade apresentar um grande movimento migratório e que por desconhecimento da legislação, ingenuidade ou falta de condições financeiras, essa população não licenciava as suas construções.

No entanto, a partir da década de 1980, as leis de anistia acabam se tornando cada vez mais frequentes, sendo que nas décadas de 1990 e 2000, o número de leis de anistia e prorrogações a essas aumentam consideravelmente, em conjunto com o grande aumento no número de loteamentos clandestinos. Os textos destas leis de anistia são praticamente os mesmos, mudando apenas o prazo de sua vigência, limites de área construída e a exclusão de determinadas atividades.

Como aponta Chuster (2000, p. 182), 
Em algumas dessas leis, procurou-se introduzir penalizações concomitantemente à regularização, estabelecendo uma taxa a ser recolhida aos cofres públicos, proporcionalmente à metragem pleiteada. Esse procedimento era exceção, e por vezes, tão logo sancionado pela Prefeitura, era imediatamente alterado por uma nova lei, geralmente de iniciativa do poder legislativo, derrogando o pagamento dessas taxas ou mesmo tornando-as irrisórias. Portanto, a penalização imposta pelas taxas, que tinha entre os objetivos restringir e inibir a construção clandestina e irregular, tornava-se inócua ou irrisória.

Neste sentido, vê-se que a promulgação de inúmeras leis de anistia, com pouca ou nenhuma punição aos loteamentos clandestinos acabou favorecendo esta prática no município. Os loteamentos clandestinos surgem no território sem nenhum estudo técnico ou ambiental, ocupam áreas de proteção e preservação ambiental, não possuem infraestrutura e causam vários danos ao meio ambiente.

Chuster op.cit. realizou uma pesquisa entre o período de 1978 a 1997, onde observou a ocorrência e a vigência das leis de anistia, e chega à conclusão que os picos e tempo de vigência se dão justamente nos anos de eleições para vereadores e prefeito, como aconteceu em 1982 e 1996. Em 1989, o pico coincide com a realização das eleições presidenciais (Collor x Lula) como mostra a Figura 26.

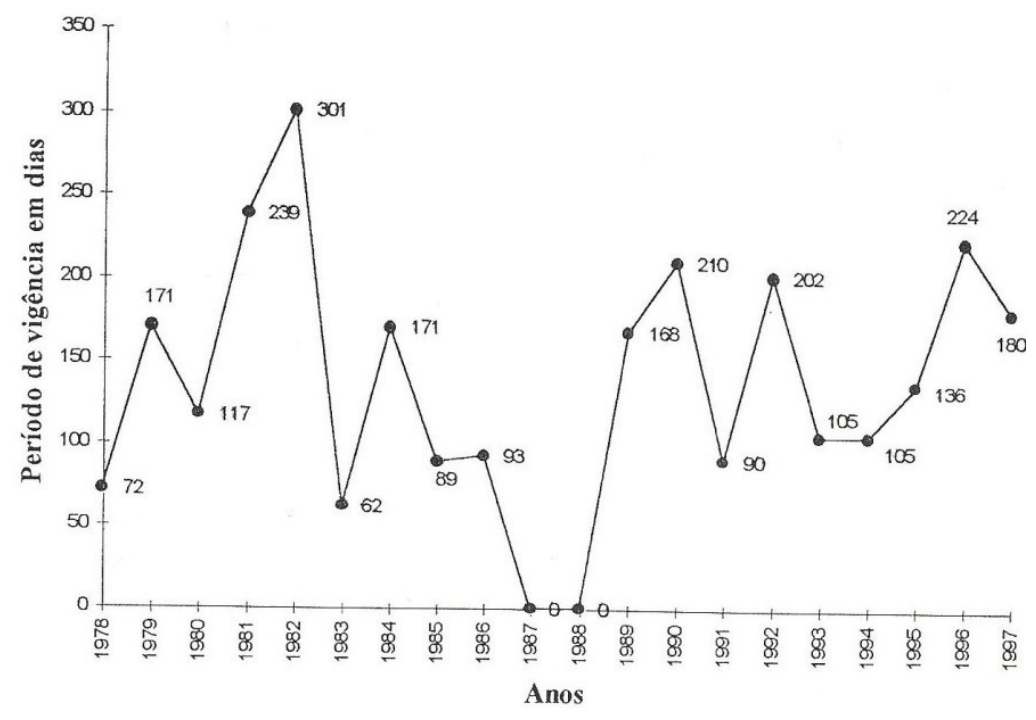

Figura 26 - Vigência das leis de regularização.

Fonte: CHUSTER (2000, P. 183).

O autor op. cit. ainda complementa dizendo que no período analisado em sua pesquisa, ou seja, em 7.300 dias, observou-se que em 2.735 dias, ou seja, 37,4\% do tempo, vigorou 
alguma lei de anistia às construções clandestinas e irregulares. $\mathrm{O}$ autor conclui que, "é como se os instrumentos de regulação como o Código de Edificações e a Lei de Zoneamento, com aquela infinidade de artigos e dispositivos não mais existissem, sendo suplantados por leis com pouco mais de meia dúzia de artigos, que em um piscar de olhos, consolidam e perpetuam as edificações antes consideradas marginais" (CHUSTER, 2000, p. 183).

As leis de anistia não são acompanhadas de nenhuma política pública e de nenhum planejamento urbano; todo o trabalho dos técnicos, das análises, das discussões sobre o zoneamento e plano diretor se perdem. As leis de anistia impuseram um ciclo vicioso, com consequências danosas ao planejamento urbano, como nos mostra Chuster (2000, p. 184),

Edificações sem espaços para estacionamento de veículos, estabelecimentos comerciais com acessos inadequados, desrespeito aos recuos e afastamentos, taxas de ocupação e impermeabilização acima do permitido, área construída excedendo ao coeficiente de aproveitamento máximo, prédios residenciais com mais pavimentos do que o permitido e atividades funcionando em locais proibidos pela Lei de Zoneamento [...].

Os loteamentos clandestinos acarretam vários danos urbanísticos e ambientais, que afetam não somente a população que vive nestes loteamentos, mas a cidade como um todo. Os reflexos na cidade são e serão inevitáveis: vias congestionadas, enchentes e o desconforto estético e visual proporcionado pelo não respeito aos recuos e afastamentos, que contribuem ainda com a diminuição dos espaços destinados ao verde nas propriedades particulares (CHUSTER, 2000).

Não só a paisagem e o meio ambiente são afetados, a própria estrutura e funcionamento dos órgãos municipais de posturas e fiscalização sofrem com essas leis. Como nos mostra Chuster (2000, p. 184), “a comunidade em geral será sempre perdedora, o planejamento urbano será sempre comprometido em detrimento dessas leis clientelistas e imediatistas. Não haverá Plano Diretor, Lei de Zoneamentos, Código de Obras, Código de Posturas que consigam suplantar os fatos consumados e "legalmente" regularizados".

$\mathrm{Na}$ maioria das vezes, essas leis de anistia não são acompanhadas de uma política pública, são imediatistas, procuram solucionar o problema momentâneo, sem pensar no futuro da cidade. Muitas destas leis, infelizmente, perdem o seu cunho social, permitindo que sejam regularizados verdadeiros absurdos.

O problema dos loteamentos clandestinos e irregulares não ocorre somente em São José dos Campos, mas em âmbito nacional. Conforme o Instituto Polis (2005), na falta de 
uma política nacional, desde meados da década de 1980, diversos municípios têm enfrentado o problema do desenvolvimento urbano informal, sempre com muita dificuldade.

No entanto, o Estatuto da Cidade (Lei n ${ }^{\circ} 10.257 / 2001$ ) traz normas e diretrizes que possibilitam a regularização fundiária ${ }^{33}$, e desta forma, a ordem jurídica reconheceu o direito social dos ocupantes de assentamentos informais à moradia.

A Constituição Federal de 1988 reconhece o direito à moradia como direito básico. O Estatuto da Cidade, juntamente com a Medida Provisória $n^{0}$ 2.220/01, instituem vários instrumentos para implementar a regularização fundiária, como: Usucapião Especial de Imóvel Urbano (individual/coletivo), Concessão de Uso Especial para Fins de Moradia (individual/coletivo), Concessão de Direito Real de Uso (CDRU) e as Zonas Especiais de Interesse Social (ZEIS) (INSTITUTO PÓLIS, 2005).

Todavia, as políticas de regularização fundiária não podem ser formuladas de maneira isolada e necessitam ser combinadas com outras políticas públicas preventivas, para quebrar o ciclo de exclusão que tem gerado a informalidade. Regularizar sem interromper o ciclo de produção da irregularidade, além de renovar o sofrimento da população, provoca a multiplicação permanente da demanda por recursos públicos (INSTITUTO PÓLIS, 2005).

É preciso compreender, também, que o principal objetivo da regularização fundiária é o de estabelecer a função social da propriedade urbana, eassim, dar acesso à terra e à moradia, à população economicamente excluída. No entanto, o que se tem observado, é que grande parte dos beneficiados nesse processo de regularização fundiária muitas vezes são proprietários de loteamentos de médio e alto padrão, que realizaram parcelamento irregular do solo, em áreas rurais e de proteção e preservação ambiental, e que encontram aparato legal na legislação para a regularização e valorização de suas posses. Desta forma, é importante que o processo de regularização fundiária ocorra de forma justa, sem degradar o meio ambiente, e que atenda ao seu papel, que é o de garantir a função social da propriedade (REANI, 2007).

Como coloca Leonelli (2003), ao parcelar uma terra privada, está se definindo o uso coletivo. Uso e destinação que todos os cidadãos terão que compartilhar nesta e nas futuras gerações, portanto, a aprovação de loteamentos consiste em ato do poder público municipal da mais alta responsabilidade quanto à qualidade de vida urbana.

Ressalta-se ainda que o processo de expansão de loteamentos ilegais é intrínseco ao processo de urbanização brasileira, que ocorreu de forma rápida e acelerada, com forte ação

33 O Instituto Pólis (2005, p. 25), define regularização fundiária como: "A regularização fundiária é processo de intervenção pública em áreas urbanas ocupadas por assentamentos informais, processo que abrange a dimensão jurídica referente à titulação dos terrenos, articulada as dimensões urbanísticas e ambiental centrada na regularização do parcelamento e dos parâmetros de uso e ocupação do solo". 
da especulação imobiliária, formando-se, assim, a cidade legal e a cidade ilegal. Como aponta Carvalho (1998, p. 24),

[...] a produção do espaço urbano nas cidades brasileiras, isto é, a abertura de novos loteamentos, não atende apenas à necessidade de abrigar gente em suas várias atividades, mas, também, e, principalmente, serve como instrumento de apropriação/ redistribuição da riqueza social. Busca-se, não a satisfação de uma necessidade da comunidade, mas o lucro, independente dos seus custos para o conjunto da população.

Segundo Campos Filho (2001, p. 48), “a especulação imobiliária urbana, de um modo geral, é, no quadro do capitalismo, uma forma pela qual os proprietários de terra recebem uma renda transferida dos outros setores produtivos da economia, especialmente através dos investimentos públicos na infraestrutura e serviços urbanos, que são os meios coletivos de produção e consumo em nível do espaço urbano". Pode-se ainda dizer que esse fenômeno representa um verdadeiro "tributo fundiário urbano" que todos pagam, mas que vai direto para o bolso do empreendedor.

A dinâmica de ocupação do solo urbano produzida pelo mercado imobiliário gera vazios urbanos para a sua posterior valorização, causando a fragmentação do espaço urbano, o contínuo crescimento e, ao mesmo tempo, adensamento e aspersão da periferia, o aprofundamento da segregação e exclusão socioterritorial (REANI, 2007).

Conforme Santos (1993, p.95), "as cidades crescem adotando um modelo geográfico de crescimento espraiado, com um tamanho desmesurado, que é causa e é efeito da especulação". O autor aponta ainda que a especulação imobiliária deriva de dois movimentos convergentes: a superposição de sítio social ao sítio natural; e a disputa entre atividades ou pessoas por melhor localização, sendo que esta possui maior valor, sem acesso à população de menor renda.

Segundo Villaça (s.d., p. 7), “o espaço, enquanto base material das localizações, tornase uma mercadoria altamente disputada, presa fácil da especulação e, finalmente, inclusive pela impossibilidade de sua distribuição equitativa, o produto cuja divisão melhor exibe a luta de classes". Dessa forma, a maior causa dessas áreas isoladas é a especulação imobiliária, que promove grandes vazios ou espalhamento urbano, expulsando os pobres para a periferia.

Como afirma o Ministério das Cidades (2004,p. 39), 
O modelo de desenvolvimento sócio-econômico que comandou a urbanização acelerada no Brasil produziu cidades fortemente marcadas pela presença das chamadas "periferias". Dezenas de milhões de brasileiros não tem tido acesso ao solo urbano e à moradia senão através de processos e mecanismos ilegais, auto-construindo um habitat precário, vulnerável e inseguro em favelas, loteamentos e conjuntos habitacionais irregulares, loteamentos clandestinos, cortiços, casas de frente e fundo, bem como nas ocupações de áreas públicas, encostas, áreas de preservação, beiras de reservatórios e rios. Todo esse processo foi o resultado de séculos de dominação e apropriação privada das terras/áreas públicas, decorrendo daí um aparato jurídico-institucional, econômico, social e ideológico que definiu a propriedade da terra como um valor fundamental de controle das classes dominantes.

Neste sentido, vê-se que a expansão dos loteamentos ilegais está ligada a fatores conjunturais, que envolvem uma acelerada urbanização, forte especulação imobiliária, grande desigualdade social, déficit habitacional, descaso do governo e falta de políticas públicas sociais. O Estatuto da Cidade vem ao encontro deste problema, traz normas e diretrizes que buscam regularizar a cidade ilegal e incorporá-la à cidade legal, no entanto, é fundamental que o processo de regularização fundiária seja acompanhado de planejamento urbano eficaz e políticas públicas socioambientais, de modo a inibir a ilegalidade e evitar que esta continue se perpetuando nos municípios brasileiros.

No município de São José dos Campos parte dos loteamentos clandestinos foi incorporada às Zonas Especiais de Interesse Social através da Lei 165/97 e da Lei 428/2010. Todavia, parte destes loteamentos não foi delimitada como ZEIS e nem são contabilizados pela Prefeitura. A criação das ZEIS trouxe pouca ou praticamente nenhuma mudança às pessoas que vivem nestes locais; a regularização fundiária nunca existiu de fato e não houve melhorias na infraestrutura do local. Muitos desses loteamentos não possuem rede de água e esgoto, ruas asfaltadas, coleta de lixo e outros serviços urbanos. Desta forma, falta sintonia entre legislação federal e legislação municipal, entre teoria e prática.

\subsection{A Legislação Ambiental de São José dos Campos}

O município de São José dos Campos possui inúmeras leis ambientais. Por meio de pesquisa no Arquivo Público Municipal e na Câmara Municipal de Vereadores, fez-se o levantamento das principais leis ambientais municipais que incidem sobre o município. 
Em 18 de maio de 1941, no jornal Correio Joseense, foi publicada matéria que informava sobre a finalização da estação de tratamento de água, localizada na margem direita do Rio Paraíba do Sul. Em 01 de agosto de 1943, foi publicado o Decreto n ${ }^{\circ}$ 13.487, que cria no município o Horto Florestal, que fica subordinado à Secretaria da Agricultura, Indústria e Comércio, com o fim de incentivar o reflorestamento das nossas matas.

Pode-se observar, também, que no Plano Diretor de 1961, já existia a preocupação com a emissão de gases poluentes pelas indústrias, sendo decretado que estas deveriam se localizar em áreas afastadas da área urbana, e também, a preocupação com a poluição das águas do Rio Paraíba do Sul.

No entanto, a atenção dirigida ao meio ambiente passa a ganhar maior respaldo legal a partir da década de 1970, quando são promulgadas diversas leis municipais de cunho ambiental, como se pode ver no levantamento a seguir:

\section{- $\quad$ Lei Municipal no $1.759 / 75$}

Declara que todo sistema de despejo de resíduos de qualquer natureza, nas bacias hídricas, deverá atender aos requisitos técnicos estabelecidos na legislação federal ou estadual, inclusive prévio tratamento. Caberá à CETESB a fiscalização.

\section{- $\quad$ Lei Municipal no 2143/79 (Revogada pela lei $n^{\circ}$ 2.773/83, pela lei 3.656/89 e} pela Lei 4.617/94)

A primeira lei do município de São José dos Campos que mostra claramente preocupação com a proteção ao meio ambiente é a Lei Municipal no 2143 de 19 de março de 1979. Esta lei cria o Conselho Municipal de Combate à Poluição e Proteção ao Meio Ambiente (CMCP), apenas consultivo, com o objetivo de promover e coordenar atividades de combate à poluição ambiental. $\mathrm{O}$ Art. $2^{\circ}$ considera:

Poluição qualquer alteração das propriedades físicas, químicas ou biológicas do meio ambiente (solo, água e ar), causada por qualquer substância sólida, líquida, gasosa ou em qualquer estado da matéria, e também sonora, que, direta ou indiretamente, seja nociva ou ofensiva à saúde, à segurança e ao bem estar das populações: cria condições inadequadas para fins domésticos, agropecuários, industriais e outros: ou ocasione danos à fauna e à flora.

O Conselho é criado com a participação de representantes técnicos da prefeitura, e também, da sociedade civil. O Art. $5^{\circ}$ estabelece como tarefas do Conselho: 
a) propor normas gerais para o controle, prevenção e correção da poluição ambiental;

b) propor normalização, uniformização e sistematização da legislação municipal sobre controle e combate à poluição e proteção ao meio-ambiente;

c) estimular a criação e o cumprimento da legislação federal, estadual e municipal de combate à poluição e preservação do meio-ambiente;

d) organizar e programar planos municipais e regionais de controle da poluição ambiental;

e) cooperar com os órgãos e entidades especializados na preservação do meioambiente e no controle da poluição ambiental;

f) assessorar o Poder Executivo e o Poder Legislativo do Município em assuntos de sua competência, inclusive quanto à legislação sobre edificação, posturas, zoneamento urbano e uso do solo;

g) coordenar estudos sobre poluição ambiental e seu controle, prevenção e correção;

h) colaborar com as populações ou grupos de pessoas atingidas por quaisquer meios de poluição ambiental;

i) promover campanhas de divulgação educativa e de orientação da opinião pública, em assuntos de poluição ambiental e uso adequado dos recursos naturais.

Parágrafo único. Os projetos de loteamentos urbanos ou rurais, bem como de implantação industrial no Município, deverão ser obrigatoriamente submetidos à apreciação do C.M.C.P.

Neste sentido, fica evidente que as questões ambientais passam a ser discutidas com maior força no município a partir desse momento. A criação do Conselho Municipal envolve diferentes agentes, que poderão discutir o tratamento das questões ambientais, seja no estabelecimento de normas, seja na organização de programas municipais específicos para o tratamento ambiental, além de incentivar estudos sobre a poluição e preservação do meio ambiente, e também, criar campanhas educativas para a proteção dos recursos naturais.

No mais, os novos projetos de loteamentos urbanos ou rurais, bem como de implantação industrial no município, passaram a ser obrigatoriamente submetidos à apreciação do Conselho Municipal de Combate à Poluição e Proteção ao Meio Ambiente.

Esta lei foi revogada pela Lei Municipal n 2.773, de 1983, porém praticamente sem modificações, apenas alterando a sigla do Conselho de CMCP, para COMAM (Conselho Municipal de Meio Ambiente) e aumentando o número de representantes, tanto de técnicos da prefeitura, como da câmara municipal e da sociedade civil. A lei é novamente revogada em 1989, aumentando o número de representantes no COMAM, incorporando novos agentes do setor imobiliário, que passam a ter maior representatividade. 


\section{- $\quad$ Lei Municipal $n^{0} 2.163 / 79$ (Revogada pela $\left.n^{\circ} 8.195 / 10\right)$}

Esta lei cria a Reserva Florestal Boa Vista, área de fazenda de propriedade do município localizada no Bairro Santa Cruz da Boa Vista, porém a lei não estipula a área da reserva.

Em 2010, esta lei é revogada pela Lei Municipal $n^{\circ} 8.195$, que modifica o nome da Reserva Florestal para Parque Natural Municipal Augusto Ruschi - PNMAR. Nesta nova legislação, os limites são detalhadamente definidos.

A Lei $n^{\circ}$ 8.195/10, em seu Art. $2^{\circ}$, determina que: "a criação do PNMAR tem como objetivos básicos a preservação de seu ecossistema natural de grande relevância ecológica e beleza cênica, a realização de pesquisas científicas, o desenvolvimento de atividades de educação e interpretação ambiental, de recreação em contato com a natureza e de turismo ecológico". O Parque está enquadrado na categoria de Unidade de Conservação Integral, submetendo-se aos critérios e normas definidos pelo Sistema Nacional de Unidades de Conservação - SNUC, por meio da Lei Federal n ${ }^{\circ}$ 9.985/00. Neste sentido, vê-se que a cidade já na década de 1970 contava com uma área de preservação do meio ambiente, refletindo certa responsabilidade ambiental.

Em 2004, uma nova legislação vem contribuir ainda mais com esta Unidade de Conservação, a Lei Complementar $\mathbf{n}^{\mathbf{0}}$ 280/04, cria a Zona de Amortecimento da Reserva Florestal Augusto Ruschi - ZA-RFAR, entende-se por Zona de Amortecimento - ZA, o entorno de uma unidade de conservação, onde as atividades humanas estão sujeitas às normas e restrições específicas, com o propósito de minimizar os impactos negativos sobre a unidade.

O Art. 3 aponta que as atividades e obras que causem ou que possam causar impacto ao meio ambiente, em especial as de terraplanagem, abertura de estradas e vias, construções, captações, derivações, represamentos e transposições de corpos d'água, mineração, plantio, roçada e cortes de mata e árvores, uso de agrotóxicos na ZA-RFAR deverão ser submetidas à prévia aprovação da Secretaria de Planejamento e Meio Ambiente, mediante a apresentação de projeto técnico assinado por profissional habilitado e instruído com as licenças e outorgas exigíveis, nos termos da legislação vigente.

O não cumprimento da Lei Complementar implicará na imposição de multa no valor de $\mathrm{R} \$ 136,97$ a $\mathrm{R} \$ 2.054,55$, aplicada em dobro caso a irregularidade não seja sanada após a aplicação da primeira multa, sem prejuízo do embargo sumário da obra ou atividade.

Conforme a lei, caberá ao Departamento de Fiscalização e Posturas Municipais da Prefeitura Municipal apresentar à Secretaria de Planejamento e Meio Ambiente, 
trimestralmente, relatório circunstanciado sobre a situação da Reserva Florestal Augusto Ruschi e sua Zona de Amortecimento - ZA-RFAR.

Desta forma, a Unidade de Conservação, criada pela Lei Municipal no 2.163/79, passa a ser mais protegida e a receber maiores cuidados do poder público.

\section{- $\quad$ Lei Municipal no 2.230/79}

Institui o "Prêmio Ecologia", que visa através de concurso conscientizar a população joseense e obter apoio para preservação dos patrimônios do meio ambiente. A premiação caberia á melhor reportagem sobre o tema. Quem julgaria os trabalhos eram quatro membros de livre escolha do Prefeito, um membro do Lions Club e um membro do Rotary Club. Porém, tal programa teve pouca repercussão e aplicação.

\section{- $\quad$ Lei Municipal n ${ }^{\mathbf{0} 2.338 / 80}$}

Cria o Conselho de Proteção ao Patrimônio Histórico de São José dos Campos, com a finalidade de prover a conservação do acervo de bens imóveis, públicos ou particulares, que, tendo qualquer relação com o passado, representem fontes de informações sobre a História do Município. Compete ao Conselho fazer o levantamento dos imóveis de interesse histórico e paisagístico, indicar os imóveis que devem ser tombados e restaurados.

Com esta lei, observa-se um maior cuidado com o espaço construído de São José dos Campos e a necessidade de pensar a proteção do patrimônio histórico e paisagístico do município, ou seja, conservar as características históricas do município e a sua identidade.

\section{- $\quad$ Lei Municipal no 2.387/80 (Revogada pela Lei Municipal $n^{0}$ 3.522/89 e pela}

\subsection{7/89)}

A referida lei trata da licença para extração de areia de cava. Torna necessário laudo da CETESB, que comprove que a atividade não acarretará qualquer ataque à paisagem, à flora e à fauna, que não causará o rebaixamento do lençol freático e que não provocará o assoreamento de rios, lagos ou represas, nem erosão. Será ainda necessário o parecer do Departamento Nacional de Obras e Saneamento, entre outros.

Tal legislação é uma primeira tentativa de regulamentar a extração de areia no município, atividade que já vinha ocorrendo há um bom tempo sem nenhuma fiscalização ou regulamentação, o que acabou provocando inúmeros danos ambientais ao longo dos rios que cortam o município, principalmente do Rio Jaguari e Rio Paraíba do Sul. 
A Lei Municipal $n^{\circ} 3.522 / 89$, que revoga a Lei $n^{\circ} 2.387 / 80$, coloca medidas mais restritivas e torna obrigatório o Estudo e Relatório de Impacto Ambiental e audiência pública para autorização da exploração de areia no município:

Art. $1^{\circ}$ Dependerá de estudo de impacto ambiental e respectivo Relatório de Impacto Ambiental (RIMA), a serem previamente submetidos à audiência pública e à aprovação do Conselho Municipal do Meio Ambiente, o licenciamento para extração de areia no Município (Lei Municipal n 3.522/89).

Demais leis que tratam da exploração dos recursos minerais em leitos de rios no município:

- $\quad$ Lei Municipal n $\mathbf{n}^{\mathbf{2}}$ 2.495/81: A lei proíbe a extração de areia no Rio Jaguari.

- Lei Municipal no 3.522/89: Dispõe sobre a licença para extração de areia no município. A exploração de areia dependerá de estudo de impacto ambiental e respectivo Relatório de Impacto Ambiental (RIMA), a serem previamente submetidos à audiência pública e à aprovação do Conselho Municipal do Meio Ambiente.

- $\quad$ Lei Municipal no 3.666/89: Dispõe sobre a exploração de minerais integrantes da classe II, nos leitos dos rios.

- Lei Municipal no 3.667/89: Dispões sobre a exploração de Minerais, pelo processo de cava. Esta última lei estabelece em seu Art. $1^{\circ}$ restrições para exploração de minerais:

$\S 1^{\circ} \mathrm{A}$ exploração não será permitida em trechos de rios que:

I - Atravessem o perímetro urbano do Município;

II - Estejam a menos de 400 metros a jusante e a montante de pontes, captações de água e obras de travessia que tenham seu apoio assentado sobre o leito do rio;

III - Tenham em suas margens vegetação ciliar de significativa importância, conforme parecer do órgão técnico competente da Prefeitura e/ou do DPRN (Departamento de Proteção aos Recursos Naturais da Secretária do Meio Ambiente do Estado);

IV - Estejam compreendidos em Áreas de Proteção dos Mananciais ou de Proteção Ambiental.

$\S 2^{\circ}$ Excepcionalmente a Prefeitura poderá autorizar o desassoreamento nos trechos de que trata o parágrafo anterior, desde que tecnicamente comprovada a necessidade da melhoria das condições de escoamento das águas pelo canal do rio, ouvido o Conselho Municipal do Meio Ambiente.

- $\quad$ Lei Municipal no 3.794/91: Dispõe sobre todo e qualquer tipo de extração de areia em rios ou cursos d'água do município. 
Tais leis procuram coibir a prática da exploração mineral em leitos de rios no município, definindo regras e normas para que esta atividade gere menos impactos ambientais a São José dos Campos.

\section{- $\quad$ Lei Municipal no 2.685/83}

A lei torna obrigatória a arborização de todas as vias públicas oficializadas do município. No entanto, tal legislação nunca foi amplamente exercida, apenas uma parte do município possui vias públicas arborizadas, principalmente nos bairros nobres.

\section{- $\quad$ Lei Municipal no 2.792/84 (Alterada pela lei 2.996/85 e Revogada pela Lei}

\section{$\left.n^{0} 3.721 / 90\right)$}

A referida lei municipal declara Área de Proteção Ambiental - APA - a região urbana e rural do Banhado de São José dos Campos. A lei traz em anexo a descrição perimétrica da área a ser protegida.

Todavia, a APA do Banhado sofre alterações com aprovação da Lei de Zoneamento de 1990, permitindo o uso residencial em parte da APA, sendo que o perímetro da APA sofre alteração pela lei 4.068/91.

A criação da APA do Banhado tem apoio do Governo Estadual, por meio do Conselho Estadual do Meio Ambiente e da Secretaria do Meio Ambiente do Ministério do Interior, além do Legislativo Municipal.

A promulgação da APA do Banhado proibiu a instalação de atividades industrial, comercial e de extração. É permitido o parcelamento do solo para fim residencial somente unifamiliar em zonas delimitadas. Tal legislação foi alterada pela Lei $n^{\circ} 2.996 / 85$, a qual estabelece o perímetro para zona integrante à APA, que poderá ser parcelada para residência unifamiliar. A lei também autoriza atividades comerciais na zona delimitada. Atualmente, é regulamentada pelo Plano Diretor e Lei de Zoneamento Urbano.

\section{- $\quad$ Lei Municipal no 3.021/85}

A referida lei dispõe sobre a criação de Elementos, Setores e Zonas de Preservação e institui o Fundo de Preservação do Patrimônio Histórico, Artístico, Paisagístico e Cultural. Os Elementos e Setores de Preservação referem-se aos imóveis que possuem valor histórico, cultural e arquitetônico. As Zonas de Preservação $(\mathrm{ZP})$ referem-se às áreas ambientais que merecem ser preservadas. 
Art. $4^{\circ}$ Os bens classificados como SP e ZP não poderão ser objeto de remembramento, desdobro de lotes, demolição, reforma, ampliação, reconstrução, novas edificações, desmatamento ou movimento de terras, sem prévia autorização da Secretaria Municipal de Planejamento e Informática após a manifestação do COMPHAC.

Conforme o Art. $4^{\circ}$, os Setores e Zonas de Preservação passam a receber uma maior atenção quanto ao uso do solo, visando, assim, proteger o meio ambiente natural e construído nessas áreas. No entanto, a lei não específica e determina onde estão e quais são essas áreas, sendo bastante vaga.

\section{- $\quad$ Lei Municipal no 3.329/88 (Revogada pela Lei Municipal no 3.721/90)}

A lei veda a instalação de usinas de concreto pré-misturado em qualquer parte do município. No entanto, foi revogada pela Lei Municipal 3.721/90, que dispõe sobre o zoneamento do solo, sendo a partir de então permitida a instalação deste tipo de indústria no município. Para tanto, esta deverá seguir a lei de zoneamento:

Art. 133. Para os efeitos desta Lei, são estabelecidas as categorias de uso, a seguir individualizadas, com as respectivas siglas e características básicas: [...]

XIX - I5 - Indústria Tipo I5 - Indústrias e pólos petroquímicos, carboquímicos e cloroquímicos, usinas nucleares, termo-elétricas, usinas de concreto usinado e outras fontes não industriais de grande impacto ambiental ou extrema periculosidade. (LEI 3.721/90).

Contudo, na mesma Lei n 3.721/90, no seu Art. 162 aponta que: "Fica expressamente proibida a instalação no município de indústrias do tipo I5, descrita no inciso XIX do artigo 133 desta Lei”. Fica, assim, proibida a instalação de indústrias altamente poluidoras no município:

Art. 164. Fica expressamente proibido, em todo o território do Município, a instalação ou ampliação de:

I - Indústrias produtoras de cloro-soda com célula de mercúrio;

II - Indústrias de defensivos agrícolas organoclorados, excetuados aqueles especificados pelo órgão federal do meio ambiente;

III - Indústrias cujos efluentes finais contenham substâncias não degradáveis de alto grau de toxidade, de acordo com os critérios estabelecidos pelo órgão do meio ambiente;

IV - Indústrias que lancem substâncias cancerígenas em seus efluentes finais. 
Neste sentido, com a lei de zoneamento 3.271/90, fica vedada a instalação de indústrias com alto potencial poluidor em São José dos Campos, Tal fiscalização fica sob competência da CETESB e de órgão específico da Prefeitura de São José dos Campos.

\section{- $\quad$ Lei Municipal no 3.334/88}

A lei estipula que não serão aprovados projetos de construção civil, de todo ou qualquer tipo, que impliquem no corte ou eliminação de árvore pública. O corte ou eliminação somente serão aceitos quando não houver nenhuma possibilidade de alteração do projeto de construção, capaz de evitar o corte ou a eliminação da arborização pública.

\section{- $\quad$ Lei $\mathbf{n}^{\circ} \mathbf{3 . 4 2 9 / 8 8}$}

A lei estipula que o Poder Executivo realizará audiência pública antes da aprovação de projetos de implantação industrial, com exceção das indústrias classificadas pela Lei 2.263/80 como I1 e I2.

- $\quad$ Lei Municipal $n^{\circ}$ 4.212/92

Declara Área de Proteção Ambiental (APA) o trecho da Serra da Mantiqueira no Município de São José dos Campos.

\section{- $\quad$ Lei Municipal $n^{\circ}$ 4.244/92}

Institui o concurso "A rua mais verde", que tem como objetivo incentivar o plantio de árvores na área urbana, fornecendo mudas e auxílio para o plantio. Porém, tal programa teve pouca repercussão e aplicação.

\section{- $\quad$ Lei Complementar $n^{0}$ 068/92}

Cria a APA 6, em complemento à lei de zoneamento urbano de 1990. A APA 6 se caracteriza como: “zona de uso em área de proteção ambiental que, por suas características de várzea, composta por terrenos de formação hidromórfica ou de aluvião, se destina, preferencialmente, a usos agrícolas, admitida a implantação de atividades de lazer com parâmetros próprios compatíveis ao meio físico local" (Art. 1. Lei 068/92).

\section{- $\quad$ Lei Municipal no 4.618/94}

Cria o Fundo Municipal de Conservação Ambiental (FUNCAM), com a finalidade de concentrar recursos para o desenvolvimento e execução de projetos de proteção ambiental e 
melhoria da qualidade de vida da população de São José dos Campos. Para tanto, contará com as dotações orçamentárias consignadas no orçamento do município; o produto da arrecadação das multas, oriundas de ações fiscais na área de meio ambiente; doações, entre outros. O FUNCAM fica sob a administração do Conselho Municipal de Meio Ambiente. Porém, tal fundo nunca foi viabilizado.

\section{- $\quad$ Lei Municipal no 4.636/94}

A presente lei estabelece normas para evitar a poluição do Rio Paraíba do Sul e demais cursos d'água do município. Para tanto, determina que as indústrias que se utilizam de recursos hídricos, situadas no território do município, somente poderão efetuar despejos industriais à montante de sua respectiva captação. A lei proíbe a instalação de sistemas de captação de água e de despejos industriais em afluentes fluviais diversos, e também, determina que todo sistema de despejo de resíduos, de qualquer natureza, nas bacias hídricas, deverá atender aos requisitos técnicos estabelecidos na legislação federal e estadual, inclusive prévio tratamento.

\section{- $\quad$ Lei Municipal no 4.928/96}

Inclui a área que abriga o antigo Sanatório Vicentina Aranha na categoria de Zonar de Preservação (ZP), nos termos da Lei Municipal nº 3.021/85.

\section{- $\quad$ Lei Municipal $n^{\circ}$ 4.954/96}

Declara de proteção ambiental a área desapropriada pelo Município à Tecelagem Parahyba S/A e à Fazenda São José Agropecuária Ltda.

\section{- $\quad$ Lei Municipal no 5.098/97}

Institui o programa "Nossa Praça", que prevê a conservação de logradouros públicos, em regime de colaboração, por particulares, que ficarão com a responsabilidade pela conservação, ajardinamento e tratamento paisagístico de determinada praça.

\section{- $\quad$ Lei Municipal no 5.192/98}

Consiste na implantação do Projeto "Pequeno Jardineiro", que visa à educação e assistência do menor carente, com ênfase na área da ecologia. O Projeto prevê a formação do menor quanto à educação ambiental e iniciação ao trabalho. Porém, tal programa teve pouca repercussão e aplicação. 


\section{- $\quad$ Lei Municipal no 5.409/99}

Estabelece convenio entre a Prefeitura de São José dos Campos e a CETESB, com intervenção da Fazenda Pública Estadual e da Universidade de São Paulo, objetivando à instalação de estação de monitoramento da qualidade do ar em São José dos Campos.

\section{- $\quad$ Lei Municipal $n^{0}$ 5.441/99}

A presente lei regulamenta o fechamento de loteamentos, vilas e ruas sem saída situadas em áreas unicamente residenciais, estabelecendo o acesso controlado de pessoas e veículos a essas áreas. A lei foi alterada pelo Decreto Municipal $\mathrm{n}^{\circ} 10.969 / 03$ e pela Lei Municipal $\mathrm{n}^{\mathrm{o}}$ 8.098/10 (que autoriza o fechamento de loteamentos também na zona predominantemente industrial), sendo objeto da Ação Direta de Inconstitucionalidade $n^{\circ}$ 6875900, por meio do Tribunal de Justiça do Estado de São Paulo, que julgou improcedente a ação. Portanto, os loteamentos fechados passam a ser regulamentados e autorizados no município.

Porém, como vem sendo estudado por diversos pesquisadores, a criação desse tipo de loteamento acaba gerando o agravamento da segregação urbana e prejudica o ordenamento do espaço e circulação viária.

\section{- $\quad$ Lei Municipal $\mathbf{n}^{\circ} \mathbf{5 . 6 5 5 / 0 0}$}

Com esta lei, o município de São José dos Campos estabelece um convênio com a Fundação Valeparaibana de Ensino (FVE) e Universidade do Vale do Paraíba (UNIVAP) para a realização de estudo das microbacias e macrozoneamento hidrográfico do Município.

\section{- $\quad$ Lei Municipal $n^{0}$ 5.680/00}

Cria o Instituto de Pesquisa e Planejamento Urbano de São José dos Campos IPPSJC, entidade autárquica municipal autônoma de direito público interno, com sede e foro neste município.

O IPPSJC seria um órgão aos moldes do IPPUC (Curitiba), que contribuiria para o planejamento urbano do município, para apoiar os trabalhos das Secretarias e demais órgãos municipais, elaborar ações, diretrizes, projetos e programas, prestar assistência técnica, entre outros, com o objetivo de proporcionar o melhor planejamento e desenvolvimento do município. Porém, tal órgão funciona como uma ONG, com o nome Instituto de Pesquisa, Administração e Planejamento, com pouca atuação no município. 
- $\quad$ Decreto Municipal $\mathbf{n}^{0} \mathbf{1 0 . 6 2 9 / 0 2}$

O presente decreto cria um grupo de trabalho multidisciplinar que irá cuidar, pesquisar e fiscalizar as emissões eletromagnéticas, por antenas de telefonia móvel no município. O grupo será formado por técnicos das Secretarias de Saúde, Meio Ambiente e Obras. A lei trata ainda da aquisição de equipamentos para maior controle e fiscalização das fontes emissoras de eletromagnetismo.

No entanto, até o momento não existe nenhum tipo de controle ou estudo sobre as emissões eletromagnéticas no município, nem mesmo um mapeamento das antenas de telefonia móvel, ou uma política para sua fixação.

\section{- $\quad$ Lei Municipal no 6.473/03}

A presente lei cria o Programa Agenda 21 de São José dos Campos, com a finalidade de normatizar, facilitar e integrar as ações necessárias à implementação da "Agenda 21 da Conferência das Nações Unidas sobre o meio ambiente e desenvolvimento - Rio 92”. Desta forma, cria-se um comitê, composto por diferentes agentes do poder público e da sociedade civil organizada.

A lei descreve a importância de existir contato e intercâmbio entre o Comitê e Procuradoria e Curadoria do Meio Ambiente, e também, entre ONGs, entidades ambientalistas e empresários. As principais atribuições do Comitê são:

I - elaborar o documento "Agenda 21 - São José dos Campos", que consistirá em organizar, com base na "Agenda 21" produzida pela Conferência Rio-92 da ONU, as ações voltadas ao cumprimento desta no Município;

II - organizar anualmente o diagnóstico ambiental do Município e selecionar os indicadores apropriados para os problemas identificados, que sirvam para monitorar de forma sistemática a situação ambiental do Município;

III - elaborar um plano de ação que contenha objetivos estratégicos, diretrizes, metas setoriais, prioridades de investimentos, ações de curto, médio e longo prazos, indicadores de projetos e programas para implantação, monitoramento, avaliação, revisão e definição de responsabilidades pela execução dos mesmos;

IV - organizar um banco de dados sócio-econômico-ambiental do Município;

V - produzir relatórios sobre a situação ambiental do Município, com uso dos indicadores selecionados, que mostrem as tendências ambientais e da qualidade do meio ambiente e avaliem os resultados alcançados com as ações implementadas;

VI - propor e selecionar instrumentos legais necessários à implementação do Programa AGENDA 21 SÃO JOSÉ DOS CAMPOS;

VII - divulgar publicamente todas as etapas e os resultados alcançados pelo Programa AGENDA 21 SÃO JOSÉ DOS CAMPOS;

VIII - apoiar e promover a constituição de parcerias entre a Administração Pública Municipal e os outros setores sociais, visando a implementação da AGENDA 21 SÃO JOSÉ DOS CAMPOS;

IX - sugerir às autoridades municipais e aos Órgãos Públicos Estaduais e Federais instalados no Município medidas internas que possam reduzir os impactos negativos de suas próprias ações ao meio ambiente e programas de treinamento e capacitação de servidores municipais; 
$\mathrm{X}$ - apoiar, estimular, organizar e buscar parcerias e patrocínios a eventos como conferências, congressos, simpósios, palestras e cursos voltados à implementação da AGENDA 21 SÃO JOSÉ DOS CAMPOS.

No entanto, na prática, a Agenda 21 Local nunca existiu. Houve reuniões e discussões sobre o tema, mas nada foi determinado e posto em ação.

\section{- $\quad$ Lei Municipal no 6.288/03}

A referida lei institui o projeto "Recanto dos Pássaros", que tem como objetivo a plantação de árvores frutíferas nos terrenos públicos (praças, canteiros, margens de rios, estradas e outros). Porém, tal programa teve pouca repercussão e aplicação.

\section{- $\quad$ Lei Municipal no 6.431/03}

A lei trata do armazenamento e destinação de carcaças de pneus e câmaras de ar e estipula que as empresas fabricantes destes produtos ficam obrigadas a recolher periodicamente as carcaças de pneus e câmaras em locais apropriados para o correto armazenamento do produto, até que o mesmo receba destinação final adequada, sem agredir o meio ambiente, e também, a orientar e alertar o consumidor sobre os riscos que o armazenamento inadequado de carcaças pode causar à saúde e ao meio ambiente.

A lei prevê ainda que o não cumprimento das normas acarretará em multa no valor de R\$ 200,00, aplicável em dobro em caso de reincidência.

Porém, a lei nunca foi colocada em prática. Os pneus não têm um destino específico, eles podem ser entregues, em pequena quantidade, nos Pontos de Entrega Voluntária (PEVs).

\section{- $\quad$ Lei Municipal no 6.493/04 (Alterada pela Lei Municipal no 7.338/07)}

Declara o complexo formado pela antiga Tecelagem Parayba e Fazenda Santana do Rio Abaixo, como Zona de Preservação (ZP). As Zonas de Preservação regulamentam o Uso e Ocupação do Solo em regiões envoltórias de bens de interesse histórico, cultural, arquitetônico, paisagístico ou ambiental, visando à sua valorização, proteção e preservação. $\mathrm{O}$ perímetro da ZP foi ampliado pela Lei Municipal n 7.338/07.

\subsection{9/09}

Lei Municipal $n^{\circ}$ 6.690/04, Lei Municipal $n^{\circ}$ 7.112/06 e Lei Municipal $n^{\circ}$

Institui a Política Municipal de Educação Ambiental. A lei define em seu Art. $1^{\circ}$ Educação Ambiental como "os processos por meio dos quais o indivíduo e a coletividade constroem valores sociais, conhecimentos, habilidades, atitudes e competências voltadas para 
a conservação do meio ambiente, bem de uso comum do povo, essencial à sadia qualidade de vida e sua sustentabilidade (LEI MUNICIPAL 6690/04).

A lei coloca como sendo fundamental o ensino da educação ambiental, sendo algo que deve estar presente em todos os níveis de ensino, em todas as esferas de governo, municipal, estadual e federal.

A educação ambiental passa a ser incumbida ao poder público, às instituições educativas, aos órgãos integrantes da gestão pública municipal, aos meios de comunicação de massa, às empresas e instituições públicas e privadas e à sociedade como um todo, tendo como objetivo o engajamento de toda a sociedade na conservação, recuperação, melhoria do meio ambiente e melhores práticas educativas; em suma, o fortalecimento da cidadania, bem como a proteção do meio ambiente saudável.

Conforme o Art. 8, as atividades vinculadas à Política Municipal de Educação Ambiental devem ser desenvolvidas na educação em geral e na educação escolar, por meio da capacitação de recursos humanos; fomento e desenvolvimento de estudos, pesquisas e experimentações; produção e divulgação de material educativo; acompanhamento e avaliação; desenvolvimento de programas educacionais ao ar livre em caráter de ensino formal e nãoformal.

O Art. 10 determina que "a educação ambiental será desenvolvida como uma prática educativa integrada, contínua e permanente em todos os níveis e modalidades do ensino formal". O Art. 11 estipula que "a dimensão ambiental deve constar dos currículos de formação de professores, em todos os níveis e em todas as disciplinas”.

Desta forma, a Lei Municipal no 6.690/04 institui a Política Municipal de Educação Ambiental, determina ações e meios para que a Educação Ambiental passe a integrar todo e qualquer sistema de ensino. Porém, a lei não estabelece nenhuma medida prática, projeto ou programa que institua a Política Municipal de Educação Ambiental.

Em 2006, é estipulada uma nova lei, Lei Municipal $n^{\circ} 7.112$, que cria a Política Municipal de Educação Ambiental. A nova lei não faz nenhuma menção à lei anterior; ela é muito mais simplista, apresenta os objetivos da lei e a criação de um Núcleo Gestor com a participação de diferentes agentes ligados à Prefeitura, representantes de indústrias, vereadores, sociedade civil e outros. O Núcleo Gestor fica incumbido de revisar, a cada dois anos, o Programa Municipal de Educação Ambiental.

Desta forma, em 2006, é promulgado o Programa Municipal de Educação Ambiental, com o slogan "Semeando idéias para uma vida melhor", tendo como base o Programa Nacional de Meio Ambiente. Porém, pode-se perceber que muito do programa intercambiou o 
campo das ideias e teorias. Na prática, as ações foram poucas. Passados mais de cinco anos desse Programa vê-se poucas realizações, e não houve nenhuma revisão até o momento. A Secretaria Municipal de Meio Ambiente desenvolve alguns projetos que não constam no programa, como o Projeto de Revitalização de Nascentes, Projeto Horta Urbana e Projeto Trilhas no Parque, segundo informações da Secretaria Municipal de Meio Ambiente. Existem muitas parcerias entre a Secretaria de Educação e a de Meio Ambiente, sendo que muitos dos funcionários que trabalham com educação ambiental são professores.

Ainda sobre a Educação Ambiental, tem-se a Lei Municipal n 7.789 de 16 de janeiro de 2009, que implanta a disciplina de Educação Ambiental na grade curricular das escolas do Município. No entanto, a Educação Ambiental não foi instituída como uma disciplina, mesmo porque esta não deve ser vista como uma disciplina e deve fazer parte do conteúdo programático de todas as séries.

\section{- $\quad$ Lei Municipal no 7.146/06}

Esta lei municipal institui o Plano Integrado de Gerenciamento e o Sistema de Gestão Sustentável de Resíduos da Construção Civil e Resíduos Volumosos, de acordo com o previsto na Resolução do CONAMA nº 307, de 05 de julho de 2002.

A lei proíbe o descarte de resíduos da construção civil e resíduos volumosos em áreas de "bota fora", encostas, corpos d'água, lotes vagos, passeios, vias e outras áreas públicas, áreas não licenciadas e áreas protegidas por Lei. Determina lugares específicos para a disposição dos resíduos da construção civil e resíduos volumosos, e o disciplinamento e regularização deste serviço, como disposto no Art.4:

[...] $\S 2^{\circ}$ O Plano Integrado de Gerenciamento de Resíduos da Construção Civil contido no Sistema de Gestão Sustentável de Resíduos da Construção Civil e Resíduos Volumosos é constituído por um conjunto integrado de áreas físicas e ações, descritas a seguir:

I - Uma rede de Pontos de Entrega para Pequenos Volumes de Resíduos da Construção Civil e Resíduos Volumosos, implantada em bacias de captação de resíduos.

II - Serviço Disque Coleta para Pequenos Volumes, de acesso telefônico a pequenos transportadores privados de Resíduos da Construção Civil e Resíduos Volumosos.

III - Uma rede de Áreas para Recepção de Grandes Volumes, tais como, Áreas de Transbordo e Triagem, e Áreas de Reciclagem, quando necessárias, e Aterros de Resíduos da Construção Civil. 
IV - Ações para a informação e educação ambiental dos munícipes, dos transportadores de resíduos e das instituições sociais multiplicadoras, definidas em programas específicos.

V - Ações para o controle e fiscalização do conjunto de agentes envolvidos, definidas em programa específico.

VI - Ação de gestão integrada a ser desenvolvida por Núcleo Permanente de Gestão que garanta a unicidade das ações previstas no Plano Integrado de Gerenciamento e exerça o papel gestor que é competência do Poder Público Municipal.

Assim, a lei determina uma série de medidas e programas que visam à melhor destinação dos resíduos gerados pela construção civil, em destaque a criação de pontos de coletas desse material (PEV - Ponto de Entrega Voluntária).

O Art.9 estipula que os geradores de grandes volumes de resíduos da construção civil, públicos ou privados, devem anunciar nos projetos de gerenciamento os responsáveis pelos serviços de transporte e destinação de resíduos, devendo estes serem licenciados pelo Poder Público, e determina ainda que, para obter o "Habite-se", deverá apresentar documentação de controle comprovadora do correto transporte, triagem e destinação dos resíduos gerados.

A legislação prevê, nos Art. 17 e 18, a gestão sustentável de resíduos da construção civil e resíduos volumosos, estes deverão passar por triagem, sempre que possível, processo de reutilização, desmontagem e reciclagem, que evitem sua destinação final a aterro sanitário. O Art. 20 cria o Núcleo Permanente de Gestão, que será responsável por coordenar as ações integradas, previstas no Plano Integrado de Gerenciamento de Resíduos da Construção Civil. A lei estipula penalidades e multas pelo não cumprimento das normas estabelecidas.

Tal legislação é um grande avanço, pois regulamenta a destinação correta dos resíduos da construção civil, e também, na regulamentação da coleta seletiva, promovendo a gestão sustentável dos resíduos volumosos.

\section{- $\quad$ Lei Municipal no 7.217/06}

Cria normas e procedimentos para o serviço de coleta e disposição final de pilhas, baterias e lâmpadas de mercúrio nos estabelecimentos que comercializarem esses componentes. O estabelecimento deverá dispor de recipiente coletor apropriado para seu depósito conforme regulamento. Porém, na prática, são poucos os estabelecimentos que possuem local correto para o descarte destes materiais. 


\section{- $\quad$ Lei Complementar no 357/08}

Institui a Política Municipal de Saneamento Básico. O Art. $3^{\circ}$ aponta que "É garantido a todos o direito a níveis adequados e crescentes de salubridade ambiental e de exigir dos responsáveis medidas preventivas, mitigadoras, compensatórias ou reparadoras em face de atividades prejudiciais ou potencialmente prejudiciais à salubridade ambiental”. Desta forma, demonstra-se a importância de criar novas normas e diretrizes para um saneamento básico de melhor qualidade no município, pensando-se também na melhoria da qualidade do meio ambiente.

A lei destaca como objetivo a universalização do acesso aos serviços públicos de saneamento básico de águas e esgoto.

Por meio da Lei Complementar n. 371/08, o Poder Executivo Municipal cria convênio com a Companhia de Saneamento Básico do Estado de São Paulo - SABESP, ficando assim responsável pela captação, adução e tratamento de água bruta; adução, reservação e distribuição de água tratada; coleta, transporte, tratamento e disposição final de esgotos sanitários.

\section{- $\quad$ Lei Municipal no 7.815/09}

Esta lei está em acordo com a Lei Federal n ${ }^{\circ}$ 12.305/10, que institui a Política Nacional de Resíduos Sólidos. A lei municipal $\mathrm{n}^{\mathbf{0}} 7.185 / 09$ visa estabelecer normas específicas e disciplinar os serviços municipais de limpeza urbana e manejo dos resíduos sólidos. Conforme o Art. $2^{\circ}$, são objetivos desta lei:

I - a implantação da gestão integrada dos resíduos sólidos no Município;
II - o uso sustentável e eficiente dos recursos naturais;
III - a preservação e a melhoria da qualidade do meio ambiente, da saúde pública e a recuperação das áreas degradadas por resíduos sólidos;

IV - a inclusão social de catadores nos serviços de coleta seletiva;

V - a redução da quantidade e da nocividade dos resíduos sólidos, evitando os problemas de saúde pública por eles gerados, por meio da erradicação dos pontos de disposição inadequados;

VI - a universalização da coleta seletiva em todo território municipal.

Desta forma, vê-se que a legislação tem como objetivo cumprir função social e ambiental, seja integrando os catadores de rua a serviços de coleta seletiva, seja pela universalização da coleta seletiva em todo o município e a busca por um meio ambiente saudável. 
A lei prevê medidas de educação ambiental que visem à redução na geração de resíduos, e ainda, a reciclagem e recuperação de resíduos. Prevê o incentivo ao uso de matérias recicláveis.

Trata, também, da coleta seletiva dos resíduos recicláveis, que será feita porta a porta, em um determinado dia, em cada bairro. Destaca ainda a possibilidade de criar Locais de Entrega Voluntárias (LEVs), para que a população possa levar, voluntariamente, os resíduos recicláveis gerados.

O resíduo sólido que não puder ser reciclado, recuperado ou reutilizado terá como destino final o aterro sanitário, conforme as normas ambientais vigentes.

A legislação anterior, Lei Municipal $\mathbf{n}^{\mathbf{0}}$ 3.718/90, que dispõe sobre o serviço de limpeza pública, não aborda a questão da coleta seletiva, ou mesmo da reciclagem. No entanto, a lei prevê a coleta separada para resíduos sólidos sépticos provenientes dos serviços de saúde, e também, para resíduos industriais. A coleta seletiva é abordada nos Planos Diretores de 1995 e 2006.

A Lei Municipal no 3.718/90 determina que a coleta dos resíduos provenientes de processo industrial deverá ser realizada a critério do órgão estadual de meio ambiente, de acordo com a sua classificação. Determina ainda, que caberá ao órgão municipal (URBAM), instalar e operar aterro industrial em seu território, nos termos da legislação ambiental. A legislação atual determina que cabe aos geradores de resíduo industrial a destinação correta deste material, que não poderá ser feita no Aterro Sanitário do município.

\section{- $\quad$ Lei Municipal no 8.064/10}

Implanta o programa Mutirão Ambiental nos Bairros, devendo contemplar todos os bairros da cidade com a realização de corte, poda, plantio de árvores e realização de palestras educativas alusivas ao Meio Ambiente. A lei determina que cada cidadão que participar do Programa Mutirão Ambiental nos Bairros receberá um diploma. O programa teve muito pouca repercussão na prática. Porém, tal programa teve pouca repercussão e aplicação até o momento.

\section{- $\quad$ Lei Municipal $n^{0}$ 8.293/10}

Torna obrigatório o plantio de árvores nas calçadas defronte a todas as unidades residenciais e lotes de terreno em novos empreendimentos licenciados pela Prefeitura Municipal. 
- Lei Complementar $n^{0}$ 423/10

A referida lei determina que a execução de qualquer tipo de atividade, serviço, obra, construção, cerca, muro, gradil, tapume, muro de arrimo, garagem de embarcação, de máquinas ou equipamentos, terraplanagem, similares e congêneres a ser desenvolvida em Área de Preservação Permanente - APP de córregos, rios, lagoas, nascentes e áreas de várzea, independentemente de eventual licenciamento por órgãos estaduais e federais, deverá ter prévia aprovação da Prefeitura Municipal, que fará análise da existência de interesse público para sua liberação.

\subsection{Lei Orgânica de São José dos Campos: aspectos ambientais}

A Lei Orgânica é considerada a Constituição Municipal, ou seja, a lei maior do município traz o conjunto de normas jurídicas que regem o município, em acordo com a Constituição Federal e Estadual. A Lei Orgânica de São José dos Campos foi promulgada em 05 de abril de 1990, tendo a sua última emenda em 08 de dezembro de 2011 (emenda $\left.n^{\circ} 076 / 11\right)$.

Em relação aos aspectos ambientais, a Lei determina, no Art. 21, como sendo competência do município: "estabelecer normas de prevenção e controle de ruídos, de poluição do meio ambiente, da terra, do ar e das águas”. O Art. 22 aponta como competência do município, Estado e União: "V - proteger o meio ambiente e combater a poluição em qualquer de suas formas; VI - preservar as florestas, a fauna, a flora e o solo".

A Lei Orgânica trata no Título VI - Do desenvolvimento econômico, em seu Capítulo I - do Meio Ambiente, no qual dispõe normas e diretrizes que visam garantir um meio ambiente ecologicamente equilibrado e protegido para todos.

O Art. 230 aponta que o Poder Público Municipal, em colaboração com o Estado, assumirá os seguintes cuidados:

I - proteção, preservação e recuperação do meio ambiente, em suas mais variadas formas;

II - preservação das florestas, da fauna e da flora, das paisagens naturais e dos sítios arqueológicos;

III - registro, acompanhamento e fiscalização de concessões de direito de pesquisa e exploração de recursos hídricos e minerais em seu território;

IV - promoção da ecologia como ciência e sua divulgação nos meios de comunicação, assim como na rede escolar, através de um trabalho de esclarecimento e conscientização públicas;

V - execução, com a colaboração da União, do Estado e de outros órgãos e instituições, de programas de recuperação do solo, de reflorestamento e aproveitamento de recursos hídricos; 
VI - exercício do poder de polícia administrativa na vigilância e na fiscalização da preservação do meio ambiente, dispondo através de lei, das penalidades por infrações ou danos à comunidade e à natureza.

Neste sentido, o poder público municipal se compromete em adotar políticas que visem à proteção e preservação do meio ambiente em suas variadas formas. No entanto, afirma que a proteção ao meio ambiente é responsabilidade tanto do município, como do Estado e da União.

O Art.231 estabelece que para a implantação de qualquer atividade pública ou privada, causadora de danos à saúde e ao bem-estar da população, ou ainda, aos recursos naturais, deverá ser realizado estudo de impacto ambiental e audiência pública.

A Lei aborda ainda a questão da necessidade de tratamento dos resíduos sólidos e efluentes dos esgotos, a importância em proteger a fauna e a flora e prevê sanções para exploração dos recursos naturais, e ainda, a criação de cinturões verdes.

Em seu Art. 235, determina que as atividades consideradas modificadoras do meio ambiente deverão obter Estudo de Impacto Ambiental (EIA) e Relatório de Impacto Ambiental (RIMA), e também, a realização de audiência pública, para a qual devem ser especialmente convidadas as entidades de defesa do meio ambiente.

O Art. 236 estabelece que o município participará do sistema integrado de gerenciamento de recursos hídricos. Os recursos hídricos possuem destaque, ressaltando-se a sua importância, e impondo-se várias medidas, como o uso racional da água, zoneamento de áreas sujeitas a inundações, proibição do descarte de efluentes urbanos e industriais em qualquer corpo d'água e zelo pela capacidade de infiltração no solo.

A Lei Orgânica prevê ainda como competência do município a educação ambiental em todos os níveis de ensino e a recuperação das áreas degradadas nas margens do Rio Paraíba do Sul.

O Art. 241 determina as principais áreas ambientalmente protegidas: "Os Rios Paraíba do Sul, Buquira e do Peixe, a Reserva Florestal Augusto Ruschi (Fazenda Boa Vista), a área ocupada pelo antigo Sanatório Vicentina Aranha, o Banhado e o Distrito de São Francisco Xavier, são espaços territoriais especialmente protegidos e sua utilização far-se-á na forma da lei, dentro de condições que assegurem a preservação do meio ambiente". Conforme a Lei Orgânica, o município fica ainda submetido: "a implantar e manter áreas verdes de preservação permanente, de acordo com os parâmetros fixados pela Organização Mundial de Saúde" (Art. 246). 
Conforme o Art. 240, é vedada a instalação de termelétrica no município. O Art. 248 proíbe a utilização de metais pesados por meio de qualquer processo de extração, produção e beneficiamento, que possa resultar na contaminação do ambiente natural.

O Art. 271 reafirma a saúde como direito fundamental de todos, conforme a Constituição Federal de 1988. Para tanto, o Art. 272 coloca que o direito à saúde implica em direitos fundamentais, entre eles o respeito ao meio ambiente e controle da poluição ambiental.

Nota-se que muitas das medidas ambientais atualmente adotadas no município já estavam previstas desde 1990, no entanto, muito do que foi promulgado na Lei Orgânica ainda não possui regulamentação ou foi recentemente instituído por lei. 


\section{As Políticas Públicas Ambientais: Discurso e Prática em São José Dos Campos}

O município de São José, embora já tivesse zoneamento urbano em 1932 e tenha sido uma das primeiras cidades do país a possuir Plano Diretor, apresenta inúmeras irregularidades em seu ordenamento espacial.

A ação do Estado sempre esteve muito presente no município, porém a sua atuação esteve marcada no setor econômico. As esferas sociais e ambientais não receberam a mesma atenção, e isto pode ser visto nos inúmeros conflitos socioambientais existentes no território joseense.

Para elucidar a questão das políticas públicas ambientais na esfera local, será feita uma análise dos problemas ambientais levantados ao longo do estudo do município de São José dos Campos e sua legislação, evidenciando quais políticas foram previstas e quais foram adotadas na prática.

Pretende-se destacar os principais conflitos ambientais vividos por São José dos Campos, com base na legislação urbanística e ambiental, e analisar a evolução desses conflitos, e como a legislação e as políticas públicas ambientais se fizeram presentes ou não no desenvolvimento e crescimento deste município. Para tanto, os pontos de conflitos foram divididos em cinco temas: Zoneamento Urbano, Meio Ambiente, Indústrias, Loteamentos Clandestinos e Resíduos Urbanos. 
Todos os temas apresentam questões e incertezas que foram levantadas durante o estudo da legislação municipal. Busca-se analisar estas questões através de mapas, dados estatísticos, trabalho de campo, entrevistas e imagens de satélite. A base cartográfica foi fornecida pela Prefeitura Municipal de São José dos Campos, por meio do CD-ROM "Cidade de Viva - 2011", e também, por meio de levantamentos bibliográficos no Arquivo Público Municipal e Secretaria Municipal de Planejamento Urbano. Os mapas apresentados foram desenvolvidos nos softwares AutoCAD® e Spring®.

Ao final deste trabalho, é apresentado a Tabela 9 (EM ANEXO), com a compilação de todas as leis de São José dos Campos analisadas nesta pesquisa, e buscou-se levantar os principais pontos abordados em cada legislação, principalmente, no que envolve a questão ambiental, e estabelecer um parecer sobre o que foi realmente colocado em prática e o que ficou apenas no discurso político. Neste sentido, diante de todas as leis municipais analisadas, foram levantadas 126 ações de melhorias urbanísticas, ambientais e sociais para o município de São José dos Campos, como mostra a Tabela 9 (EM ANEXO). Como se pode analisar dentre as ações previstas, apenas $21 \%$ foram executadas, $30 \%$ não foram executadas, $39 \%$ foram parcialmente executadas e $10 \%$ não foi possível avaliar. Desta forma, a maior parte das ações ficou apenas no papel.

\subsection{Zoneamento Urbano}

O zoneamento urbano é uma política adotada pelo município de São José dos Campos há muito tempo. Já em 1932, a cidade teve o seu primeiro zoneamento. De lá para cá, as mudanças na estrutura interna e na dinâmica urbana de São José dos Campos foram muitas e refletiram-se no uso do solo urbano.

Foram analisadas as mudanças nas zonas de uso do solo, de São José dos Campos, com o intuito de averiguar se a política de zoneamento foi exercida de forma efetiva e planejada, se houve continuidade entre as leis de zoneamento e se estas foram respeitadas.

Para tanto, por meio de mapas e tabelas, foi comparado as leis de zoneamento urbano da cidade no período de 1960 a 2010. Inicialmente, estabeleceu-se uma classe padrão, agrupando as zonas de uso pelas suas semelhanças, conforme a classificação das zonas nas leis de zoneamento urbano do período. Assim, chegou-se à classe final, como mostra a tabela a baixo. 
Tabela 2-Zoneamento urbano: agrupamento de zonas e classe final

\section{CLASSE FINAL}

\begin{tabular}{|c|c|c|c|}
\hline $\mathbf{Z C}$ & \multicolumn{3}{|l|}{ Zona central } \\
\hline ZR & \multicolumn{3}{|l|}{ Zona residencial } \\
\hline $\mathbf{Z M}$ & \multicolumn{3}{|l|}{ Zona mista } \\
\hline ZI & \multicolumn{3}{|l|}{ Zona industrial } \\
\hline ZPA & \multicolumn{3}{|l|}{ Zona de proteção ambiental } \\
\hline ZCHR & \multicolumn{3}{|l|}{ Zona de chácaras } \\
\hline ZEPH & \multicolumn{3}{|c|}{ Zona especial de proteção do patrimônio histórico, paisagístico e cultural } \\
\hline ZVU & \multicolumn{3}{|l|}{ Zona de vazio urbano } \\
\hline ZEIS & \multicolumn{3}{|c|}{ Zona de especial interesse social (loteamentos clandestinos de baixo padrão) } \\
\hline ZAI & \multicolumn{3}{|c|}{ Zona de assentamento informal (loteamentos clandestinos de alto padrão) } \\
\hline ZEA & \multicolumn{3}{|l|}{ Zona especial aeroportuária } \\
\hline \multirow{2}{*}{\multicolumn{4}{|c|}{ 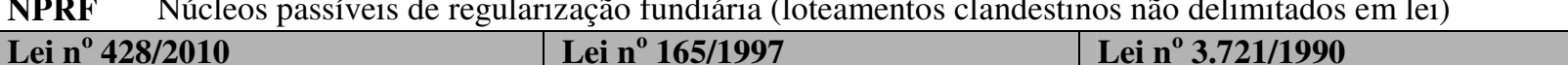 }} \\
\hline & & & \\
\hline $\begin{array}{l}\text { ZC }=2 \\
\text { ZR }=2 \\
\text { ZM= } \\
\text { ZI }=\text { Z } \\
\text { ZPA }= \\
\text { ZCHR } \\
\text { ZEPH } \\
\text { ZVU }= \\
\text { ZEIS } \\
\text { ZAI }= \\
\text { ZEA= } \\
\text { NPRF }\end{array}$ & $\begin{array}{l}\text { 2 } \\
\text { 2, 3 } \\
\text { I, 2, 3, 4, 5, 6, 7, } 8 \text { /ZQA } \\
\text { E1, 2, 3 } \\
\text { UPI, ZUD } \\
\text { ACHR, ZPA } 2 \\
\text { ZEPH } \\
\text { o se aplica } \\
\text { EIS } \\
\text { A } \\
\text { JPRF }\end{array}$ & 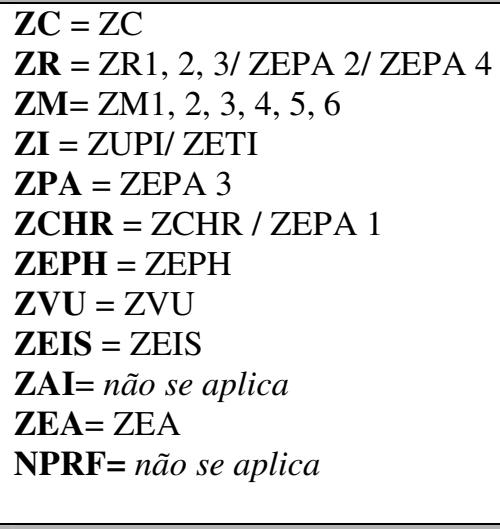 & 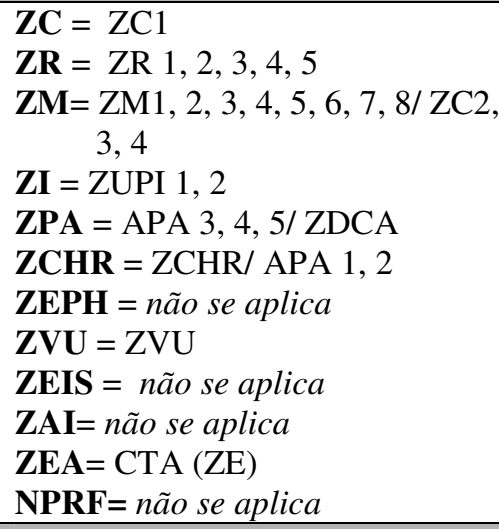 \\
\hline Lei $\mathrm{n}^{0}$ & 63/1980 & Lei $n^{0} 1606 / 1971$ & Zoneamento de Massa - 1961 \\
\hline $\begin{array}{l}\text { ZC }=2 \\
\text { ZR }=2 \\
\text { ZM }= \\
\text { ZI }=2 \\
\text { ZPA = } \\
\text { ZCHR } \\
\text { ZEPH } \\
\text { ZVU }= \\
\text { ZEIS } \\
\text { ZAI= } \\
\text { ZEA= } \\
\text { NPRF }\end{array}$ & $\begin{array}{l}1,2,3 \\
2,3,4 / \mathrm{ZE} 1,2,6,78,10, \\
12 \\
4 \\
3 \\
\text { ão se aplica } \\
\text { âo se aplica } \\
\text { o se aplica } \\
\text { io se aplica } \\
\text { se aplica } \\
\text { A- ZE } 5 \\
\text { â se aplica }\end{array}$ & $\begin{array}{l}\text { ZC }=\text { Zona central } / Z C \\
\text { ZR }=\text { ZPH } \\
\text { ZM= ZPC } \\
\text { ZI }=\text { ZPI/ ZI } \\
\text { ZPA = ZE Banhado } \\
\text { ZCHR = não se aplica } \\
\text { ZEPH = não se aplica } \\
\text { ZVU = não se aplica } \\
\text { ZEIS = não se aplica } \\
\text { ZAI }=\text { não se aplica } \\
\text { ZEA }=\text { CTA } \\
\text { NPRF }=\text { não se aplica }\end{array}$ & $\begin{array}{l}\text { ZC }=\text { não identificada } \\
\mathbf{Z R}=\text { residencial } \\
\mathbf{Z M}=\text { não se aplica } \\
\mathbf{Z I}=\text { industrial } \\
\mathbf{Z P A}=\text { áreas verdes } \\
\mathbf{Z C H R}=\text { não se aplica } \\
\mathbf{Z E P H}=\text { não se aplica } \\
\mathbf{Z V U}=\text { não se aplica } \\
\mathbf{Z E I S}=\text { não se aplica } \\
\mathbf{Z A I}=\text { não se aplica } \\
\mathbf{Z E A}=\text { CTA } \\
\mathbf{N P R F}=\text { não se aplica }\end{array}$ \\
\hline
\end{tabular}

* A área do Distrito de São Francisco Xavier não foi analisada.

A última lei de zoneamento de 2010 serviu de base para a delimitação das classes, sendo acrescida a zona de vazio urbano (ZVU), que não aparece na lei de 2010, mas aparece nas leis de 1997 e 1990. Buscou-se agrupar as zonas, estabelecendo um número menor de classes e unindo as características comuns entre as zonas, com o objetivo maior de analisar as questões ambientais. As zonas foram agrupadas com base no texto de lei que as definem. Verificando, por exemplo, se a zona permite o uso industrial ou não, se é somente de proteção ambiental ou permite o uso residencial. 
A lei de zoneamento $n^{0}$ 428/2010 teve a Zona de Urbanização Controlada (ZUC), a Zona de Qualificação (ZQA) e a Zona de Urbanização Específica (ZUE), que são áreas que permitem o uso misto, residencial, comercial, serviços e industrial, agrupadas e incorporadas à classe final ZM. A Zona de Proteção Ambiental 2 foi agrupada à Zona de Chácara, pois permite a ocupação de baixa densidade e parte dela já vem sendo loteada em condomínios fechados. A Zona de Proteção Ambiental 1 ficou numa classe separada como ZPA, por ser considerada área de proteção ambiental com uso restrito.

$\mathrm{Na}$ lei de zoneamento $\mathrm{n}^{\mathrm{o}}$ 165/1997, tem-se que as Zonas Especiais de Proteção Ambiental (ZEPA) 2 e 4 permitem a ocupação urbana de baixa densidade e são ocupadas por condomínios fechados de alto padrão, e por isso foram incorporadas à zona residencial (ZR) na classe final. Porém, a ZEPA 3 configura-se, conforme a lei, como de grande valor ambiental e paisagísticos, tendo maiores restrições quanto ao seu uso, sendo assim considerada ZPA na classe final. A ZEPA 1 foi incorporada à classe final ZCHR, pois o próprio texto da lei a define como área de chácara de recreio.

O zoneamento urbano de 1990, Lei n $\mathrm{n}^{\mathrm{3}}$ 3.721, teve a Área de Proteção (APA) 1 e 2 incorporadas à classe final ZCHR, uma vez que estas zonas permitiam o uso residencial unifamiliar de baixa densidade e chácara urbana. Na classe final ZPA, foram incorporadas as Zonas de Proteção Ambiental (APA) 3, 4 e 5 e a Zona de Domínio dos Cursos D’água (ZDCA), por apresentarem características semelhantes, com o objetivo de preservação ambiental. A Zona de Proteção de Mananciais (ZPM), mencionada na lei de 1990, não aparece registrada em mapa oficial, ou seja, na prática esta zona não é delimitada e por isso não aparece no mapa final desta tese.

A lei de zoneamento urbano ${ }^{\circ}$ 2.263/1980 teve agrupada a Zona Central (ZC) 2, 3 e 4 e a Zona de uso Especial (ZE) 1, 2, 4, 6, 7, 8, 9, 10, 11 e 12, e definidas como ZM na classe final, uma vez que são áreas que permitem o uso misto, diversificado. $\mathrm{Na}$ lei de zoneamento urbano Lei $\mathrm{n}^{\mathrm{o}}$ 1.606/1971, não houve modificações nas zonas definidas, apenas a mudança quanto à nomenclatura. A Zona de predominância Recreacional $(\mathrm{ZpR})$ não aparece no mapa final, pois esta foi apenas apontada em lei, porém, a ZpR não foi delimitada e identificada em mapa oficial, na prática ela não foi efetivada. O zoneamento de massa de 1961 tampouco sofreu modificações; apenas alterações na nomenclatura das zonas.

Desta forma, apresenta-se a seguir o conjunto de mapas na Figura 27 que mostram a evolução das leis de zoneamento urbano de São José dos Campos de 1961 a 2010. 


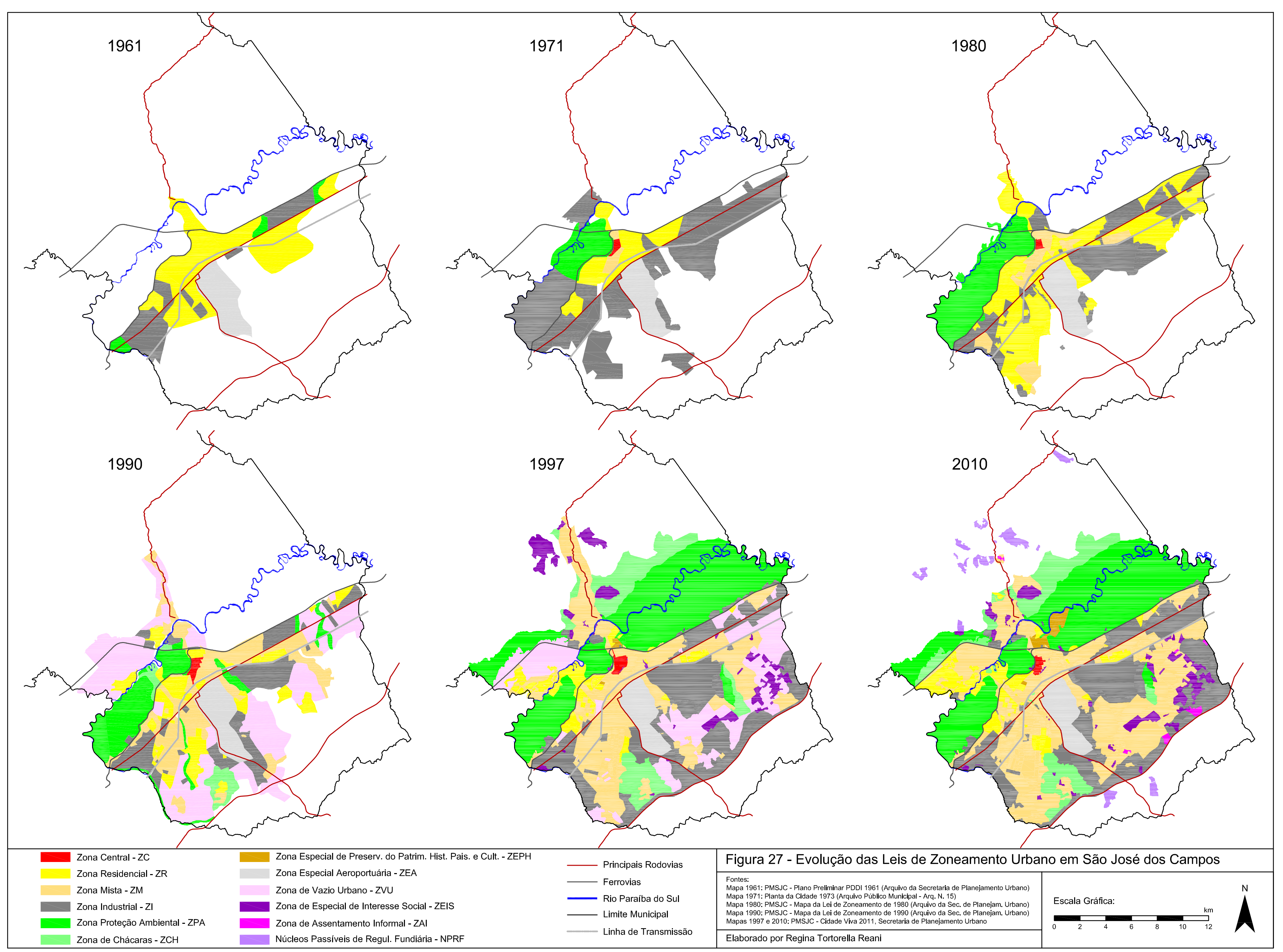


Ao se observar o conjunto de mapas, nota-se que as mudanças nas leis de zoneamento urbano são muitas. Praticamente, a cada lei, tem-se uma nova configuração do espaço urbano; falta continuidade entre uma lei e outra; muitas vezes, não houve respeito ao que a lei determinava, observam-se vários pontos de mudanças no uso do solo. Os estudos sobre os mapas da Figura 27 foram complementados pelo gráfico apresentado na Figura 28 e pelas Tabela 3 e Tabela 4.

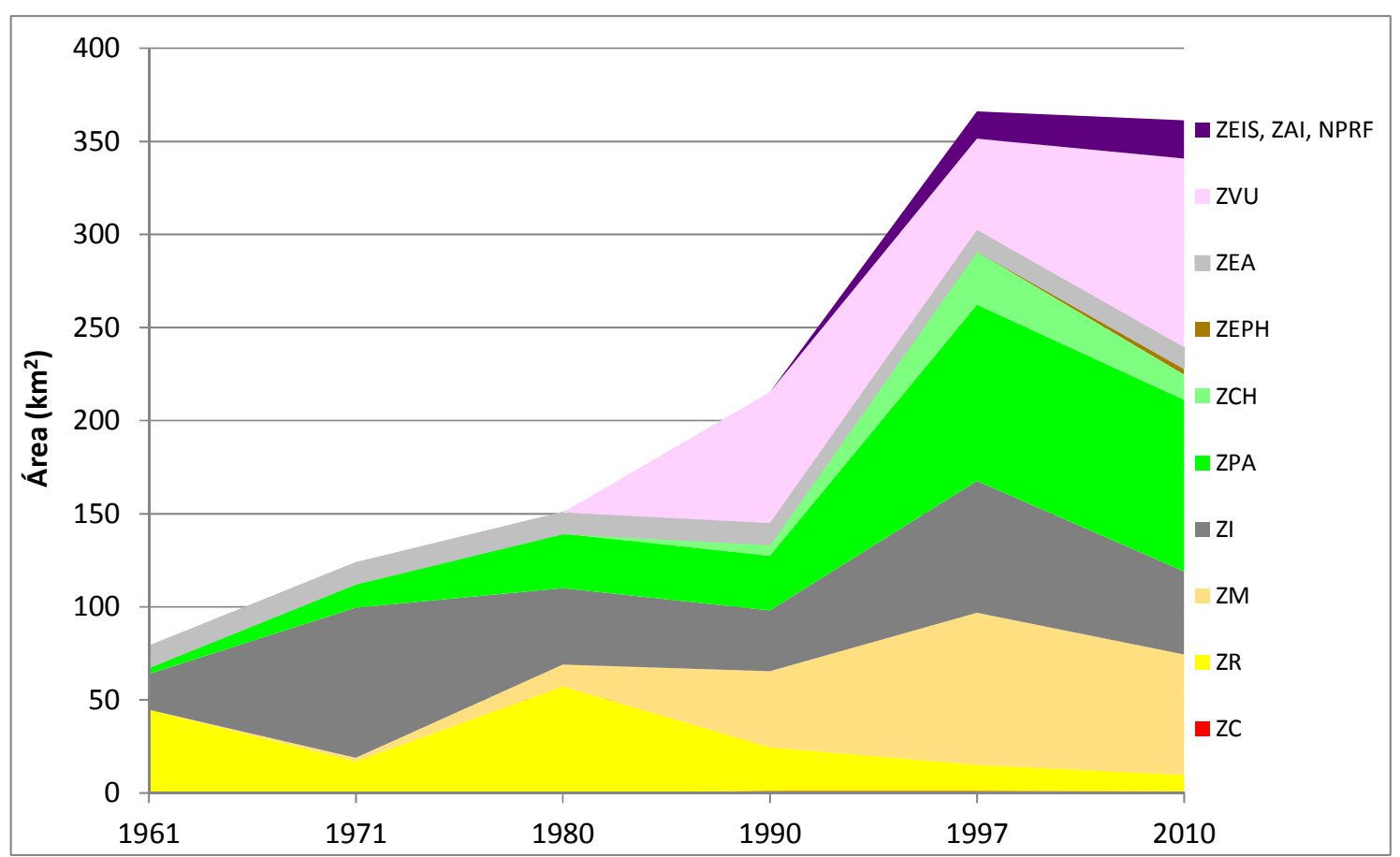

Figura 28 - Evolução das áreas nas Leis de Zoneamento de São José dos Campos.

Tabela 3 - Evolução das áreas em km² nas Leis de Zoneamento de São José dos Campos.

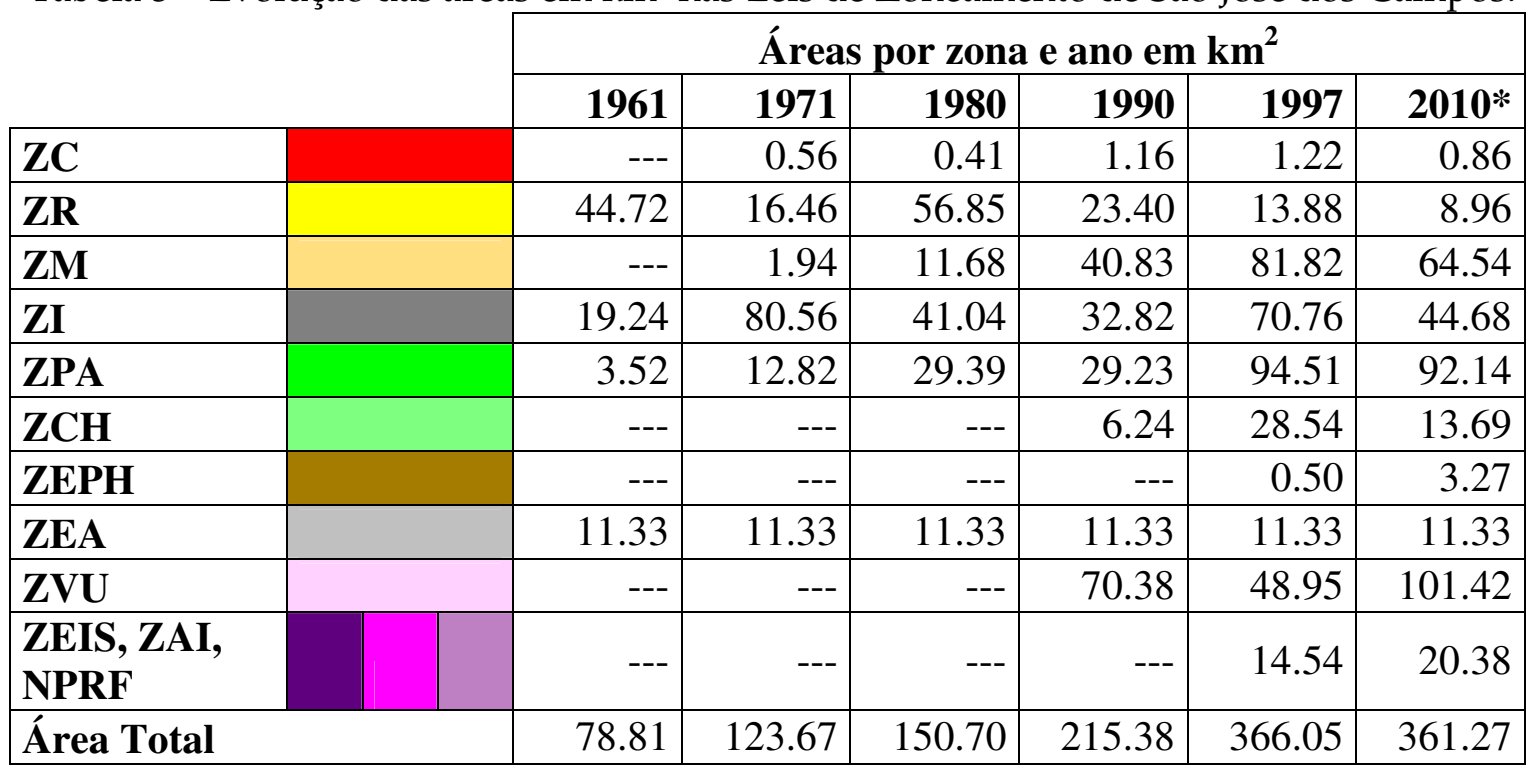


Tabela 4 - Evolução das áreas em porcentagem nas Leis de Zoneamento de São José dos Campos.

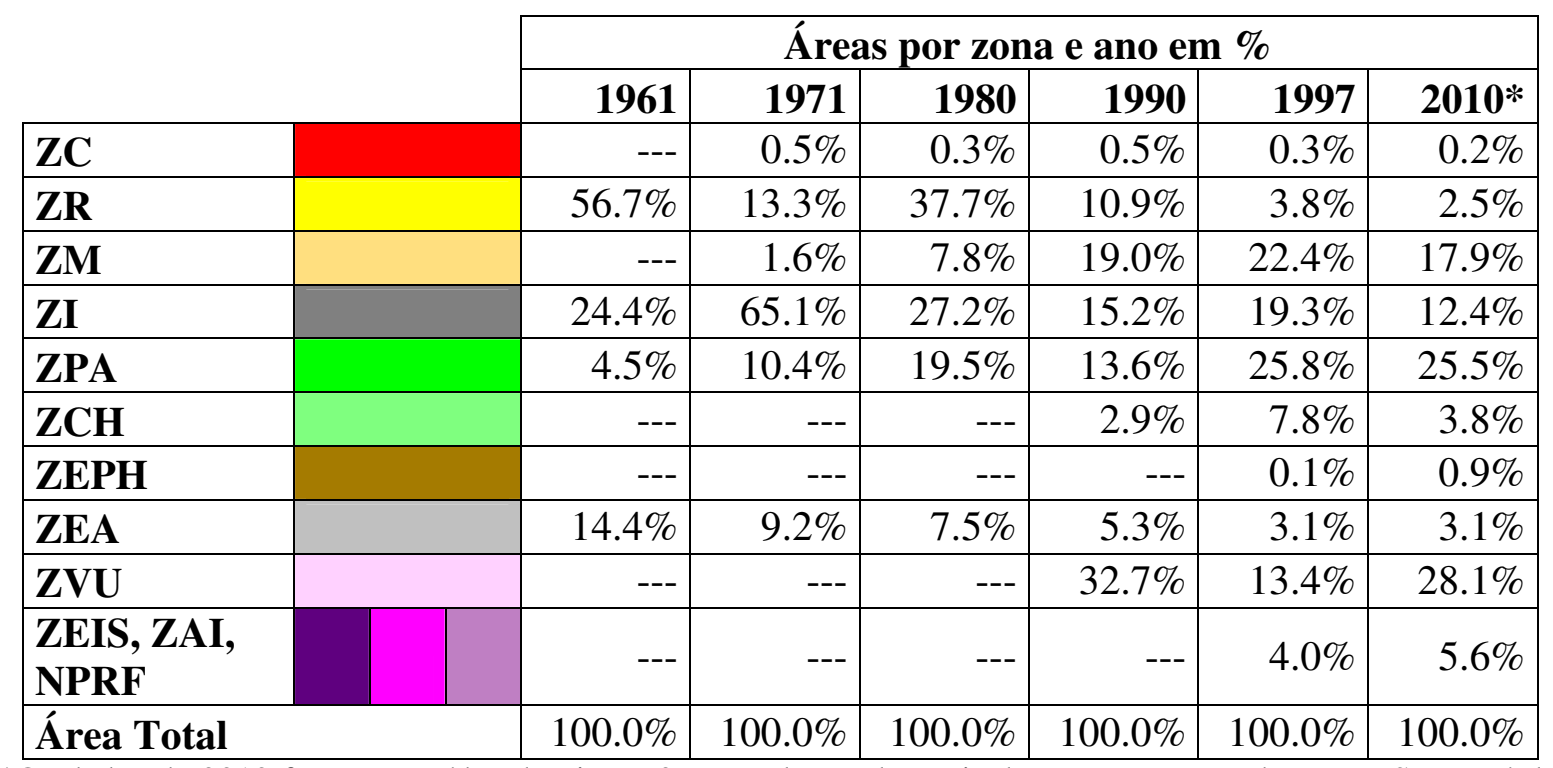

*Os dados de 2010 foram extraídos da Figura 27 - Evolução das Leis de Zoneamento Urbano em São José dos Campos e complementados pelas informações sobre vazios urbanos contidas no Caderno Diagnóstico da Lei de Zoneamento 2010 (p. 24), que mostram os vazios urbanos existentes em São José dos Campos em 2009.

Como se pode observar no gráfico e tabelas acima, a área zoneada de 1961 aumentou de $78,8 \mathrm{~km}^{2}$ para $361,27 \mathrm{~km}^{2}$ em 2010, ou seja, em 50 anos, o município aumentou o seu perímetro urbano em $358 \%$, porém o crescimento populacional neste mesmo período foi de 709\%; aumentou de 77.533 em 1960 para 627.544 habitantes em 2010. O município sofreu um crescimento não só em sua área, mas principalmente em seu número de habitantes.

No zoneamento de massa de 1961 tem-se uma cidade marcada predominantemente pelo uso residencial. Já em 1971, vive-se um novo contexto, pois o uso do solo é marcado pelo predomínio do uso industrial. O uso industrial é permitido às margens do Rio Paraíba do Sul, indo contra as propostas do zoneamento 1961. As áreas de proteção ambiental se concentram em parte do Banhado, e não mais distribuídas pelo território. O uso industrial é permito em meio à área residencial e ocupa $65,1 \%$ do perímetro urbano. Este zoneamento é fortemente marcado pela ação do Estado militar, com foco na industrialização e desenvolvimento.

No mapa de 1980, vê-se a expansão da área urbana, indo além dos limites colocado pelo Rio Paraíba do Sul e a ocupação de suas margens. O uso residencial volta a predominar. O Banhado é valorizado e protegido por lei. No mapa de 1990, vêem-se grandes mudanças. A área urbana tem uma nova expansão. A cidade é marcada pelo uso misto do solo e pelo grande número de vazios urbanos. Uma parte do Banhado é ocupada por chácaras de recreio e pelo uso residencial. Novas áreas de proteção ambiental são criadas em meio à área urbana. A área da APA do Banhado sofre uma pequena redução. 
Em 1997, vê-se a expansão da área urbana, o predomínio do uso misto e o aumento no número de zonas industriais. A área do Banhado diminui em relação à área definida em 1990 e ao PDDI-1995, devido ao avanço da zona residencial. As demais áreas de proteção ambiental no meio urbano, delimitadas em 1990, praticamente desaparecem. O número de vazios urbanos é bastante significativo. Neste mapa, aparecem as ZEIS, ou seja, as áreas onde os loteamentos clandestinos foram delimitados, sendo que estes se encontram na periferia da cidade.

No mapa de 2010, tem-se a retração do perímetro urbano na região norte. Os vazios urbanos não aparecem no mapa, mas na prática eles ainda existem e correspondem a $28 \%$ do perímetro urbano, como mostra a Tabela 4. Das áreas de vazios urbanos, tem-se que 10,2\% estão em ZR, 14,4\% em ZCH, 46,4\% em ZM e 29,1\% em ZI (Caderno Diagnóstico Zoneamento 2010, p. 24). Na maior parte da cidade o uso do solo é definido como uso misto, no entanto, há grande presença do uso industrial. Vê-se o aumento no número de ZEIS (loteamentos clandestinos de baixo padrão) e a delimitação da ZAI (loteamentos clandestinos de alto padrão) e dos Núcleos Passíveis de Regularização (NPRF), que são novos loteamentos clandestinos não incorporados às ZEIS, e entre estes, têm-se lotes de baixo e alto padrão.

Desta forma, pode-se observar que nem sempre há sintonia entre as leis de zoneamento; muitas vezes, há mudanças drásticas no uso do solo entre uma lei e outra. Observam-se conflitos entre o uso residencial e o uso industrial, e também, entre o uso residencial e ambiental. As áreas de proteção ambiental, em especial o Banhado, sofrem uma grande descaracterização pelo avanço do uso residencial, e por outro lado, temos a expansão da área urbana e aumento no número de vazios urbanos. Todas essas mudanças no uso do solo têm relação direta com a qualidade de vida urbana e com o equilíbrio ambiental, trazendo grandes alterações ao ambiente urbano.

Por meio da análise do conjunto de mapas, observa-se que o município de São José dos Campos apresentou uma grande expansão urbana nas últimas décadas. Houve crescimento das zonas mistas, surgindo novas centralidades ou subcentros, descaracterizando de certa forma o zoneamento funcional e possibilitando um maior dinamismo urbano. As zonas industriais são marcantes no município, e vê, através delas o forte perfil industrial que a cidade apresenta. Pode-se ver ainda, a grande pressão urbana sobre a área do Banhado, que teve parte de sua área transformada em zona residencial, com moradias de alto padrão em condomínios fechados. O meio ambiente, que deveria ser de uso de todos, passa a ser privilégio de poucos. 
O município é marcado pelo grande número de vazios urbanos, que poderiam ser mais bem aproveitados, evitando a expansão da área urbana. Nos dois últimos mapas de 1997 e de 2010, vê-se que parte dos loteamentos clandestinos existentes no município são mapeados, estes representam uma grande área, houve um aumento no número e tamanho desses loteamentos de 1997 a 2010, e não se efetivou uma política de fiscalização e regularização desses loteamentos. Neste sentido, faltam políticas públicas mais eficazes de ocupação dos vazios urbanos, controle da expansão urbana e de proteção ambiental, em especial do Banhado.

As leis de Zoneamento Urbano e os Planos Diretores determinam o macrozoneamento urbano, ou seja, definem o que é área urbana e área rural, área de expansão urbana e área de proteção ambiental, direcionando o crescimento da cidade. Na Figura 29, comparam-se as áreas definidas na Carta das Unidades Territoriais de Características Físicas e Antrópicas Homogêneas de 1995, no Macrozoneamento do PDDI-1995, no Macrozoneamento de PDDI2006 e no Zoneamento Urbano de 2010 (zoneamento este redefinido e agrupado conforme critérios definidos na Tabela 2 - Zoneamento urbano: agrupamento de zonas e classe final).

O Macrozoneamento do PDDI-1995 segue as orientações definidas pela Carta das Unidades Territoriais de Características Físicas e Antrópicas Homogêneas, sendo que as Unidades 1, 4, 6, e 7, definidas como uso restrito e de valor ambiental, foram definidas como APA I, APA II, APA III e APA IV, consideradas áreas ambientais protegidas. A Unidade 5, que possui restrições devido às características geomorfológicas e permite o uso agrícola, foi dividida em Zona Rural e Zona de Expansão Urbana II. A Unidade 2 indicada para o desenvolvimento urbano intensivo foi consolidada como Zona Urbana, e a Unidade 3 indicada para o desenvolvimento urbano, mas com restrições quanto aos fundos de vales, drenagem, encostas e processos erosivos, foi considerada Zona de Expansão Urbana I. Desta forma, o macrozoneamento definido no PDDI-1995 busca respeitar o levantamento físico e antrópico realizado no estudo da Carta das Unidades.

O Macrozoneamento definido no PDDI-2006 segue as orientações da Carta das Unidades e do PDDI-1995, porém com algumas modificações. A Zona de Expansão Urbana I se consolida como Zona Urbana. Parte da Zona de Expansão Urbana II é incorporada à Zona Urbana, e a outra parte se consolida como Zona Rural. As APAs I, II e III têm os mesmos limites estabelecidos e não sofrem alterações. Porém, a APA IV tem parte de sua área modificada para Zona Urbana, sendo ocupada em sua maior parte por condomínio fechados de alto padrão. 

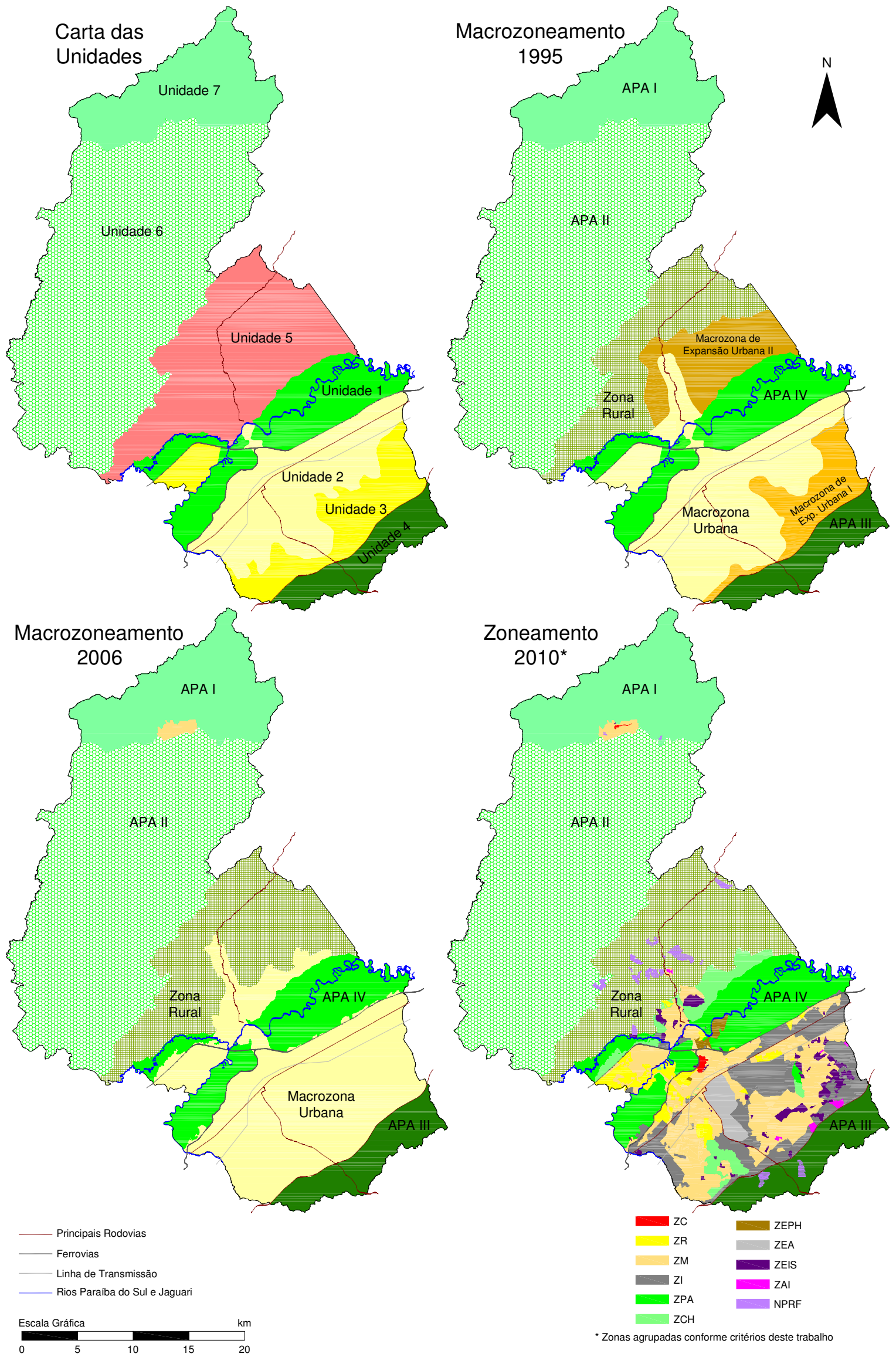

Figura 29 - Carta das Unidades, PDDI-1995, PDDI-2006 e "Zoneamento 2010". 
No Zoneamento de 2010, notam-se modificações no macrozoneamento, sobretudo nas Áreas de Proteção Ambiental. A presença de loteamentos clandestinos é identificada principalmente nas APA III e IV. A APA IV novamente tem sua área diminuída e convertida para zona urbana. Por meio dos mapas na Figura 27, observa-se que a APA IV (do Banhado) definida em 1995, possuía uma área de $105,04 \mathrm{~km}^{2}$, porém, essa mesma APA no zoneamento 2010 possui uma área de $93,73 \mathrm{~km}^{2}$. Desta maneira, a APA IV sofreu uma redução de $10 \%$ em sua área total.

Por meio da comparação do macrozoneamento estabelecido nos últimos quinze anos, é possível identificar a perda de área de proteção ambiental no município. O meio ambiente em vários pontos sofre degradação pela expansão urbana. Não houve continuidade nas políticas de proteção à APA IV, que foi e é ocupada por loteamentos de alto padrão econômico. Como se vê, a especulação imobiliária e o capital têm falado mais alto. A área de proteção ambiental, que incide sobre o Banhado vem sendo transformada em moradias de luxo, atraída pela presença de áreas verdes com grande riqueza paisagística, no entanto, estas se tornam menor e menos rica, devido à expansão urbana. A área que deveria ser privilegiada por todos é revertida para satisfação de poucos.

As leis de zoneamento urbano já na década de 1970 proibiam o parcelamento de terrenos com declividade igual ou superior a 30\%. Ao se comparar o mapa de declividade da cidade com o arruamento 2011 (PMSJC- CD Cidade Viva), como mostra a Figura 30, percebe-se que a cidade se estende por uma imensa área plana, com declividade entre $0 \mathrm{a}$ $15 \%$. No entanto, em várias localidades, observam-se pontos de ocupação urbana em áreas com declividade superior a $30 \%$. 


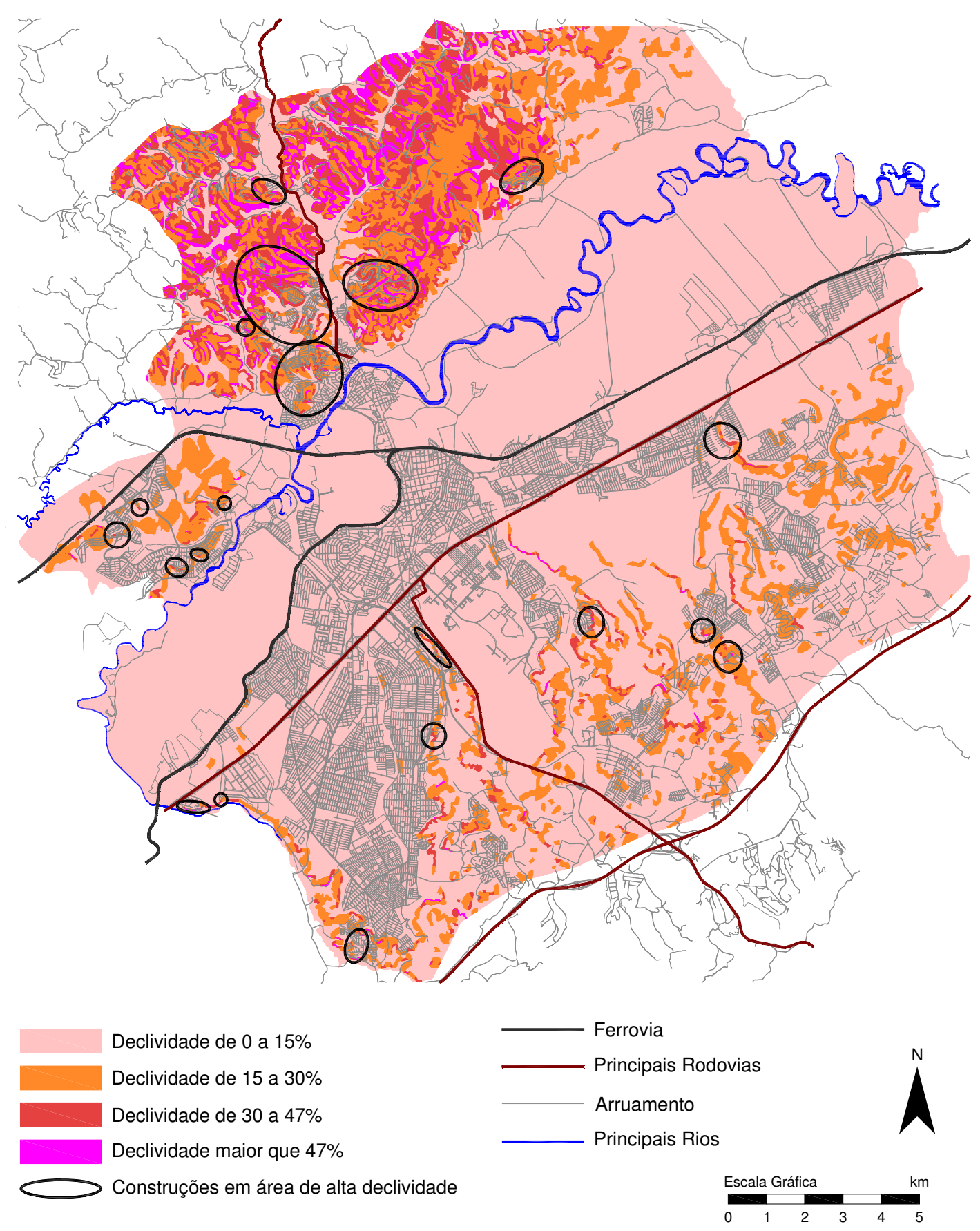

Figura 30 - Mapa de declividade e arruamento 2010

A ocupação em áreas com declividade acentuada pode causar o movimento de massas e desmoronamentos, pois são áreas com maior suscetibilidade à erosão e instabilidade das encostas, sendo consideradas áreas frágeis e impróprias à ocupação humana, Existe um alto risco para as pessoas que vivem nesses locais. O mapa da Figura 30 mostra que ocorre um desrespeito a lei, principalmente na região norte do município, onde se tem a expansão de loteamentos legais e ilegais em áreas de alto risco ambiental, podendo causar graves danos à população que vive nesse local. 


\subsection{Meio Ambiente}

O meio ambiente em São José dos Campos sempre foi valorizado, diante da grande riqueza paisagística que o Banhado representa e da densa rede hídrica existente no município. As primeiras leis urbanísticas municipais já buscavam proteger a vista para o Banhado, até este se tornar uma Área de Proteção Ambiental. As leis ambientais federais, estaduais e municipais buscam proteger a Serra da Mantiqueira e os recursos hídricos.

As leis ambientais criaram várias Áreas de Proteção Ambiental no município, bem como Áreas de Preservação Permanente e Áreas Verdes, no entanto, nem sempre essas áreas foram respeitadas. $\mathrm{O}$ acelerado crescimento urbano do município e a especulação imobiliária muitas vezes ocasionaram o parcelamento irregular do solo. Mudanças pontuais na Lei de Zoneamento atendem interesses particulares, sem pensar na preservação ambiental e no bem coletivo, degradando áreas de grande valor ambiental.

A fiscalização das leis ambientais no território, as ONGs, diversas instituições e órgãos, como o Conselho Municipal de Meio Ambiente, a CETESB, a Polícia Ambiental, a Promotoria Pública, são de grande relevância para a proteção e preservação das áreas de interesse ambiental, seja através da fiscalização, seja por meio da educação ambiental e da elaboração de políticas públicas ambientais.

\subsection{1. Áreas de Proteção Ambiental (APA)}

As Áreas de Proteção Ambiental são áreas que apresentam relevante interesse público, sendo demarcadas no território nacional como de interesse para a proteção ambiental, a fim de assegurar o bem-estar das populações humanas e conservar ou melhorar as condições ecológicas locais (Lei Federal no 6.902/81).

Conforme a Lei Federal no 9985/00, que regulamenta o Sistema Nacional de Unidades de Conservação, a área de proteção ambiental pode ser definida como:

\footnotetext{
A Área de Proteção Ambiental é uma área em geral extensa, com um certo grau de ocupação humana, dotada de atributos abióticos, bióticos, estéticos ou culturais especialmente importantes para a qualidade de vida e o bem-estar das populações humanas, e tem como objetivos básicos proteger a diversidade biológica, disciplinar o processo de ocupação e assegurar a sustentabilidade do uso dos recursos naturais (Art. 15, Lei Federal 9985/00).
} 
A APA pode ser formada por terras públicas ou privadas, onde são estabelecidas medidas restritivas para o uso do solo visando à proteção do meio ambiente. O município de São José dos Campos possui APAs criadas por leis Federais, Estaduais e Municipais, que correspondem a uma área de $739,55 \mathrm{~km}^{2}$, equivalente a $67,2 \%$ do Município, como mostra a Figura 31.

A APA Federal foi instituída pelo Decreto 87.561/82 e apresenta medidas de recuperação e proteção ambiental da Bacia Hidrográfica do Rio Paraíba do Sul, abrangendo parcialmente as Bacias Hidrográficas do Rio do Peixe e do Rio Buquira, as cabeceiras do Córrego Vidoca e do Ribeirão Putins e o Reservatório do Jaguari. O Decreto possui caráter genérico, não sendo regulamentado pelos órgãos federais. Apenas em projetos de loteamento, é exigido percentual maior de área verde quando da aprovação desses empreendimentos (Caderno Diagnóstico da Lei de Zoneamento, 2010).

As Áreas de Proteção Ambiental estaduais foram instituídas pela Lei $n^{\circ}$ 11.262/02, abrangendo a APA Estadual de São Francisco Xavier, cujo perímetro corresponde à APA I, municipal, denominada APA da Serra da Mantiqueira, e as APAs do Banhado e do Jaguari, que englobam também parte dos terrenos situados na APA IV municipal, definida no Plano Diretor do Município (Lei 306/06). A APA de São Francisco Xavier/Serra da Mantiqueira possui regulamentação, inclusive plano de manejo; já as demais APAs estaduais do Banhado e do Jaguari não foram regulamentadas e apresentam apenas restrições vedando o parcelamento do solo para fins urbanos, a instalação de indústria poluente, a ampliação da área das indústrias existentes, o uso de técnicas de manejo do solo capazes de provocar a erosão das terras ou o assoreamento dos cursos d'água, a remoção da cobertura vegetal existente, a exploração mineral e a utilização da área para chácaras de recreio (Caderno Diagnóstico da Lei de Zoneamento, 2010). 

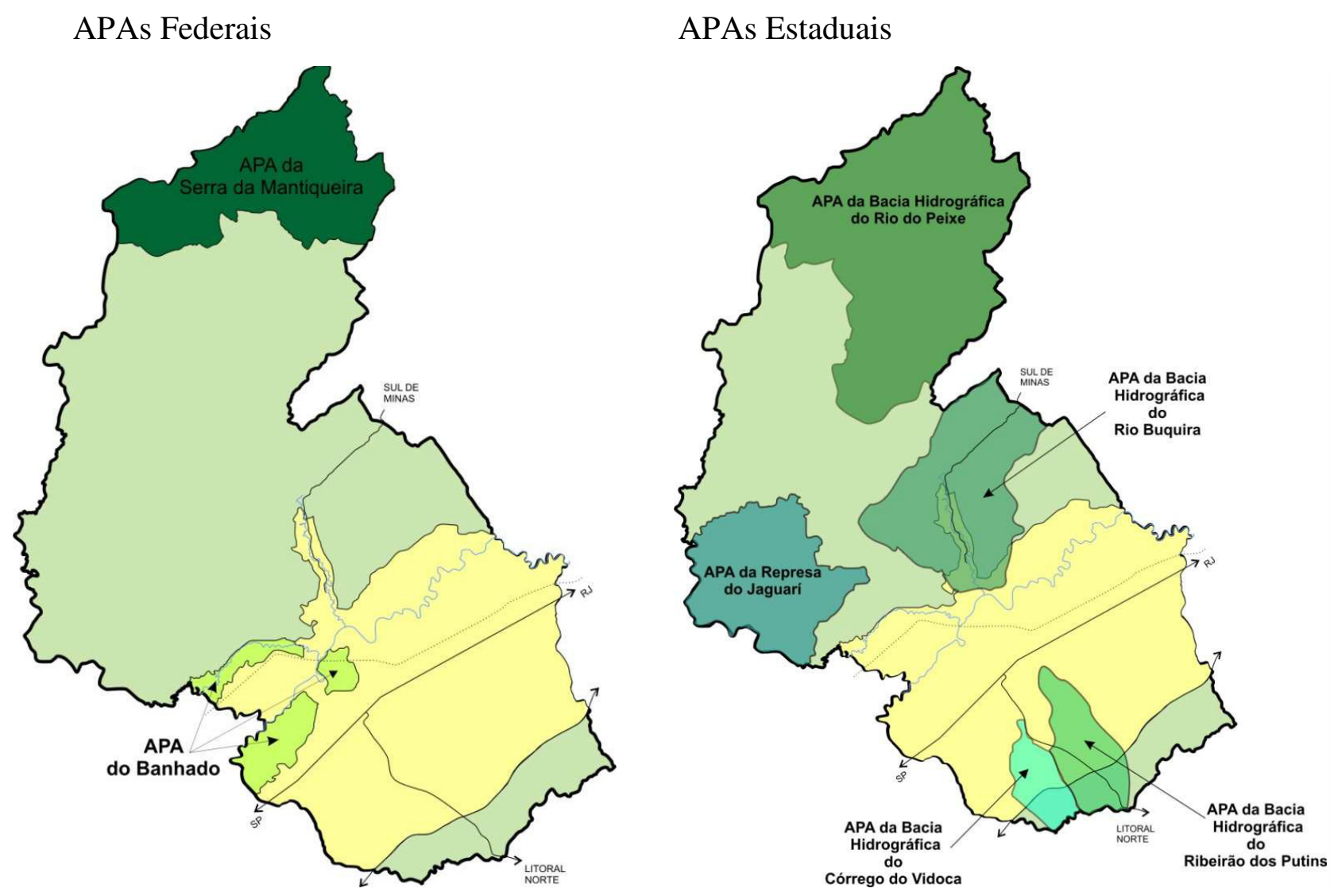

APAs Municipais (PDDI 2006)

Figura 31 - Áreas de Proteção Ambiental em São José dos Campos.

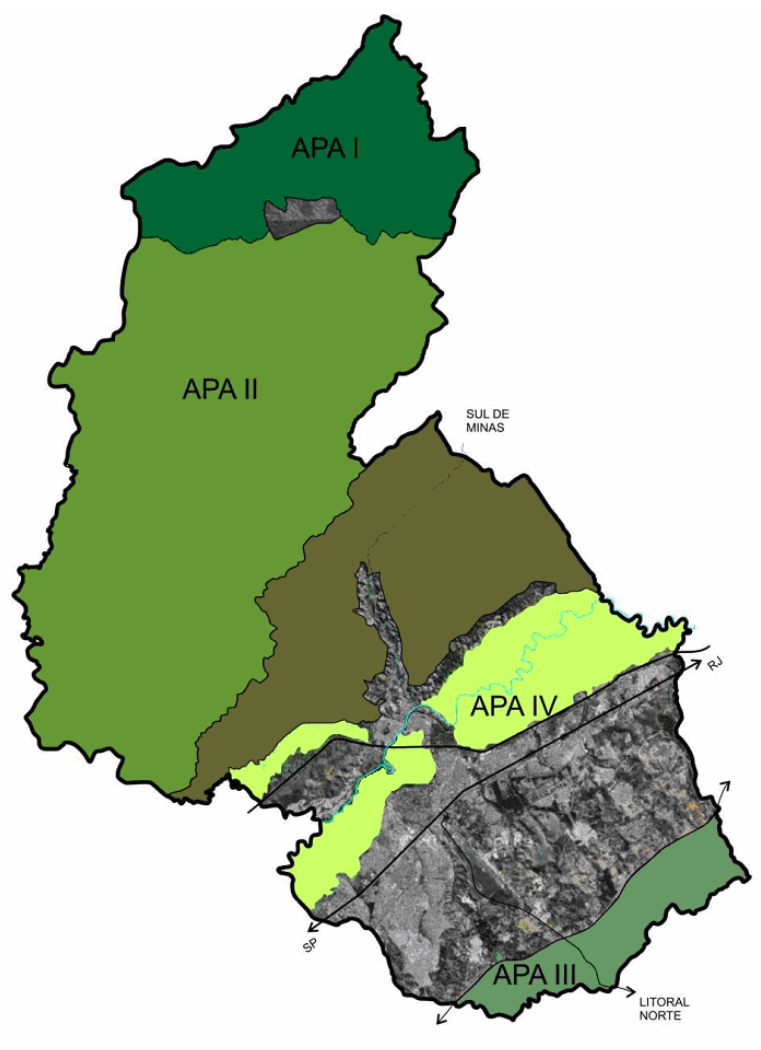

Fonte: PMSJC (2010). 
Em relação às Áreas de Proteção Ambiental municipais, tem-se a primeira criada em 1984, que é a APA do Banhado (Lei 2792/84). Na década de 1990, a Lei de Zoneamento 3.721/90, vai instituir cinco APAs; as APAS 1 e 2 permitem a ocupação de baixa densidade, a APA 3 possui características de várzea, sendo permitido apenas o uso agrícola. As APAs 4 e 5 permitem o uso apenas recreacional (lazer, hospedagem, clubes). A Lei 068/92 institui a APA 6, sendo área de várzea permitindo o uso agrícola e recreacional. A maioria dessas APAs incide sobre a APA do Banhado. Embora o número de APAs aumente, a área de proteção ambiental não aumenta; na verdade, houve uma perda com essa nova legislação, uma vez que a Lei de Zoneamento diminui o número de restrições quanto ao uso do solo na APA do Banhado, permitindo o uso residencial em parte dela, como mostra a Figura 32.

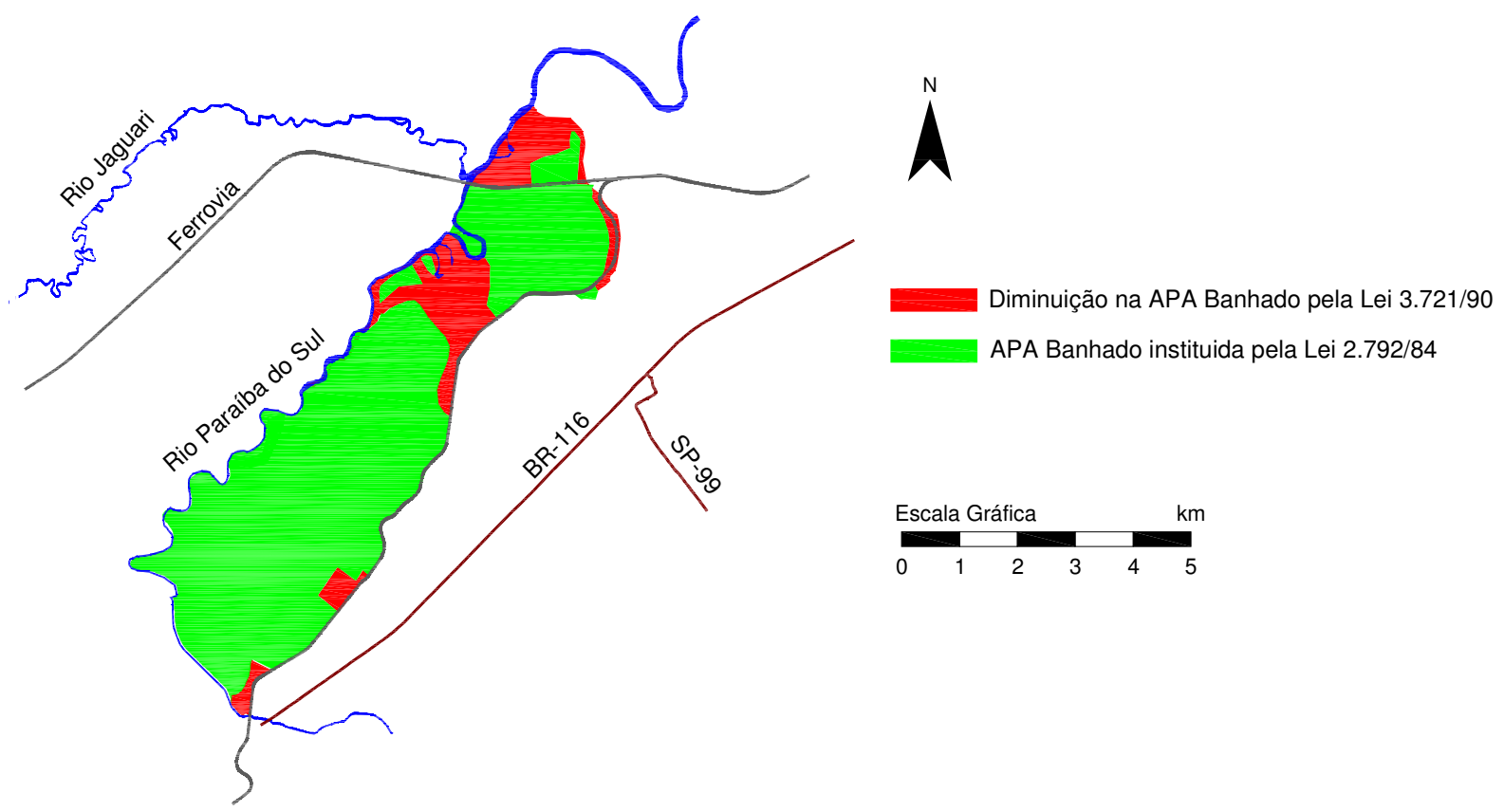

Figura 32 - APA do Banhado em 1984 e alterações conforme a Lei 3.721/90.

Em 1992, tem-se a criação da APA da Mantiqueira em consonância com a Secretaria Estadual do Meio Ambiente (Lei Municipal 4.212/92 e Lei Estadual 11.262/02).

O PDDI de 1995, através de estudos mais aprofundados, com apoio de técnicos do INPE e IPT, e por meio da análise de Cartas de Declividade, Carta Hipsométrica, Carta de Hidrografia e Cobertura Vegetal, Mapa Geológico do Estado de São Paulo e outros, elabora "A carta das unidades territoriais das características físicas, antrópicas homogêneas de São José dos Campos", com o objetivo de identificar as potencialidades e limitações para ocupação e uso do território do município. Através deste estudo, o PDDI 1995 vai propor o macrozoneamento urbano e instituir quatro APAs Municipais. 
A APA I possui declividade acentuada superior a $60 \%$ e risco geológico, sendo considerada imprópria para o desenvolvimento humano. A APA II possui alto potencial de risco geológico e forte erodibilidade, sendo inadequada a qualquer instalação urbana; caracteriza-se também como área de recarga dos aquíferos subterrâneos, sendo importante a sua preservação para a recarga dos mananciais para abastecimento d'água da região. A APA III apresenta relevo ondulado, com pontos de alta declividade e cabeceiras de drenagem e possui alto risco geológico, sendo inadequada a expansão urbana. As APAs I, II e III estão localizadas na zona rural. A APA IV encontra-se em meio à área urbana, apresenta alta restrição à implantação de atividades urbanas, necessitando de normas específicas de uso e ocupação, com o objeto principal da proteção ambiental. É permitida atividade de lazer com taxa mínima de impermeabilidade (PDDI-1995).

Como mostra a Figura 33 a Lei de Zoneamento nº165/97 impõe mudanças à APA IV, permitindo o uso residencial e industrial em algumas regiões, reduzindo a área ambiental no município. A lei cria uma nova área de proteção ambiental em meio à área urbana. Já a Lei de Zoneamento $n^{\circ}$ 428/10 ratifica estas alterações, realizadas na APA IV. Porém, parte da área ambiental que se encontrava em meio a área urbana, definida pela lei de zoneamento de 1997, é revertida para uso residencial e industrial

No PDDI-2006, as APAs são mantidas com o mesmo número e descrição previsto pelo PDDI-1995. Desta forma, há uma dissintonia entre as APA IV prevista no Macrozoneamento dos Planos Diretores de 1995 e 2006, com a Lei de Zoneamento de 1997 e 2010, pois, conforme Plano Diretor, a APA IV apresenta restrições quanto às atividades humanas, já as Leis de Zoneamento permitem o uso residencial e a construção de loteamentos de alto padrão nesta mesma área. 


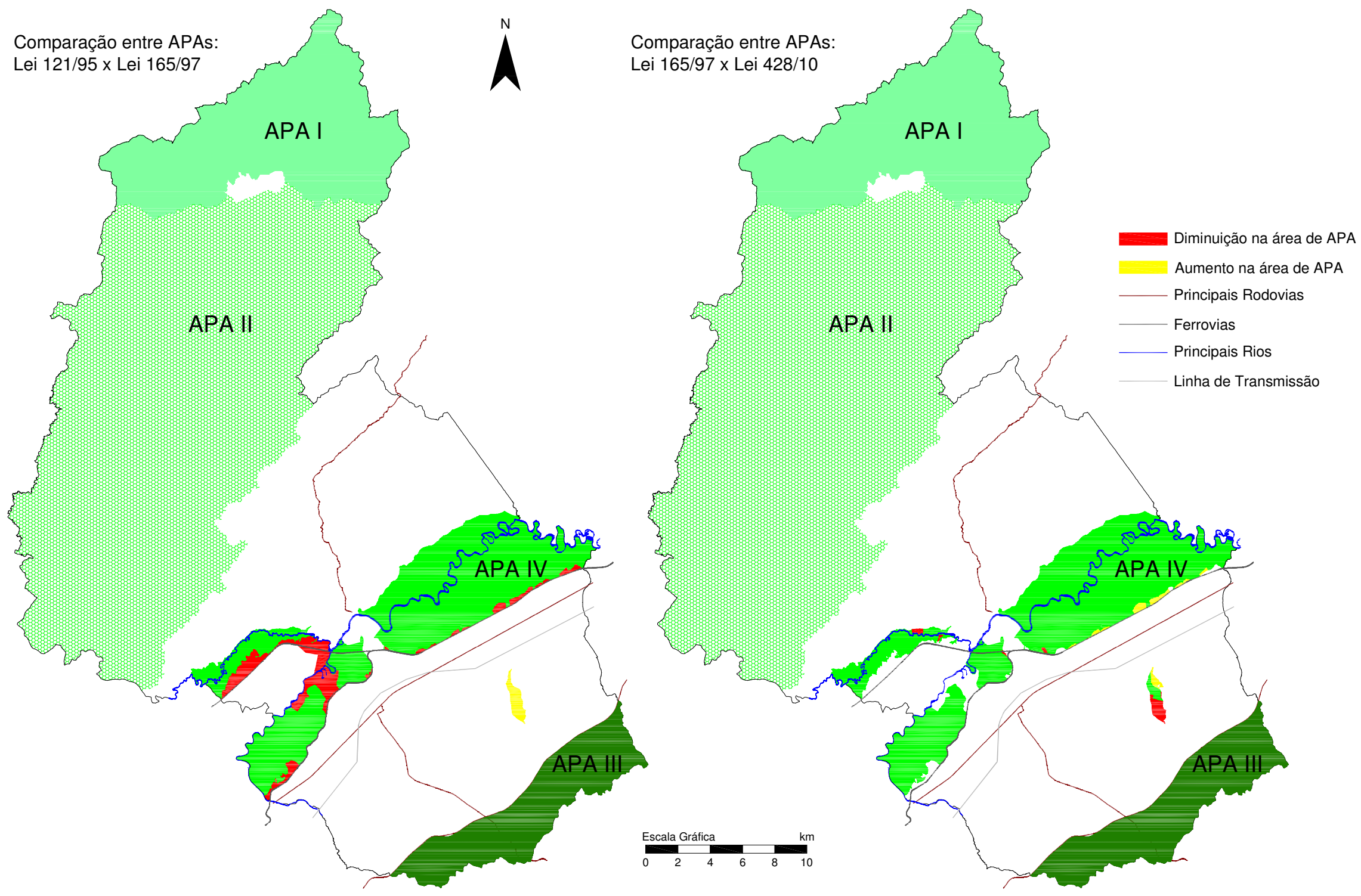

Figura 33 - APA IV definida no PDDI-1995 e as mudanças em sua área conforme as Leis de Zoneamento 1997 e Zoneamento 2010. 
O município possui uma Unidade de Conservação de Uso Integral, que está inserida na Área de Proteção Ambiental da Bacia do Rio Paraíba do Sul, o "Parque Natural Municipal Augusto Ruschi” - PNMAR. Inicialmente, foi denominado como Reserva Florestal Boa Vista, pela Lei $2.163 / 79$, sendo que pela mesma lei, foi proibido o desmatamento e a retirada de qualquer espécie da fauna e flora da Reserva. Por meio do Decreto 5.573/86, a área passou a ser denominada Reserva Ecológica Augusto Ruschi. Em 2010, pela Lei 8.195, é criado o Parque Natural Municipal Augusto Ruschi, com visitas monitoradas com fins de educação ambiental e pesquisa cientifica. A Unidade de Conservação possui uma área de $2.434,854$ $\mathrm{km}^{2}$.

\subsubsection{Banhado}

A Área de Proteção Ambiental do Banhado em São José dos Campos é uma área verde, de grande beleza paisagística, uma extensa planície cortada pelo Rio Paraíba do Sul. O Banhado é assim denominado, pois nos períodos de cheia do Rio Paraíba, esta grande planície era inundada pelas águas do rio, mas com a construção das Represas de Santa Branca e de Paraibuna nos anos de 1940, as vazantes do Rio Paraíba ficaram mais controladas, e a área não é mais inundada. O Banhado compõe um cenário único integrado à paisagem joseense, como mostra a Figura 34.

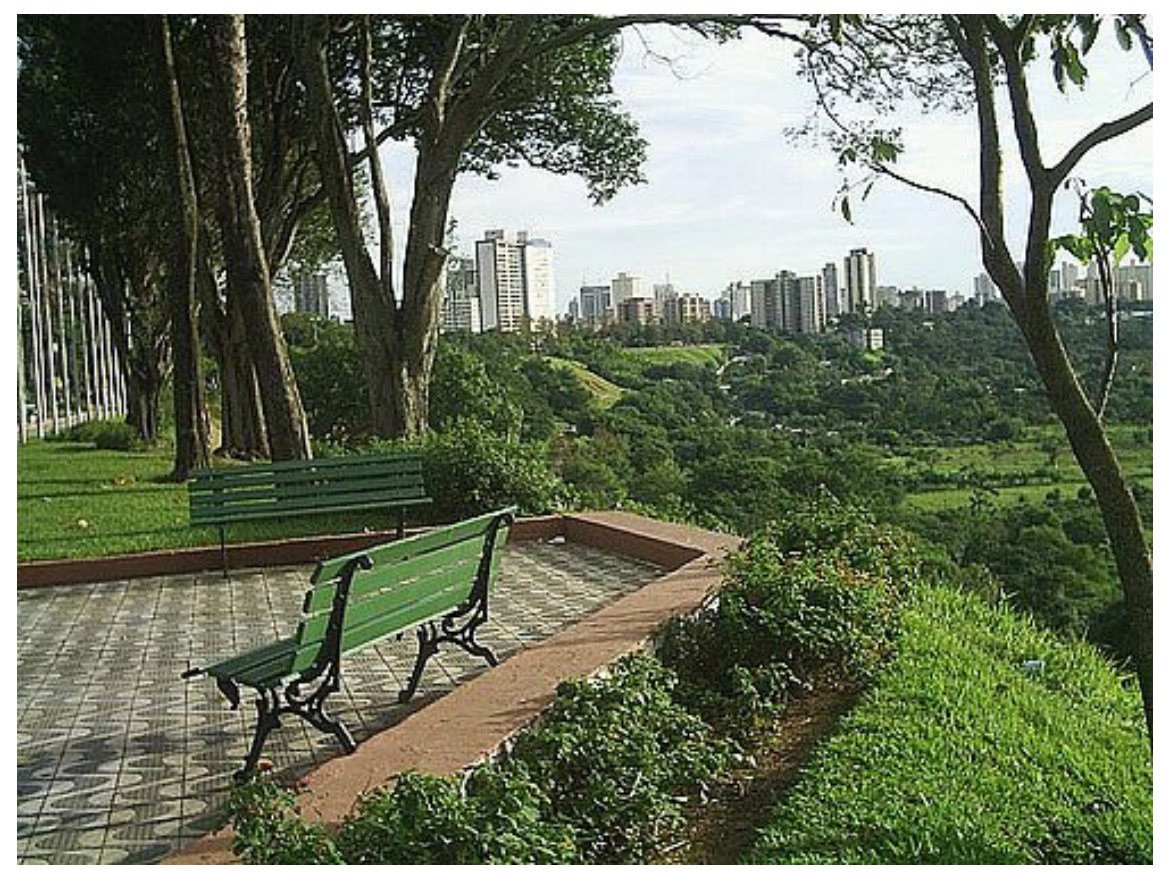

Figura 34 - Banhado próximo a área central de São José dos Campos.

Fonte: PMSJC (2010). 
A beleza do Banhado sempre foi algo muito valorizado pelos joseenses. Em 1935, quando a cidade se torna Estância Climatérica e Hidromineral e recebe verbas do Estado, passa por um processo de regulamentação do uso do solo. As intervenções na Av. São José, que contorna o Banhado na área central, buscavam privilegiar a vista para esta paisagem. $\mathrm{O}$ primeiro zoneamento em 1932, revisado em 1935, já demarcava a área do Banhado.

A Lei de zoneamento 1.606/71, em seu Art. 18, proíbe edificações voltadas para o Banhado, bem como em seu talude, entre a Rua Luiz Jacinto e a Avenida São José (Figura 35), buscando assim, preservar a vista para o Banhado. O Plano Diretor de 1971 previa a criação de um Parque no Banhado, com equipamentos esportivos, de recreação, culturais, estacionamentos, jardins zoológico e botânico, recinto para feiras e exposições, implantação de viveiros municipais de plantas para arborização e ajardinamento. $\mathrm{O}$ projeto para o parque chegou a ser traçado, mas nunca saiu do papel.

Na década de 1980, a nova lei de zoneamento 2.263/80, cria a Zona Especial do Banhado (ZE-3), que permitia o uso exclusivamente recreacional, cultural, esportivo e turístico, determinando assim, o uso restrito dessa área e evitando o parcelamento do solo. A lei ainda amplia a faixa "non edificandi" no entorno do banhado (quadro nº, Lei 2.263/80), como mostra a Figura 36, privilegiando a vista para o local.

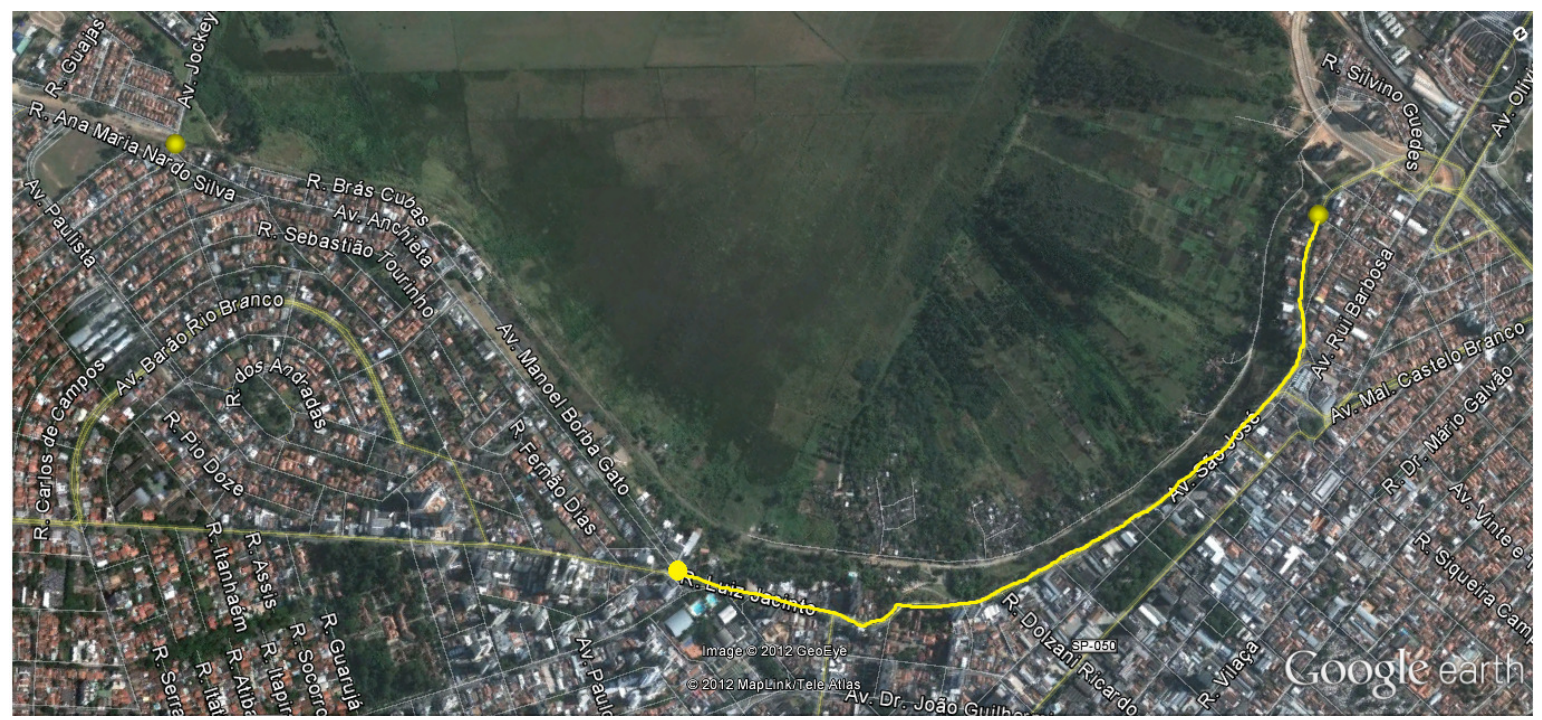

Figura 35 - Área não edificante no Banhado (Lei 1606/71). Imagem do Google Earth - 2011. 


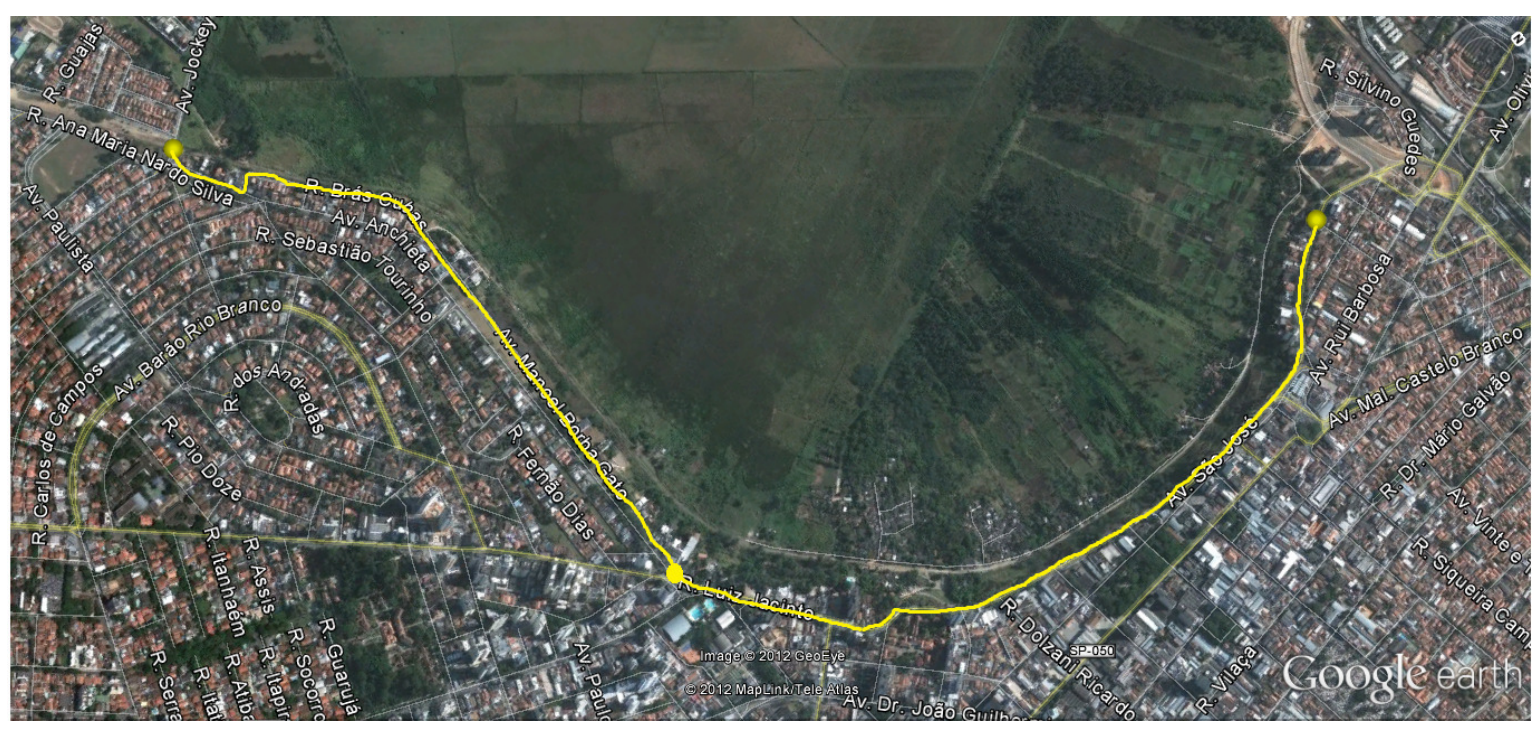

Figura 36 - Zona não edificante- Talude do Banhado (Lei 2.263/80).

Imagem do Google Earth 2011.

Em 1984, a Lei no 2.792 cria a Área de Proteção Ambiental (APA) do Banhado, e desta forma, efetiva por lei a área do Banhado a ser preservada, impondo normas e regras para o seu uso, tornando esta área ambiental protegida para as futuras gerações. Conforme o Art. 2, fica proibido ou restringido:

I - A implantação de atividades industriais, assim como alteração do processo produtivo daquelas já existentes, quando diminuir a conformidade.

II - O parcelamento do solo, com exceção daqueles destinados a residências exclusivamente unifamiliares, nas zonas a serem defini das por lei.

III - A implantação de atividades comerciais, de serviços e institucionais, exceto nas zonas a serem definidas por lei.

IV - A implantação de novas atividades extrativas.

V - A realização de obras de terraplanagem e a abertura de canais, quando essas iniciativas importarem em sensível alteração das condições ecológicas.

VI - O exercício de atividades capazes de provocar acelerada erosão das terras e/ou acentuado assoreamento dos corpos d'água.

VII - O emprego de defensivos e fertilizantes agrícolas que contribuam para a deterioração dos recursos hídricos.

VIII - A supressão ou derrubada de florestas e demais formas de vegetações naturais situadas:[conforme Código Florestal].

IX - Outras atividades potencialmente causadoras de degradação ambiental.

Neste sentido, o uso do solo na área do Banhado passaria a ser mais bem planejado, através da determinação de restrições às atividades que gerassem danos ao meio ambiente. No entanto, a Lei de zoneamento 3.721/90 descaracteriza totalmente a APA do Banhado delimitada em 1984 e vai dividi-la em APA-1, APA-3, APA-4, ZR-1 e ZR-3. A Lei 68/92 acrescenta a APA-6, sendo que apenas as APAs 4 e 6 não permitiam o parcelamento do solo (ver Figura 32). Nas demais zonas criadas, permite-se a implantação de residência unifamiliar de baixa densidade, dando margem para a implantação de Loteamentos de Alto Padrão na 
região, como o Residencial Esplanada do Sol, Chácara Condomínio Eucaliptos, o Condomínio Serimbura e o Loteamento Jardim do Golf, estes dois últimos em fase de implantação, como mostra a Figura 37. Assim, o que deveria ser Área de Proteção Ambiental é loteado, um bem comum, o meio ambiente, passa a ser privilégio de poucos.

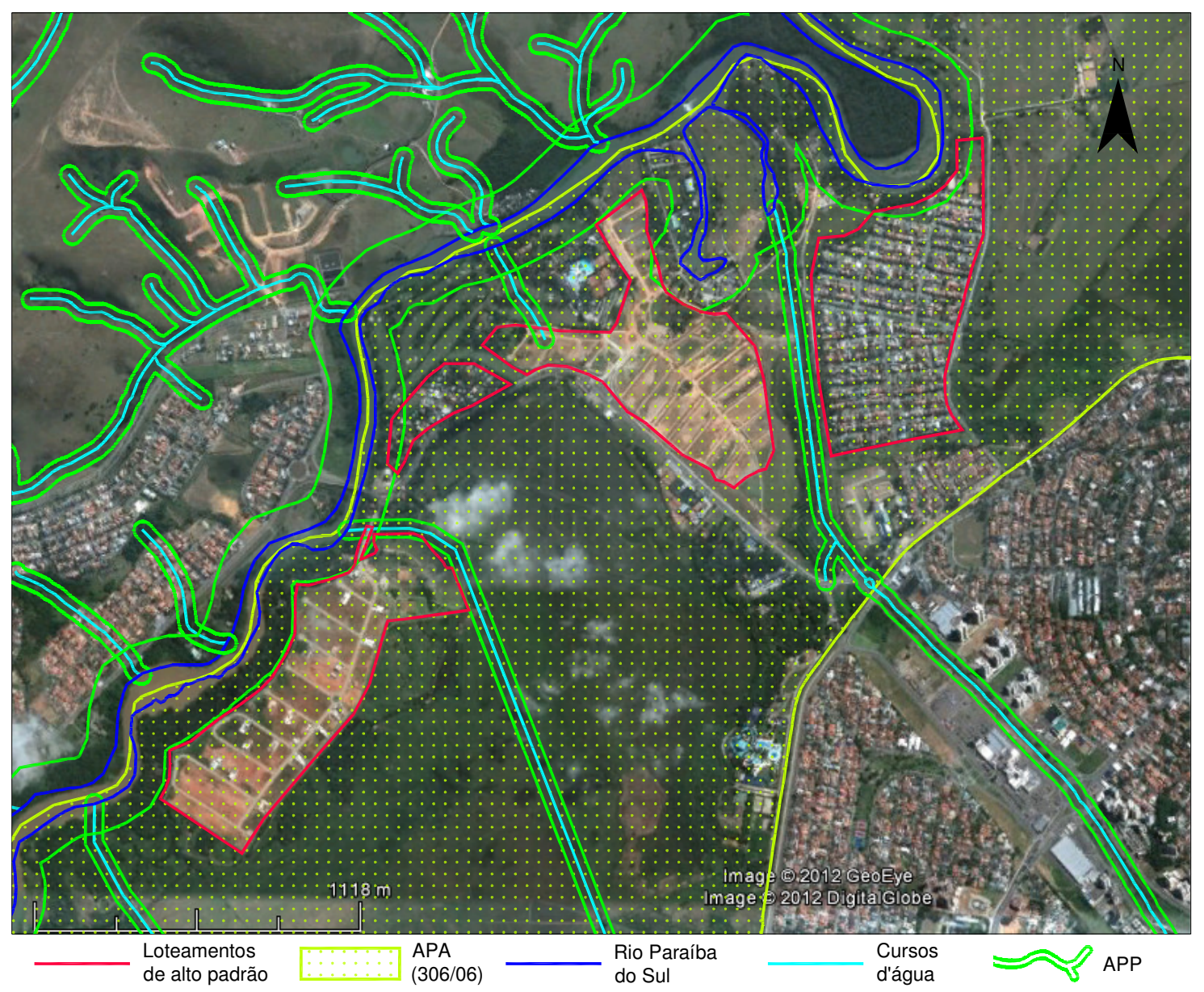

Figura 37 - Loteamentos de Alto Padrão na APA do Banhado.

Fonte: Google Earth® (2011) e PMSJC-Cidade Viva (2011).

O Plano Diretor de 1995 vai propor uma nova delimitação das áreas de proteção ambiental no município. Para tanto, apoia o seu estudo na "Carta das unidades territoriais das características físicas, antrópicas homogêneas de São José dos Campos”. Desta forma, a área do Banhado tem os seus limites restabelecidos, como APA-IV, em meio à área urbana, e passa a ser considerada imprópria para o desenvolvimento urbano e à implantação de obras viárias, sendo permitidas somente atividades agrícolas e atividades de lazer.

A Lei de Zoneamento n⿳0165/1997 vai trazer algumas modificações à APA-IV (do Banhado), que passa a ser dividida em Zonas de Especial Proteção Ambiental: ZEPA 2, 3 e 4. A ZEPA 3 é a maior área e mantém as mesmas atribuições da APA-IV. Já as ZEPA 2 e 4, que 
estão em meio à ZEPA 3, passam a ter uso diferenciado. Na ZEPA 2, passa a ser permitida a ocupação urbana de baixa densidade, e na ZEPA 4, é permitido o uso residencial unifamiliar. Nas ZEPA 2 e 4, estão sendo construídos condomínios fechados de luxo (o Serimbura e o Loteamento Jardim do Golf). Desta forma, fica claro que essas alterações pontuais na legislação, foram para atender aos interesses da especulação imobiliária e do capital. Tal mudança é concretizada pela Lei de Zoneamento $n^{\circ} 428 / 2010$, que torna a ZEPA 4 e a ZEPA 2, como Zona Residencial 1. No mais, a Lei de zoneamento $\mathrm{n}^{\circ} 165 / 1997$ cria Zonas de Transição Industrial (ZETI) inseridas dentro da APA IV.

O Banhado é ocupado desde 1931 pela favela conhecida como "Vila Nova Esperança", próximo ao cento da cidade, como mostra a Figura 38. O Poder Público já realizou ações na tentativa de remover as famílias que vivem no local, e transferi-las para Projetos de Habitação em áreas afastadas. Uma parte foi removida, mas a maioria se recusa a sair do local, ocupado há mais de 80 anos. O Poder Público se mostra bastante rígido na remoção de famílias de baixa renda da APA do Banhado, porém, se mostra muito liberal quanto a ocupação por moradias de alto padrão, inclusive modificando o uso do solo nas Leis de Zoneamento Urbano.

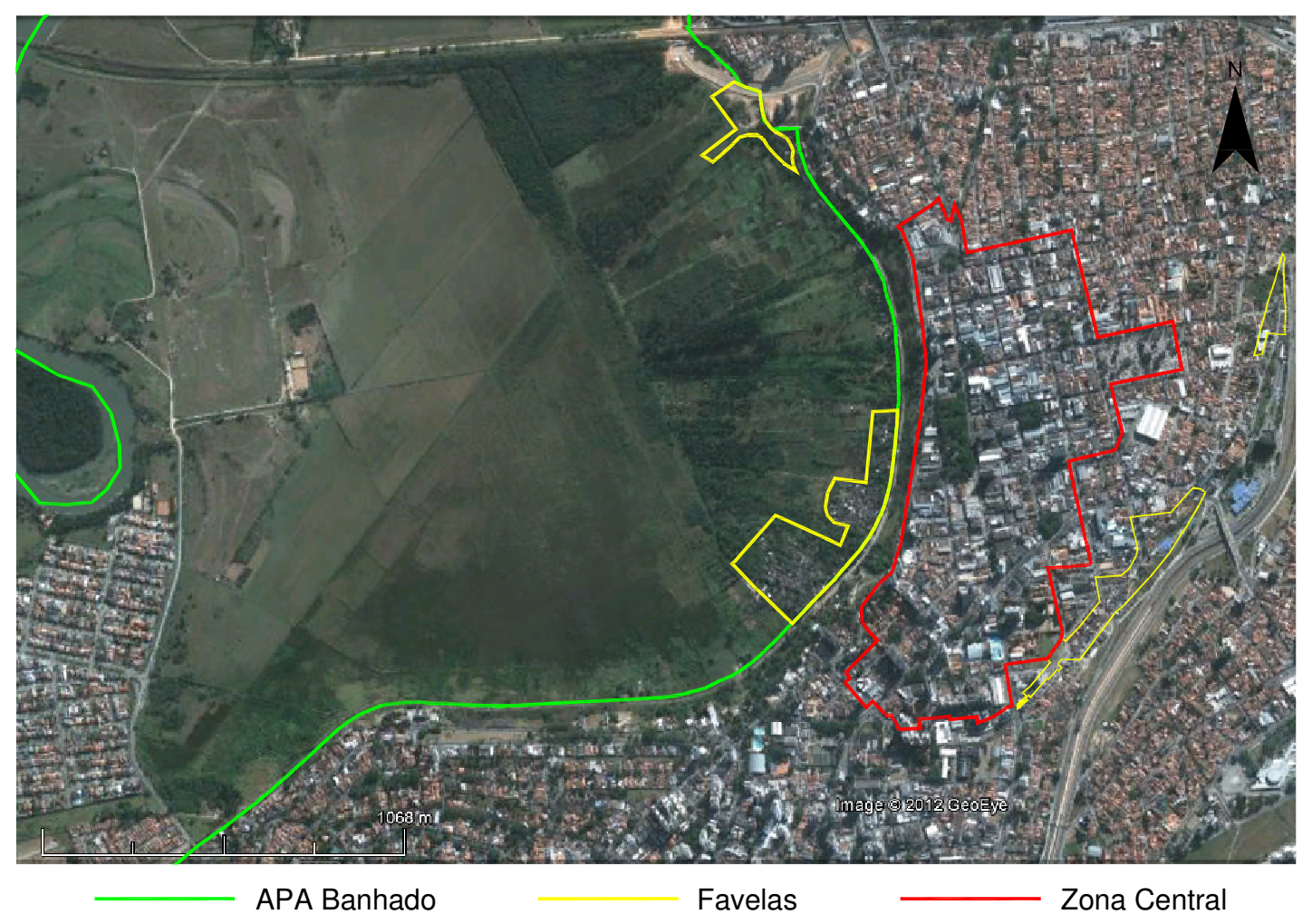

Figura 38 - "Favela Vila Nova Esparança" na APA do Banhado.

Fonte: Google Earth® (2011) e PMSJC - Cidade Viva (2011). 
Desta forma, vemos que a APA do Banhado sofreu significativas alterações, sofrendo reduções na sua área original ao longo dos anos. Da área da APA do Banhado, como já visto, definida no PDDI-1995, houve uma redução de 10\% em relação a Lei de Zoneamento Urbano de 2010. A maior perda de área de proteção ambiental no Banhado ocorre pela expansão urbana, através de moradias de luxo. O Poder Público tem sido omisso e até mesmo conivente com esta situação. O meio ambiente, a riqueza paisagística representada pelo Banhado, tem se perdido em meio aos interesses econômicos.

\subsection{2. Áreas de Preservação Permanente (APPs)}

As Áreas de Preservação Permanente são áreas protegidas, cobertas ou não por vegetação nativa, com a função ambiental de preservar os recursos hídricos, a paisagem, a estabilidade geológica e a biodiversidade, facilitar o fluxo gênico de fauna e flora, proteger o solo e assegurar o bem-estar das populações humanas (Código Florestal).

As APPs devem ser respeitadas, seja em área rural ou urbana. Conforme o Código Florestal (Lei 4.771/65, alterada pela Lei $7.803 / 89)^{34}$, as florestas e demais formas de vegetação natural devem ser preservadas quando situadas:

a) ao longo dos rios ou de qualquer curso d'água desde o seu nível mais alto em faixa marginal cuja largura mínima será:

- de 30 metros para os cursos d'água de menos de 10 metros de largura;

- de 50 metros para os cursos d'água que tenham de 10 a 50 metros de largura;

- de 100 metros para os cursos d'água que tenham de 50 a 200 metros de largura;

- de 200 metros para os cursos d'água que tenham de 200 a 600 metros de largura;

- de 500 metros para os cursos d'água que tenham largura superior a 600 metros;

b) ao redor das lagoas, lagos ou reservatórios d'água naturais ou artificiais;

c) nas nascentes, ainda que intermitentes e nos chamados "olhos d'água", qualquer que seja a sua situação topográfica, num raio mínimo de 50 metros de largura;

d) no topo de morros, montes, montanhas e serras;

e) nas encostas ou partes destas, com declividade superior a $45^{\circ}$, equivalente a $100 \%$ na linha de maior declive;

f) nas restingas, como fixadoras de dunas ou estabilizadoras de mangues;

g) nas bordas dos tabuleiros ou chapadas, a partir da linha de ruptura do relevo, em faixa nunca inferior a 100 metros em projeções horizontais;

h) em altitude superior a 1.800 metros, qualquer que seja a vegetação.

\footnotetext{
${ }^{34}$ A revisão e alteração do Código Florestal está em tramitação no Congresso Nacional.
} 
A Lei Federal $n^{\circ}$ 6766/79, que disciplina o parcelamento do solo urbano, determina a reserva de faixa não edificável de 15 metros ao longo das águas correntes e dormentes e das faixas de domínio público das rodovias e ferrovias. Analisando a legislação de São José dos Campos, vê-seque nem todas são elaboradas de acordo com as Leis Federais vigentes.

A primeira lei municipal de zoneamento urbano promulgada após a aprovação do Código Florestal, a Lei $\mathrm{n}^{\circ}$ 1.606/71, prevê a reserva de faixa não edificante, nunca inferior a 15 metros, às margens de águas correntes e dormentes de faixas de domínio público ocupadas com ferrovias, rodovias e dutos. Nestas faixas, conforme a legislação, nenhuma construção seria permitida. No entanto, a lei foi revogada por um novo zoneamento, a Lei $n^{\circ} 2.263 / 80$, e este não menciona em seu texto a reserva de faixas não edificantes. Ambas as Leis de Zoneamento de São José não mencionavam o Código Florestal em seu texto.

No entanto, a Lei do Zoneamento Urbano de São José é revisada em 1990 e passa a incluir as APPs em seu texto. A Lei no 3.721/90, em seu Artigo 4, determina que não poderá ocorrer o parcelamento do solo em APPs, em consonância ao Código Florestal, mas, no entanto, possibilita que as APPs sejam destinadas como áreas verdes. Porém, em seu Art. 15, determina faixas não edificantes de apenas 15 metros, que poderão ser utilizadas para sistema viário ou áreas verdes, entrando assim, em contradição com o Código Florestal.

Já a Legislação de Zoneamento n $165 / 97$ determina que o parcelamento do solo para fins urbanos e a implantação de novos loteamentos devem respeitar as APPs de acordo com o Código Florestal. O PDDI 95 não trata da questão das APPs em específico. Já o PDDI 2006 e a Lei de Zoneamento 428/10 enfatizam a importância em respeitar as APPs e determinam que não poderá ser parcelado solo para fins urbanos nas referidas áreas.

Como se vê na Figura 39, existem muitos conflitos entre as Áreas de Preservação Permanente e a ocupação urbana; muitas vezes, as APPs não são respeitadas. Córregos são canalizados, e ruas, avenidas e vias expressas são construídas em suas margens. Os loteamentos invadem as APPs, desviam os cursos d'água e causam erosão e o assoreamento de córregos. 


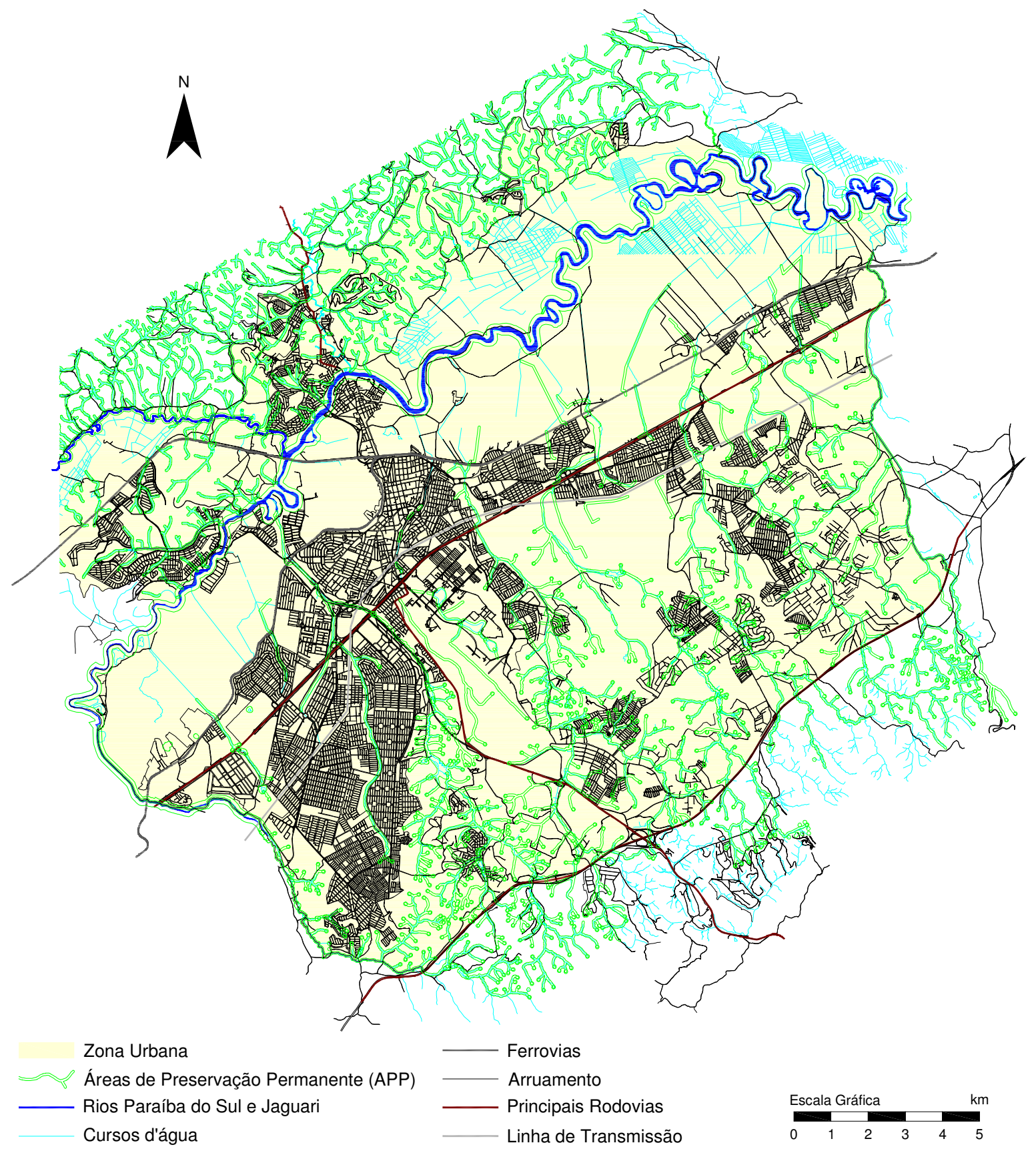

Figura 39 - Áreas de Preservação Permanente (APPs) e Arruamento 2010.

O município apresenta vários pontos sujeitos a alagamentos e inundações, entre eles o Mirante do Buquirinha (loteamento clandestino), Vila Corintinha, Vila São Pedro, Vila São Benedito, Residencial Cambuí, Jardim Souto, Parque Santa Rita, Chácaras São José, Sítio Bom Jesus, Residencial São Francisco, Jardim do Lago e Jardim São Leopoldo (Plano Municipal de Saneamento Básico - PMSJC, 2008). O PDDI-1995 levantou áreas sujeitas a inundações no Jardim Pararangaba, Vila Cristina, Vila Guarani, Galo Branco e em áreas próximas ao Córrego Senhorinha (PDDI-1995, p.115 e mapa 28). 
A ocupação das áreas de preservação permanente, além de prejudicar o regime hídrico do município, poluir e assorear córregos, acaba tendo efeitos negativos direto sobre a própria população que ocupa essas áreas, que sofre com alagamentos e inundações. Tal ação, além de trazer prejuízos sociais e ambientais, traz inúmeros gastos ao poder público.

\subsection{3. Áreas Verdes Urbanas}

Área verde pode ser definida como: "o espaço de domínio público que desempenhe função ecológica, paisagística e recreativa, propiciando a melhoria da qualidade estética, funcional e ambiental da cidade, sendo dotado de vegetação e espaços livres de impermeabilização" (Resolução CONAMA 369/2006).

As áreas verdes têm importante papel na melhor da qualidade ambiental nas áreas urbanas, além de representarem áreas de lazer e recreação e de convívio social. Do ponto de vista ambiental, as áreas verdes são importantes por possibilitarem a presença da vegetação no meio urbano, evitar a impermeabilização do solo, promover melhorias no clima urbano e na qualidade do ar, da água e do solo. Porém as áreas verdes também têm papel importante no bem estar social. Como afirma Meunier (2008), as áreas verdes são de grande relevância à vida humana, à saúde física e mental:

[...] A freqüência responsável às áreas verdes urbanas como praças, parques, refúgios e jardins, é uma oportunidade para o exercício de convivência solidária entre pessoas e natureza, para o estreitamento dos vínculos familiares e estabelecimento de novas relações de amizades. A simples contemplação nas áreas verdes possibilita uma experiência estética única, permitindo que se vivencie a harmonia dos elementos naturais [...].

As áreas verdes são locais onde há predomínio de vegetação, como praças, parques e jardins públicos, que desempenham função estética, de lazer e amenizam os impactos ambientais. As árvores plantadas nas calçadas fazem parte da Arborização Urbana, estão em áreas impermeabilizadas, e não são classificadas como áreas verdes.

Diante da relevância das áreas verdes para a qualidade ambiental urbana, analisou-se a inserção de áreas verdes nas políticas públicas de São José dos Campos. As áreas verdes passam a ganhar maior repercussão nas leis urbanísticas do município a partir da década de 1970.

Embora o zoneamento de massa, proposto em 1961, determine a existência de áreas verdes, estas estão localizadas na periferia da cidade, longe do centro urbano. As áreas verdes 
em meio à área urbana só começam a ser previstas em lei a partir da lei de zoneamento em 1971.

O zoneamento de 1971, Lei $\mathrm{n}^{0} 1.606$, previa a criação de zonas de predominância recreacional $(\mathrm{ZpR})$, que compreendiam as áreas verdes livres destinadas à recreação. No entanto, estas zonas não são delimitada, e não são criadas. O Plano Diretor de 1971, Lei 1.623, que é aprovado dois meses depois da lei de zoneamento, em seu Art. 10, determina a implantação de um Sistema Verde, que tinha como objetivo básico o desenvolvimento das atividades do ar livre e de recreação. Porém, tal Sistema Verde não teve êxito, pois segundo Bologna (2000) foi prevista a criação de cento e cinquenta áreas verdes, mas apenas três foram efetivadas.

As Leis de zoneamento $n^{\circ} 2.263 / 80,3.721 / 90$ e 165/97 determinam que, para a aprovação de novos loteamentos, se faz necessária a existência de áreas verdes, que não podem ser inferior a $10 \%$ da área total. Já a última lei de zoneamento nº 428/10 mostra uma regressão, determina um percentual de apenas $5 \%$ de áreas verdes nos novos loteamentos, diminuindo pela metade a área verde exigida. A Lei Orgânica Municipal (1990) determina em seu Art. 258, que as áreas definidas em projetos de loteamento como verdes não, poderão, em qualquer hipótese, ter alterados sua destinação, fim e objetivos originariamente estabelecidos.

A Lei Orgânica, em seu Art. 246, submete o município “a implantar e manter áreas verdes de preservação permanente, de acordo com os parâmetros fixados pela Organização Mundial de Saúde".

O estudo do Caderno Diagnóstico do Plano Diretor de 1995 destaca a importância das áreas verdes e da arborização urbana, entre outras funções, para tornar a vida na cidade mais agradável. O estudo aponta um índice ideal de área verde de $22,50 \mathrm{~m}^{2}$ por habitação, tendo como base estudos realizados em Curitiba e São Paulo. A Prefeitura aponta que em cada habitação vive em média cinco pessoas, e estabelece o índice de $4,5 \mathrm{~m}^{2}$ de área verde por habitante (Caderno Diagnóstico PDDI 1995). Diante destes números, o Caderno Diagnóstico indica que há uma carência de áreas verdes no município. A Figura 40 mostra, em destaque, a área de carência de áreas verdes. 


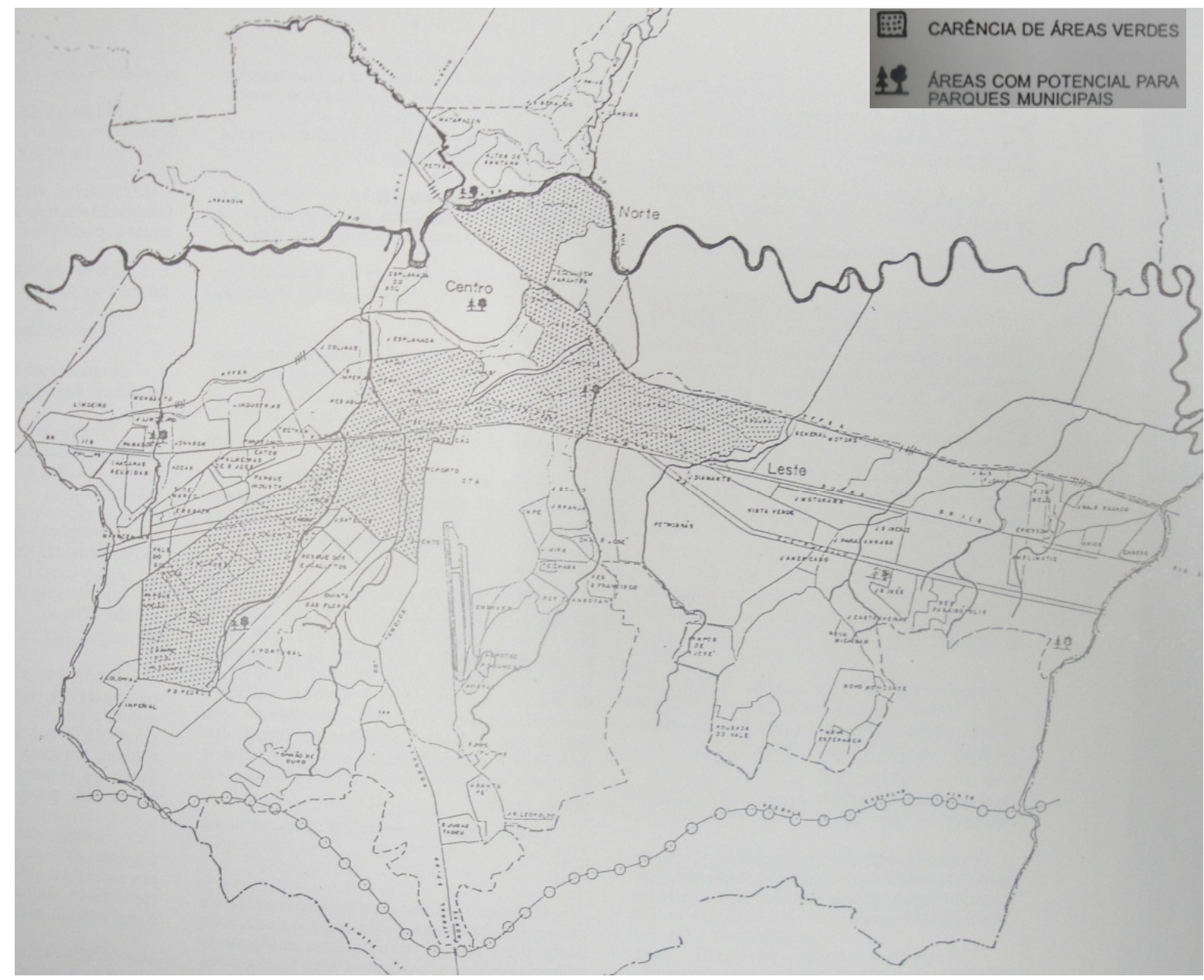

Figura 40 - Mapa da área de carência de áreas verdes.

Fonte: Caderno diagnóstico PDDI-1995 (mapa 16).

Diante dos estudos realizados, no Plano Diretor de 1995, Lei no 121/95, é aprovado o programa de áreas verdes e arborização urbana. Após o PDDI de 1995 houve, avanço na incorporação de novas áreas verdes ao município, no entanto, apenas uma parte das medidas previstas no programa foi efetivada na prática. O PDDI de 2006 propõe um novo índice de área verde, de $12 \mathrm{~m}^{2}$ por habitante, com a justificativa de que este índice vem sendo usado por vários municípios. O município de São José dos Campos possui um índice geral de 13,68 $\mathrm{m}^{2}$ de área verde por habitante. No entanto, este índice não é atingido igualmente em todas as regiões do município, como mostra a Tabela 5. 
Tabela 5 - Índice potencial de áreas verdes por habitante por setor socioeconômico.

\begin{tabular}{|c|c|c|c|c|}
\hline Setor Socioeconômico & Área (m2) & $\begin{array}{c}\text { População } \\
\text { Estimada } \\
* *\end{array}$ & $\begin{array}{l}\text { Índice Potencial de } \\
\text { Área verde e lazer } \\
\text { públicos / habitante }\end{array}$ & Região \\
\hline Alto da Ponte & $212.950,21$ & 30.036 & 7,09 & Norte \\
\hline Santana & $546.951,35^{*}$ & 14.457 & 37,83 & Norte \\
\hline Centro & $238.420,28$ & 17.080 & 13,95 & Centro \\
\hline Jd. Paulista & $102.374,83$ & 19.483 & 5,25 & Centro \\
\hline Vila Industrial & $274.982,13$ & 34.398 & 7,99 & Leste \\
\hline Eugênio de Melo & $172.459,00$ & 16.336 & 10,55 & Leste \\
\hline $\begin{array}{c}\text { Pararangaba - Campos S. } \\
\text { José }\end{array}$ & $740.644,00$ & 26.223 & 28,24 & Leste \\
\hline Vista Verde & $270.877,03$ & 15.339 & 17,66 & Leste \\
\hline Jd. Granja & $193.314,00$ & 19.119 & 10,11 & Sudeste \\
\hline CTA & não considerado & não considerado & não considerado & --- \\
\hline $\begin{array}{c}\text { Vila São Bento - Torrão } \\
\text { de Ouro }\end{array}$ & $242.521,17$ & 13.545 & 17,90 & Sul \\
\hline Campos dos Alemães & $451.142,64$ & 47.304 & 9,53 & Sul \\
\hline Bosque dos Eucaliptos & $454.534,00$ & 37.563 & 12,10 & Sul \\
\hline Jardim Satélite & $422.723,00$ & 25.794 & 16,38 & Sul \\
\hline Jd. Oriente - Jd. Morumbi & $371.389,11$ & 45.539 & 8,15 & Sul \\
\hline Parque Industrial & $499.707,50$ & 34.061 & 14,67 & Sul \\
\hline Jd. das Indústrias & $203.759,77$ & 18.964 & 10,74 & Oeste \\
\hline Urbanova - Jd. Aquarius & $826.114,02$ & 11.144 & 74,13 & Oeste \\
\hline $\begin{array}{l}\text { V. Adyanna - Jd. } \\
\text { Esplanada }\end{array}$ & $355.556,06$ & 30.625 & 11,60 & Centro \\
\hline São Francisco Xavier & $79.048,00$ & 1.901 & 4,58 & ---- \\
\hline $\begin{array}{c}\text { Favelas / ocupações } \\
\text { irregulares }\end{array}$ & 690 & 6.477 & 0,10 & ---- \\
\hline B. Freitas - Sertãozinho & $57.410,86$ & 10.623 & 5,40 & Norte \\
\hline Pq. Novo Horizonte & $423.509,43$ & 29.873 & 14,17 & Leste \\
\hline Putim & $185.800,74$ & 20.027 & 9,27 & Sudeste \\
\hline $\begin{array}{c}\text { Capão Grosso - Bom } \\
\text { Retiro }\end{array}$ & $73.749,83$ & 15.136 & 4,87 & Leste \\
\hline Total & $7.400 .829,00$ & 541,047 & 13,68 & \\
\hline
\end{tabular}

*Incluso o Parque da Cidade (516.000 m²) /**Pesquisa de Habitação realizada pelo NEPO/Unicamp em 2004.

Fonte: Caderno diagnóstico do PDDI 2006 (p. 93).

As regiões Norte, Leste e Oeste, que juntas possuem 222.589 habitantes, representando $41 \%$ da população joseense, atendem ao índice de áreas verdes determinado pela Prefeitura. Já as regiões Centro, Sudeste e Sul, que juntas possuem 318.458 habitantes, não atingem o índice de áreas verdes. Desta forma, 59\% da população joseense não atinge o índice de áreas verdes, adotado pela Prefeitura de São José dos Campos.

Neste sentido, o Plano Diretor de 2006 (Lei 306/06) promulga o "Sistema de áreas verdes e de lazer", que tem como objetivo implantar sistemas de lazer e recreação públicos e promover o aumento no índice de áreas verdes. Para tanto, a lei prevê a criação de quinze novos parques urbanos, como mostra a Figura 41. 


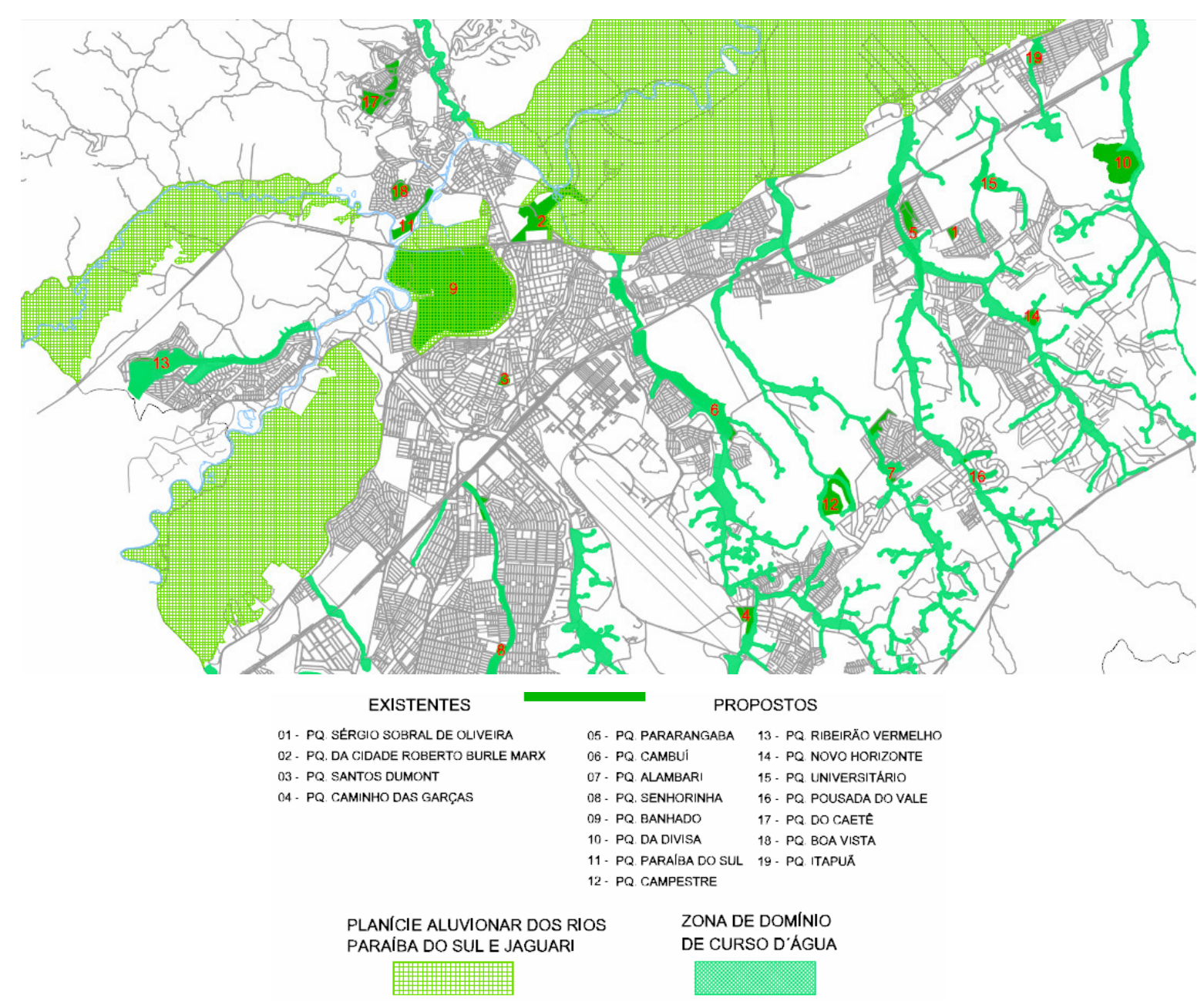

Figura 41 - Mapa Parques Urbanos previstos em São José dos Campos.

Fonte: Plano Diretor (Lei 306/06 - mapa 7).

No entanto, até o início de 2012, apenas o Parque Senhorinha $\left(\mathrm{n}^{\circ} 08\right)$ tinha sido finalizado e entregue a população, e outros dois, o Parque Paraíba do Sul (n $\left.{ }^{0} 11\right)$ e o Parque Cambuí ( $\left.n^{\circ} 06\right)$ estavam em fase de implantação. Em relação ao restante dos 12 parques previstos, estes não foram efetivados, ficaram apenas no papel. Atualmente, o município conta com seis Parques Urbanos: Parque Sergio Sobral de Oliveira, Parque da Cidade, Parque Santos Dumont, Parque Caminho das Garças, Parque Senhorinha e Parque Vicentina Aranha.

\subsubsection{Fiscalização Ambiental}

A ação de fiscalização desempenhada pelo poder público, ONGs e ambientalistas é fundamental para a efetivação das políticas públicas ambientais. Para que a legislação seja efetivada na prática, para que as normas e diretrizes previstas sejam respeitadas pela população, é preciso que haja uma ação contínua de orientação e fiscalização, caso contrário, 
as políticas públicas não são exercidas, pois muitas vezes, os interesses econômicos particulares se impõem aos interesses coletivos, trazendo danos ao meio ambiente e a qualidade de vida. Como preconiza Santos (1996, p. 48), "as cidades são criadas para a economia e não para os cidadãos".

Durante análise da legislação ambiental e urbanística de São José dos Campos pode-se observar vários casos de desrespeito à legislação vigente, como o desmatamento de Áreas de Proteção Ambiental e Preservação Ambiental, a construção de loteamentos em áreas impróprias, o descarte de resíduos sólidos em áreas não permitidas, o esgoto sendo lançado nos córregos e rios sem tratamento, indústrias poluidoras instaladas em meio à área urbana etc. O descumprimento da legislação causa vários danos ao meio ambiente, como o assoreamento de rios, a erosão, deslizamento de terra, enchentes, a poluição da água e do ar. O não cumprimento da legislação, ou mesmo a alteração da legislação por interesses particulares e econômicos, como as inúmeras alterações pontuais que ocorrem nas leis de zoneamento urbano, sem estudo aprofundado e sem atender aos interesses do coletivo, acabam gerando a degradação do meio ambiente e perda da qualidade ambiental urbana.

Desta forma, a atuação da fiscalização ambiental é de grande relevância no cumprimento das políticas públicas ambientais. Em várias leis analisadas, é apontada a importância em ampliar o número de agentes fiscais para assegurar o cumprimento da legislação municipal.

O município de São José dos Campos conta com uma unidade de Companhia Ambiental do Estado de São Paulo - CETESB, que é a agência do Governo do Estado responsável pelo controle, fiscalização, monitoramento e licenciamento de atividades geradoras de poluição. A CETESB é um órgão fiscalizador e licenciador de atividades consideradas potencialmente poluidoras, e também, licencia atividades que impliquem no corte de vegetação e intervenções em áreas consideradas de preservação permanente e ambientalmente protegida. A unidade da agência em São José dos Campos desempenha uma importante ação de fiscalização e monitoramento das políticas públicas ambientais no município.

São José dos Campos possui um pelotão da Polícia Ambiental, do Governo do Estado, composto por trinta policiais, sendo que destes, nove trabalham com a fiscalização em campo. Conforme entrevista realizada na polícia ambiental, a maior parte da fiscalização é feita por denúncias, são feitas de 6 a 8 denúncias por dia. O Soldado Messias nos informou que antes o policiamento era feito por ronda, mas atualmente o número de denúncias aumentou muito e com isso não há mais tempo para fiscalizar, só dá para correr atrás das denúncias (Entrevista 
com Soldado Messias da Polícia Ambiental de São José dos Campos, em 10 de julho de $2012 *)$.

Como mostra o gráfico na Figura 42, houve um aumento no número de infrações ao longo destes últimos 10 anos. Em 2001, foram registrados 89 AIAs, e em 2011, foram registrados 124 AIAs. Nota-se um crescimento de 39,3\% de 2001 para 2011. Ao analisarmos os últimos cinco anos, o aumento no número de AIAs foi ainda maior. Em 2006, foram registrados 62 AIAs, assim, houve um aumento de 100\% no número de autos de infração ambiental de 2006 para 2011. A Polícia Ambiental desempenha um importante papel na fiscalização e monitoramento do meio ambiente, e se nota isso pelo alto número de denúncias que o pelotão recebe por dia, e pelo aumento no número de autos de infrações ambientais.

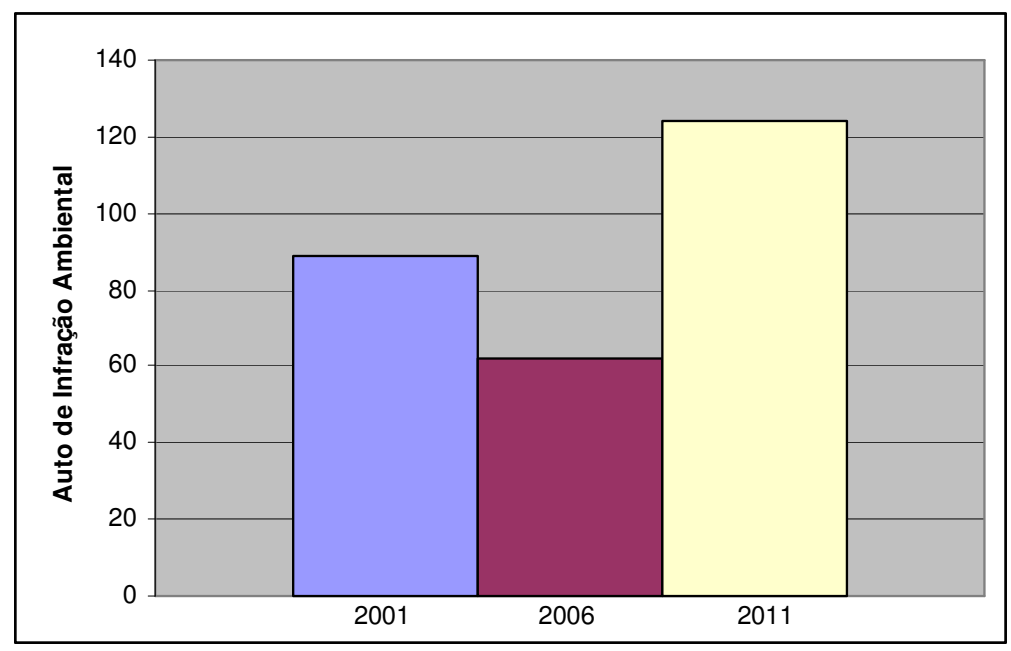

Figura 42- Autos de Infração Ambiental (AIA) de São José dos Campos.

Fonte: Policia Ambiental, 2012*.

São José dos Campos conta, também, com agentes fiscais que estão ligados à Secretaria de Meio Ambiente. Porém, o número de fiscais ambientais é muito baixo. Em 2005, quando a Secretaria foi criada, existia apenas um fiscal, e atualmente, conta com três fiscais. A Tabela 6 abaixo mostra o levantamento feito através do trabalho dos fiscais da Secretaria do Meio Ambiente.

Tabela 6- Fiscalização pela Secretaria Municipal do Meio Ambiente

\begin{tabular}{|l|c|c|c|c|c|c|c|c|c|}
\hline & Denúncias & Autos & Notificações & $\begin{array}{c}\text { Intervenção } \\
\text { APP }\end{array}$ & $\begin{array}{c}\text { Corte de } \\
\text { árvores }\end{array}$ & Queimadas & $\begin{array}{c}\text { Entulho } \\
\text { irregular }\end{array}$ & $\begin{array}{c}\text { Poluição do } \\
\text { ar e da água }\end{array}$ & Outros \\
\hline $\mathbf{2 0 1 1}$ & 270 & 104 & ---- & $42 \%$ & $24 \%$ & $17 \%$ & $14 \%$ & ---- & $3 \%$ \\
\hline $\mathbf{2 0 1 0}$ & 457 & 137 & 107 & $17 \%$ & $28 \%$ & $4 \%$ & $14 \%$ & $30 \%$ & $7 \%$ \\
\hline $\mathbf{2 0 0 9}$ & 435 & 60 & 110 & $49 \%$ & ---- & $44 \%$ & ---- & --- & $1 \%$ \\
\hline
\end{tabular}

(Nos espaços não preenchidos não foi possível ter acesso a informação)

Fonte: Secretaria do Meio Ambiente (2012) 
Como se pode ver, das denúncias, a maioria está relacionada à intervenção inadequada em Áreas de Preservação Permanente (APPs), como movimentação de terra não autorizada, supressão de árvores/desmatamento, abertura irregular de vala em área de preservação do Rio Paraíba, corte ilegal de árvores, queimadas, depósito de entulhos em áreas impróprias, poluição do ar e da água. Todos estes danos causados ao meio ambiente estão enquadrados em leis municipais e federais que dispõem sobre infrações ambientais, como nas Leis Municipais $n^{\circ}$ 423/10 (atividade em APP), $n^{\circ}$ 7815/09 (Limpeza Urbana e Manejo dos Resíduos Sólidos), n²67/03 (Código de Edificações), nº 428/10 (Zoneamento Urbano), Nº 306/06 (Plano Diretor) e Leis Federais no 4771/65 (Código Florestal) e no 9605/98 (Crimes Ambientais).

O Poder Público procura inibir as infrações ambientais através de ações educativas, notificações e multas, além dos infratores serem obrigados a recuperar a área degradada e efetuar a compensação ambiental pelo prejuízo causado. Em 2011, a Prefeitura de São José dos Campos fez acordos para o plantio de mais de 34 mil mudas de árvores nativas. Esse plantio foi a partir dos termos de compensação ambiental de empreendimentos licenciados pela Secretaria de Meio Ambiente, plantadas em áreas de preservação permanente (APP) do município e nas proximidades dos locais de onde foram retiradas. Em 2010, a Prefeitura atuou no plantio de mais de 16 mil mudas de árvore a partir de programas de reflorestamento e compensação ambiental (Secretaria do Meio Ambiente, PMSJC, 2012).

A proteção do meio ambiente conta ainda com a ajuda de ONGs (Organizações NãoGovernamentais), formadas por grupo de pessoas que atuam junto à sociedade e ao poder público em defesa do meio ambiente, através de denúncias, projetos, ações, campanhas e protestos em favor de um meio ambiente mais equilibrado, saudável e preservado. Em São José dos Campos, algumas ONGs se destacam, como: Instituto Eco Solidário, Centro de Amigos da Natureza (CAMIN), Vale Verde, Instituto Ecológico de Proteção aos Animais (IEPA) e o Grupo Consciência Ecológica (GCE).

O meio ambiente em São José conta também com colaboração do Conselho Municipal do Meio Ambiente, um órgão colegiado e consultivo, formado por diferentes instituições e representantes, que tem como objetivo promover e coordenar a preservação do meio ambiente. Este órgão foi criado em 1979, sendo denominado de Conselho Municipal de Combate à Poluição e Proteção ao Meio Ambiente, e a partir de 1983, passa a ser denominado de Conselho Municipal do Meio Ambiente (COMAM). A partir de 1994, pela Lei 4.617, o COMAM se torna um órgão autônomo que tem como atribuições: 
I - Assessorar, estudar e propor diretrizes para a política municipal de meio ambiente;

II - Colaborar nos planos e programas de expansão e desenvolvimento municipal, mediante recomendações referentes à proteção do meio ambiente no município;

III - Estudar e propor normas e procedimentos visando a proteção e a recuperação ambiental do município;

IV - Promover e colaborar na execução de programas intersetoriais de proteção da flora, da fauna e dos recursos naturais do município;

V - Fornecer subsídios técnicos para esclarecimentos, relativos à defesa do Meio Ambiente, aos órgãos públicos e principalmente à comunidade;

VI - Colaborar em campanhas educacionais relativas a saneamento básico, poluição das águas, do ar e do solo, proteção da fauna e da flora;

VII - Colaborar na execução de programas de Educação Ambiental a serem ministrados na rede de ensino e com atividades curriculares ou extracurriculares que despertem a consciência de preservação do meio ambiente;

VIII - Manter intercâmbio com as entidades oficiais e privadas de pesquisas e de atividades ligadas a defesa ou recuperação do meio ambiente;

IX - Prever os possíveis casos de degradação e de queda de qualidade de vida que ocorram ou possam ocorrer no Município, diligenciando no sentido de sua superação e apresentando ao Poder Executivo as providências que julgar necessárias;

$\mathrm{X}$ - Opinar sobre a implantação de empreendimentos potencialmente causadores de degradação ambiental e ou risco ambiental, após a análise dos Estudos e Relatórios de Impacto Ambiental (EIA/RIMA) ou Análise de Riscos exigíveis, em consonância com a Lei Orgânica do Município de São José dos Campos e com as Resoluções do CONAMA;

XI - Dar ampla publicidade de suas decisões, resoluções e estudos, e eventuais denúncias sobre transgressões à legislação ambiental;

XII - Convidar, através do Prefeito, qualquer Secretário Municipal ou seu representante, para participar de suas reuniões;

XIII - Administrar e gerir o Fundo Municipal de Meio Ambiente.

O COMAM é composto pela Secretaria Executiva (dois servidores da administração municipal indicado pela Prefeitura Municipal), Câmara Técnica (composta por técnicos, órgãos e entidades de notória especialização em assuntos de meio ambiente) e pela Câmara Social (composta por representantes dos órgãos, entidades ou grupos sociais). O COMAM possui 37 membros, e fazem parte do COMAM: Prefeitura Municipal de São José dos Campos; Câmara Municipal; Sociedades e Movimentos de Moradores de Bairros; Instituto Nacional de Pesquisas Especiais - INPE; Instituto Tecnológico de Aeronáutica - ITA; Universidade do Vale do Paraíba - UNIVAP; Grupo Avançado de Meio Ambiente do V. Paraíba - GAMAVAP; Centro das Indústrias do Est. São Paulo - CIESP; Ordem dos Advogados do Brasil - OAB; Sindicato dos Trabalhadores de Água, Esgoto e Meio Ambiente - SINTAEMA; Sindicato dos Petroleiros - SINDIPETRO; Conselho Intersindical de Saúde do Trabalhador; Sindicato dos Engenheiros; Conselho Municipal de Saúde - COMUS; Polícia Florestal; CETESB; SABESP; Departamento de Águas e Energia Elétrica - DAEE; Sindicato da Indústria de Construção - SINDUSCON; Entidades Ambientalistas; Representantes da Sociedade por Relevantes Serviços Prestados na Área de Meio Ambiente; Sindicato de 
Ciências e Tecnologia - SINDCAT; Sindicato dos Trabalhadores em Indústrias Químicas e Farmacêuticas; Sindicato Rural; Sindicato dos Trabalhadores Rurais; Associação dos Engenheiros a Arquitetos de São José dos Campos.

Desta forma, os agentes fiscais municipais, a polícia ambiental, a CETESB, o Ministério Público, as ONGs, os grupos ambientalistas, as sociedades de amigos do bairro etc, têm papel fundamental na preservação do meio ambiente. São estes órgãos, entidades e grupos sociais que atuam na proteção e fiscalização do meio ambiente, para que as políticas públicas ambientais sejam cumpridas de forma justa e igualitária, para que o meio ambiente seja usufruído com respeito e de forma saudável, sendo fundamental que estes ajam com ética e a favor dos interesses coletivos.

\subsection{Indústrias}

Embora o município de São José tivesse seu desenvolvimento e crescimento apoiado nos sanatórios, o poder público desde a década de 1920 buscava investir no setor industrial, oferecendo incentivos fiscais. Já nesta década, tem-se a instalação de duas grandes fábricas na cidade: a primeira, Bonadio S.A. - Fábrica de Louças Santo Eugênio (1921) - que trabalhava com manufatura de louças de pó de pedra e outros artigos de cerâmica, e a segunda, a Tecelagem Parahyba, que atuava na fabricação de cobertores. Ambas as fábricas se instalaram próxima a linha férrea e a área urbana, sendo que a empresa Bonadio (Figura 43) estava mais integrada a área urbana, e a Tecelagem Parahyba (Figura 44) estava localizada mais próxima ao Banhado.

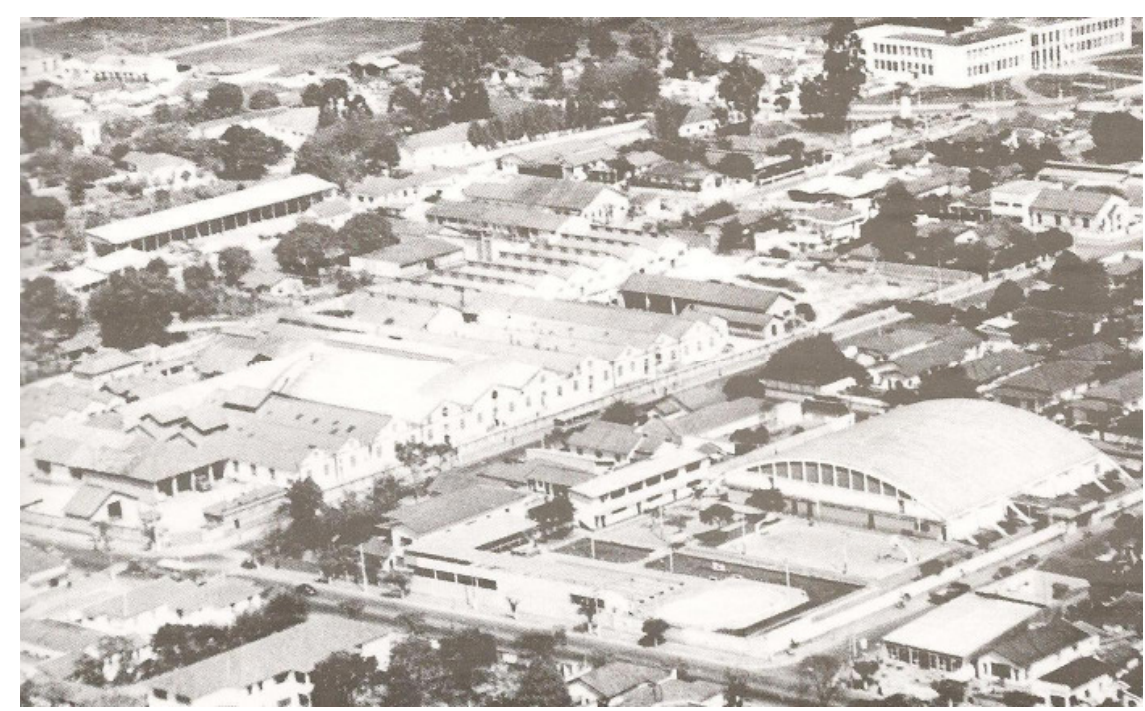

Figura 43 - Bonadio S.A. - Fábrica de Louças Santo Eugênio. Fonte: SANTOS (2006, p.79). 


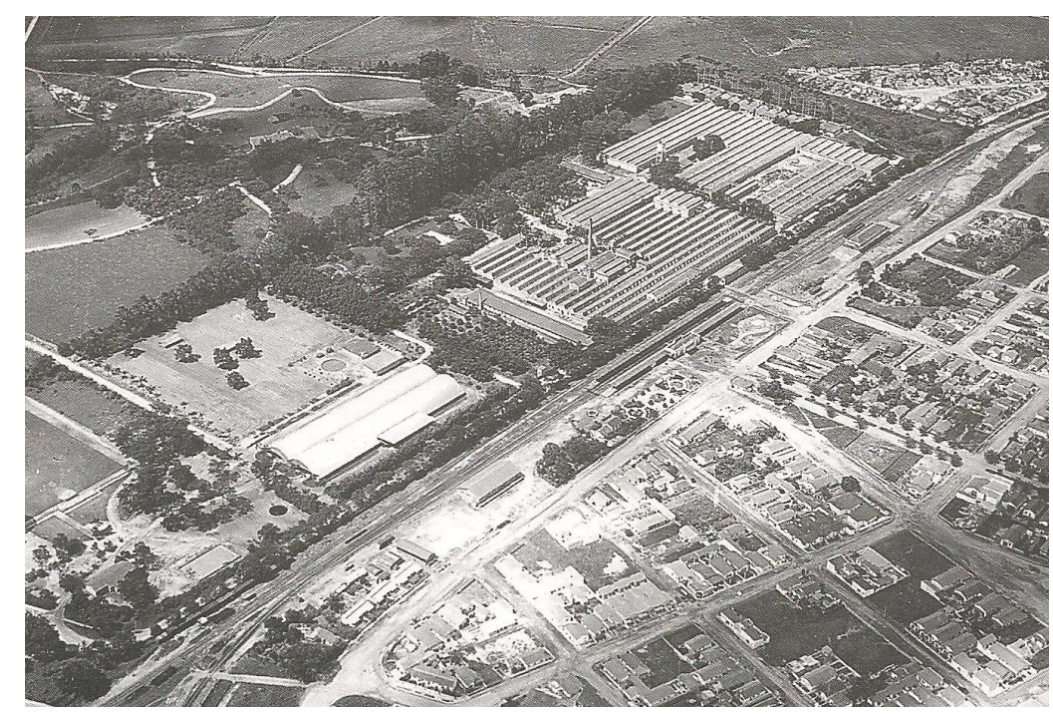

Figura 44 - Tecelagem Parahyba.

Fonte: SANTOS (2006, p.89).

Na década de 1930, as empresas Bonadio S.A e Tecelagem Parahyba apresentam grande crescimento, atraindo uma maior mão de obra. Em 1935, a Cooper, indústria de laticínios, se instala próxima ao Distrito de Santana. Neste período, São José já apresenta certo despontamento industrial em relação aos municípios vizinhos.

Em 1932, pelo Ato $\mathrm{n}^{\circ} 110$, o município vai contar com seu primeiro zoneamento urbano, marcando o início do planejamento urbano da cidade, que é então dividida em zona residencial, zona sanatorial e zona comercial. Em 1935, o zoneamento é revisto, e a cidade conta, também, com a zona industrial. Este primeiro zoneamento busca direcionar o crescimento da cidade, sendo um avanço no planejamento municipal, porém, algumas das novas indústrias que se instalam na cidade não vão respeitar as zonas especificadas pela legislação local, se instalando em meio à zona residencial e sanatorial.

$\mathrm{Na}$ década de 1940, a cidade passa por um novo crescimento industrial recebendo novas indústrias, entre elas transnacionais de grande porte: a Cerâmica Weiss em 1941, a Vigor em 1943, Rhodia (Companhia Rhodosá de Rayon em 1946), e o CTA, em 1947. A Cerâmica Weiss se instala fora da zona industrial, como determinava o zoneamento urbano, e vai se instalar em meio à zona residencial.

A Rhodia (Companhia Rhodosá de Rayon), por sua vez, se instala às margens do Rio Paraíba do Sul (Figura 45), uma indústria química altamente poluidora, que passa a descartar no Rio Paraíba Sul uma grande quantidade de resíduos químicos e poluentes, além da poluição atmosférica. 


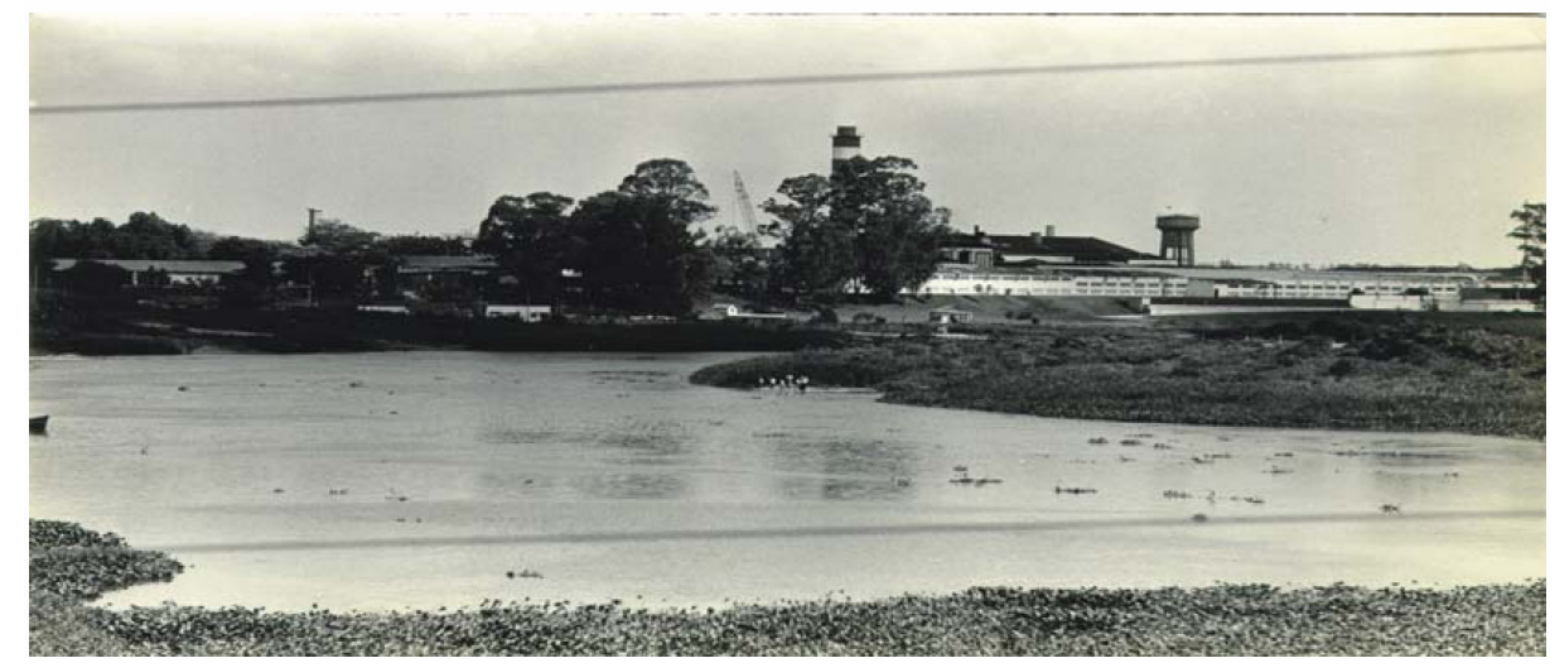

Figura 45 - Vista parcial das instalações da Rhodia as margens do Rio Paraíba.

Fonte: SOUZA (2008).

A inauguração da Rodovia Presidente Eurico Gaspar Dutra (BR-116) em 1951 atraiu novas e grandes indústrias ao município na década de 1950, entre elas a Johnson \& Johnson (1954), a Ericsson I (1954), a Kanebo (1956), a General Motors (1957), a Eaton (1957) e a Alpargatas (1959). A maioria destas indústrias vai se instalar ao longo da Via Dutra. O zoneamento proposto em 1935 se torna defasado em relação ao grande desenvolvimento do município.

A transição da fase sanatorial para a nova fase industrial não foi acompanhada por políticas públicas; não houve uma nova lei de zoneamento urbano; as indústrias passam a se instalar no município seguindo interesses próprios, muitas vezes em meio à área residencial. Como exemplo, tem-se a KANEBO e a ERICSSON I. Na Figura 46, pode-se ver a fábrica da KANEBO cercada por residências, já a ERICSSON I diante da impossibilidade ampliação de suas instalações, acaba se transferindo, em 1974, para o Distrito de Eugenio de Melo, sendo que a fábrica inicial dá origem ao primeiro Shopping Center da cidade, o Center Vale, inaugurado em 1987. 


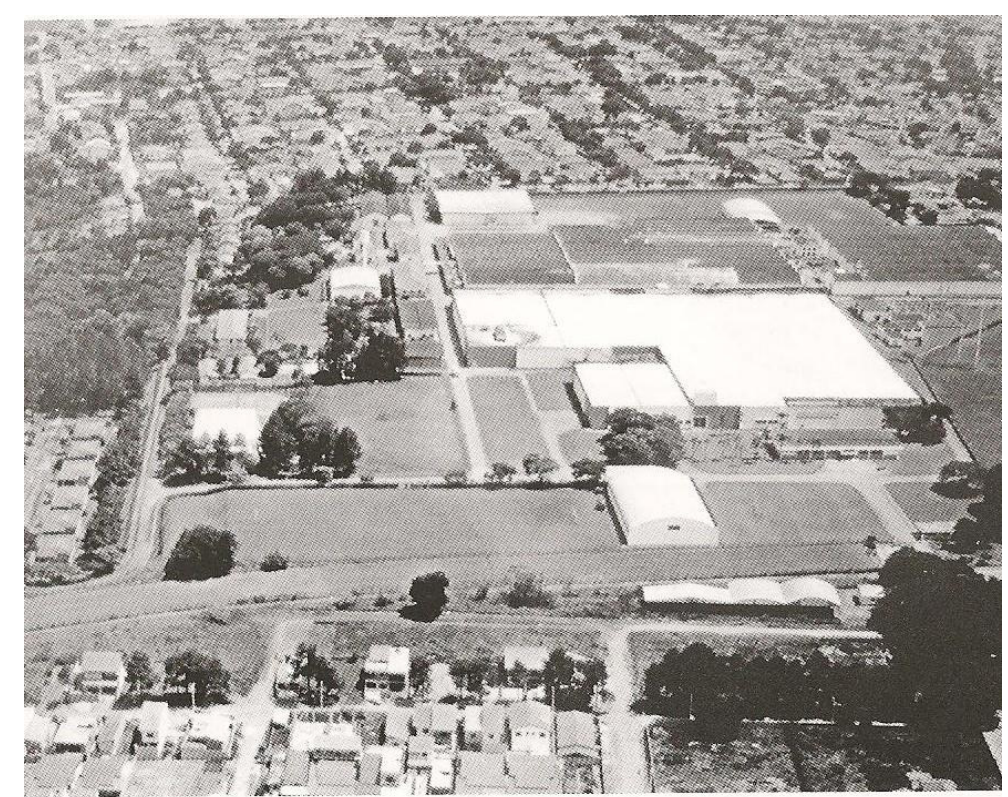

Figura 46 - Fábrica da KANEBO.

Fonte: SANTOS (2006, p. 155).

Em 1961 um novo zoneamento é proposto para o município, o zoneamento de massa, desenvolvido pela equipe da FAU-USP juntamente com o primeiro Plano Diretor do município. Uma das principais questões apontadas nesse Plano Diretor é a necessidade de afastar as indústrias poluidoras das áreas residenciais, e para tanto, foi feito estudo da direção dos ventos e proposto o zoneamento de massa. Outra preocupação do zoneamento de massa de 1961 era preservar a captação de água para a população. Neste sentido, já havia preocupação com a poluição do ar e da água no município desde a década de 1960.

Neste período novas indústrias de grande porte chegam ao município, entre elas a Bendix/Bundy (1961), o INPE (1961), a Avibrás (1961), a FSRA (1962), a Matarazzo-IRFM (1962) e a Kodak (1969).

Comparando o mapa de zoneamento de massa (1961) com o mapa da localização de indústrias até a década de 1970, como mostra a Figura 47, pode-se observar que o zoneamento de massa procurou seguir a localização das indústrias já existente. As zonas industriais ficaram demarcadas no entorno das grandes indústrias já instaladas e nas proximidades da Rodovia Dutra. Entre as indústrias instaladas na década de 1950, apenas a Kanebo e a Ericsson estão fora do que viria a ser considerada zona industrial, passando a se encontrar em zona residencial. Na década de 1960, todas as grandes indústrias que se instalam no município seguem o zoneamento de massa, se instalando na zona industrial. Nenhuma indústria de grande porte se instala nas margens do rio Paraíba do Sul. Apenas a indústria Matarazzo (IRFM), produtora de fios sintéticos, está localizada às margens do Rio Jaguari em meio à 
zona rural. Vê-se desta forma, que o Plano Diretor de 1961, no que tange às questões industriais, foi efetivado na cidade, o que possibilitou ao município crescer de forma planejada. Na década de 1970, a REVAP e a Ericson II se instalam em meio à zona residencial definida no zoneamento de massa de 1961e a Philips em meio às áreas verdes.

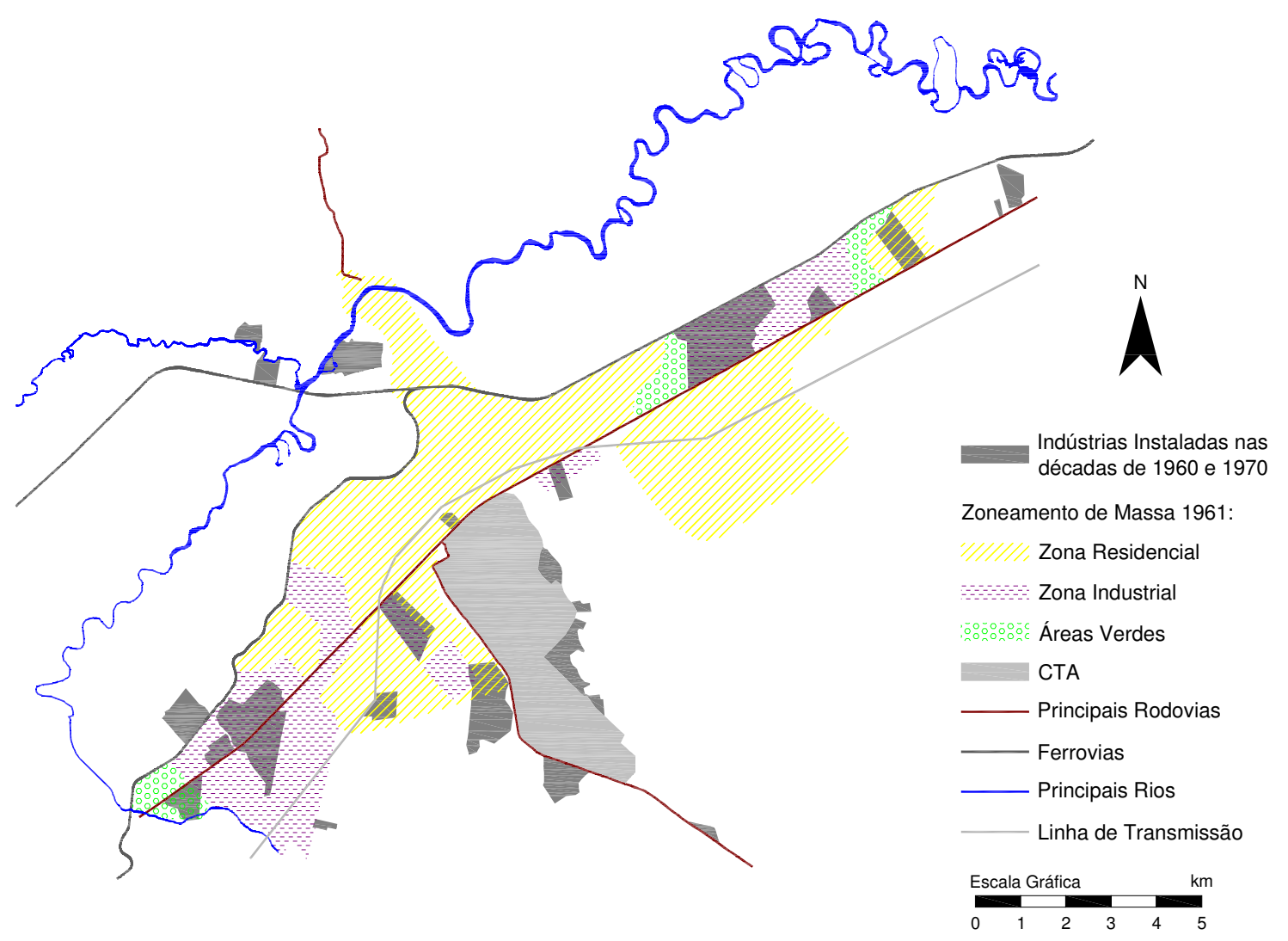

Figura 47 - Zoneamento de massa e indústrias na década de 1960 e1970.

Na década de 1970, o município ganha um novo zoneamento urbano e um novo Plano Diretor, sob a coordenação do arquiteto e urbanista Jorge Wilhein, desenvolvido em tempos de ditadura militar. Assim, neste período, as novas políticas de planejamento urbano visam ao desenvolvimento econômico, dando pouca atenção às questões ambientais. Nesse sentido, há um grande aumento no tamanho e número de zonas industriais, sendo que grande parte das áreas residenciais e áreas verdes do zoneamento de massa de 1961 passa a ser considerada zona industrial.

Entre as indústrias que se instalam no município na década de 1970, pode-se destacar a Panasonic (1970), a Embraer (1970), a Hitachi (1972), a Engesa (1973), Ericsson II (1973), a Philips (1974), a Granja Itambi (1974), Monsanto (1974), Santista (1974), a Kone -Krupp (1976) e a Minisa (1976). A maior parte destas indústrias se localiza no entorno da Rodovia 
Dutra. Todas estas indústrias seguem o zoneamento urbano proposto em 1971, como foi possível observar através da comparação de mapas de Santos (2006) e o PDDI - 1971. Apenas a indústria Santista está localizada fora do perímetro urbano, às margens do Rio Jaguari. Tal indústria não respeita a faixa mínima de área não edificável, desrespeitando o Código Florestal. Foi possível observar também que as áreas verdes determinadas no zoneamento de massa de 1961 se tornam zona industrial pelo zoneamento de 1971, sendo que a Philips vai se instalar numa dessas áreas.

$\mathrm{Na}$ década de 1980, se instalam no município as empresas REVAP (Refinaria Henrique Lages - Petrobrás - 1980), a Tectran (1982), a Orion (1982) e a Panasonic (1983). A Revap, refinaria de petróleo, chega ao município pela ação do estado, sendo parte do II PND, ela se instala às margens da Rodovia Dutra, num imenso platô, entre o Córrego Alambari e Rio Parangaba, e modifica o sentido da expansão da cidade. Tal indústria é considerada grande poluidora, sendo muitas vezes alvo de protesto pelos moradores, devido ao lançamento de partículas poluidoras na atmosfera, acarretando fuligem, prejudicando a qualidade do ar na cidade e causando doenças respiratórias. A indústria se instala em meio à área urbana e vai acarretar grandes danos à qualidade de vida dos bairros arredores e de toda cidade.

A instalação da REVAP foi realizada em desacordo com a legislação vigente, pois a área onde ela se instala estava prevista como área de expansão urbana, sendo que a maior parte da área de expansão estava prevista como área residencial. Conforme se pode visualizar na Figura 48, a REVAP se instala em uma área onde já havia aprovação para loteamento. Os estudos preliminares do Plano Diretor de 1971 apontam a existência de arruamento de loteamento, onde vem a se instalar a refinaria de petróleo.
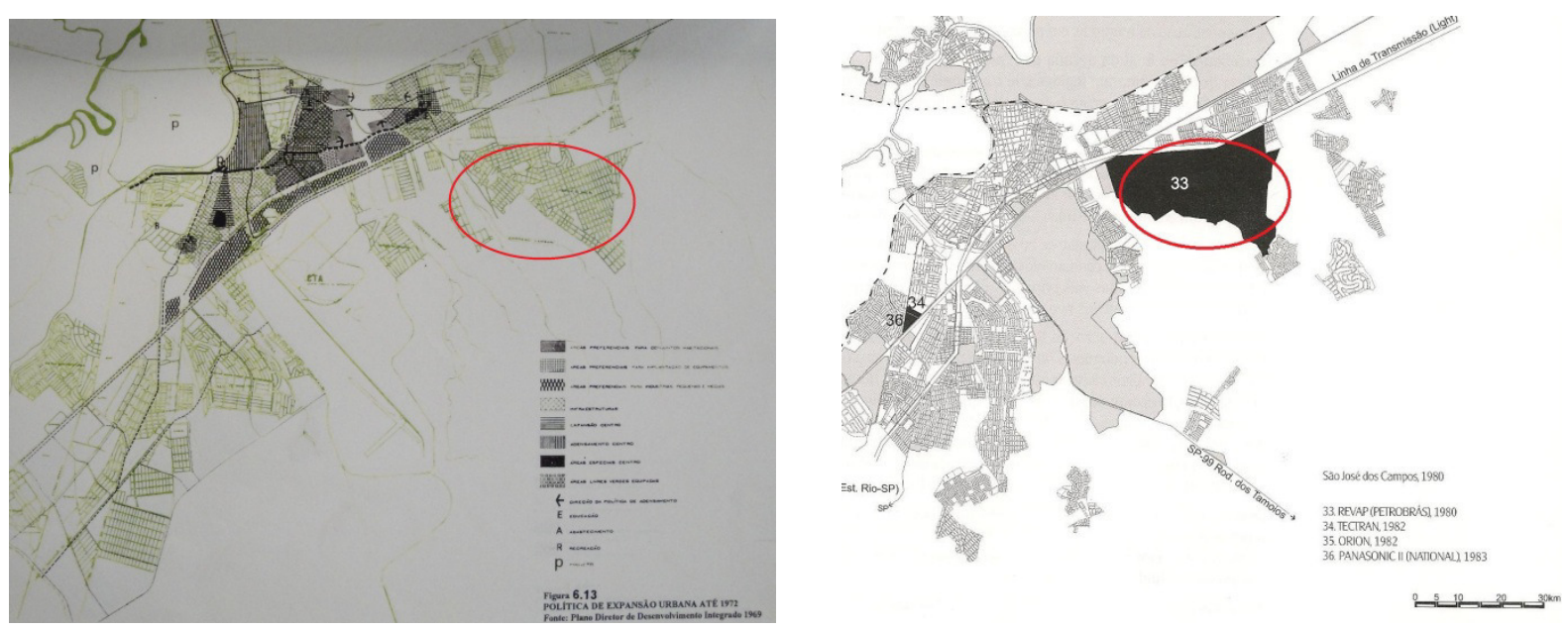

Figura 48 - Plano Diretor de 1971 (loteamento aprovado) e REVAP instalada em 1980. Fonte: Plano Preliminar (1971) e Santos (1996). 
Conforme determina a lei de zoneamento de 1.607/71, no artigo 7, as indústrias perigosas e que geram poluição deveriam se instalar fora da área de expansão urbana, mas na prática não é isso que ocorre.

$\S 1^{\circ}$ São consideradas nocivas ou perigosas, as indústrias que produzem mau cheiro, ruídos incômodos, poluem água, ponham em risco a saúde dos habitantes ou ameacem as construções vizinhas.

$\S 2^{\circ}$ A Prefeitura Municipal indicará a localização das indústrias nocivas e/ou perigosas, preferencialmente em áreas que já possuem infraestrutura e adequação para esse fim, fora da área de expansão urbana. (Lei de Zoneamento1.606/71, Artigo $7^{\circ}$ )

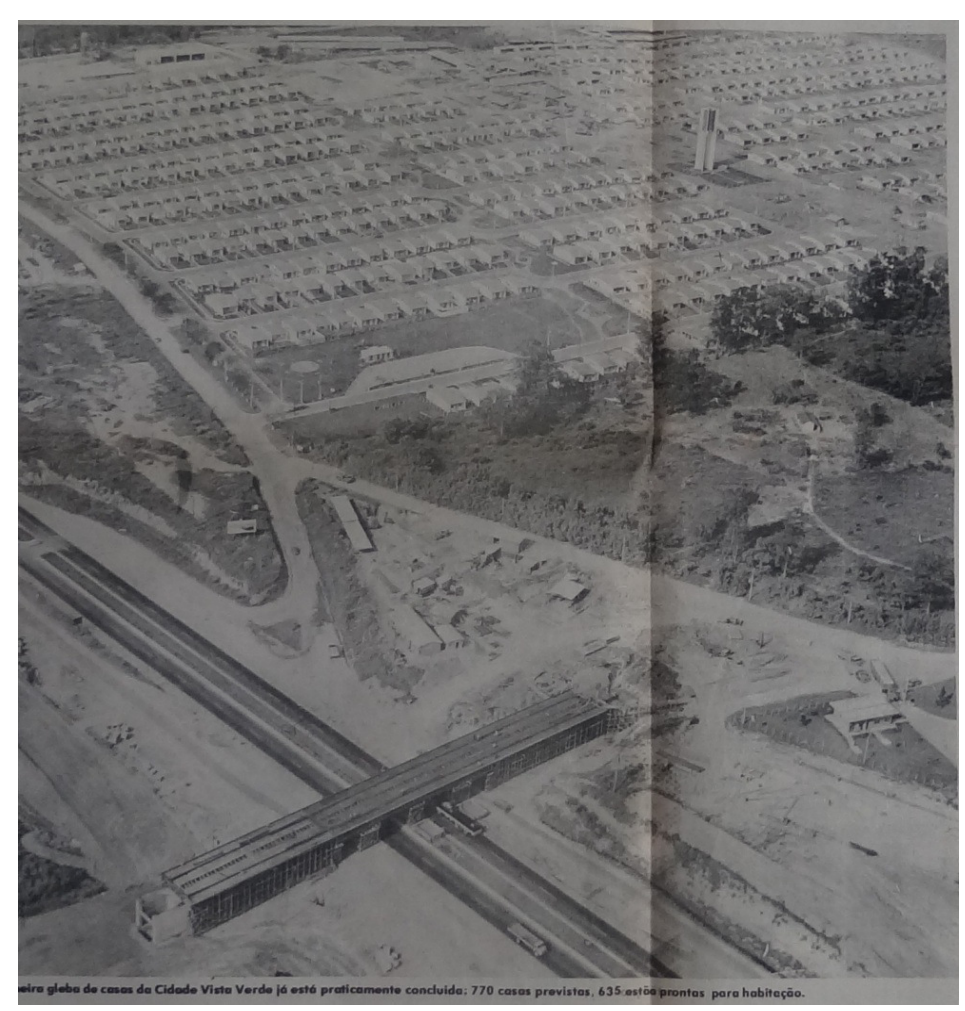

Figura 49 - Construção do bairro Vista Verde.

Fonte: Jornal Correio Joseense (1974).

NA Figura 49, nota-se a construção do bairro Vista Verde e do viaduto que dá acesso ao bairro, conforme informa a propaganda do loteamento: "na Cidade Vista Verde não são vendidas apenas casas, mas todo um conjunto ambiental racional planejado: grandes áreas verdes com estudos paisagísticos, ruas sem cruzamento [...]” (Correio Joseense, 1974). No entanto, pouco tempo depois dá se início à construção da REVAP nas proximidades do bairro.

Desta forma, é possível observar que a instalação da REVAP, uma indústria estatal, não segue a legislação urbana vigente, é construída sem respeito às leis que visam o melhor 
planejamento e ordenamento da cidade, sendo efetivada sem considerar as características ambientais do município e estudos realizados, como a direção dos ventos. A Revap é imposta, trazendo grandes mudanças à cidade. Na década de 1980, buscando evitar que novas indústrias poluidoras se instalem no município, a Lei de Zoneamento 2.264/80 proíbe a instalação de indústrias de alto potencial poluidor no município.

Analisando as políticas de zoneamento urbano e plano diretor do município na década de 1970 e 1980, fica claro que não houve um plano pensado conforme as características ambientais e sociais do municípios. As políticas não foram pensadas em longo prazo. As leis eram imediatistas e visavam assegurar o crescimento industrial do município, apenas ratificando a localização das indústrias existentes no município. O zoneamento de massa de 1961 praticamente não é levado em consideração. Áreas verdes e áreas residenciais se tornam áreas industriais. As indústrias poluidoras passam a se localizar em meio à área urbana, e não em áreas afastadas, como o primeiro zoneamento preconizava. A legislação muitas vezes não é respeitada, nem mesmo pelos órgãos públicos, como é o caso da instalação da REVAP.

Na década de 1990, o eixo da Rodovia Dutra continua sendo a principal área de atração de novas indústrias; tem a instalação da Tectelcom (Tecsat, 1997), a Century (1998), a Johnson Controls (1998) e a Solectron (1999), que seguem a orientação prevista no zoneamento urbano de 1990. Na década de 2000, tem-se uma diminuição na instalação de indústrias de grande porte no município e o aumento no número de indústrias de médio e pequeno porte. 




Figura 50 - Indústrias de grande porte, APA e APPs.

Fonte: Santos (2006) e PMSJC - Cidade Viva (2011).

A Figura 50 confronta as indústrias de grande porte instaladas no município com os córregos existentes e áreas de preservação permanente. Vê-se que algumas indústrias invadem as APPs do Rio Paraíba do Sul e do Rio Jaguari, sendo que, entre elas, destaca-se a Rhodia, que possui alto potencial poluidor. No mais, são várias as indústrias que se instalam sobre córregos e APPs, desrespeitando o Código Florestal e a legislação municipal. 
Desta forma, busca-se analisar as indústrias de grande porte que se instalaram no município de 1920 a 2010. Procura-se relacionar a instalação destas indústrias às políticas públicas previstas no referido período. Foram analisadas 40 indústrias de grande porte.

Em um estudo realizado pela Secretaria de Planejamento Urbano de São José dos Campos, no ano de 2004, foi apontada a existência de 1013 indústrias no município. Destas, 912 contribuíram com uma pesquisa de cadastro de indústrias. A pesquisa constatou que das 912 indústrias, 46,3\% são indústrias de pequeno porte. Das indústrias analisadas, $53 \%$ estão instaladas no município há menos de 7 anos, e apenas 10,4\% estão instaladas há mais de 20 anos. A Prefeitura de São José dos Campos (2010) contabiliza que existem atualmente no município 1.450 indústrias, que empregam aproximadamente 38 mil pessoas.

Em entrevista à CETESB, foi relatado que as empresas que causam maiores danos ambientais são as de pequeno porte, pois muitas vezes não possuem alvará e licenciamento ambiental. As grandes indústrias, como a Monsanto, Revap (Petrobrás), a Radice Group (antiga Rhodia), a Panasonic, a General Motors, EMBRAER, as distribuidoras de gás, entre outras, são consideradas empresas prioritárias para a CETESB, por seu grande porte e quantidade de produção, e por possuírem risco ambiental, e assim, exigem mais atenção e maior número de vistorias. Desta forma, estas indústrias, que são consideradas com maior potencial poluidor, acabam sendo fiscalizadas com maior rigidez, e assim, poluindo menos; já para as pequenas indústrias, falta mais fiscalização. Como informou a CETESB, a maior parte das vistorias só ocorre quando há denúncias, e quando não há denúncias, não há vistorias; deste modo, as pequenas e médias indústrias acabam sendo menos vistoriadas por este órgão ambiental.

Em pesquisa realizada nos arquivos do "Jornal VNews", no período de janeiro de 2010 a janeiro de 2012, foi possível verificar que em dois anos foram várias as notícias relacionadas à contaminação de água, fumaça, fuligem ou mau cheiro, de origem nas indústrias Revap (Petrobrás) e na Radice Group (antiga Rhodia), e também, reclamações de moradores e multas da CETESB aplicadas a estas duas empresas por poluição ao meio ambiente.

Como vemos na Figura 51, muitas das indústrias de grande porte da cidade são as principais fontes de poluição do ar. O PDDI de 1995 aponta praticamente todas as indústrias de grande porte como fontes de poluição. Já o estudo de Carvalho et al. (2012) identifica as principais fontes de poluição. Pode-se ver que muitas destas fontes de poluição estão próximas as áreas urbanas, o que prejudica a qualidade do ar. 


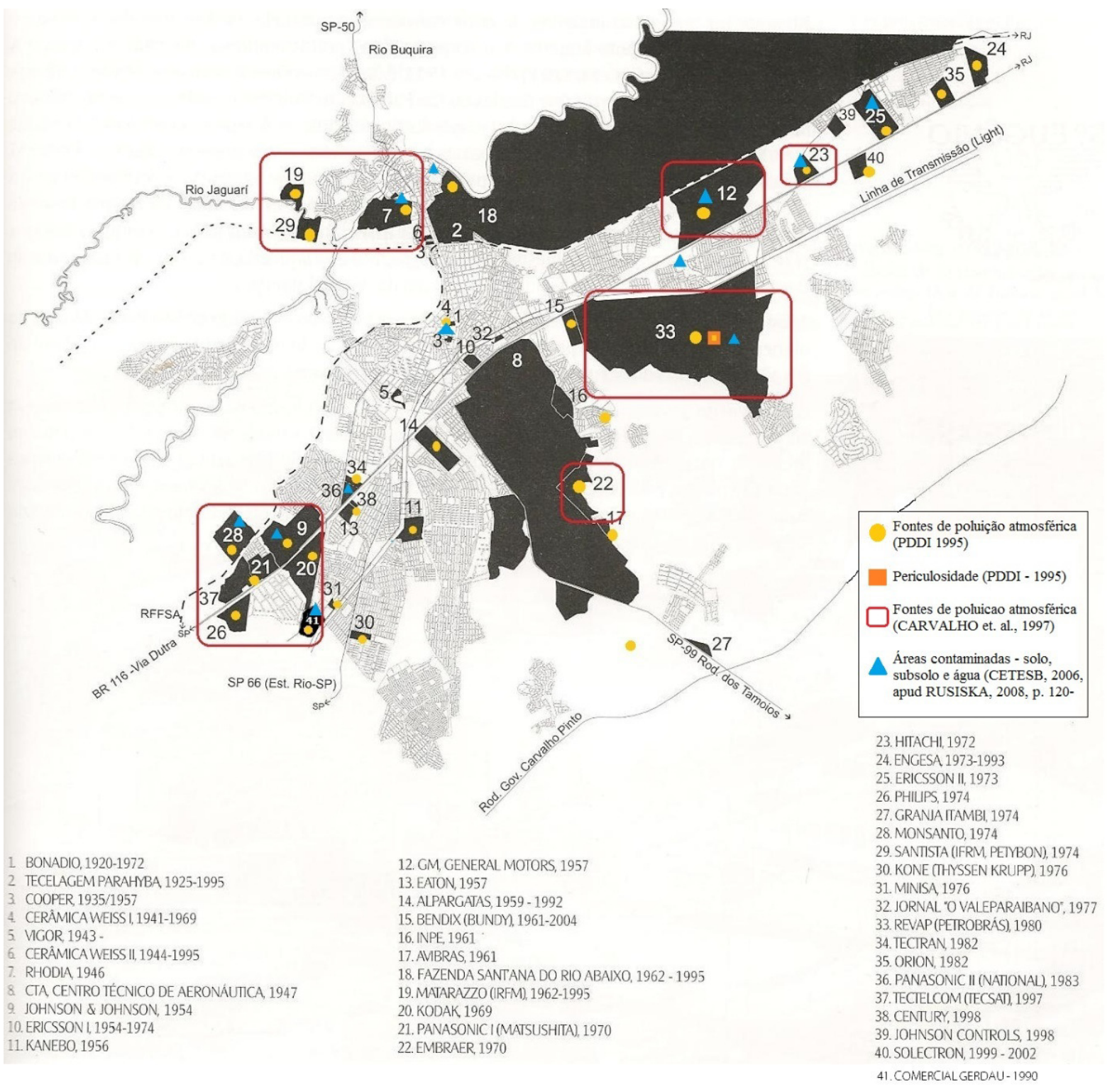

Figura 51 - Indústrias e fontes de poluição atmosférica em São José dos Campos ${ }^{35}$. Fonte: Santos (2006);PDDI (1995);Carvalho et al. (2012);Rusiska(2008) - Elaborado por Reani.

Em um estudo realizado por Carvalho et al. (2012), sobre a dispersão de poluentes em São José dos Campos foi constatado que o município não possui condições físicas adequadas para o estabelecimento de indústrias que gerem alta poluição do ar. Segundo Medeiros (1996, apud CARVALHO et.al., 2012), "nos vales e nas bacias comprimidas entre montanhas, como é o caso de São José dos Campos, a qualidade do ar fica comprometida pela dificuldade da dispersão dos poluentes, não sendo áreas propícias à implantação de indústrias com grande potencial poluidor". Molion (1980, apud Carvalho et al. 2012), afirma que a radiação do sol

\footnotetext{
${ }^{35}$ É importante ressaltar que algumas das indústrias que se destacam como fontes de poluição no PDDI de 1995, já tiveram suas atividades encerradas, como é o caso da Alpargatas, Bendix, Solectron, Kodak,KANEBO, entre outras.
} 
nas encostas dos vales interfere na circulação do ar no vale; o ar mais frio fica concentrado no fundo do vale dificultando a dispersão dos poluentes.

Carvalho et al. (1997) concluiu em sua pesquisa que "São José dos Campos tem forte predomínio de situações de calmaria, pois cerca de $40 \%$ das observações realizadas são de calmaria". Por este motivo e por São José Campos estar localizada dentro de um vale (em geral, menos favorável a dispersão de poluentes), a cidade não é propícia à instalação de empresas com alto potencial poluidor.

O autor afirma ainda que, através do estudo dos ventos na região, pode-se concluir que: "a poluição gerada à leste da cidade tende a ser levada para o Centro e os bairros Jardim Satélite, Bosque dos Eucaliptos, Jardim Morumbi, Parque Industrial e outros, potencializando assim, ainda mais, a poluição gerada no centro da cidade e nestes bairros, onde estão localizados os maiores aglomerados urbanos da cidade" (CARVALHO et al. 2012).

Desta forma, fica claro que os investimentos e intervenções realizadas pelo Estado na região tinham objetivos especificamente econômicos; os aspectos sociais e ambientais não foram privilegiados pelo governo, sendo assim, a cidade de São José que teve seu desenvolvimento inicial apoiado em suas características ambientais, bom clima e bons ares,

ganhando o Título de Estância Climatérica e Hidromineral, é transformada pela ação do Estado e do capital, em cidade industrial e polo tecnológico, sendo que a qualidade ambiental deixa de ser primordial, dando maior ênfase as questões econômicas.

\subsubsection{Extração minerária: areia}

O Vale do Paraíba, desde 1949, se configura como polo abastecedor de areia para a construção civil, principalmente para a Região Metropolitana de São Paulo (MONTANHEIRO, 2009). A exploração da areia em São José dos Campos teve grande crescimento nas décadas de 1960 e 1970, com a construção do metrô em São Paulo e as Rodovias Bandeirantes e Imigrantes (PDDI-1995).

No entanto, estudos mostram que a extração da areia causa vários danos ambientais. Montanheiro (2009), em estudo realizado pelo Instituto Geológico (IG), aponta alguns dos impactos ambientais causados pela extração de areia no Rio Paraíba do Sul: desequilíbrio das variáveis hidráulicas; aprofundamento e alargamento do canal; mudanças da forma do rio. Segundo Mechi e Sanches (2010), para a extração de areia, são necessárias escavações vultuosas e que resultam em grande volume de rejeitos, e traz vários impactos negativos ao meio ambiente. Segundo os autores op. cit., toda atividade de mineração implica supressão de 
vegetação ou impedimento de sua regeneração. A atividade, também, pode acarretar erosão e assoreamento dos corpos d'água. A qualidade da água à jusante do empreendimento pode ficar prejudicada, devido á turbidez e pela poluição causada por substâncias lixiviadas e carreadas ou contidas nos efluentes das áreas de mineração, tais como óleos, graxa, metais pesados. O regime hidrológico dos cursos d'água e dos aquíferos pode ser alterado, quando se faz uso desses recursos na lavra (desmonte hidráulico), além de causar o rebaixamento do lençol freático. O rebaixamento de calha de rios com a lavra de seus leitos pode provocar a instabilidade de suas margens, entre muitos outros danos ambientais (MECHI; SANCHES, 2010).

Em São José dos Campos, ambientalistas e ONGs vão discutir a questão da exploração da areia no município. Neste sentido, atendendo à pressão dos ambientalistas, diante dos inúmeros problemas ambientais acarretados por essa atividade, em 1980, é promulgada a primeira lei municipal que vai regulamentar a extração de areia, que já vinha ocorrendo há muito tempo no município sem normas e regras.

A Lei 2.387, de 15 de dezembro de 1980, regulamenta a licença para extração de areia de cava. Conforme a legislação, a empresa minerária só poderá explorar a jazida por três anos e deverá apresentar laudo da CETESB, que comprove que a atividade não causará danos à paisagem, não haverá rebaixamento do lençol freático, não provocará assoreamento e erosão.

Posteriormente, a Lei ${ }^{\circ}$ 2.495/81 vai proibir a extração de areia no Rio Jaguari. Em 1989, a legislação é alterada e se torna mais restritiva; novas medidas de cunho ambiental são exigidas para extração de areia no município. A Lei n ${ }^{\circ}$ 3.522/89 torna obrigatório o Estudo de Impacto Ambiental e Relatório de Impacto Ambiental, que serão submetidos a audiências públicas e à aprovação do Conselho Municipal do Meio Ambiente, para o licenciamento da extração de areia no município.

A Lei $n^{\circ} 3.667 / 89$ vai ao encontro das leis municipais em vigor e proíbe a exploração da areia no perímetro urbano em Áreas de Preservação Permanente (APP), em Áreas de Proteção Ambiental (APA) e em áreas em que haja plano hidroagrícola pelo Estado.

O PDDI 1995 destaca o problema econômico ambiental da exploração mineral da areia no leito do Rio Paraíba do Sul e afirma: “A exploração é extremamente rentável para o setor privado, mas traz poucos lucros ao município e grandes danos ambientais" (Caderno Diagnóstico do PDDI 1995). O plano prevê a criação de um zoneamento minerário e a gestão integrada entre os municípios do Vale do Paraíba. 
Neste sentido, tem-se que a Secretaria do Meio Ambiente (SMA) do Governo do Estado de São Paulo, em 16 de setembro de 1996, baixa a Resolução SMA 42/96, que disciplina o licenciamento ambiental dos empreendimentos minerários de extração de areia na Bacia Hidrográfica do Rio Paraíba do Sul. Em 22 de setembro de 1999, é aprovada a Resolução SMA 28/99, que específica o zoneamento ambiental para mineração de areia no subtrecho da bacia hidrográfica do Rio Paraíba do Sul, como mostra a Figura 52.

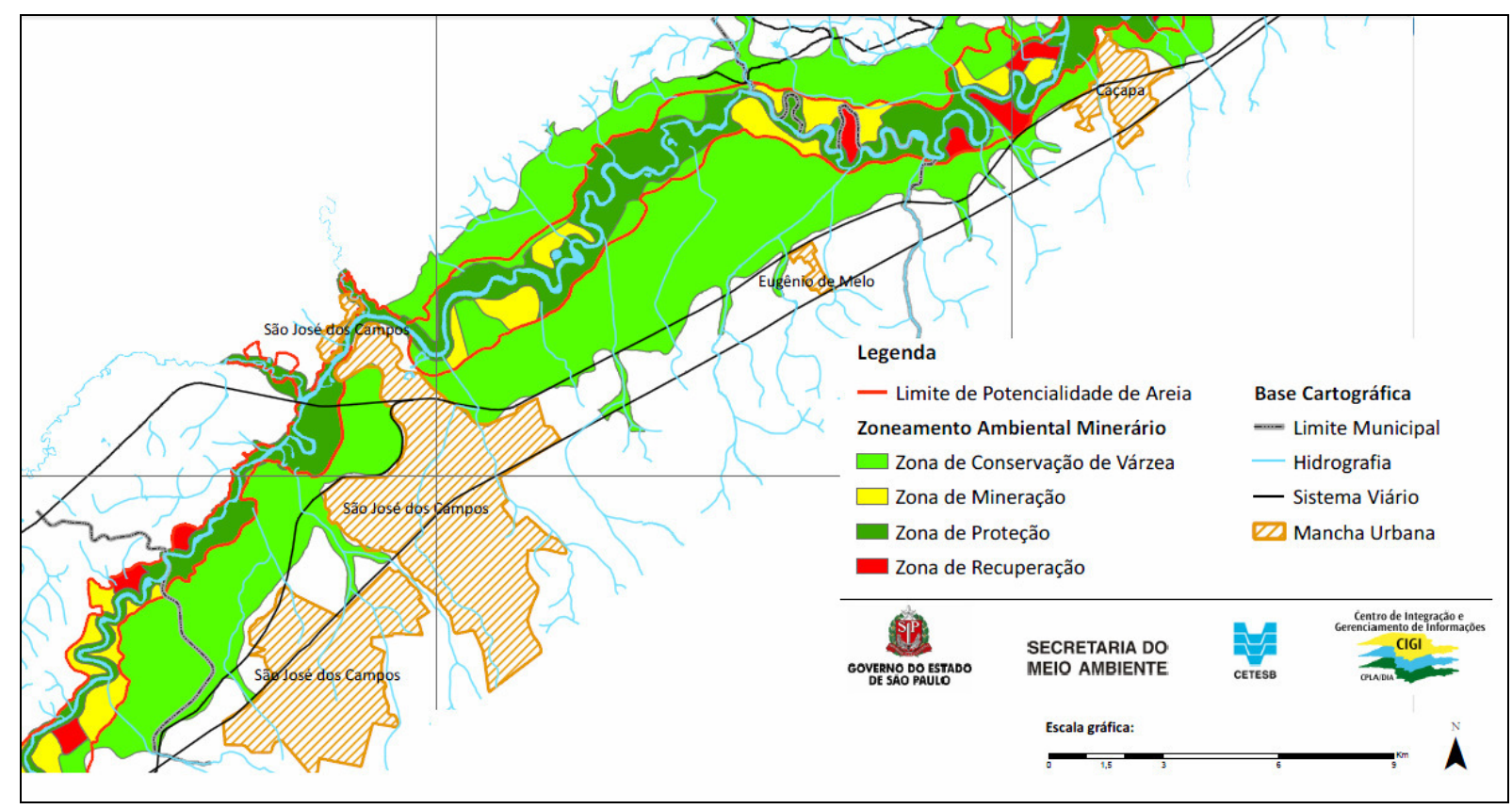

Figura 52 - Zoneamento Ambiental para Atividade de Extração de Areia na Várzea do Rio Paraíba do Sul (Recorte trecho São José dos Campos) - Resolução SMA 28/99. Fonte: Resolução SMA 28/99, Governo do Estado de São Paulo.

Complementando a Resolução SMA 28/99, a Lei Orgânica de São José dos Campos, alterada em 2001, em seu Artigo 259, determina que as áreas de várzea dos Rios Paraíba do Sul e Jaguari deverão ser protegidas como patrimônio ambiental e paisagístico. Em relação à atividade mineraria, a legislação determina que: “As atividades minerárias somente poderão ser exercidas nas áreas definidas no zoneamento regional ambiental minerário elaborado pela Secretaria de Estado do Meio Ambiente de São Paulo, obedecidas às legislações municipais, estaduais e federais, ficando vedada esta atividade na área denominada "Concha do Banhado".

Desta forma, a extração de areia está inviabilizada no município de São José dos Campos, há mais de dez anos. Os municípios vizinhos a São José dos Campos permitem a extração minerária da areia. Nos últimos dois anos, há uma pressão muito grande por parte do 
Sindicato dos Mineradores e das Empresas Mineradoras para que volte a ser permitida a exploração da areia em São José. Existe um projeto sendo analisado pela Câmara Municipal.

Em âmbito estadual, em abril de 2011, por meio da Resolução SMA nº 16/2011, foi criado um Grupo de Trabalho (GT) para rever o "Zoneamento Ambiental de áreas com atividade minerária de extração de areia na bacia hidrográfica do Rio Paraíba do Sul no Estado de São Paulo". O objetivo é rever a necessidade ou não da expansão da área de incidência do zoneamento e disciplinar as medidas de recuperação das áreas degradadas.

No entanto, os movimentos ambientalistas são contra a permissão da extração da areia no município, uma vez que a atividade gera inúmeros danos ao meio ambiente. Os reflexos do período em que a extração era permitida no município estão presentes até hoje na paisagem joseense. Das 15 cavas abertas no município, apenas uma foi recuperada. Nos municípios vizinhos onde ocorre a exploração da areia, há casos de desrespeito às leis ambientais vigentes, exploração além da área definida no zoneamento minerário e cavas abandonadas sem a devida recuperação ambiental.

A extração da areia é uma atividade altamente lucrativa, porém poucos têm acesso a esse lucro. Há uma grande perda em qualidade ambiental para o beneficiamento de poucos empresários. O reflexo no valor da areia comercializado no município seria muito pequeno, não compensaria a grande perda ambiental, gerada por esta atividade econômica. Vê-se que, neste caso, o município de São José dos Campos, vem tomando uma postura bastante crítica em favor do meio ambiente, proibindo a exploração da areia e dando maior valor à qualidade ambiental joseense.

\subsection{Loteamentos Clandestinos}

No primeiro Plano Diretor de São José dos Campos, em 1961, já é apontado o problema do crescimento de loteamentos invadindo as zonas rurais, periféricas ao núcleo urbanizado, sem nenhuma “ordem racional” (PLANO PRELIMINAR, 1961, p.07). Neste período, é estabelecido o zoneamento de massa do município, criando zonas de uso e delimitando a área rural e urbana do município; são promulgadas leis que visam inibir a especulação imobiliária e trazer um mínimo de infraestrutura aos novos loteamentos, como rede de água, luz e requisitos urbanísticos, estabelecendo, desta forma, regras para a aprovação de novos loteamentos.

Porém, desde o início, a lei de zoneamento nunca foi rigorosamente acatada; novos loteamentos surgiram, desrespeitando a legislação vigente. No Plano Diretor de 1971, o 
problema do crescimento periférico desordenado é novamente colocado em pauta, e também, a questão do aumento de vazios urbanos. Novas políticas são adotadas buscando inibir a expansão urbana e a ocupação de vazios urbanos, porém, tais políticas acabam elevando o valor da terra e novos loteamentos clandestinos surgem em desacordo às normas vigentes. A Lei de Zoneamento Urbano de 1971, realizada em acordo com o Plano Diretor (1971), determina normas para o uso e ocupação do solo, porém, em muitos casos, tal legislação não foi cumprida. Já em 1974, surge a primeira de várias leis de anistia aos loteamentos clandestinos. A década de 1970 marca o início da expansão dos loteamentos clandestinos no município, como se pode ver na Figura 53.
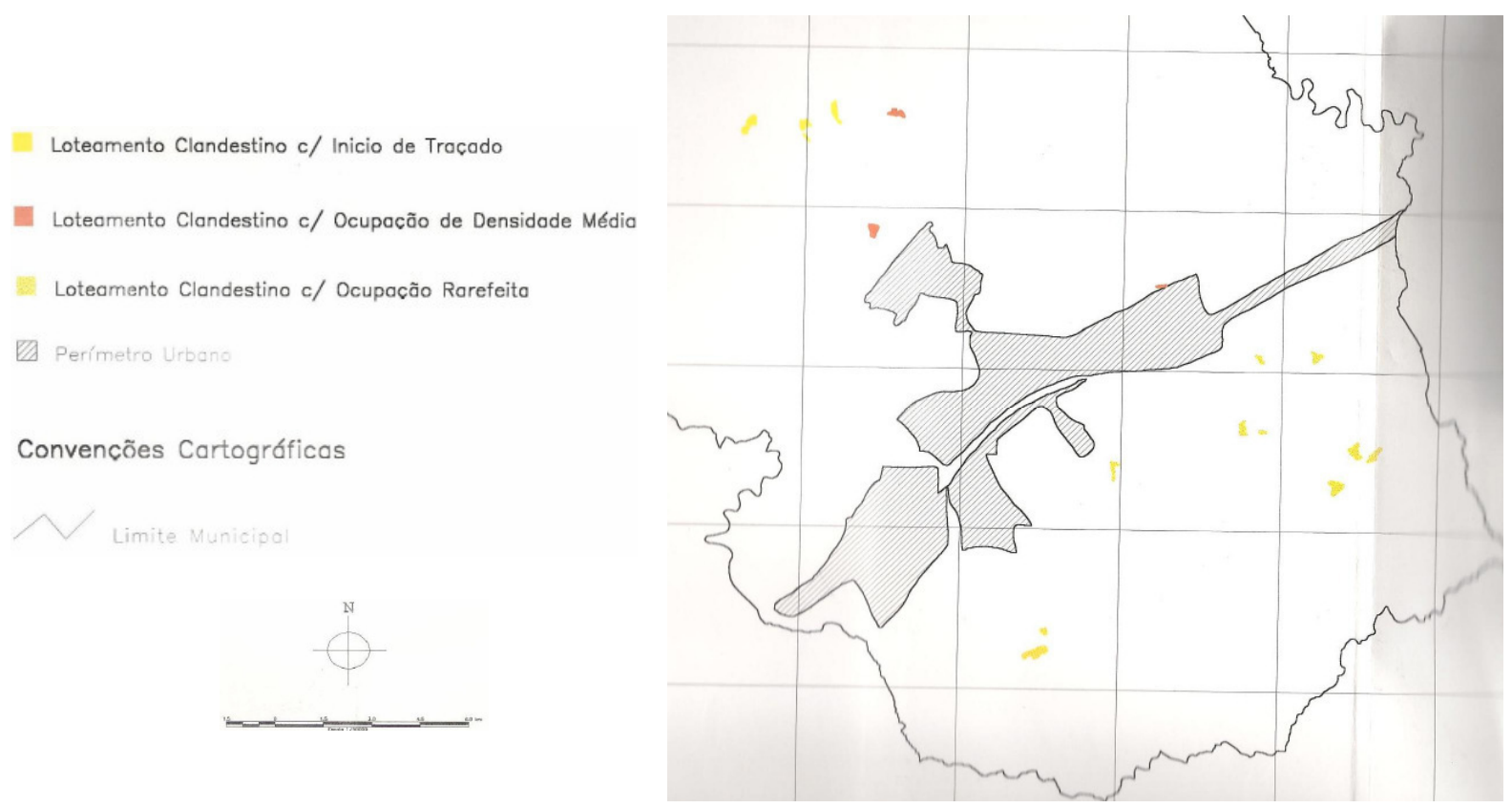

Figura 53 - Loteamentos Clandestinos em São José dos Campos - 1977.

Fonte: GOUVÊA (2003, p. 89).

Como se pode visualizar na Figura 53, já em 1977, havia vários loteamentos clandestinos espalhados pelo território em meio à zona rural. Eram 17 núcleos, sendo que muitos deles ainda estavam se formando, ou seja, tinham uma ocupação rarefeita, principalmente nas regiões Sul e Leste. Já na região Norte do município, nota-se dois loteamentos clandestinos consolidados, com uma ocupação de densidade média, e outros em início do traçado. A maioria destes loteamentos encontra-se bem distante do perímetro urbano, porém ligados a este por meio de estradas de terra.

A nova lei de zoneamento urbano em 1980 procura ser mais rígida e detalhista, retrai o perímetro urbano na tentativa de ocupar os vazios urbanos, mas tal política acabou elevando o 
preço do solo e surgem inúmeros loteamentos clandestinos novos na cidade. Tal lei passa por várias alterações atendendo aos requisitos da especulação imobiliária, e novamente leis de anistia são promulgadas, beneficiando a proliferação dos loteamentos clandestinos.

A proliferação dos loteamentos clandestinos em São José dos Campos se acentuou a partir da década de 1980, como consequência do acelerado processo de urbanização e industrialização do município. A população de baixa renda encontrou na zona rural, através dos loteamentos clandestinos, acesso a moradia, muitas vezes precárias e com nenhuma infraestrutura. A falta de fiscalização pelo poder público, aliada a inúmeras leis de anistia e ação da especulação imobiliária, permitiu que tal prática se proliferasse no município.

Analisando a Figura 54, no mapa de 1985, vê-se um grande aumento no número de loteamentos clandestinos em relação ao mapa de 1977, passando a existir por volta de 45 núcleos de loteamentos clandestinos. Observa-se o surgimento de novos loteamentos, bem como a expansão e o adensamento dos já existentes.

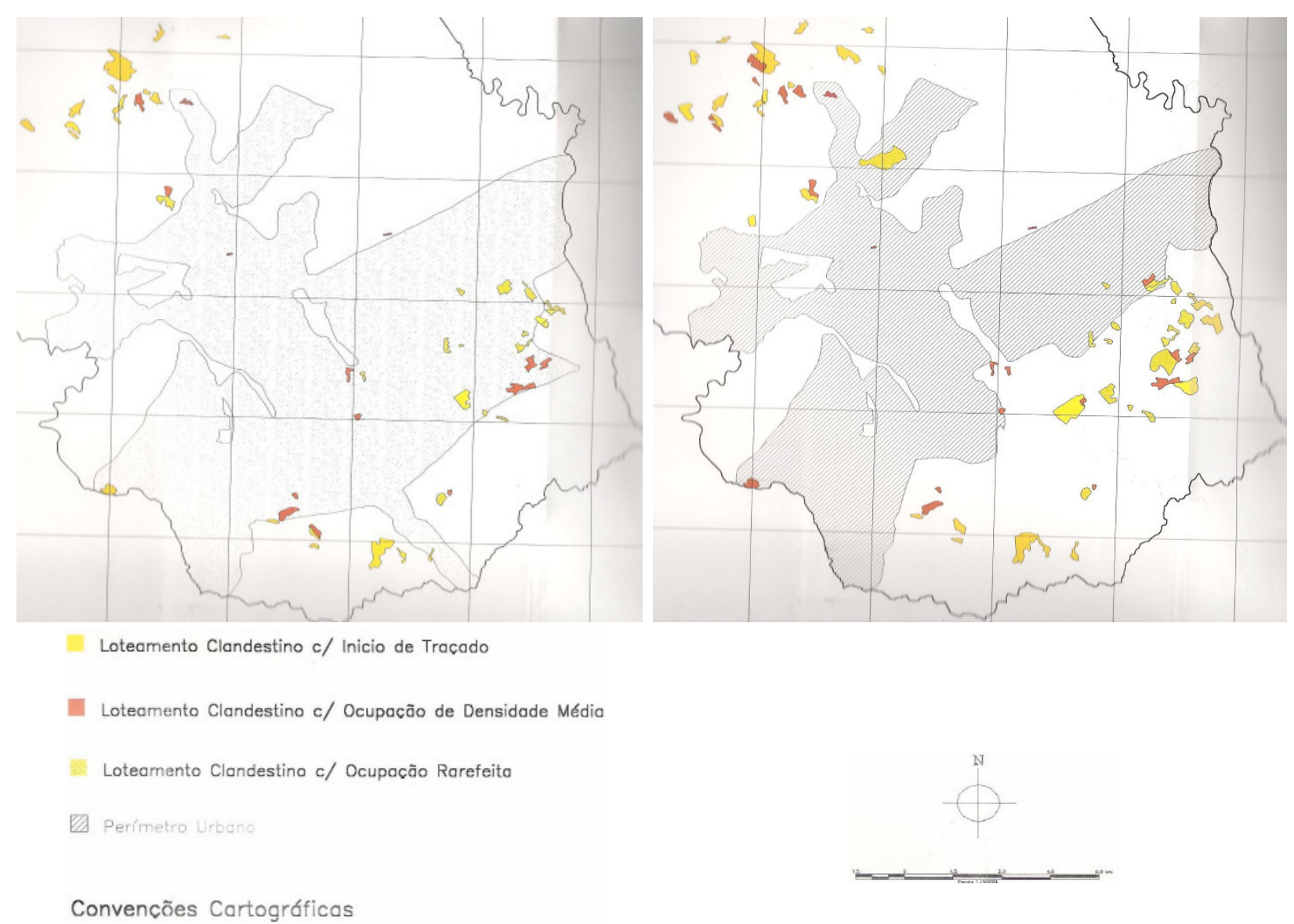

Figura 54 - Loteamentos Clandestinos em São José dos Campos em 1985 e 1988. Fonte: GOUVÊA (2003, p.92 e 93). 
No período de 1985 a 1988, ou seja, em apenas três anos, vê-se um grande aumento dos loteamentos clandestinos, tanto em número, que já passa de 60, como em área e densidade. Há maior concentração de loteamentos clandestinos na Zona Leste do município. Conforme estudos realizados por Gouvêa (2003), verificou-se que, na década de 1980, houve um grande "boom" no surgimento e adensamentos dos loteamentos clandestinos no município.

Em 1990, a nova lei de zoneamento é promulgada, sendo mais criteriosa e exigente quanto ao parcelamento do solo, traz novas normas e regras para a elaboração do projeto e aprovação de loteamento. No entanto, a lei não consegue impedir a proliferação de novos loteamentos clandestinos; inúmeras leis de anistia aos loteamentos clandestinos são aprovadas na câmara municipal; não há fiscalização e punição contra a falta de cumprimento das regras.

Em 1995, o município estabelece o novo Plano Diretor e neste novamente aparece o problema da proliferação dos loteamentos clandestinos, que passa a ganhar maiores proporções; a área rural é intensamente parcelada para fins urbanos. Uma das causas apontadas pelo Plano Diretor é o enfraquecimento do setor rural e a descapitalização do produtor rural, que levou ao aumento de terras ociosas nesta área.

No Caderno Diagnóstico do Plano Diretor de 1995, é apontada a existência de 108 loteamentos clandestinos que não seguem as leis vigentes no município, ocupam áreas de proteção e preservação ambiental e não possuem infraestrutura, trazendo inúmeros danos ao meio ambiente, como o desmatamento de vegetação nativa, assoreamento e poluição de cursos d'água.

A Figura 55 mostra o mapa com a localização dos loteamentos clandestinos existentes no município de São José dos Campos em 1995, embora o texto do caderno diagnóstico (PDDI-1995) afirme existir em 108 loteamentos clandestinos, é apontada no mapa a localização de 94 loteamentos clandestinos. Vê-se que a maioria destes loteamentos está localizada na porção leste e norte do município. 


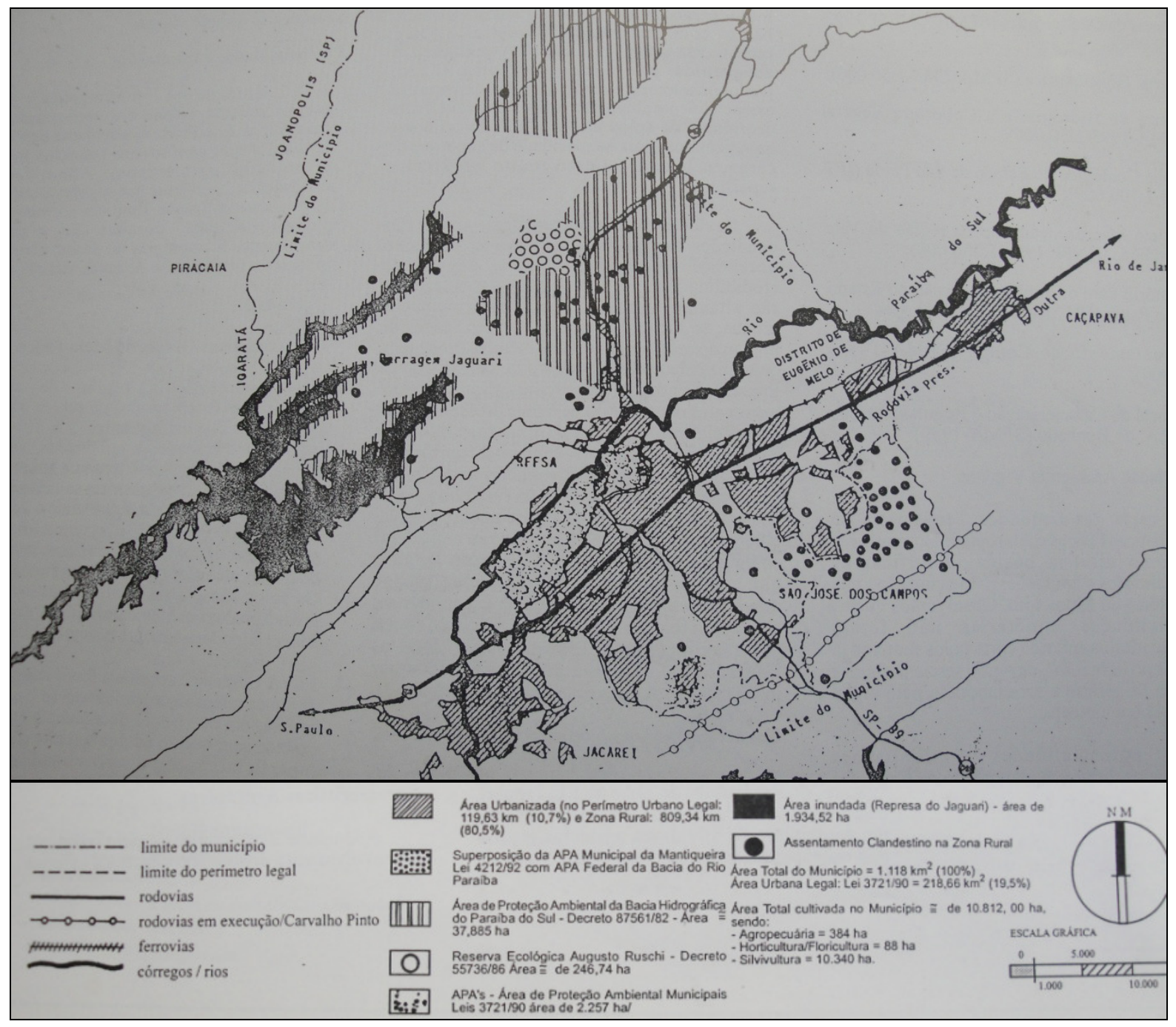

Fonte: Caderno Diagnóstico PDDI - 1995.

Figura 55 - Mapa da Localização dos Loteamentos Clandestinos em 1995.

O PPDI-1995 estabelece normas que buscam regularizar a situação desses loteamentos clandestinos, criando bolsões específicos que seriam regularizados, de forma a incorporar 50 loteamentos clandestinos à área urbana. As ZEIS foram destinadas à promoção de habitação de interesse social e à regularização fundiária e urbanística de áreas ocupadas irregularmente por assentamentos habitacionais de população de baixa renda. Foram criadas as ZEIS, mas essas não foram operacionalizadas e não se regulamentou a habitação de interesse social. Os loteamentos clandestinos não deixam de existir e não contam com nenhum tipo de infraestrutura ou serviço.

No intuito de proibir o surgimento de novos loteamentos clandestinos e produzir o crescimento ordenado e planejado da cidade, o PPDI de 1995 desenvolveu a "Carta das Unidades Territoriais", levando-se em consideração os aspectos físicos do município, e 
através desta, foi pensado como seria efetivado o ordenamento, uso e ocupação do solo, porém novos loteamentos clandestinos continuaram surgindo no município.

A nova Lei de Zoneamento de 1997 procura deixar claro que é proibido o parcelamento do solo para fins urbanos na zona rural. O zoneamento é elaborado com base no Plano Diretor de 1995 e na Carta das Unidades Territoriais. A Lei amplia a área do perímetro urbano e aumenta a oferta de lotes populares, mas a proliferação dos loteamentos clandestinos continua sem solução.

A Figura 56 mostra os loteamentos clandestinos existentes em 1997. É possível observar que surgem menos loteamentos clandestinos novos, mas vê-se o adensamento e expansão dos loteamentos clandestinos já existentes. Embora existam vários loteamentos clandestinos espalhados pela cidade, a Região Leste é a que concentra maior número, caracterizando-se como uma área muito explorada para a prática clandestina.

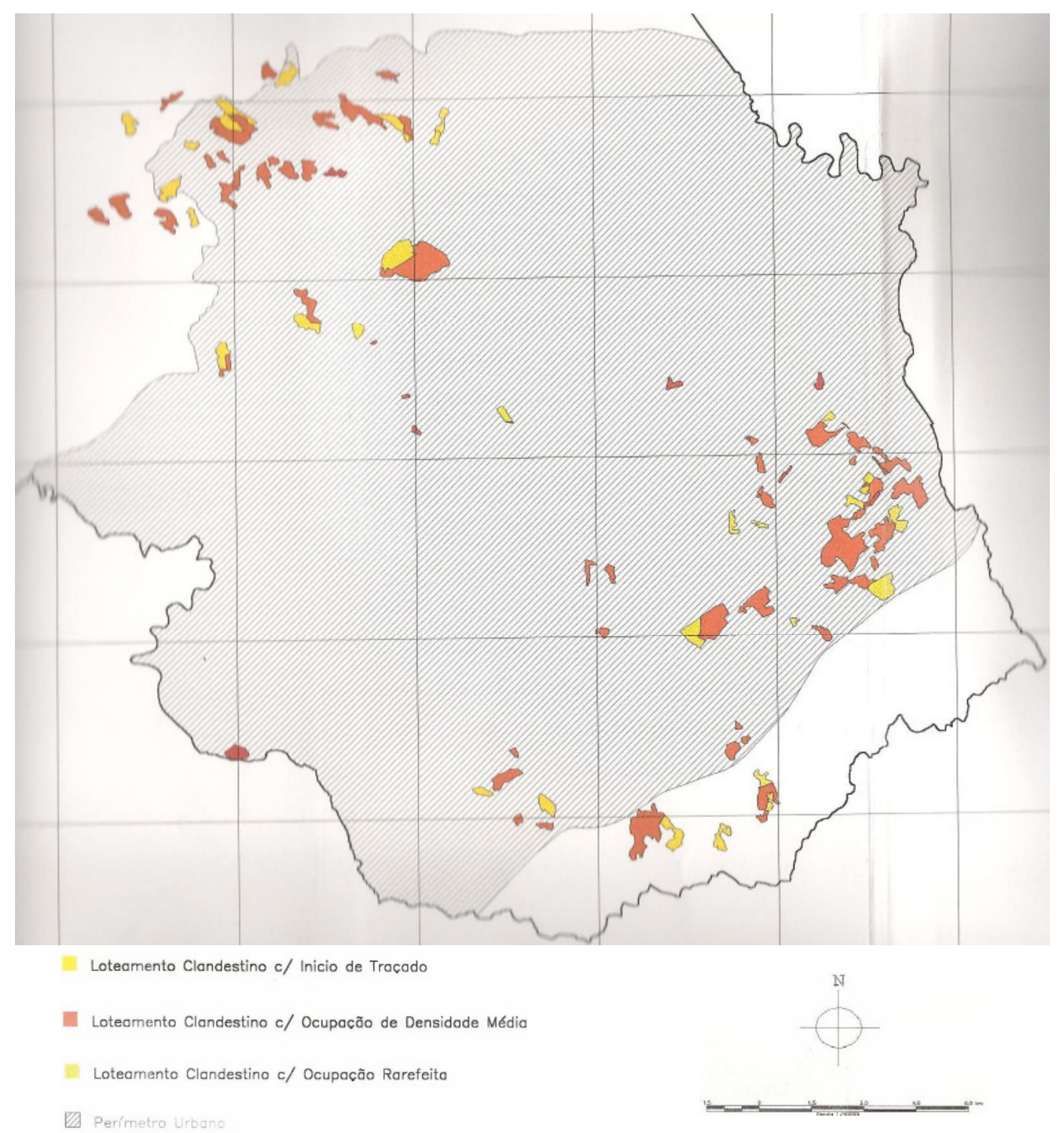

Figura 56 - Loteamentos Clandestinos em São José dos Campos em 1997. 
A Figura 57, desenvolvida por Gouvêa (2003), mostra que, em 1985 e 1988, tem-se uma maior porcentagem de loteamentos com ocupação rarefeita e início de traçado, enquanto que em 1997, diminui a porcentagem de loteamentos em início de traçado e aumenta muito a ocupação com médio adensamento.

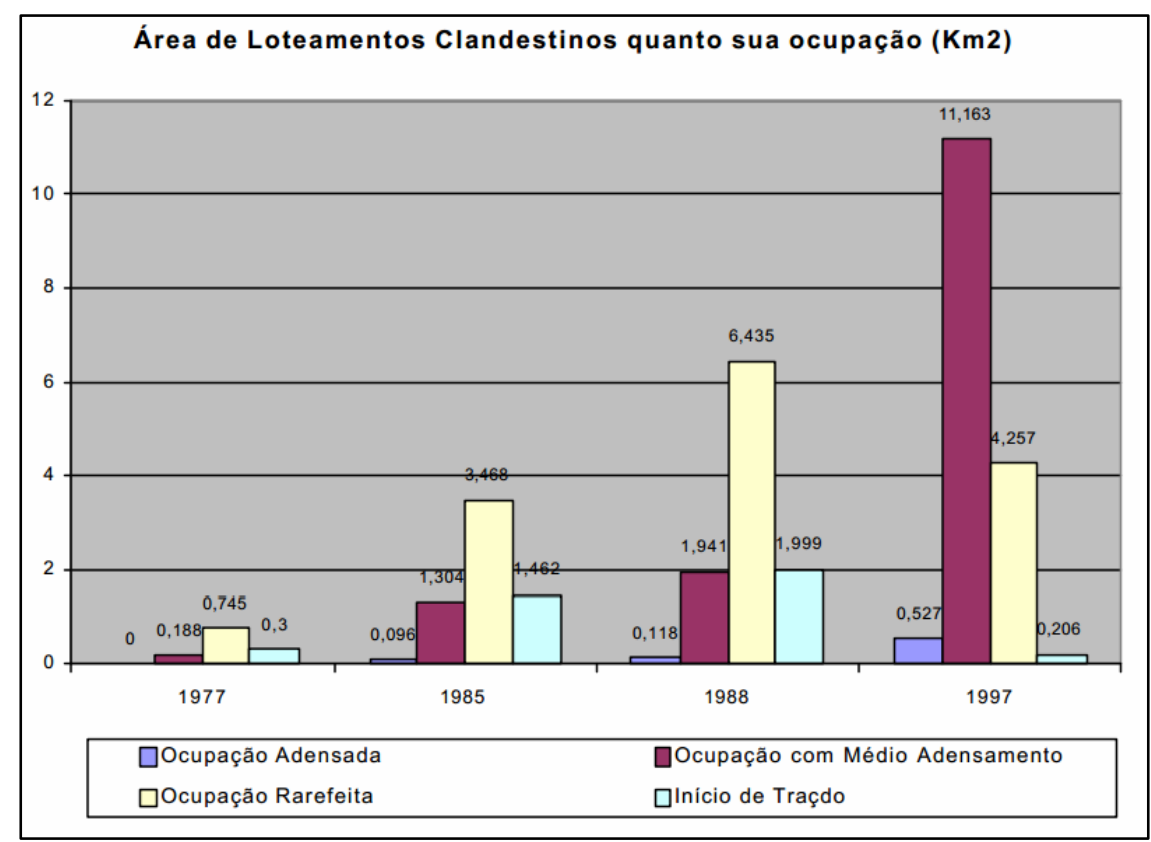

Figura 57 - Densidade das Ocupações Clandestinas (\%). Fonte: GOUVÊA (2003, p. 101).

Como afirma Gouvêa (2003, p. 101), “apesar de não ter havido um aumento na quantidade destes loteamentos, como ocorrido nos anos 80, o grande adensamento verificado também configura uma situação preocupante". A quantidade de pessoas vivendo em loteamentos clandestinos passa a ser cada vez maior, habitando em moradias precárias, sem a infraestrutura adequada, causando vários danos ao meio ambiente, além dos danos sociais.

$\mathrm{Na}$ Figura 58, vê-se que a área dos loteamentos clandestinos vem crescendo proporcionalmente à área urbana legal. Os loteamentos clandestinos só aumentam; não houve retrocesso em sua prática, o que prova que as leis de zoneamento e planos diretores nunca conseguiram barrar esta prática no município. 


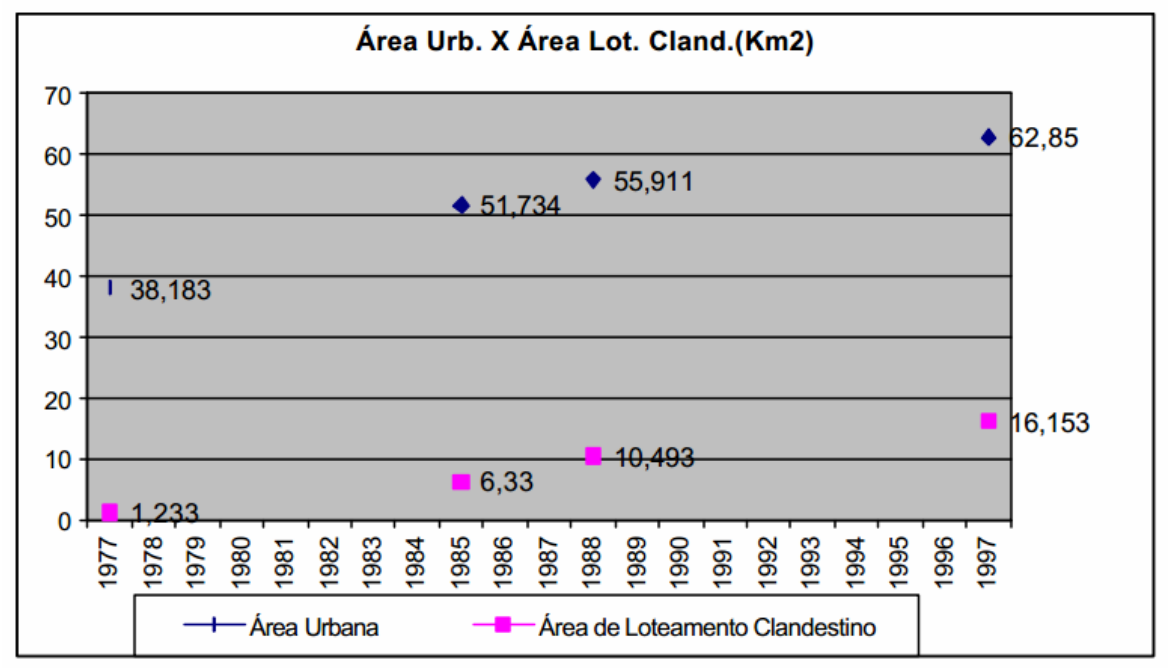

Figura 58 - Área Urbana Legal x Área de Loteamento Clandestino.

Fonte: GOUVÊA (2003, p. 100).

Conforme dados do IBGE (1981, apud GOUVÊA, 2003), 78\% da população residindo há mais de 10 anos em São José dos Campos possuíam um rendimento médio mensal de até três salários mínimos. Em 1991, esse percentual cai para 74\%, sendo que destes, $51 \%$ não possuem rendimento ou recebem até no máximo um salário mínimo. Desta forma, é nítida a concentração de população de baixa renda no município.

Entre 1976 e 1997, a prefeitura, com apoio do governo federal e estadual, realizou 13 programas habitacionais, ofertando 10.325 moradias. No entanto, a maioria dos programas habitacionais e loteamentos realizados no período atendia à classe $\mathrm{C}$; eram tidos como populares, mas não atendiam à população mais carente do município (GOUVÊA, 2003). A falta de uma política habitacional que atingisse a classe menos favorecida economicamente, o acelerado crescimento populacional, as crises financeiras e a perda do poder aquisitivo da população e o grande déficit habitacional são alguns dos fatores que estimularam o mercado ilegal de terras, proliferando os loteamentos clandestinos em São José dos Campos.

$\mathrm{Na}$ lei de zoneamento $\mathrm{n}^{\circ} 165$ de 1997 , as ZEIS aparecem delimitadas e mapeadas, porém muitos dos loteamentos clandestinos que se encontram na zona rural não fazem parte das ZEIS. Embora haja a inclusão de loteamentos clandestinos em ZEIS, praticamente nada mudou, pois não houve regularização fundiária; esses loteamentos não possuem infraestrutura, como rede de água e esgoto, as moradias são precárias, e a população possui baixíssima qualidade de vida.

Conforme entrevista realizada na divisão de regularização fundiária, ligada à Secretaria de Habitação, até o ano 2000 praticamente não havia fiscalização que impedisse o 
surgimento de novos loteamentos clandestinos. A fiscalização era feita por uma empresa terceirizada. Somente em 2000, que a Prefeitura passa a contratar fiscais para trabalhar no monitoramento dos loteamentos clandestinos. No entanto, o número de fiscais ainda é muito baixo, são apenas dois fiscais concursados e oito cadastradores terceirizados da empresa AVALON (que apenas fazem o monitoramento e repassam as informações aos fiscais para fazer as notificações e autuações).

Desta forma, até antes de 2000, não existia uma política efetiva de fiscalização que impedisse o surgimento de novos loteamentos; o poder público não tinha, ou preferia não ter, nenhum controle sobre a expansão irregular da cidade; a legislação que regulamentava o crescimento ordenado do espaço não era colocada em prática de forma abrangente, apenas parte da cidade cumpria as leis.

No estudo do Plano Diretor de 2006, o problema dos loteamentos clandestinos persiste novamente; estes não deixam de existir e ainda aumentam em número e tamanho. O PDDI aponta a necessidade de regularizar esses loteamentos e de aumentar a fiscalização, evitando o surgimento de novos loteamentos clandestinos.

A nova lei de zoneamento urbano $\mathrm{n}^{\circ} 428$ de 2010 , destaca novamente o problema dos loteamentos clandestinos, que até hoje estão sem solução. Dos loteamentos clandestinos existentes no município, apenas um, o Jardim Mesquita, foi regularizado em agosto de 2011. Os demais loteamentos clandestinos existentes no município estão na mesma situação há anos, alguns estão delimitados por ZEIS, mas a grande parte não goza de nenhuma infraestrutura, e a população vive em condições precárias.

Como se observa na Figura 59, a maioria dos loteamentos está localizada na periferia da cidade, muitos ocupam a zona rural e áreas de proteção ambiental. Muitos são cortados por córregos e invadem áreas de preservação permanente. Como estes loteamentos não possuem infraestrutura mínima, como rede de água e esgoto e coleta de lixo, estes córregos ficam sujeitos à poluição. Para a implantação desses loteamentos, não há estudo e respeito a regras; a mata nativa é desmatada; os córregos são assoreados; áreas com alta declividade são ocupadas, podendo causar movimentação de terra e erosão. 


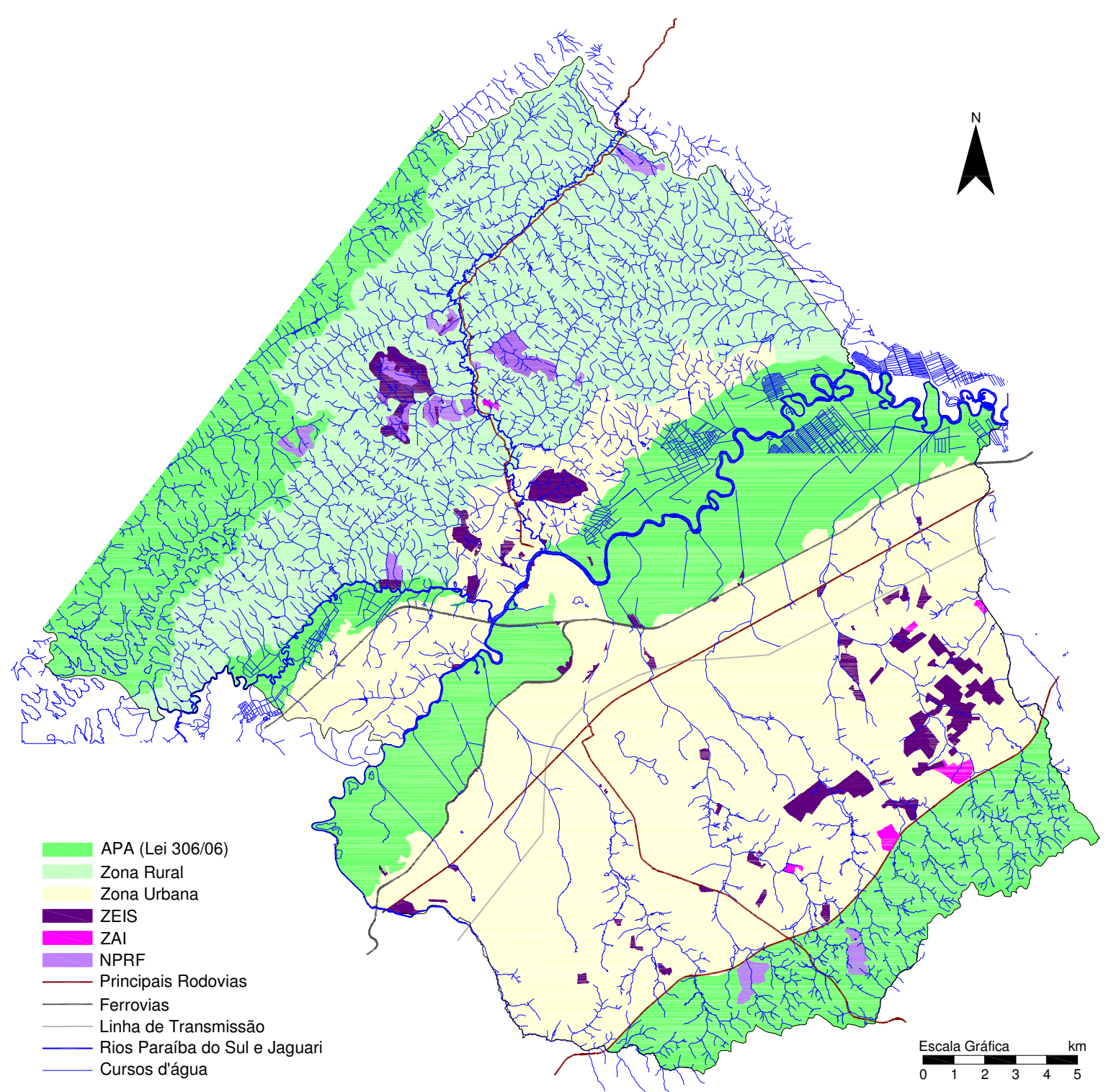

Figura 59 - Loteamentos Clandestinos, APAs e Cursos d'água ${ }^{36 .}$

Conforme estudo realizado pela Prefeitura de São José dos Campos intitulado "Projeto: Levantamento dos Loteamentos Clandestinos Existentes no Município de São José dos Campos", em 1996, existiam 86 loteamentos clandestinos, com uma população de 18.080 habitantes, representando 3,36\% da população total do município (GOUVÊA, 2003). A população residente nestes loteamentos caracteriza-se na maior parte como de baixa renda, e as condições nos loteamentos é bastante precária, sendo carente de infraestrutura (rede de esgoto, água, iluminação pública, coleta de lixo e pavimentação). Foram também encontrados loteamentos de médio e alto padrão, construídos em desacordo com a lei de zoneamento urbano, em áreas de proteção ambiental.

${ }^{36}$ ZEIS: Zonas de Especiais de Interesse Social; ZAI: Zonas de Assentamento Informal; NPRF: Núcleos Passíveis de Regularização Fundiária 
Em outro estudo, realizado pelo Grupo de Pesquisas Econômicas da Univap (2001), este apontou a existência de 26.722 pessoas vivendo em loteamentos clandestinos, representando 5,13\% da população total de São José dos Campos. Segundo esta mesma pesquisa, 50\% das famílias que vivem nestes loteamentos pertencem à Classe $\mathrm{C}$, e cerca de $30 \%$ pertencem a Classe D, os $20 \%$ restante são ocupados pela classe média-alta e classe alta.

A Figura 59 mostra que os loteamentos clandestinos estão classificados como ZEIS, ZAI e NPRF. As Zonas Especiais de Interesse Social (ZEIS) são áreas ocupadas por loteamentos clandestinos, sub-habitações e favelas, ocupadas por população de baixa renda e tem como objetivo obter a regularização fundiária com fim social, como já previsto no PDDI1995. As Zonas de Assentamento Informal (ZAI) são áreas ocupadas por parcelamentos clandestinos ou irregulares, ocupados por população de alto poder aquisitivo, sem aprovação dos órgãos competentes. A Lei de Zoneamento $\mathrm{n}^{\circ} 428$ de 2010, no Art. 139, aponta que as ZEIS ficam sujeitas às diretrizes específicas do órgão competente pela regularização fundiária, e o Art. 140 prevê a regularização da ZAI e incorporação desta às zonas de uso classificadas conforme a lei. A Lei ainda prevê; em seu Art. 282, que todos os parcelamentos clandestinos ou assentamentos informais com características urbanas localizados em zona rural deverão ser transformados em bolsões urbanos através de legislação específica, quando de sua efetiva regularização fundiária.

Já os loteamentos que são classificados como NPRF, são caracterizados como Núcleos Populacionais Passíveis de serem transformados em bolsões urbanos para fins de regularização fundiária (conforme mapa 6 - ANEXO 26 da Lei 428/10). Porém, no texto de lei, não há menção a estes núcleos; eles apenas aparecem no mapa. Os loteamentos clandestinos classificados como NPRF ocupam áreas de preservação permanente e áreas de proteção ambiental. Por meio de análise de imagens do Google Earth® (2011), pode-se observar que a maior parte desses núcleos é ocupada por moradias de médio e alto padrão, pois apresentam lotes grandes e com piscina, com características de chácara de recreio.

A Lei não estabelece diferenças entre parcelamentos clandestinos ou irregulares de baixo e alto padrão, permitindo a regularização de todos os assentamentos informais existentes no município e a transformação destes em bolsões urbanos, em meio à área rural e áreas de proteção ambiental. Os loteamentos clandestinos tiveram um aumento de área de 40\% do zoneamento de 1997 para o de 2010 (Tabela 3). A falta de punição e de fiscalização, aliadas a leis permissivas propiciam a proliferação dos loteamentos clandestinos no município. Atualmente, levantamento oficial realizado pela Prefeitura de São José dos Campos afirma existirem 94 loteamentos clandestinos no município, mas pesquisas 
acadêmicas, jornais e outras fontes divulgam a existência de mais de 150 loteamentos clandestinos no município.

Tal questão se arrasta há anos sem solução, e, ao mesmo tempo em que se tem a expansão irregular da cidade, por meio da proliferação dos loteamentos clandestinos, tem-se que $28 \%$ da mancha urbana são vazios urbanos. Assim, a zona urbana poderia ser melhor ocupada, aproveitando os investimentos já realizados pelo poder público em serviços e infraestrutura (rede de água e esgoto, ruas pavimentadas, iluminação pública, praças, escolas, unidades básicas de saúde etc), ao invés de expandir a cidade e criar novos gastos aos cofres públicos. A falta de uma política habitacional frente ao grande déficit habitacional, voltada para a população de mais baixa renda, agravou a situação vivida pelo município. A população de baixa renda encontra nos loteamentos clandestinos a única forma de moradia; esta situação acaba sendo explorada pela especulação imobiliária e política local. O acelerado crescimento urbano do município acentuou ainda mais o problema. Vê-se cada vez mais a diferenciação entre a cidade legal e a cidade ilegal.

Fica claro que durante todos esses anos não houve uma rigorosa aplicação das políticas públicas ambientais; muitas vezes ela existiu somente no papel, não se fazendo cumprir. O caso da proliferação dos loteamentos clandestinos durante décadas mostra que, muitas vezes, o que existe em teoria não é colocado em prática, falta fiscalização e se fazerem cumprir as regras e normas previstas em lei. As políticas locais precisam ser mais bem aplicadas.

\subsubsection{Favelas}

Conforme Rosa Filho (2002), as primeiras favelas surgem em São José dos Campos na década de 1930. A primeira, em 1931, foi a favela do Banhado, conhecida como "Vila Nova Esperança", e depois, em 1932, surgiu a "Favela Linha Velha", conhecida hoje como Santa $\mathrm{Cruz}^{37}$.

O desenvolvimento industrial de São José dos Campos atraiu um grande número de migrantes que vinham de cidades vizinhas, Sul de Minas Gerais e Nordeste em busca de trabalho. Em 1970, o município já contava com quatro núcleos de favelas, com um total de 1.926 habitantes. Em 1980, o município passa a contar com 12 núcleos de favelas, espalhadas em diferentes pontos da cidade, com 3.721 moradores. Os primeiros anos da década de 1990,

\footnotetext{
${ }^{37}$ O Caderno Diagnóstico do PDDI 1961 cita a "Favela Linha Velha", como a única existente na cidade nessa época, a "Favela do Banhado", não é mencionada.
} 
foi um período de recessão econômica; ocorre um aumento no número de favelas no município, passando a existir 21 núcleos de favelas. No ano de 2000, são 22 núcleos de favelas, com 9.130 moradores. À medida que o município de São José dos Campos crescia em população e economia, também, crescia o número de favelas. O desenvolvimento econômico e crescimento populacional não foram acompanhados pelo aumento no número de empregos no município e por políticas sociais (ROSA FILHO, 2002).

A Figura 60 mostra a evolução no número de favelas e da população vivendo em favelas. Vê-se que houve diminuição no número de favelas, mas aumento na população que passa a viver em favelas. Tal problema nunca foi resolvido, e a população vivendo em condições precárias aumentou nos últimos anos.

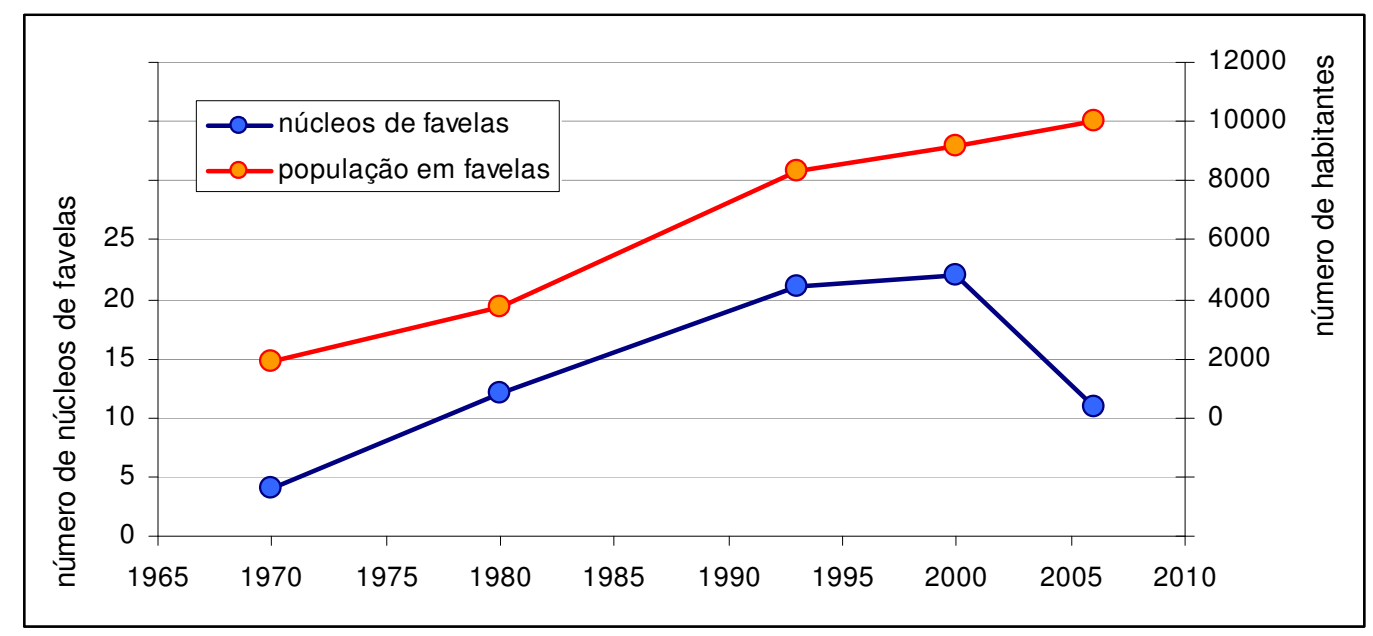

Figura 60 - Evolução das favelas em São José dos Campos.

Fonte: PDDI (2006); ROSA FILHO (2002).

O Primeiro Plano Diretor (1961), elaborado pela equipe da FAU-USP, já trazia em seus estudos preliminares uma análise sobre a favela da "Linha Velha", a única (segundo o Plano Preliminar de 1961) existente na cidade naquele período. O Plano Diretor tinha como proposta um plano de desfavelamento, buscando melhorar a qualidade de vida da população residente na favela e proibir o surgimento de novas favelas, e também, formar uma parceria com a Caixa Econômica e a criação de um fundo de habitação.

Tal plano de desfavelamento não saiu do papel. A favela da "Linha Velha" só sofreu intervenção no final da década de 1970, quando parte da favela foi removida, para a construção do Anel Viário e do Paço Municipal. No entanto, a intervenção foi parcial, 150 famílias foram transferidas para um conjunto habitacional, as famílias que permaneceram na favela "Linha Velha” encontram-se ainda vivendo em situação precária. 


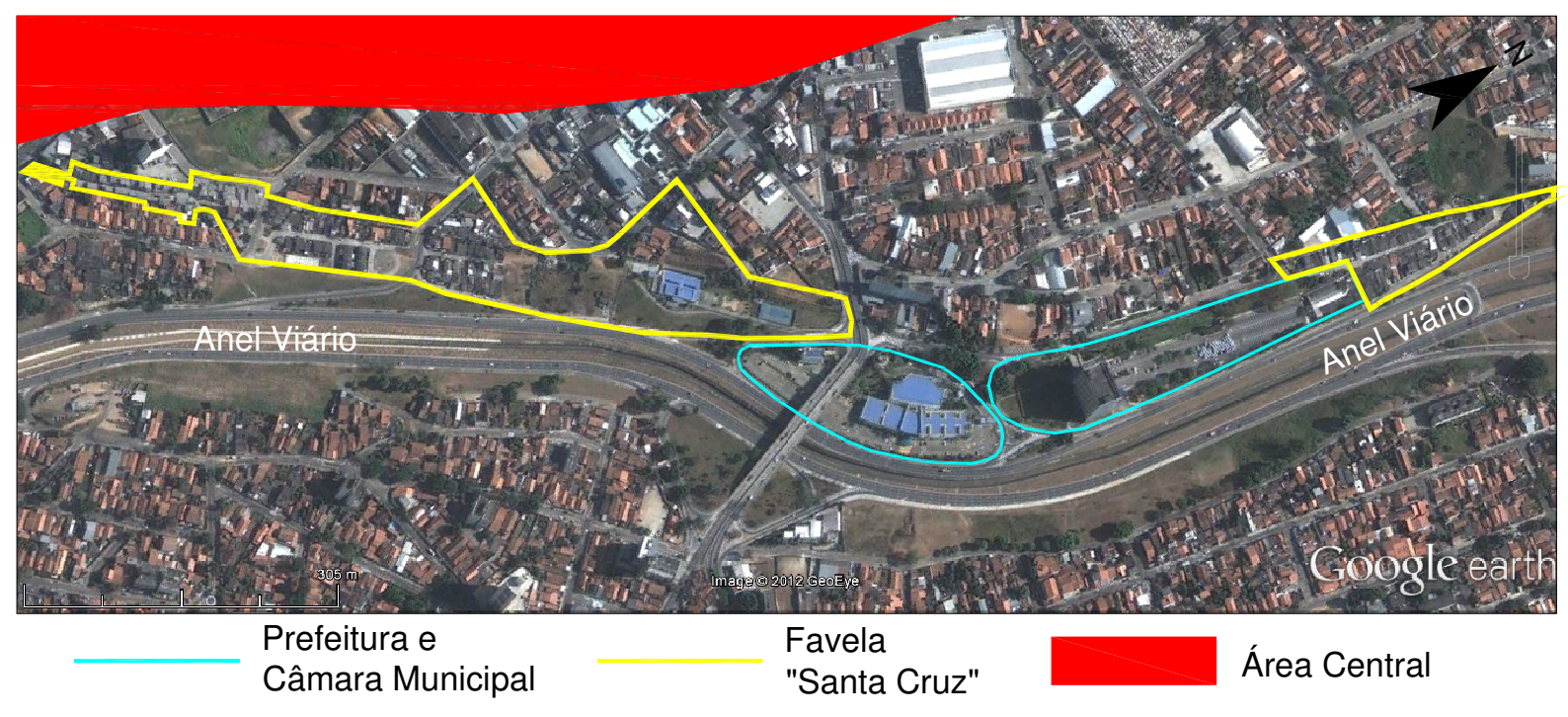

Figura 61 - Localização da "Favela Santa Cruz". Fonte: Google Earth® (2011); PMSJC - Cidade Viva (2011).

O PDDI de 1971 também traz entre seus objetivos a questão do desfavelamento, porém, foram tomadas medidas pontuais, que não resolveram o problema. Em 1974, foi realizado o primeiro levantamento do déficit habitacional no município. Foram erradicadas algumas favelas, porém o objetivo maior era viabilizar a execução de obras no sistema viário e construção do Paço Municipal.

Com recursos públicos, em 1979, foram construídos o Jardim Morumbi, Jardim Colonial e Bosque dos Eucaliptos, conhecido como Campo dos Alemães, uma área de 2.132.600,00 m2, e também, o Conjunto Habitacional Nosso Teto do Putim, no Bairro Pernambucana. Em 1990, foram construídos os Conjuntos Habitacionais D. Pedro I e D. Pedro II. Em 1992 foi realizada a reurbanização da favela Vila Abel, área composta por 31 famílias. Em 1993, houve a ampliação do Conjunto Habitacional Nosso Teto (Putim). Todas essas medidas eram pontuais, não houve uma política habitacional estruturada, que resolvesse problema da habitação no município (Caderno Diagnóstico PDDI - 1995).

$\mathrm{Na}$ década de 2000, foram realizadas várias parcerias com o Governo Federal, Estadual e com o BID, quando foram construídos novos conjuntos habitacionais, procurando atingir a classe mais necessitada, e também, erradicar as favelas no município. No entanto, o município apresenta ainda um grande déficit habitacional e vários núcleos de favelas. Conforme o caderno diagnóstico do PDDI de 2006, existe no município 11 núcleos de favelas, onde residem 1.700 famílias, constituindo quase 10.000 pessoas. Conforme dados da Secretaria de Habitação, em 1996, existiam 14 mil inscritos em programas de habitação; em 
2005, eram 18 mil inscritos e em 2011, esse número chegou a 26 mil inscritos em busca da casa própria.

A Figura 62 mostra a localização das favelas existentes no município. Conforme a Lei de Zoneamento de 2010, o município possuía vinte núcleos de favelas mapeados. A maior parte das favelas incide em Áreas de Preservação Permanente e Áreas de Proteção Ambiental, localizando-se próximo a zona central.

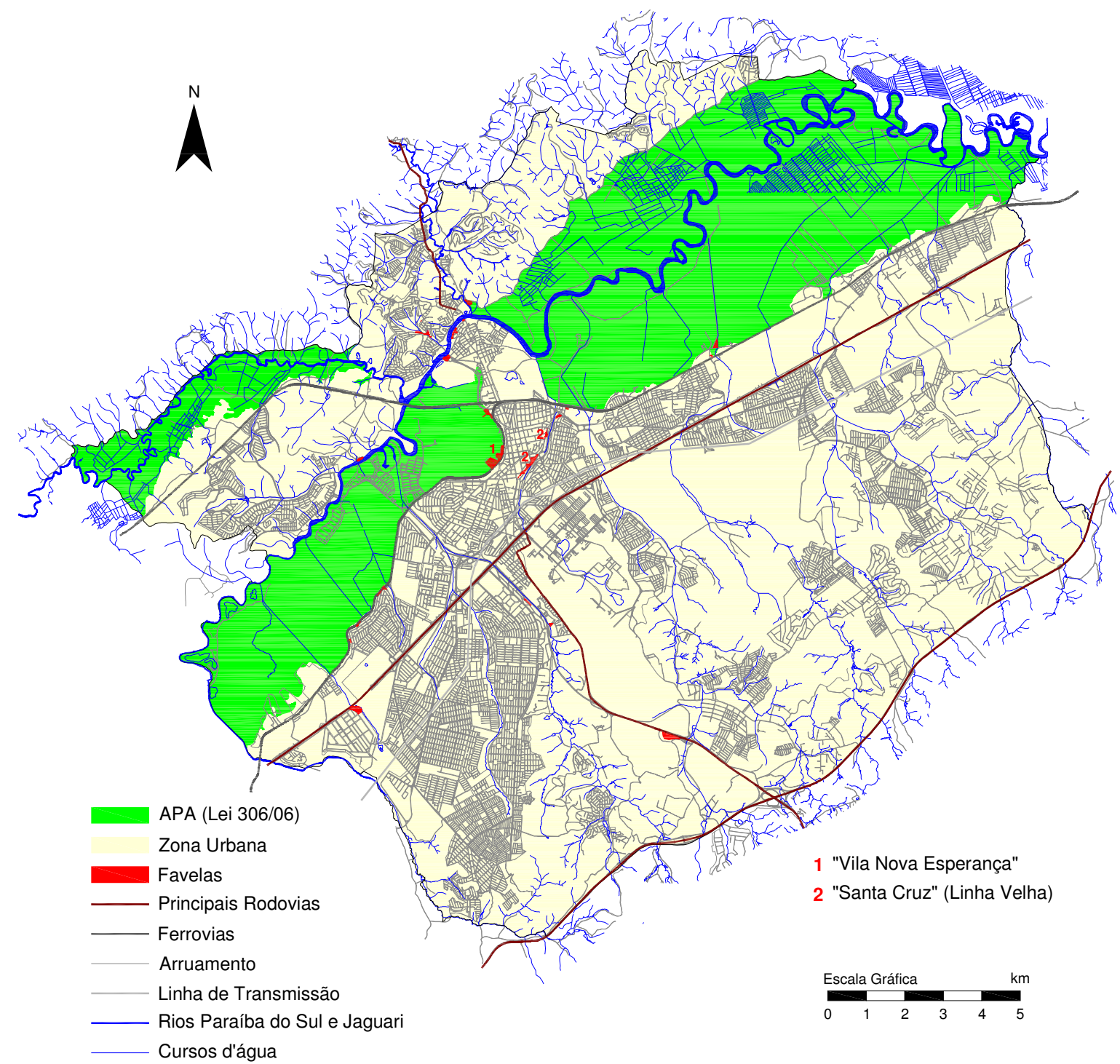

Figura 62 - Localização de favelas em São José dos Campos, APA e Cursos d'água.

Os loteamentos clandestinos e as favelas representam um grande problema social e ambiental, pois nessas áreas não há rede de esgoto, não há coleta de lixo adequada, são ocupadas áreas de proteção e preservação ambiental, ocorre o desmatamento da vegetação nativa, assoreamento e poluição dos cursos d'água, muitas vezes as moradias são precárias e 
falta todo tipo de infraestrutura. Os loteamentos clandestinos e favelas, também, se tornam um problema urbanístico, pois crescem sem ordenamento territorial e planejamento, acarretando problemas ambientais urbanos, como enchentes, deslizamento de terra e adensamento urbano.

Um estudo realizado pela Prefeitura Municipal de São José dos Campos, em parceria com a Universidade Estadual de Campinas (Unicamp) em 2004, denominado "Atlas das Condições de Vida em São José dos Campos”, procurou traçar o perfil socioeconômico da população urbana do município. A pesquisa dividiu o território estudado em 24 setores socioeconômicos, no qual se destaca o Setor 22, denominado de "Favelas e Ocupações Irregulares", Setor 24: "Freiras e Sertãozinho" e Setor 30: "Capão Grosso, Bom Retiro e Serrote", sendo que estes dois últimos setores (são ocupados por loteamentos clandestinos).

Conforme esta pesquisa, só o Setor 22: Favelas e Ocupações Irregulares, possui uma população de 6.500 habitantes. A pesquisa mostra que nos setores 22,24 e 30 se concentra o maior índice de analfabetos, desempregados, negros, crianças, jovens e população das classes econômicas D e E.

Do ponto de vista ambiental e de infraestrutura urbana, estes setores apresentam dados bastantes críticos. No setor $22,75 \%$ dos domicílios estão situados em locais que não possuem pavimentação, guias e sarjetas. Apenas $56 \%$ do Setor 22 possuem iluminação pública, e $24 \%$ das habitações estão próximas a rios ou córregos, distante apenas 10m destes (PMJSC, UNICAMP, 2004).

Em relação à infraestrutura de rede de esgoto, nas Favelas e Ocupações Irregulares (setor 22), a situação é bastante grave; $59 \%$ dos domicílios despejam o esgoto diretamente nos cursos d'água, e 19\% direcionam os dejetos para valas. Já nos setores Capão Grosso/Bom Retiro/Serrote, cerca de $75 \%$ dos escoadouros estão ligados a fossas rudimentares. No caso de Freitas/Sertãozinho, em torno de $54 \%$ dos domicílios estão ligados a fossas sépticas não conectadas à rede coletora de esgotos (PMJSC, UNICAMP, 2004).

Em relação à coleta de lixo domiciliar Setores Freitas/Sertãozinho e Capão Grosso/Bom Retiro/Serrote apresentam 75,5\% e 66,5\%, respectivamente, de área de abrangência da coleta seletiva. A situação mais precária é observada nas Favelas e Ocupações Irregulares, onde $74 \%$ dos domicílios colocam o lixo em caçambas e apenas $11 \%$ possui coleta de lixo domiciliar. Nenhum dos três setores apresenta coleta seletiva porta a porta (PMJSC, UNICAMP, 2004).

Como se vê, as condições de vida nas favelas e loteamentos clandestinos é bastante precária; falta todo tipo de serviço, o que torna a vida das pessoas nestes lugares ainda mais difícil; não há higiene, segurança e conforto. Além do problema social, vê-se que tais 
condições também prejudicam o meio ambiente, como o desmatamento e poluição dos córregos, pela falta de infraestrutura que estes locais apresentam.

\subsection{Resíduos Urbanos}

A coleta de resíduos sólidos no município de São José dos Campos é realizada pela Urbanizadora Municipal S/A (URBAM) ${ }^{38}$. A URBAM foi fundada em 10 de outubro de 1973; funciona como uma sociedade de economia mista, e tem a Prefeitura de São José dos Campos como sua acionista majoritária.

Desta forma, a prefeitura remunera a URBAM para que essa faça a limpeza urbana do município. A URBAM é assim responsável pela gestão integrada dos resíduos sólidos do município, que compreende sete tipos de coleta, sendo: coleta da varrição, coleta dos resíduos dos serviços de saúde, coleta domiciliar comum, coleta seletiva, coleta de animais mortos, coleta de pilhas e baterias e de lixo eletrônico.

Após a coleta, esses diferentes tipos de resíduos são transportados para a Estação de Tratamento dos Resíduos Sólidos - ETRS, que compreende o Centro de Triagem de Recicláveis, o Aterro Sanitário, a Central do Biogás, a Central de Operações da Coleta, o Transbordo de Resíduos Críticos, Transbordo de Resíduos de Serviços de Saúde (RSS) e a Sala Ambiental (Mini Auditório e Mini Museu do Lixo). A ETRS possui uma área física total de $481.246 \mathrm{~m}^{2}$, sendo 91,6\% ocupada pelo aterro sanitário e 8,4\% pelas demais instalações.

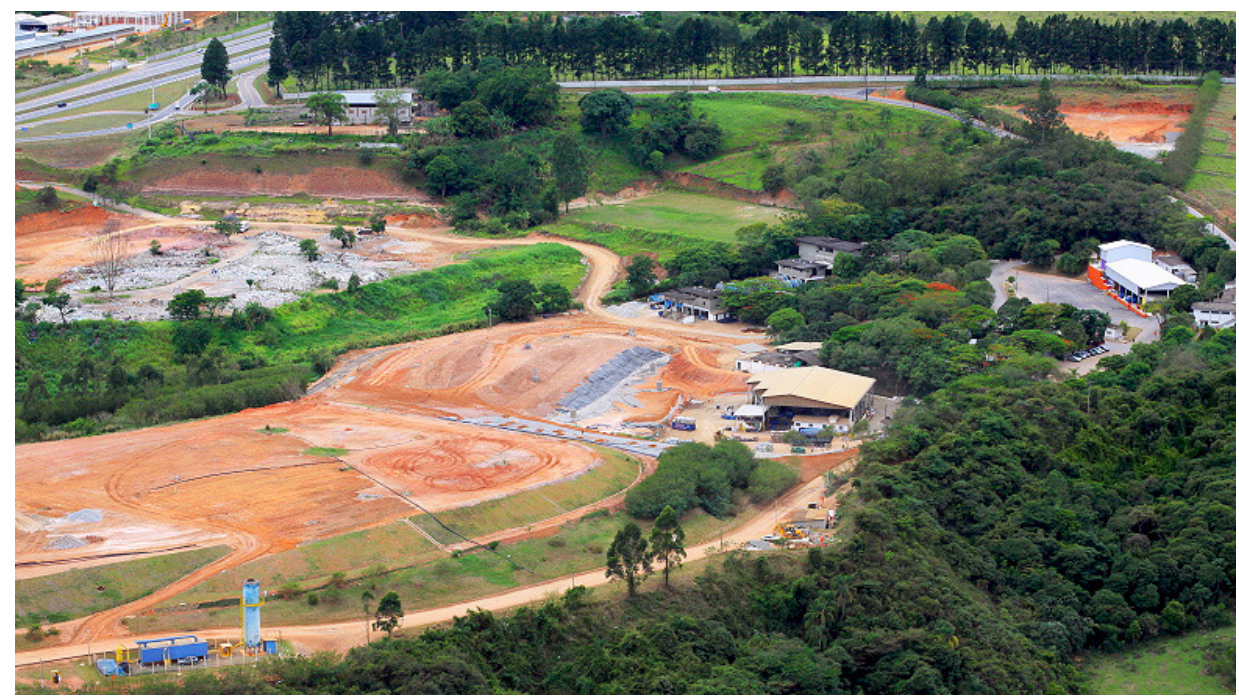

Figura 63 - Estação de Tratamento de Resíduos Sólidos em São José dos Campos. Fonte: Prefeitura (2010).

\footnotetext{
38 Os dados foram levantados através de entrevista na Urbam (Com o Sr. Rodrigo - Engenheiro Ambiental, o Sr. Rogério - Coordenador do Centro de Triagem, e com Sr. André - Acessor) e por meio de pesquisa no site da URBAM (www.urbam.com.br).
} 
A porção que corresponde ao Aterro Sanitário começou a ser utilizada em 1987; possui uma área de $440.688 \mathrm{~m}^{2}$, sendo que parte desta área $\left(288.372 \mathrm{~m}^{2}\right.$ - Células 1,2 e 3$)$ está com as atividades encerradas, restando apenas a área de $152.316 \mathrm{~m}^{2}$ (Células 4 e 5), com previsão de vida útil de mais dez anos, contrariando assim, a previsão feita pelo PDDI de 1995, de que o aterro sanitário estaria esgotado em 2005. O mesmo passou por uma ampliação e aumentou a sua capacidade, tendo vida útil prevista até 2022 (Figura 63).

Todos os dias são depositados no aterro sanitário, em média, 520 toneladas de resíduos sólidos urbanos (URBAM, 2010). O Aterro Sanitário conta com uma Central de Biogás, criada em 2008. Segundo a URBAM (2012), o biogás é resultado da decomposição do lixo que está confinado no Aterro e é composto principalmente pelo gás metano, 21 vezes mais impactante na atmosfera que o dióxido de carbono $\mathrm{CO}_{2}$, e pelo gás sulfídrico $\mathrm{H}_{2} \mathrm{~S}$, causador de odores desagradáveis. Com base em estimativas, de 2008 a 2014, a cidade deixará de lançar 820 mil toneladas de $\mathrm{CO}_{2}$ equivalente na atmosfera. Para se ter uma ideia, isso equivale à poluição gerada por toda a frota de automóveis de São José dos Campos (177 mil veículos), durante 38 meses (URBAM, 2012).

No Aterro Sanitário existem quatro centrais de armazenamento de chorume, que é diariamente transportado e tratado pela SABESP.

O aterro sanitário de São José dos Campos possui uma boa avaliação perante a CETESB e teve sua nota ampliada de 8,8 (ano de 2009) para 9,6 (ano de 2010). A pontuação foi publicada pelo órgão em maio de 2011 no Inventário Estadual de Resíduos Sólidos Domiciliares (ano base 2010). O aterro de São José ficou em segundo lugar entre os aterros sanitários municipais paulistas que recolhem mais de 100 toneladas/dia de resíduos.

A URBAM não recolhe resíduo industrial e não recolhe resíduo da construção civil. Os próprios geradores desses tipos de resíduos precisam cuidar da destinação correta. Porém, a Lei 3.718/89, no Art. 27, diz que compete a URBAM instalar e operar aterro industrial no território joseense. No entanto, o que existe na verdade no município é um aterro industrial privado, da empresa Essencis-Ecossistema, o que é vantajoso para o município. Como a responsabilidade do resíduo industrial é do próprio gerador, não há previsão ou vontade do poder público em tomar a frente da destinação de resíduos industriais.

Para a coleta dos resíduos da construção civil, a prefeitura criou os Pontos de Entrega Voluntária (PEVs), com a Lei 7.146/06. O PEV é um equipamento público destinado ao recebimento de pequenos volumes de resíduos da construção civil e resíduos volumosos, gerados e entregues pelos munícipes, podendo ainda ser coletados e entregues por pequenos transportadores diretamente contratados pelos geradores (Figura 64). Entre os objetivos do 
PEV, destaca-se a intenção em extinguir em toda a cidade os pontos "clandestinos" de descarte dos resíduos da construção civil (entulho), e consequentemente, os "lixões" ainda existentes, evitando assim, que restos de materiais e de construção sejam depositados em áreas públicas e áreas de proteção ambiental, como rios e córregos.

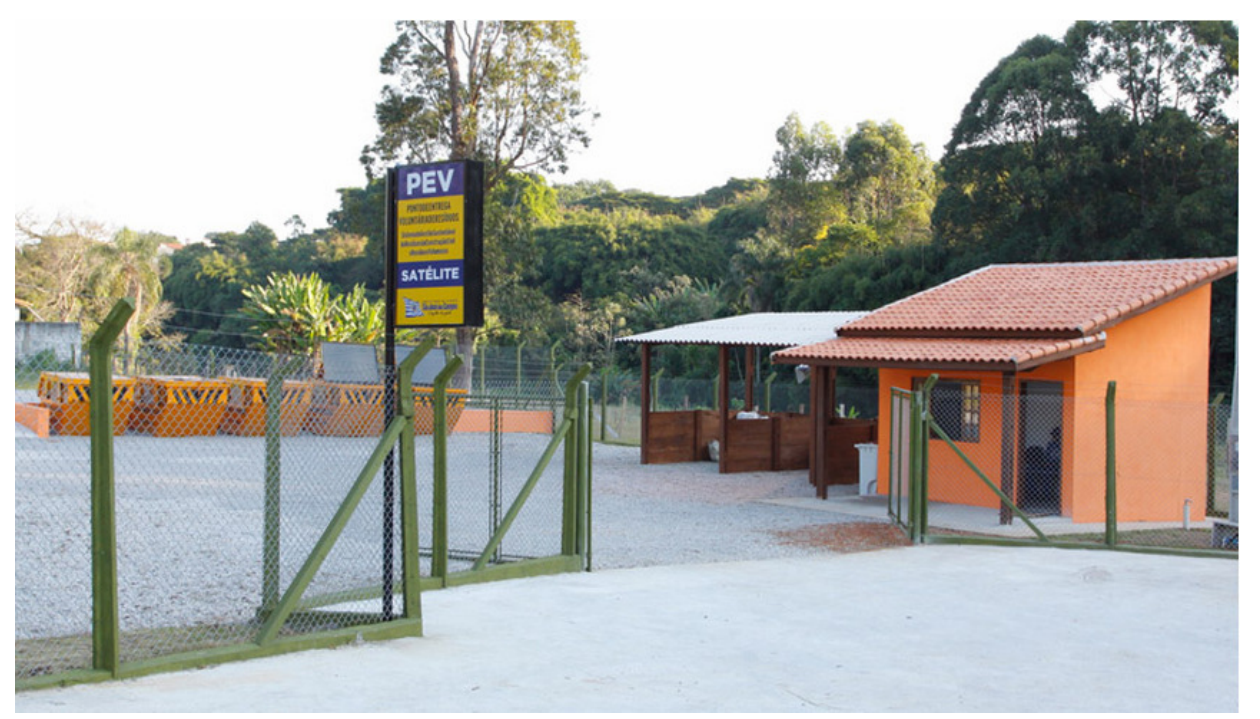

Figura 64 - Fachada do Ponto de Entrega Voluntária instalado no Jardim Satélite.

Fonte: SEMEA (2012).

Os PEVs estão habilitados a receber restos de obras de construção (tábuas, tijolos, telhas, tubulações, pisos), móveis e equipamentos domésticos (sofás, cadeiras, geladeiras), pilhas, baterias, lâmpadas fluorescentes inteiras, restos de poda, tinta e óleo de cozinha. Os PEVs recebem resíduo de construção civil de pequenos geradores, que produzem até um metro cúbico $\left(1 \mathrm{~m}^{3}\right)$ de resíduos (aproximadamente uma caçamba de um veículo utilitário pequeno) em pequenas reformas. Porém, os grandes geradores, que produzem acima de um metro cúbico $\left(1 \mathrm{~m}^{3}\right)$ de resíduos - devem encaminhar os resíduos de entulho para empresas recicladoras ou aterros privados licenciados.

Embora a Lei de criação dos PEVs seja de 2006, somente em 2011 eles foram efetivamente implantados, atualmente existem sete PEVs espalhados pelo município, como é possível ver na Figura 65. A Prefeitura tem a pretensão de aumentar o número de PEVs, pois ainda existem muitos pontos de depósito de resíduos de construção irregulares na cidade, que poluem as áreas verdes e córregos do município, trazendo danos ao meio ambiente urbano. Segundo o Plano Municipal de Saneamento Básico, existem no município cerca de 150 pontos de disposição clandestina, cuja maior incidência ocorre em Áreas de Preservação 
Permanente (APP), áreas públicas sem ocupação, terrenos baldios e nas próprias vias públicas.

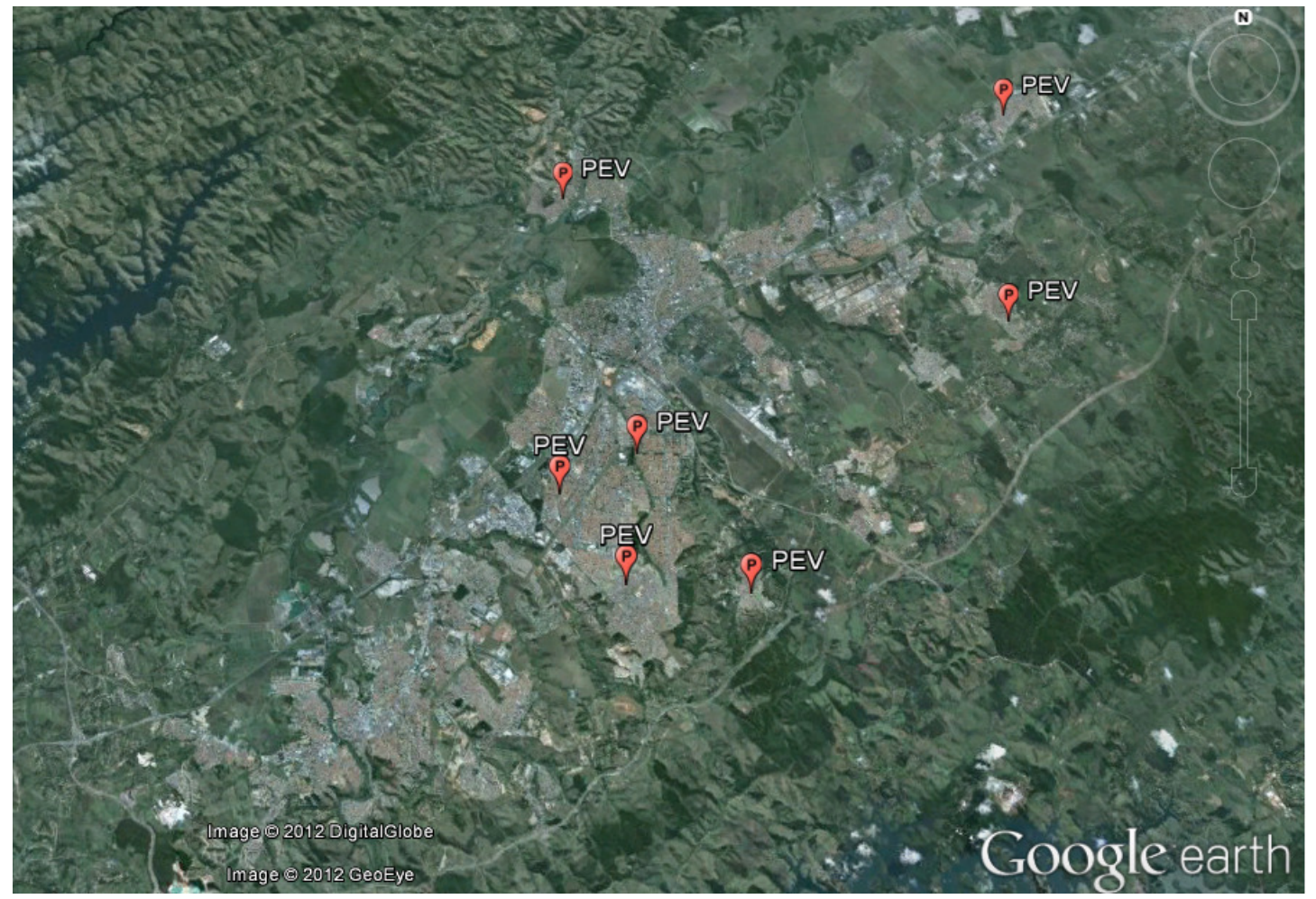

Figura 65 - Localização dos PEVs.

Fonte: Google Earth e SEMEA (2012).

\subsubsection{A coleta seletiva}

Em relação à coleta seletiva realizada no município, esta tem como objetivo o recolhimento dos resíduos recicláveis separados nos domicílios, comércio, serviços etc., visando destiná-los para a reciclagem. Tal prática gera a economia dos recursos da natureza, preservação da natureza e diminui o volume de lixo disposto no Aterro Sanitário.

A coleta seletiva em São José dos Campos teve início em 1989/1990, com o Projeto "Luxo do Lixo". Este nome conota a ideia de que jogar o lixo fora é um luxo, pois parte deste lixo pode ser reaproveitada, ou seja, um cidadão estaria se dando o luxo de jogar fora produtos que ainda podem ter utilidade. O projeto começou de uma forma bastante simples, tinha como objetivo a conscientização e a sensibilização das pessoas e o número de funcionários envolvidos era muito pequeno e contava com grande empenho e ação de voluntários. 
A coleta era parcial, começou com apenas dois bairros de alto padrão (Esplanada I e II), com 700 residências. Inicialmente, foi feita uma campanha porta a porta, nas escolas, igrejas, Lions Clube e Rotary, com o objetivo de conscientizar e sensibilizar a população sobre a importância da coleta seletiva e preservação do meio ambiente. A princípio, o projeto contava com apenas um caminhão caçamba reaproveitado da sucata do município. Foi reaproveitada ainda uma oficina desativada na ETRs, esteiras, prensas e fragmentadora abandonadas, contando apenas com dez funcionários e empenho de ambientalistas. $\mathrm{O}$ valor arrecadado com a venda do material reciclável era destinado ao Fundo Municipal de Assistência Social, que repassava para obras de habitação popular, como a compra de materiais de construção (vasos sanitários) para a população do conjunto habitacional em construção no Campo dos Alemães. Assim, os cidadãos que contribuíam com o projeto estavam protegendo a natureza e ajudando a população carente do município (EIGENHER, 1993).

Em 1993, o Projeto Luxo do Lixo atinge 17 bairros, com diferentes classes sociais, abordando 13.100 residências e uma população de 56 mil habitantes. O projeto passa a contar com dois caminhões e duas Kombi, e com isso passa a recolher diariamente 3,5 toneladas de resíduos. "A cada novo lançamento, cada residência, cada morador foi visitado e sensibilizado a integrar-se ao projeto" (EIGENHER, 1993, p. 74).

Com o tempo, a coleta seletiva em São José foi ganhando maior repercussão. Em 1998, são utilizados quatro caminhões para fazer a coleta porta a porta, 66 funcionários e aumenta consideravelmente a média diária da coleta seletiva de 3,5 toneladas em 1990 para 12 toneladas em 1998. O número de bairros atendidos passa de 17 para 121, como se pode ver na Tabela 7.

Tabela 7 - Avaliação do sistema de coleta seletiva

\begin{tabular}{|l|l|l|}
\hline Caracterização & $\mathbf{1 9 9 3}$ - Cempre & $\mathbf{1 9 9 7}$ - Urbam \\
\hline População atendida & $58.224(12 \%$ total $)$ & 296.294 (60\%total) \\
\hline Número de bairros atingidos & 17 & 121 \\
\hline Número de residências atingidas & 14.480 & 75.859 \\
\hline Média diária de coleta seletiva & $3,5 \mathrm{t}$ & $12 \mathrm{t}$ \\
\hline Custo médio mensal do programa & $8.688 \mathrm{US} \$ / \mathrm{mês}$ & $87.345 \mathrm{U} \$ / \mathrm{mês}$ \\
\hline Arrecadação média mensal com a venda & $3.015 \mathrm{US} \$ / \mathrm{mês}$ & $14.691 \mathrm{U} \$ / \mathrm{mês}$ \\
\hline Quantidade média mensal de rejeitos & $8 \mathrm{t} / \mathrm{mês}$ & $62 \mathrm{t} / \mathrm{mês}$ \\
\hline Média mensal de toneladas coletadas & $74 \mathrm{t} / \mathrm{mês}$ & $310 \mathrm{t} / \mathrm{mês}$ \\
\hline Média mensal de toneladas comercializadas & $55 \mathrm{t} / \mathrm{mês}$ & $211 \mathrm{t} / \mathrm{mês}$ \\
\hline Custo médio por tonelada coletada & $181 \mathrm{US \$}$ & $283 \mathrm{U} \$$ \\
\hline
\end{tabular}

Fonte: ASSIS (1998, p.70). 
Como mostra a Tabela 7, em quatro anos a coleta seletiva em São José dos Campos passou por um grande avanço. No entanto, este avanço não foi tão propício; $\mathrm{v}^{\wedge}$-seque houve um crescimento de quase seis vezes em relação à população atendida pela coleta seletiva, mas apenas um aumento de quatro vezes em relação à média diária da coleta seletiva. O custo do programa aumentou o seu valor em dez vezes, do valor do custo inicial. Desta forma, houve um aumento do valor do programa, da área e da população atingida pela coleta seletiva, mas que não foi proporcional à quantidade de material reciclável coletado.

Atualmente, com o programa conhecido como "São José Recicla", houve um maior investimento em pessoal, aumentando a infraestrutura para 8 caminhões coletores; 160 funcionários, que atuam na separação dos resíduos coletados; criou-se uma equipe de divulgação e educação ambiental, que conta com 4 funcionários, com o objetivo de conscientizar a população.

Conforme dados da URBAM, em 2010, todo o município é atendido pela coleta seletiva, sendo que $95 \%$ da população recebem a coleta porta a porta e $5 \%$ podem levar o material reciclável até os Ecopontos (onde a coleta seletiva não funciona porta a porta, a população pode levar os materiais recicláveis e depositá-los em contêineres localizados em locais de acesso público). No entanto, estes números mostram a área de abrangência da coleta seletiva, e não a participação real da sociedade, na separação do material reciclável.

Conforme a URBAM (2010) é coletada uma média de 41,65 toneladas de materiais recicláveis/dia. Deste modo, se são coletados 484,45 toneladas na coleta comum, e 41,65 toneladas na coleta seletiva, apenas $7,91 \%$ do total de resíduos coletados pelo município é reciclado. Este número pode ser ainda menor, pois nem todo material da coleta seletiva pode ser reciclável, conforme informações do coordenador do Centro de Triagem. Do total coletado, apenas $65 \%$, ou seja, somente 27,07 toneladas são recicladas por dia; o restante é direcionado ao Aterro Sanitário. Sendo assim, de todo o resíduo sólido coletado pela URBAM, apenas 5,14\% é efetivamente reciclado, como mostra a Figura 66. 


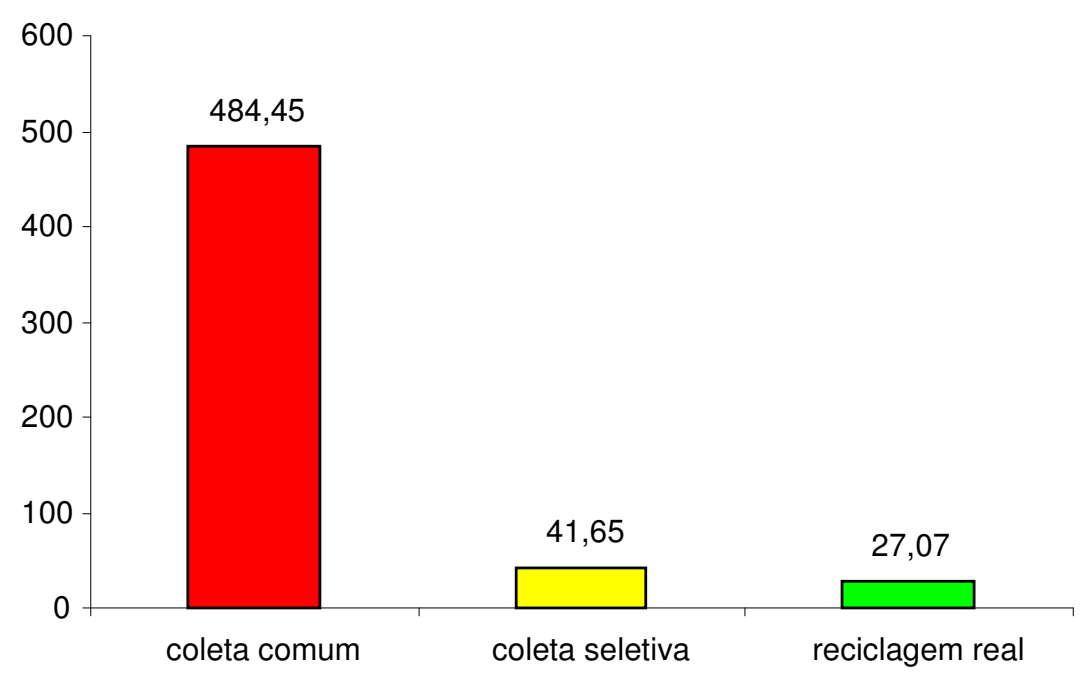

Figura 66 - Coleta seletiva e Coleta comum em toneladas/dia.

Fonte: URBAM (2010).

Por meio da Tabela 8, pode-se perceber que de 2007 a 2010, ou seja, em três anos a quantidade de resíduo reciclável coletado dobrou. No entanto, a quantidade de resíduo reciclável coletada ainda é muito baixa em relação à quantidade total de resíduos sólidos produzidos pelo município, dos quais apenas $5,14 \%$ é reciclado. Não podemos deixar de considerar, também, que a quantidade de resíduos sólidos produzidos pela população também aumentou.

Tabela 8 - Evolução dos resíduos coletados em São José dos Campos.

\begin{tabular}{|c|c|c|}
\hline Ano & $\begin{array}{c}\text { Coleta Seletiva } \\
\text { Toneladas/dia }\end{array}$ & $\begin{array}{c}\text { Coleta Comum } \\
\text { Toneladas/dia }\end{array}$ \\
\hline $1993^{*}$ & 3,5 & --- \\
\hline $1997^{*}$ & 12 & 302 \\
\hline $2006 *$ & 20 & 329 \\
\hline $2007 "$ & 22,26 & 408,89 \\
\hline $2008 "$ & 27,19 & 436,13 \\
\hline $2009 "$ & 38,21 & 475,67 \\
\hline $2010 "$ & 41,65 & 484,45 \\
\hline
\end{tabular}

Fonte: *CEMPRE (2010) e “URBAM (2012).

Os gráficos do Cempre (Compromisso Empresarial para Reciclagem) na Figura 67, Figura 68 e Figura 69 mostram alguns dados diferentes. Vê-se uma queda na coleta seletiva em 2004 e 2006, que volta a crescer em 2008, porém houve aumento da população atendida em 2006, e neste mesmo ano, houve um aumento no gasto com a coleta seletiva. Nota-se 
assim, algumas divergências; o aumento na população atendida e o aumento com os gastos da coleta seletiva não são proporcionais ao aumento dos resíduos recicláveis na coleta seletiva no município.

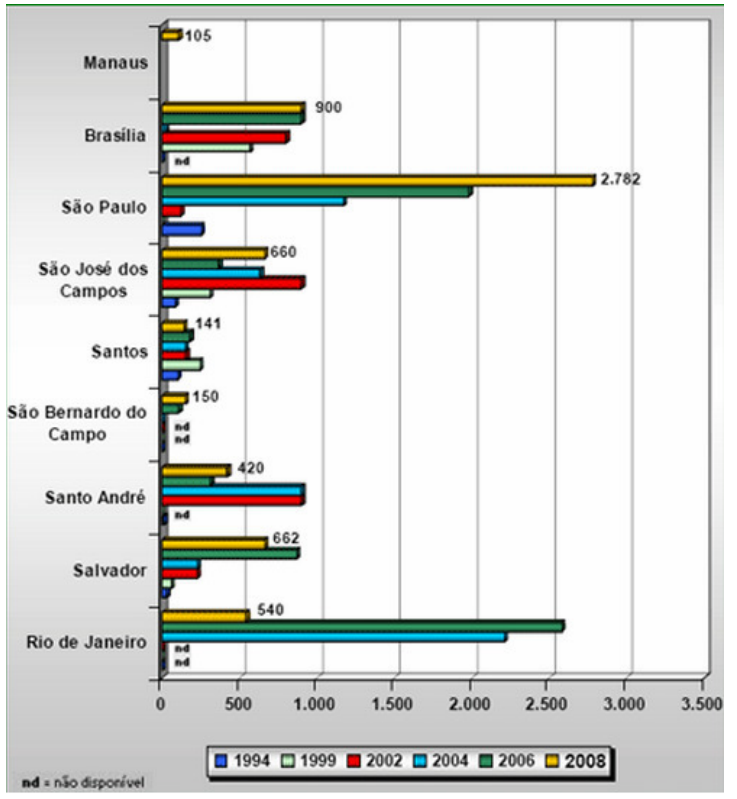

Figura 67 - Escala de Coleta Seletiva (ton/mês).

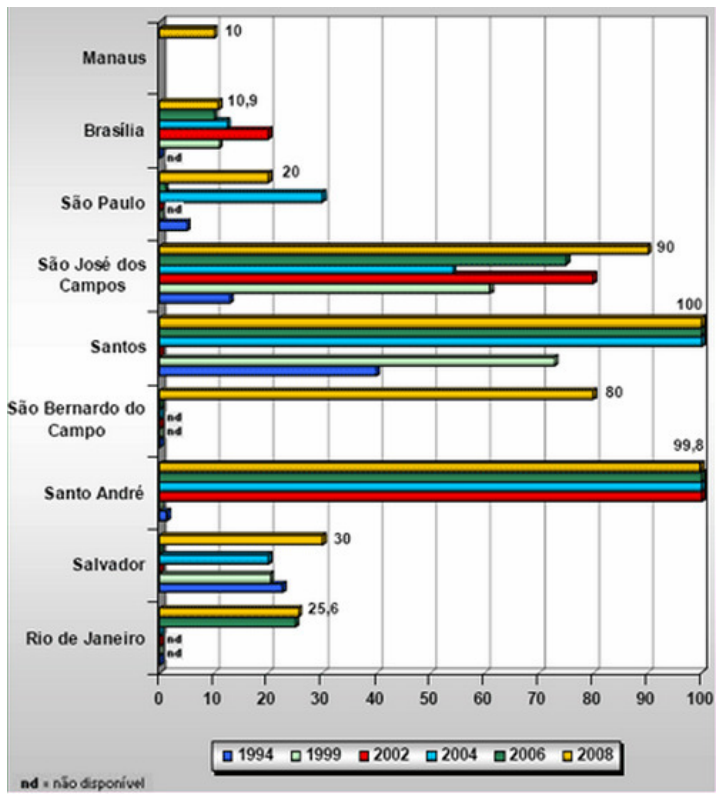

Figura 68 - População atendida pela coleta seletiva (\%).

Fonte: Cempre (2008).

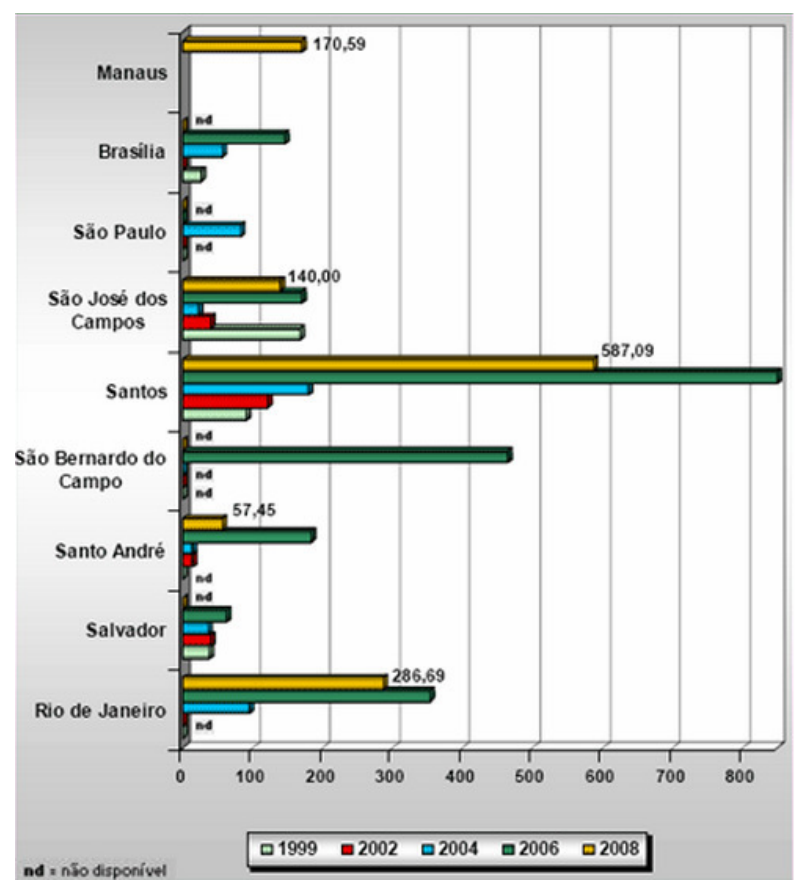

Figura 69 - Custos com Coleta Seletiva (US\$/tonelada).

Fonte: Cempre (2008). 
Conforme escreve Assis (1998), embora tenha ocorrido certa melhoria no gerenciamento integrado dos resíduos sólidos, os dados que apontam a eficiência da coleta seletiva indicam que "o que antes chamava atenção para o programa de São José - a participação da população - caiu significativamente, aumentando, portanto, os custos da coleta" (ASSIS, 1998, p. 71). A autora afirma que para, dar continuidade ao programa, é preciso retornar às residências, reforçando o trabalho de conscientização e sensibilização da população.

Conforme estudo realizado sobre a caracterização dos resíduos da coleta domiciliar em São José dos Campos, constatou-se que 43,3\% são recicláveis, 51\% são compostáveis, 4,7\% são rejeitos e $1 \%$ são materiais perigosos (ASSIS, 1998, p. 64). Assim, percebe-se que grande parte do material que poderia ser reciclado está indo para o Aterro Sanitário.

A coleta seletiva é algo que requer grande investimento financeiro. Um caminhão da coleta seletiva tem um custo três vezes maior do que o da coleta comum; o número de empregados no centro de triagem também é bem maior. Conforme a URBAM, todo resíduo coletado na coleta seletiva e passado pelo centro de triagem gera um lucro ${ }^{39}$ de apenas $10 \%$ em relação ao que o município investiu. No entanto, o ganho ambiental é muito grande, pois estamos reciclando matéria-prima, evitando o desperdício dos recursos naturais, uma menor poluição do ar, do solo e da água, além de diminuir o volume de resíduos no aterro sanitário. O programa ainda emprega vários funcionários, tendo, também, cunho social.

Neste sentido, pode-se observar que a efetivação da coletiva seletiva em São José ocorreu de forma bastante lenta. Aos poucos, ela foi crescendo, aumentando o número de funcionários, melhorando a infraestrutura e aumentando a sua capacidade de coleta. Porém, embora tenha existido avanço desde a criação do programa de coleta seletiva no município, a quantidade de material reciclável coletado ainda é muito baixa. Ainda que a área de abrangência da coleta seletiva atinja praticamente toda a cidade, ela não está presente no diaa-dia das pessoas; é possível observar que são poucas as escolas, empresas, comércio e domicílios que separam o lixo; grande parte da população é mal informada sobre os dias de coleta seletiva e como deve ser a separação do lixo, ou mesmo, não tem uma conscientização e sensibilização sobre a importância desse ato.

A URBAM realiza mutirões de conscientização ambiental nos bairros da cidade, sendo visitado um bairro a cada três meses, ou seja, em um ano são visitados apenas quatro bairros, sendo que o município tem mais de noventa bairros. Vê-se que, o avanço na infraestrutura não

\footnotetext{
39 Todos os dias são comercializados de 5 a 6 caminhões com material reciclado. Assim, aproximadamente 35 toneladas são comercializadas, e 15 toneladas são rejeitos da coleta seletiva do município.
} 
foi acompanhado por projetos educativos. A parte da sensibilização e conscientização ficou à margem deste processo, e sendo assim, o número real de pessoas que contribuem com a coleta seletiva ainda é muito baixo. Neste sentido, falta uma política de conscientização e ampla divulgação da coleta seletiva em São José dos Campos.

Atualmente, o Centro de Triagem está na sua capacidade máxima, embora ainda tenha capacidade para ampliação, caso fossem contratados mais funcionários. Conforme o Coordenador do Centro de Triagem, caso houvesse um aumento no número de funcionários e o trabalho passasse a ser realizado em três turnos, a capacidade do Centro de Triagem poderia passar para 90 a 100 toneladas por dia de resíduo reciclável.

Deste modo, é importante que a prefeitura intensifique o trabalho de conscientização ambiental, levando até as pessoas a informação sobre a importância do ato de reciclar, fazendo com que mais pessoas participem da coleta seletiva, e também, mostrando para todos como a separação do lixo deve ser feita, pois grande parte do resíduo recolhido pela coleta seletiva não pode ser reciclado por estar sujo ou mal separado pela população. No entanto, como pode-se perceber através das entrevistas, devido ao alto custo da coleta seletiva, não há iniciativas da prefeitura em realizar esta ampliação. Porém, ressalta-se que embora o lucro financeiro seja baixíssimo, existe um grande ganho social e ambiental. As Figura 70 a73 retratam o trabalho de reciclagem no centro de triagem:

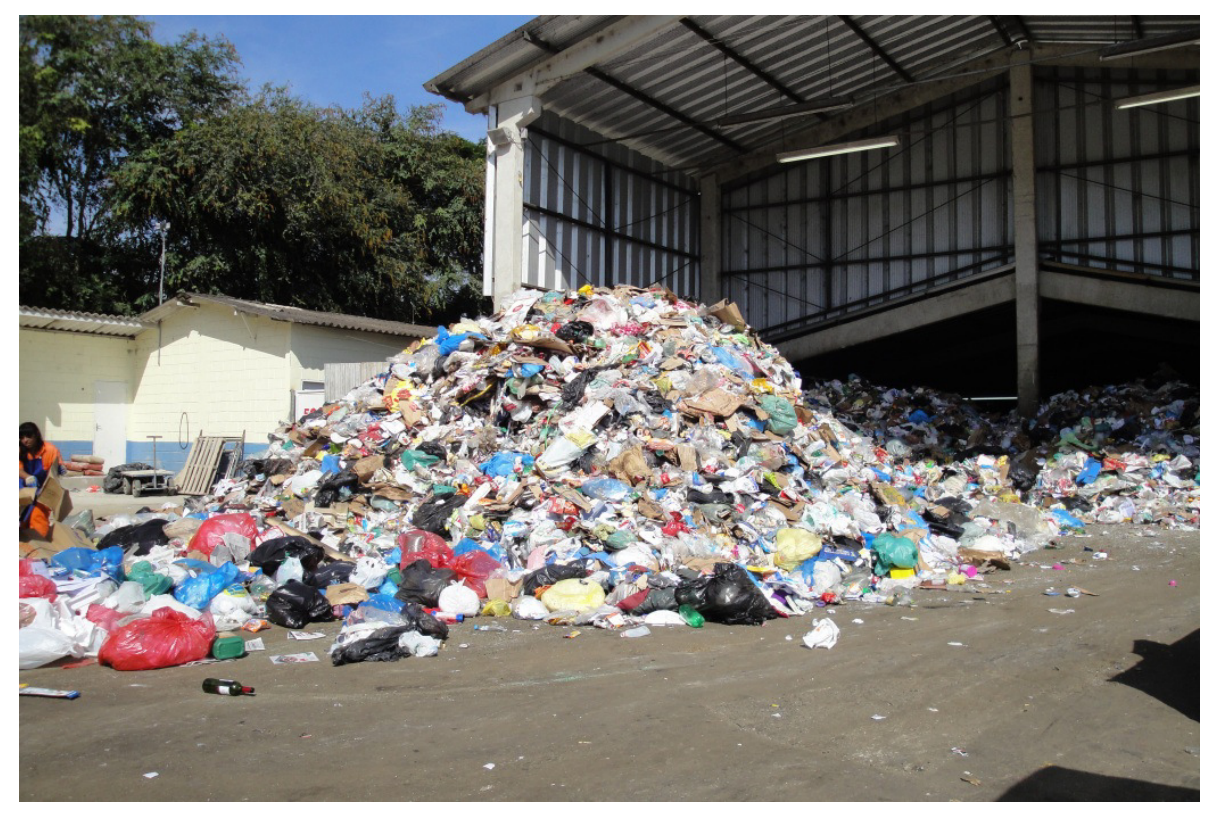

Figura 70 - Chegada do material recolhido pela Coleta Seletiva.

Fonte: Arquivo pessoal. 


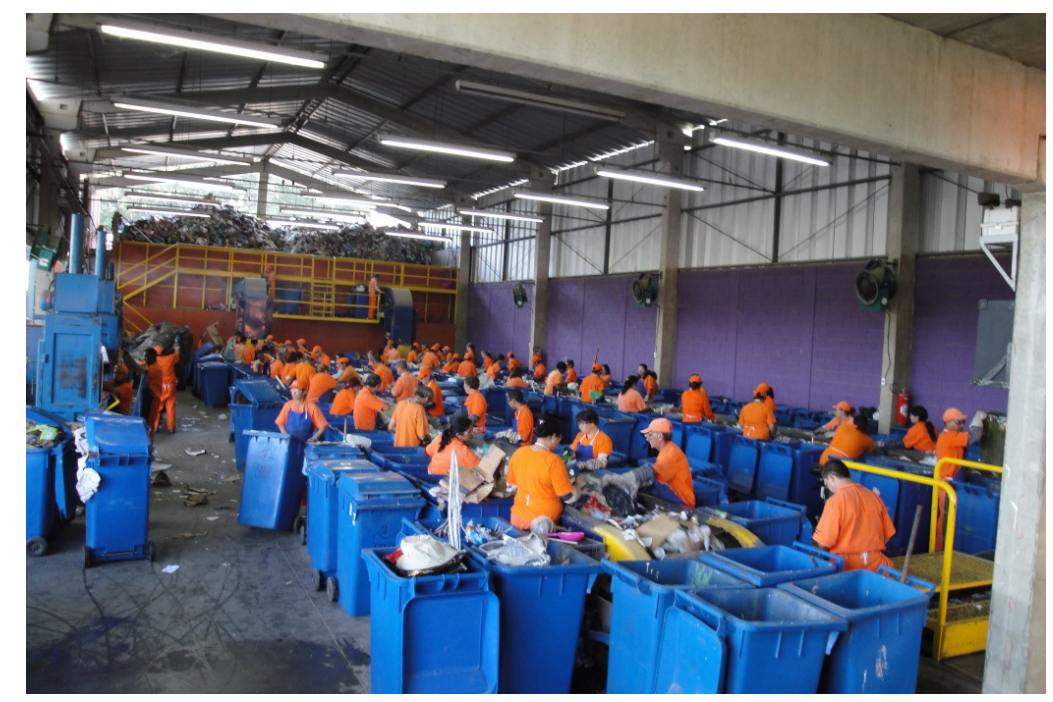

Figura 71 - Separação do material reciclável nas esteiras. Fonte: Arquivo pessoal.

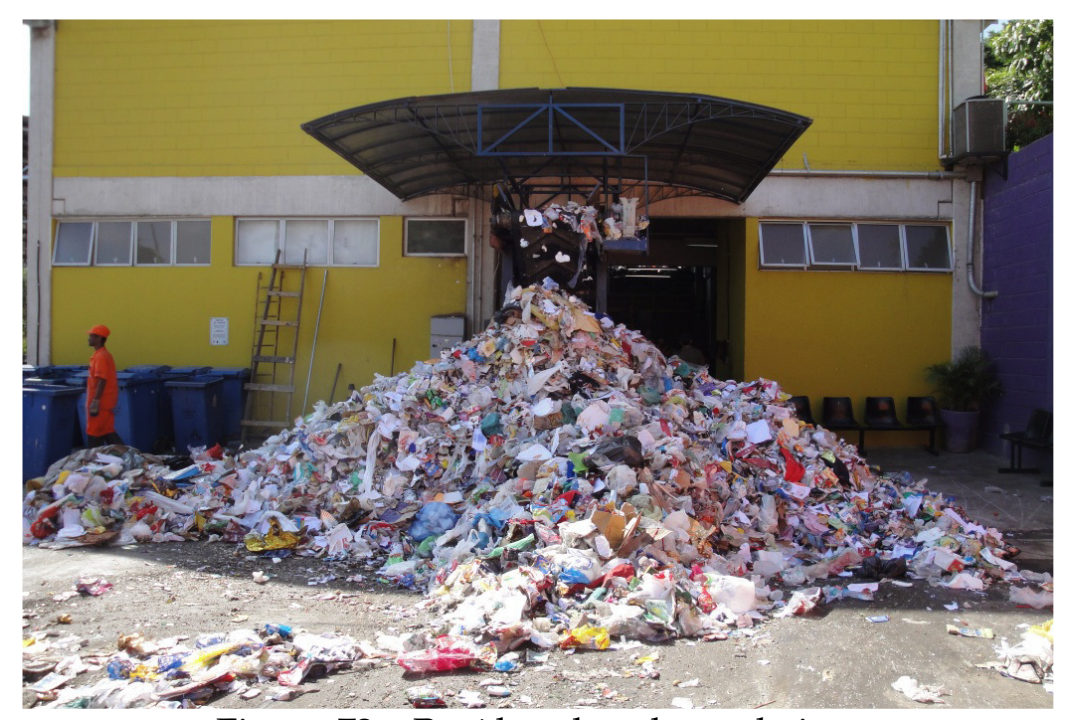

Figura 72 - Resíduo da coleta seletiva. Fonte: Arquivo pessoal.

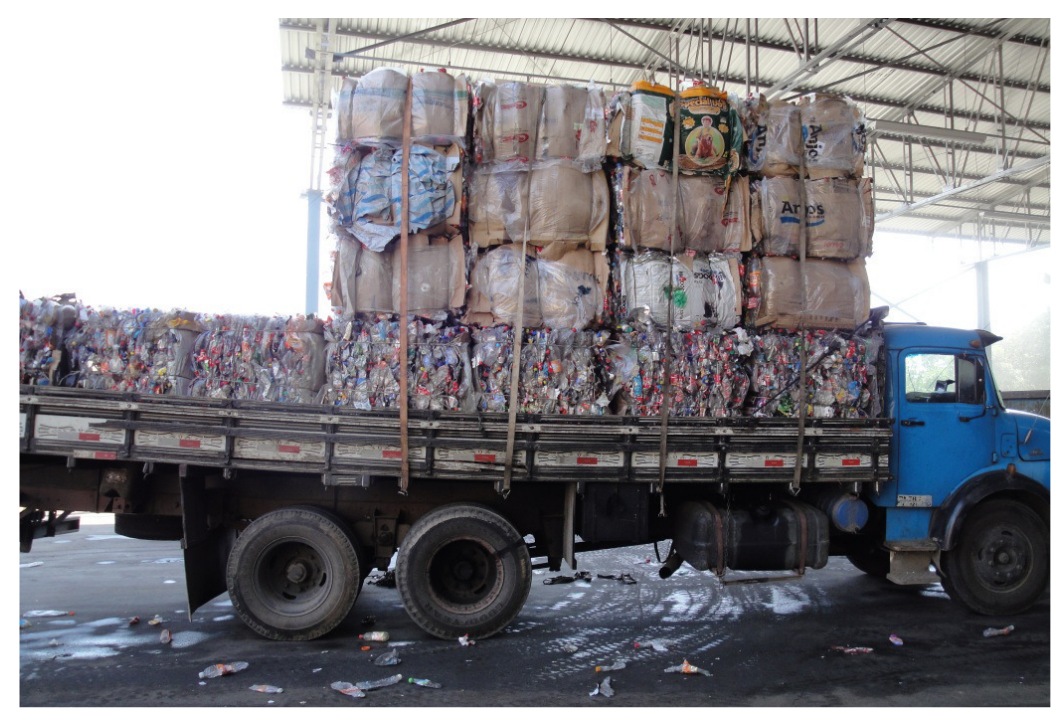

Figura 73 - Caminhão carregado com material reciclável. 
A Figura 70 retrata a chegada do material recolhido na coleta seletiva, onde inicialmente são separados os resíduos de maior volume e, o restante vai para as esteiras. A Figura 71 mostra o material da coleta seletiva passando pelas esteiras no centro de triagem, onde os funcionários separam vidros, papel, plástico, metal e o material não reciclável em contêineres ${ }^{40}$. Na Figura 72, pode-se ver a parte da coleta seletiva que não é reciclada. Como é possível visualizar, grande quantidade do material coletado não é reciclável e tem como destino final o aterro sanitário. Na Figura 73, pode-se visualizar caminhão sendo carregado com fardos de garrafa pet prensado, que foi vendido para uma empresa particular para a reciclagem do material.

\subsubsection{Saneamento: Tratamento de esgoto}

O município de São José dos Campos vem sendo atendido pela SABESP nas questões de abastecimento de água e esgotamento sanitário desde 1976, quando aderiu ao Plano Nacional de Saneamento (PLANASA).

Conforme dados da Prefeitura e da Sabesp, o abastecimento de água atinge 100\% da área regularmente urbanizada, sem contabilizar os loteamentos clandestinos, estimando-se um índice total de $94 \%$ da população. A principal fonte de abastecimento de água do município é o Rio Paraíba do Sul.

Em relação ao número da população assistida pela coleta de esgoto, o índice é menor, pois atinge apenas $86 \%$ da população regularmente urbanizada, ou seja, sem contar os loteamentos clandestinos. O principal receptor dos esgotos é, também, o Rio Paraíba do Sul.

Segundo a Prefeitura (2008), no período 1995-2007, o percentual de esgoto tratado do Município passou de $10 \%$ para $46 \%$, em relação à área atendida por rede coletora de esgoto. No entanto, dados disponibilizados pela Prefeitura (2012) mostram que em 2009, esse número passou para $53 \%$, e em 2010 para $88 \%$, sem contabilizar os loteamentos clandestinos e irregulares que não possuem rede de esgoto.

O Plano Municipal de Saneamento Básico (PMSJC, 2008) informa que o sistema é dividido em seis bacias principais de esgotamento, sendo bacia do Buquira, da zona norte do município, bacia Lavapés da zona central e parte da zona leste, através da bacia do Cambuí,

\footnotetext{
${ }^{40}$ Nas esteiras, também, passa o material da coleta seletiva que não pode ser reciclado, por estar sujo ou por não ser reciclável (orgânico, fralda descartável, etc.), porém, parte também não é reciclada pela velocidade da esteira, que não permite uma separação eficaz, pode-se perceber durante a visita ao local que algumas sacolas nem chegam a serem abertas.
} 
bacia do Vidoca da zona sul e oeste, Bacia do Paranangaba da zona Leste do município, Bacia do Alambari da zona leste, e bacia do Peixe, do distrito de São Francisco Xavier.

A distribuição percentual aproximada de coleta e tratamento de esgotos destas bacias hidrográficas, conforme o Plano Municipal de Saneamento Básico (2008), correspondia a:

- Bacia do Peixe- com $99 \%$ de coleta e com $100 \%$ de tratamento.

- Bacia do Lavapés - com $99 \%$ de coleta e com $85 \%$ de tratamento.

- Bacia do Buquira- $85 \%$ de coleta e com $65 \%$ de tratamento.

- Bacia do Vidóca - $95 \%$ de coleta e com $0 \%$ de tratamento ${ }^{41}$.

- Bacia do Alambari - 90\% de coleta e com 50\% de tratamento.

- Bacia do Paranangaba- com $90 \%$ de coleta e com $20 \%$ de tratamento.

Conforme o Plano Municipal de Saneamento Básico (2008) e dados da Prefeitura de São José dos Campos (2012) existe um acordo com a Sabesp, em contrato, que tem o objetivo de universalizar a rede de água e esgoto em todo o município, e ampliar o sistema de tratamento de esgoto, buscando atingir 100\% de esgoto tratado. As metas colocadas são:

- Meta - Cobertura mínima do serviço de coleta de esgoto ${ }^{42}$ :

\begin{tabular}{|l|c|c|c|c|c|c|}
\hline ANO & 2010 & 2012 & 2016 & 2020 & 2025 & 2038 \\
\hline COLETA & (atual) & & & & & \\
Maior ou igual a: & $87,4 \%$ & $92 \%$ & $98 \%$ & $99 \%$ & $99 \%$ & $99 \%$ \\
\hline
\end{tabular}

- Meta - Tratamento de todos os esgotos coletados:

\begin{tabular}{|l|c|c|c|c|c|c|}
\hline ANO & 2010 & 2012 & 2016 & 2020 & 2025 & 2038 \\
\hline TRATAMENTO & $\begin{array}{c}\text { (atual) } \\
88 \%\end{array}$ & $94 \%$ & $100 \%$ & $100 \%$ & $100 \%$ & $100 \%$ \\
Maior ou igual a: & $88 \%$ & & & & \\
\hline
\end{tabular}

Conforme a legislação analisada, o problema da falta de tratamento de esgoto já vem sendo discutido há muito tempo no município. O Plano Diretor de 1995 destaca que apenas $1,5 \%$ do esgoto coletado eram tratados e aponta a necessidade de programa de controle e tratamento do esgoto doméstico do município.

Em 1997 a Sabesp inaugura a Estação de Tratamento de Esgoto Lavapés em São José dos Campos. Em 2008, a porcentagem de esgoto tratado é de $46 \%$ do que é coletado. Em

\footnotetext{
${ }^{41}$ Os dados são referentes a 2008. Após a construção da Estação Elevatória de Esgoto do Córrego Vidoca, em 2010, parte do esgoto passou a ser tratado.

42 Exclui áreas irregulares e áreas de obrigação de fazer de terceiros.

Estas metas incluem o atendimento aos loteamentos listados, que estão em processo de regularização pela PMSJC. A operadora em exercício assinará Termo de Ajuste de Conduta, TAC, juntamente com a PMSJC, para a efetiva regularização de cada loteamento, à medida que o Ministério Público assim admitir.
} 
2009, esse número aumenta para 53\%, e em 2010, com a inauguração da Estação Elevatória de Esgoto do Córrego Vidoca, a porcentagem de esgoto tratado sobe para $88 \%$ do que é coletado no município, conforme dados da Prefeitura de São José (2012). Porém, esta porcentagem de $88 \%$ de esgoto tratado começou a ser questionada no começo de 2011.

A Estação Elevatória de Esgoto do Córrego Vidoca começou a ser construída em 2005 e foi entregue em 2010 às vésperas das eleições estaduais e federais, com dois anos de atraso. Foram gastos mais de 44 milhões de reais na obra. Porém, após a entrega da obra várias denúncias foram feitas por vereadores e meios de comunicação ${ }^{43}$, que mostram que parte do esgoto que vai para o córrego Vidoca continua sendo despejado neste córrego sem nenhum tratamento. A estação de tratamento não teria capacidade para coletar todo esgoto. Sendo assim, parte do esgoto ainda continua sendo despejado in natura no córrego. Conforme contato com o Sistema Municipal de Informações em Saneamento Básico (Simisa), foi informado que a Estação Elevatória de Esgoto do Córrego Vidoca só foi finalizada pela Sabesp em setembro de 2011 (contrato 9.834/04).

Notícias veiculadas nos meio de comunicação apontam ainda que, algumas das estações de tratamento de esgoto estão abandonadas. O jornal VNews noticiou, em 25 de janeiro de 2011, a existência de estações elevatórias de esgoto em estado de abandono; em uma delas, havia até gente morando. No lugar das máquinas existia cama, cadeira, geladeira, e a pessoa que vivia no local foi entrevistada e diz viver no local há um ano e oito meses.

Como noticiado, não existe vigilância nas estações; o maquinário foi roubado, e sem este maquinário, não há tratamento de esgoto, que continuou sendo jogado in natura nos córregos. Conforme publicação no Jornal VNews, em 09 de fevereiro de 2011, a própria Sabesp admite que algumas das Estações estavam paradas há 3 anos e que o esgoto continuou sendo despejado in natura direto no Rio Paraíba do Sul. A justificativa é que o vandalismo e o furto de máquinas atrapalhou o trabalho. A Figura 74 mostra o estado de abandono da Estação da Vila Terezinha.

\footnotetext{
43 Jornal "O Vale", quinta-feira, 19 de Janeiro de 2011.

Vereador Wagner $\quad$ Balieiro, em 20 de Janeiro de 2011. http://www.wagnerpt.org/site/publish/Not cias 12/Sabesp lan a esgoto no Vidoca.shtml Jornal VNews em 05 de junho de 2009, http://www.vnews.com.br/noticia.php?id=50994 Jornal VNews em 25 de janeiro de 2011, http://www.vnews.com.br/noticia.php?id=88809
} 

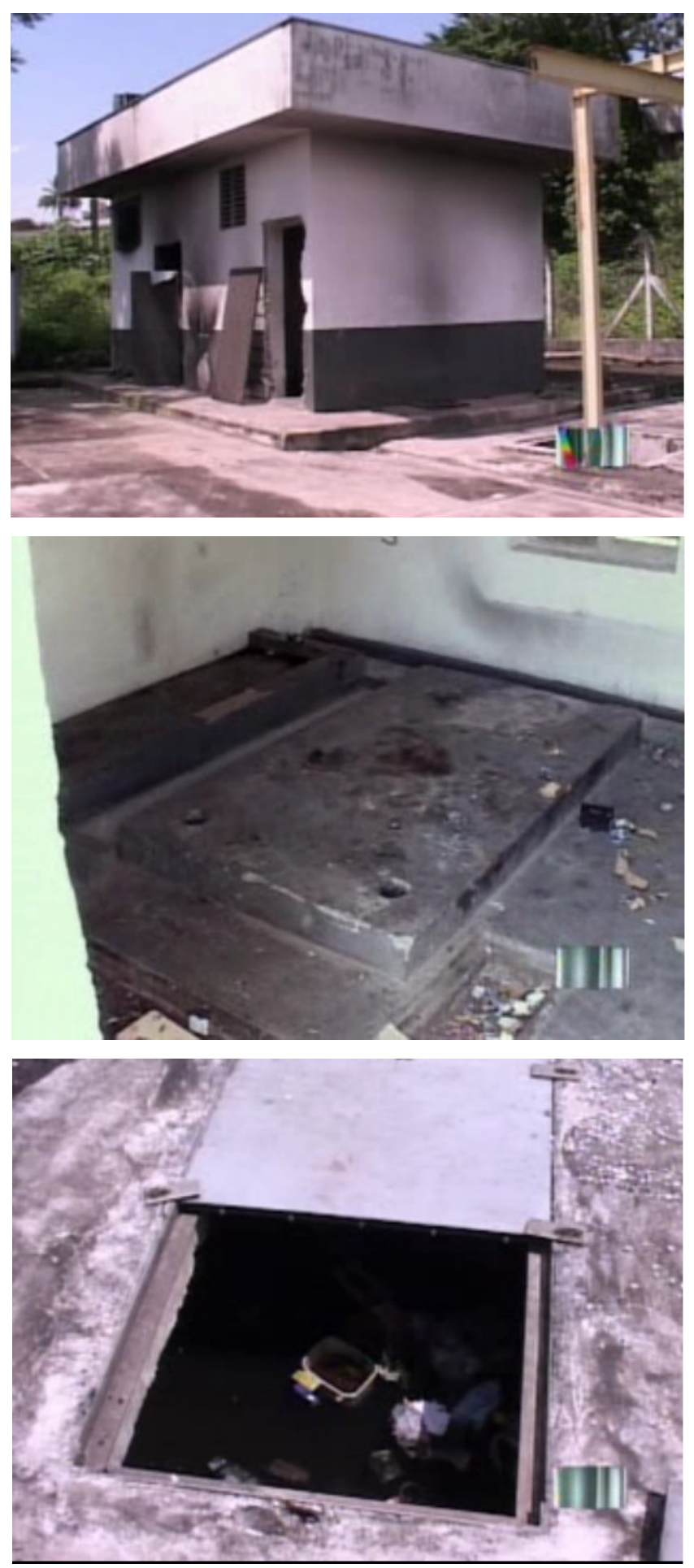

Figura 74 - Fotos da Estação Vila Terezinha em estado de abandono.

Fonte: Jornal VNews (2011).

Por meio de trabalho de campo, entrevista e pesquisa em notícias veiculadas em diferentes meios de comunicação, foi possível verificar que o Plano Municipal de Saneamento Básico e a Política de Saneamento Básico vêm sendo seguida apenas parcialmente. Nem toda população é atendida pela coleta de esgoto, e nem todo esgoto é tratado. Existe uma grande 
parcela do esgoto coletado que não é tratada e é descartada in natura nos córregos e rios do município, contrariando a legislação vigente, que determina a proibição do descarte de efluentes urbanos e industriais em qualquer corpo d'água (LEI ORGÂNICA, 1990).

Uma cidade tão próspera como São José dos Campos, considerada polo tecnológico e aeroespacial, abordou nos últimos anos a questão da coleta e tratamento de esgoto com certo descaso. Só a partir de 2010, a cidade passou a ter tratamento de esgoto em mais da metade do esgoto coletado. A Sabesp, enquanto prestadora de serviço, não cumpriu todas as metas estabelecidas pela legislação, e por outro lado, a Prefeitura tem sido omissa em não fiscalizar e exigir melhorias da empresa. No entanto, vê-se certo avanço no saneamento básico de São José dos Campos, que de forma lenta vem apresentando melhorias no sistema de coleta e tratamento de esgoto, mas ainda hoje a cidade continua poluindo os córregos e rios urbanos com o despejo de esgoto in natura.

No entanto, laudos emitidos pela CETESB e SABESP, em 2011, apontam que o município possui a qualidade da água entre boa e regular na maioria das amostras colhidas e analisadas ao longo do ano. Porém, os dados da análise do Rio Paraíba do Sul, quando deixa o município, são diferentes, a classificação da qualidade da água no Rio Paraíba fica como regular, e em alguns períodos ruim (CETESB, 2011). 


\section{Conclusão}

A Geografia, ciência que tem como objeto de estudo o espaço geográfico e as relações entre sociedade e natureza, contribui para a melhor organização do espaço e o planejamento urbano. O espaço visto como social e produto do homem, pode ser mais bem planejado, tanto na sua produção como no seu uso, por meio do conhecimento geográfico. É preciso descrever, explicar e compreender o espaço, para assim, poder agir sobre ele.

O Estado se mostra o grande agente modificador do espaço, dotador de infraestrutura, equipamentos urbanos e inúmeras ações que criam e modificam o espaço. O Estado intervém no espaço por meio de leis, decretos e ações, porém, muitas vezes as intervenções do Estado refletem os interesses das classes dominantes e do capital, aumentando as desigualdades sociais e a degradação ambiental.

Neste sentido, vê-se no espaço certa “desorganização" expressa na segregação espacial, nos conflitos socioambientais e nos inúmeros problemas urbanos. O Estado e a sociedade, por meio do planejamento urbano e de novas práticas, como a gestão participativa e democrática, mostram-se fundamentais para a melhor organização do espaço nas cidades.

Os problemas ambientais urbanos se tornam cada vez mais graves e requerem maior atenção. O planejamento urbano é um instrumento fundamental da política urbana para combater esses problemas. Desde quando surge o conceito de planejamento urbano nas cidades industriais, este aparece como uma preocupação na resolução dos problemas urbanos. A valorização de espaços verdes, o saneamento e a higiene urbana estão no princípio do planejamento urbano. Novas correntes do planejamento urbano, chamadas por alguns autores de pós-modernas, defendem o fortalecimento da esfera local, a maior atenção aos problemas ambientais urbanos e a importância da igualdade e da democracia no processo de tomada de decisões. 
No Brasil, o planejamento urbano teve pouca atuação prática, se pautava basicamente em leis de zoneamento urbano e planos diretores, sem ter participação da população. As políticas públicas urbanas eram voltadas para os anseios da elite dominante; apenas uma parte da cidade era planejada e recebia as dotações do Estado, a chamada cidade legal; a outra parte da cidade crescia sem planos, sem regras e sem leis, sendo designada por muitos autores como cidade ilegal.

Em 2001, a aprovação do Estatuto da Cidade traz um novo fôlego à política urbana no Brasil e novas perspectivas para o planejamento urbano na esfera local. A gestão democrática e participativa e novos instrumentos urbanos deram força a um novo planejamento urbano. Porém, em muitas cidades, o Estatuto da Cidade tem tido pouca aplicabilidade prática. No município de São José dos Campos, vê-se avanços na gestão democrática e participativa, porém, na prática, existe pouca transparência nas audiências públicas. Na própria revisão da lei de zoneamento em 2010, muitas decisões foram tomadas sem o conhecimento da população, e a lei foi aprovada sem que a população pudesse opinar sobre essas mudanças.

Nos últimos anos, surgi nas cidades a existência de uma cidadania-ambiental, em que os cidadãos têm se mostrado mais participativos, reivindicam e exigem os seus direitos. As atuações de ONGs, ambientalistas e sociedade civil organizada se mostram de grande valor para as discussões de novas políticas públicas no meio urbano. Porém, falta uma maior correlação entre sociedade e Estado na tomada de decisões, transparência nas negociações, políticas mais justas e igualitárias, que atinjam os interesses de toda a sociedade, que garantam uma melhor qualidade de vida à população e um meio ambiente saudável, produzindo assim, cidades sustentáveis. Acredita-se que as cidades brasileiras têm passado por mudanças na sua estrutura urbana, porém, ainda há muito que avançar. É preciso ampliar a gestão democrática e participativa, fortalecer a proteção ao meio ambiente, fazer planejamento urbano com maior justiça e igualdade social, e se fazer cumprir o que foi planejado com a mesma igualdade.

O município de São José dos Campos é um exemplo de cidade que teve grande ação do Estado, com certo planejamento urbano e intervenções urbanísticas. A cidade de São José dos Campos passou por grandes transformações. Inicialmente, teve seu desenvolvimento calcado em seus aspectos naturais, bons ares e clima agradável, onde o Estado se aproveita desses elementos para a construção de sanatórios. Porém, as características naturais dão lugar ao desenvolvimento tecnológico; as grandes áreas planas e sua localização geográfica e a forte ação do Estado vão atrair indústrias e o desenvolvimento tecnológico. A paisagem natural dá 
cada vez mais lugar à segunda natureza, à paisagem construída, marcada pela segregação social e degradação do meio ambiente.

Diferente de muitas cidades brasileiras, São José dos Campos já em 1932 possuía zoneamento urbano e vai ser uma das primeiras cidades do país a possuir Plano Diretor. As primeiras políticas previstas para a cidade já mostravam preocupação com as questões ambientais, principalmente com a localização das indústrias geradoras de poluição. Porém, embora existisse a preocupação e as leis, nem sempre estas foram respeitadas e elaboradas com justiça e igualdade. Hoje, o município colhe as consequências do não cumprimento de parte dessas leis e da falta de um planejamento com equidade.

Como se pode analisar, o primeiro Plano Diretor em 1961 apresenta um rico estudo, leva em consideração os aspectos sociais e ambientais da cidade, porém, pouco do que foi planejado é posto em prática; o poder econômico e a especulação imobiliária se sobrepõem aos interesses do meio. Já o Plano Diretor de 1971 (Lei 1.623/71) deixa clara a vocação industrial assumida pelo município, o plano é elaborado pensando. principalmente, no desenvolvimento econômico. O meio ambiente ganha pouca ou quase nenhuma atenção, os aspectos sociais são pouco mencionados. A ação do Estado militar é marcante neste período. A produção do espaço joseense é fortemente manipulada pelas intervenções realizadas pelo Estado. A implantação da Refinaria Henrique Lage, sem nenhum estudo ambiental e em desrespeito às leis municipais, é um exemplo. Tal indústria trouxe grandes modificações à qualidade ambiental e ao ordenamento da cidade.

O PDDI de 1971 é acompanhado da Lei de Zoneamento Urbano (1.606/71); o uso do solo industrial é privilegiado no município, sendo que $65,1 \%$ do espaço urbano joseense é definido como zona industrial e zona predominantemente industrial. Como aspecto positivo desta legislação, destaca-se a criação da zona especial do Banhado e a proteção da vista para esta rica paisagem da cidade.

A Lei de Zoneamento Urbano de 1980 (2.263/80) aumenta as zonas residenciais e diminui as zonas industriais, que passam a ocupar 27,2\% do território. A instalação de indústria com alto potencial poluidor fica proibida no município. Em 1990, a nova Lei de Zoneamento Urbano (3.721/90) cria um grande número de zonas de uso e corredores. Permite a ocupação residencial na área do Banhado, as questões ambientais têm pouco reconhecimento. Nas décadas de 1980 e 1990, o município passa por um grande crescimento demográfico e expansão urbana, surgem grandes vazios urbanos e a proliferação de loteamentos clandestinos. 
As políticas públicas adotadas no município até 1990 são essencialmente de cunho econômico, marcadas pela forte ação do Estado, do capital industrial e pela especulação imobiliária. O meio ambiente é pouco valorizado, destacando-se apenas a proteção ao Banhado, sendo que a Lei Municipal 2.792/84 cria a área de proteção ambiental do Banhado. Porém, esta tem parte de sua área ocupada por loteamentos fechados de alto padrão, formalizados pelas leis de zoneamento urbano (Leis 3.721/90, 165/97 e 428/10).

O Plano Diretor de Desenvolvimento Integrado de 1995 se insere sobre um novo contexto político e social. O meio ambiente passa a ser valorizado pelo mundo todo - o desenvolvimento sustentável ganha grande repercussão com a ECO-92. O planejamento urbano de São José dos Campos é elaborado com base nas características físicas e antrópicas do município, tendo por referência a "Carta das Unidades Territoriais de Características Físicas e Antrópicas Homogêneas" elaborada em parceria com o INPE e IPT. Foram realizadas audiências públicas, e a população pode participar da elaboração do PDDI-1995. $\mathrm{Na}$ teoria, o planejamento é bem feito; prioriza tanto o econômico como o social e o ambiental, porém, na prática, nem tudo que é planejado ocorre como deveria. Tem-se, como exemplo, a ocupação de parte da área de proteção ambiental do Banhado por condomínios de luxo, além da falta de rede coletora de esgoto e de tratamento do esgoto, gerando a poluição dos córregos urbanos, bem com a proliferação dos loteamentos clandestinos em áreas de proteção e preservação ambiental.

O PDDI-1995 previa novos instrumentos da política urbana, que mais tarde seriam efetivados pelo Estatuto da Cidade, porém, estes não se concretizam na prática, como o parcelamento ou edificação compulsória, imposto predial e territorial progressivo no tempo, desapropriação, operações urbanas, entre outros. Desta forma, os instrumentos que permitiriam reduzir a ação da especulação imobiliária e garantir a função social da propriedade urbana são postergados e nunca chegaram a se efetivar no município.

A nova Lei de Zoneamento Urbano (165/97) vai de encontro à parte das políticas ambientais previstas no PDDI-1995, pois permite a ocupação residencial em grande parte da APA-IV, inclusive modificando parte da zona de uso de APA-IV para zona residencial. Os loteamentos clandestinos são identificados e delimitados como ZEIS, porém, na prática, não houve nenhuma mudança, e o parcelamento irregular do solo continuou existindo no município. O número de vazios urbanos continuou elevado, e não houve políticas para sua ocupação, sendo que a zona urbana sofreu uma nova expansão.

Já o Plano Diretor de Desenvolvimento Integrado (Lei 306/06) foi elaborado após a aprovação do Estatuto da Cidade, porém, isto pouco influenciou as políticas urbanas adotadas. 
Embora tenham ocorrido audiências públicas para discutir e elaborar o plano diretor de forma participativa, estas não aconteceram de forma clara e transparente. Muitos artigos foram incorporados à legislação sem debate junto à população. Os novos instrumentos da política urbana, previstos no Estatuto da Cidade, não são adotados pelo município, deixando clara a forte ação da especulação imobiliária e dos interesses econômicos, que prevalecem sobre o social e o ambiental.

A Lei de Zoneamento Urbano de 2010 (428/10) é elaborada e promulgada sem a transparência, clareza e participação democrática necessária como preconiza o Estatuto da Cidade. O zoneamento urbano (428/10) efetiva a regularização dos loteamentos de alto padrão construídos na APA do Banhado e diminui a porcentagem de área verde obrigatória para os novos loteamentos. A lei determina normas mais rígidas para aprovação de novos loteamentos e retrai o perímetro urbano, e ainda, determina novas regras para verticalização do município. Como a sua aprovação é recente, esta última lei de zoneamento pôde ser pouco analisada nesta tese.

Por meio do levantamento cartográfico, trabalho de campo, entrevista e pesquisa documental realizados, observa-se que muitas das políticas e ações previstas não foram efetivadas na prática, o que ocasionou inúmeros problemas sociais e ambientais ao município. Como se pode analisar, das 126 ações ambientais, sociais e urbanísticas estudadas nesta tese, por meio do levantamento das Leis Ambientais municipais, Lei Orgânica, Planos Diretores e Zoneamento Urbano, apenas $21 \%$ foram realmente executadas, $30 \%$ não foram executadas, $39 \%$ foram parcialmente executadas e $10 \%$ não puderam ser avaliadas. Estes dados mostram que na maioria das vezes o que se é planejado não é colocado em ação. De todos os problemas ambientais urbanos analisados, vê-se que muitos não foram solucionados; alguns foram amenizados e outros se agravaram.

Em relação às políticas públicas de zoneamento urbano, vê-se que muitas vezes não houve continuidade entre uma lei e outra. Observam-se vários conflitos de uso do solo, principalmente entre o uso residencial e o industrial, entre o uso residencial e o ambiental e entre o urbano e o rural, com grande pressão para a ocupação urbana na zona rural e áreas de proteção ambiental. O espaço urbano de São José passou por grandes modificações a cada lei de zoneamento, todas essas alterações tiveram relação direta sobre a qualidade de vida e ambiental da cidade. Faltaram políticas públicas mais eficazes quanto à ocupação dos vazios urbanos, à fiscalização dos loteamentos clandestinos, à ocupação de áreas com declividade superior a 30\% e à ocupação das áreas de proteção e preservação ambiental, em especial do Banhado. 
O município, embora apresente desde 1984 a sua primeira Área de Proteção Ambiental (APA), não soube protegê-la com eficácia. A APA IV ou APA do Banhado perdeu $10 \%$ de sua área na última década. A APA se situa em meio à área urbana e vem sendo constantemente invadida por loteamentos fechados de alto padrão que foram formalizados pelas leis de zoneamento urbano, mudando o seu uso para zona residencial. A APA também sofre com a ocupação de favelas, loteamentos clandestinos e indústrias. Nos últimos anos a APA III, na divisa entre zona rural e urbana, também vem sendo ocupada por loteamentos clandestinos. O meio ambiente é degradado em favor dos interesses econômicos.

As Áreas de Preservação Permanente (APPs) nem sempre foram respeitadas, sendo transformadas em ruas, avenidas e vias expressas, além de serem ocupadas por favelas, loteamentos legais e ilegais e por condomínios de luxo. Como consequência, nota-se a erosão, o assoreamento dos córregos e poluição dos cursos d'água, e a existência de diversos pontos sujeitos a inundações e alagamentos na cidade.

Ao longo do estudo da legislação, observam-se várias diretrizes que previam o aumento das áreas verdes urbanas e a criação de novos parques urbanos. Porém, na grande maioria das vezes, os parques previstos não foram criados. As áreas verdes urbanas são essenciais para o equilíbrio ambiental urbano e para o lazer, proporcionando melhor bem estar aos moradores da cidade, porém não houve uma política eficaz para sua implantação.

Quanto à instalação das indústrias no município, nota-se que muitas desrespeitam as leis de zoneamento e planos diretores. As leis vão sendo estabelecidas buscando validar as instalações industriais já existentes, são elaboradas em cima do que existe e não propõe um ordenamento industrial de fato. Muitas indústrias se instalam próximos a rios e córregos, geram poluição da água, do ar e do solo. A instalação da Refinaria de Petróleo Henrique Lage pelo governo federal ocorreu sem nenhum estudo ambiental. As leis ambientais e urbanísticas existentes no município não foram respeitadas, nem pelos órgãos federais. Tal fato evidencia a forte ação do Estado no município e a prevalência do poder econômico sobre o meio ambiente.

O município apresenta ainda, inúmeros loteamentos clandestinos de baixo e alto padrão, que surgem no início da década de 1970 e se proliferam ao longo dos anos. Não houve política efetiva de contenção desses loteamentos e nem de regularização fundiária. Muitos destes loteamentos encontram-se em áreas de proteção ambiental e de preservação ambiental, não possuem nenhuma infraestrutura, como rede de água e esgoto e coleta de lixo, trazendo vários danos ao meio ambiente. Nos loteamentos de baixo padrão, as moradias são precárias, e as pessoas vivem em péssimas condições de higiene. Muitas vezes, para a 
instalação desses loteamentos clandestinos, houve desmatamento, assoreamento e poluição de córregos, degradando o meio ambiente ao seu redor. O município ainda possui várias favelas com milhares de pessoas vivendo em condições precárias. Existe um grande déficit habitacional no município, falta uma política habitacional efetiva, que regularize a situação dos loteamentos clandestinos e retire a população das favelas, ofertando moradia digna e melhores condições de vida.

O PDDI-2006 e a Lei de Zoneamento 2010 prevêem que todos os loteamentos clandestinos, independente da classe econômica e da localização, sejam regularizados. A falta de punição e de fiscalização aliadas a leis permissivas propiciam a proliferação dos loteamentos clandestinos no município. O caso do aumento dos loteamentos clandestinos durante décadas mostra o não cumprimento das leis, muitas vezes a cidade cresce sem regras e sem nenhum ordenamento.

Em relação à questão dos resíduos sólidos, o município de São José possui aterro sanitário, sendo classificado pela CETESB como um dos melhores do estado de São Paulo; o aterro sofreu uma nova expansão em 2012, porém a sua capacidade de suporte está se esgotando. Tal questão vem trazendo discussões ao município, uma vez que o poder público pretende instalar um incinerador de resíduos, o que além de envolver grandes gastos, aumentaria a poluição do ar na cidade. Uma alternativa para a diminuição dos resíduos sólidos é a reciclagem. A Prefeitura realiza a coleta seletiva desde o início da década de 1990. Inicialmente, o projeto teve uma boa repercussão, sendo aplicado em poucos bairros e foi acompanhado de um trabalho de conscientização ambiental. Atualmente, a coleta seletiva porta a porta atinge $95 \%$ da cidade; no entanto, a ampliação do projeto não foi acompanhada de educação ambiental. Houve aumento na área atendida, novos investimentos e aumento dos gastos com o projeto, porém a proporção de material reciclável coletado não foi proporcional à expansão do projeto. O município recicla apenas 5,14\% dos resíduos produzidos pela população.

Uma política positiva em relação aos resíduos sólidos foi a criação dos pontos de entrega voluntária $(\mathrm{PEV})$, com o objetivo de recolher resíduos volumosos em pequena quantidade. Em 2011, a Prefeitura criou sete PEVs. Porém, ainda existem no município cerca de 150 pontos de disposição clandestina, cuja maior incidência ocorre em Áreas de Preservação Permanente (APP), áreas públicas sem ocupação, terrenos baldios e nas próprias vias públicas. Desta forma, é necessária a criação de novos PEV, evitando a degradação ambiental em diversos pontos da cidade. 
A coleta e tratamento de esgoto é outra questão que merece maior atenção do município. Atualmente, a rede coletora de esgoto atinge apenas $88 \%$ da área urbanizada, não contabilizando os inúmeros loteamentos clandestinos e favelas existentes no município. $\mathrm{O}$ tratamento do esgoto foi algo que demorou a ser priorizado. Em 1995, apenas 1,5\% do esgoto coletado era tratado, até 2009, o tratamento de esgoto atingia apenas $53 \%$ do que era coletado, em 2010, 88\% do esgoto passou a ser tratado, porém essa última porcentagem vem sendo alvo de discussões, uma vez que existem várias estações da Sabesp em estado de abandono e sem equipamentos para o tratamento de esgoto.

São José dos Campos é uma cidade que bem ou mal teve planejamento urbano. Nem sempre as políticas públicas urbanísticas, ambientais e sociais foram respeitadas. Porém, é possível reconhecer na cidade as áreas onde o planejamento urbano foi bem sucedido, e outras, onde ele não foi aplicado.

O município de São José apresenta uma boa qualidade de vida, estando entre as melhores cidades do Brasil no índice de desenvolvimento humano, porém esta qualidade não é atingida igualmente por todos. Durante muito tempo, o planejamento urbano visou apenas ao crescimento e desenvolvimento econômico. Nota-se a forte ação do setor industrial e imobiliário, que prevaleceram sobre o setor social e ambiental. A pujança econômica do município não foi acompanhada por políticas públicas sociais e ambientais adequadas. Hoje, a cidade vivencia inúmeros problemas socioambientais. O meio ambiente e o social têm se perdido em meio aos interesses econômicos. 


\section{Bibliografia}

ASSIS, Vera. São José dos Campos. In: EIGENHEER, Emilio Maciel (org.). Coleta seletiva de lixo. Rio de Janeiro: In-Folio, 1998.

BOLOGNA, Sonia Maria Fonseca. A experiência dos planos diretores de São José dos Campos: Instrumentos eficazes de planejamento urbano ou obras de consulta acadêmica. 263 f. Dissertação (mestrado) - Universidade do Vale do Paraíba, Instituto de Pesquisa e Desenvolvimento, São José dos Campos, 2000.

BONDESAN, Altino. São José em quatro tempos. São Paulo: Ed. Bentivegna, 1967.

BONETI, Lindomar Wessler. Políticas públicas por dentro. Ijuí: Ed. Unijuí, 2006.

BRAGA, Roberto. Estrutura urbana e sustentabilidade ambiental em cidades de porte médio: uma análise da cidade de Rio Claro-SP. III Congresso Luso Brasileiro para o Planejamento Urbano, Regional, Integrado e Sustentável - PLURIS, 2008.

CAMPOS FILHO, C. M. Cidades Brasileiras: Seu Controle ou Caos - o que os cidadãos devem fazer para a humanização das cidades no Brasil. 40 Edição. São Paulo: Studio Nobel, 2001.

CANO, Wilson (coord.). Estudos de casos de municípios de Campinas, Sumaré, São José dos Campos e São José do Rio Preto. Campinas: Unicamp, Relatório Final, v.4, parte III, 1990.

Raízes da concentração industrial em São Paulo. 4.ed. Campinas: Unicamp. Instituto de Economia. 1998. 1995.

CARLOS, Ana Fani Alessandri. A (re)produção do espaço urbano. São Paulo: Edusp, 2008.

O espaço urbano: novos escritos sobre a cidade. São Paulo: Edição eletrônica Labur. 2007.

O lugar no/do mundo. São Paulo, Hucitec. 1996.

O Meio Ambiente Urbano e o Discurso Ecológico. Revista do Departamento de Geografia, São Paulo, n. 08, p. 75-78, 1994.

A cidade. 8. ed. São Paulo: Editora Contexto. 2005.

CARLOS, Ana Fani Alessandri (Org.). Os caminhos da reflexão sobre a cidade e o urbano. São Paulo: Edusp,1994.

CARVALHO, E. R. C. Um estudo sobre as ações empreendedoras no município de São José dos Campos (SP) no período de 1993 a 2008. (Dissertação de Mestrado). Instituto de Pesquisa e Desenvolvimento, Universidade do Vale do Paraíba. 2009. 
CARVAlho, Pompeu F. de; BRAGA, Roberto (orgs.). Perspectivas de Gestão Ambiental em Cidades Médias. Rio Claro: LPM-UNESP, 2001.

CARVAlho, Pompeu F. de. Perspectivas sócio ambientais de Reestruturação de Periferias Urbanas em Cidades Médias Paulistas: o caso de Rio Claro - SP, Rio Claro, Relatório de Pesquisa CNPQ, 1998.

CARVAlho, Alysson. et al. (Orgs). Políticas Públicas. 1. Reimpressão. Belo Horizonte: Editora UFMG, 2002.

CARVALHO, Willian Ferreira; BERARDO, João Luis; ASSIS, João Pereira de; GUEDES, Roberto Lage; ARAI, Nelson. Dispersão de poluentes na cidade de São José dos Campos. Disponível em < http://mtc-m15.sid.inpe.br/col/cptec.inpe.br> Acesso em: 10 junho de 2012.

CASTELLS, Manuel. A questão urbana. Rio de Janeiro: Paz e Terra, 1983.

CAVALCANTI, Clovis (org.). Meio ambiente, desenvolvimento sustentável e políticas públicas. São Paulo: Cortez: Recife: Fundação Joaquim Nabuco, 1999.

CUNHA, S.; COELHO, M. C. N. Política e gestão ambiental. In: CUNHA, S.; GUERRA, A. J. T (orgs). A questão ambiental: diferentes abordagens. Rio de Janeiro: Bertrand, 2003.

COMISSÃO MUNDIAL SOBRE MEIO AMBIENTE E DESENVOLVIMENTO (CMMAD). Nosso Futuro Comum. 2 ed. Rio de Janeiro: Ed. da FGV, 1991.

CHOAY, Françoise. O urbanismo: utopias e realidades - uma antologia. Editora Perspectiva: São Paulo, 1965.

CHUSTER, Vitor. O zoneamento em São José dos Campos: 1971 a 1997. Dissertação (mestrado) - Universidade do Vale do Paraíba, Instituto de Pesquisa e Desenvolvimento, São José dos Campos, 2000.

CORRÊA, Roberto Lobato. O Espaço Urbano. 2.ed. Rio de Janeiro: Editora Ática, 1993.

Trajetórias geográficas. 3.ed. Rio de Janeiro: Bertrand Brasil, 2005.

. Espaço: um conceito-chave da Geografia. In: CASTRO, Iná Elias de; COSTA GOMES, Paulo C. e CORRÊA, Roberto L. (org). Geografia: conceitos e temas. Rio de Janeiro: Bertrand Brasil, 2006.

Região e organização espacial. 8 ed. São Paulo: Ática, 2007.

COSTA, Wanderley Messias da. O Estado e as políticas territoriais no Brasil. São Paulo: Contexto, 1988.

COSTA, P. E. O. Legislação urbanística e crescimento urbano em São José dos Campos. (Dissertação de Mestrado). Faculdade de Arquitetura e Urbanismo, da Universidade de São Paulo, 2007.

COSTA, Sandra Maria Fonseca da, SOUZA, Adriane Aparecida Moreira de, BARROS, Nanci e NOVAES JUNIOR, René. Processo de horizontalizarão e verticalização em São Jose dos Campos de 1950 a 2000. In: PAPALI, M. A. (org.) Histori(cidade)s: um olhar multidisciplinar. São José dos Campos: Univap. São Paulo: Annablume, 2008.

DAMIANI, A. et al. Espaço no fim de século: a nova raridade. São Paulo: Editora Contexto, 1999.

DAVIS, Kingsley et al. A Urbanização da Humanidade. Rio de Janeiro, 1972.

EIGENHEER, Emilio Maciel (org). Coleta seletiva de lixo. Rio de Janeiro: ISER, 1993. 
FIGUeiredo, V. D. M., População e Qualidade de Vida Urbana em Santa Maria - RS Estudo de Caso: Bairro Urlândia. (Dissertação de mestrado). Instituto de Geogciências e Ciências Exatas da Universidade Estadual Paulista, Campus Rio Claro, 2001.

GEORGE, Pierre. O meio ambiente. São Paulo: Difusão Européia do Livro, 1973.

GOMES DA SILVA, G. et al. Entre Vila e Cidade: São José dos Campos no Final do Século XIX. In: PAPALLI, M.A. e ZANETTI, V. (orgs). Câmara Municipal de São José dos Campos: Cidade e Poder. São Paulo: Intergraf. Série São José dos Campos: História e Cidade, vol. 2. 2009.

GOUVÊA, Rosana Aparecida Ravanelli. O espaço urbano e a clandestinidade: um estudo de caso dos loteamentos clandestinos no município de São José dos Campos - SP. 235 f. Dissertação (mestrado) - Universidade do Vale do Paraíba. São José dos Campos, 2003.

GOTTDIENER, M. A Produção Social do Espaço Urbano. Tradução: Geraldo G. De Souza. São Paulo: Edusp,1993.

GRUPO DE PESQUISAS ECONÔMICAS DA UNIVAP. Loteamentos Clandestinos. Revista Univap v.9, n13 - UNIVAP, 2001.

GUERRA, Antonio José Teixeira; CUNHA, Sandra Baptista (Org). Impactos ambientais urbanos no Brasil. Rio de Janeiro: Bertrand Brasil, 2001.

HARVEY, David. A produção capitalista do espaço. São Paulo: Annablume, 2005.

Condição Pós-moderna. São Paulo: Ed Loyola. 1992.

A Justiça Social e a Cidade. São Paulo: Hucitec, 1973.

IPEA, IBGE, UNICAMP, IE, NESUR, SEADE. Caracterização e tendências da rede urbana do Brasil: redes urbanas regionais: Sudeste. vol. 5. Brasília: IPEA, 2001.

JACOBI, Pedro. Cidade e meio ambiente: percepções e práticas em São Paulo. São Paulo: Annablume, 2000.

JACOBI, Pedro. Poder Local, Políticas Sociais e Sustentabilidade. Revista Saúde e Sociedade. N. 8(1):31-48. 1999.

KUBRUSLY, Violêta Saldanha. Gestão sócio-ambiental urbana e o geoprocessamento como apoio estratégico para análise do território: o caso da bacia hidrográfica do Guarapiranga (Tese de Doutorado), Faculdade de Filosofia, Letras e Ciências Humanas, Universidade de São Paulo. São Paulo, 2001.

LEFEBVRE, Henri. Le droit á la ville . Éditions Anthropos. Paris, 1968.

La production de I'espace. Paris: Anthropos, 1974.

LENCIONI, Sandra. Reestruturação urbano-industrial no Estado de São Paulo: a região da metrópole desconcentrada. In: Território: globalização e fragmentação. São Paulo: Hucitec, 1998.

Observações sobre os conceitos de cidade e urbano. Revista GEOUSP: Espaço e Tempo, São Paulo, No 24, 2008.

LEONELLI, Gisela C. V. Da gleba ao lote: dinâmica e produção da insustentabilidade ambiental urbana. (Dissertação de Mestrado). Escola de Engenharia de São Carlos. Universidade de São Paulo. São Carlos, 2003.

LESSA, S. N. São José dos Campos: o planejamento e a construção do polo regional do Vale do Paraíba. (Tese de doutorado). Instituto de Filosofia e Ciências Humanas, Universidade Estadual de Campinas, 2001. 
A construção do polo regional do Vale do Paraíba: planejamento regional e ordenamento territorial de São José dos Campos. In: PAPALLI, M.A. e ZANETTI, V. (orgs). Os Campos da Cidade: São José Revisitada. São Paulo: Intergraf. Série São José dos Campos: História e Cidade, vol. 1. 2008

LOBÃO, Isabella Guimarães. O Processo de planejamento urbano na vigência do Estatuto da Cidade: os casos dos Planos Diretores de 2006 de São José dos Campos e de Pindamonhangaba. 372f. (Dissertação de Mestrado) Faculdade de Arquitetura e Urbanismo. Universidade de São Paulo. São Paulo, 2007.

MARCONDES, Maria J. de A. Cidade e Natureza: proteção dos mananciais e exclusão social. São Paulo: Studio Nobel, 1999.

MARICATO, Ermínia. As idéias fora do lugar e o lugar fora das idéias. In: ARANTES, O. VAINER, C. e MARICATO, E. A cidade do pensamento único: desmanchando consensos. Petrópolis: Vozes, 2000.

Construindo a política urbana [documento on line]. 2005. Disponível em: <http://www.usp.br/fau/depprojeto/labhab/biblioteca/textos/maricato_construindopolitic aurb.pdf $>$ Acesso em 7 de abril de 2010.

MECHI, André; SANCHES, Djalma Luiz. Impactos ambientais da mineração no Estado de São Paulo. Revista Estudos Avançados. Vol.24, n.68. São Paulo, 2010.

MELLO, Neli Aparecida de. Políticas territoriais na Amazônia. São Paulo: Annablume, 2006.

MEUNIER, Isabelle. Por que as áreas verdes são tão importantes para uma cidade? Universidade Federal de Pernambuco, 2008

MENDONÇA, Francisco de Assis. Geografia e meio ambiente. 5.ed. São Paulo: Contexto, 2001.

MINISTÉRIO DAS CIDADES. Planejamento territorial urbano e política fundiária. Cadernos do Ministério das Cidades 3. Brasília, 2004.

Planejamento Territorial Urbano e Política Fundiária com Inclusão social. Secretária Nacional de Programas Urbanos. Disponível em: $<$ www.cidades.gov.br/index.php?option $=\quad$ content\&task $=$ section \&id=\&menupid=203\&menutp=progurb5> Acesso em: 10 de janeiro de 2005 .

MONTANHeIRo, Tarcisio José (Coord). Projeto Paraíba do Sul: potencialidade de areia. Edição Digital. Instituto Geológico. Secretaria do Meio Ambiente. Governo do Estado de São Paulo. 2009. Disponível em: < http://www.igeologico.sp.gov.br/ler noticia.asp?id=330 > Acesso em 05 de maio de 2011.

MORAES, A. C. R. e COSTA, W. M. da. Geografia crítica: a valorização do espaço. São Paulo, Hucitec, 1984.

MORAES, A. C. R. Meio ambiente e ciências humanas. São Paulo: Hucitec, 2005.

. Notas sobre formação territorial e políticas ambientais no Brasil. Revista Território. Rio de Janeiro, ano IV, n. 7, p. 43·50, jul./dez. 1999.

MOREIRA, Ruy. Pensar e ser em geografia: ensaios de história, epistemologia e ontologia do espaço geográfico. São Paulo: Contexto, 2008.

MOREIRA, A.C.M.L., Plano diretor e função social da propriedade urbana. In: CEPAM. Estatuto da Cidade. São Paulo: Cepam, 2001.

MORELLI, A. F. Identificaçãoo e transformação das unidades da paisagem no município de São José dos Campos (SP) de 1500 a 2000. (Tese de Doutorado) Instituto do Geociências e Ciências Exatas - Campus Rio Claro da Universidade Estadual Paulista, 2002. 
OLIVEIRA, Jose Oswaldo Soares de. São José dos Campos: evolução histórica e diretrizes urbanas. São Jose dos Campos, São Paulo: J.O.S. de Oliveira, 1999.

PAPALI, M.A., ALMEIDA, V.Z., ACEDO DEL OMO, M.J. São José dos Campos e sua História. Prómemória. Câmara municipal de São José dos Campos. Disponível em: < http://www.camarasjc.sp.gov.br/promemoria/>, Acesso em: 10 de maio de 2011.

REANI, Regina Tortorella e CRIVELARO, S.H.R. Planejando Cidades com a Biodiversidade. In: Anais do II Congresso Luso Brasileiro para o Planejamento Urbano, Regional, Integrado e Sustentável (PLURIS), Braga-Portugal, 2006.

REANI, Regina Tortorella. Parcelamento irregular do solo como forma de produção de periferia: o caso de Jundiaí/SP. Dissertação de Mestrado. Centro de Ciências Exatas e Tecnologia. Universidade Federal de São Carlos. São Carlos, 2007.

RIBEIRO, L.C.Q. e CARDOSO, A.L. Planejamento urbano no Brasil: paradigmas e experiências. Espaço e Debates, no 37. São Paulo, 1994.

RODRIgUeS, A. M. Produção e consumo do e no espaço: problemática ambiental urbana. (Arquivo digital), 2005.

ROLNIK. R. Planejamento e gestão: um diálogo de surdos? IN: CEPAM. Estatuto da Cidade. São Paulo: Cepam, 2001

ROSA FILHO, Artur. As políticas públicas do poder Municipal na remoção e/ou reurbanizaçãoo de favelas no Município de São José dos Campos. (Dissertação de Mestrado), Universidade do Vale do Paraíba, Instituto de Pesquisa e Desenvolvimento, São José dos Campos, 2002.

SACHS, Ignacy. Caminhos para o desenvolvimento sustentável. 3. ed. Rio de Janeiro: Garamond, 2008.

Estratégias de transição para o século XXI: Desenvolvimento e meio ambiente. São Paulo, SP: Studio Nobel Fundap, 1993.

SANTOS, Ademir Pereira dos. De cobaia a feiticeiro (ou para se ler paisagens urbanas recentes em São José dos Campos). In: Cadernos do CIRC - Centro de Informações e Referências Culturais. São José: a cidade, a cultura e seu tempo. Ano I - n.1. São José dos Campos: Fundação Cassiano Ricardo, 1996.

São José dos Campos: arquitetura industrial. São José dos Campos: Fundação Cassiano Ricardo, 2006.

SANTOS, Milton. 0 espaço do cidadão. 7 ed. São Paulo: Editora da Universidade de São Paulo, 2007.

Espaço e método. 5. ed. São Paulo: EDUSP, 2008.

Por uma outra globalização: do pensamento único a consciência universal. 18ed. Rio de Janeiro: Record, 2009.

Por uma economia política da cidade. São Paulo: Hucitec. 1994

A natureza do espaço: técnica e tempo, razão e emoção. 4. ed. São Paulo: Edusp, 2008.

Por uma Geografia nova: da crítica da geografia a uma geografia crítica. São Paulo: Hucitec, 1978.

Técnica, espaço, tempo: globalização e meio técnico-ceintífico-informacional. 2. ed. São Paulo: Hucitec, 1996. 
SANTOS, Milton e SILVEIRA, Maria Laura. O Brasil: Território e sociedade no início do século XXI. Rio de Janeiro: Record, 2001.

SCARLATO, F. C. População e urbanização brasileira. In: ROSS, J.L.S. (org). Geografia do Brasil. São Paulo: Edusp, 1995.

SAULE JR, N.; ROLNIK, Raquel. Estatuto da Cidade: novos horizontes para a reforma urbana. Cadernos Pólis 4, São Paulo: Pólis, 2001.

SILVA-SÁNCHES, Solange S. Cidadania ambiental: novos direitos no Brasil. São Paulo: Humanitás (FFLCH/USP) e Annablume, 2000.

SOUSA, A. M. S; SOARES, L. L. Modernidade e Urbanismo Sanitário: São José dos Campos. São José dos Campos. Fundação Cultural Cassiano Ricardo: São Paulo, 2002.

SOUZA, Adriane A. Moraes de. A especialização do lugar: São José dos Campos como Centro de Tecnologia aeroespacial no país. (Tese de Doutorado - Programa de Pós-graduação em Geografia Humana). Faculdade de Filosofia, Letras e Ciências Humanas, Universidade de São Paulo. São Paulo, 2008.

SOUZA, Celina. "Estado do campo" da pesquisa em políticas públicas no Brasil. In: Revista Brasileira de Ciências Sociais. vol.18, n.51, São Paulo, 2003.

. Estado da arte da pesquisa em políticas públicas. In: Gilberto Hochman, Marta Arretche e Eduardo Marques (orgs) Políticas públicas no Brasil. Rio de Janeiro: Editroa Fiocruz, 2007.

SOUZA, Marcelo Lopes de. Mudar a cidade: uma introdução crítica ao planejamento e à gestão urbanos. 4. ed. Rio de Janeiro: Bertrand Brasil, 2003.

SOUZA, Marcelo Lopes de, e RODRIGUES, Glauco Bruce. Planejamento urbano e ativismos sociais. São Paulo: UNESP, 2004.

STEINBERGER, Marília (org). Território, ambiente e políticas públicas espaciais. Brasilia: Paralelo 15 e LGE Editora, 2006.

TODESCO, Carolina. Presença ausente e ausência presente do Estado na produção do espaço para o turismo no Vale do Ribeira Paulista. Revista Confins. n.9 [on line]. 2010. Disponível em: < http://confins.revues.org/6484>. Acesso em: 21 de abril de 2011.

TODESCO, Carolina. Estado e terceiro setor na organização do espaço para o turismo no Vale do Ribeira. 208f. (Dissertação de Mestrado), Faculdade de Filosofia, Letras e Ciências Humanas, Universidade de São Paulo, 2007.

TRINCA FIGHERA, Delfina. Estado e território: suas relações e a globalização. In: SANTOS, Milton; Silveira, Maria Laura; Souza, Maria Adélia A. de. Território: globalização e fragmentação. São Paulo: HUCITEC, 1996,

TROPPMAIR, Helmunt. Biogeografia e Meio Ambiente. Ed. do Autor: Rio Claro, 1992.

VAINER, Carlos B. Pátria, empresa e mercadoria - notas sobre a estratégia discursiva do Planejamento Estratégico Urbano. In: ARANTES, O. VAINER, C.B. e MARICATO, E. A cidade do pensamento único: desmanchando consensos. Rio de Janeiro: Vozes, 2009.

VEIGA, José Eli da. Desenvolvimento Sustentável: O desafio do Século XXI. Rio de Janeiro: Ed. Garamond, 2005.

VIANNA, Paula Vilhena Carnevale. Saúde e cidade: uma relação inscrita no espaço e no tempo; a fase sanatorial de São José dos Campos (SP) e sua influencia sobre os serviços de saúde da década de 1980. (Tese de Doutorado). UNIFESP. Universidade de São Paulo. 2004. 
VIANNA, Paula Vilhena Carnevale; ELIAS, Paulo Eduardo M. Cidade sanatorial, cidade industrial: espaço urbano e política de saúde em São José dos Campos. Caderno de Saúde Pública, Rio de Janeiro, 23(6):1295-1308, jun, 2007.

VILLAÇA, Flávio. Espaço Intra-Urbano. São Paulo: Studio Nobel, 1998.

Uma contribuição para a história do planejamento no Brasil. In: DEÁK, C.; SCHIFFER, S.

R. (Org.). O processo de urbanização no Brasil. São Paulo: Edusp, 1999.

. A crise do planejamento urbano. São Paulo em Perspectiva. (9) 2. 1995. Disponível em: http://201.55.54.204/produtos/spp/v09n02/v09n02_07.pdf > Acesso em 22 de fevereiro de 2010 .

\section{REFERÊNCIAS ELETRÔNICAS:}

CÂMARA MUNICIPAL DE SÃO JOSÉ DOS CAMPOS. Leis Municipais. Disponível em: < http://www.ceaam.net/sjc/legislacao/> Acesso em: 10 de maio de 2011.

CARTA DE ATENAS, $1933 . \quad$ Disponível em: http://portal.iphan.gov.br/portal/baixaFcdAnexo.do?id=233 > Acesso em 15 de agosto de 2010.

CEMPRE (Compromisso Empresarial para Reciclagem). CEMPRECICLOSOFT2008. Disponível em: < http://cempre.tecnologia.ws/ciclosoft 2008.php> Acesso em 10 de abril de 2012.

CEMPRE (Compromisso Empresarial para Reciclagem). Cempre Informa. Número 113 setembro/outubro 2010. Disponível em: < http://cempre.tecnologia.ws/ciclosoft 2008.php > Acesso em 10 de abril de 2012.

CETESB (Companhia Ambiental do Estado de São Paulo) http://www.cetesb.sp.gov.br

Resolução SMA 28/99, Zoneamento ambiental para atividade de extração de areia na Várzea do Rio Paraíba do Sul. Disponível em: <http://www.ambiente.sp.gov.br/wp/cpla/files/2011/09/mapa-paraibadosul.pdf> Acesso em: 23 de maio de 2012.

Google Earth® 2012. Imagens de São José dos Campos. (C2012 Map Link/Tele Atlas. Image@ 2012 DigitalGlobe. (Data da Imagem 9/2/2011). Acesso em: 15 de julho de 2012.

IBGE - INSTITUTO BRASILEIRO DE GEOGRAFIA E ESTATISTICA. Disponível em: < http://www.ibge.gov.br>.Acesso em: 10 out. 2010.

INSTITUTO PÓLIS. Estatuto da cidade: guia para implementação pelos municípios e cidades. Disponível em: < http://www.polis.org.br/publicacoes/ download/150.html>. Acesso em 2005.

JORNAL VNews. Disponível em: < http://www.vnews.com.br/> Acesso em: 12 de maio de 2012.

SEADE - FUNDAÇÃO SISTEMA ESTADUAL DE ANÁLISE DE DADOS. Informações dos Municípios Paulistas. Disponível em: < http://www.seade.gov.br/cgi-bin/lingcv98/spd 01.ksh > Acesso em: 15 set de 2010.

SECRETARIA DE DESENVOLVIMENTO ECONÔMICO. (Prefeitura Municipal de São José dos Campos). $<$ http://www.sjc.sp.gov.br/secretarias/desenvolvimento_economico.aspx > Acesso em 18 março de 2012.

SECRETARIA DE OBRAS. (Prefeitura Municipal de São José dos Campos). Sistema Municipal de Informação em Saneamento Básico. Disponível em: < http://www.sjc.sp.gov.br/secretarias/obras/simisa.aspx> Acesso em 18 março de 2012. 
SECRETARIA DE PLANEJAMENTO URBANO. (Prefeitura Municipal de São José dos Campos). Disponível em: < http://www.sjc.sp.gov.br/secretarias/planejamento_urbano.aspx> Acesso em 18 março de 2012.

SEMEA (Secretaria Municipal de Meio Ambiente- PMSJC) Disponível em: <http://www.sjc.sp.gov.br/secretarias/meio ambiente.aspx> Acesso em 18 março de 2012.

SEMEA (Secretaria Municipal de Meio Ambiente - PMSJC). Lista de Notícias. Disponível em: < http://www.sjc.sp.gov.br/secretarias/meio ambiente/lista.aspx> Acesso em: 10 abril de 2012.

SEMEA (Secretaria Municipal de Meio Ambiente- PMSJC). Pontos de Entrega Voluntária (PEVs). Disponível em: <http://www.sjc.sp.gov.br/secretarias/meio ambiente/pev.aspx> Acesso em: 10 abril de 2012 .

SMA (Secretaria do Meio Ambiente do Estado de São Paulo). Disponível em: < http://www.ambiente.sp.gov.br/ >._Acesso em 27 março de 2012.

URBAM (Urbanizadora Municipal S/A). Disponível em: <http://www.urbam.com.br>

$<$ http://www.urbam.com.br/SiteNovo/Servicos/ETRS.aspx $>$

$<$ http://www.urbam.com.br/SiteNovo/Servicos/LimpezaPublica.aspx>

<http://urbam.com.br/SiteNovo/Servicos/ColetaSeletiva.aspx>

$<$ http://urbam.com.br/SiteNovo/Servicos/Reciclagem.aspx>

\section{LEGISLAÇÃO CONSULTADA:}

BRASIL. Lei no 4.771, de 15 de setembro de 1965. Institui o novo código florestal. (Revogado pela Lei no 7.803, de18 de julho de 1989). Disponível em:< http://www.planalto.gov.br/ccivil 03/leis/14771.htm> Acesso em: 10 de fev. de 2011.

BRASIL. Lei no 6.766, de19 de dezembro de 1979. Dispõe sobre o Parcelamento do Solo Urbano e dá outras Providências. Disponível em: < http://www.planalto.gov.br/ccivil_03/leis/l6766.htm> Acesso em: 10 de fev. de 2011.

BRASIL. Lei no 6.938, de 31 de agosto de 1981. Política Nacional do Meio Ambiente. Disponível em: < http://www.planalto.gov.br/ccivil_03/leis/16938.htm> Acesso em: 10 de fev. de 2011.

BRASIL. Constituição da República Federativa do Brasil de 1988. Disponível em: < http://www.planalto.gov.br/ccivil_03/constituicao/constitui\%C3\%A7ao.htm> Acesso em: 10 de fev. de 2011.

BRASIL. Lei no 10.257, de10 de julho de 2001. Regulamenta os arts. 182 e 183 da Constituição Federal, estabelece diretrizes gerais da política urbana e dá outras providências. (Estatuto da Cidade). Disponível em: < http://www.planalto.gov.br/ccivil 03/leis/leis 2001/l10257.htm> Acesso em: 10 de fev. de 2011.

BRASIL. Lei no 9.985, de 18 de julho de 2000. Institui o Sistema Nacional de Unidades de Conservação da Natureza e dá outras providências. Disponível em: < http://www.planalto.gov.br/ccivil_03/leis/19985.htm> Acesso em: 10 de fev. de 2011.

BRASIL. Lei no 6.902, de 27 de abril de 1981. Dispõe sobre a criação de Estações Ecológicas, Áreas de Proteção Ambiental e dá outras providências. . Disponível em: <http://www.jusbrasil.com.br/legislacao/110257/lei-6902-81> Acesso em: 10 de fev. de 2011.

BRASIL. Lei no 9.605, de12 de fevereiro de 1998. Dispõe sobre as sanções penais e administrativas derivadas de condutas e atividades lesivas ao meio ambiente, e dá outras providências. (Crimes Ambientais). Disponível em: http://www.planalto.gov.br/ccivil 03/leis/l9605.htm> Acesso em: 10 de fev. de 2011.

BRASIL. Resolução CONAMA 306/2006. Dispõe sobre os casos excepcionais, de utilidade pública, interesse social ou baixo impacto ambiental, que possibilitam a intervenção ou supressão de vegetação em Área de Preservação Permanente - APP. Disponível em: < http://www.mma.gov.br/port/conama/legiabre.cfm?codlegi=489 > Acesso em: 10 de fev. de 2011.

SÃO PAULO. Resolução SMA No 42, de 16 de setembro de 1996. Disciplina o licenciamento ambiental dos empreendimentos minerários de extração de areia na Bacia Hidrográfica do Rio Paraíba do Sul. Disponível em: http://licenciamento.cetesb.sp.gov.br/legislacao/estadual/resolucoes/1996 Res SMA 42.pdf $>$ Acesso em: 10 de maio de 2011.

SÃO PAULO. Resolução SMA No 28, de 22 de setembro de 1999. Dispõe sobre o zoneamento ambiental para mineração de areia no subtrecho da bacia hidrográfica do Rio Paraíba do Sul 
inserido nos municípios de Jacareí, São José dos Campos, Caçapava, Taubaté, Tremembé e Pindamonhangaba, e dá providências corre latas. Disponível em: < http://licenciamento.cetesb.sp.gov.br/legislacao/estadual/resolucoes/1999 Res SMA 28.pdf $>$ Acesso em: 10 de maio de 2011.

SÃO JOSÉ DOS CAMPOS. Lei Municipal no 1.606, de 13 de setembro de 1971. Disponível em: < http://www.ceaam.net/sjc/legislacao/>. Acesso em: 20 jul. 2011.

SÃO JOSÉ DOS CAMPOS. Lei Municipal no 1.623, de 30 de novembro de 1971. Institui o Plano Diretor de Desenvolvimento Integrado do Município de São José dos Campos, e dá outras providências. Disponível em: < http://www.ceaam.net/sjc/legislacao/>. Acesso em: 20 jul. 2011.

SÃO JOSÉ DOS CAMPOS. Lei Municipal no 2.263, de 04 de janeiro de 1980. Dispõe sobre o parcelamento, uso e ocupação do solo do Município e dá outras providências. Disponível em: < http://www.ceaam.net/sjc/legislacao/>. Acesso em: 20 jul. 2011.

SÃO JOSÉ DOS CAMPOS. Lei Municipal no 3.721, de 25 de janeiro de 1990. Dispõe sobre o parcelamento, uso e ocupação do solo do Município de São José dos Campos e dá outras providências. Disponível em: < http://www.ceaam.net/sjc/legislacao/>. Acesso em: 20 jul. 2011.

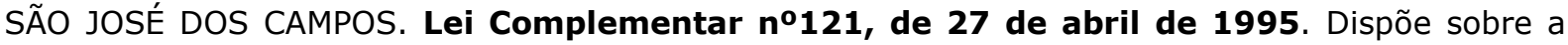
Política Territorial e Urbana do Município, institui o Plano Diretor de Desenvolvimento Integrado da Cidade de São José dos Campos, e dá outras providências. Disponível em: < http://www.ceaam.net/sjc/legislacao/>. Acesso em: 20 jul. 2011.

SÃO JOSÉ DOS CAMPOS. Lei Complementar no 165, de 15 de dezembro de 1997. Dispõe sobre a ordenação do território mediante controle do parcelamento, do uso e da ocupação do solo no Município de São José dos Campos. Disponível em: < http://www.ceaam.net/sjc/legislacao/>. Acesso em: 20 jul. 2011.

SÃO JOSÉ DOS CAMPOS. Lei Complementar no 306, de 17 de novembro de 2006. Aprova e institui o Plano Diretor de Desenvolvimento Integrado - PDDI do Município de São José dos Campos para o próximo decênio e dá outras providências. Disponível em: < http://www.ceaam.net/sjc/legislacao/>. Acesso em: 20 jul. 2011.

SÃO JOSÉ DOS CAMPOS. Lei Complementar no 428, de 9 de agosto de 2010. Estabelece as normas relativas ao parcelamento, uso e ocupação do solo em São José dos Campos, e dá outras providências. Disponível em: < http://www.ceaam.net/sjc/legislacao/>. Acesso em: 20 jul. 2011.

\section{PREFEITURA DE SÃO JOSÉ DOS CAMPOS:}

PMSJC - PREFEITURA MUNICIPAL DE SÃO JOSÉ DOS CAMPOS. Cidade Viva 2011, Banco de dados do Spring. [CD-ROOM]. Secretaria Municipal de Planejamento Urbano. São José dos Campos. 2011.

Plano Municipal de Saneamento Básico. 2008. Disponível em: < http://www.sjc.sp.gov.br/secretarias/obras/simisa/plano municipal.aspx> Acesso em: $10 \mathrm{de}$ abril de 2012.

Jornal Correio Joseense. Arquivo Público Municipal. São José dos Campos. 1935-1967.

A cidade. Disponível em: < http://www.sjc.sp.gov.br/acidade/> Acesso em: 12 de agosto de 2010.

- Plano Preliminar do Plano Diretor de Desenvolvimento Integrado 1961. CPEU,FAU,USP. Arquivo da Secretaria de Planejamento Urbano de São José dos Campos. Paço Municipal. São José dos Campos. 1961.

. Plano Preliminar do Plano Diretor de Desenvolvimento Integrado 1971. SERET S/A. Arquivo da Secretaria de Planejamento Urbano de São José dos Campos. Paço Municipal. São José dos Campos. 1971.

Plano Preliminar do Plano Diretor de Desenvolvimento Integrado 1995. UNESP. Arquivo da Secretaria de Planejamento Urbano de São José dos Campos. Paço Municipal. São José dos Campos. 1995.

Mapa da Lei de Zoneamento de 1980. Arquivo da Secretaria de Planejamento Urbano de São José dos Campos. Paço Municipal. São José dos Campos. 1980.

Mapa da Lei de Zoneamento de 1990. Arquivo da Secretaria de Planejamento Urbano de São José dos Campos. Paço Municipal. São José dos Campos. 1990.

Mapa da Lei de Zoneamento de 1997. Arquivo da Secretaria de Planejamento Urbano de São José dos Campos. Paço Municipal. São José dos Campos. 1997.

Mapa da Lei de Zoneamento de 1971. Arquivo 15. Arquivo Público Municipal. São José dos Campos. 1973.

Planta da Cidade de 1936. Arquivo 18.2. Arquivo Público Municipal. São José dos Campos. 1936. 
Caderno Diagnóstico do Plano Diretor de 1995. Disponível em: < http://www.sjc.sp.gov.br/secretarias/planejamento_urbano.aspx>. Acesso em: 08 de jun de 2010.

Caderno Diagnóstico do Plano Diretor de 2006. Disponível em: <http://www.sjc.sp.gov.br/secretarias/planejamento urbano.aspx>. Acesso em: 08 de jun de 2010.

Galeria de Fotos. Disponível em: < http://www.sjc.sp.gov.br/galeria-de-fotos/acidade.aspx>. Acesso em: 23 de jul. de 2010.

Caderno Diagnóstico da Lei de Zoneamento de 2010. Disponível em: <http://www.sjc.sp.gov.br/secretarias/planejamento urbano.aspx>. Acesso em: 08 de jun de 2010.

Atlas das Condições de Vida em São José dos Campos - 2004. NEPO/Unicamp. Disponível em: <http://www.sjc.sp.gov.br/secretarias/planejamento urbano.aspx>. Acesso em: 08 de jun de 2010.

Cadastro das Indústrias em São José dos Campos - 2004. Disponível em: <http://www.sjc.sp.gov.br/secretarias/planejamento urbano.aspx>. Acesso em: 08 de jun de 2010.

- São José em dados - 2008. Disponível em: $<$ http://www.sjc.sp.gov.br/secretarias/planejamento urbano.aspx>. Acesso em: 08 de jun de 2010.

\section{ENTREVISTAS}

- CAMIN (ONG) -- Vera Assis e Profa Delma de Mattos Vida, realizada em 05 de julho de 2012.

- CETESB - Valéria, Analista ambiental, realizada em 2 de julho de 2012.

- POLÍCIA AMBIENTAL - Soldado Messias, realizada em 10 de julho de 2012.

- SECRETARIA MUNICIPAL DE HABITAÇÃO - Adalberto, supervisor divisão de regularização fundiária, realizadas em 14 de junho de 2012.

- SECRETARIA MUNICIPAL DE MEIO AMBIENTE - Bióloga Rosana, realizada em 05 de outubro de 2011.

- URBAM - Engenheiro Ambiental Rodrigo, realizada em 10 de fevereiro de 2012.

- URBAM - Sr. Rogério - Coordenador do Centro de Triagem e Sr. André - Acessor, realizada em 15 de junho de 2012 . 
Tabela 9 - Análise da Legislação de São José dos Campos

\begin{tabular}{|c|c|c|c|}
\hline LEI & POLÍTICAS AMBIENTAIS PREVISTAS & POLÍTICAS AMBIENTAIS ADOTADAS & PARECER \\
\hline \multicolumn{4}{|l|}{ PLANO DIRETOR } \\
\hline \multirow[t]{4}{*}{$\begin{array}{l}\text { O Primeiro Plano } \\
\text { Diretor (1961) }\end{array}$} & - Zoneamento de massa. & $\begin{array}{l}\text { - O zoneamento de massa passou a dividir a cidade nas zonas: } \\
\text { residencial, comercial, industrial, federal (CTA) e áreas verdes. } \\
\text { Foi revogado pelo zoneamento } 1971 \text {, que trouxe grandes } \\
\text { mudanças ao que havia sido planejado em } 1961 \text {. }\end{array}$ & $\begin{array}{l}\text { Parcialmente } \\
\text { Executado }\end{array}$ \\
\hline & - Separar a poluição industrial das áreas residenciais. & $\begin{array}{l}\text { - Durante a vigência da legislação não se instalaram indústrias } \\
\text { poluidoras na área urbana. Foi respeitado até a aprovação do } \\
\text { novo zoneamento em } 1971 \text {. }\end{array}$ & Executado \\
\hline & - Preservar a captação de água para a população. & $\begin{array}{l}\text { - Durante a vigência da legislação não se instalaram indústrias } \\
\text { poluidoras ao longo do Rio Paraíba do Sul. }\end{array}$ & Executado \\
\hline & - Inibir a especulação imobiliária (Lei nº 5.261 de 1959). & $\begin{array}{l}\text { - Já nesta época surgem os primeiros loteamentos clandestinos, } \\
\text { outros loteamentos são construídos sem os requisitos } \\
\text { necessários. Aumentam as áreas de vazios urbanos. }\end{array}$ & Não Executado \\
\hline \multirow{7}{*}{$\begin{array}{l}\text { Anhaia Mello e } \\
\text { L. B. Birkhoz }\end{array}$} & $\begin{array}{l}\text { - Proibir a aprovação de loteamentos sem condições mínimas de } \\
\text { benefícios públicos, tais como: rede de água e luz elétrica (Lei no } \\
657 / 60 \text { ). }\end{array}$ & $\begin{array}{l}\text { - Tais exigências elevaram o preço da terra, posteriormente a } \\
\text { prefeitura através dos Decretos } 1437 / 71,1792 / 74,1826 / 75 \\
\text { concedeu alvará de construção para } 21 \text { loteamentos irregulares }\end{array}$ & Não Executado \\
\hline & $\begin{array}{l}\text { - Delimitar o loteamento de uso urbano e rural (Decreto } n^{\circ} \\
\text { 286/54). }\end{array}$ & $\begin{array}{l}\text { - O parcelamento do solo para fins urbanos continuou a ocorrer } \\
\text { na área rural. }\end{array}$ & Não Executado \\
\hline & - Criação de um consórcio para o Vale do Paraíba. & $\begin{array}{l}\text { - Na década de } 1970 \text { tivemos a criação do Consórcio de } \\
\text { Desenvolvimento do Vale do Paraíba e Litoral Norte (CODIVAP). }\end{array}$ & Executado \\
\hline & $\begin{array}{l}\text { - Criação de um órgão de planejamento urbano, com poder } \\
\text { deliberativo, ligado direto ao prefeito. }\end{array}$ & $\begin{array}{l}\text { - Tal órgão foi previsto em outras legislações municipais, mas } \\
\text { nunca foi efetivado. }\end{array}$ & Não Executado \\
\hline & - Plano de desfavelamento da favela denominada "Linha Velha". & $\begin{array}{l}\text { - O projeto não foi colocado em prática, somente no final da } \\
\text { década de } 1970 \text {, apenas uma parte da favela foi removida. }\end{array}$ & Não Executado \\
\hline & $\begin{array}{l}\text { - Ampliação da captação e da adução; ampliação da rede de } \\
\text { distribuição e ampliaça do sistema de controle e eliminação das } \\
\text { perdas e do desperdício. }\end{array}$ & $\begin{array}{l}\text { Em 1968, a Prefeitura contratou uma empresa especializada e } \\
\text { concluiu o novo Plano de Abastecimento de água e esgoto para a } \\
\text { cidade, cumprindo as diretrizes do PDDI (BOLOGNA, 2000). }\end{array}$ & Executado \\
\hline & $\begin{array}{l}\text {-Ampliar e investir na estação de tratamento de esgoto, e também, } \\
\text { ampliar a abrangência do sistema de rede de esgoto. }\end{array}$ & $\begin{array}{l}\text { Em } 1963 \text { foi executada a lagoa de oxidação para o tratamento } \\
\text { de esgoto, a primeira do país. (BOLOGNA, 2000). }\end{array}$ & Executado \\
\hline \multirow[t]{2}{*}{$\begin{array}{l}\text { O PDDI de } 1971 \\
\text { (Lei no } 1.623 / 71)\end{array}$} & $\begin{array}{l}\text { - Divide o município em três áreas, para efeito do uso do solo: } \\
\text { área urbana, área de expansão urbana e área rural: } \\
\text { - Prevê a ocupação dos vazios urbanos, principalmente na região } \\
\text { sul. } \\
\text { - Prevê a ocupação da várzea do Rio Paraíba. }\end{array}$ & $\begin{array}{l}\text { - A ocupação dos vazios urbanos não ocorreu; } \\
\text { - Com a criação da Refinaria de Petróleo Henrique Lage, na } \\
\text { região nordeste, a cidade passa a ter um novo vetor de } \\
\text { crescimento; } \\
\text { - A malha urbana é novamente estendida e os vazios urbanos } \\
\text { aumentam novamente. } \\
\text { - A ocupação da várzea do Rio Paraíba é proposta sem estudo } \\
\text { ambiental, felizmente tal fato não se concretizou. }\end{array}$ & Não Executado \\
\hline & - Inibir a expansão horizontal da cidade. & $\begin{array}{l}\text { - Tal prática elevou o preço da terra e gerou a expansão dos } \\
\text { loteamentos clandestinos. }\end{array}$ & Não Executado \\
\hline
\end{tabular}




\begin{tabular}{|c|c|c|c|}
\hline \multirow[t]{3}{*}{ Jorge Wilhein } & - Prevê a criação de um Sistema Verde, para recreação ao ar livre. & $\begin{array}{l}\text { - Como aponta Caderno Diagnóstico do PDDI- 2006, a } \\
\text { implantação do Sistema Verde não teve êxito. Das } 150 \text { áreas } \\
\text { verdes previstas para } 1980 \text {, apenas três foram incluídas no } \\
\text { Plano Plurianual e implantadas. }\end{array}$ & Não Executado \\
\hline & $\begin{array}{l}\text { - Ampliação do Sistema de Esgotos Sanitários (tendo prioridade: a } \\
\text { Bacia do Lavapés e Parte da Bacia do Serimbura). }\end{array}$ & $\begin{array}{l}\text { - Houve ampliação da rede coletora de esgoto, porém o } \\
\text { tratamento de esgoto não é ampliado. }\end{array}$ & Executado \\
\hline & $\begin{array}{l}\text { - Programa de desfavelamento. } \\
\text { - Desfavelamento da "Linha Velha". }\end{array}$ & $\begin{array}{l}\text { - Os projetos habitacionais não atendiam a demanda do } \\
\text { município, novas favelas surgem no período. Não existia uma } \\
\text { política de habitação. } \\
\text { - Apenas uma parte da favela foi removida, com o objetivo maior } \\
\text { de construir o Anel Viário e o Paço Municipal. }\end{array}$ & Não Executado \\
\hline \multirow[t]{6}{*}{$\begin{array}{l}\text { O PDDI de } 1995 \\
\left.\text { (Lei } n^{\circ} 121 / 95\right) \\
\text { Sob assessoria da } \\
\text { UNESP }\end{array}$} & $\begin{array}{l}\text { - Ordenar o município com base nas diretrizes constantes na } \\
\text { "Carta das Unidades Territoriais de Características Físicas e } \\
\text { Antrópicas Homogêneas", que identifica as potencialidades e } \\
\text { limitações para seu uso e ocupação. } \\
\text { - Macrozona Urbana, Macrozona de Expansão Urbana I e II, } \\
\text { Macrozona Rural, e Área de Proteção Ambiental (APA) I, II, III e IV }\end{array}$ & $\begin{array}{l}\text { - O Macrozoneamento do município em } 1995 \text { foi elaborado com } \\
\text { base nas orientações descritas na Carta das Unidades } \\
\text { Territoriais. Porém, na lei de zoneamento de } 1997 \text {, a área de } \\
\text { APA IV é alterada permitindo o uso residencial e industrial em } \\
\text { parte dela. }\end{array}$ & $\begin{array}{l}\text { Parcialmente } \\
\text { Executado }\end{array}$ \\
\hline & $\begin{array}{l}\text { - Incorporar loteamentos clandestinos a macrozona urbana na } \\
\text { região sudeste, aumentando o número de terras urbanizáveis e a } \\
\text { diminuição dos preços fundiários, e os demais loteamentos } \\
\text { clandestinos serão delimitados em bolsões específicos para } \\
\text { posterior inclusão no perímetro urbano e regularização urbanística } \\
\text { e fundiária. }\end{array}$ & $\begin{array}{l}\text { As ZEIS foram criadas pela lei de zoneamento } 165 / 1997 \text {. Porém, } \\
\text { os loteamentos clandestinos não foram regularizados e nem } \\
\text { integrados a área urbana, e ainda enfrentam inúmeros } \\
\text { problemas de infraestrutura, como a falta de rede de água e } \\
\text { esgoto. }\end{array}$ & Não Executado \\
\hline & $\begin{array}{l}\text { - Promover a elaboração do Plano Minerário do Município, } \\
\text { integrando neste processo a participação dos Municípios do médio } \\
\text { Vale do } \\
\text { - Promover a regulamentação do zoneamento minerário baseada } \\
\text { nas diretrizes estabelecidas no "Plano Minerário"; }\end{array}$ & $\begin{array}{l}\text { - A Secretaria do Meio Ambiente (SMA), do Governo do Estado } \\
\text { de São Paulo, promulga a Resolução SMA 42/96, que disciplina o } \\
\text { licenciamento ambiental dos empreendimentos minerários de } \\
\text { extração de areia na Bacia Hidrográfica do Rio Paraíba do Sul, e } \\
\text { a Resolução SMA } 28 / 99 \text {, especifica o zoneamento ambiental para } \\
\text { mineração de areia no subtrecho da bacia hidrográfica do Rio } \\
\text { Paraíba do Sul. } \\
\text { - No município de São José a mineração da areia está proibida, } \\
\text { mas existe uma forte pressão na câmara dos vereadores, para } \\
\text { que a exploração seja liberada. }\end{array}$ & Executado \\
\hline & - Criar o Fundo Municipal de Desenvolvimento Urbano. & $\begin{array}{l}\text { - Não é criado o Fundo Municipal, mas apenas o Conselho } \\
\text { Municipal de Desenvolvimento Urbano. }\end{array}$ & $\begin{array}{l}\text { Parcialmente } \\
\text { Executado }\end{array}$ \\
\hline & $\begin{array}{l}\text { - Criar o Instituto de Pesquisa e Planejamento Urbano do } \\
\text { Município. }\end{array}$ & $\begin{array}{l}\text { - Novamente é apontada a necessidade de criar um Instituto de } \\
\text { Planejamento Urbanao, mas a idéia não se concretiza. }\end{array}$ & Não Executado \\
\hline & - Institucionalizar a política ambiental do Município. & $\begin{array}{l}\text { - O PDDI de } 1995 \text { avança nas questões ambientais, faz um } \\
\text { estudo das características físicas do município e propõe o } \\
\text { ordenamento do espaço urbano com bases nestas } \\
\text { características, mas na prática o plano é parcialmente aplicado. }\end{array}$ & $\begin{array}{l}\text { Parcialmente } \\
\text { Executado }\end{array}$ \\
\hline
\end{tabular}




\begin{tabular}{|c|c|c|c|}
\hline & $\begin{array}{l}\text { - Criar um inventário das principais fontes de produção, emissão } \\
\text { de detritos, líquidos e gasosos instalados no Município. }\end{array}$ & $\begin{array}{l}\text { - Foi apenas mapeado as fontes poluidoras, mas não existe um } \\
\text { inventário sobre elas. }\end{array}$ & $\begin{array}{l}\text { Parcialmente } \\
\text { Executado }\end{array}$ \\
\hline & - Criar um Programa de controle da qualidade do ar e sonora. & - O programa não foi efetivado. & Não Executado \\
\hline & $\begin{array}{l}\text { - Criar um Programa de controle das atividades que apresentam } \\
\text { periculosidade significativa. }\end{array}$ & - O programa não foi efetivado & Não Executado \\
\hline & $\begin{array}{l}\text { - Programa de controle e tratamento de esgotos domésticos do } \\
\text { Município (O município coleta apenas } 81 \% \text { do esgoto doméstico e } \\
\text { trata apenas } 1,5 \% \text { do esgoto doméstico. Os rios e córregos } \\
\text { urbanos, como Vidoca, Cambuí, Senhoria, entre outros, são } \\
\text { altamente poluídos - PDDI 1995). }\end{array}$ & $\begin{array}{l}\text { - Em } 1997 \text { a Sabesp inaugura a Estação de Tratamento de } \\
\text { Esgoto Lavapés, a porcentagem de esgoto tratado sobe de 1,5\% } \\
\text { para } 46 \% \text {. }\end{array}$ & $\begin{array}{l}\text { Parcialmente } \\
\text { Executado }\end{array}$ \\
\hline & - Programa de controle da qualidade das águas. & $\begin{array}{l}\text { - O PDDI de } 1995 \text { dá maior atenção aos recursos hídricos, e é } \\
\text { mais criterioso quanto a ocupação de APPs, no entanto, o } \\
\text { controle sobre a qualidade da água só é efetivamente realizado a } \\
\text { partir da aprovação da Portaria Federal } 518 / 2004\end{array}$ & Não Executado \\
\hline & - Programa de controle e prevenção da erosão urbana. & $\begin{array}{l}\text { - Em 1999, teve início o programa de macrodrenagem, } \\
\text { envolvendo diferentes órgãos de pesquisa, buscando ordenar o } \\
\text { uso e ocupação do solo. }\end{array}$ & $\begin{array}{l}\text { Parcialmente } \\
\text { Executado }\end{array}$ \\
\hline & $\begin{array}{l}\text { - Programa de controle e disposição de resíduos sólidos (ampliar o } \\
\text { aterro sanitário, ampliação da coleta seletiva, reativação da usina } \\
\text { de compostagem, aproveitamento do gás no aterro sanitário). }\end{array}$ & $\begin{array}{l}\text { - Todas as propostas foram realizadas. (atualmente a usina de } \\
\text { compostagem está desativada). }\end{array}$ & Executado \\
\hline & $\begin{array}{l}\text { - Programa de áreas verdes e arborização urbana: } \\
\text { (inventário da arborização urbana, aproveitamento de áreas "non } \\
\text { edificandi" para aumento das áreas verdes; transformação da } \\
\text { Reserva Florestal Augusto Ruschi em Parque Municipal; } \\
\text { zoneamento ao longo de córregos, rios e áreas de várzeas). }\end{array}$ & $\begin{array}{l}\text { - Como o próprio Caderno Diagnóstico do Plano Diretor de } 2006 \\
\text { ressalta, após o PDDI de } 1995 \text { houve uma maior atenção a } \\
\text { arborização urbana. No entanto, não foi desenvolvido o } \\
\text { inventário, parte das faixas non edificandi não foram } \\
\text { respeitadas, a Reserva Florestal não se tornou um parque, mas } \\
\text { uma unidade de conservação, não aberta ao público. }\end{array}$ & $\begin{array}{l}\text { Parcialmente } \\
\text { Executado }\end{array}$ \\
\hline & - Programa de educação ambiental. & $\begin{array}{l}\text { - Não houve um programa de educação ambiental, mas alguns } \\
\text { temas foram trabalhados individualmente. O Programa de coleta } \\
\text { seletiva foi bem assimilado pela população e ganhou repercussão } \\
\text { no município. Porém, o programa de proteção aos recursos } \\
\text { hídricos não foi desenvolvido. Houve pouca ação em relação aos } \\
\text { demais programas ambientais previstos em lei. }\end{array}$ & $\begin{array}{l}\text { Parcialmente } \\
\text { Executado }\end{array}$ \\
\hline & $\begin{array}{l}\text { - Instituir e regulamentar o plano municipal de manejo e utilização } \\
\text { de recursos hídricos; }\end{array}$ & $\begin{array}{l}\text { - Não existe um plano de manejo, mas um conjunto de ações } \\
\text { tomadas pela Secretaria Municipal de Meio Ambiente, Obras e } \\
\text { Planejamento urbano. }\end{array}$ & $\begin{array}{l}\text { Parcialmente } \\
\text { Executado }\end{array}$ \\
\hline & $\begin{array}{l}\text { - Criação e regulamentação das Zeis para loteamentos } \\
\text { clandestinos. }\end{array}$ & $\begin{array}{l}\text { - As Zeis foram delimitadas pela Lei de Zoneamento } 165 / 97 \text {, } \\
\text { porém na prática não houve mudanças, não houve regularização } \\
\text { e nem melhorias de infraestrutura nessas áreas. }\end{array}$ & $\begin{array}{l}\text { Parcialmente } \\
\text { Executado }\end{array}$ \\
\hline & $\begin{array}{l}\text { - Adotar de novos instrumentos da política urbana, entre eles: } \\
\text { parcelamento ou edificação compulsória, imposto predial e } \\
\text { territorial progressivo no tempo, desapropriação, operações } \\
\text { urbanas, operação interligada, zonas especiais de interesse social. }\end{array}$ & $\begin{array}{l}\text { - Os instrumentos não são viabilizados pela própria lei, assim, os } \\
\text { instrumentos que permitiriam reduzir a ação da especulação } \\
\text { imobiliária e garantir a função social da propriedade urbana são } \\
\text { postergados. }\end{array}$ & Não Executado \\
\hline $\begin{array}{l}\text { O PDDI de } 2006 \\
\text { (Lei }\end{array}$ & - Regularizar os loteamentos clandestinos. & $\begin{array}{l}\text { - Os loteamentos clandestinos não foram regularizados. Somente } \\
\text { em 2011, apenas } 1 \text { loteamento foi regularizado. A Prefeitura }\end{array}$ & Não Executado \\
\hline
\end{tabular}


- Fortalecer a Política de Controle e Fiscalização dos loteamentos clandestinos e irregulares.

- Continuar o processo de regularização fundiária e urbanização das áreas de assentamentos subnormais, adequando-as aos parâmetros urbanísticos e ambientais estabelecidos.

- Transformar os parcelamentos clandestinos localizados na área rural em bolsões urbanos para fins de regularização fundiária.

- Construção de uma nova estação de tratamento de esgoto, a Estação de Reversão da Bacia do Vidoca.

- Implantação do emissário do Ribeirão do Vidoca até a Estação Elevatória Vidoca e demais obras que ampliem o abastecimento de água e a coleta de esgoto.

- Elaboração de uma Agenda 21 local.

Elaborar o inventário das principais fontes fixas de poluição do ar, da água e dos resíduos sólidos instalados no Município.

Estudo investigativo da ocorrência de ozônio.

Regulamentar o Fundo Municipal de Conservação Ambiental FUMCAM.

- Promover a implantação de parques lineares, de lazer e/ou ecológicos (implantar 15 Parques urbanos - mapa 6, anexo ao PDDI - 2006).

Promover o aumento do índice de áreas verdes por habitante.

- Delimitar a Zona Rural do Município em: - Áreas de Proteção Ambiental: APA I, APA II e APA III; - Zona de Amortecimento da Reserva Florestal Augusto Ruschi ZA-RFAR;

Delimita dentro do perímetro da Zona Urbana à Área de Proteção Ambiental IV - APA-IV.

- Reforçar a fiscalização ambiental, consolidar e ampliar a Guarda contabiliza a existência de 94 loteamentos clandestinos, dados não oficiais estimam a existência de 150 .

A partir de 2000, a Prefeitura contrata novos fiscais, no entanto, apenas dois fiscais são da prefeitura, outros oito fiscais pertencem a uma empresa terceirizada e não podem autuar.

- Embora as ZEIS estejam delimitadas, não houve melhorias e infraestrutura nos loteamento, muitos não possuem rede de água e esgoto.

- Houve a delimitação de ZEIS, porém parte dos loteamentos clandestinos não foram incorporados. Porém, a regularização fundiária não foi concretizada, na prática nada mudou.

- A obra só foi entregue em 2010, e a mesma não tem a capacidade de tratar todo o esgoto coletado. O município trata $88 \%$ do esgoto coletado (este número vem sendo questionado).

Embora tenha sido criado um Comitê para discutir a Agenda 21 (Decreto Municipal no $11.430 / 04$ ), houve pouco empenho do poder público, e poucas vezes houve a efetivo encontro deste comitê, com isso nunca foi desenvolvida a Agenda 21 de São José dos Campos.

A Prefeitura até o momento não desenvolveu inventário sobre as fontes fixas de poluição.

Existe uma parceria sendo planejada entre o INPE e PMSJC para o estudo da poluição do ar e ocorrência de ozônio.

Conforme entrevista na Secretaria Municipal de Meio Ambiente o FUMCAM não foi criado, pois o COMAM não é um órgão deliberativo, por isso este fundo ambiental não pode ser viabilizado, e provavelmente não vai acontecer.

Somente um parque foi efetivado (Parque Senhorinha) e dois parcialmente (Parque Paraíba do Sul e Parque Cambuí), os outros doze parques urbanos previstos no PDDI 2006, não foram colocados em prática.

A prefeitura criou novos parques, embora num número menor do que previsto. A compensação ambiental por corte de árvores tem sido mais rígida. Existe um projeto de Revitalização de Nascentes da SEMEA que promove o plantio de árvores.

- As áreas foram delimitadas dando continuidade ao PDDI de 1995.

- A área de APAIV foi reduzidas em relação ao PDDI-1995.

- A APA IV sofreu alterações pela Lei de zoneamento urbano, sendo parte dela transformada em zona residencial.

- Não existe guarda ambiental, apenas fiscais ambientasi. Em
Parcialmente

Executado

Não Executado

Não Executado

Parcialmente

Executado

Não Executado

Não Executado

Não Executado

Parcialmente

Executado

Parcialmente

Executado

Parcialmente

Executado

Parcialmente 


\begin{tabular}{|c|c|c|c|}
\hline & Ambiental prevista na legislação municipal. & $\begin{array}{l}\text { 2005, quando a Secretaria foi criada, existia apenas um fiscal, e } \\
\text { atualmente, conta com três fiscais. O número de fiscais ainda é } \\
\text { muito baixo. } \\
\text { - O município conta também, com um pelotão da policia } \\
\text { ambiental do Estado de São Paulo. }\end{array}$ & Executado \\
\hline & - Implantar o Plano Integrado de Educação Ambiental. & $\begin{array}{l}\text { - Foi criado o Programa Municipal de Educação Ambiental, porém } \\
\text { este ficou somente no campo das ideias e teorias. Na prática } \\
\text { existem medidas pontuais de educação ambiental, programas e } \\
\text { projetos isolados. }\end{array}$ & $\begin{array}{l}\text { Parcialmente } \\
\text { Executado }\end{array}$ \\
\hline & $\begin{array}{l}\text { - Promover a proteção das várzeas do Rio Paraíba do Sul e do } \\
\text { Jaguari, principalmente nas regiões de contato com áreas em } \\
\text { processo de urbanização; }\end{array}$ & $\begin{array}{l}\text { - O Rio Jaguari teve a construção de duas indústrias em suas } \\
\text { margens no final da década de } 1960 \text { e } 1970 \text {. A sua margem } \\
\text { esquerda vem sendo ocupado por chácaras de recreio, tendo um } \\
\text { loteamento adensado próximo ao trecho urbano. O Rio Paraíba, } \\
\text { também, vem sofrendo com expansão urbana, tendo suas } \\
\text { margens ocupadas por loteamentos. A mata ciliar, de ambos os } \\
\text { rios, em muitas áreas, não encontra-se preservada }\end{array}$ & $\begin{array}{l}\text { Parcialmente } \\
\text { Executado }\end{array}$ \\
\hline & $\begin{array}{l}\text { - Ampliar o Aterro Sanitário Municipal em consonância com a } \\
\text { legislação; }\end{array}$ & $\begin{array}{l}\text { - O aterro foi ampliado com aprovação e boa avaliação pela } \\
\text { CETESB. }\end{array}$ & Executado \\
\hline & $\begin{array}{l}\text { - Ampliar a coleta seletiva visando atingir todos os bairros do } \\
\text { Município; }\end{array}$ & $\begin{array}{l}\text { - A coleta seletiva porta a porta atinge } 95 \% \text { da cidade, os outros } \\
5 \% \text { podem se utilizar dos Ecopontos. Porém, a ampliação da } \\
\text { coleta seletiva não foi acompanhada de medidas educativas, } \\
\text { grande parte da população não sabe e não participa da coleta } \\
\text { seletiva. A maioria dos Ecopontos não funciona. }\end{array}$ & $\begin{array}{l}\text { Parcialmente } \\
\text { Executado }\end{array}$ \\
\hline & $\begin{array}{l}\text { - Promover ações de educação ambiental, visando ampliar a } \\
\text { conscientização da importância da coleta seletiva; }\end{array}$ & $\begin{array}{l}\text { - Houve ampliação da área de coleta seletiva, mas esta não foi } \\
\text { acompanhada da conscientização da população, faltou um } \\
\text { trabalho social, o que é prejudicial ao programa da coleta } \\
\text { seletiva. }\end{array}$ & Não Executado \\
\hline & $\begin{array}{l}\text { - Estabelecer plano de uso e ocupação das bacias hidrográficas, em } \\
\text { especial quanto à proteção das áreas de fundos de vale, dos corpos } \\
\text { d'água e de áreas de recarga de aqüíferos; } \\
\text { - Instituir e regulamentar o Plano Municipal de Manejo e utilização } \\
\text { de recursos hídricos; }\end{array}$ & $\begin{array}{l}\text { - Foi elaborado o mapa de macrodrenagem urbana e apontada } \\
\text { medidas para o uso adequado das bacias. } \\
\text { - Não existe um Plano de Manejo dos Recursos Hídricos, mas um } \\
\text { conjunto de ações que partem das Secretarias Municipais de } \\
\text { Meio Ambiente, Obras e Planejamento Urbano, porém são } \\
\text { tomadas medidas pontuais, falta a efetivação de um plano a } \\
\text { longo prazo. }\end{array}$ & $\begin{array}{l}\text { Parcialmente } \\
\text { Executado }\end{array}$ \\
\hline ZONEAMENTO UR & BANO & & \\
\hline $\begin{array}{l}\text { Ato } n^{\circ} 110 \text { de } 1932 \text { e } \\
\text { Código de Obras de } \\
1954\end{array}$ & $\begin{array}{l}\text { - Divide a cidade em Zona Industrial; Zona Comercial; Zona } \\
\text { Residencial; Zona Sanatorial; Zona Aeronáutica. }\end{array}$ & $\begin{array}{l}\text { - Já na década de } 1930 \text { e } 40 \text { algumas indústrias se instalam em } \\
\text { meio a zona residencial e sanatorial. }\end{array}$ & $\begin{array}{l}\text { Parcialmente } \\
\text { Executado }\end{array}$ \\
\hline $\begin{array}{l}\text { Leis municipais } \\
\text { no } 1575 / 70, \\
\text { no } 1576 / 70, \\
\text { no } 1578 / 70 \\
1606 / 71\end{array}$ & $\begin{array}{l}\text { - Estabelece faixas não edificantes de } 15 \text { metros à margem de } \\
\text { águas correntes e dormentes, de faixas de domínio público de } \\
\text { rodovias e dutos. }\end{array}$ & $\begin{array}{l}\text { - Como pudemos visualizar na Figura } 39 \text { de APPs, a área } \\
\text { urbanizada se expande sobre as APPs, canalizando e soterrando } \\
\text { córregos. } \\
\text { - A indústria Santista se instala as margens do Rio Jaguari. } \\
\text { - Ao longo das rodovias as faixas foram respeitadas na maior }\end{array}$ & $\begin{array}{l}\text { Parcialmente } \\
\text { Executado }\end{array}$ \\
\hline
\end{tabular}




\begin{tabular}{|c|c|c|c|}
\hline \multirow{8}{*}{$\begin{array}{l}\text { Parcelamento, uso } \\
\text { do solo } \\
\text { Zoneamento }\end{array}$} & & parte do território. & \\
\hline & $\begin{array}{l}\text { - Não permite loteamentos em terrenos alagadiços e sujeitos a } \\
\text { inundações e onde as condições geológicas não sejam propicias à } \\
\text { edificação. }\end{array}$ & $\begin{array}{l}\text { - O Caderno Diagnóstico do PDDI-1995 aponta áreas de } \\
\text { alagamentos e sujeitas a inundações, porém, estas encontra em } \\
\text { áreas adensadas. }\end{array}$ & $\begin{array}{l}\text { Parcialmente } \\
\text { Executado }\end{array}$ \\
\hline & $\begin{array}{l}\text { - Proíbe o parcelamento de terrenos com declividade igual ou } \\
\text { superior a } 30 \% \text {. }\end{array}$ & $\begin{array}{l}\text { - Como vimos na Figura } 30 \text { existe parcelamento sendo realizado } \\
\text { em áreas com alta declividade, principalmente na região norte } \\
\text { do município. }\end{array}$ & $\begin{array}{l}\text { Parcialmente } \\
\text { Executado }\end{array}$ \\
\hline & $\begin{array}{l}\text { - Divide a área urbana em: Zona de Predominância comercial } \\
\text { (ZpC); Zona de Predominância Habitacional (ZpH); Zona de } \\
\text { Predominância Recreacional (ZpR); Zona de Predominância } \\
\text { Industrial (Zpl);Zona Industrial (ZI); Zona Especial (ZE); Zona de } \\
\text { Expansão Urbana (ZeU); Reserva de áreas livres nas zonas de } \\
\text { expansão;Zona Central (ZC). }\end{array}$ & $\begin{array}{l}\text { - O zoneamento é realizado com forte presença do uso } \\
\text { industrial. } \\
\text { - As áreas de ZpR não são definidas. }\end{array}$ & $\begin{array}{l}\text { Parcialmente } \\
\text { Executado }\end{array}$ \\
\hline & - A área do Banhado, é considerada ZE, e passa a ser protegida. & - A delimitada uma área de proteção no Banhado. & Executado \\
\hline & $\begin{array}{l}\text { - Considera nocivas ou perigosas, as indústrias que produzem mau } \\
\text { cheiro, ruídos incômodos, poluem água, ponham em risco a saúde } \\
\text { dos habitantes ou ameacem as construções vizinhas. Estas } \\
\text { deverão se localizar preferencialmente em áreas que já possuem } \\
\text { infra-estrutura e adequação para esse fim, fora da área de } \\
\text { expansão urbana. }\end{array}$ & $\begin{array}{l}\text { - A Refinaria de Petróleo Henrique Lage (REVAP - PETROBRÁS), } \\
\text { se instala em meio a área de expansão urbana, em área onde já } \\
\text { estava previsto loteamento urbano, trazendo grandes mudanças } \\
\text { ao desenvolvimento da cidade. }\end{array}$ & Não Executado \\
\hline & - Procura coibir a expansão horizontal e os vazios urbanos. & $\begin{array}{l}\text { - A cidade cresce sem respeitar o zoneamento proposto, surgem } \\
\text { inúmeros loteamentos clandestinos e vazios urbanos. }\end{array}$ & Não Executado \\
\hline & $\begin{array}{l}\text { - O decreto no } 1792 / 74 \text { aprova vários loteamentos clandestinos, e } \\
\text { coloca a importância de adotar medidas de vigilância e fiscalização } \\
\text { que coíbam novos loteamentos clandestinos. }\end{array}$ & $\begin{array}{l}\text { - Não há fiscalização e vigilância em relação aos loteamentos } \\
\text { clandestinos. }\end{array}$ & Não Executado \\
\hline \multirow[t]{3}{*}{$\begin{array}{l}\text { Lei Municipal } \mathrm{n}^{\circ} \\
2.263 \text { de 1980: } \\
\text { Parcelamento, Uso e } \\
\text { Ocupação do solo }\end{array}$} & $\begin{array}{l}\text { - Divide o município em } 22 \text { zonas: ZR-1, ZR-2, ZR-3,ZC-1,ZC-2, } \\
\text { ZC-3, ZC-4, ZE-1, ZE-2, ZE-3, Zona do CTA, ZE-4, ZE-5, ZE-6, ZE- } \\
\text { 7, ZE-8, ZE-9, ZE-10, ZE-11, ZE-12, ZI-3, ZI-4 } \\
\text { - Divide o município em } 17 \text { corredores }\end{array}$ & $\begin{array}{l}\text { - O zoneamento é realizado porém este não é seguido com rigor, } \\
\text { temos a expansão de loteamentos clandestinos, a área de } \\
\text { proteção ambiental é ocupada pelo uso residencial. }\end{array}$ & $\begin{array}{l}\text { Parcialmente } \\
\text { Executado }\end{array}$ \\
\hline & $\begin{array}{l}\text { - A zona de uso ZI-5, que abrigaria as indústrias de alto potencial } \\
\text { poluidor, não foi aprovada. Restringindo as indústrias poluidoras na } \\
\text { cidade. }\end{array}$ & $\begin{array}{l}\text { - Após a instalação da REVAP, fica vedada a instalação de } \\
\text { indústrias de alto potencial poluidor, na cidade. }\end{array}$ & Executado \\
\hline & $\begin{array}{l}\text { - Retração no perímetro urbano com o objetivo de reduzir os vazios } \\
\text { urbanos. }\end{array}$ & $\begin{array}{l}\text { - O perímetro urbano foi reduzido, o que elevou o preço da terra, } \\
\text { e aumentou o número de loteamentos clandestinos, os vazios } \\
\text { urbanos não deixam de existir. }\end{array}$ & $\begin{array}{l}\text { Parcialmente } \\
\text { Executado }\end{array}$ \\
\hline
\end{tabular}




\begin{tabular}{|c|c|c|c|}
\hline \multirow[t]{2}{*}{$\begin{array}{l}\text { Lei Municipal no } \\
\text { 3.721 de 1990: } \\
\text { Parcelamento, Uso e } \\
\text { ocupação do solo }\end{array}$} & $\begin{array}{l}\text { - Proíbe o parcelamento do solo em: } \\
\text { Terrenos alagadiços e sujeitos à inundação, antes de tomadas pelo } \\
\text { interessado as providências para assegurar-Ihe o escoamento das } \\
\text { águas. As obras necessárias para esse fim poderão ser projetadas, } \\
\text { quando for o caso, juntamente com as das vias de circulação; } \\
\text { Em terrenos que tenham sido aterrados com material nocivo à } \\
\text { saúde pública, sem que sejam previamente saneados; } \\
\text { Em terrenos com declividade superior a } 30 \% \text { (trinta por cento), } \\
\text { considerada a natural } \\
\text { Em áreas de preservação ecológica, assim declaradas por lei; } \\
\text { Em áreas onde a poluição impeça condições sanitárias suportáveis, } \\
\text { até coração; } \\
\text { Em áreas de preservação permanente, conforme estabelecido } \\
\text { na Lei Federal no } 4.771 \text { (Código Florestal). }\end{array}$ & $\begin{array}{l}\text { - Em algumas áreas do município ocorre o parcelamento solo em } \\
\text { áreas de alta declividade. } \\
\text { - APA-IV vem sendo loteada em condomínios de luxo. } \\
\text { - As APPs são ocupadas pela expansão urbana, sem respeito as } \\
\text { leis. }\end{array}$ & $\begin{array}{l}\text { Parcialmente } \\
\text { Executado }\end{array}$ \\
\hline & $\begin{array}{l}\text { - Divide o município em } 31 \text { zonas: ZR-1, ZR-2, ZR-3, ZR-4, ZR-5, } \\
\text { ZC-1, ZC-2, ZC-3, ZC-4, ZUPI-1,ZUPI-2, ZM-1, ZM-2, ZM-3, ZM-5, } \\
\text { ZM-6, ZM-7, ZM-8, APA-1, APA-2, APA-3, APA-4, APA-5,ZE, ZDCA, } \\
\text { ZUI, ZVU, ZCHR, ZPM. }\end{array}$ & $\begin{array}{l}\text { O zoneamento foi parcialmente efetivado. Os loteamentos } \\
\text { clandestinos invadem a zona rural e a APA. A ZPM não é } \\
\text { efetivada. Parte da APA } 3 \text { é ocupada por loteamentos de alto } \\
\text { padrão. }\end{array}$ & $\begin{array}{l}\text { Parcialmente } \\
\text { Executado }\end{array}$ \\
\hline \multirow{5}{*}{$\begin{array}{l}\text { Lei } \\
\text { Complementar no } \\
165 \text { de 1997: } \\
\text { Ordenação do } \\
\text { Território, } \\
\text { Parcelamento, do } \\
\text { uso e ocupação } \\
\text { do solo }\end{array}$} & $\begin{array}{l}\text {-Proíbe o parcelamento do solo para fins urbanos na zona rural do } \\
\text { Município. }\end{array}$ & $\begin{array}{l}\text { - Novos loteamentos clandestinos surgem após a promulgação } \\
\text { da lei. Não houve uma política séria de fiscalização. }\end{array}$ & Não Executado \\
\hline & $\begin{array}{l}\text { - Passa a permitir o loteamento para fins de Chácara de Recreio } \\
\text { somente em zona urbana ou de expansão urbana. }\end{array}$ & $\begin{array}{l}\text { A zona de chácara é ampliada, mas esta não barra a expansão } \\
\text { dos loteamentos clandestinos na zona rural. }\end{array}$ & $\begin{array}{l}\text { Parcialmente } \\
\text { Executado }\end{array}$ \\
\hline & $\begin{array}{l}\text { - Determina que não poderão ser parcelados para fins urbanos: } \\
\text { Terrenos alagadiços ou sujeitos a inundação antes de executadas } \\
\text { as obras e serviços que assegurem a perfeita drenagem das águas; } \\
\text { Terrenos que tenham sido aterrados com materiais nocivos à } \\
\text { saúde pública, sem que sejam previamente saneados; } \\
\text { Terrenos com declividade igual ou superior a } 30 \% \text { (trinta por } \\
\text { cento), considerada a sua cota natural; } \\
\text { Terrenos nos quais as condições geológicas não aconselham a } \\
\text { edificação; } \\
\text { Áreas de preservação ecológica ou naquelas onde a poluição } \\
\text { impeça condições sanitárias suportáveis até sua correção; } \\
\text { Em áreas de preservação permanente, nos termos e limites } \\
\text { estabelecidos na Lei Federal no } 4.771 / 65 \text {. }\end{array}$ & $\begin{array}{l}\text { - Em algumas áreas do município ocorre o parcelamento solo em } \\
\text { áreas de alta declividade. } \\
\text { - APA-IV vem sendo loteada em condomínios de luxo. } \\
\text { - As APPs são ocupadas pela expansão urbana, sem respeito as } \\
\text { leis. }\end{array}$ & $\begin{array}{l}\text { Parcialmente } \\
\text { Executado }\end{array}$ \\
\hline & $\begin{array}{l}\text { - Determina que ao longo das águas correntes e dormentes, das } \\
\text { faixas de domínio público das rodovias, estradas municipais, } \\
\text { ferrovias e dutos, será obrigatória a reserva de faixa "non } \\
\text { aedificandi" de, no mínimo, } 15,00 m \text { (quinze metros) de cada lado. }\end{array}$ & $\begin{array}{l}\text { - Como pudemos visualizar na Figura } 39 \text {, a área urbanizada se } \\
\text { expande sobre as APPs, canalizando e soterrando córregos. } \\
\text { - Ao longo das rodovias as faixas foram respeitadas na maior } \\
\text { parte do território. }\end{array}$ & $\begin{array}{l}\text { Parcialmente } \\
\text { Executado }\end{array}$ \\
\hline & $\begin{array}{l}\text { - As macrozonas urbana e de expansão urbana I e II estabelecidas } \\
\text { na Lei do Plano Diretor, ficam subdivididas em } 22 \text { zonas de uso: } \\
\text { ZR, ZR2, ZR3, ZCHR, ZM1, ZM2, ZM3, ZM4 ZM5, ZM6, ZC, ZEPA1, } \\
\text { ZEPA2, ZEPA3, ZUPI, ZETI, ZEA, ZVU, ZEPH, ZEIS, ZESFX, ZEPA4. }\end{array}$ & $\begin{array}{l}\text { - O municipio sofre modificações em seu zoneamento urbano, e } \\
\text { este mais uma vez é parcialmente efetivado. Na prática a várias } \\
\text { modificações pontuais nas zonas de uso. }\end{array}$ & $\begin{array}{l}\text { Parcialmente } \\
\text { Executado }\end{array}$ \\
\hline
\end{tabular}




\begin{tabular}{|c|c|c|c|}
\hline & $\begin{array}{l}\text { - A instalação de novas indústrias no município, deve ser } \\
\text { acompanhada de laudo ambiental e reserva de áreas para uso } \\
\text { público. }\end{array}$ & $\begin{array}{l}\text { - As normas para instalação de novas indústrias têm sido mais } \\
\text { rígidas e fiscalizadas pelo órgão responsável. }\end{array}$ & $\begin{array}{l}\text { Não foi possível } \\
\text { avaliar }\end{array}$ \\
\hline \multicolumn{4}{|l|}{ LEI ORGÂNICA } \\
\hline \multirow[t]{7}{*}{+2} & $\begin{array}{l}\text { - estabelece normas de prevenção e controle de ruídos, de poluição } \\
\text { do meio ambiente, da terra, do ar e das águas. } \\
\text { - visa proteger o meio ambiente e combater a poluição em } \\
\text { qualquer de suas formas. }\end{array}$ & $\begin{array}{l}\text { - O plano diretor de } 2006 \text { e lei de zoneamento de } 2010 \text { prevêem } \\
\text { o estudo de impacto de vizinhança. Novas políticas foram } \\
\text { adotadas, porém, ainda há poluição das águas e do ar no } \\
\text { município. }\end{array}$ & $\begin{array}{l}\text { Parcialmente } \\
\text { Executado }\end{array}$ \\
\hline & $\begin{array}{l}\text { - determina o registro, acompanhamento e fiscalização de } \\
\text { concessões de direito de pesquisa e exploração de recursos } \\
\text { hídricos e minerais em seu território; }\end{array}$ & $\begin{array}{l}\text { A exploração mineraria da areia no município está controlada. } \\
\text { Porém, a Sabesp ainda não realiza o tratamento de todo esgoto } \\
\text { coletado no município, além das inúmeras ligações clandestinas. }\end{array}$ & $\begin{array}{l}\text { Parcialmente } \\
\text { Executado }\end{array}$ \\
\hline & $\begin{array}{l}\text { - determina o exercício do poder de polícia administrativa na } \\
\text { vigilância e na fiscalização da preservação do meio ambiente, } \\
\text { dispondo através de lei, das penalidades por infrações ou danos à } \\
\text { comunidade e à natureza }\end{array}$ & $\begin{array}{l}\text { Vemos um aumento no número de autos de infração ambiental, } \\
\text { porém, durante anos os loteamentos clandestinos se proliferam } \\
\text { no município ocupando APAs e APPs, sem nenhum controle por } \\
\text { parte do poder público, e sem punição aos loteadores. }\end{array}$ & $\begin{array}{l}\text { Parcialmente } \\
\text { Executado }\end{array}$ \\
\hline & $\begin{array}{l}\text { - estabelece que para a implantação de qualquer atividade pública } \\
\text { ou privada, causadora de danos a saúde e ao bem-estar da } \\
\text { população, ou ainda, aos recursos naturais, deverá ser realizado } \\
\text { estudo de impacto ambiental e audiência pública. }\end{array}$ & Não foi possível avaliar. & $\begin{array}{l}\text { Não foi possível } \\
\text { avaliar }\end{array}$ \\
\hline & $\begin{array}{l}\text { - estabelece que o município participe do sistema integrado de } \\
\text { gerenciamento de recursos hídricos. } \\
\text { - proíbe o descarte de efluentes urbanos e industriais em qualquer } \\
\text { corpo d'água. }\end{array}$ & $\begin{array}{l}\text { Embora houve um avanço no sistema de tratamento do esgoto a } \\
\text { partir de } 2010, \text { ainda há o descarte esgoto não tratado em parte } \\
\text { do município. }\end{array}$ & $\begin{array}{l}\text { Parcialmente } \\
\text { Executado }\end{array}$ \\
\hline & $\begin{array}{l}\text { - prevê a educação ambiental em todos os níveis de ensino e a } \\
\text { recuperação das áreas degradadas nas margens do Rio Paraíba do } \\
\text { Sul. }\end{array}$ & $\begin{array}{l}\text { Não existe uma política efetiva de educação ambiental no } \\
\text { município, apenas medidas pontuais. }\end{array}$ & $\begin{array}{l}\text { Parcialmente } \\
\text { Executado }\end{array}$ \\
\hline & $\begin{array}{l}\text { - submete o município "a implantar e manter áreas verdes de } \\
\text { preservação permanente, de acordo com os parâmetros fixados } \\
\text { pela Organização Mundial de Saúde" }\end{array}$ & $\begin{array}{l}\text { Nem todos os bairros da cidade possuem o índice de áreas } \\
\text { verdes almejado pela Prefeitura. }\end{array}$ & $\begin{array}{l}\text { Parcialmente } \\
\text { Executado }\end{array}$ \\
\hline \multicolumn{4}{|c|}{ LEGISLAÇÃO AMBIENTAL } \\
\hline $\begin{array}{l}\text { Lei Municipal no } \\
1.759 / 75\end{array}$ & $\begin{array}{l}\text { - Declara que todo sistema de despejo de resíduos de qualquer } \\
\text { natureza, nas bacias hídricas, deverá atender aos requisitos } \\
\text { técnicos estabelecidos na legislação federal ou estadual, inclusive } \\
\text { prévio tratamento. }\end{array}$ & $\begin{array}{l}\text { - Até } 2010 \text { o município de São José dos Campos tratava apenas } \\
53 \% \text { do esgoto coletado. }\end{array}$ & Não Executado \\
\hline $\begin{array}{l}\text { Lei Municipal } \text { no }^{\circ} \\
2143 / 79 \\
\text { (Revogada pela } \\
\text { lei } n^{\circ} 2.773 / 83 \text {, e } \\
\text { pela } \\
3.656 / 89)\end{array}$ & $\begin{array}{l}\text { - Cria o Conselho Municipal de Combate à Poluição e Proteção ao } \\
\text { Meio Ambiente (CMCP), modificado posteriormente para Conselho } \\
\text { Municipal de Meio Ambiente (COMAM), órgão apenas consultivo. }\end{array}$ & $\begin{array}{l}\text { - Foi criado Conselho que aborda as questões ambientais, } \\
\text { formado por diferentes atores, que está funcionado até hoje, } \\
\text { com reuniões uma vez por mês, o COMAM. }\end{array}$ & Executado \\
\hline $\begin{array}{l}\text { Lei Municipal } n^{\circ} \\
2.163 / 79 \\
\text { (Revogada pela }\end{array}$ & $\begin{array}{l}\text { - Cria a Reserva Florestal: Parque Natural Municipal Augusto } \\
\text { Ruschi (PNMAR) - unidade de conservação de uso integral. }\end{array}$ & $\begin{array}{l}\text { - A reserva foi criada e atualmente é considerada Unidade de } \\
\text { Conservação Integral. }\end{array}$ & Executado \\
\hline
\end{tabular}




\begin{tabular}{|c|c|c|c|}
\hline$\left.n^{\circ} 8.195 / 10\right)$ & & & \\
\hline $\begin{array}{l}\text { Lei Municipal } n^{\circ} \\
2.230 / 79\end{array}$ & - Institui o "Prêmio Ecologia". & - O projeto teve pouca repercussão, sendo instinto. & Não Executado \\
\hline $\begin{array}{l}\text { Lei Municipal } n \\
02.338 / 80\end{array}$ & $\begin{array}{l}\text { - Cria o Conselho de Proteção ao Patrimônio Histórico de São José } \\
\text { dos Campos. }\end{array}$ & - O conselho foi criado e tem forte atuação. & Executado \\
\hline $\begin{array}{l}\text { Lei Municipal } n^{\circ} \\
2.387 / 80 \\
\text { (Revogada pela } \\
\text { Lei Municipal } n^{\circ} \\
3.522 / 89 \text { e pela } \\
\text { 3.667/89) } \\
\text { Lei Municipal no } \\
2.495 / 81 \\
\text { Lei Municipal no } \\
3.522 / 89 \\
\text { Lei Municipal } n^{\circ} \\
3.666 / 89 \\
\text { Lei Municipal } n^{\circ} \\
3.667 / 89 \\
\text { Lei Municipal } n^{\circ} \\
3.794 / 91\end{array}$ & $\begin{array}{l}\text { - Procura coibir a prática exploração mineral em leitos de rios no } \\
\text { município. }\end{array}$ & $\begin{array}{l}\text { - Não há extração mineral de areia no município, mas existe } \\
\text { uma forte pressão por parte de sindicatos, e a questão vem } \\
\text { sendo discutida na Câmara dos Vereadores. }\end{array}$ & Executado \\
\hline $\begin{array}{l}\text { Lei Municipal } n^{\circ} \\
2.685 / 83\end{array}$ & $\begin{array}{l}\text { - Torna obrigatória a arborização de todas as vias públicas } \\
\text { oficializadas do município. }\end{array}$ & $\begin{array}{l}\text { - Em muitas ruas não há arborização, atualmente a Prefeitura } \\
\text { tem um projeto de doação de mudas para aqueles que quiserem } \\
\text { plantar uma árvore na calçada. }\end{array}$ & $\begin{array}{l}\text { Parcialmente } \\
\text { Executado }\end{array}$ \\
\hline $\begin{array}{l}\text { Lei Municipal } \text { no }^{\circ} \\
2.792 / 84 \\
\text { (Alterada pela lei } \\
2.996 / 85 \quad \text { a } \\
\text { Revogada pela } \\
\text { Lei } n^{\circ} 3.721 / 90 \text { ) }\end{array}$ & $\begin{array}{l}\text { - Declara Área de Proteção Ambiental - APA - a região urbana e } \\
\text { rural do Banhado de São José dos Campos. }\end{array}$ & $\begin{array}{l}\text { - A APA foi delimitada e efetivada, porém, sofre modificações } \\
\text { pela lei de zoneamento de } 1990 .\end{array}$ & Executado \\
\hline $\begin{array}{l}\text { Lei Municipal no } \\
3.021 / 85\end{array}$ & $\begin{array}{l}\text { - Cria Elementos, Setores e Zonas de Preservação. } \\
\text { - Institui o Fundo de Preservação do Patrimônio Histórico, Artístico, } \\
\text { Paisagístico e Cultural. }\end{array}$ & $\begin{array}{l}\text { - O município tem preservado seu patrimônio histórico, como a } \\
\text { Tecelagem Parahyba e o Sanatório Vicentina Aranha. }\end{array}$ & Executado \\
\hline $\begin{array}{l}\text { Lei Municipal } n^{\circ} \\
3.329 / 88 \\
\text { (Revogada pela } \\
\text { Lei Municipal } n^{\circ} \\
3.721 / 90 \text { ) }\end{array}$ & $\begin{array}{l}\text { - É vedada a instalação de usinas de concreto pré-misturado em } \\
\text { qualquer parte do município. } \\
\text { - Proíbe a instalação de indústrias altamente poluidoras no } \\
\text { município. }\end{array}$ & $\begin{array}{l}\text { - Após esta lei não foram instaladas indústrias que venham a } \\
\text { causar grande poluição e danos ambientais ao município. }\end{array}$ & Executado \\
\hline $\begin{array}{l}\text { Lei Municipal } \mathrm{n}^{\circ} \\
3.334 / 88\end{array}$ & $\begin{array}{l}\text { - Determina que não serão aprovados projetos de construção civil, } \\
\text { de todo ou qualquer tipo, que impliquem no corte ou eliminação de } \\
\text { árvore pública. O corte ou eliminação, somente será aceito quando } \\
\text { não houver nenhuma possibilidade de alteração do projeto de }\end{array}$ & $\begin{array}{l}\text { - Há uma maior restrição a poda de árvores, principalmente de } \\
\text { espécies em extinção. }\end{array}$ & $\begin{array}{l}\text { Parcialmente } \\
\text { Executado }\end{array}$ \\
\hline
\end{tabular}




\begin{tabular}{|c|c|c|c|}
\hline & $\begin{array}{l}\text { construção capaz de evitar o corte ou a eliminação da arborização } \\
\text { pública. }\end{array}$ & & \\
\hline Lei $\mathrm{n}^{\circ} \mathbf{3 . 4 2 9 / 8 8}$ & $\begin{array}{l}\text { - Determina a realização de audiência pública antes da aprovação } \\
\text { de projetos de implantação industrial, com exceção das indústrias } \\
\text { classificadas pela Lei } 2.263 / 80 \text { como I1 e I2. }\end{array}$ & $\begin{array}{l}\text { - A implantação de indústrias em São José passou a ser melhor } \\
\text { estudada. }\end{array}$ & Executado \\
\hline $\begin{array}{l}\text { Lei Municipal } n^{\circ} \\
4.212 / 92\end{array}$ & $\begin{array}{l}\text { - Declara Área de Proteção Ambiental (APA), o trecho da Serra da } \\
\text { Mantiqueira no Município de São José dos Campos. }\end{array}$ & - A APA foi criada e efetivada. & Executado \\
\hline $\begin{array}{l}\text { Lei Municipal } n^{\circ} \\
4.244 / 92\end{array}$ & $\begin{array}{l}\text { - Institui o concurso "A rua mais verde", que tem como objetivo } \\
\text { incentivar o plantio de árvores na área urbana, fornecendo mudas } \\
\text { e auxilio para o plantio. }\end{array}$ & - O projeto teve pouca repercussão, sendo instinto. & Não Executado \\
\hline $\begin{array}{l}\text { Lei } \\
\text { Complementar } n^{\circ} \\
068 / 92\end{array}$ & $\begin{array}{l}\text { - Cria a APA 6, em complemento a lei de zoneamento urbano de } \\
1990 .\end{array}$ & - A APA foi criada e efetivada. & Executado \\
\hline $\begin{array}{l}\text { Lei Municipal } n^{\circ} \\
4.618 / 94\end{array}$ & - Cria o Fundo Municipal de Conservação Ambiental (FUMCAM). & - O FUMCAM não foi efetivado. & Não Executado \\
\hline $\begin{array}{l}\text { Lei Municipal } \mathrm{n}^{\circ} \\
4.636 / 94\end{array}$ & $\begin{array}{l}\text { - Estabelece normas para evitar a poluição do Rio Paraíba do Sul e } \\
\text { demais cursos d'água do Município. } \\
\text { - Determina que as indústrias que se utilizam de recursos hídricos, } \\
\text { situadas no território do Município, somente poderão efetuar } \\
\text { despejos industriais a montante de sua respectiva captação. }\end{array}$ & $\begin{array}{l}\text { - A partir do PDDI de } 1995 \text { existe uma maior fiscalização por } \\
\text { parte do poder público e CETESB em relação aos recursos } \\
\text { hídricos. }\end{array}$ & $\begin{array}{l}\text { Parcialmente } \\
\text { Executado }\end{array}$ \\
\hline $\begin{array}{l}\text { Lei Municipal } n^{\circ} \\
4.928 / 96\end{array}$ & $\begin{array}{l}\text { - Inclui a área que abriga o antigo Sanatório Vicentina Aranha na } \\
\text { categoria de Setor de Preservação (SP). }\end{array}$ & $\begin{array}{l}\text { - O Sanatório encontra-se preservado, e com prospectiva de } \\
\text { restauração. }\end{array}$ & Executado \\
\hline $\begin{array}{l}\text { Lei Municipal } \mathrm{n}^{\circ} \\
4.954 / 96\end{array}$ & $\begin{array}{l}\text { - Declara de proteção ambiental a área desapropriada pelo } \\
\text { Município à Tecelagem Parahyba S/A e à Fazenda São José } \\
\text { Agropecuária Ltda. }\end{array}$ & $\begin{array}{l}\text { A Tecelagem e a Fazenda fazem parte do Parque da Cidade e } \\
\text { são considerados área de proteção ambiental. }\end{array}$ & Executado \\
\hline $\begin{array}{l}\text { Lei Municipal } n^{\circ} \\
5.098 / 97\end{array}$ & - Institui o programa "Nossa Praça". & - O projeto teve pouca repercussão, sendo instinto. & Não Executado \\
\hline $\begin{array}{l}\text { Lei Municipal } n^{\circ} \\
5.192 / 98\end{array}$ & - Implantação do Projeto "Pequeno Jardineiro. & - O projeto teve pouca repercussão, sendo instinto. & Não Executado \\
\hline $\begin{array}{l}\text { Lei Municipal } \mathrm{n}^{\circ} \\
5.409 / 99\end{array}$ & $\begin{array}{l}\text { - Instalação de estação de monitoramento da qualidade do ar em } \\
\text { São José dos Campos. }\end{array}$ & $\begin{array}{l}\text { - A CETESB mantém na cidade uma estação manual de } \\
\text { monitoramento da fumaça e SO2, e também, uma estação } \\
\text { automática de monitoramento da qualidade do ar que mede as } \\
\text { partículas inaláveis (MP10), dióxido de enxofre (SO2), ozônio } \\
\text { (O3), e parâmetros meteorológicos (direção e velocidade de } \\
\text { vento, temperatura e umidade relativa), em funcionamento } \\
\text { desde 2000. }\end{array}$ & Executado \\
\hline $\begin{array}{l}\text { Lei Municipal } n^{\circ} \\
5.441 / 99\end{array}$ & $\begin{array}{l}\text { - Regulamenta o fechamento de loteamentos, vilas e ruas sem } \\
\text { saída. } \\
\text { - A lei foi alterada pelo Decreto Municipal no } 10.969 / 03 \text { e pela Lei } \\
\text { Municipal no } 8.098 / 10 \text { (que autoriza o fechamento de loteamentos, } \\
\text { também, na zona predominantemente industrial). }\end{array}$ & $\begin{array}{l}\text { - O Poder Público cria normas e leis que regulamentam o } \\
\text { fechamento de loteamentos no município. A cada ano aumenta o } \\
\text { número de loteamentos fechados no município. }\end{array}$ & \\
\hline
\end{tabular}




\begin{tabular}{|c|c|c|c|}
\hline $\begin{array}{l}\text { Lei Municipal } n^{\circ} \\
5.655 / 00\end{array}$ & $\begin{array}{l}\text { - Estabelece convenio com a Fundação Valeparaibana de Ensino } \\
\text { (FVE) e Universidade do Vale do Paraíba (UNIVAP) para a } \\
\text { realização de estudo das microbacias e macrozoneamento } \\
\text { hidrográfico do Município. }\end{array}$ & $\begin{array}{l}\text { - Após o PDDI de } 1995 \text { a Prefeitura realizou convenio com vários } \\
\text { órgãos e instituições para o estudo da macrodrenagem urbana. }\end{array}$ & Executado \\
\hline $\begin{array}{l}\text { Lei Municipal no } \\
5.680 / 00\end{array}$ & $\begin{array}{l}\text { Cria o Instituto de Pesquisa e Planejamento Urbano de São José } \\
\text { dos Campos - IPPSJC. }\end{array}$ & $\begin{array}{l}\text { - O Instituto, já previsto, em leis anteriores, não foi efetivado na } \\
\text { prática. Apenas em } 2009 \text { é criada a ONG - Instituto de } \\
\text { Pesquisa, Administração e Planejamento (IPPLAN). }\end{array}$ & Não executado \\
\hline $\begin{array}{l}\text { Decreto Municipal } \\
\text { no } 10.629 / 02\end{array}$ & $\begin{array}{l}\text { - Cria um grupo de trabalho multidisciplinar que irá cuidar, } \\
\text { pesquisar e fiscalizar as Emissões Eletromagnéticas, por antenas } \\
\text { de telefonia móvel no município. }\end{array}$ & $\begin{array}{l}\text { - Até o momento não houve nenhum estudo em relação as } \\
\text { pesquisas de emissões eletromagnéticas, por antenas de } \\
\text { telefonia móvel, nem mesmo uma lei regulamentando a fixação } \\
\text { de antenas. }\end{array}$ & Não executado \\
\hline $\begin{array}{l}\text { Lei Municipal no } \\
6.473 / 03\end{array}$ & - Cria o Programa Agenda 21 de São José dos Campos. & - A Agenda 21 não foi desenvolvida pelo município. & Não executado \\
\hline $\begin{array}{l}\text { Lei Municipal } n^{\circ} \\
6.288 / 03\end{array}$ & - Institui o projeto "Recanto dos Pássaros". & - O projeto teve pouca repercussão, sendo instinto & Não executado \\
\hline $\begin{array}{l}\text { Lei Municipal no } \\
6.431 / 03\end{array}$ & $\begin{array}{l}\text { - Trata do armazenamento e destinação de carcaças de pneus e } \\
\text { câmaras de ar, e estipula que as empresas fabricantes destes } \\
\text { produtos ficam obrigadas a recolher periodicamente as carcaças de } \\
\text { pneus e câmaras, sem agredir o meio ambiente. }\end{array}$ & $\begin{array}{l}\text { - Os pneus são entregues nos PEVs e muitos ainda são jogados } \\
\text { em terrenos baldios. Em entrevista em algumas lojas de troca de } \\
\text { pneu, fomos informados que isso é um grande problema, eles } \\
\text { pagam a particulares para que os pneus velhos sejam retirados } \\
\text { da loja. }\end{array}$ & Não executado \\
\hline $\begin{array}{l}\text { Lei Municipal } n^{\circ} \\
6.493 / 04 \\
\text { (Alterada pela Lei } \\
\text { Municipal no } \\
7.338 / 07 \text { ) }\end{array}$ & $\begin{array}{l}\text { - Declara o complexo formado pela antiga Tecelagem Parayba e } \\
\text { Fazenda Santana do Rio Abaixo, como Zona de Preservação (ZP). }\end{array}$ & $\begin{array}{l}\text { - A Tecelagem e a Fazenda estão preservadas, sendo utilizada } \\
\text { para instalação de órgãos públicos como: CETESTB, Policia } \\
\text { ambiental, Secretaria do Meio Ambiente, Fundação Cultural } \\
\text { Cassiano Ricardo, etc. }\end{array}$ & Executado \\
\hline 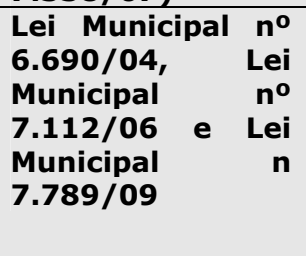 & $\begin{array}{l}\text { - Institui a Política Municipal de Educação Ambiental. } \\
\text { - A educação ambiental passa a ser incumbida ao poder público. } \\
\text { - Implanta a disciplina de Educação Ambiental na grade curricular } \\
\text { das escolas do Município. }\end{array}$ & $\begin{array}{l}\text { - Não há uma política de educação ambiental, mas somente } \\
\text { medidas pontuais, com destaque aos projetos de Revitalização } \\
\text { de Nascentes, Horta Urbana, Trilhas no parque e Combate a } \\
\text { queimadas. } \\
\text { - A educação ambiental não pode ser uma disciplina como } \\
\text { previsto na lei federal. Deve ser um tema complementar, } \\
\text { abordado por todas as ciências. }\end{array}$ & $\begin{array}{l}\text { Parcialmente } \\
\text { Executado }\end{array}$ \\
\hline $\begin{array}{l}\text { Lei Municipal no } \\
7.146 / 06\end{array}$ & $\begin{array}{l}\text { - Institui o Plano Integrado de Gerenciamento e o Sistema de } \\
\text { Gestão Sustentável de Resíduos da Construção Civil e Resíduos } \\
\text { Volumosos. } \\
\text { - Determina lugares específicos para a disposição dos resíduos da } \\
\text { construção civil e resíduos volumosos. } \\
\text { - Prevê, nos Art. } 17 \text { e } 18 \text {, a gestão sustentável de resíduos da } \\
\text { construção civil e resíduos volumosos, estes deverão passar por } \\
\text { triagem, sempre que possível processo de reutilização, } \\
\text { desmontagem e reciclagem que evitem sua destinação final a } \\
\text { aterro sanitário. }\end{array}$ & $\begin{array}{l}\text { - Os PEVs (Ponto de Entrega Voluntária) foram criados somente } \\
\text { em } 2011 \text {. Foram criados } 7 \text { PEVs, mas ainda existem mais de } 150 \\
\text { pontos de deposição clandestina de resíduos. } \\
\text { - Nos PEVs criados existe a separação do material para possível } \\
\text { reciclagem. }\end{array}$ & $\begin{array}{l}\text { Parcialmente } \\
\text { Executado }\end{array}$ \\
\hline Lei Municipal no $^{\circ}$ & - Cria normas e procedimentos para serviço de coleta e disposição & - Nos PEVs é possível fazer a entrega deste tipo de material, e & Parcialmente \\
\hline
\end{tabular}




\begin{tabular}{|c|c|c|c|}
\hline $7.217 / 06$ & $\begin{array}{lllll}\text { final de pilhas, baterias e lâmpadas de mercúrio } & \text { nos } \\
\text { estabelecimentos que comercializarem esses componentes. } & \\
\end{array}$ & alguns estabelecimentos privados, também, oferecem o serviço. & Executado \\
\hline $\begin{array}{l}\text { Lei } \\
\text { Complementar no } \\
357 / 08\end{array}$ & $\begin{array}{l}\text { - Institui a Política Municipal de Saneamento Básico. } \\
\text { - Aponta como objetivo a universalização do acesso aos serviços } \\
\text { públicos de saneamento básico de águas e esgoto. }\end{array}$ & $\begin{array}{l}\text { - Em 2010, temos } 87 \% \text { do esgoto coletado, e } 88 \% \text { do que é } \\
\text { coletado tratado. O abastecimento de água atinge } 94 \% \text { da } \\
\text { população. }\end{array}$ & $\begin{array}{l}\text { Parcialmente } \\
\text { Executado }\end{array}$ \\
\hline $\begin{array}{l}\text { Lei Municipal no } \\
7.815 / 09\end{array}$ & $\begin{array}{l}\text { - Disciplina os serviços de limpeza urbana e manejo dos resíduos } \\
\text { sólidos e define os objetivos da gestão integrada e compartilhada } \\
\text { de resíduos sólidos, com vistas à prevenção e ao controle da } \\
\text { poluição, à proteção e a recuperação da qualidade do meio } \\
\text { ambiente, e a promoção da saúde pública. } \\
\text { - Um dos objetivos previstos é a universalização da coleta seletiva } \\
\text { em todo território municipal. } \\
\text { - Prevê medidas de educação ambiental que visem a redução na } \\
\text { geração de resíduos, e ainda, a reciclagem e recuperação de } \\
\text { resíduos. Prevê o incentivo ao uso de matérias recicláveis. } \\
\text { - Determina que a coleta seletiva será feita porta a porta. } \\
\text { - Determina a existência de Aterro Industrial para o adequado } \\
\text { descarte do resíduo industrial. }\end{array}$ & $\begin{array}{l}\text { - A coleta seletiva porta a porta atinge } 95 \% \text { do município, para o } \\
5 \% \text { restante existem ECO pontos de entrega voluntária. } \\
\text { - O principal problema que envolve a coleta seletiva é a falta de } \\
\text { conscientização da população e a falta de políticas educacionais } \\
\text { que fortaleçam a importância da reciclagem, que mostrem como } \\
\text { os resíduos devem ser separados, e que divulguem como } \\
\text { funciona a coleta seletiva no município. } \\
\text { - Quanto ao Aterro Industrial, existe um particular no município. }\end{array}$ & $\begin{array}{l}\text { Parcialmente } \\
\text { Executado }\end{array}$ \\
\hline $\begin{array}{l}\text { Lei Municipal no } \\
8.064 / 10\end{array}$ & $\begin{array}{l}\text { - Implanta o programa Mutirão Ambiental nos Bairros devendo } \\
\text { contemplar todos os Bairros da Cidade com a realização de corte, } \\
\text { poda, plantio de árvores e realização de palestras educativas } \\
\text { alusivas ao Meio Ambiente. A lei determina que cada cidadão que } \\
\text { participar do Programa Mutirão Ambiental nos Bairros receberá um } \\
\text { diploma. }\end{array}$ & - O projeto não foi implantado. & Não Executado \\
\hline $\begin{array}{l}\text { Lei Municipal no } \\
8.293 / 10\end{array}$ & $\begin{array}{l}\text { - Torna obrigatório o plantio de árvores nas calçadas defronte a } \\
\text { todas as unidades residenciais e lotes de terreno em novos } \\
\text { empreendimentos licenciados pela Prefeitura Municipal. }\end{array}$ & $\begin{array}{l}\text { - Em entrevista a Secretaria do Meio Ambiente nos foi relatado } \\
\text { que para a abertura de novos loteamentos tem se exigido o } \\
\text { plantio de árvores e compensação ambiental no próprio } \\
\text { loteamento. }\end{array}$ & $\begin{array}{l}\text { Não foi possível } \\
\text { avaliar }\end{array}$ \\
\hline $\begin{array}{l}\text { Lei } \\
\text { Complementar no } \\
423 / 10\end{array}$ & $\begin{array}{l}\text { - A referida lei determina que a execução de qualquer tipo de } \\
\text { atividade, serviço, obra, construção, cerca, muro, gradil, tapume, } \\
\text { muro de arrimo, garagem de embarcação, de máquinas ou } \\
\text { equipamentos, terraplanagem, similares e congêneres a ser } \\
\text { desenvolvida em Área de Preservação Permanente - APP de } \\
\text { córregos, rios, lagoas, nascentes e áreas de várzea, } \\
\text { independentemente de eventual licenciamento por órgãos } \\
\text { estaduais e federais, deverá ter prévia aprovação da Prefeitura } \\
\text { Municipal, que fará análise da existência de interesse público para } \\
\text { sua liberação. }\end{array}$ & $\begin{array}{l}\text { - Há uma maior atenção em relação as APPs, porém muitas } \\
\text { construções e obras ocorrem sem o conhecimento do poder } \\
\text { público. Se faz necessário uma maior fiscalização das questões } \\
\text { ambientais. }\end{array}$ & $\begin{array}{l}\text { Não foi possível } \\
\text { avaliar }\end{array}$ \\
\hline
\end{tabular}

